
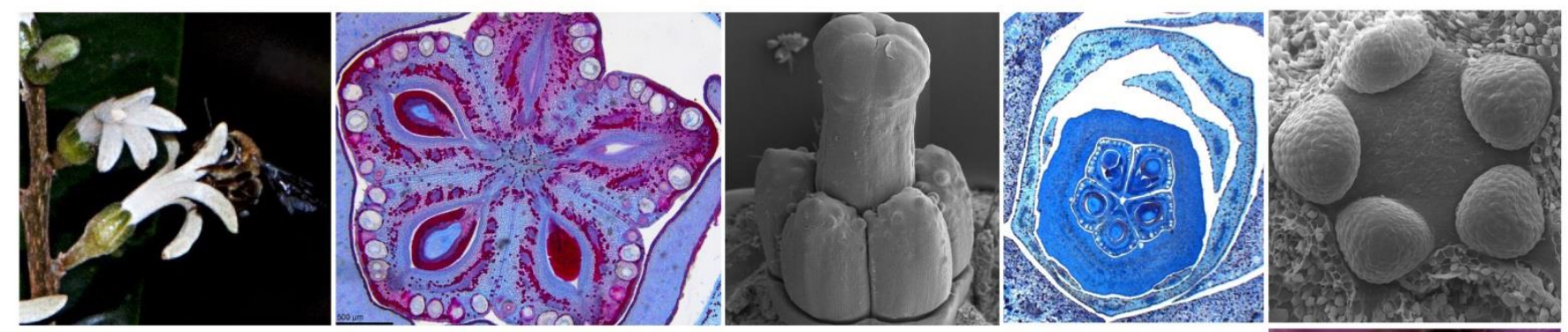

Juliana Hanna Leite El Ottra

Estrutura floral de Galipeinae (Rutaceae) e suas implicações na sistemática, evolução e biologia do grupo

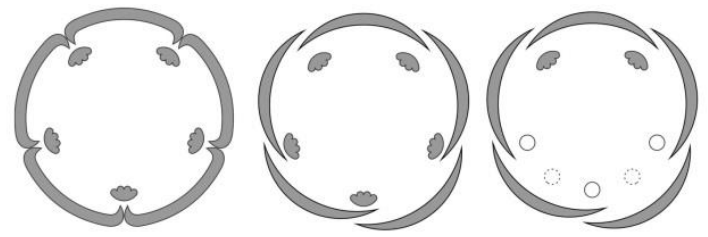

Floral structure in Galipeinae (Rutaceae) and its implications in the evolution, systematics and biology of the group
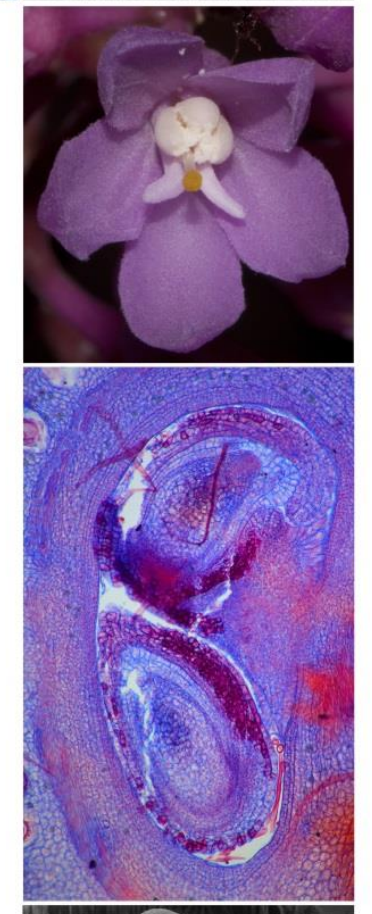

São Paulo

2014
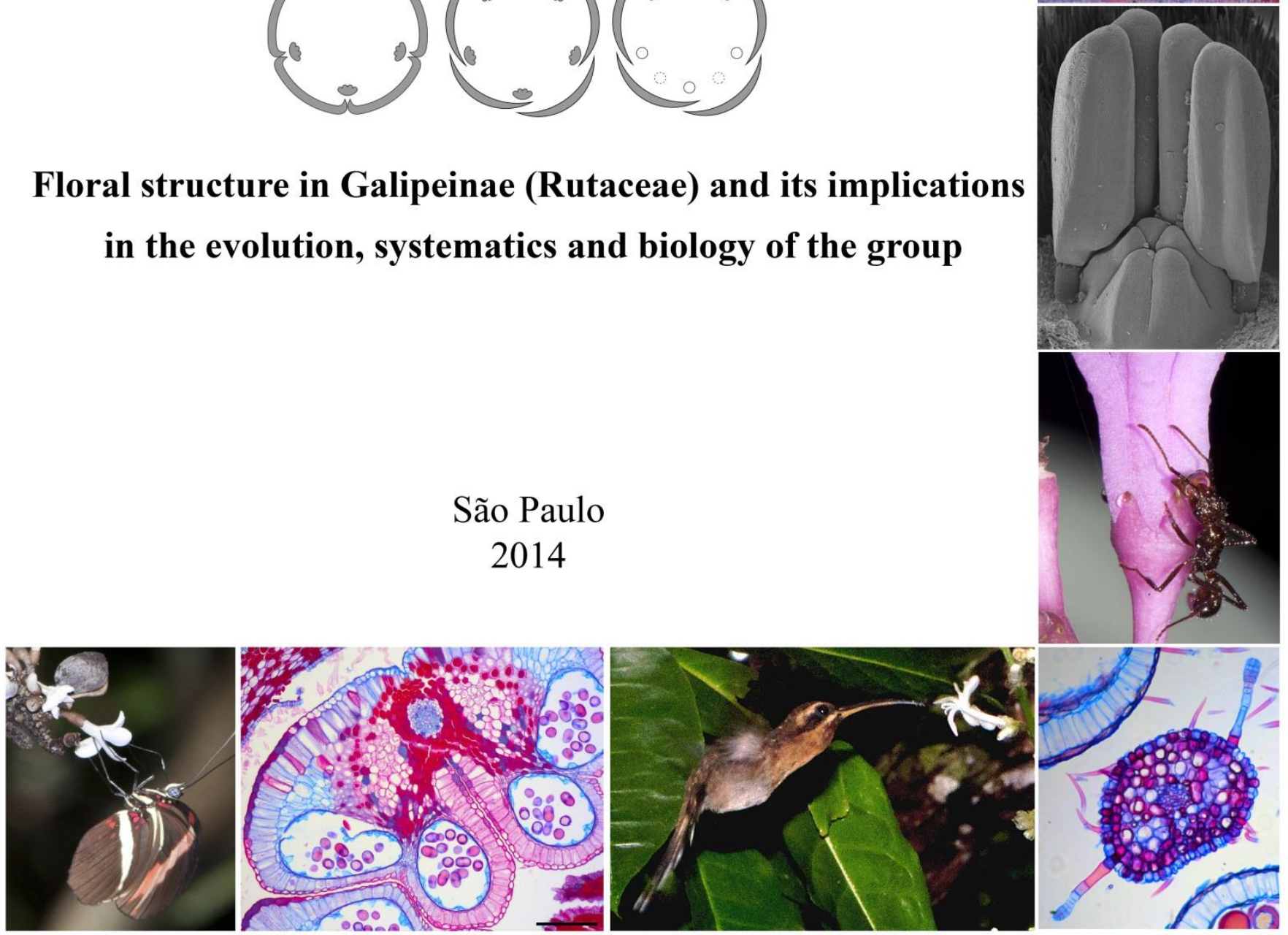

Juliana Hanna Leite El Ottra

Estrutura floral de Galipeinae (Rutaceae) e suas implicações na sistemática, evolução e biologia do grupo

Floral structure in Galipeinae (Rutaceae) and its implications in the evolution, systematics and biology of the group

Tese apresentada ao Instituto de Biociências da Universidade de São Paulo, para a obtenção de Título de Doutor em Ciências Biológicas, na Área de Botânica.

Orientador: José Rubens Pirani

Co-orientador: Emerson Ricardo Pansarin

São Paulo

Setembro de 2014 



\section{El Ottra, Juliana Hanna Leite}

Estrutura floral de Galipeinae (Rutaceae) e suas implicações na sistemática, evolução e biologia do grupo

Número de páginas: 309

Tese (Doutorado) - Instituto de Biociências da Universidade de São Paulo. Departamento de Botânica.

1. Estrutura floral 2. Biologia floral 3. Rutaceae. I. Universidade de São Paulo. Instituto de Biociências. Departamento de Botânica.

\section{Comissão Julgadora:}

Prof(a). Dr(a).

Prof(a). Dr(a).
Prof(a). Dr(a).

Prof(a). Dr(a).

Prof. Dr. José Rubens Pirani

Orientador 

Dedico à minha família 

"O quê?? Valho mais que uma flor Porque ela não sabe que tem cor e eu sei, Porque ela não sabe que tem perfume e eu sei, Porque ela não tem consciência de mim e eu tenho consciência dela? Mas o que tem uma coisa com a outra Para que seja superior ou inferior a ela? Sim tenho consciência da planta e ela não a tem de mim. Mas se a forma da consciência é ter consciência, que há nisso? A planta, se falasse, podia dizer-me: E o teu perfume? Podia dizer-me: Tu tens consciência porque ter consciência é uma qualidade humana E eu não tenho consciência porque sou flor, não sou homem. Tenho perfume e tu não tens, porque sou flor. Mas para quê me comparar, se eu sou eu E a flor é a flor? Ah, não comparemos coisa nenhuma; olhemos..." 



\section{Agradecimentos}

Gostaria de agradecer primeiramente à instituição me recebeu e que possibilitou o desenvolvimento das diferentes partes deste trabalho, o Instituto de Biociências da Universidade de São Paulo (IB-USP), à todos os seus professores e funcionários, por terem possibilitado meus estudos desde a fase de graduação até o presente momento.

Agradeço á Fundação de Amparo à Pesquisa do Estado de São Paulo (FAPESP), pela bolsa e auxílio financeiro concedidos a este projeto.

Em especial, agradeço ao meu orientador José Rubens Pirani (IB-USP) por ter me recebido como sua aluna, pela orientação desde os tempos de IC, pela confiança e entusiasmo em nosso trabalho, e por ter me passado um grupo tão lindo de plantas a ser estudado.

Ao professor Peter Endress (UZH), pela colaboração no manuscrito publicado, pelas riquíssimas sugestões e correções que em muito contribuíram para o aperfeiçoamento das análises estruturais aqui apresentadas.

Ao professor Diego Demarco (IB-USP), pela colaboração neste trabalho, pela atenção dada às minhas dúvidas técnicas e teóricas, pelo treinamento das bolsistas TT3 deste projeto e pelos novos protocolos fornecidos, que consequentemente resultaram em um avanço considerável na qualidade das lâminas elaboradas, bem como na análise das mesmas.

Ao meu co-orientador Emerson Ricardo Pansarin (FFCLRP-USP), pelo auxílio na fase de elaboração do projeto, nas fases iniciais dos trabalhos de campo, e pelas sugestões e correções do trabalho.

Aos professores do Laboratório de Anatomia Vegetal (IB-USP): Veronica Angyalossy, Gregório Ceccantini, Nanuza Luiza de Menezes, e Gladys Flávia Melo-de-Pinna, por tudo que me ensinaram desde os tempos de graduação. Aos técnicos deste mesmo laboratório, Gisele R. O. Costa, Tássia C. Santos e Irwandro R. Pires, pelos inúmeros auxílios ao longo deste trabalho.

Aos professores do Laboratório de Sistemática Vegetal (IB-USP): Renato Melo-Silva, Lúcia G. Lohmann, e Paulo T. Sano, por tudo que me ensinaram desde os tempos de graduação. Aos queridos técnicos deste mesmo laboratório (do passado e do presente), Fabiana Begale, Viviane Jono, Roberta Figueiredo e Abel R. Cangussu, pelos inúmeros auxílios, conversas e cafezinhos. 
Às professoras de minha banca de qualificação Lúcia G. Lohmann, Silvana Buzato e Gladys Flávia Melo-de-Pinna (IB-USP), pelas correções e sugestões ao projeto nesta ocasião.

Aos queridos colegas dos Laboratórios de Sistemática Vegetal e Anatomia Vegetal do IB-USP (do passado e do presente), pela ótima convivência, em especial à: Carla Verna, Carolina Bastos, Giuliano Locosselli, Gustavo Burin, Julio Majcher, Karen Sasaki, Karina Bertechine, Keyla Rodrigues, Luíza Teixeira, Marcelo Pace, Mariana Victorio, Juliana Brasileiro, Paula Elbl, Rafael da Silva Cruz, Raquel Koch, Mario Albino, Renata Lemos, Marília Duarte, Thália Gama, Vítor Barão, Yasmim Hirao (até aqui, Lab. Veg.), Alexandre Zuntini, Annelise Frazão, Augusto Giareto, Beatriz Gomes, Benoit Loulie, Caetano Oliveira, Carolina Siniscalchi, Caroline Andrino, Carolina Agostini, Cintia Luz, Euder Glendes, Gisele Gomes, Guilherme Antar, Gustavo Heiden, Herbert Serafim, Juliana Lovo, Juliana Rando, Jenifer Lopez, Jéssica Franscisco, Kyoshi Beraldo, Kamila Drequeceler, Leandro Assis, Leonardo Borges, Luiz Henrique, Livia Echternacht, Marcelo Kubo, Marcelo Devecchi, Marcelo Trovó, Maria Ana Farinaccio, Maria Cláudia, Maria Fernanda, Mariane S. Sousa, Mauricio Watanabe, Miriam Kaehler, Paulo Baleeiro, Paulo Gonella, Pedro Fiaschi, Vania Pretti, Virginia França (Lab. Sist.).

Aos atuais pós-docs Anselmo Nogueira e Fabiana Firetti (IB-USP) pelas valiosas discussões sobre ecologia e flores, sugestões e auxílios ao longo do trabalho; à Suzana Alcantara (IB-USP) pelo auxílio inicial no entendimento dos estudos sobre evolução floral.

Às bolsistas TT3 FAPESP, pelo auxílio fundamental ao projeto para que os resultados aqui apresentados fossem alcançados: Keyla Rodrigues, Cíntia Luz e Raquel Koch (IB-USP).

Aos meus pais, Toninho e Jô, por sempre terem apoiado meus estudos, pelos diversos auxílios ao longo de minha vida, pelo carinho, e pelo exemplo de trabalho; ao meu irmão Daniel, pelas diversas ajudas (emergenciais ou não) de cunho técnico-científico-eletrônicobiológico.

Ao Thomas, por compartilhar comigo o entusiasmo pelo mundo vegetal, pelo apoio, paciência e carinho. 


\section{ÍNDICE GERAL}

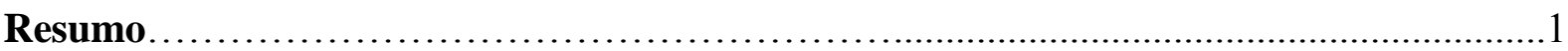

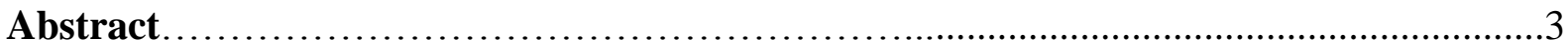

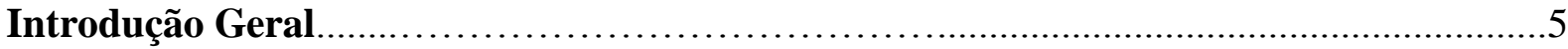

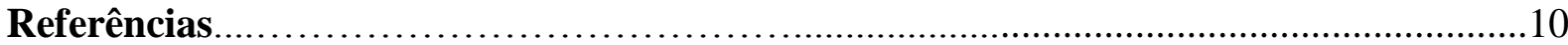

Capítulo 1. "Comparative floral structure in Galipeinae (Rutaceae) and its implications in the evolution, systematics and biology of the group" (em inglês)...................13

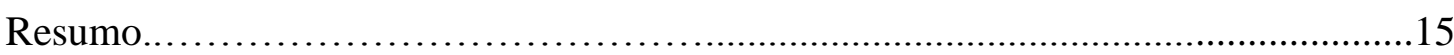

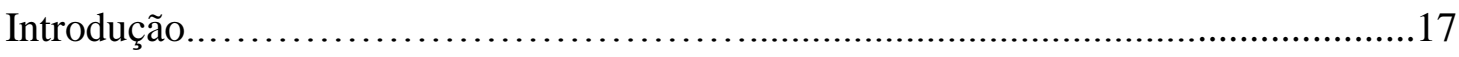

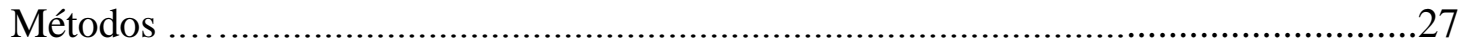

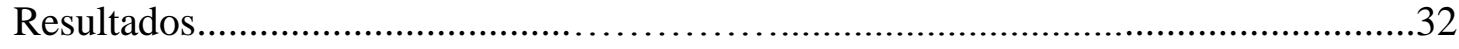

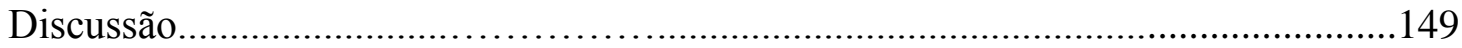

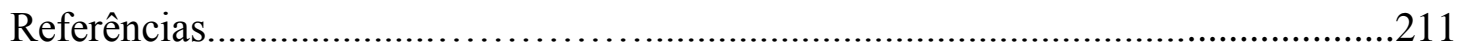

Capítulo 2. "Tackling pollination of tubular flowers in Rutaceae: a case study of Almeidea rubra A.St.-Hil. (Galipeinae, Rutaceae)" (em inglês)......................................221

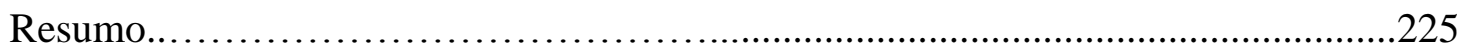

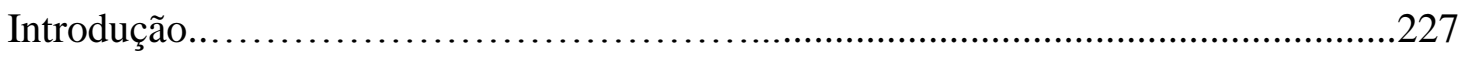

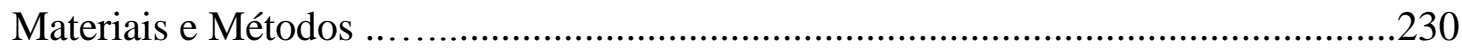

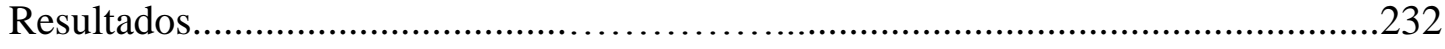

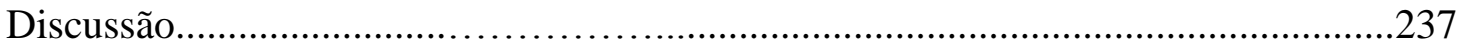

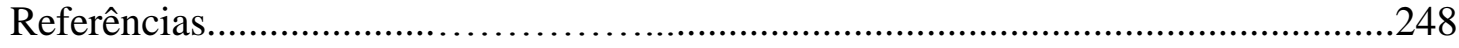

Capítulo 3. Biologia floral e polinização de duas espécies de Galipeinae (Galipeeae, Rutaceae) endêmicas de Mata Atlântica, com ênfase nos aspectos funcionais das estruturas florais (em português)................................................................225

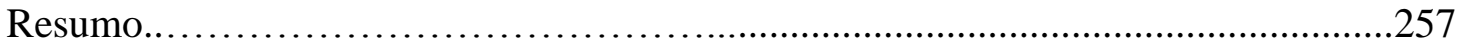

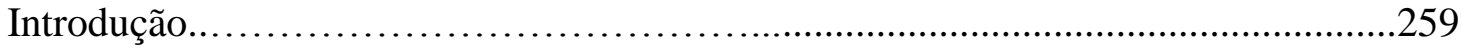

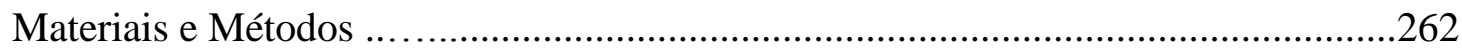

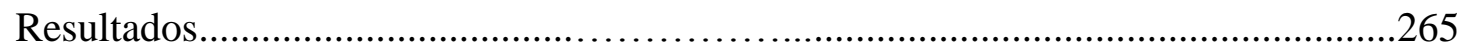

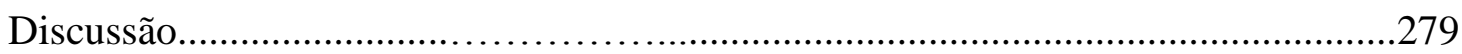

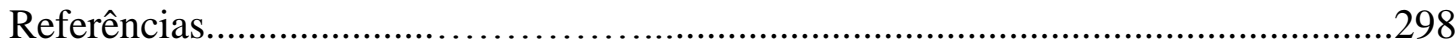

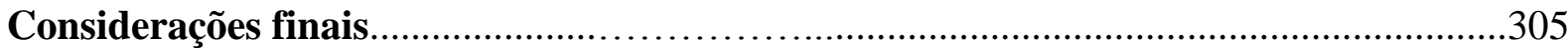

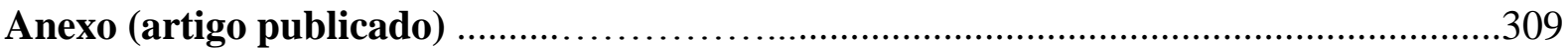




\section{ÍNDICE DE FIGURAS}

\section{Capítulo 1}

Figures 1-3: Galipeinae. Buds and flowers at anthesis .37-39

Figure 4: Adiscanthus fusciflorus. Sections of floral buds 41

Figure 5: Photomicrographs of microtome sections of floral buds Adiscanthus fusciflorus.... .42

Figure 6: Adiscanthus fusciflorus. Photographs and SEM micrographs .43

Figures 7: Almeidea lilacina and A. rubra. Sections of floral buds....

Figure 8: Photograph and photomicrographs of flowers and advanced buds of Almeidea rubra and A. limae.

Figures 9, 10: Photomicrographs of microtome sections of floral buds of Almeidea. 51,52

Figure 11: SEM micrographs of floral buds of Almeidea. .53

Figure 12: Angostura bracteata. Sections of floral buds. 58,59

Figure 13: Photomicrographs of microtome sections of floral buds of Angostura bracteata. 60

Figure 14: SEM micrographs of Angostura bracteata. .61

Figure 15: Conchocarpus cyrtanthus. Sections of floral buds.... 72,73

Figure16: Conchocarpus concinnus. Sections of floral buds. .74

Figure 17: Conchocarpus odoratissimus. Sections of floral buds 74,75

Figure 18: Photomicrographs of microtome sections of floral buds of Conchocarpus cyrtanthus.......76

Figures 19, 20: Photomicrographs of microtome sections of floral buds of Conchocarpus concinnus and $C$. odoratissimus. $.77,78$

Figure 21, 22: Photomicrographs of microtome sections of floral buds of Conchocarpus macrocarpus, C. obovatus and C. mastigophorus 79,80

Figure 23: Ertela bahiensis. Sections of floral buds 84,85

Figure 24: Photomicrographs of microtome transections of floral buds of Ertela bahiensis.... . .86

Figures 25, 26: SEM micrographs of Ertela bahiensis and E. trifolia. 87,88

Figure 27: Neoraputia trifoliata. Sections of floral buds. $.92,93$

Figures 28, 29: Photomicrographs of microtome sections of floral buds of Neoraputia trifoliata and N. alba.... $.94-95$

Figure 31: Raputiarana subsigmoidea. Sections of floral buds. 100,101

Figures 32, 33: Photographs and photomicrographs of microtome sections of floral buds of Raputiarana subsigmoidea 102,103 
Figure 34: Rauia resinosa. Sections of floral buds

Figures 35, 36: Photomicrographs of microtome sections of floral buds of Rauia nodosa and

R. resinosa 110,111

Figure 37: SEM micrographs of Rauia resinosa.

Figure 38: Ravenia spectabilis. Sections of floral buds

120, 211

Figure 39: Photomicrographs of microtome sections of floral buds of Ravenia spectabilis...... 122

Figure 40: Ravenia infelix. Photomicrographs of microtome transections of floral buds...

Figure 41: Sigmatanthus trifoliatus. Sections of floral buds

128,129

Figure 42: Photomicrographs of microtome sections of floral buds of Sigmatanthus trifoliatus

Figure 43: Photomicrographs of microtome sections of floral buds of Sigmatanthus trifoliatus and Spiranthera odoratissima ...

Figure 44: Spiranthera odoratissima. Sections of floral buds....

Figure 45: Photomicrographs of microtome sections of floral buds of Spiranthera odoratissima.....135

Figure 46: SEM micrographs of Spiranthera odoratissima 136

Figure 47: Metrodorea nigra. Sections of floral buds 140

Figure 48: Metrodora nigra. Photomicrographs of microtome sections of floral buds....

Figure 49: Photographs and SEM micrographs of Metrodorea nigra....

Figure 50: Hortia oreadica. Sections of floral buds. 146,147

Figure 51: Photomicrographs of microtome sections of floral buds of Hortia oreadica. 148

Figure 52: Schematic diagrams of the main patterns of corolla aestivation and floral symmetry in

Galipeinae and closely related genera. 204,205

\section{Capítulo 2}

Figure 1: Photographs, photomicrographs and SEM micrographs of Almeidea rubra. 235

Figure 2: Floral visitors of Almeidea rubra 236

\section{Capítulo 3}

Figura 1: Conhocarpus macrophyllus, Rutaceae.

Figura 2: Visitantes florais de Conchocarpus macrophyllus, Rutaceae. 276

Figura 3: Angostura bracteata, Rutaceae. 277

Figura 4: Visitantes florais de Angostura bracteata, Rutaceae. 278 



\section{RESUMO}

Galipeinae (Galipeeae, Rutoideae) é a subtribo mais diversificada de Rutaceae na região Neotropical. Evidências moleculares recentes sustentam a monofilia do grupo. Embora a delimitação dos gêneros e espécies da subtribo seja baseada principalmente em características florais, existem poucos estudos detalhados sobre a estrutura floral de representantes da subtribo, o que dificulta o uso acurado dos caracteres florais em estudos sobre sistemática e evolução do grupo. Além disso, pouco se sabe sobre as implicações funcionais dessas características na biologia das espécies, sendo necessários mais estudos ecológicos, ainda escassos sobre o grupo. Neste contexto, analisamos comparativamente a estrutura floral de diversos gêneros de Galipeinae e de gêneros americanos proximamente relacionados, apresentando descrições detalhadas e discutindo a implicação dos resultados na sistemática e evolução do grupo. Adicionalmente, investigamos as implicações funcionais de algumas características florais de Galipeinae, por meio do estudo da biologia floral e polinização de três táxons do grupo (Almeidea rubra, Conchocarpus macrophyllus e Angostura bracteata), e com base em dados da literatura e de observações pontuais feitas sobre outras espécies. Como principais resultados das análises estruturais, encontramos diversas características florais que sustentam a monofilia de Galipeinae, excluindo-se uma espécie, Adiscanthus, como a prefloração coclear ascendente ou oblíqua da corola, filetes achatados dorsiventralmente, carpelos com região sincárpica basal curta alcançando menos da metade do comprimento do ovário. Encontramos ainda características florais sustentando o par de gêneros-irmãos Adiscanthus e Hortia, como a conexão posgenital das pétalas apenas na fase de botão, por meio da conexão de células epidérmicas curtas com projeções cuticulares, antera com feixe vascular ramificado no ápice bem como na base, ápice das pétalas inflexo no centro do botão. Outras feições florais reportadas no presente trabalho auxiliam na sustentação de relações filogenéticas recentes no nível genérico ou infragenérico. Em relação ao papel funcional das feições florais de Galipeinae, a sinorganização das peças de diferentes verticilos revelou padrões variados nas espécies aqui estudadas e a arquitetura floral resultante parece refletir diretamente no acesso ao néctar e na polinização. Discutimos essas questões ecológicas ao nível familiar, notadamente em relação a polinizadores nectarívoros de língua e/ou bico relativamente longo, como lepidópteros e aves. Destaca-se ainda a evidência de que a hercogamia seja amplamente distribuída nas Galipeinae, e alguns aspectos funcionais da monossimetria do androceu de algumas espécies são apresentados. Finalmente, os atributos florais analisados em algumas espécies indicam maior especialização floral voltada aos principais grupos de polinizadores, os lepidópteros, notadamente características ligadas ao 
tubo floral, ao volume e concentração do néctar, ao odor floral e à presença de delicadas plataformas de pouso na flor. Este estudo permitiu identificar diversas hipóteses a serem exploradas em futuros estudos integrativos sobre a estrutura floral, biologia, polinização e evolução em Rutaceae. 


\section{ABSTRACT}

Galipeinae (Galipeeae, Rutoideae) is the most diversified subtribe of Rutaceae in the Neotropical region. Recent molecular phylogenies support the monophyly of the group. Even though the circumscription of taxa in the subtribe is based mainly on floral traits, there are few detailed studies on the floral structure of the group, preventing an accurate use of floral features in systematic and evolutionary studies. Furthermore, the functional implications of the floral features to the biology of the species in the group still need support from ecological studies, since these are scarce. In this context, we analyzed comparatively the floral structure of several genera of Galipeinae and closely related american genera, presenting detailed descriptions and discussing the relevance of the findings to the systematics and evolution of the group. Additionally we investigated the functional implications of some floral features on an ecological approach, through floral biology and pollination studies of three species of the group (Almeidea rubra, Conchocarpus macrophyllus e Angostura bracteata), as well as based on literature data and field observations on other species. Here we found that floral features strongly support the Galipeinae clade without Adiscanthus, such as cochlear aestivation of petals (either ascending or oblique), filaments dorsiventrally flattened, and a short basal syncarpous zone of carpels, with usually less than half-length of the ovary. The close relationship of Adiscanthus and Hortia, indicated by current molecular phylogenies, is supported by structural features, such as the postgenital connection of petals formed through the interlocking of short epidermal cells and cuticle projections only in bud stage; anthers with the vascular bundle forked towards its apex and base; and petal tips inwardly bent in the centre of the bud. Floral features further support other phylogenetic relationships recently found at the generic or infrageneric levels. Regarding the functional role of floral features, the synorganization of organs of different floral whorls shows several patterns among the studied species, and the resulting floral architecture seems to influence on the nectar access to pollinators. These ecological issues are discussed at the familiar level, notably their relation to long-tongued and/or long-beaked nectarivorous pollinators, such as lepidopterans and birds. Also, we found evidence that herkogamy is a widespread feature in Galipeinae, and the functional role of the androecium monosymmetry is now reported for some species. Finally, floral features indicate in some species floral specialization toward the main groups of pollinators found (lepidopterans), such as nectar volume and concentration, floral tube features, scent and delicate landing platforms. In this study we have also identified a series of hypotheses to be explored in future integrative studies with floral structure, biology, pollination and evolution in Rutaceae. 



\section{INTRODUÇ̃̃O GERAL}

\section{Galipeinae (Rutaceae): sistemática, evolução, estrutura floral e seus aspectos funcionais}

A subtribo Galipeinae, da tribo Galipeeae [anteriormente Cuspariinae e Cusparieae em Engler, (1931); nomes inválidos de acordo com Kallunki \& Pirani (1998)], é o grupo de Rutoideae (Rutaceae) mais diversificado da região Neotropical. Atualmente o grupo compreende 26 gêneros e cerca de 130 espécies, exclusivamente neotropicais, com numerosos casos de endemismos restritos a áreas de pequena extensão. Sua ocorrência abrange desde o sul do México e ilhas do Mar do Caribe, até a América do Sul, sendo que a maioria de seus representantes habita o interior de florestas úmidas de terras baixas (Groppo et al., 2008; Kubitzki et al., 2011). As plantas dessa subtribo são distintas dos demais grupos de Rutoideae principalmente por características florais. Suas flores são geralmente tubulares, polissimétricas a mais comumente monossimétricas, com estaminódios (geralmente três) e anteras basifixas (geralmente duas), apendiculadas em muitos gêneros (Morton \& Kallunki, 1993; Kallunki \& Pirani, 1998; Kubitzki et al., 2011). Elas exibem variados graus de união entre os verticilos florais, muitas vezes apenas superficiais, como entre filetes e entre estes e as pétalas, entre anteras e seus apêndices basais, e a conação completa ou parcial dos carpelos. Adicionalmente, possuem geralmente um disco nectarífero intraestaminal envolvendo o ovário, característica esta comum à maioria das outras famílias de Sapindales. Os frutos de Galipeinae são em maioria folículos ou cápsulas deiscentes, secos. Todas estas características foram tradicionalmente utilizadas para o reconhecimento dos gêneros e espécies no grupo (e.g., Engler, 1874, 1931), sendo de modo semelhante utilizadas também nos estudos modernos de morfologia e sistemática na subtribo (Ramp, 1988; Kallunki, 1992, 1998; Kallunki \& Pirani, 1998; Pirani, 1999, 2004; Pirani et al., 2010; Kubitzki et al., 2011; El Ottra et al., 2013).

No entanto a taxonomia da subtribo é complexa. Além da existência de muitos gêneros monotípicos (dez) ou com menos de cinco espécies (oito), os limites genéricos muitas vezes não são claros (e.g. Conchocarpus, Kallunki \& Pirani, 1998). Existem exceções em todos os caracteres morfológicos supracitados (e.g., algumas espécies ou gêneros apresentam os cinco estames férteis e/ou flores de pétalas livres, Groppo et al., 2008; Kubitzki et al., 2011). Adicionalmente, todos os gêneros de Galipeinae são definidos por combinações únicas de poucos estados de caracteres, sendo qualquer um destes isoladamente também compartilhado com um ou mais gêneros, o que torna difícil a delimitação de alguns grupos. Aparentemente, 
estados de caracteres similares teriam surgido independentemente ou por reversão na subtribo (Kallunki, 1998).

Apesar da dificuldade na taxonomia de alguns grupos, estudos filogenéticos revelam que a maioria das espécies de Galipeinae parece constituir um grupo monofilético bem sustentado por dados macromoleculares, exceto por uma espécie (Adiscanthus fusciflorus Ducke, Groppo et al., 2008, 2012; Kallunki \& Groppo, 2007; Groppo et al., in prep.). Ainda, o clado onde se inserem as Galipeinae constitui um grupo monofilético composto por outros grupos americanos de Rutoideae (denominado "American clade" por Groppo et al., 2012). No entanto até o momento nenhuma possível sinapomorfia morfológica foi encontrada sustentando o clado Americano, bem como para a maioria das relações entre seus gêneros. Apenas uma breve caracterização morfológica, utilizando-se principalmente dados de morfologia floral, foi apresentada para o clado das Galipeinae sem Adiscanthus e grupos proximamente relacionados (Groppo et al., 2008). Além disso, nota-se certa imprecisão na delimitação dos estados de caracteres florais nos poucos estudos de evolução de caráter a nível familiar (e.g. "carpelos mais ou menos unidos", Groppo et al., 2008), o que é uma consequência da falta de estudos detalhados sobre a estrutura floral do grupo (El Ottra et al., 2013, anexo).

De fato, existem poucos estudos morfoanatômicos florais relevantes sobre Rutaceae e ainda insuficientes para o entendimento profundo da ampla diversidade de flores existente no grupo (Souza et al., 2003). Dentre as Galipeinae e grupos Americanos proximamente relacionados, há escasso trabalhos detalhados sobre a estrutura floral. Dentre estes, a maioria é de cunho descritivo, como os de Marquete (1981) e Souza et al. (2003), descrevendo a estrutura floral de espécies de Pilocarpus; o de Souza et al. (2004) sobre Metrodorea nigra A.St.-Hil, enfocando principalmente a histologia da flor e na estrutura dos óvulos e anteras. Dentre os trabalhos comparativos mais amplos tratando de diversos representantes da família, apenas o de Gut (1966) e Ramp (1988) incluiram espécies de Galipeeae, enfocando sobretudo a estrutura do gineceu de Pilocarpus pennatifolius Lem. (Pilocarpinae), e Erythrochiton brasiliensis Nees \& Mart. (Galipeinae). Apenas mais recentemente novos trabalhos foram feitos dentro do contexto comparativo, buscando não apenas elucidar a estrutura floral em detalhe, mas também buscando subsídios para a sistemática e evolução floral de Galipeinae: Pirani et al. (2010) estudaram detalhadamente a estrutura floral de cinco representantes de Galipea, e El Ottra et al. (2013, anexo) efetuaram uma análise avaliando como e por qual extensão os órgãos florais são unidos em cinco representantes da subtribo. Como um dos principais achados deste último estudo, concluiu-se que a extensão e diversidade de fusões 
dos órgãos florais de Galipeinae exibe muitas singularidades dentro da ordem Sapindales (El Ottra et al., 2013, anexo).

Adicionalmente, nestes trabalhos mais recentes, algumas das características florais mais marcantes de Galipeinae foram discutidas considerando as possíveis implicações funcionais destas feições na ecologia das espécies. Notadamente, o papel do tubo floral em relação à canalização do acesso ao néctar pelos visitantes florais, bem como na proteção do néctar pela diluição pela chuva foi discutido, não apenas em Galipeinae, bem como em relação a outras Rutaceae com flores tubulosas (El Ottra et al., 2013, anexo). Também, a ocorrência de duas anteras na porção posterior da flor da maioria dos representantes de Galipeinae, sendo estas usualmente fundidas posgenitalmente (e.g. Galipea, Pirani et al., 2010), foi relacionada à estabilização da estrutura do androceu nesta porção da flor, bem como à polinização nototríbica. No entanto, essas discussões se basearam em estudos provenientes de outros grupos com feições florais semelhantes (e.g. Faegri \& van der Pijl, 1979; Endress, 1994; Westerkamp \& Claßen-Bockhoff, 2007) ou nos escassos dados sobre biologia floral e polinização de Galipeinae [i.e., apenas um estudo detalhado, sobre Galipea jasminiflora (A.St.-Hil.) Engl., Piedade \& Ranga, 1994]. Ainda, a análise dos trabalhos de cunho taxonômico de representantes de Galipeinae nos permite notar que outras feições florais, como flores hercogâmicas, estaminódios e simetria floral variável (e.g. Engler, 1931; Kallunki \& Pirani, 1998; Piedade \& Ranga, 1994) seriam também interessantes características a serem abordadas em estudos de biologia floral e polinização. De fato, estas características já foram reportadas influenciando os modos de polinização, reprodução e evolução das espécies em outros grupos de Angiospermas (e.g. Webb \& Lloyd, 1986; Neal et al., 1998; Walker-Larsen \& Harder, 2000; Ronse Decraene \& Smets, 2001; Endress, 2011). A evolução da morfologia floral pode ser influenciada por vários fatores, dentre estes, notadamente, a pressão seletiva por parte dos polinizadores (Stebbins, 1970; Fenster et al., 2004). Portanto, dada a diversidade e importância das características florais na sistemática de Galipeinae, o estudo das mesmas, considerando a polinização e biologia floral das espécies, poderia contribuir com novas informações acerca dos fatores que podem ter atuado na evolução floral deste grupo tão diverso de Rutoideae. 


\section{Objetivos}

Frente às informações acima expostas, os objetivos gerais desta tese são:

(1) Analisar a estrutura floral de diversos gêneros de Galipeinae, apresentando descrições detalhadas e discutindo a implicação dos resultados na sistemática e evolução do grupo, bem como em hierarquias sistemáticas mais abrangentes quando possível;

(2) Investigar as possíveis implicações funcionais de algumas características florais de Galipeinae no contexto da ecologia das espécies, por meio do estudo da biologia floral e polinização de três táxons do grupo, bem como baseado em dados da literatura e de observações feitas sobre outras espécies ao longo deste projeto.

Para alcançar os objetivos gerais acima mencionados, três estudos diferentes foram realizados durante este doutorado, cujos objetivos específicos e demais tópicos são apresentados nas partes seguintes desta tese.

\section{Estrutura geral da tese}

A tese é composta por esta introdução geral, seguida por três capítulos (em formato de manuscritos), considerações finais e um anexo. Cada capítulo apresenta formatação adequada à revista que submetemos ou planejamos submeter cada manuscrito. Em linhas gerais, os capítulos e o anexo contêm os seguintes estudos:

Capítulo 1 - consiste no primeiro estudo comparativo sobre a estrutura floral de Galipeinae e gêneros americanos proximamente relacionados, abrangendo uma ampla amostragem de espécies da subtribo. Além de apresentar as descrições e ilustrações das características florais estudadas, também buscamos detectar entre os caracteres analisados quais seriam possíveis sinapomorfias de diferentes clados do grupo, considerando o contexto atual da sistemática e filogenia de Rutoideae. Adicionalmente, discutimos as possíveis trajetórias evolutivas de alguns caracteres florais, bem como sua relevância considerando a macrossistemática atual de Sapindales e rosídeas. Finalmente, discutimos as implicações funcionais de outros caracteres florais estudados relacionados à biologia floral e polinização das espécies, gerando novas hipóteses a serem testadas em estudos futuros integrando estrutura e função destas feições florais. Planejamos submeter este capítulo na forma de dois manuscritos para a revista Botanical Journal of the Linnean Society, com a co-autoria de Diego Demarco, José Rubens Pirani e Peter K. Endress. 
Capítulo 2 - consiste em um primeiro estudo de caso, sobre a biologia floral e polinização Almeidea rubra A.-St.-Hil. (Galipeinae) em uma área de Mata Atlântica do Espírito Santo. Adicionalmente neste trabalho contextualizamos a funcionalidade dos tubos florais em Angiospermas, dado que é uma característica bem marcante das Galipeinae, ponderando também as implicações funcionais desta e de outras feições florais no contexto ecológico observado. Ainda, comparamos estes achados com os dados de morfologia floral e polinização já documentados sobre outros representantes da família com arquitetura floral semelhante, notadamente alguns representantes australianos da tribo Boronieae. Com esta comparação buscamos mais subsídios para corroborar a hipótese de evolução floral convergente nestes dois grupos de Rutaceae (El Ottra et al., 2013). Este manuscrito foi submetido para a revista Australian Journal of Botany, com a co-autoria de José Rubens Pirani e Emerson Ricardo Pansarin.

* Capítulo 3 - consiste em um segundo estudo de caso, sobre a biologia floral e polinização de duas espécies coocorrentes e co-florescentes de Galipeinae em uma área de Mata Atlântica no Espírito Santo. Neste capítulo discutimos também as implicações funcionais das feições florais no contexto ecológico observado, articulando estes resultados com os demais já apresentados nos capítulos 1 e 2 a esse respeito. Planejamos submeter este capítulo na forma de um manuscrito para a revista Plant Systematics and Evolution, com a coautoria de José Rubens Pirani e Emerson Ricardo Pansarin.

Anexo: Trata-se de um estudo iniciado em período prévio ao doutorado, motivado pela complexidade e variados graus de união e fusão entre verticilos florais e sua importância na sistemática de Galipeinae. Nele avaliamos como e por qual extensão os órgãos florais são unidos em cinco representantes da subtribo, e discutimos as implicações dos resultados encontrados na sistemática e evolução do grupo. Este trabalho foi publicado nos Annals of Botany, em co-autoria com José Rubens Pirani e Peter K. Endress. 


\section{Referências}

El Ottra JHL, Pirani JR, Endress PK. 2013. Fusion within and between whorls of floral organs in Galipeinae (Rutaceae): structural features and evolutionary implications. Annals of Botany 111: 821-837.

Endress PK. 1994. Diversity and evolutionary biology of tropical flowers. Cambridge: Cambridge University Press.

Endress PK. 2011. Evolutionary diversification of the flowers in angiosperms. American Journal of Botany 98: 370-396.

Engler A. 1874. Rutaceae. In Martius, CPF, Eichler, AG, eds. Flora brasiliensis, 12. Leipzig: Friedrich Fleischer, 75-196.

Engler A. 1931. Rutaceae. In: Engler A, Prantl K, eds. Die natürlichen Pflanzenfamilien, 2nd edn, 19a. Leipzig: Engelmann, 187-359.

Faegri L, van der Pijl L. 1979. The principles of pollination ecology, 3rd edn. New York: Pergamon Press.

Fenster CB, Armbruster WS, Wilson P, Dudash MR, Thomson, JD. 2004. Pollination syndromes and floral specialization. Annual Review of Ecology Evolution and Systematic 35: 375-403.

Groppo M, Pirani JR, Salatino MLF, Blanco SR, Kallunki JA. 2008. Phylogeny of Rutaceae based on two noncoding regions from cpDNA. American Journal of Botany 95: 985-1005.

Groppo M, Kallunki JA, Pirani JR, Antonelli, A. 2012. Chilean Pitavia more closely related to Oceania and Old World Rutaceae than neotropical groups: evidence from two cpDNA non-coding regions, with a new subfamilial classification of the family. PhytoKeys 19: 9-29.

Gut BJ. 1966. Beiträge zur Morphologie des Gynoeceums und der Blütenachse einiger Rutaceen. Botanische Jahrbücher für Systematik 85: 151-247.

Kallunki JA. 1992. A revision of Erythrochiton sensu latu (Cuspariinae, Rutaceae). Brittonia 44: 107139.

Kallunki JA. 1998. Revision of Ticorea Aubl. (Rutaceae, Galipeinae). Brittonia 50: 500-513.

Kallunki JA, Pirani JR. 1998. Synopses of Angostura Roem. \& Schult. and Conchocarpus J. C. Mikan. Kew Bulletin 53: 257-334.

Kallunki JA, Groppo M. 2007. Phylogenetic analyses of the subtribe Galipeinae (Rutaceae).URL:2007.botanyconference.org/engine/search/index.php?func=detail\&aid=1344. Date of last access: 12 Mar. 2014.

Kubitzki K, Kallunki JA, Duretto M, Wilson PG. 2011. Rutaceae. In: Kubitzki K, ed. Flowering Plants. Eudicots: Sapindales, Cucurbitales, Myrtaceae (The Families and Genera of Vascular Plants). Hamburg: Springer, 276-356.

Marquete O. 1981. Anatomia e vascularização foliar e floral de Pilocarpus organensis Occhioni \& Rizzini (Rutaceae). Arquivos do Jardim Botânico do Rio de Janeiro 25: 117-159.

Morton CM, Kallunki JA. 1993. Pollen Morphology of the subtribe Cuspariinae (Rutaceae). Brittonia 45: 286-314. 
Neal PR, A Dafni, M Giurfa. 1998. Floral symmetry and its role in plant-pollinator systems: terminology, distribution, and hypotheses. Annual Review of Ecology and Systematics. 29:345-373.

Pirani JR. 1999. Estudos taxonômicos em Rutaceae: revisão de Helietta $e$ Balfourodendron (Pteleinae). Análise cladística de Pteleinae. Sinopse de Rutaceae do Brasil. Tese de livre docência, Universidade de São Paulo, Brasil.

Pirani JR. 2004. Three new species of Galipea (Rutaceae, Galipeinae) from Brazil. Botanical Journal of the Linnean Society 144: 365-373.

Pirani JR, El Ottra JHL, Menezes NL. 2010. Morfoanatomia da flor de cinco espécies de Galipea Aubl. e seu significado na evolução de flores tubulosas entre as Rutaceae neotropicais. Revista Brasileira de Botânica 33: 301-318.

Piedade LH, Ranga NT. 1993. Ecologia da polinização de Galipea jasminiflora Engler (Rutaceae). Revista Brasileira de Botânica 16: 151-157.

Ramp E. 1988. Struktur, Funktion und systematische Bedeutung des Gynoeciums bei den Rutaceae und Simaroubaceae. PhD Thesis, Universität Zürich: Switzerland.

Ronse Decraene LP, Smets EF. 2001. Staminodes: Their Morphological and Evolutionary Significance. The Botanical Review 67: 351-402.

Souza LA, Mourão KSM, Moscheta IS, et al. 2003. Morfologia e anatomia da flor de Pilocarpus pennatifolius Lem. (Rutaceae). Revista Brasileira de Botanica 26: 175-184.

Souza LA, Moscheta IS, Mourão KSM, Rosa SM. 2004. Morphology and anatomy of the flowers and anthesis of Metrodorea nigra St. Hill (Rutaceae). Brazilian archives of Biology and. Technology 47: 107-112.

Stebbins GL. 1970. Adaptive radiation of reproductive characteristics in angiosperms. I. Pollination mechanisms. Annual Review of Ecology and Systematics 1: 307-326.

Walker-Larsen J, Harder LD. 2000. The evolution of staminodes in angiosperms: patterns of stamen reduction, loss, and functional re-invention. American Journal of Botany 87: 1367-1384

Webb CJ, Lloyd DG. 1986. The avoidance of interference between the presentation of pollen and stigmas in angiosperms II: Herkogamy. New Zealand Journal of Botany 24: 163-178.

Westerkamp C, Claßen-Bockhoff R. 2007. Bilabiate flowers: the ultimate response to bees? Annals of Botany 100: 361-374. 



\section{CAPÍTULO 1}

Comparative floral structure in Galipeinae (Rutaceae) and its implications in the evolution, systematics and biology of the group 



\section{ABSTRACT}

Galipeinae (Galipeeae, Rutoideae) is the most diversified subtribe of Rutaceae in the Neotropical region. The circumscription of the subtribe is based mainly on a variety of floral traits. However, few detailed studies have been conducted on the floral structure of the group. Additionally, molecular phylogenetic studies demonstrated that the genus Adiscanthus, formerly placed in Galipeinae, is in fact sister to Hortia (former Toddalioideae). All these groups are included in a larger clade, named the "American clade" of Rutoideae. The present study aimed to assess potential morphological synapomorphies of these new clades, and to provide a broader comparative account of the floral structure of the Galipeinae and closely related American genera. Also, the functional implications of some floral features are discussed, as their relevance in higher systematic levels. We found that floral features strongly support the Galipeinae clade excluding Adiscanthus, such as cochlear aestivation of petals (either ascending or oblicue), filaments dorsiventrally flattened, and a short basal syncarpous zone of carpels (usually less than half-length of the ovary). Contrastingly, Adiscanthus and Hortia share (among other features) postgenital connection of petals formed by interlocking of short epidermal cells and cuticle projections only in bud stage, anthers with the vascular bundle forked towards its apex and base, and petal tips inwardly bent in the centre of the bud. Additionally floral features further support some other generic or infrageneric relationships. Gynoecium features are especially similar to other groups of Rutaceae, such as those related to vascularization and histology. Furthermore, ovule structure supports ordinal or supraordinal relationships. The role of synorganization and floral architecture in relation to nectar access and pollination is discussed. Herkogamy was found to be a widespread feature of Galipeinae. Finally, our results indicate that floral monosymmetry is conspicuously diverse within the subtribe and probably evolved more than once within the American clade. The floral monosymmetry associate with some other androecium features (basal appendages, synanthery and anther histology) may have special biological functions. We also have identified a series of hypotheses to be explored in future integrative studies on floral structure, biology, pollination and evolution in the group.

KEYWORDS: apocarpous gynoecium - nectary disc - floral biology - floral architecture floral symmetry - obdiplostemony - anatomy - Rutoideae - Sapindales - synorganization. 



\section{INTRODUCTION}

\section{Rutaceae systematics and the subtribe Galipeinae}

Rutaceae currently consists of approximately 2,100 species distributed in 154 genera, occurring in tropical and subtropical regions all over the world, mainly in tropical America, South Africa and Australia (Porter \& Elias, 1979; Kubitzki et al., 2011). The most distinctive feature of the family is the presence of translucent dots in their leaves and also spread in nearly all organs. These correspond to secretory cavities, which produce aromatic volatile oils, often accompanied by secretory cells in parenchymatous tissues (Metcalfe \& Chalk, 1950; Kubitzki et al., 2011). Rutaceae is a member of Sapindales, order also comprising Simaroubaceae, Meliaceae, Sapindaceae, Anacardiaceae, Burceraceae, Kirkiaceae, Nitrariaceae, and Biebersteiniaceae (APG, 2009). According to the current molecular phylogenies, Simaroubaceae and Meliaceae would be the most closely related families to Rutaceae (Salvo et al., 2008; APG, 2009). Among eudicots, Sapindales is placed in the malvid clade (or rosid II), within the larger rosids clade (APG, 2009; Stevens, 2001).

Major contributions toRutaceae systematics were made by Adolf Engler (Engler, 1874, 1931). In his monograph (1931), a comprehensive systematic treatment of the family, he recognized seven subfamilies, which were maintained with slight modifications by Scholz (1964) in the last edition of the Engler's Syllabus der Pflanzenfamilien. The seven subfamilies were: Rutoideae (the bulk of the family), Dictyolomatoideae, Flindersioideae, Toddalioideae, Spathelioideae, Aurantioideae (or Citroideae) and Rhabdodendroideae, but the latter was subsequently excluded from Rutaceae (Fay et al., 1997).

However, since then studies from several areas of knowledge provided evidences that the subdivisions of the family proposed by Engler (1931) are artificial, and pointed to the need for a deep review of the infrafamilial classification of Rutaceae. Among such studies, we can highlight: the analyses of secondary metabolites by Silva et al. (1988); the chromosome study by Stace (1993); the cladistic analyses based on molecular data made by Chase et al. (1999), Scott et al. (2000), Poon et al.(2007) and Groppo et al. (2008, 2012). Such analyses have provided evidences or have corroborated that several of the groups proposed by Engler are not monophyletic, particularly Toddalioideae and Rutoideae. Yet, morphological features traditionally used to circumscribe the subfamilies, such as the degree of carpel connation and dehiscence or indehiscence of the fruit, show to be inappropriate for that purpose, since they are highly homoplastic and do not support monophyletic groups at that hierarchic level (Groppo et al., 2008). On the other hand, evidence coming from molecular systematic and 
chromosome studies support the monophyly only of the genera traditionally included in the subfamily Aurantioideae, and of the monogeneric subfamilies Spathelioideae and Dictyolomatoideae (Stace, 1993; Chase et al., 1999; Guerra et al., 2000; Scott et al., 2000; Morton et al., 2003; Groppo et al., 2008). Thus, it was concluded that all other subfamilies sensu Engler should be reviewed, as well as the circumscription of their tribes and some subtribes, once these have emerged as non-monophyletic and not resolved in the molecular phylogenies (Chase et al., 1999; Groppo et al., 2008).

In this context, more recent molecular systematic studies presented a new circumscription of the subfamilies, reducing them into two large monophyletic groups that are sister to each other: Cneoroideae (Spathelioideae in Appelhans et al., 2011, but correctly denominated Cneoroideae as pointed out by Groppo et al., 2012) and Rutoideae (Groppo et al., 2012; Stevens, 2001). Rutoideae, in this new definition, is the largest subfamily, consisting of two main clades: one containing all genera traditionally included in Aurantioideae (the Citrus group), plus the sister group Chloroxylum and Ruta; and another clade containing other representatives of Rutoideae (without Ruta), Toddalioideae and Flindersioideae (the "RTF" clade, Groppo et al., 2012). This wider circumscription of Rutoideae led to the reduction of the traditional subfamily Aurantioideae to the level of tribe (i.e. Aurantieae, Groppo et al., 2012). The other subfamily, Cneoroideae, consists of the members from the former monogeneric subfamilies Dictyolomatoideae and Spathelioideae, plus genera so far positioned in other families of Sapindales (i.e. genera before placed in Cneoraceae, Simaroubacae, Meliaceae, Sapindaceae, Ptaeroxylaceae, Appelhans et al., 2011). Whereas a new circumscription at tribal level in Cneoroideae has been presented by Appelhans et al. (2011), this has not been done yet in Rutoideae (except for tribe Aurantieae, by Groppo et al., 2012). Although strongly supported by molecular evidence, no potential morphological synapomorphy to the "RTF" clade has been found so far. Also, the tribal and subtribal relations remain to be solved for most of the Rutaceae groups (Stevens, 2001).

In the molecular phylogeny of Groppo et al. (2012) within the RTF clade of Rutoideae emerged a smaller clade comprising genera from South and Central America (mainly tropical) that the authors informally denominated as "American clade". Within the American clade are included all genera usually treated in the subtribes Pilocarpinae and Galipeinae, the only groups of tribe Galipeeae [previously Cusparieae in Engler (1931), invalid name according to Kallunki \& Pirani (1998)]. Galipeinae (previously Cuspariinae, invalid name), the main focus of the present study, comprises 26 exclusively Neotropical genera and about 130 species, distributed from South America to South of Mexico and West Indies (Groppo et al., 2008; 
Kubitzki et al., 2011), mostly in moist lowland forests (Kubitzki et al., 2011). The group is distinguished from the rest of the subfamily mainly by floral features. Their flowers are usually tubular, polysymmetric to (most commonly) monosymmetric, with variable number of staminodes (usually three) and mostly two stamens with anther usually bearing basal appendages (Morton \& Kallunki, 1993; Kallunki \& Pirani, 1998). There are several forms and degrees of union between floral whorls in Galipeinae, many times only superficially, as the union os stamens among themselves and their fusion with petals, the union of anthers and their basal appendages, and the partial to complete connation of carpels. An intrastaminal nectariferous disc is usually present, surrounding the ovary, a feature common to several Sapindalean families. Fruits in Galipeinae are mostly dry, dehiscent folicules or capsules. All these features have been used to distinguish genera and species in the group (e.g. Engler, 1874, 1931), and this procedure persists today (Ramp, 1988; Kallunki, 1992, 1998b; Kallunki \& Pirani, 1998; Pirani, 1999, 2004; Pirani et al., 2010; Kubitzki et al., 2011; El Ottra et al., 2013).

The taxonomy of the subtribe Galipeinae is complex. In addition to the existence of many monotypic genera (ten) or with less than five species (eight), the generic boundaries are not yet clear in several cases (e.g. Conchocarpus, Kallunki \& Pirani, 1998). There are exceptions to all morphological characters mentioned above (e.g., some species or genera present five fertile stamens and/or free petals, Groppo et al., 2008; Kubitzki et al., 2011). Additionally, all Galipeinae genera are defined by single combinations of a few character states, and any particular character is also shared with one or more genera, which makes it difficult to circumscribe some groups. Apparently, similar character states would have originated independently or by reversion in the subtribe (Kallunki, 1998b).

Changes in circumscription of the genera in the subtribe have also occurred steeply over the last 31 years. Emmerich (1978) redefined the Raputia complex, describing the new genera Neoraputia, Sigmatanthus and Raputiarana, floral features being most important for the new division of the group. The genus Erythrochiton Nees \& Martius sensu lato was revised by Kallunki (1992). The author divided Erythrochiton sensu lato into three different genera: Erythrochiton s.str., Toxosiphon, and Desmotes. These shared the presence of a large colorful calyx with valvate aestivation, and the first feature has been raised as potential morphological evidence of the monophyly of the group. Also in the review of Raputia and Ticorea, the floral features were important for the new generic delimitation (Kallunki 1994, 1998b). Yet, among the ongoing taxonomic studies, there are the reviews of Galipea (J.R. Pirani, in prep.), and of Rauia (J.A. Kallunki, in prep.). Kallunki \& Pirani (1998) presented a new circumscription for 
Angostura and Conchocarpus, genera of problematic taxonomy, especially the latter. Conchocapus is the largest and most heterogeneous genus of Galipeinae (Pirani, 1999), and in the phylogenies obtained with a larger number of species of the subtribe, the genus was found to be not monophyletic (Kallunki \& Groppo, 2007; Bruniera, 2010). Therefore, it is considered that some species of the genus should be removed given its positioning in the phylogeny, as well as for having atypical character states (Kallunki \& Pirani, 1998; Kallunki \& Groppo, 2007). Additionally, a molecular phylogenetic study carried out for the genus Almeidea showed that this is not monophyletic either, but that it is closely related to a group composed by several species of Conchocarpus (Bruniera, 2010).

The study of Groppo et al. (2008) was the first to include six Galipeinae genera in a molecular phylogeny, based on plastid markers rps-16 and trnL-trnF. In spite of not having found support for Galipeinae as a monophyletic group, the genera with tubular flowers formed a robust clade that was informally denominated by the authors as "Angostura-Sigmatanthus clade". The only Galipeinae genus that did not emerge in this clade was Adiscanthus, which was clustered as a sister group of Hortia. Whereas Adiscanthus is a monotypic Amazonian genus, Hortia have ten neotropical species, which have been recently revised (Groppo \& Pirani, 2012). Hortia was traditionally positioned in Engler's classification (1931) in the subfamily Toddalioideae (mostly paleotropical), subtribe Toddalinae, due to its actinomorphic, bisexual, isotemonous flowers, and baccate fruits. The morphological features that would support the close relationship between Hortia and Adiscanthus would be the scarcely branched habit, simple leaves, dialipetalous corolla with valvate aestivation, and bearded petals. Differently, the presence of a tubular flower is a possible morphological synapomorphy of the remaining Galipeinae (without Adiscanthus, Groppo et al., 2008; Kubitzki et al., 2011; El Ottra et al., 2013). Other more recent molecular phylogenies so far also corroborated the exclusion of Adiscanthus from the Galipeinae (Groppo et al., 2012; Groppo et al. in prep., this latter with a larger number of Galipeinae representatives analyzed, 15 genera and 40 species).

In addition to Hortia and Adicanthus, other American genera have emerged next to the Galipeinae clade in recent phylogenetic studies (Groppo et al., 2012; Dias et al., in press; Groppo et al., in prep.). Thus Hortia and Adicanthus would be a sister group of a larger clade consisting of Pilocarpinae genera (i.e., Esenbeckia, Metrodorea, also included in the tribe Galipeeae, former Cusparieae of Engler, 1931) and other former Toddalioideae genera (i.e., Helietta and Balfourodendron, Pteleinae, Engler, 1931). Those two clades together form the sister group of the Galipeinae (Adiscanthus excluded). Additionally, Choisya (Rutoideae, 
Zanthoxylae, Choisyinae, Engler, 1931) is placed further outside these clades, as it is the sister genus of all other genera of the American clade (Groppo et al., 2012). According to Dias et al. (in press), other Pilocarpinae genera such as Raulinoa and Pilocarpus would also be closely related to the Pilocarpinae and Toddalioideae taxa included in the study of Groppo et al. (2012). However, so far, no potential morphological synapomorphy has been found supporting the American clade, as well as for most of the relationships between its genera. Only a brief morphological characterization mainly based on floral morphology was made to the Galipeinae and closely related American groups (Groppo et al., 2008, Kubitzki et al. 2011). Hence, new detailed morphological studies are necessary to improve the taxonomic circumscription as well as to achieve a better understanding of the evolution of the group.

\section{Comparative studies of the floral structure of Rutaceae and Galipeinae, and their implications in the systematic, evolution and biology of the groups}

In Rutaceae there are a few comparative on floral structure, still insufficient to understand the wide diversity of flowers in the group (Souza, 2003). Among these studies, the following can be highlighted: Moore (1936), based on data by Saunders (1934), showed that floral vascularization does not provide corroboration for the subfamiliar subdivision and tribes proposed by Engler (1931); Tilson \& Bamdford (1938) studied representatives of the former Aurantioideae, showing how floral structure support or not the division in tribes and subtribes; Gut (1966) studying the gynoecium of representatives of the subfamilies concluded that Rutoideae have weakly united carpels, whereas in the former Toddalioideae and Aurantioideae, syncarpous carpels predominate; Ramp (1988), based on the study of the gynoecium structure of 57 species of 30 genera of the family, concluded that the Toddalioideae was an artificial group; studies of the flowers of Zanthoxylum species corroborate the recognition of that genus with no distinction of the segregate Fagara, an old controversy in the group (Yamazaki ,1988; Beurton,1994); Caris et al. (2006) studying the floral structure and development of Cneorum, a genus of controversial positioning in Sapindales, revealed its closer relationship to Rutaceae, as shown by previous molecular phylogenies. Other studies have focused on specific issues of morphology and vascularization of single floral organs, as discs and partial syncarpy of carpels (Guédes, 1973; Tilak \& Nene, 1976, 1978).

Among the Galipeinae and closely related American groups, there are few detailed studies on floral structure, mainly descriptive. Marquete (1981) and Souza et al. (2003) described the floral structure of Pilocarpus species. Souza et al. (2004) studied Metrodorea 
nigra A.St.-Hil., focusing mainly on the histology of the flower and the structure of pollination organs. Among broader comparative studies with Rutaceae, only Gut (1966) and Ramp (1989) included Galipeeae representatives, focusing mainly on gynoecium features (in Pilocarpus pennatifolius Lem., Pilocarpinae, and Erythrochiton brasiliensis Nees \& Mart, Galipeinae). Only more recently have new studies been carried out under a comparative approach, seeking not only to elucidate the floral structure of the species, but also to contribute to systematic and evolutionary studies of Galipeinae (Pirani et al., 2010; El Ottra et al., 2013).

First, Pirani et al. (2010) described the floral structure of five Galipea species [G. jasminiflora (A.St.-Hil.) Engl., G. carinata Pirani, G. ciliata Taub., G. dasysperma GómezLaur. \& Q. Jiménez and G. laxiflora Engl.]. Among their major findings is highlighted the unusual structure of the floral tube. This is formed in Galipea by the adnation of stamens to petals in their lower part and by the coherence of petals and adherence of stamens to petals by intertwining trichomes in their margins of their distal part (a case of postgenital union). In fact, Kallunki and Pirani, in their taxonomic treatments for Galipeinae genera (e.g. Kallunki, 1992, 1998a, 1998b, 2009; Kallunki \& Pirani 1998), had already reported different types of unions between stamens and petals. Furthermore, in their studies they have used the terms connation and adnation in the usual meaning (i.e. referring to the union between segments of a same whorl or between segments of different whorls), but they additionally employed the term 'coherent' when segments of the same whorl are joined only through intertwining trichomes, and 'adherent' for the same condition between organs of different whorls. A similar type of postgenital union was reported by Hartl (1957) as "false sympetalae", to the tubular corolla of Correa (Rutoideae, Boronieae, Correinae, Engler, 1931). However, in Correa the tube is formed by the postgenital interlocking of papillate epidermal cells and cuticular projections (Hartl, 1957). Considering these histological differences, and that Correa is distantly related to Galipeinae according to phylogenetic studies (Groppo et al., 2008), the occurrence of homoplasy in the evolution of tubular flowers in Rutaceae was assumed (Pirani et al., 2010). Yet, Pirani et al. (2010) found anther features that could assist the taxonomy of Galipea. Most of the species of this genus present notched basal appendages of anthers, which are usually large and laterally connate in most of their extension. Contrastingly, these appendages were found to be small and shortly connate in a species of doubt positioning, Galipea dasysperma Gómez-Laur. \& Q. Jiménez, a characters that would support its removal from the genus. In relation to gynoecium features, Pirani et al. (2010) observed that they are not completely syncarpic as previously described for Galipea. 
In fact in most of the cases, just the observation based on stereomicroscopic analysis alone (as made in taxonomical studies) is insufficient to clearly determine how and to what extent floral organs are really united in Galipeinae, and whether or not there is fusion of organs. However, even if imprecisely determined at times, such features are currently used to distinguish genera and species of the subtribe (e.g. Engler, 1874, 1931; Kallunki, 1992, 1998b; Pirani \& Kallunki, 1998), as well as in evolutionary studies on a familiar level. For instance, Groppo et al. (2008) coded the union of carpels as 'ovary with some degree of apocarpy vs. full syncarpy', which reflects a weak precision in the analysis of morphological states due to the lack of detailed floral studies in the group (El Ottra et al., 2013).

Thus, given the complexity and variable degrees of union and fusion between floral whorls and their importance in the systematic of Galipeinae, El Ottra et al. (2013) carried out a detailed study evaluating how and to what extent the floral organs are united in five representatives of the subtribe. They found that the floral tube was formed by synorganization of stamens and petals in all species, exhibiting three main patterns: 1. Conchocarpus heterophyllus and C. minutiflorus have a floral tube formed by marginal coherence of petals and adherence of filaments to petals due to intertwining trichomes; 2. Erythrochiton brasiliensis has a tube formed by the congenital fusion of petals and filaments; and 3. Galipea spp., and Conchocarpus macrophyllus have a floral tube distally with the first pattern, and proximally with the second pattern. Additionally, they proposed a hypothetical pathway of evolution of the floral tube, considering this structure homologous among Galipeinae. According to this scheme, the plesiomorphic state of the floral tube initially would be a "tube formed by the coherence of petals and stamens by intertwining of trichomes", with further evolution of the congenital fusion of petals and stamens at the base of the tube, but retaining the postgenital coherence distally. Finally, the most derived state in the evolution of the tube would be the congenital fusion between petals and stamens in the entire length of the tube. However, the reduced taxonomic sampling of the study would limit the corroboration of this hypothesis at a subtribal level and in a phylogenetic context, since for most of the species there is a lack of detailed studies on the floral structure, and relationships among the species have not been well established yet in phylogenetic studies (El Ottra et al., 2013). They also found that the gynoecium of the studied species of Galipeinae shows great variability in the extent of fusion of carpel flanks.Even though different structures for the mature gynoecium were found in each genus, all genera show postgenitally fused carpel apices, a feature described earlier for other members of Rutaceae (Gut, 1966; Ramp, 1988; El Ottra et al., 2013). In summary, El Ottra et al. (2013) concluded that the floral features studied are shared by groups of genera and species, and thus have the potential to be used in future studies of 
character evolution in Galipeinae, as well as they may represent possible synapomorphies for clades in this group. However, they point out that to further support their hypothesis, similarly studying the floral structure of a higher number of Galipeinae representatives would be necessary, as well as interpreting the data on a phylogenetic context, to achieve a better understanding of the floral evolution of the group. Moreover, the authors concluded that on a more comprehensive level of systematic hierarchy, the degree and diversity of fusions of floral organs in Galipeinae is somewhat singular within the order Sapindales (El Ottra et al., 2013).

Recently, a series of studies characterized in detail the floral structure of several large clades of Angiosperms. Among these, the flowers of Sapindales families have been studied, and an extensive bibliographic review on their floral structure was presented (i.e., Bachelier \& Endress, 2008, 2009; Bachelier et al., 2011). Also, the systematic implication of the data was discussed considering the current phylogenetic context of the families; and it has been found that several floral features support the clades from molecular phylogenetic studies at different hierarchical levels (at generic, subfamily, familiar, ordinal to supra-ordinal levels). Thus far, the families Kirkiaceae (Bachelier \& Endress, 2008), Burseraceae, Anacardiaceae (Bachelier \& Endress, 2009) and Nitrariaceae (Bachelier et al., 2011) have been studied. In relation to Rutaceae, those studies only could mention the scarce and earlier literature about the floral structure of the family, notably the comparative studies focusing on the gynoecium, made by Gut (1966) and Ramp (1989), as also Engler (1931) focusing the overall morphology of the flower. In fact, no comprehensive and detailed study has been carried out about the floral structure of Rutaceae, considering all floral organs and in the modern phylogenetic context.

Following the research line of floral structure and macrossystematics of Angiosperms, other wider comparative studies have been made focusing on the floral structure in large clades of Angiosperms at a supra-ordinal level (Endress \& Matthews 2006, 2012; Endress, 2010b). Alternatively, other studies have focused on specific floral features, considering their occurrence in all group of Angiosperms (e.g. floral symmetry, ovule structure, among others; Endress, 2001, 2011a, 2011b, 2012). Studies focusing on large clades have been important in characterizing the floral structure of new groups of orders or families that only recently have been recognized by molecular phylogenies, thus providing great advances in the knowledge of floral structure of the different clades of eudicotyledons (Endress, 2010b). Especially for the rosids clade, in which Sapindales is placed, a broad floral characterization and evolutionary trends was presented by Endress \& Matthews (2006). Ovule features have shown great relevance in the characterization of rosids groups, such as integument thickness, ovule 
curvature, among others. In relation to the studies where specific floral features were analyzed throughout Angiosperms, some floral features were found to represent potential key innovations in the evolution of several clades (e.g. synorganization of organs, monosymmetry, compitum, among other, Endress, 2011). Given the large bulk of literature raised in these studies, it was also seen that for many Angiosperms groups, there is still a lack of detailed data about their floral structure, not only for clades recently found by molecular systematic studies, but also for families and orders recognized long ago (Endress \& Matthews 2006, 2012; Endress, 2010b, 2011a). Thus, it was concluded that new comparative floral studies are needed at all hierarchical levels, from the most inclusive to the most comprehensive clade of Angiosperms. Also, functional studies of certain floral features, integrating different areas of knowledge, are needed to understand why certain traits are so widely distributed in some groups, what role is in the biology of the species, and why these same traits are so rare in other groups. Therefore, a new view for floral morphological studies is defended, so that these represent an integrative approach, which is, however, a challenge (Endress, 2011a; Endress \& Matthews, 2012).

In fact, the study of the flower comprises several areas of knowledge such as ecology, morphology, anatomy, histology, biology of development, systematics, embryology, molecular biology and evolutionary biology. However, those studies are rarely done in concert. Generally, the flower is studied only under the approach of a single area of biology, which, as a consequence, restrains the knowledge of how floral features can be functionally linked (Glover, 2007; Endress, 2011a). Evolutionary developmental studies would be an example of how an integrative approach can generate great advances in the understanding of the floral structure, in addition to expanding the subjects to be explored in flower studies (e.g. Coen \& Meyerowitz, 1991; Coen \& Nugent, 1994; Almeida et al., 1997). In order to understand why and how flowers present their current structural diversity, it is necessary to know not only the molecular control of the floral features, but also the phylogeny of the groups, and the functional consequences of the floral structures in the ecology of the species (Glover, 2007). However, for most Angiosperm groups, the functional implications of the floral features are greatly unknown (Endress, 1994; Schönenberger \& Balthazar, 2012).

For some floral features of Rutaceae, interesting functional implications have been reported in the biology and pollination of the groups. Ramp (1989) analyzed the growth of the pollen tube in the style for some species of the family and their relation to the formation level of the compitum. He observed that below the level of the compitum, there was a considerable decrease in the number of pollen tubes growing, indicating the role of this structure in the 
selection of pollen grains in gynoecium parts, as reported for other Angiosperms (Carr \& Carr, 1961). In relation to Rutaceae representatives with tubular flowers (i.e. Galipeinae and Boronieae, as Correa), the role of this floral architecture has been previously discussed regarding the restriction and channeling of access to nectar by floral visitors, as well as the protection of nectar from dilution caused by rain, as reported for other groups with tubular flowers (Faegri \& van der Pij1, 1979; Endress, 1994; Westerkamp \& Claßen-Bockhoff, 2007; El Ottra et al., 2013). In relation to the androecium, the occurrence of only two anthers in posterior position for most representatives of Galipeinae, along wiht their usual postgenital fusion (e.g. Galipea, Pirani et al., 2010), was assumed to be functionally linked to the stabilization of the androecium structure, as well as pollen economy and nototribic pollination, as similarly reported for other Angiosperm groups with similar androecium display (Faegri \& van der Pijl, 1979; Westerkamp \& Claßen-Bockhoff, 2007; El Ottra et al., 2013). However, such interferences were based on a single detailed study on the floral biology and pollination of Galipea jasminiflora (Piedade \& Ranga, 1994). In fact, there are scarce studies available on floral biology of the representatives of Galipeinae as a whole, which limits the understanding of functional implications of floral structures in the biology of the species (El Ottra et al., 2013).

Other floral structures already reported in systematics studies appear to have potential functional implications in the biology of Galipeinae. Engler (1931) and Eichler (1878) reported a variety of floral symmetry types for the subtribe and closely related groups. Engler (1931) recognized a 'gradation' of types of symmetry, ranging from strongly polysymmetric to monosymmetric. Such variation on floral symmetry has never been studied in relation to pollination systems. In fact, monosymmetric flowers are usually related to bee pollination, at least in their initial evolutionary stages (Donoghue et al., 1998). Yet, Engler (1931) realized that in the groups with strongly monosymmetric flowers, androecium organs were mainly responsible for this symmetry plane, as staminodes were located in the abaxial (anterior) position in the flowers of Galipeinae. Current studies on diversity and evolution of staminodes in Angiosperms show that those structures are conserved in the evolution of the groups only when staminodes assume new functions in the floral biology of the species. Otherwise, staminodes usually are quickly lost during evolution (Walker-Larsen \& Harder, 2000). The fact that most Galipeinae have staminodes in the anterior portion of the flower would indicate that staminodes likely assume important floral functions in the group. However, this was never explored in the floral biology of Galipeinae. Yet the presence of two fertile stamens and five staminodes (instead of three, such as in the haplostemonous flowers of the group) in 
many species is intriguing, given that in these cases two of them are placed in antepetalous position (Engler, 1931; Pirani et al. 2010). Engler (1931) found these additional staminodes a striking feature, since there are no obdiplostemonous representatives proximately related to Galipeinae in their traditional classification. Yet, Pirani et al. (2010) raised the hypothesis that such antepetalous structures could represent petal appendages, not homologous to staminodes. More detailed studies on the androecium of Galipeinae are needed to clarify this issue.

Other floral features may present interesting functional implications in the biology of Galipeinae, such as the occurrence of herkogamy (i.e., the spatial separation between pollen liberation and pollen receipt, Webb \& Lloyd, 1986). Despite the fact that this phenomenon has only been reported for G. jasminiflora (Piedade \& Ranga, 1993), detailed analysis of some of the taxonomic descriptions of Galipeinae species indicate that the occurrence of herkogamy may be more frequent than currently reported for the subtribe (e.g., Kallunki \& Pirani, 1998; Kallunki, 2009, where they describe anthetic flowers with different levels of anthers and/or stigma presentation within the floral tube, or exserted from it). Thus, it becomes clear that Galipeinae is a group upon which several issues about floral structures can be studied from a functional perspective, with interesting implication in the biology of the species. Moreover, a detailed study on the floral structure of the group can contribute either to support the monophyletic groups recently found through molecular phylogenies (in different hierarchical levels), or can come to assist in the codification of character states for evolutionary studies with the group.

In this context, the objectives of this study are: (1) to present detailed descriptions about the floral structure of several species of Galipeinae and closely related groups, discussing the implication of the findings to the systematics and evolution of the American clade of Rutoideae, as well as in the macrossystematic context of Sapindales and rosids groups; (2) to present the functional implications of some of the floral features in the biology of the species.

\section{METHODS}

The floral structure of buds shortly before anthesis, and/or young buds and anthetic flowers, of 22 species of 11 genera of Galipeinae were studied (see Table 1 for herbarium material and floral stages analyzed). Also, two closely related species of neotropical Rutoideae were studied (Groppo et al. 2008, 2012) for further comparison: Metrodorea nigra (tribe Galipeeae, subtribe Pilocarpinae, Engler, 1931), and Hortia oreadica (former classified in subfamily Toddaliodeae, tribe Toddalieae, subtribe Toddaliinae by Engler, 1931; currently 
emerging as sister to Adiscanthus, both as members of the "American clade" in the phylogenies by Groppo et al., 2008, 2012; Adiscanthus was traditionally treated as a Galipeinae member, and is also included in the present study).Voucher specimens are deposited in the herbarium of the Universidade de São Paulo (SPF) when not otherwise mentioned in Table 1. Samples of most species were collected in the Atlantic Forest of Espírito Santo State, Bahia, and of Rio Grande do Norte State (Brazil). Two species were collected in "Cerrado" (Brazilian savannahs) of Minas Gerais State (Spiranthera odoratissima and $H$. oreadica), and two species [Adiscanthus fusciflorus and Raputiarana subsigmoidea] were collected in the Amazonian Forest of Manaus (Amazonas State) and Acre State (Brazil). Samples of Ravenia spectabilis, native from Cuba, were obtained from a cultivate plant in the Botanical Garden of Rio de Janeiro. Additional samples of Ertela trifolia were obtained from plants cultivated at the USP Faculty of Sciences at Ribeirão Preto, São Paulo State.

Flowers and buds were fixed in FAA 50\% (Johansen, 1940), and stored in 70\% ethanol. Floral structure was analyzed under stereomicroscope, light microscopy, and for some species scanning electron microscopy was also employed (see Table 1). The overall morphology of the flowers was analyzed using a Leica M125 stereomicroscope. For light microscopy, the material was dehydrated in an ethanol-butanol series and then infiltrated and embedded in paraffin or paraplast (based on the protocol of Johansen, 1940). The embedded material was sectioned using a rotary microtome and a standard microtome knife D. The sections were stained with astra blue $1 \%$ and safranin $1 \%$ in ethanol $50 \%$ (following the protocol of Bukatsch, 1972), and mounted in Canada balsam or Permount. Permanent slides of the microtome sections were deposited at the Instituto de Biociências, Universidade de São Paulo (IB-USP).

For SEM studies, the fixed material was dissected, dehydrated in an ethanol series and critical-point dried. The floral organs were mounted on stubs and sputter-coated with gold. Observations were made with a Zeiss DMS- 940 scanning electron microscope.

The serial microtome sections are based on advanced floral buds collected shortly before anthesis when not otherwise mentioned. Anthetic flowers were used for stereomicroscopic analysis, and their isolated organs were used for SEM analysis in some cases. Similarly, young floral buds were studied, and in few cases serial microtome sections were also made (when the required developmental stages were available, Table 1).

The slides were analyzed using a Leica DM 4000B microscope, and photomicrographs were taken with a Leica DFC 425 digital camera. Additionally, diagrams of the outline of 
floral organs, nectary disc, postgenitally fused areas, pollen tube transmitting tract (PTTT) and main vascularization patterns of the serial microtome sections of floral buds were represented in illustrations. Subsequently, digital line drawings were made. All floral diagrams are oriented so that the subtending bract (or leaf) is below the flower, and the inflorescence axis above. Descriptions of organs generally are made from the top of the floral bud, downwards to the floral base.

Floral biology data was gathered as reported in literature, or as seen in this study, especially regarding floral scents, reward and herkogamy. Evolutionary inferences on character evolution are based on current circumscriptions of monophyletic groups in Rutaceae in the phylogenies of Groppo et al. (2008, 2012). Subfamiliar division follows Groppo et al. 2012 and APG III (APG 2009, Stevens, 2001). Since no recent tribal or subtribal formal classification was proposed for most of Rutaceae, we cite Engler's (1931) tribal and subtribal subdivisions, with notes to the position of the genera in current phylogenies.

Terminology for floral structure follows Endress \& Stumpf (1991) for anther structure, and Endress (2010) and Bachelier \& Endress (2009) for obdiplostemonous flowers; Leinfellner (1950) and Weberling (1989) for apocarpous and syncarpous gynoecium; Weberling (1989), Endress (1994) and Endress \& Igersheim (2000) for general carpel structure and closure; Endress (1994, 2011b) and Bachelier \& Endress (2009) for structure of ovules. Terminology regarding the union or fusion of organs is that of El Ottra et al. (2013). Additionally we use the term "postgenital connection" in a wide sense, considering all kinds of postgenital union without fusion (i.e. without undergoing additional periclinal cell divisions in the region between adjacent margins of the united organs, and thus keeping the suture region clearly discernible). Floral bud length was measured in advanced buds, from the base of the flower to the tip of the petals, and in their range we considered small as equal or less than $6 \mathrm{~mm}$, medium-size up to $25 \mathrm{~mm}$, and large equal or larger than $26 \mathrm{~mm}$ (the larger flowers have up to $40 \mathrm{~mm}$ ). Concernig the position of the floral organs in the flower, the terms 'posterior side' or 'adaxial side' are used as synonyms, refering to the side of a flower which is directed towards the inflorescence axis and away from the subtending bract (or leaf). Similarly the terms 'anterior side' or 'abaxial side' refer to the side of the flower which is directed away from the inflorescence axis and next to subtending bract (or leaf; e.g. Weberling, 1989). 
Table 1: List of studied taxa of netropical Rutoideae, Rutaceae, all belonging in the "American clade" of the phylogenies by Groppo et al. $(2008,2012)$; the collections studied; floral stages and type of analysis (abbreviations: LM, light microscopy; SEM, scanning electron microscopy; ST, stereomicroscopy).

\begin{tabular}{ll}
\hline Taxa studied & Collection details $\quad$ Floral stage and type of analysis \\
\hline
\end{tabular}

Galipeeae, Galipeinae

Adiscanthus fusciflorus Ducke

Almeidea coerulea (Ness \& Mart.)

A.St.-Hil.

Almeidea limae I.M. Silva

Almeidea rubra A.St.-Hil.

Angostura bracteata (Nees \& Mart.) Kallunki

Conchocarpus concinnus Kallunki

Conchocarpus cyrtanthus Kallunki

Conchocarpus macrocarpus (Engl.)

Kallunki \& Pirani

Conchocarpus mastigophorus

Kallunki

Conchocarpus obovatus (Nees \&

Mart.) Kallunki \& Pirani

Conchocarpus odoratissimus (Lindl.)

Kallunki \& Pirani

Ertela trifolia (L.) Kuntze

Ertela bahiensis (Engl.) Kuntze

Neoraputia alba (Nees \& Mart.)

Emmerich ex Kallunki

Neoraputia trifoliata (Engl.)

Emmerich ex Kallunki

Raputiarana subsigmoidea (Ducke)

Emmerich

Rauia nodosa (Engl.) Kallunki

Rauia resinosa Ness \& Mart.
Young buds (SEM, LM), advanced

buds (LM, ST), anthetic flowers (SEM,

ST)

C. P. Bruniera 88

[SPFR]

C. P. Bruniera 79

[SPFR]

C. P. Bruniera $109 \quad$ Young buds (SEM, LM), advanced

[SPFR], J.H.L.El Ottra buds (LM, ST), anthetic flowers (SEM, 58,240

ST)

J. H. L. El Ottra 113;

M. Groppo 2038

[SPFR]

\section{J.H.L.El Ottra 122}

J.H.L.El Ottra 99, 238

J. H. L. El Ottra s/n (cult. IB - USP, Brazil)

J. H. L. El Ottra 88

J. H. L. El Ottra 57

J. H. L. El Ottra 102

M. Groppo s/n (cult. Ribeirão Preto, Brazil); Costa 126 [INPA]

J. H. L. El Ottra 120

J. H. L. El Ottra 97

M. Groppo 2024

[SPFR]

J. H. L. El Ottra 230

J. H. L. El Ottra 121, 123

J.H.L.El Ottra 114,119; Young buds (SEM, LM), advanced J. R. Pirani 1128
Young buds (SEM), advanced buds (LM, ST), anthetic flowers (ST)

Advanced buds (LM, ST), anthetic

Advanced buds (LM, ST), anthetic flowers (ST)

Advanced buds (LM, ST), anthetic flowers (ST)

Advanced buds (LM, ST), anthetic flowers (ST)

Advanced buds (LM, ST), anthetic flowers (ST)

Advanced buds (LM, ST), anthetic flowers (ST)

Young buds (SEM), advanced buds (SEM, ST), anthetic flowers (SEM, ST)

Young buds (SEM, LM), advanced buds (LM, ST), anthetic flowers (SEM, $\mathrm{ST})$

Advanced buds (LM, ST), anthetic flowers (SEM, ST)

Young buds (SEM), advanced buds (LM, ST), anthetic flowers (SEM, ST)

Young buds (ST), advanced buds (LM), anthetic flowers (ST)

Advanced buds (LM, ST), anthetic flowers (ST)

buds (ST), anthetic flowers (SEM, ST) flowers (ST) 
Table 1 (Continued)

\begin{tabular}{lll}
\hline Taxa studied & Collection details $\quad$ Floral stage and type of analysis \\
\hline
\end{tabular}

Ravenia infelix Vell.

Ravenia spectabilis (Lindl.) Planch. ex Griseb.

Sigmatanthus trifoliatus Huber ex Emmerich

Spiranthera odoratissima A.St.- Hil.

Galipeeae, former in Pilocarpinae, currently in a clade not including Pilocarpus

Metrodorea nigra A.St.-Hil.

M. Groppo 1111

Former Toddalieae, Toddaliinae, currently in the "American clade"

Hortia oreadica Groppo, Kallunki \& Pirani JBRJ, RJ, Brazil)
J. R. Pirani 6118, 6087

Young buds (ST), advanced buds (LM, ST), anthetic flowers (SEM, ST)

J.H.L.El Ottra s/n (cult. Young buds (ST), advanced buds (LM, ST), anthetic flowers (ST)

J. H. L. El Ottra 235 Young buds (ST), advanced buds (LM), anthetic flowers (ST)

Young buds (SEM, LM), advanced buds (LM, ST), anthetic flowers (SEM, ST)

Young buds (SEM), advanced buds (LM, ST), anthetic flowers (ST)

Advanced buds (LM, ST), anthetic flowers (ST) 


\section{RESULTS}

Some of the floral features analyzed are equally shared by or very similar among the taxa studied. All flowers are bisexual, pentamerous (e.g. Figs 1- 4, 7, 12, 15, 20, 41). The corolla becomes longer than sepals early in development and protects the inner organs in young and advanced buds in most genera (e.g. Figs 1E, 3E, 10A, 8C). Exceptions are Ravenia and Ertela species, where the calyx lobes are relatively larger than petals for a longer period during development, and thus protect the inner organs in young buds (but latter the petals also expand and become larger, attractive and protective organs; Figs 3B, C). Anthers are dithecal, with a septum between the two pollen sacs, tetrasporangiate (except Sigmathanthus trifoliatus, polisporangiate), with longitudinal dehiscence, introrse (e.g. Figs 4C, 19D, 32G, 35F, 36I). The androecium of most species of Galipeinae includes some staminodes, usually three to five (rarely 1). These are filament-like structures bearing no thecae. Staminodes are lacking in a few Galipeinae taxa (Adiscanthus fusciflorus, Spiranthera odoratissima, Almeidea limae and some specimes of A. rubra), and in Metrodorea nigra and Hortia oreadica. Staminodes are placed on the anterior (abaxial) side of the flower and are in antesepalous position in haplostemonous flowers. However, in some species two additional antepetalous staminodes (rarely one or three) occur; antepetalous staminodesare always missing on the posterior (adaxial) side of the flower. The tips of the staminodes lie either close to the mouth of the corolla or are exserted from it (e.g. Figs 1H, J, 2B, D, F, 3A, D, E, 7D, 15B, 17C, 41D). The nectary organ is an intrastaminal disc, annular to cupular in shape, in most species (except Adiscanthus fusciflorus). The disc may have a common base with outer or inner floral organs to a variable extent among species.

The gynoecium structure is relatively uniform in several features. The gynoecium is of Angiosperm type 4 (see cross section series, e.g. Figs 4, 7, 12, 15, 16, 17; see Endress \& Igersheim, 1999). The gynoecium is apocarpous in most species (i.e. without intercarpellary congenital fusion in most of its extent; except in Hortia oreadica and Metrodorea nigra, see details in the description of these species). Additionally, carpel apices are postgenitally fused to various degrees.. In the taxa with apocarpous gynoecium, carpels are congenitally fused at the base of the ovary at centre, but in different extension among species. There is always one single style, which is formed by the postgenital fusion of the five young carpel apices (e.g. Figs 6D-G, 10B, 11B, 14H-J, 15 A, D-I, 17A, E-I, 25D-F, 30B-E; 37C-H; 46B-G). Stigmatic lobes are postgenitally fused for most of their lenght (except in Ravenia spectabilis and Almeidea limae), with variable shape (e.g. Figs 6H, 11H, 14J, 25C, 30G, 40H, 49E-I). Ovary locules are lined by two to several layers of small cells with densely stained cytoplasm, 
apparently in meristematic activity (e.g. Figs 5A, 10C, 13F, 18E, 20G, H, 28H, 32A, B, 35H, $42 \mathrm{E}$ ); these layers later develop into the endocarp in the fruiting stage (according to Ramp, 1988; Souza et al., 2005). There is one strand of pollen tube transmitting tract (PTTT) per carpel. These may unite and form a compitum at the stigmatic regions and/or upper level of style (e.g. Figs 15D, E, 20C, D, 22B, 29E, F, 47C, 48F). In the style, PTTT is located at the inner angle of the postgenitally fused ventral slit, as observed in most species, running downwards to the ovary (Figs 4D-E, 7E-I, 12E-H, 15D-G, 16C-D, 24C, 31D-G, 42C). In some cases, the path of this tissue is not visible along the entire gynoecium length (in Rauia resinosa) or in the stigmatic/ovary region, probably due to incomplete maturation of the PTTT in advanced buds. Also in the ovary region, delimitation of the PTTT is problematic in most taxa analyzed, since in this region PTTT is restricted to a strand of few cells or as one single layer of cells, which are very similar to the layers of small meristematic cells lining the ovary locules (Figs 47C, D, 48F, 50C). The placentae are usually superposed to almost collateral, more rarely collateral (only in Metrodorea nigra). They are located at mid-level of the ovaries (e.g. Figs 4A, F-H, 13F, 16E, 15H, 17G, 34F-G, 43A, 51A). In most of the species, there are two ovules per carpel, mostly superposed, bitegmic, crassinucelar and anatropous (except when not otherwise indicated, observed for advanced buds only; e.g. Figs $4 \mathrm{~A}, 5 \mathrm{C}, 10 \mathrm{C}, 17 \mathrm{~A}, 20 \mathrm{~A}, 28 \mathrm{G}, 31 \mathrm{~A}, 35 \mathrm{H}, 36 \mathrm{~B}, 42 \mathrm{E}, 45 \mathrm{D}, 51 \mathrm{~A})$.

Carpel vascularization is also very similar in all studied species, with slight variations. In carpels, one to two median dorsal vascular bundles appear at the upper part of the ovary. These can be more or less reduced in size or may divide into smaller bundles (weakly differentiated, Figs 7G-K, 12I-J, 15E, G-H, 23F-G, 38G, H, 41H-J, 50D-H). The dorsal bundles may form in some cases a more or less continuous band of vascular tissue, arcshaped, along the lower region of ovary (Figs 4D-H, 16D-G, 17H,I, 21B, 27G-I, 31G-J, 47EF). In the ventral region, there is one conspicuous lateral bundle per carpel, which appears just below the stigmatic region. These run downwards to the style base, where they usually split into two main bundles before entering in the ovary. In this region, additional lateral bundles appear (except in Ertela). Downwards at the level of placenta, the two main lateral bundles closer to the end of carpel margins give off to small bundles, which supply the ovules. Below the placenta these two bundles usually unite into a single median ventral bundle; and the additional lateral bundles may merge with them at lower regions of the ovary (Figs 4D-H, 7EJ, 12E-I, 15D-F, 16C, D, 17E, F, 21B, 23D-G, 31C-I, 51C-G). In some cases, the lateral bundles of one carpel may merge with the lateral bundles of the adjacent carpels, thus forming synlateral bundles close to the floral base (e.g. Figs 17G, 27F-H, 38F-H, 41E-K, 47C-E, 50H). 
In the following descriptions, for cases in which species of the same genus share a very similar floral structure, we present a common generic description; and only the deviating features between species are highlighted.

\section{Galipeeae, Galipeinae}

\section{Adiscanthus fusciflorus (Figs 1A, 4-6)}

\section{Morphology and aspects of floral biology}

Flowers are polysymmetric, haplostemonous. Floral buds have ca. $20 \mathrm{~mm}$ long. Petals are straight in their upper part and subglobose in their lower part in advanced buds. After anthesis only the upper two thirds of petals are reflexed and coiled; their bases only become slightly slackened and surround the gynoecium and nectary (this located on the gynophore). Thus except for the androecium, the inner floral organs are not entirely exposed after anthesis (Fig. 1A). The calyx is very short, congenitally fused, cupular, sometimes with five inconspicuous deltoid lobes (Figs 4A, K, 6A). Petals are thick, with valvate aestivation in bud. Their tips are bent inwards in centre (Figs 4B-I, 6B). They are postgenitally connected in bud by the interlocking of short epidermal cells and their cuticular projections along their entire length (Fig. 5A). After anthesis petals are no longer connected in fully opened flowers (Fig. 1A). In their upper part, petals are thicker and have a short median adaxial ridge; lower down they are thinner towards their margins, have a sinuous surface, and have a large and wide median ventral protuberance from where they unite first to the floral base (as seen in transverse section, Fig. 4B-J). The five stamens are fertile (Fig. 4C). Filaments are rounded at their apex, more or less triangular downwards their bases, as seen in transverse sections (Fig. 4D-I). Anthers are large to very large (ca. $9 \mathrm{~mm}$ ), dorsifixed in their half or close to their half (Fig. 6C), persistent, sagittate, versatile; they have a mid-thick connective. Endothecium-like tissue is continuous over the connective, in its dorsal and ventral sides. Between each theca there is one deep ventral furrow along most of its length above the filamentattachment. Below this level each theca has two short sterile projections in its dorsal-lateral region; also at its lower level anthers have a deep dorsal furrow (Fig. 4C-D). Anthers have long fertile bases below the connective region (Figs. 4 A-D, 5E, 6B). Carpels are abruptly bulged up on the dorsal side above the level of the base of the style, so that the 5-lobed style (in transection) is sunken into it for ca. one-third of the ovary length (anacrostylous carpels). In this dorsal bulging area, there is a marked elevation of the locule above the level of the style base (Figs. $4 \mathrm{~A}, \mathrm{D}, \mathrm{E}, 6 \mathrm{E})$. However developmental observations of the young carpels show that this 
dorsal elevation of carpels initiates only after the elongation of the style has started (Fig. 6FH, E). The stigma is inconspicuouslly five-lobed, capitate but not conspicuously enlarged, with short unicellular papillae over its surface (ca. $45 \mu \mathrm{m}$; Figs $5 \mathrm{D}, 6 \mathrm{D}$, I). The single style is long, solid from its upper level to mid-level. Lower down carpels are fused only at flanks, and thus a central furrow is formed, which runs downwards to the style base (Fig. 4D-E). Immediately below the base of the style, carpels are apocarpous, and this apocarpous zone extends from the uppermost level of ovary down to mid-level of ovary. From this level towards its bases, carpels are congenitally united first in the centre, and below also at their flanks (at the lower third of the ovary, approximately). At the ovary base, carpels are completely fused (Fig. 4G-H). The placentation is marginal and axile (Fig. 4 A, F-G). The outer integument of the ovule is thicker than the inner only in its upper part, where the zig-zag micropyle is formed. Ovules are slightly campylotropous (Fig. 5 C-D). Below the ovary there is a short and stout gynophore (ca. $250 \mu \mathrm{m}$ ), broader than the base of the locules (Fig. 4A, I). The nectary tissue lies around the periphery of the gynophore (Fig. 4I). At the floral base, gynophore (and part of the nectary tissue), filaments and petals have a common base (Fig. 4A, I, J).

The main color of the perianth at anthesis is deep-red, contrasting with the inner side of the corolla and stamens, which are white to creamy. The flowers are scentless during the day. They are herkogamous since at anthesis the stigma is presented below the anther level (Fig. 6D). The gynoecium and nectary are partially hidden within the subglobose base of the corolla, which have at this level long and numerous white trichomes (Fig. 1A, Fig. 4A). According to Kallunki (2005), anthers are coiled at anthesis.

\section{Anatomy}

Sepal bundles branch profusely and are numerous in their upper level. Close to the floral base, part of the lateral sepal bundles form synlaterals, while others merge with the five main traces lower down (Fig. 4K-M). Petals have one to three main vascular bundles, and may have up to 12 lateral bundles. At the floral base, petals have one vascular trace (Fig. 4K). Each anther has two vascular bundles in its upper level, which join lower down forming one broad band of vascular tissue. Close to the level of filament attachment, each band of vascular bundles give off to two bundles, which extend downwards to supply the long fertile bases of thecae (Figs 4D, 5E). The broad band of vascular tissue in filaments has different forms along its length; in its upper level it may be ring-shaped or semi-annular, and towards its bases it may be more or less triangular (Fig. 4D-I). At the floral base, each stamen has one vascular trace (Fig. 4K). In the upper region of the gynophore, the dorsal vasculature of carpels 
branches off to small bundles that supply the nectary in this same region (Fig. 4H-I), branching into smaller bundles lower down. At the uppermost level of the gynophore, the nectary has numerous small phloematic vascular bundles. Closer to the floral base, there are larger vascular bundles in the nectary composed of xylem and phloem strands, closer to the periphery of the nectary tissue. At floral base, nectary traces merge with each other, forming larger traces; also, nectary traces merge with petal and filament traces, forming trace complexes with them (Fig. 4I-L). At the upper level of the gynophore, ventral bundles and other additional lateral bundles of carpels converge towards the center and form a central vascular complex of the gynoecium (Fig. 4I). At the level of common bases of stamens and gynophore, some of the nectary vascular bundles merge with the dorsal bundles of carpels, forming five trace complexes which merge to the central trace complex (Fig. 4J). Lower down, the trace complex of nectary and stamen traces converge to this central complex; below also the petals plus nectary traces and the remainder nectary traces also converge to the central vasculature (Fig. 4J-L). At the lowermost level of the floral base first the synlateral traces of the calyx merge with this central vasculature, and lower down also the main sepal traces, forming then the pedicel vasculature (Fig. 4L-M).

\section{Histology}

Sepals and petals are provided with numerous apparently glandular spherical structures of uncertain nature (maybe galls) close to their dorsal surface. Their cells possess densely stained granular cytoplasm, surrounded by one layer of tanniferous cells (Figs 5G, 6A). On the adaxial side of petals, from mid-level to the base, there are numerous long and thin-walled unicelular tanniferous trichomes (Figs 5F, 6B, D). Anthers have cells with very large intercellular spaces at the connective region (Fig. 5B). The gynophore bears small stomata on its surface (Fig. 6J). Tanniferous cells are dispersed in the mesophyll of all floral organs. The epidermis of the adaxial side of petals (and also the hypodermis in some parts), filaments, style, external surface of the carpels, and the outer integument are tanniferous (Fig. 5A, C-F). Secretory cavities are present in sepals, petals and gynoecium. Druses or raphides were not found. 

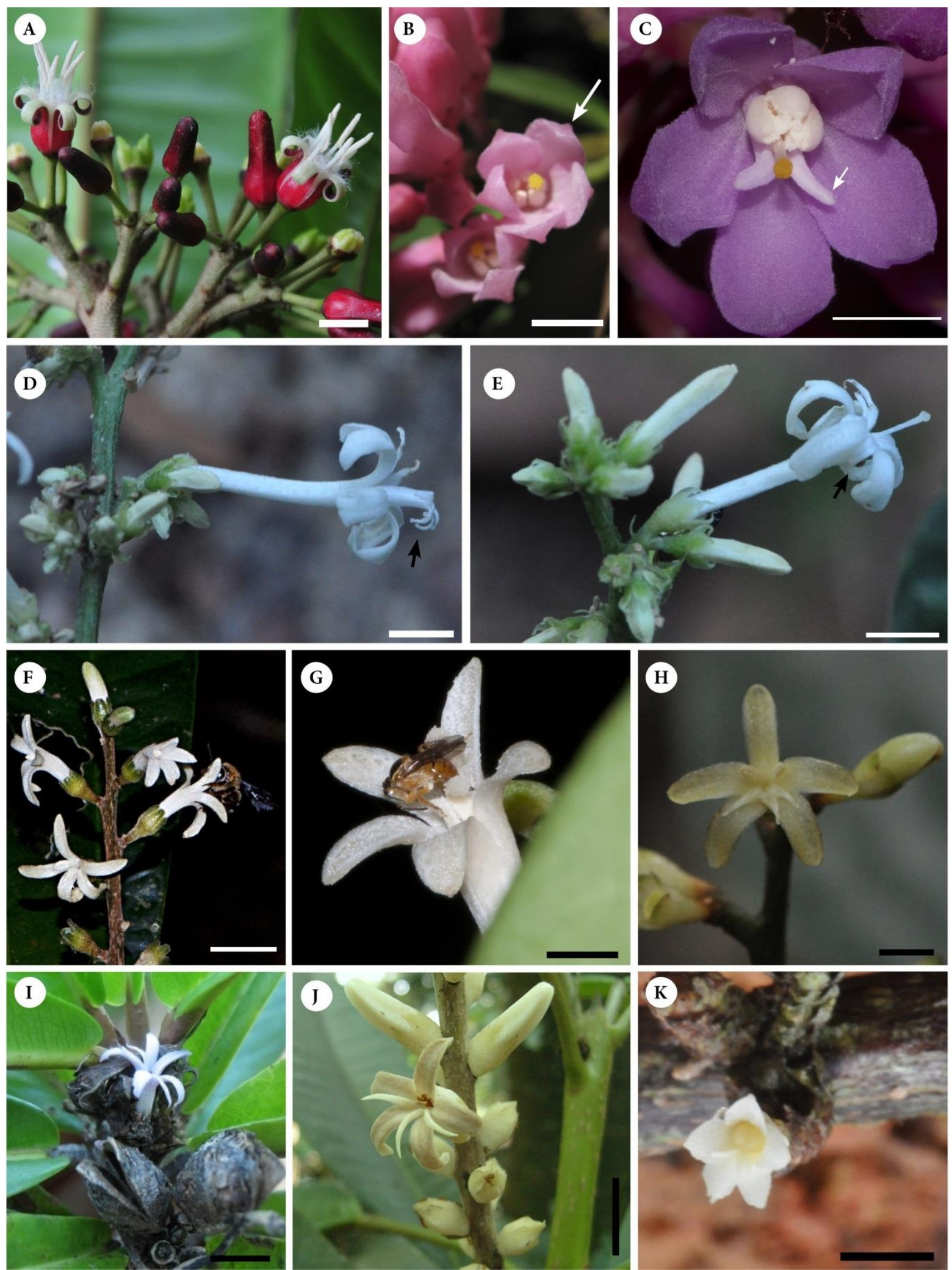

Figure 1: Galipeinae. Buds and flowers at anthesis. (A) Adiscanthus fusciflorus. (B-C) Almeidea rubra. (A) Strictly polysymmetric flower with pronounced adaxial ridge (arrow); (B) Monosymmetric flower (arrow indicate staminode). (D-E) Angostura bracteata (D, male phase, arrows indicate staminodes; E, female phase). (F-G) Conchocarpus cyrtanthus. (F) Part of inflorescence and one putative pollinator (large-sized bee). (G) Detail of one flower, visited by a small bee, colleting pollen. (H) Conchocarpus concinnus. (I) C. odoratissimus, flower among old fruits of the previous flowering season. (J) C. macrocarpus. (K). C. mastigophorus. Scale bars: (A$\mathrm{C})=1 \mathrm{~cm} ;(\mathrm{D}, \mathrm{E}, \mathrm{K})=0,5 \mathrm{~cm} ;(\mathrm{F})=1,3 \mathrm{~cm} ;(\mathrm{G}, \mathrm{I})=0,7 \mathrm{~cm} ;(\mathrm{H})=35 \mathrm{~mm} ;(\mathrm{J})=1,2 \mathrm{~cm}$. 

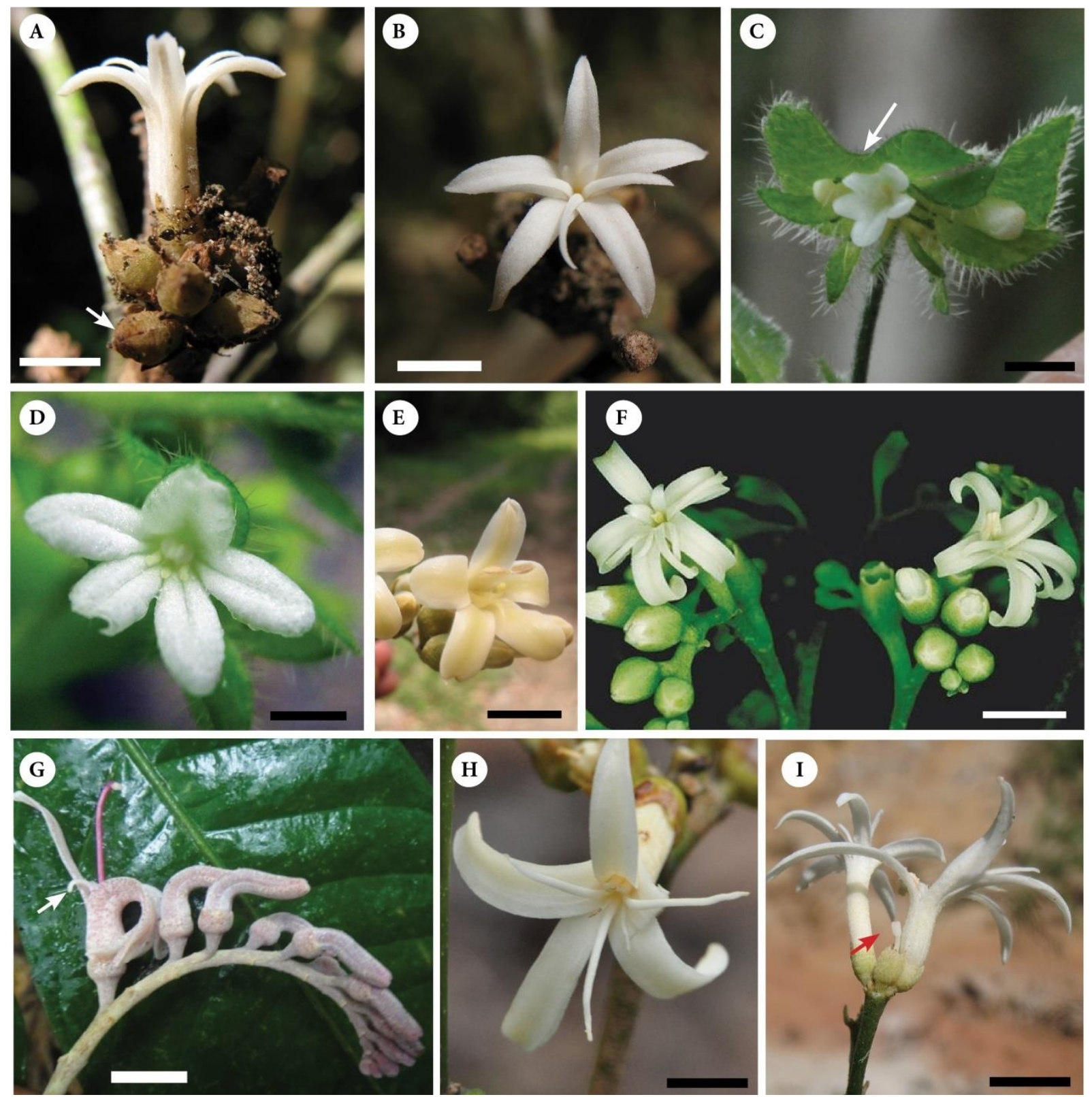

Figure 2: Galipeinae. Buds and flowers at anthesis. (A-B) Conchocarpus obovatus (arrow indicates calyx lobes bent over the ovary). (C) Ertela bahiensis (arrow indicates large bract). (D) Ertela trifolia. (E) Neoraputia alba. (F) Neoraputia trifoliata. (G) Raputiarana subsigmoidea (arrow indicates fertile filament curved backwards and lacking anthers). (H) Rauia nodosa. (I) Rauia resinosa. Scale bars: $(A)=0,7 \mathrm{~cm} .(B)=0,5 \mathrm{~cm} ;(C, D)=0,25 \mathrm{~cm} ;(D)=1 \mathrm{~cm} ;(E, F, H)=1 \mathrm{~cm} ;(G)=1,5 \mathrm{~cm} ;(I)=0,5 \mathrm{~cm}(D$, F, fotos concedidas por J.R. Pirani). 

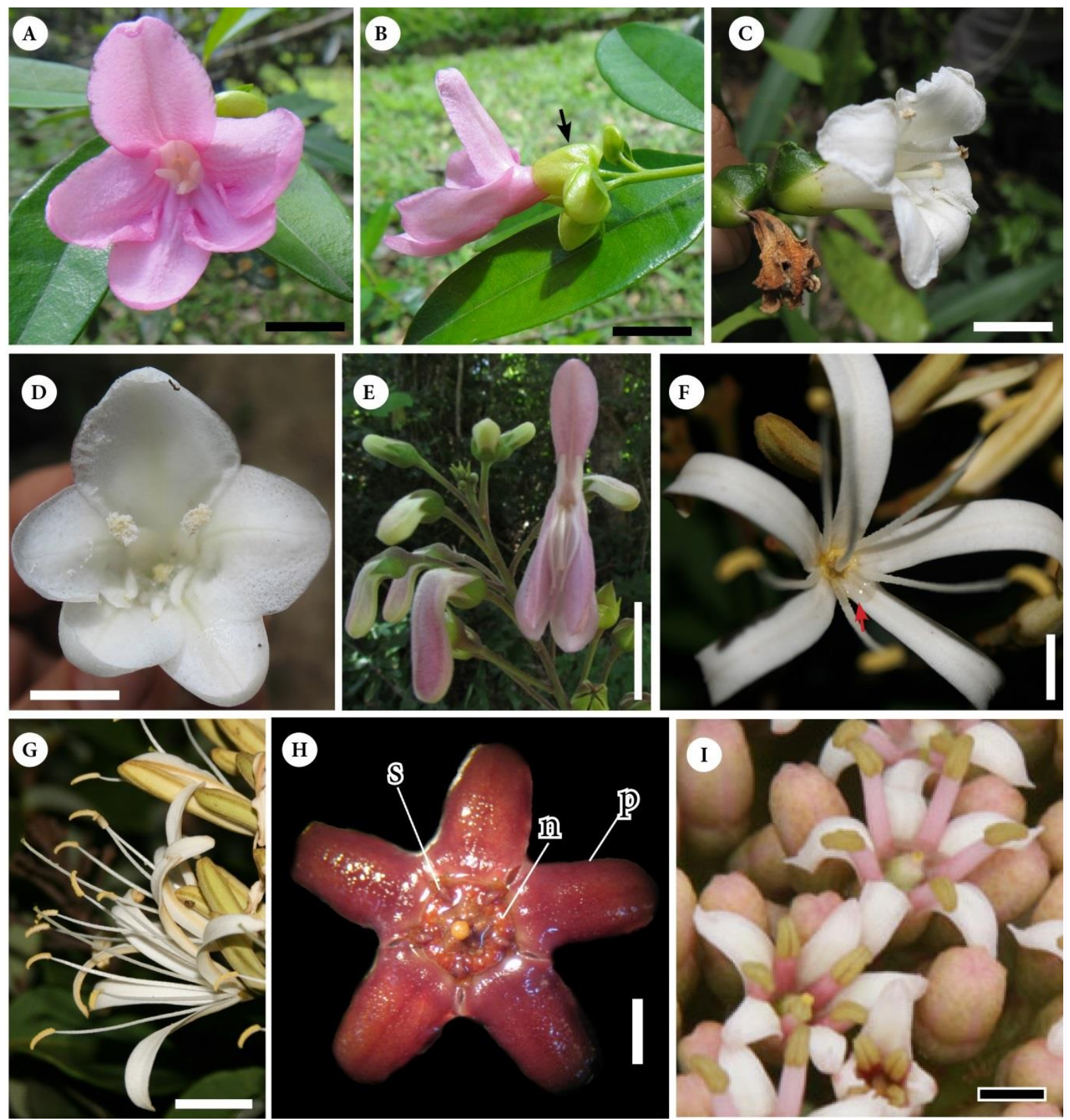

Figure 3: Galipeeae. Buds and flowers at anthesis. (A-B) Ravenia spectabilis (Galipeinae, arrow indicates one of the larger outer sepal). (C-D) Ravenia infelix (Galipeinae). (E). Sigmatanthus trifoliatus (Galipeinae). (F, G) Spiranthera odoratissima (Galipeinae). (F) Frontal view (arrow indicates nectar drop). (G) Side-view. (H) Metrodorea nigra (Pilocarpinae). I. Hortia oreadica (former Toddalioideae, Toddaliinae). Scale bars: $(A, F)=0,8 ;(B-D)=1 \mathrm{~cm} ;(E, G)=1,5 \mathrm{~cm} ;(H)=2 \mathrm{~mm} ;(I)=3$ mm (E, foto de Wallace M. B. São Mateus; I, foto concedida por Henrique N. Moreira; F, foto de Elza M. Guimarães Santos). 

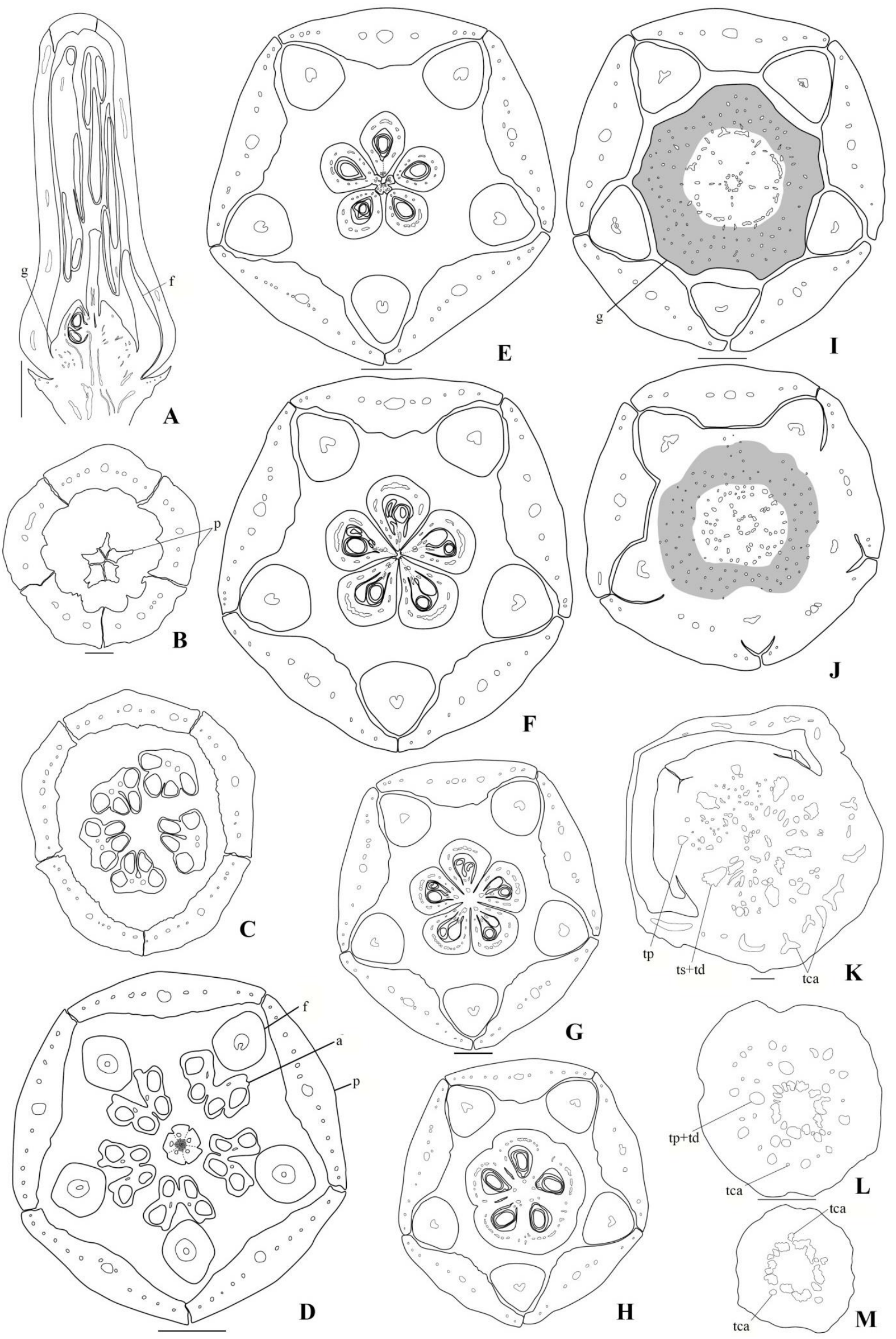
Figure 4: Adiscanthus fusciflorus. Sections of floral buds. (A) Longisection. (B-M) Transections: successive levels, from the top, downward. Morphological surface indicated by thicker continuous lines, vasculature by thinner continuous lines; postgenitally fused areas indicated by broken lines; pollen tube transmitting tissue (PTTT), dark grey; nectariferous tissue, light gray (in the longitudinal section, only morphological surfaces and vascularization are represented). (B) Uppermost level of petals. (C) Mid-level of anthers. (D) Lower level of anthers. (E) Upper level of ovary and style base. (F) Upper level of placenta. (G) Mid-level of ovary. (H) Lower level of ovary, below placenta. (I) Gynophore and nectary level. (J) Level of common base of petals, stamens, nectary and gynoecium. (K) Lowermost level of petal bases and the short calyx (on the left side). (L) Level of main and lateral calyx traces. (M) Lowermost level of the floral base. Abbreviations: a, anther; f, filament; g, gynophore; p, petal; tc, trace of calyx; ts+td, trace complex of stamen plus disc; tp, trace of petal; $\mathrm{tp}+\mathrm{td}$, trace complex of petal plus disc. Scale bars: $(A)=2 \mathrm{~mm}(\mathrm{~B}-\mathrm{M})=1 \mathrm{~mm}$. 

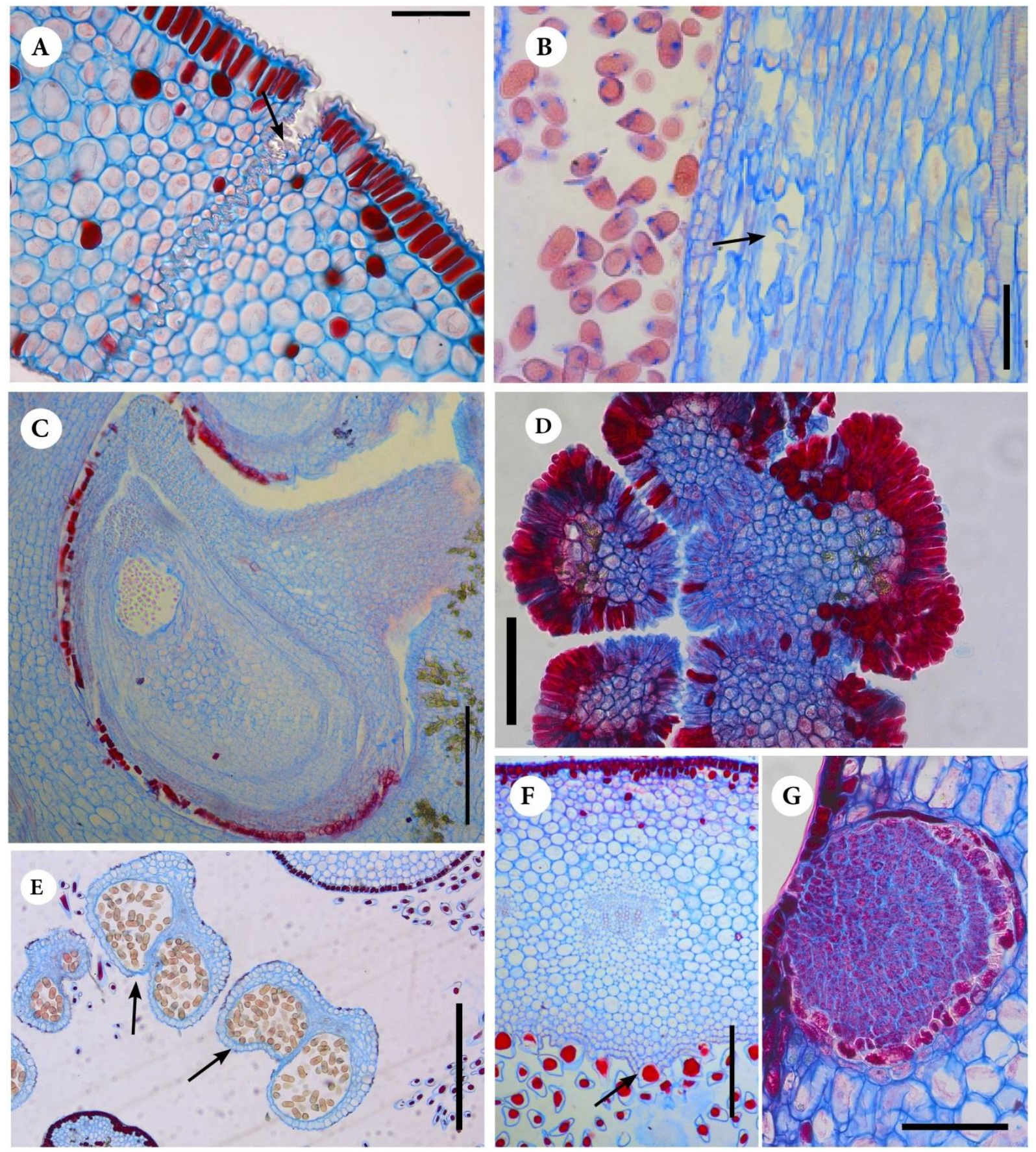

Figure 5: Photomicrographs of microtome sections of floral buds Adiscanthus fusciflorus. (A) Transection through the postgenitally connected petals (arrow indicates cuticular projections). (B, C) Longisections. (B) Detail of anther, connective with large intercellular spaces (resembling spongy parenchyma, arrow). (C) Lower ovule. (D-F). Transections. (D) Detail of the stigmatic region. (E) Detail of the lowermost level of one anther (arrows indicating thecae bases). (F-G) Details of petals, with numerous long and thin-walled unicellular tanniferous trichomes $(\mathrm{F}$, arrow); glandular structures of uncertain nature $(G)$. Scale bars: $(A)=50 \mu \mathrm{m} ;(B, D, G)=100 \mu \mathrm{m} ;(C, F)=200 \mu \mathrm{m} ;(E)=500 \mu \mathrm{m}$. 

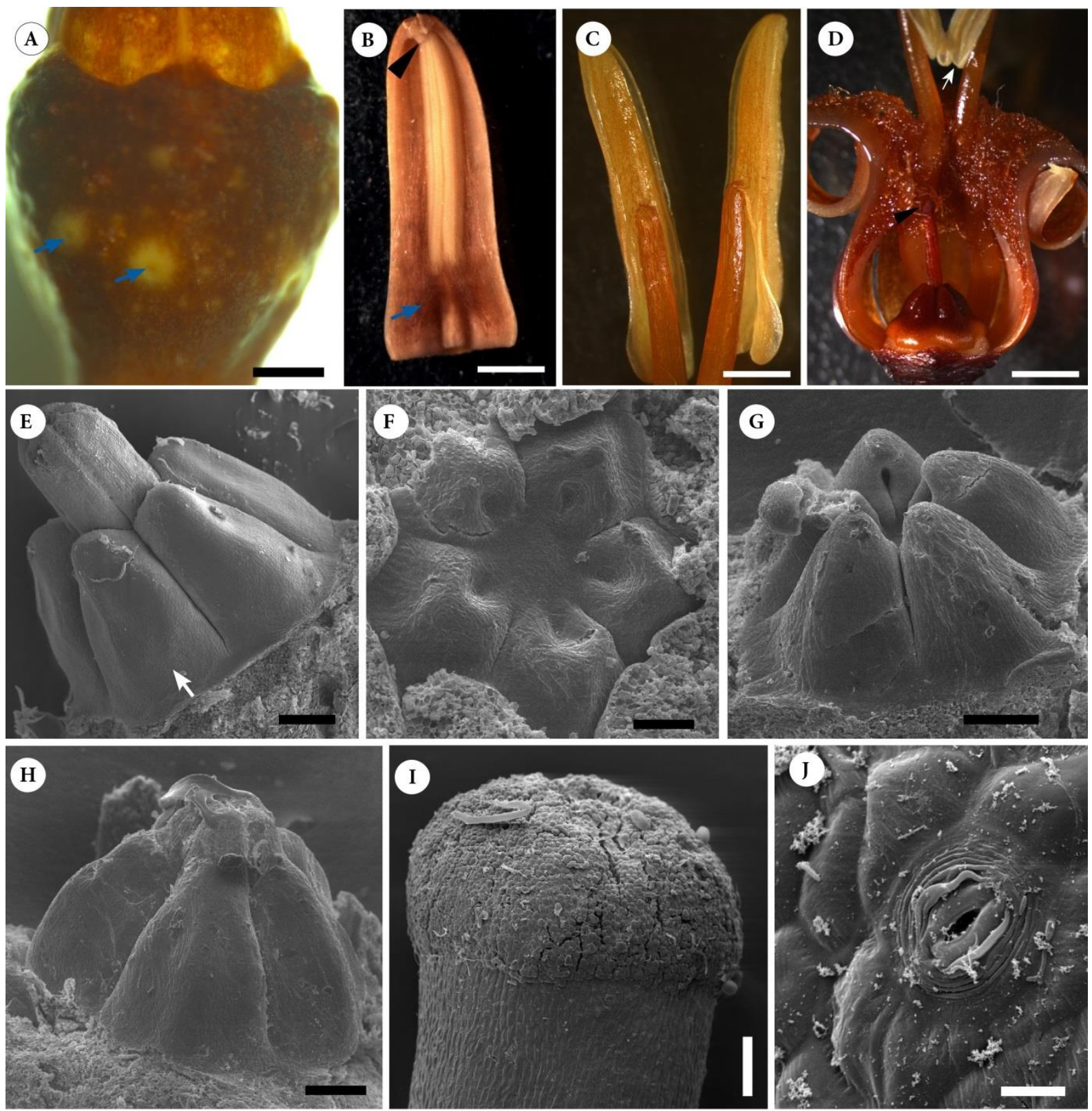

Figure 6: Adiscanthus fusciflorus. (A-D) Photographs. (A) Young bud with conspicuous spherical depressions on the calyx (probably galls, arrows). (B) Two petals and adjacent stamen of one advanced bud (arrow indicate the tuft of trichomes on the adaxial surface of petal; arrowhead indicate the tip of petals, inwardly bent). (C) Two anthers (dorsal view). (D) Anthetic flower longitudinally opened, showing the recessed stigma (arrowhead) and the base of exserted anthers (arrow). (E-J) SEM micrographs. (E-H) Carpel development. (E) Young carpels, beginning differentiation of the style, from the side (arrow indicates united bases). (F) View from above, showing five young carpels. (G) Later stage than E. (H) Style elongating. (I) Mature stigma. (J) Stomata on gynophore surface (at the nectary level). Scale bars: $(A)=2 \mathrm{~mm} ;(B)=3 \mathrm{~mm} ;(C)=2 \mathrm{~mm} ;(D)=4 \mathrm{~mm} ;(E)=200 \mu \mathrm{m} ;(F)=50$ $\mu \mathrm{m} ;(\mathrm{G}, \mathrm{H})=100 \mu \mathrm{m} ;(\mathrm{J})=10 \mu \mathrm{m}$. 
Almeidea (A. coerulea, A. limae and A. rubra) (Figs 1B, C, 7-11)

Morphology and aspects of floral biology

Since A. rubra show a wide variation in floral size, two floral types were studied, a larger one and a smaller one (Fig. 8Ce', Cb').

The flowers are polysymmetric to slightly monosymmetric, haplostemonous (flowers are mostly polysymmetric, accordingly to Pirani, 1999 and Brunieira, 2010; Figs 1A, B, 8A, $\mathrm{B}, 7 \mathrm{D}-\mathrm{E})$. Flowers range from ca. $9 \mathrm{~mm}$ to $20 \mathrm{~mm}$ (9 $\mathrm{mm}$ in A. coerulea; $12 \mathrm{~mm}$ to $20 \mathrm{~mm}$ in A. rubra; $19 \mathrm{~cm}$ in A. limae). Floral buds are straight. Sepals form five triangular lobes in the upper part, with acute tips (Fig. 8C). They have open aestivation in advanced buds. Below this region, sepals are thinner towards their congenitally fused margins, forming a slightly five-angled undulate surface (Fig. 7 G-J). Extrafloral nectaries at the apices of sepals have been reported for Almeidea species (Silva, 1988; Bruniera, 2010). In this region, the epidermis of sepals has five rounded apertures (Fig. 11C). Petals are polysymmetric, to slightly monosymmetric (some flowers of A. rubra; Figs 1C, 8A), thick (most specimens of A. rubra and A. limae) to thin (some samples of A. rubra, A. coerulea), and in their distal portion they may form five reflexed spreading blades. The tip of petals may be rounded to acute . Corolla aestivation is ascending to oblique cochlear along most of the length, but at the bases, they are shortly valvate to slightly open (Figs 7B-J, 9A). Petal tips overlap each other at the uppermost part of the floral bud (Fig. 7A, B). Although a floral tube is observed macroscopically in Almeidea species, the union between petals and stamens is fragile in several specimes dissected. In fact once the flower dries out in the herborization process, they appear as dialipetalous, since petals and filaments are easily separated at the floral tube region. In this same region, the coherence of petals and adherence of filaments to petals by intertwining trichomes in its margins occurs. However, in A. limae and some A. rubra specimens very few trichomes are observed; and it seems that just the imbrication of petals at their lower half is the main responsible factor for the maintenance of the tubular architecture of the flower (Figs 8Cc'd', 9C- D; Bruniera 2010). The petals of A. limae have a longitudinal ridge along its middle abaxial region, and this is considered the distinctive feature of this species in relation to other Almeidea species (Fig. $8 \mathrm{Cf}^{\prime}$ ). This longitudinal ridge is seen in transverse sections as an abruptly thicker median region at the abaxial side of petals (Fig. 9A, B). However, a similar ridge is also seen in most A. rubra specimens analyzed, being thiner in some of them (Figs 7C-F, 8Ca' b'), more conspicuous in others (Fig. 8Cc'd'e'), and very similar to the condition observed in A. limae (Fig. 8 Cf'). The androecium is composed of three to five fertile stamens and none to two staminodes. In cases when three anthers are present, these are 
adjacent to the innermost two petals (Figs 7D, 8A). When staminodes are present, the androecium is monosymmetric, and when these are absent, polysymmetric (all five fertile stamens, Figs 1C, 8A, 9A). Filaments are free in their entire length, but postgenitally adherent to petals in the floral tube region. Staminodes are somewhat rounded at the uppermost level, and lower down they gradually became dorsiventrally flattened, wider, and more or less triangular at the floral tube region; in this same region they precisely alternate to petals (Fig. 7C-L). The filaments of staminodes are narrower than the filaments of fertile stamens in their entire length. Anthers are small ( $2 \mathrm{~mm}$ in A. coerulea) to midsized (ca. $4 \mathrm{~mm}$ in A. rubra and A. limae), near-basal dorsifixed, slighlty X-shaped (A. coerulea) to sagittate (A. limae, A. rubra), introrse (Fig. 7A). Endothecium -like tissue is broadly developed on the connective side of thecae (Fig. 9E). The connective is thin to mid-thick. Between each theca there is one deep ventral furrow and a shallow dorsal furrow along most of its length (Fig. 7C-D). The anthers may be postgenitally connected by the interlocking of short epidermal papillae, as observed in some A. rubra specimens (Figs 8A, 9G, 11J). In the remaining A. rubra, A. coerulea and A. limae, this conections were not seen, but the same papillae are present (Fig. 9E, F). There is an intrastaminal nectariferous cupular disc, which encompasses the ovary approximately at its lower third to its upper half; the disc is thicker toward its base (Figs 7A, 8D, E). Carpels are antepetalous, acrostylous (A. limae and A. coerulea) to anacrostylous ( $A$. rubra), as they are slighlty bulged up on the dorsal side above the level of the base of the style (Figs 8D, E, 7A). The stigma is conspicuously five-lobed in most specimens analyzed, capitate, postgenitally fused at flanks, forming a short canal in the centre (Figs 10E-F, 11H). However, some specimens of A. rubra and A. limae have free carpel tips, and five stigmatic lobes are formed (Fig. 11I). The surface of the stigma may be rugose (A. coerulea and some A. rubra, Fig. $11 \mathrm{H}$ ) or not (A. limae and some A. rubra, Fig. 11I), slightly papillose, with short unicelullar papillae (ca. $15 \mu \mathrm{m}$, Fig. 10E). The single style is shorter in A. coerulea, and longer in A. rubra and A. limae. It is completely postgenitally fused, except at center, where a small furrow is formed from mid-level of style to its base (Fig. 7F). At the uppermost level of the ovary, this furrow becomes wider, and capels are postgenitally united at the innermost part of their flanks, free at the centre (Fig. 7G). Immediately below, and still above locules level, carpels are completely free (in one sample of A. rubra this union extends until the uppermost part of the locules). The free zone extends approximately until the lower third of the ovary (Figs 7A, 8 D-E). Below this region, carpels are congenitally united first by its center and also lower by its flanks, then becoming completely congenitally united close to the base of the locules (Fig. 7J-K). Below the locules, carpels share a commom base with the nectary disc. This common base is more extensive in larger flowers of $A$. rubra than in the smaller flowers 
of the same species, A. limae and A. coerulea (Figs 7K, L, $10 \mathrm{H}$ ). The placentation is marginal and ovules are antitropous. In one specimen of $A$. rubra, in the upper ovule, a zig-zag micropyle was observed in advanced buds (Figs 7A, I, 10D). The outer integument is thicker than the inner, and the placenta bears an obturator made of unicellualr trichomes (in one specime of A. rubra with larger flower and A. limae) or papillae (A. coerulea, one specime of A. rubra smaller flower, Fig. 10C, D).

The sections of the gynoecium base perpendicular and parallel to the longitudinal axis of the advanced buds show an area of large celled tissue in the centre (Fig. 8D, E). Microtome sections and SEM analysis of young carpels show that this area represents part of the floral apex, which is convex when carpels are initiated (however the area is small in this stage) that is not involved in carpel formation (Figs 10A, B, 11B).

The main color of the perianth of Almeidea species is pink to lilac (Bruniera, 2010). Ants were seen gathering the secretion of the extrafloral nectaries at the apices of sepals. Several A. rubra specimens present a bright showy yellow stigma. During field work it was noticed that recent opened flowers of $A$. rubra are bright pink while older flowers discolor to pale pink or white (Fig. 1C). Also it was noticed that, in some flowers, the the initially united lobes of stigmas were later spreading (this study and C. P. Bruniera pers. obs.). Floral biology and pollination was studied in one population of A. rubra (El Ottra et al., submitted, Chapter 2). This is mainly pollinated by hummingbirds and secondarily by butterflies. The flowers of the studied population of A. rubra are protrandrous and herkogamous, since they first undergo a male phase, when pollen is released and the stigma is not receptive (stigma presented above the anthers level, characterizing approach herkogamy, Fig. 1B) followed by a female phase, when anthers start to bend outward and the stigma becomes receptive. Flowers were scentless or released a slightly citric odor. In recently opened unvisited flowers, the postgenital connection of anthers was still observed, and these surrounded the exserted stigma (Fig. 8A). Other populations of A. rubra aparenltly do not present herkogamy, and the style is displayed at the same level of anthers, indicating that heterostyly may occur in this species.

\section{Anatomy}

Sepals have one main and two to five lateral bundles at the region of the lobes $(A$. rubra and A. coerulea two to three laterals, A. limae two to five). At the congenitally fused region, sepals may have up to 40 lateral bundles (up to 24 in A. rubra, up to 20 in A. coerulea, and up to 40 in A. limae). At floral base, sepals have ten vascular traces, 5 main traces, 5 
synlateral traces (Fig. 7F-M). Petals are provided with one to three main vascular bundles and up to 13 lateral bundles at their distal region (up to 3 laterals in A. coerulea, up to 15 in the larger flower form of A. rubra, and up to 13 in A. limae (Figs 7B-D, 9A-C). Lower down these lateral bundles converge to the main bundles and merge with them, forming broad bands of vascular tissue, arc shaped (broader in A. rubra and A. limae, and smaller bands in $A$. coerulea). These bands may form one to four groups along the petals (Fig. 7 E-J). At the lower third level of petals of A. limae where they are thickest, other smaller, secondary vascular bundles appear at the lower sector of the arc. At the base of the flower, petals have one broad vascular trace (Fig. 7K). Stamens have one vascular bundle and a single vascular trace (Figs 7D-K, 9D). The nectary disc has numerous small phloematic vascular bundles along most of its length (more numerous in the larger-flowered form of $A$. rubra and in $A$. limae, Fig. 10G, H). At the floral base these merge and form larger traces radially arranged above the carpel traces, composed of xylem and phloem. At the gynophore level the ventral bundles of carpels converge more towards the centre of the flower, forming a central vascular trace complex (Fig. 7L). At the floral base, the disc traces at the antesepalous region of the flower merge first with dorsal carpel traces, and lower down also to stamen traces, then converging to the central vascular complex. The disc traces at antepetalous region of the flower merge with dorsal traces of carpels, and lower down they may also merge with the petal traces, forming five large trace complexes, which then converge to the central vasculature of the flower. They do not merge in one of the A. rubra specimen and in $A$. coerulea, where the trace complex of disc plus dorsal traces converges first to the central vasculature, followed by the five petal traces. At the lowermost level of the flower base, calyx traces converge independently to the central complex, forming the pedicel vasculature (Fig. $7 \mathrm{~K}-\mathrm{M})$.

\section{Histology}

Short bicellular lignified hais are present on the abaxial side of calyx. Unicellular lignified trichomes are present on both sides of petals and on filaments (longer and in higher density on the upper adaxial side of filaments, forming a tuft of trichomes, Fig. 11F, G). In the tips of the calyx lobes, below the rounded apertures of the putative extra-floral nectaries, no nectariferous cells are visible; instead a necrotic area with tanniferous cells or an empty cavity surrounded by apparently dying cells is observed (in young and in advanced buds, Fig. 10 I). Petals of A. rubra have a glabrous central area approximately at their lower half (Fig. 11D, E). Carpels have lignified unicellular hairs within the locules, between ovaries and at the upper part of the style; also, hooked multicellular glandular trichomes are observed on carpel flanks 
(Figs 8D, 11A). The unicellular papillae on the surface of anthers have narrow rounded tips, with striate ornamentation (Figs 9F, 11J). Stomata are observed on the surface of the nectary disc, at its upper level (Fig. 11A). Tanniferous tissue is present in the epidermis of the disc and style, in the outer integument of ovules (Fig. 10C, D, G, H). Secretory cavities are present in sepals, petals, stamens and ovary (Fig. 10G). Druses where observed in all floral organs, except in the disc.

Figure 7: Almeidea lilacina (A) and A. rubra (B-M). Sections of floral buds. (A) Longisection. (B-L) Transections: successive levels, from the top, downward. Morphological surface indicated by thicker continuous lines, vasculature by thinner continuous lines; postgenitally fused areas indicated by broken lines; pollen tube transmitting tissue (PTTT), dark grey; nectariferous tissue, light gray (in the longitudinal section, only morphological surfaces and vascularization are represented). (B) Uppermost level of petals. (C) Upper level of anthers. (D) Mid-level of anthers and stigmatic region. (E) Lower level of anthers. (F) Level of calyx lobes. (G) Transition level of the lowermost part of the style and uppermost level of the ovary. (H) Upper level of the ovary locule, above the placenta. (I) Mid-level of ovary (calyx not represented). (J) Lower level of ovary locules. (K-L) Level of common base of nectary plus ovary. (M) Level of main calyx traces. Abbreviations: ca, calyx; st, staminode; ste, style; tc, dorsal trace of carpel; tcsl, synlateral trace of calyx; tcm, main calyx trace; td, trace of disc; td+tc, trace complex of disc plus dorsal traces of carpels; tp, trace of petals; tp+td+tc, trace complex of petals plus disc plus dorsal traces of carpels; ts+td, trace complex of stamens plus disc. Scale bars: $(\mathrm{A})=1$ $\mathrm{mm} ;(\mathrm{B}-\mathrm{M})=500 \mu \mathrm{m}$. 


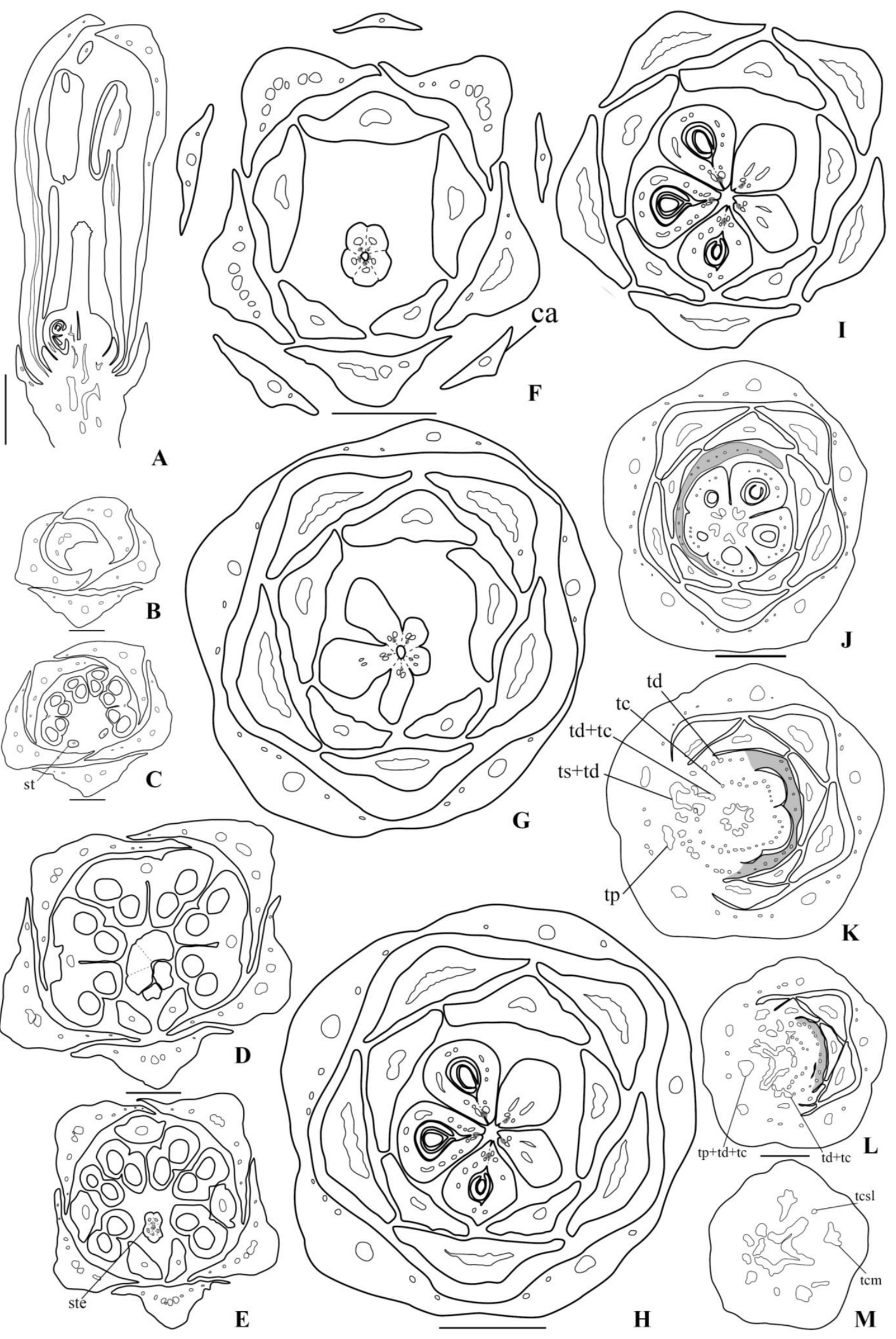



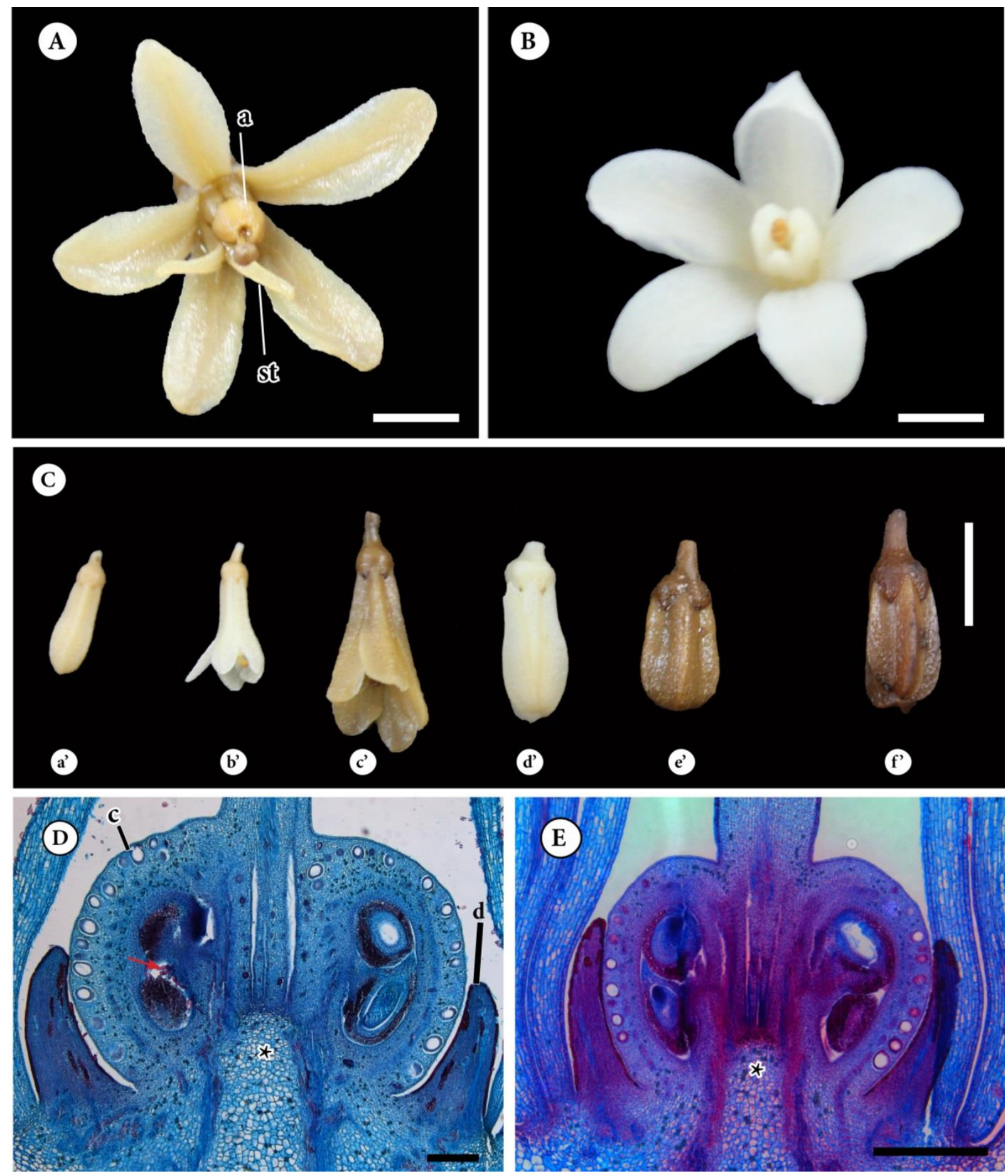

Figure 8: Photograph (A-C) and photomicrographs (D-E) of flowers and advanced buds of Almeidea rubra and A. limae. (A-B) A. rubra. Monossymetric flower, with two staminodes and three postgenitally connected anthers surrounding the stigma. (B) Polysymmetric flower with full fertile stamens. (C) Floral buds of species traditionally recognized as A. rubra (a'-e') and A. limae (f'); note the progression in size of the abaxial ridge of petals, more conspicuous in the floral buds in the right side of the figure. (D-E) Longitudinal sections of the base of floral buds of A. limae (D) and A. rubra (E), close to the median plane of carpels. (D) Acrostylous gynoecium. (E) Slightly anacrostylous gynoecium (asterisk indicate the area of large celled tissue in the centre of carpels). Abbreviations: a, anther; c, carpels; d, disc; st, staminode. Scale bars: $(A-B)=0,5 \mathrm{~cm} ;(C)=1 \mathrm{~cm} ;(D)=200 \mu \mathrm{m} ;(E)=$ $500 \mu \mathrm{m}$. 

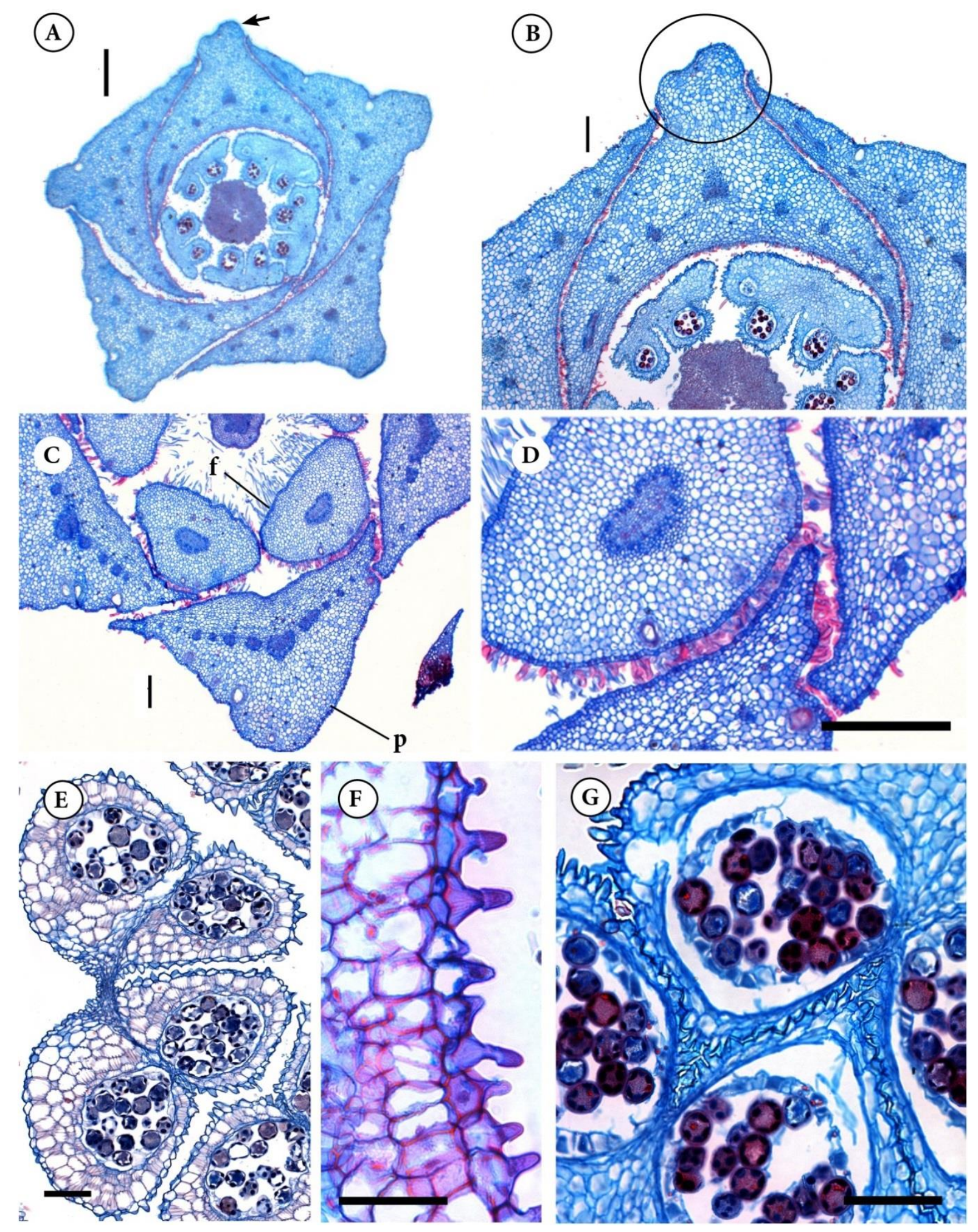

Figure 9: Photomicrographs of microtome sections of floral buds of Almeidea. (A-B) A.limae (transections). (A) Polysymmetric flower, with ascending cochlear aestivation (arrow indicate the abaxial ridge of petals). (B) Detail of A, at the region of the abaxial ridge (encircled). (C-E) A. rubra (transections). (C) Detail of the region of floral tube. (D) Detail of $\mathrm{C}$, showing the intertwining trichomes in petals and filaments. (E) Anther; note the endothecium-like tissue broadly developed on the connective side. (F) A. coerulea. Detail of epidermal papillae of anther (longitudinal section). (G) Detail of two adjacent anthers of A. rubra (transection); note postgenital connection through interlocking papillae. Abbreviations: f, filament; p, petal. Scale bars: $(A)=500 \mu \mathrm{m} ;(B-D)=200 \mu \mathrm{m}$; $(\mathrm{E}, \mathrm{G})=100 \mu \mathrm{m} ;(\mathrm{F})=50 \mu \mathrm{m}$. 

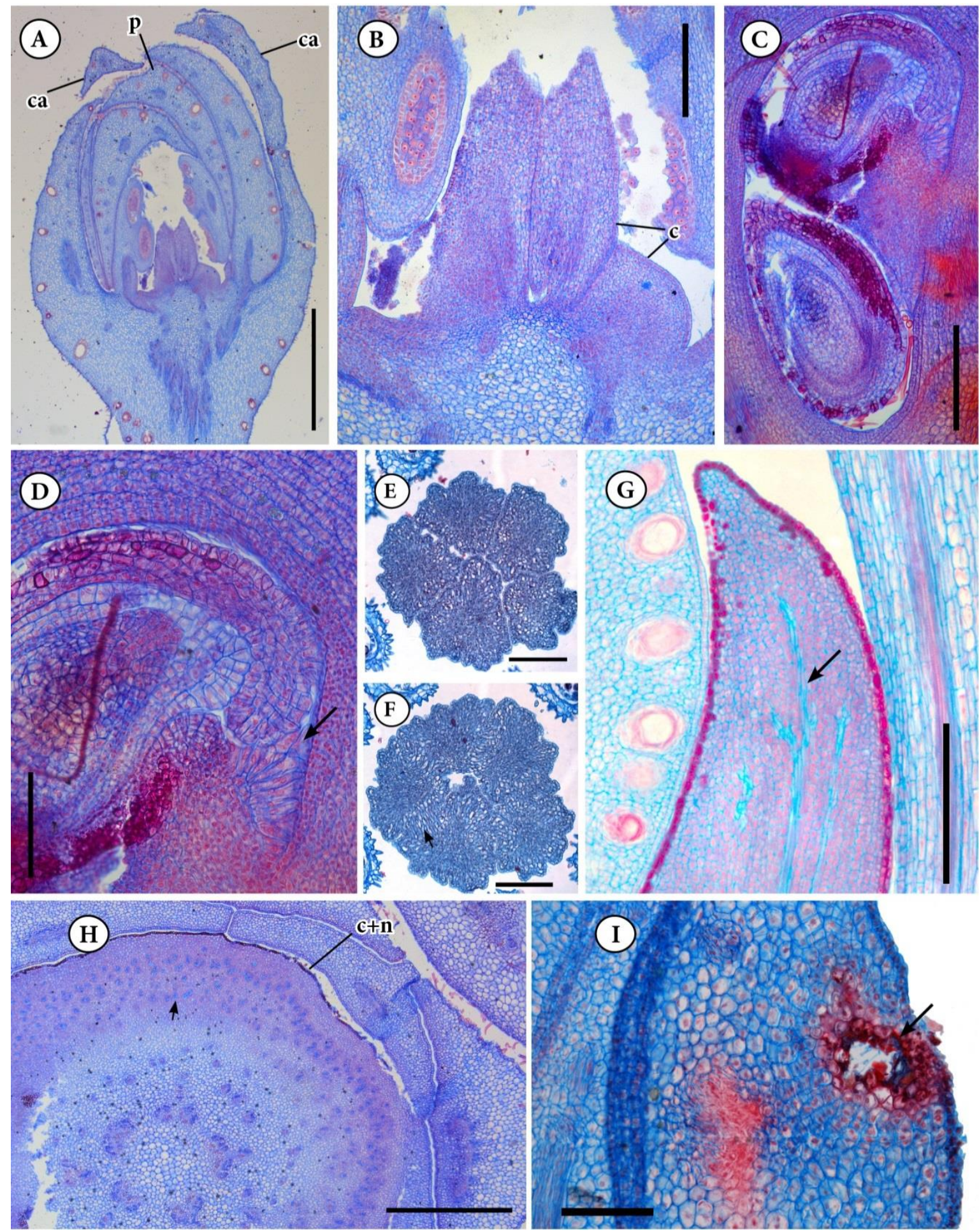

Figure 10: Photomicrographs of microtome sections of floral buds of Almeidea. (A-D) A. rubra (longitudinal sections). (A) Young floral bud. (B) Detail of B, at the median plain of carpels (note the convex shape of the floral apex and the oblique base of the young carpels). (C) Detail of one mature carpel, showing two superposed anatropous ovules. (D) Detail of C, showing the obturator (arrow) and zig-zag micropyle. (E-F) Transections of stigmatic region of A. limae. (E) Upper part, with five free lobes. (F) Lower, with postgenitally fused lobes. (G) Longitudinal section at the upper part of the nectary disc of A. rubra; note the phloematic bundles (arrow). (H) Transection close to the floral base of A. rubra; note the common base of disc plus carpels (arrow in the nectary tissue). (I) Transection of one calyx lobe of A. rubra in the region of the extra-floral nectaries; note the cavity formed by necrotic tissue (arrow). Abbreviations: c, carpel; ca, calyx; c+n; common base of carpels and nectary; p, petal. Scale bars: $(A)=1 \mathrm{~mm} ;(B, C, E, F)=200 \mu \mathrm{m} ;(D, G)=100 \mu \mathrm{m} ;(H)=500 \mu \mathrm{m} ;(\mathrm{I})=50 \mu \mathrm{m}$. 

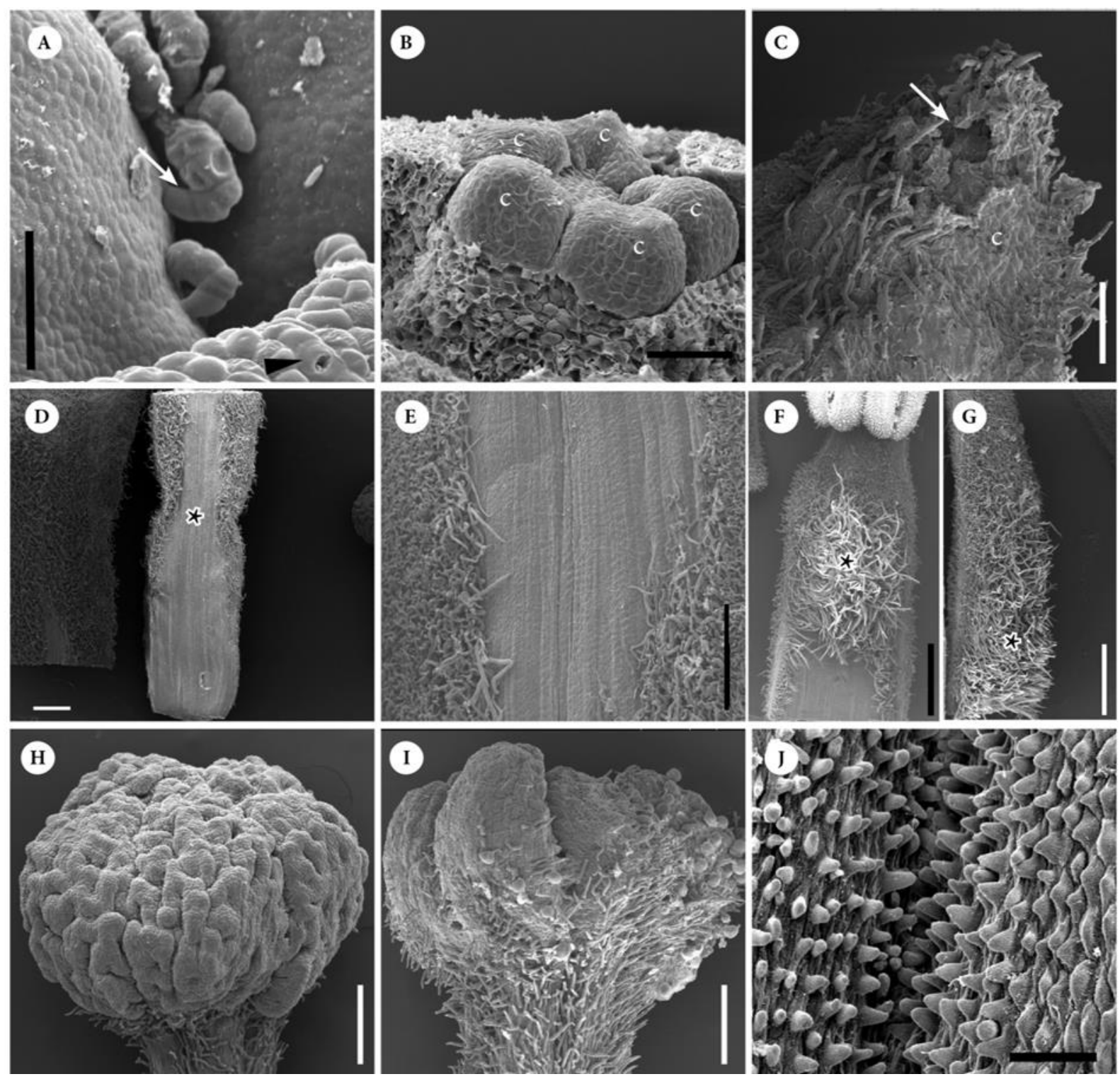

Figure 11: SEM micrographs of floral buds of Almeidea. (A) Detail of hooked multicellular glandular trichomes (arrow) on carpels of A. rubra, and one stomata on the nectary apex (arrowhead). (B) Five young carpels (c) viewed from the side. (C) One calyx lobe of A. rubra, at the region of the extrafloral nectaries, note the presence of a rounded aperture (arrow). (D) Lower half of one petal (adaxial side); note a central glabrous area (asterisk). (E) Detail of D, at the region indicated by the asterisk. (F) Detail of one fertile stamen (adaxial side), with a tuft of trichomes at the upper part of the filament (asterisk), below anthers. (G) This same level (asterisk), in the filament of one staminode. (H-I) Lateral view of stigmas from flowers of A. rubra $(\mathrm{H})$ and A. limae (I). (J) Detail of the surface of the anther of A. limae, note epidermal papillae, ornamented by striate cuticule. Scale bars: $(A, B)=50 \mu \mathrm{m}$; $(\mathrm{C}, \mathrm{E}, \mathrm{J})=100 \mu \mathrm{m} ;(\mathrm{D})=500 \mu \mathrm{m} ; \mathrm{F}, \mathrm{G}=1 \mathrm{~mm} ;(\mathrm{H}-\mathrm{I})=250 \mu \mathrm{m}$. 


\section{Angostura bracteata (Figs 1D, E, 12-14)}

\section{Morphology and aspects of floral biology}

The flowers are monosymmetric, and flower buds are ca. $23 \mathrm{~mm}$ long. Advanced buds are straight to slightly curved, but the floral tube is straight (Figs 1D, E, 12 A). Sepals have five triangular lobes, and are shortly congenitally connate at base. The lobes have open aestivation at their uppermost part; downwards they become valvate to imbricate in advanced buds, and also after anthesis (Figs 1, 12F-J). Sepals have one to multiple small abaxial protuberances, giving the overall appearance of an undulated external surface of the calyx. Also they have a broad adaxial protuberance, making sepals thin towards their margins (Figs 12F-H, 13B). Petals are thin, and the corolla is polyssymmetric to slightly monosymmetric since some flowers have the five petal blades unequally distributed, so that the three upper petal lobes are slightly separated from the other two (Fig. 12B,1E). Below this free region, approximately from their upper third to base, petals and filaments together form the floral tube, which is formed in most of its length by the adnation of filaments to the petals (Fig. 12A, D-J). Only the uppermost part of the tube is formed partially by the coherence of petals and adherence of petals to filaments by intertwining trichomes (Fig. 13A). In the distal region of the floral bud, petals overlap each other (Fig. 12A). They have ascending cochlear aestivation in their free upper parts (Fig. 12B-E). The androecium is monosymmetric, with two fertile antesepalous stamens and five smaller staminodes, three antesepalous and two antepetalous. The fertile stamens are located on the posterior side of the flower and are adjacent to the innermost petal (Fig. 12B). In their uppermost part, all staminodes are closely packed in bud, with an irregular flattened shape; lower down the staminodes become larger (Fig. 12B -D). At the tip of the floral bud, antepetalous staminodes are placed between the ventral pollen sacs of anthers and the antesepalous staminodes (almost at the centre of the bud). Lower down they are opposite to the immediately adjacent petals, alternating and at the same level with the antesepalous staminodes (Fig. 12B-C). The filaments of fertile stamens are wider than the staminodes at their short free region (Fig. 12D). Below their distal free

parts, filaments of fertile stamens and staminodes are congenitally connate and adnate to petals at different levels. This begins with the connation of the two fertile stamens followed by the adnation of the two antepetalous stamens to petals, and proceeds below to the adnation of antesepalous staminodes to petals and their lateral connation to the adjacent filaments (Fig. 12D-E). Lower down, the complete adnation of filaments to petals proceeds from the anterior part of the tube to the posterior side, forming approximately in their lower half a five-angled stamen-petal tube completely congenitally fused (Fig. 12A, F). Confluence of the meristem of 
petals and stamens, resulting in the congenital union of their lower parts, occurs relatively late in development when the upper free parts of the organs are already visible (Fig. 14A, B, E). Analysis of young stages of the androecium, seen from the dorsal side and also the microtome sections (Fig. 12C-E) show that antepetalous staminodes and antesepalous staminodes appear to have their bases nearly in the same level at the floral base. Additionally, one antepetalous staminode presented their apex slightly bent towards the inner side of the flower in young stages, which reflects the position of antepetalous staminodes in their distal region in advanced buds (Figs 12B, 14 C, D). Also, the whorl of antesepalous staminodes primordia appears before the antepetalous ones (Fig. 14B, C). Anthers are large (ca. 3,5 mm), basifixed, sterile at base (above and below the level of filament attachment, Fig. 12C). Each anther bears a basal sterile appendage, which represents only one single prolongation of both thecae bases (Fig. 12C, D). Anthers are sagittate, introrse, mostly persistent and have a thick connective. Endothecium-like tissue is continuous over most of the dorsal side of the connective side, arranged as a palissade-like layer of cells. Anthers have one deep ventral furrow between each theca and a shallow dorsal furrow along most of their length (Figs 13C, 12B). There is an intrastaminal nectariferous cupular disc, which encompasses the ovary almost to its half. Carpels are abruptly bulged up on the dorsal side above the level of the base of the style, so that the style appears sunken into it for ca. one third of the ovary length (carpels anacrostylous). The upper dorsal carpel walls are markedly thickened in the bulging dorsal region (Figs 12A, 13F, 14J). The stigma is five-lobed, the lobes postgenitally fused, frequently facing the posterior side of the flower. The stigma surface is smooth (Figs $13 \mathrm{D}-\mathrm{E}$, 14J). The style is completely postgenitally fused except at base, where a small central furrow is present (Fig. 12E, F). Below, at the uppermost part of the ovary locules, carpels are postgenitally fused at the inner part of their flanks only. Immediately below they are free (Fig. $12 \mathrm{G})$ and this free zone extends until the base of the locules, where these become congenitally fused only at center (Fig. 12H-I). Below the locules there is a short gynophore (Fig. 12 A, I, J). The placentation is marginal (Fig. 12H). Four carpels have two ovules, while one has only one ovule. The ovules are antitropous, with the outer integument thicker then the inner, and an obturator made of papillae and multicellular trichomes is present on the placenta and funiculus (Fig. 13F).

The perianth at anthesis is predominantly white. The flowers are protandrous and present approach herkogamy, with male and female phases. Recently opened flowers present the style incluse and non-receptive, while the two anthers are releasing pollen and all filaments and staminodes are exserted form the floral tube (male fase, Fig. 1D). Later on anthesis, filaments and staminodes gradually elongate and curve backwards, while 
simultaneously the style elongates outside the floral tube, exposing the receptive wet stigma (female fase, Fig. 1E). Additionally, this species present secondary pollen presentation on the staminodes, since in buds shortly before anthesis and in unvisited flowers the pollen is deposited on them. This happens because all androecia organs are closely packed in the distal part of advanced buds just prior to anther dehiscence. Floral odour is sweet-scented, which is more stronglyperceived at night. This species presents a mixed pollination system, with diurnal Lepidoptera and hummingbird as pollinators during daytime, and moths at night. All Lepidoptera used the staminodes and the lower petal lobes as landing place (El Ottra et al. in prep., Chapter 3).

\section{Anatomy}

Sepals have one main vascular bundle and up to five lateral bundles in the region of the lobes (Fig. 12F-H). At the congenitally fused region, sepals may have additionally up to 12 lateral bundles (Fig. 12I). At floral base, sepals have five main traces and five synlateral traces (Fig. 12G-L). Petals have one to three main vascular bundles (which may merge, forming broad bands of vascular tissue at the middle of petals), and may have up to seven lateral vascular bundles at their distal free parts (Fig. 12B-E). Lower down, petals have one vascular bundle in the congenitally fused region; and at floral base, a single vascular trace (Fig. 12F-K). Antesepalous and antepetalous stamens possess one vascular bundle and a single vascular trace (Fig. 12B-K). One of the antepetalous stamens is located very close to the main central vascular bundle of the immediately opposite petal, from the region where it is adnate to the petal down to the floral base. The other antepetalous staminode at its upper part is also located very close to the main central vascular bundle of the immediately opposite petal. However, lower down at the floral tube region it merges with the main petal bundle (Fig. 12D-J). Only at the floral base, it separates from the petal trace and became positioned at the same level of the other antepetalous staminode (Fig. 12K). The nectary disc has one ring of numerous small phloematic bundles along most of its length. These merge at the floral base, forming arcs of vascular bundles, composed of xylem and phloem, between the carpel traces and the petal and filament traces (Fig. 12J). The ventral bundles of carpels converge towards the center of the flower at the gynophore level, forming a central vascular complex at the floral base (Fig. 12J-K). Then, some of the dorsal traces of carpels converge towards the central complex, while others form trace complexes with part of the disc traces (Fig. $12 \mathrm{~K}$ ). Other disc traces (or disc plus dorsal traces of carpels) also form trace complexes with antesepalous stamen traces. Lower down, these trace complexes merge with the central vasculature. The antepetalous stamen traces then converge to this central vasculature and 
merge with it, followed by the petal traces (Fig. 12 L). At lower level of floral base, the sepal traces merge to the central complex, thus forming the pedicel vasculature (Fig. 12L-M).

\section{Histology}

Stellate trichomes are present on the abaxial surface of the calyx and on petals. Echinoid trichomes are present on abaxial side of petals (Fig. 14E-G). Lignified unicellular trichomes are present on petals and filaments, mostly in their upper half (Fig. 13A, C). Tanniferous cells are sparsely dispersed in petals, filaments, and outer integument. Tanniferous tissue is present in the connective of anthers, sterile basal appendages of anthers, style, and in the epidermis of the disc (Fig. 13A, C, F). Secretory cavities are present in sepals, petals, filaments and ovary. At anthesis, large glands are seen around the base of the stigmatic region and on top of the ovary wall, where they are more numerous and form small rounded protuberances (Figs 13A, B, F, $14 \mathrm{~J}$ ). They are conspicuously large in the calyx (ca. $100 \mu \mathrm{m})$ and in the uppermost part of the staminodes, making their tips somewhat spherical. Raphides were observed in sepals, petals, filaments and ovary. Small stomata are present on the upper part of the disc. The epidermal cells of anthers are shortly papillose. The smooth stigmatic surface is lined by columnar cells. 


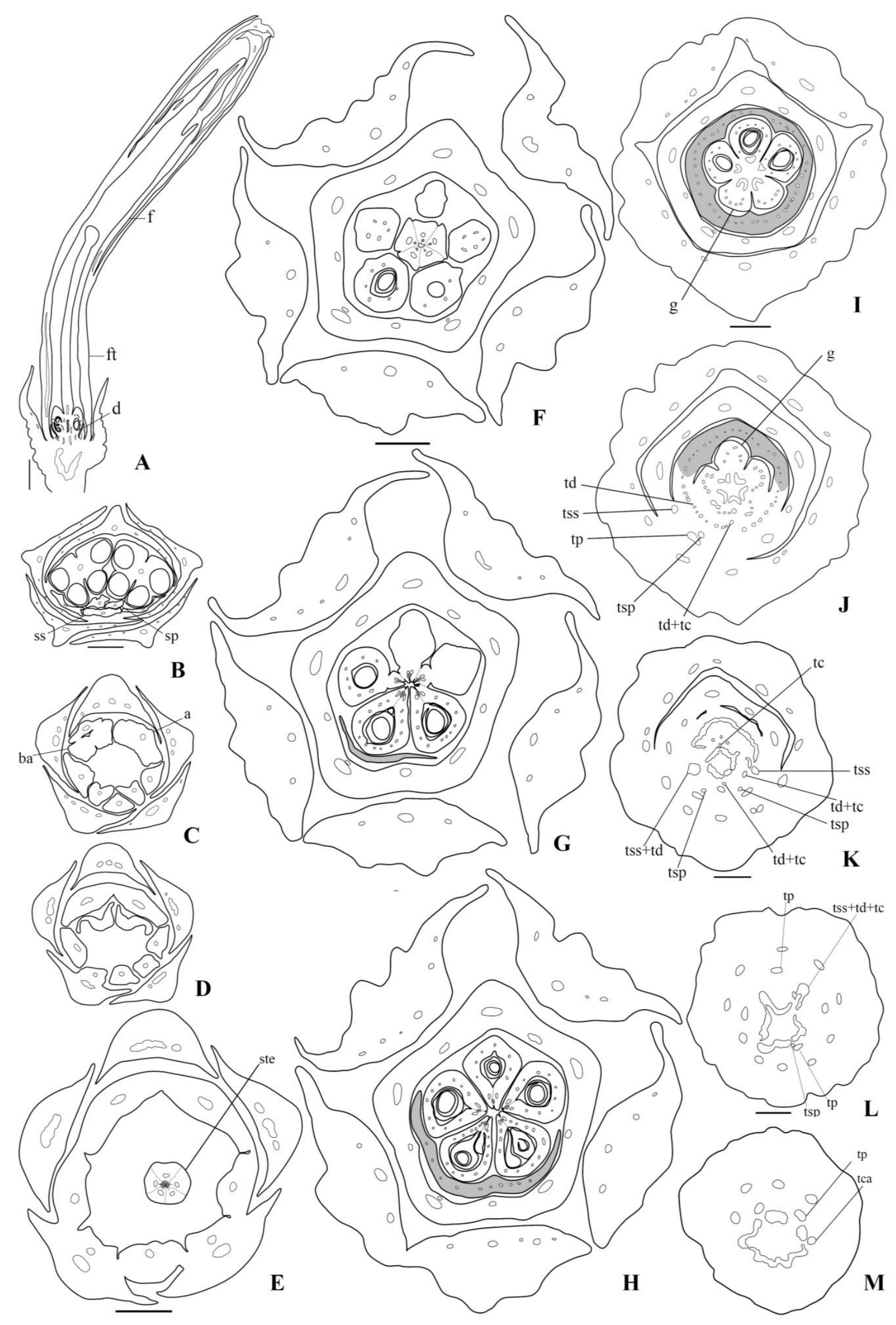


Figure 12: Angostura bracteata. Sections of floral buds. (A) Longisection. (B-M) Transections: successive levels, from the top, downward. Morphological surface indicated by thicker continuous lines, vasculature by thinner continuous lines; postgenitally fused areas indicated by broken lines; pollen tube transmitting tissue (PTTT), dark grey; nectariferous tissue, light gray (in the longitudinal section, only morphological surfaces and vascularization are represented). (B) Mid-level of anthers. (C) Lower level of anther, and upper level of basal appendages of anthers (ba). (D) Lower level of basal appendages. (E) Upper part of floral tube. (F) Uppermost part of ovary, at the level where they are dorsally bulged around the style base. (G) Level of carpels postgenitally fused by the inner flanks. (H) Upper region of the placenta. (I) Lower level of ovary locules, congenitally fused at centre and short gynophore. (J) Lower level of gynophore and floral base. (K) Level of trace complex of antesepalous staminode plus disc. (L) Level of trace complex of antesepalous stamen plus disc plus dorsal traces of carpels; entrance of antepetalous staminode trace and petal trace in the central vascular complex. (M) Lower level of floral base and pedicel vasculature. Abbreviations: a, anther; ba, basal apendages; d, disc; f, filament, ft, floral tube; g, gynophore; ss, antesepalous staminode; sp, antepetalous staminode; tc, dorsal trace of carpel; tca, trace of calyx; td, trace of disc; tp, trace of petal; $\mathrm{td}+\mathrm{tc}$, trace complex of disc plus dorsal trace of carpels; tsp, trace of antepetalous staminode; tss, trace of antesepalous staminode; tss $+\mathrm{td}$, trace complex of antesepalous stamen plus disc; tss+td+tc, trace complex of antesepalous stamen plus disc plus dorsal trace of carpels. Scale bars: $(A)=1 \mathrm{~mm} ;(B-M)=$ $500 \mu \mathrm{m}$ 

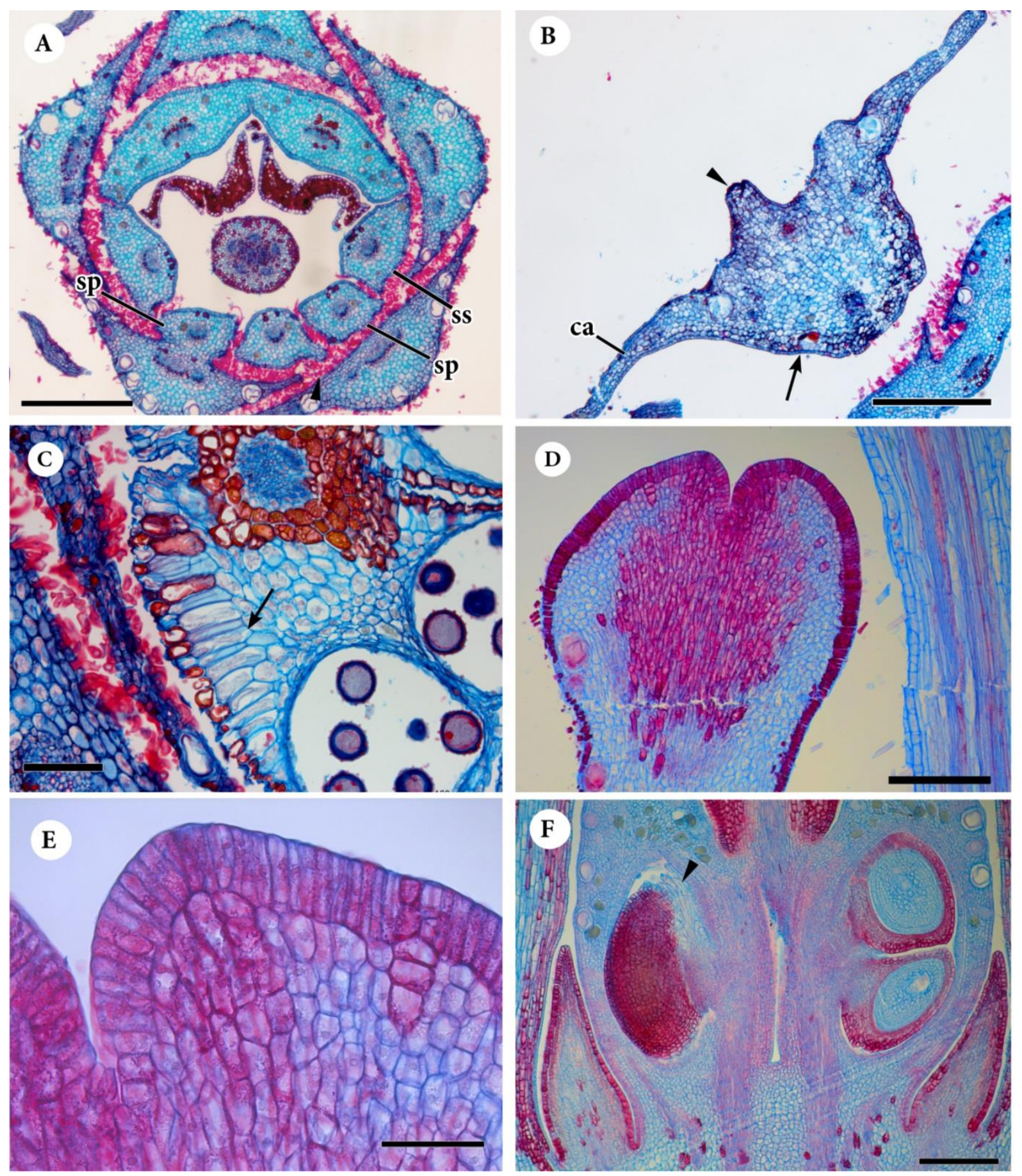

Figure 13: Photomicrographs of microtome sections of floral buds of Angostura bracteata. (A-C) Transections. (D-F) Longisections. (A) Upper part of floral tube, showing intertwining trichomes in petals and filaments (arrowhead; ss, antesepalous staminode, sp, antepetalous staminode). (B) Detail of one sepal lobe, showing one abaxial protuberance (arrowhead), ridge-shaped, one larger adaxial protuberance (arrow). (C) Detail of one anther, showing the endothecium-like tissue continuous over most part of the dorsal side of the connective (as a palissade-like layer of cells, arrow). (D) Detail of the stigmatic region. (E) Detail of the smooth surface of the stigma. (F) Base of floral bud, focusing on the median plane of two carpels (arrowhead indicate an obturator). Scale bars: $(A, B)=500 \mu \mathrm{m} ;(\mathrm{C})=$ $100 \mu \mathrm{m} ;(\mathrm{D}, \mathrm{F})=200 \mu \mathrm{m} ;(\mathrm{E})=50 \mu \mathrm{m}$. 

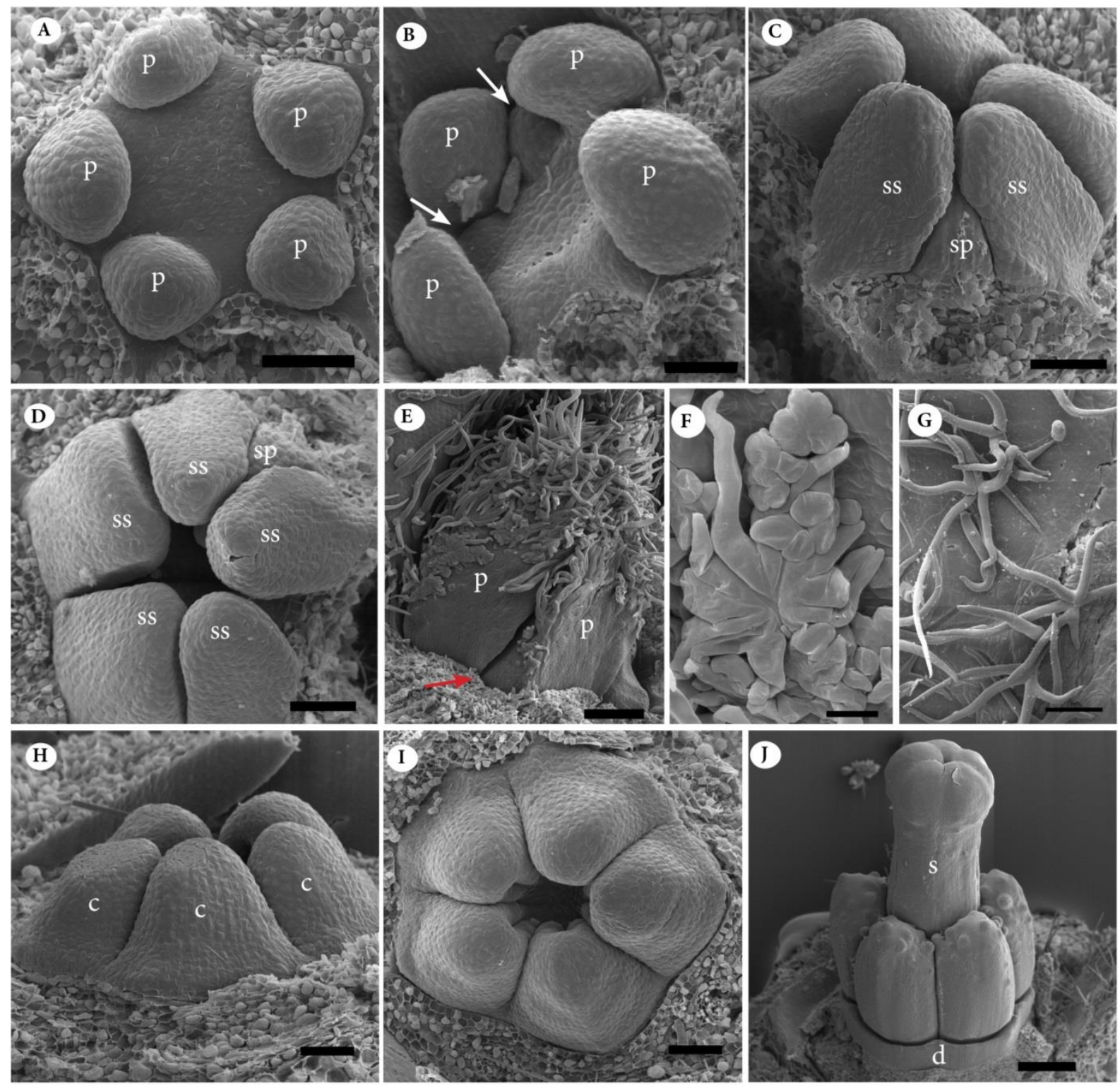

Figure 14: SEM micrographs of Angostura bracteata. (A) Five petal primordia (p). (B) Initiation of antesepalous staminodes (arrow; one petal removed). (C-D) Antesepalous staminodes (ss) elongating and one smaller antepetalous staminode (sp; the other one was removed; $\mathrm{C}$, from de side; $\mathrm{D}$, from above). (E) Young free petals (arrow at base), with echinoids and stellate trichomes. (F) Detail of one echinoid trichome on petal. (G) Detail of one stellate trichome on sepal. (H) Five young carpels (c), from the side (I) Latter stage then $\mathrm{H}$, carpels elongating (from above). (J) Carpels in advanced stage of development, with style elongating and stigmatic region differentiating (s, style; d disc). Scale bars: $(\mathrm{A}-\mathrm{D}, \mathrm{H})=50 \mu \mathrm{m} ;(\mathrm{E}, \mathrm{G})=100 \mu \mathrm{m} ;(\mathrm{F})=20 \mu \mathrm{m} ;(\mathrm{I}, \mathrm{J})=200 \mu \mathrm{m}$. 


\section{Conchocarpus cyrtanthus and C. concinnus (Figs 1F-H, 15-16, 18, 19 A-C)}

Morphology and aspects of floral biology

The flowers of both species are monosymmetric, haplostemonous. The floral tube of C. cyrtanthus is ca. $11 \mathrm{~mm}$ long, while in C. concinnus it is much smaller, ca. $4 \mathrm{~mm}$ long (Fig. $1 \mathrm{~F}-\mathrm{H})$. The floral bud and tube is straight to slightly curved in C. cyrtanthus, and straight in C. concinnus. Sepals have five lobes with rounded apices, which are gradually thicker towards their middle region as seen in transections (Figs 1F, H, 15D, 16C-D). The sepal lobes have open aestivation in $C$. cyrtanthus, and open to slightly imbricate close to the base of the lobes in C. concinnus (though Kallunki \& Pirani, 1998, observed imbricated sepals in $C$. cytanthus). Lower down, sepals are congenitally united and are thinner towards their congenitally fused margins, forming a five-undulate external surface, along most of their lenght in C. concinnus, and at the upper part of the fused region in C. cyrtanthus (Figs 15E-I, $16 \mathrm{E}-\mathrm{G})$. At the floral base, sepals have a common base with petals, stamens, disc and carpel (a short hypanthium is formed; Figs 15A, J, 16A, F-G). Petals are stiff. The corolla is only slightly monosymmetric since the five spreading blades are unequally distributed, so that one petal is located on the posterior side of the flower and the other four more or less in the anterior side (the two lateral petals and the two abaxial ones, Fig. 1F, H). Petal aestivation is ascending cochlear in $C$. cyrtanthus and at the distal region of the corolla of $C$. concinnus. Lower down, it is valvate to open in this latter species (Figs 15B-C, 16C). Petals have obtuse to rounded tips. They overlap each other at the uppermost part of the bud (Fig. 15 A, 16 A). At their free region, petals are gradually thicker toward their middle part, as seen in transections (Fig. 15B-C, 16B-D). The floral tube is formed by the coherence of petals and adherence of filaments to petals by intertwining trichomes in their uppermost part in $C$. cyrtanthus, and along most of its length in C. concinnus (Figs 15C, 18D, 16 C). Below these regions, petals are congenitally fused to stamens and form the floral tube until its base (Figs $15 \mathrm{D}-\mathrm{H}, 16 \mathrm{D}-\mathrm{E})$. The androecium have two fertile stamens and three staminodes. The filaments of the two fertile stamens are rounded at their uppermost free parts, gradually becoming somewhat flattened and wider lower down, more or less triangular at the postgenitally adherent regions. These two filaments are laterally connated at their uppermost part, and immediately below, are congenitally fused to petals in C. cyrtanthus. In both species, the filaments of fertile stamens are larger than the staminodes in their upper free parts. Anthers are located on the posterior side of the flower facing each other, and are adjacent to the innermost petal (Figs 15B, C, 16B, C). Anthers are mid-sized (ca. $3.9 \mathrm{~mm}$ in C. cyrtanthus and $1.6 \mathrm{~mm}$ in C. concinnus), basifixed, persistent, non-versatile, sagittate, 
introrse; they have a thick connective. Endothecium-like tissue is continuous over the entire dorsal side of the connective, and also broadly developed in the connective side of thecae (Fig. 19B). Between the two thecae of an anther there is a deep ventral furrow along most of their length. In C. concinnus the anthers have an apiculate apex (Fig. 16A, C). There is an intrastaminal nectariferous cupular disc, which encompasses the entire length of the ovary (or almost so). Its upper part is thicker and inflexed above the ovary. Carpels are abruptly bulged up on the dorsal side above the level of the base of the style, so that the style appears sunken into it for ca. one-quarter to one-fifth of the ovary length (carpels anacrostylous). The upper dorsal walls of carpels are thickened in the bulging region (Figs 15A, 16A, 18A). The stigma is conspicuously five-lobed in C. cyrtanthus, and not conspicuous in C. concinnus. In $C$. cyrtanthus the lobes have unequal sizes in a way that the stigmatic lobes face the anterior side of the flower (Fig. 15A). Stigmatic lobes are postgenitally fused below, where a compitum is formed. The stigma surface is non-papillose, smooth, covered by columnar-shaped cells (Fig. 18B). The single style is solid along its entire length in C. concinnus, and in most of its length in C. cyrtanthus, except at the base where carpels are free at center and a small furrow is formed (Fig. 15 F). At the uppermost level of ovary locules, carpels are postgenitally united at the centre (Fig. 16D). Immediately below, they are free down to the base of the locules (Figs 15A, G-H, 16A, D-E). At this level, carpels first become congenitally united at their flanks, lower down at center in C. cyrtanthus, and in C. concinnus first at center and lower down by their flanks (Figs 15I, J, 16F-G). This zone of basal congenital union comprises approximately one-seventh of the total length of the ovary. At the lower level of locules, carpels share a commom base with the nectary disc, stamens and petals, and lower down also with sepals, resulting in a partially inferior ovary and a short hypanthium (Figs 15A, I, J, 18A, $16 \mathrm{G})$. The partially inferior zone of the ovary comprises approximately $170 \mu \mathrm{m}$. The placentation is marginal (Figs 15H, 16E). The upper ovule is antitropous, and the lower is syntropous. In $C$. cyrtanthus the outer integument is thick and conspicuous, while the inner integument is inconspicuous, since it is visible only in the convex side of the ovule.In $C$. concinnus the ovules appear to be unitegmic. An obturator was not seen (Figs 18E, F, 19A).

The main colour of the perianth at anthesis is creamy to white (El Ottra pers. obs. and Kallinki \& Pirani, 1998). After anthesis the tip of the staminodes are exserted from the floral tube, while the two anthers are located at the mouth of the floral tube, only partially exserted by the end of anthesis. The flowers present reversal-herkogamy, since the stigma is recessed below the anthers level during the entire anthesis period (El Ottra pers. obs., and Kallunki \& Pirani, 1998). Older flowers present their anther partially curved away from the corolla throat (Fig. 1F, H). The flowers of C. cyrtanthus are slightly sweet-scented and we report visits of 
three different bees species (one small bee and two large-sized bees), several butterflies species and one hummingbird. Some of these animals also visited other flowers of Galipeinae species (butterflies in C. macrophyllus, butterflies and humingbirds in Angostura bracteata; El Ottra et al., in prep., Chapter 3), which were co-flowering in the same area during field work. Most of the insects used the lower lobes of the corolla as landing platforms; the largesized bees grabbed the lower and upper lobes once it landed, and then probed the flower. The hummingbird, butterflies and the large-sized bees appear to be pollinators, since they may contact the recessed stigma, while the small bee is likely a pollen thief (Fig. 1F, G). The calyx persists during fruit development.

\section{Anatomy}

Sepals of both species have five main vascular bundles and two to three additional smaller bundles in the region of the lobes. In the congenitally united region, there are additionally smaller lateral bundles, and the lateral-most bundles of adjacent sepals form synlaterals in $C$. cytanthus. In $C$. concinnus only five main bundles are present at the fused region of the calyx. At the floral base, ten calyx traces are present in C. cyrtanthus (five are the main traces and five are synlaterals) and only five traces in C. concinnus (Figs 15D-M, 16G). Petals have one main vascular bundle and two to four secondary bundles in the free regions (Figs 15B-C, $16 \mathrm{~B}$ ). At the floral tube region, there are five petal bundles, which extend downs the tube to the floral base. Stamens have one vascular bundle and one vascular trace. The nectary disc has numerous small phloematic vascular bundles along most of its length; at the floral base these merge and form larger traces, composed of xylem and phloem, that are radially arranged in front of the stamen traces and the petal (Figs 15H-J, 16 D-G). The ventral bundles of carpels run downwards to the hypanthium region where they converge towards the center, forming a central vasculature of the gynoecium, which is more or less pentagonal in C. cyrtanthus. At the hypanthium region, some additional lateral bundles appear at the flanks of carpels in C. cyrtanthus. At the floral base, the dorsal bundles of each carpel merge with each other, forming five dorsal traces in C. cyrtanthus, and five broad bands of traces in C. concinnus (Fig. 15K). Part of the ring of disc traces joins with the stamen traces immediately opposed, forming a disc plus stamen trace complex; whereas the other disc traces join with each other at the floral base (Fig. 15J-K). In C. cyrtanthus, some of the additional lateral traces of carpel flanks merge with some disc traces. Lower down, first the dorsal traces of carpels merge independently to the central vascular complex. Then the disc traces, disc plus lateral carpel traces, and the disc plus stamen traces also converge to this central vasculature. Finally, the petal traces merge with the synlateral traces of the sepals in $C$. 
cyrtanthus, and then these traces and the main traces of calyx merge to the central vasculature at the base of the flower and form the pedicel vasculature (Fig. 15L-M). Differently, in $C$. concinnus the five petal traces converge independently to the central vasculature, followed lower down by the five calyx traces.

\section{Histology}

Short multicellular lignified hairs are present on the calyx of both species. Unicellular hairs are present on both sides of petals and stamens, with higher densities in the upper free region of petals and filaments. Also, multicellular lignified tanniferous longer hairs are present on the uppermost level of filament (at the corolla throat, Fig. 18C, D). The disc possesses small stomata on its surface only at its upper level (Fig. 19C). Tanniferous cells are dispersed in the mesophyll of all floral organs, forming an extensive tissue in the epidermis and/or hypodermis of the disc (in C. concinnus only in the hypodermis), stigma, style, external surface of the ovary, (most developed at the dorsal bulging areas of the carpels; Fig. 18A) and in the integument (this latter only seen in C. concinnus, Fig. 19A). Also in the androecium, tanniferous cells are present in the epidermis of the anther, around its vascular bundle in the connective, and in parts of the epidermis and hypodermis of filaments (Figs 18C, D, 19B). The epidermis and hypodermis of sepals and petals have secretory cells filled with a blue-stained secretion (probably mucilage). These same cells are present in the connective (around its vascular bundle) of C. cyrtanthus (Fig. 19C), in the epidermis of anthers in C. concinnus, and within the disc and integument of both species. C. cyrtanthus have some glandular multicellular hairs at the free region of carpels, at the inner flanks of their outer walls.. Secretory cavities are present in sepals, petals, stamens and carpels, filled with a dense secretion in C. cyrtanthus (Fig. 18D). Cells with raphides are present in all floral organs, and are most numerous in the dorsal bulging areas of the carpels. Druses occur in the connective of anthers of $C$. cyrtanthus. The stigma surface is non-papillose, smooth, covered by columnar cells (Fig. 18B).

Conchocarpus macrocarpus, C. obovatus and C. odoratissimus (Figs 1I, J, 2A, B, 17, 19DF, 20-22)

Morphology and aspects of floral biology

The flowers of these three species are monosymmetric, haplostemonous. Flower buds are ca. $1.2 \mathrm{~cm}$ long (ca. $1 \mathrm{~cm}$ in C. obovatus). The floral bud and floral tube are straight (only 
slightly curved at the supper part in C. macrocarpus). Sepals form five triangular lobes in their distal part. They have open aestivation at anthesis. Below this region, sepals are fused, and are slightly thinner towards their congenitally fused margins at the upper part, forming a five-undulate internal surface in C. macrocarpa and C. obovatus (Figs 1I, J, 2A, 17G-L). Petals are stiff, and form a polysymmetric corolla in $C$. odoratissimus and $C$. obovatus, but a slightly monosymmetric one in C. macrocarpus, whose petal lobes are unequally distributed so that the uppermost petal is slightly separated from the other four lobes (the two lateral petals and the two abaxial ones). In their distal portion they form five spreading blades, with acute tips (Figs 1I, J, 2 B). Corolla aestivation is ascending to oblique cochlear along most of its length, but at base it is valvate to slightly open (Figs 17C-K, 20E, 21B, 22B). The tips of petals overlap each other at the uppermost part of the floral bud (Figs 17A, 22A). The floral tube is formed by the coherence of petals and adherence of filaments to petals by intertwining trichomes along its entire length (Figs 17 F-J, 20 E, 21D, 22D). Transverse sections of the petals show variations in shape along their length. They are longitudinally thicker in the middle abaxial region, forming a ridge-like protuberance (Figs 17 B, 22A, D), which is larger and narrower from its distal part down to its middle, gradually decreasing in size towards the petal base (Fig. 17F-K). Also in some petals, small clefts below this median protuberance are visible, where the margins of adjacent petals may dovetail at the distal region (Figs 17C, D, 22D). The androecium is monosymmetric, composed of two fertile stamens and three staminodes. The anthers are located on the posterior side of the flower and are adjacent to the innermost petal. Filaments are entirely free to each other, but postgenitally adherent to petals in the floral tube region (Figs 17D-K, 20E). Only two staminodes are congenitally united close to the floral base in C. odoratissimus (Fig. 17K, but according to Kallunki \& Pirani, 1998, this species has all filaments connated). Also the distal parts of staminodes are postgenitally connected to the adjacent ones laterally by interdigitation of papillae (Figs 20F, 21C). The staminodes have a rounded to irregular shape at the distal part, and immediately below they are somewhat triangular-shaped (Figs 17B, 20B). Lower down, all filaments (staminodes and filaments of fertile stamens) become wider triangles, dorsiventrally flattened at the floral tube region; in this same region they precisely alternate to petals (Figs $17 \mathrm{C}-\mathrm{H}$, 21C-E). In C. odoratissimus, staminodes are equally as wide as the filament of fertile stamens, as seen in transections (except at the tip of the fertile filaments, where these are constricted, Fig. 17D). Differently, in C. obovatus and C. macrocarpus, staminodes are narrower than filaments of fertile stamens, except at the constricted tip of fertile stamens (Figs 21D, E, 22F). Each stamen bears an apical sterile appendage, which represents a short sterile pointed protrusion of anther (an apiculate apex, apparently a protrusion of both the connective 
and thecae tips, Fig. 17C, D). Anthers are mid-sized, persistent, basifixed or near-basal dorsifixed, sagittate, introrse. They have a thin connective, and the endothecium-like tissue is broadly developed in the connective side of thecae (Figs 17A, D, 19D, 22F,G). Between the two thecae of an anther there is a deep ventral furrow along most of their length (Fig. 17C-D). There is an intrastaminal cupular nectariferous disc, which is thicker toward the base and encompasses the upper half of the ovary (in C.odoratissimus) or its entire length (in $C$. obovatus and $C$. macrocarpus). In $C$. obovatus and $C$. macrocarpus, the disc has five protuberances close to its base, in the free space between filaments as seen in transections (Fig. 21A, E). Carpels are acrostylous, with the locule ceiling with thickened upper walls, but not bulging (Figs 17A, 20A, 21A). The stigma is five-lobed, mostly postgenitally fused (only at flanks in C. obovatus and C. macrocarpus, forming a small furrow at its center, and this furrow extends to the upper part of the style in C. obovatus, closing lower down). The surface of the stigma is rugose, slightly papillose, with short papillae (ca. 10-12 $\mu \mathrm{m}$, Figs $17 \mathrm{D}, 20 \mathrm{D}$, 22B). The single style is short, completely postgenitally fused, except at base where carpels are not fused at the centre, then forming a furrow. Immediately below, at the uppermost level of ovary (still above locules level), carpels are completely free. This free zone extends down to the lower half of the locules, where carpels are congenitally united first in the centre, and lower down also at their flanks, becoming completely congenitally united at the base of locules (Figs 17 F-J, 21B). This zone of basal central congenital union comprises approximately half length of the ovary in C.odoratissimus, and one-fifth of the total length of the ovary in C. obovatus and C. macrocarpus (Figs 17A, 20A, 21A). Immediately below there is a short gynophore in $C$. odoratissimus, which has a commom base with the nectary disc (Figs 17I-J, 19E, F). The placentation is lateral and axilar in C. odoratissimus (Fig. 17A, G) and only lateral in C. obovatus and C. macrocarpus. Ovules are antitropous. One ovule observed in C. obovatus was slightly campylotropous (Fig. 22C). The outer integument is slighlty thicker than the inner, and an obturator made of uni- to multicellular trichomes is observed on the placenta and funiculus (Figs. 20A, G, H, 21F, 22C). In C. odoratissimus, at floral base, petals, filaments, and gynoecium share a common base (Fig. 17K).

The main color of the perianth at anthesis is light pink in $C$. odoratissimus, while in $C$. obovatus and C. macrocarpus it is white to cream. After anthesis the tips of the staminodes are exserted from the floral tube, while the two anthers are located at its mouth. The flowers present reversal-herkogamy, since the stigma is recessed below the anther during the entire anthesis (Figs 1I, 17A). Flowers are scentless during the diurnal period in C. macrocarpus, and slightly sweet scented in $C$. obovatus and $C$. odoratissimus. In $C$. obovatus the calyx persists during the initial development of the fruit, and its lobes bend over the young carpels 
just after the senescence of the corolla, apparently protecting the young fruiting carpels (Fig. 2A, B). Small ants were seen walking on the inflorescences, calyx, and within the floral tube of C. macrocarpus (Fig. 1J).

\section{Anatomy}

Sepals have one main and up to three small lateral bundles at the lobes. At the congenitally fused region, sepals may have additionally up to 36 secondary bundles (28 in $C$. odoratissimus and 15 in C. obovatus). At floral base, sepals have five main traces, and 10 lateral traces in C. odoratissimus (Fig. $17 \mathrm{G}-\mathrm{K}, \mathrm{N}$ ); in C. macrocarpus and in C. obovatus sepals have five main traces and five synlateral traces. Petals have one to three main vascular bundles, and may have up to twelve lateral bundles (Fig. 17B-J). In $C$. macrocarpus and $C$. obovatus, the main bundle merges with the lateral bundles in their lower half, forming a broad band of vascular tissue. In C. macrocarpus, other smaller secondary vascular bundles appear in the lower region of the broad band of vascular tissue, merging with it and forming a somewhat annular to semi-annular vascular complex in each petal (Fig. 21D, E). At the base of the flower, these complexes join forming five large traces of petals in these two species. Differently, in $C$. odoratissimus petals first have three vascular traces, which merge lower down forming five large trace complexes (Fig. 17L-M). Staminodes have at their distal region one main bundle and adittionally two lateral vascular bundles (Fig. 20B), but lower down these merge with the main bundle. Fertile stamens have one vascular bundle along their entire length. All stamens possess one vascular trace at floral base (Fig. 17C-K). The nectary disc has numerous small phloematic vascular bundles along most of its length; at the floral base these merge and form larger traces, composed of xylem and phloem (Figs 17H-K, 21E). In $C$. odoratissimus the five ventral bundles of carpels form synlateral bundles close to the base of the locules; also at this same level, a ring of vascular bundles appears at the center of the gynoecium (Fig. $17 \mathrm{H}-\mathrm{I}$ ). In this same species, lower down, close to the gynophore level, additional smaller lateral bundles are seen between carpel flanks; and the synlateral bundles converge toward the ring of vascular bundles at the centre of gynoecium, forming a central vascular complex of the gynoecium (Fig. 17J). In C. macrocarpus and C. obovatus the central vascular complex is formed by the five ventral bundles of carpels. In C. odoratissimus, at the level of common base of nectary plus gynoecium, the dorsal bands of vascular tissue of each carpel split in small traces and merge with the disc traces closer to them, forming small complexes (Fig. 17J). These converge first towards the central vascular complex. Lower down, the stamen traces converge to other disc traces, merging with them and forming five broad trace complexes. These, together with other disc traces, merge with the central vascular 
complex (Fig. 17K-L). Lower down, the five petal trace complexes merge with this central vasculature, and at lowest level of the floral base the sepal traces merge with the central vascular complex; first the lateral traces and then the five main sepal traces lower down, forming the pedicel vasculature (Fig. 17M ). In C. macrocarpus and C. obovatus the dorsal traces of carpels join with the disc traces, and lower down the disc traces also join the stamen traces. All these trace complexes merge with the central vasculature. At lower level, the five petal traces merge with the central vasculature, followed by the ten sepal traces (main and synlaterals), forming the pedicel vasculature.

\section{Histology}

Short bicellular lignified club-shaped hairs are present on the abaxial side of calyx and style, filled with an orange-stained secretion (not observed for C. macrocarpus). Short lignified unicellular hairs are present on the abaxial side of calyx, style and ovary (also between carpels at the empty space formed between free ovaries, Figs 20A, 21A; some were seen within the locules of ovary). Longer, lignified unicellular hairs are present on both sides of petals and on filaments. In the upper level of petals and filaments, small unicellular papillae are present (Fig. 20F). The epidermal cells of anthers are shortly papillose (Figs. 19D, 22F). Stomata are present on the upper level of the nectary disc. Tanniferous tissue is present in the epidermis of the disc and some tanniferous cells are observed in the outer integument (Figs. 20A, 21A, 22C). In C. macrocarpus and C. obovatus these cells are also present in the connective. In C. obovatus tanniferous cells are dispersed in all floral organs, forming an extensive tissue in the epidermis and hypodermis of calyx, distal region of petals, and also in the distal region of staminodes. In this same species, secretory cells filled with a blue-stained secretion (probably mucilage) are present in the epidermis and hypodermis of sepals, filaments and the connective of anthers. Additionally this same species have some secretory cells filled with dark-stained secretions in the outer integument, calyx, and epidermis of the disc and filaments (Fig. 22E, F). Secretory cavities are present in sepals, petals, stamens and carpels (especially larger in the calyx of C. obovatus). Druses are observed in all floral organs.

\section{Conchocarpus mastigophorus (Fig. 1K, 22G)}

\section{Morphology and aspects of floral biology}

The flowers in this species are monosymmetric and haplostemonous. Flower buds are ca. 6,3 mm long. The floral bud and floral tube are straight. Sepals have five triangular lobes, 
and are shortly congenitally connate at base (Fig. 1K). They have open aestivation at anthesis and are gradually thicker towards their middle region. At their fused region, sepals are also thinner towards their congenitally fused margins, forming a five-angled undulate external surface. Petals are stiff and protect the inner floral organs in advanced buds. The corolla is polysymmetric. Petals overlap each other at the uppermost part of the floral bud. In their distal portion they form five reflexed spreading blades. Corolla aestivation is oblique cochlear approximately at its upper half, becoming valvate to open downwards. The short floral tube is formed by the coherence of petals and adherence of filaments to petals by intertwining trichomes along their entire length. Petals are thicker towards the middle abaxial region in their distal parts, becoming narrower and flattened towards their bases. The androecium is monosymmetric, composed of two fertile stamens and three staminodes, all antesepalous. Anthers are located on the posterior side of the flower, facing each other, and are adjacent to the innermost petal (Fig. 22G). Filaments are entirely free, but adherent to petals in the floral tube region. Also at the distal part of staminodes, these can be postgenitally connected to adjacent ones by interdigitation of short papillae (Fig. 22G). Staminodes have a rounded to triangular shape, while the filaments of fertile stamens are triangular and wide, dorsiventrally flattened below their constricted tip. All stamens precisely alternate to petals, especially in the region where petals display open aestivation. Staminodes are smaller than filament of fertile stamens. Anthers are mid-sized (ca.2 mm) basifixed, sagittate, introrse. They have a thin connective, and the endothecium-like tissue is present in part of the dorsal and ventral sides of the connective, and also in the connective side of thecae (Fig. 22G). Between two thecae of an anther there is a ventral furrow and a shalow dorsal furrow. There is an intrastaminal nectariferous cupular disc, which encompasses the entire ovary. The basal region of the disc shows five protuberances lying in the free space between filaments. Carpels have the upper dorsal walls slightly rounded at the top of the ovary, but a dorsal bulge does not developed (carpels are acrostylous). The stigma is inconspicuously five lobed, mostly posgenitally fused. The surface of the stigma is rugose, with short papillae, in some parts with only bullate cell. The single style is short, postgenitally fused along its entire extent. In the transition level between style and upper level of ovary (above the level of the locules) carpels are first postgenitally united at the innermost part of their flanks and free at the centre. Imediately below (still above the level of the locules) carpels are completely free. This free zone extends approximately until mid-level of the ovary, where carpels are congenitally united first at the centre, and lower down also at their flanks, then becoming completely congenitally united at base. This zone of basal central congenital union comprises approximately half of the total 
length of the ovary. The placentation is marginal and axile. Ovules are antitropous. The outer integument appear to have the same thickness of the inner.

The main color of the perianth at anthesis is cream. Scent was not noticed during field collection. After anthesis the tip of the staminodes are exserted from the floral tube, while the two anthers are located at the mouth of the floral tube. The flowers appear to present reversalherkogamy since the analyzed flowers presented their stigmas recessed below the anthers level (Fig. 2K, but it was possible to analyze few flowers).

\section{Anatomy}

Sepals have one main vascular bundle, and up to three lateral bundles in the region of the lobes. In the congenitally fused region, sepals have five main bundles and up to 10 lateral bundles. At floral base, sepals have 15 traces. Petals have one main vascular bundle and may have up to five lateral bundles. At floral base, petals have one vascular trace. Stamens have one vascular bundle and a single vascular trace. The nectary disc has numerous small phloematic vascular bundles. At the floral base these merge and form larger traces composed of xylem and phloem, radially arranged in relation to the dorsal carpel traces. At the base of the carpels, the ventral bundles split in two, and then form synlaterals with the bundles of adjacent carpels. At the floral base, the synlateral bundles of carpels converge towards the center of the gynoecium and form a central vascular complex. At this same level, the dorsal vascular bundles of carpels and the additional lateral bundles become radially arranged around this central vascular complex. Lower down, part of the disc traces merge with the stamen traces, and others merge with the carpel traces (dorsal and lateral traces). These complexes then merge with the central vasculature, followed lower down by petal and calyx traces.

\section{Histology}

Lignified unicellular hairs are present on the abaxial side of calyx, petals, filaments (more densely in the lower half at their abaxial side) and on the upper part of the ovary. Unicellular epidermal papillae are present approximately at the distal two thirds of the adaxial side of staminodes and petals. The epidermis of anthers is shortly papillose (Fig. 22G). Stomata are present on the upper region of the nectary disc. Tanniferous cells were not seen. Secretory cavities are present in sepals, petals, stamens and ovary. Druses are observed in all floral organs, except in the disc. 
Figure 15: Conchocarpus cyrtanthus. Sections of floral buds. (A) Longisection. (B-L) Transections: successive levels, from the top, downward. Morphological surface indicated by thicker continuous lines, vasculature by thinner continuous lines; postgenitally fused areas indicated by broken lines; pollen tube transmitting tissue (PTTT), dark grey; nectariferous tissue, light gray (in the longitudinal section, only morphological surfaces and vascularization are represented). (B) Mid-level of anthers. (C) Upper level of fertile filament. (D) Upper part of style. (E) Mid-level of floral tube. (F) Lower level of style and ovaries dorsally bulged up. (G) Upper level of ovary locules. (H) Lower third of the ovary (lower level of placenta; calyx not represented). (I) Level of congenitally united ovary flanks (lower level of locules), and level of common bases of carpels, disc, stamens, and petals. (J) Level of inferior ovary. (K-M) Floral base. (L) Level of trace complex of stamen plus disc plus. (M) Level of main calyx traces and trace complex of petal plus synlateral calyx trace. Abbreviations: a, anther; bp, vascular bundle of petal; bn, vascular bundle of nectary; bs, vascular bundle of stamen; c, carpel; ct, main sepal trace; d, disc; ft, floral tube; lt, synlateral trace of sepal; st, staminode; td, trace of disc; tp, trace of petal; ts, trace of stamen; tss $+d$, trace complex of antesepalous stamen plus disc. Scale bars: $(\mathrm{A})=1 \mathrm{~mm} ;(\mathrm{B}, \mathrm{C}, \mathrm{E}, \mathrm{G}, \mathrm{I})=500 \mu \mathrm{m}$. 


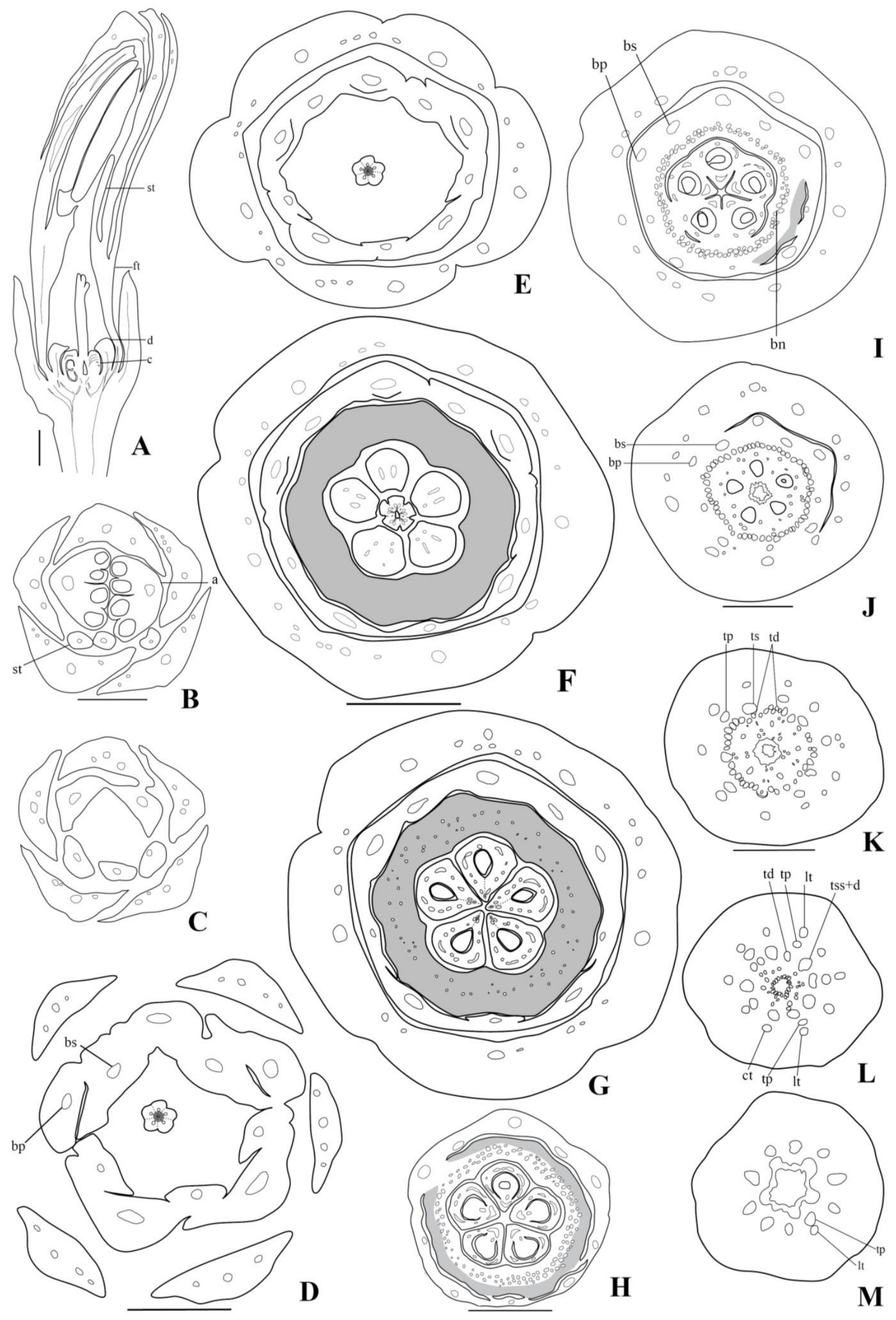



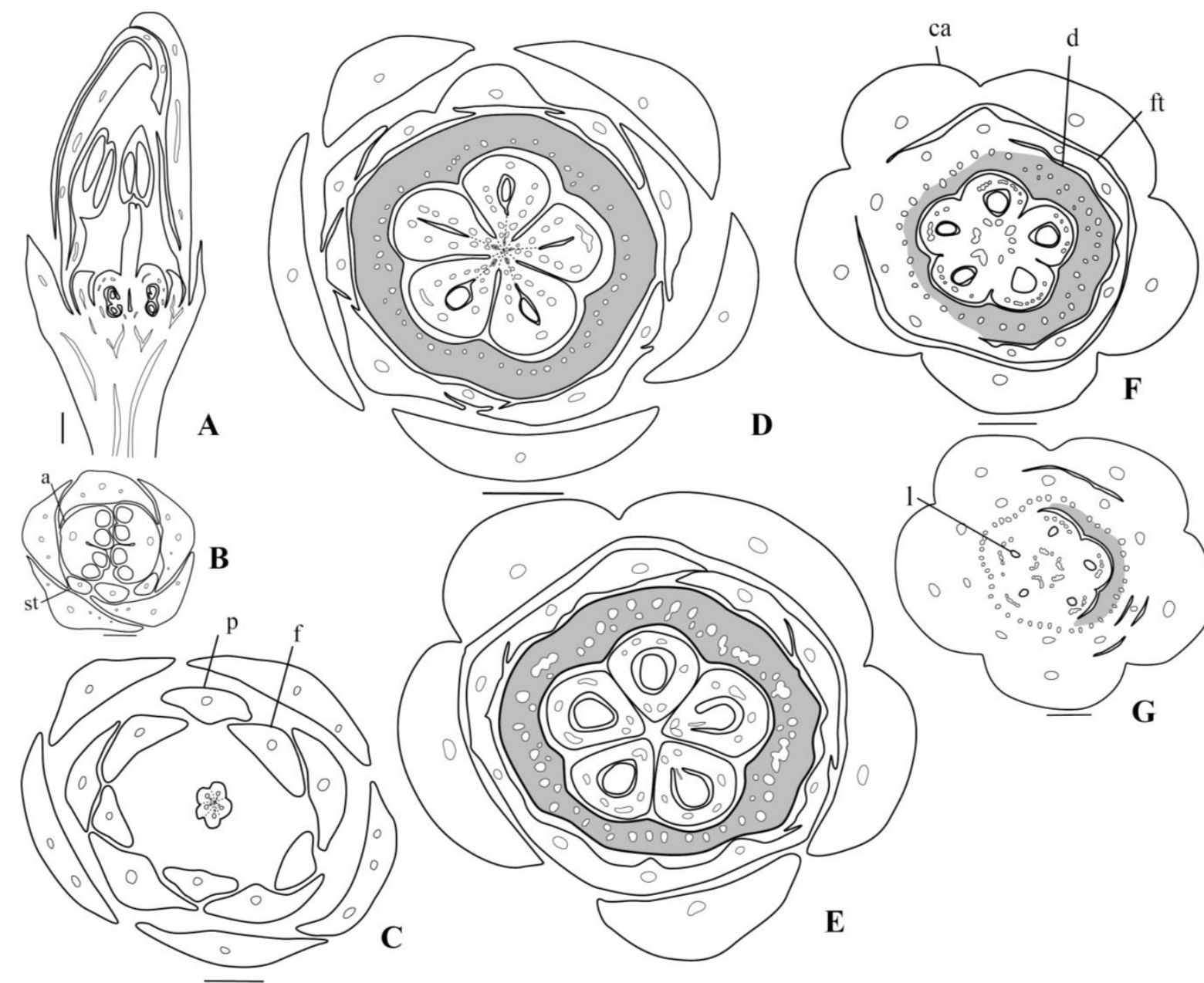

D

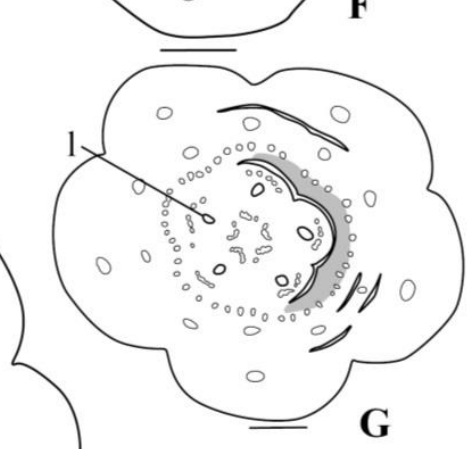

Figure16: Conchocarpus concinnus. Sections of floral buds. (A) Longisection. (B-G) Transections: successive levels, from the top, downward. Morphological surface indicated by thicker continuous lines, vasculature by thinner continuous lines; postgenitally fused areas indicated by broken lines; pollen tube transmitting tissue (PTTT), dark grey; nectariferous tissue, light gray (in the longitudinal section, only morphological surfaces and vascularization are represented). (B) Mid-level of anthers. (C) Mid-level of style. (D) Upper level of ovary locules. (E) Mid-level of ovary. (F) Level of carpels united at center and level of common bases of disc, stamens and petals. (G) Level of congenitally united ovary flanks (lower level of locules) and common bases of carpels, disc, stamens and petals (short hypanthium). Abbreviations: a, anther; ca, calyx; d, disc; f, filament; ft, floral tube; 1 , ovary locule; p, petal; st, staminode. Scale bars: $(A, D-G)=100 \mu \mathrm{m} ;(B, C)=50 \mu \mathrm{m}$.

Figure 17: Conchocarpus odoratissimus. Sections of floral buds. (A) Longisection. (B-M) Transections: successive levels, from the top, downward. Morphological surface indicated by thicker continuous lines, vasculature by thinner continuous lines; postgenitally fused areas indicated by broken lines; pollen tube transmitting tissue (PTTT), dark grey; nectariferous tissue, light gray (in the longitudinal section, only morphological surfaces and vascularization are represented). (B) Uppermost level of anthers (at the level of the sterile protrusion of thecae). (C) Upper level of the connective and basal level of sterile protrusion of thecae. (D) Lower level of anthers. (E) Mid-level of floral tube. (F) Uppermost level of ovary (above locules). (G) Mid-level of placenta. (H) Lower level of ovary. (I) Lowermost level of ovary locules and gynophore level. (J) Level of common bases of nectary and carpels. (K) Level of common bases of petals, filaments, nectary, and carpels. (L) Level of trace complexes of petals. (M) Lowermost level of floral base. Abbreviations: g, gynophore; p, petal; s, stamen; tca, main trace of calyx; ts+td, trace complex of stamen plus disc; td+tdc= trace complex of disc plus dorsal trace of carpel; tp, trace of petal. Scale bars: $(A)=1 \mathrm{~mm}(B-M)=500 \mu \mathrm{m}$. 

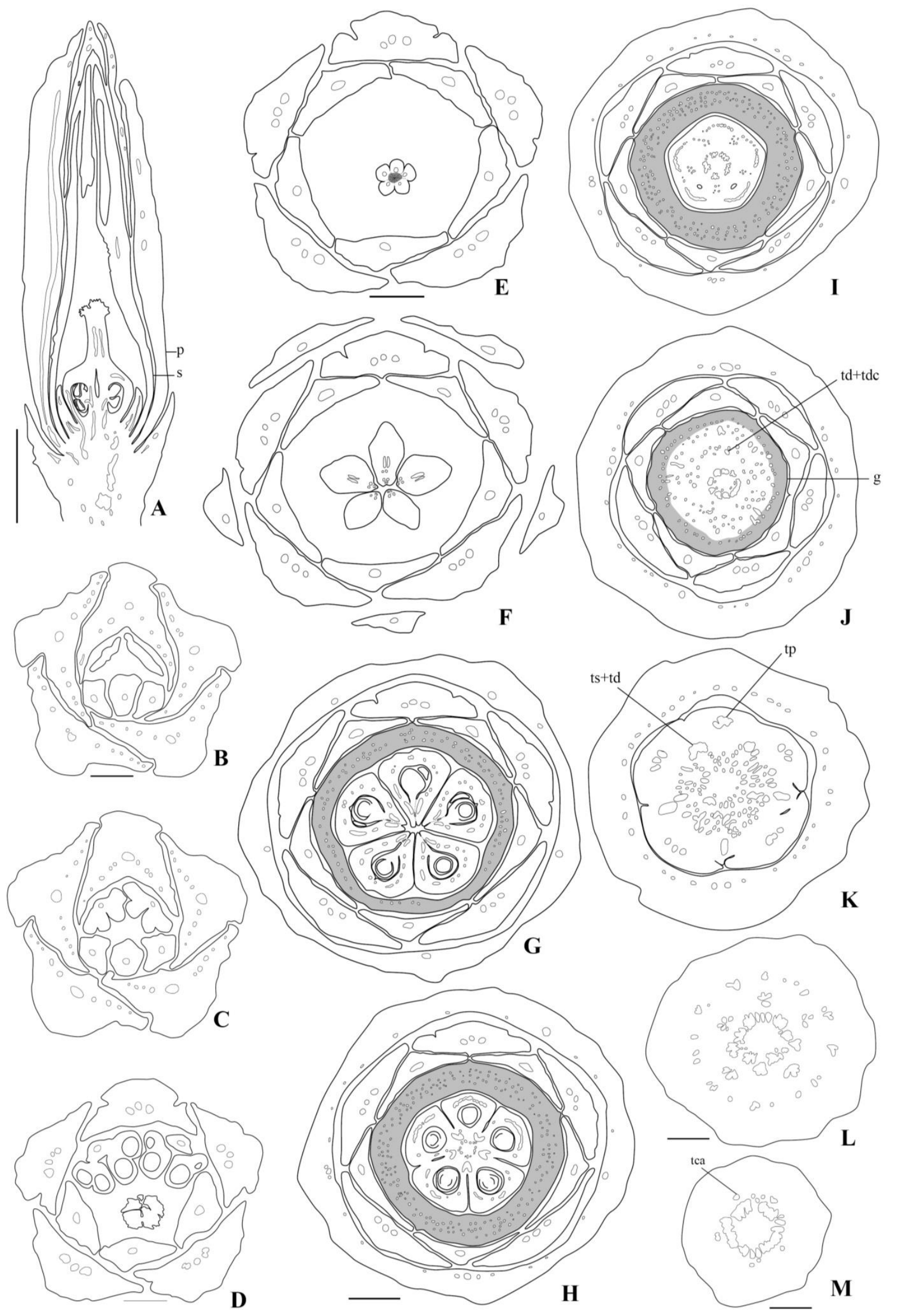

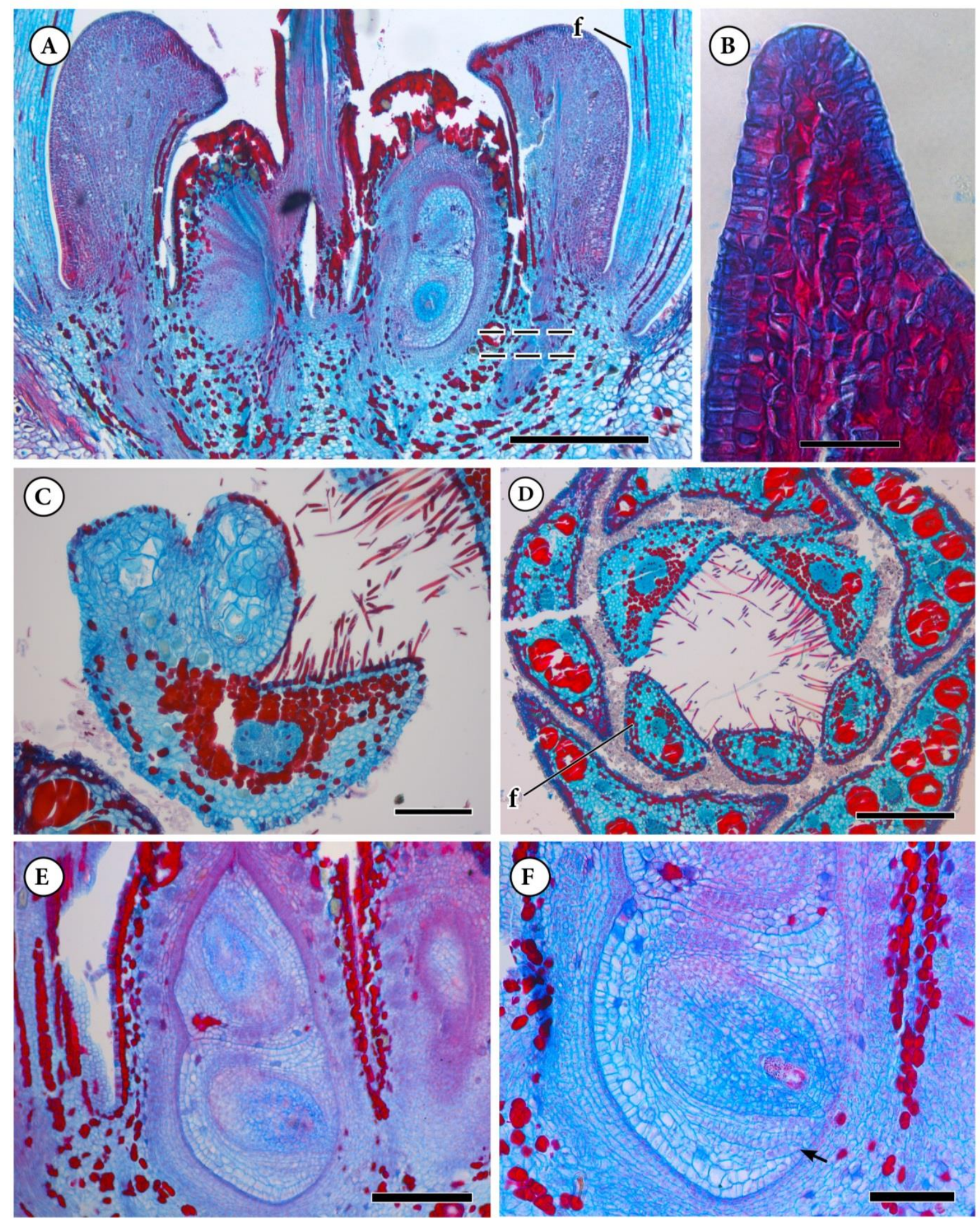

Figure 18: Photomicrographs of microtome sections of floral buds of Conchocarpus cyrtanthus. (A, B, E, F) Longisections. (C-D) Transections. (A) Base of floral bud, focusing on the median plane of carpels; hatched lines indicate approximately the short inferior region of the ovary (f, filament). (B) Detail of stigmatic surface. (C) Detail of the lowermost level one theca. (D) Upper level of filaments. (E) Detail of one carpel, with two superimposed ovules, the superior antitropous, the inferior syntropous. (F) Detail of the lower syntropous ovule (arrow indicate the inconspicuous inner integument). Scale bars: $(A, D)=500 \mu \mathrm{m} ;(B-C)=50 \mu \mathrm{m},(E)=200 \mu \mathrm{m},(F)=100 \mu \mathrm{m}$. 

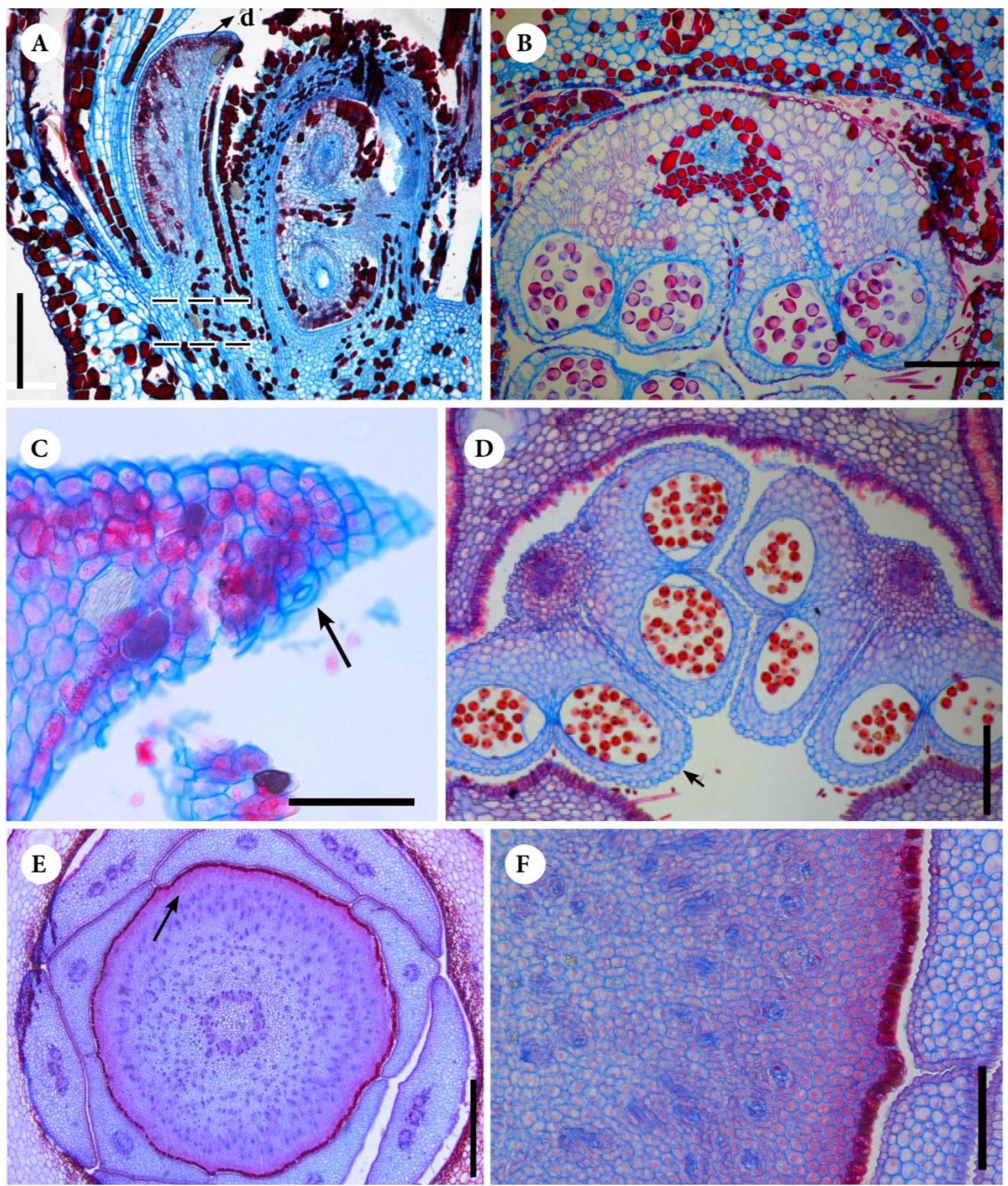

Figure 19: Photomicrographs of microtome sections of floral buds of Conchocarpus concinnus and C. odoratissimus. (A-C) C. concinnus. (A) Longisection, detail of the base of the flower, at median plane of one carpel; hatched lines indicate approximately the short inferior region of the ovary $(\mathrm{d}$, disc). (B-F) Transections. (B) Detail of one anther. (C) Detail of the upper region of the nectary disc, with one stomata (arrow). (D-F) C. odoratissimus. (D) Anthers; note the endothecium-like tissue on the connective side of thecae (arrow indicates papillate epidermis). (E) Level of common bases of carpels and nectary (arrow indicates nectariferous tissue). (F) Detail of the nectariferous tissue indicated in E. Scale bar: $(A-B, D)=200 \mu \mathrm{m} ;(C)=50 \mu \mathrm{m} ;(E)=500 \mu \mathrm{m} ;(F)=100 \mu \mathrm{m}$. 

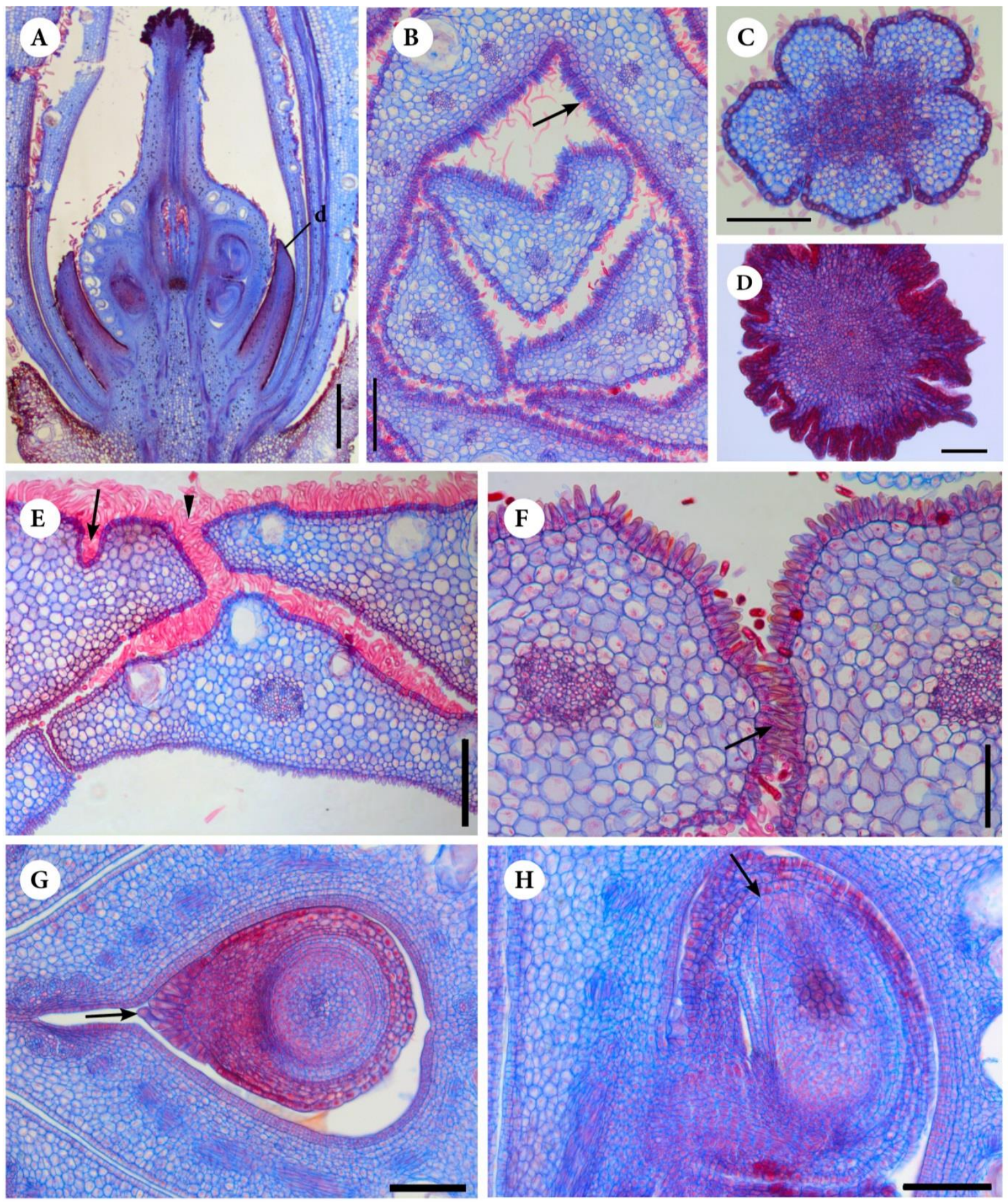

Figure 20: Photomicrographs of microtome sections of floral buds of Conchocarpus odoratissimus. (A, H) Longisections. (B-G) Transections. (A) Longitudinal sections of the base of floral bud, close to the median plane of carpels (d, disc). (B) Distal region of floral bud, at the apex of staminodes (triangular and flattened); arrow indicate papillate epidermis of petals. (C) Upper level of style, with central compitum. (D) Stigmatic region (note rugose surface). (E) Detail of the region of floral tube, showing the intertwining trichomes in petals and filaments (arrowhead indicate valvate petals, arrow indicate small clefts at the abaxial side of petal). (F) Detail at the upper level of two staminodes, postgenitally connected by interdigitated epidermal papillae (arrow). (G-H) Detail of one upper ovule. (G) Above the level of placenta, with trichomes on the funiculi (obturator, arrow). (H) Detail of the nucelus slightly protruded out of the inner integument (arrow). Scale bars: $(A)=500 \mu \mathrm{m} ;(B, E)=200$ $\mu \mathrm{m} ;(\mathrm{C}-\mathrm{D}, \mathrm{F}-\mathrm{H})=100 \mu \mathrm{m}$. 

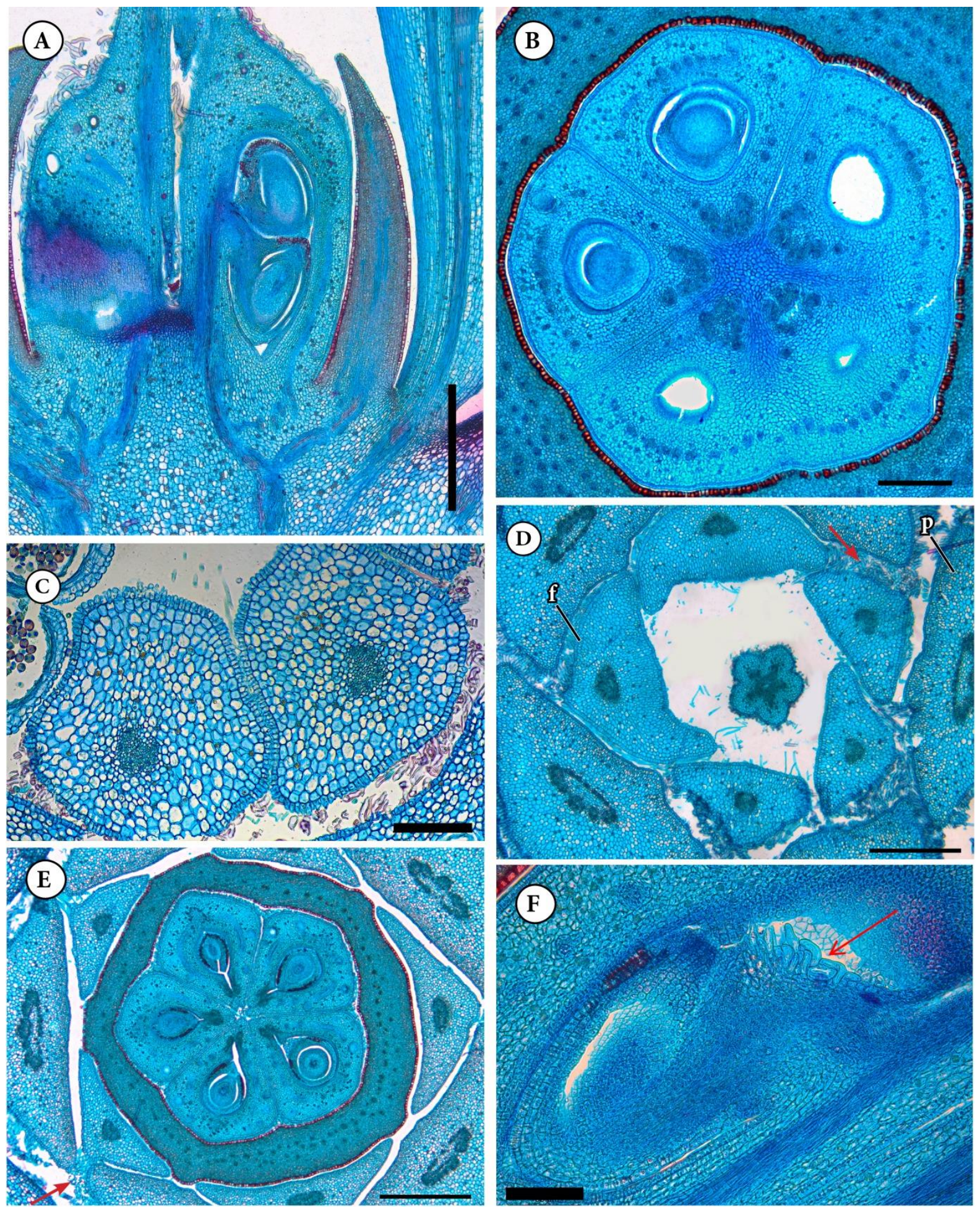

Figure 21: Photomicrographs of microtome sections of floral buds of Conchocarpus macrocarpus. (A, F) Longisections. (B- E) Transections. (A) Base of floral bud, focusing on the median plane of one carpel. (B) Lower level of ovary locules. (C) Detail of upper level of two staminodes, postgenitally connected by interdigitated epidermal papillae (arrow). (D) Mid-level of floral tube; arrow indicate intertwining trichomes (p, petal; s, fertile stamen). (E) Close to floral base, at mid-level of ovary and disc; arrow indicate valvate petals. (F) Detail of one ovule; note an obturator (arrow). Scale bars: (A, $\mathrm{E}, \mathrm{D})=500 \mu \mathrm{m} ;(\mathrm{C}, \mathrm{B})=200 \mu \mathrm{m} ;(\mathrm{F})=100 \mu \mathrm{m}$. 


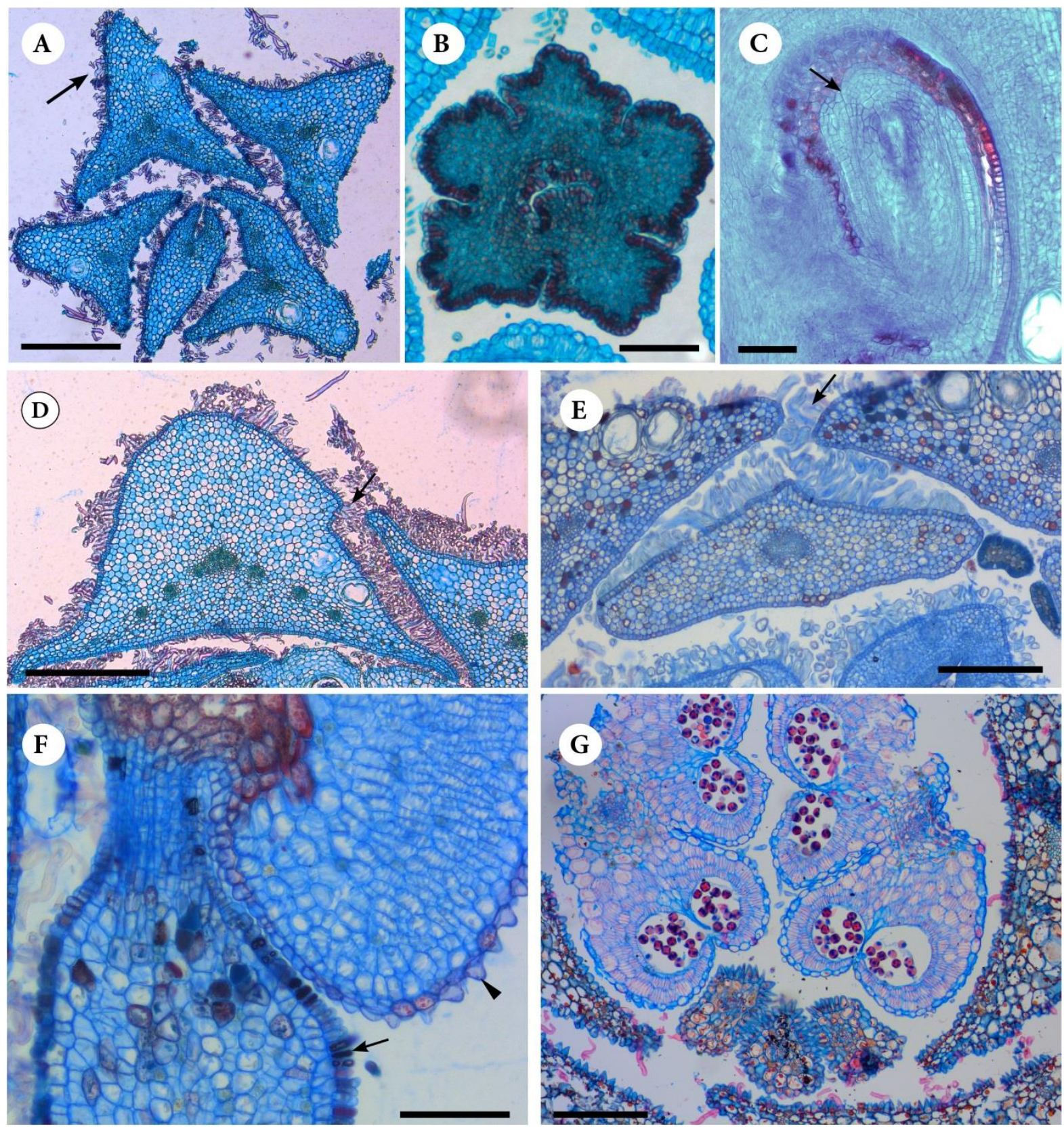

Figure 22: Photomicrographs of microtome sections of floral buds of Conchocarpus macrocarpus (A, B, D), C. obovatus (B, C, E, F) and C. mastigophorus (G). (A, B, D, E, G) Transections. (C, F) Longisections. (A) Upper level of petals, with an acute abaxial protuberance (arrow). (B) Detail of the stigmatic region. (C) Detail of one ovule (arrow showing the nucelus protusion beyond the inner integument). (D) Detail of one petal, with one small cleft below its abaxial protuberance, where the margin of one adjacent petal is postgenitally coherent by intertwining trichomes (arrow). (E) Detail of the region of floral tube, showing the intertwining trichomes in petals and filaments (arrow); note valvate petals; (F) Detail of one fertile stamen, showing papillae on the filament (arrow) and anther (arrowhead). $(\mathrm{G})$ Detail of androecium of $C$. mastigophorus. Scale bars: $(\mathrm{A}, \mathrm{D})=500 \mu \mathrm{m} ;(\mathrm{B}, \mathrm{C}, \mathrm{F})=$ $100 \mu \mathrm{m} ;(\mathrm{E}, \mathrm{G})=200 \mu \mathrm{m}$. 
Ertela (E. bahiensis and E. trifolia) (Figs 2C, D, 23-26)

Morphology and aspects of floral biology

Flowers of Ertela are monosymmetric, haplostemonous. Advanced floral buds are ca. $6 \mathrm{~mm}$ long. Floral buds are straight to slightly curved and the floral tube is straight. Sepals are leaf-like (green and similar to leaves in their texture), mostly free, congenitally connate shortly at base (Figs 2C, D, 23H-I). The sepal lobes have very unequal size and shape, with two larger outer sepals: the outermost lower sepal is larger than the other sepals and petals, followed by a large upper outer sepal, and three smaller sepals in between (Fig. 23B-H). Sepal lobes have open aestivation at their distal part, becoming valvate to quincuncial towards the floral base (Fig. 23C-H). In E. bahiensis, sepals, together with the cordiform bract of inflorescence, protect the inner floral organs in young buds, when petals are still underdeveloped (mostly the two larger sepals and the bract, Fig. 2C). Petals are thin (membranaceous), and the corolla is polysymmetric in E. bahiensis; monosymmetric in E. trifolia, since the five blades are unequally distributed, so that the uppermost petal lobe is slightly separated from the other four lobes. In the distal region of the floral bud, petals overlap each other (Figs 2C, D, 23A). Corolla aestivation is slightly oblique cochlear (Figs 2D, 23B-E). Below this free region, approximately from the upper third to the base, petals are congenitally connated and form the floral tube (Fig. 23B-G). In young stages, petals arise and develop initially free (Fig. 25 H, I). Only later their basal fusion begin, when the lobes are already developed (Fig. 26E, F). The androecium is monosymmetric, with two fertile stamens and three staminodes (Fig. 23C). The fertile stamens are located on the posterior side of the flower and are adjacent to the innermost petal. Filaments of fertile stamens and staminodes are rounded to dorsiventrally flattened with irregular shape. Filaments are constricted at their tips, and conspicuously wider below (at the upper part of the floral tube), narrowing gradually towards the base. The staminodes are also wider approximately at the same corresponding level (Fig. 26G-K). The staminodes are narrower than the filaments of fertile stamens, as seen in transections (Fig. 23C-G). All filaments and staminodes are free in E.bahiensis, shorlty adnate to petals only close to the floral base (Fig. 23C-H). Differently, E. trifolia has the tips of fertile filament and the base of anther congenitally fused laterally. Staminodes are free and slighlty adherent to petals (Fig. 26C, D, G). Anthers are small (ca. 0.6 $\mathrm{mm}$ long), basifixed, sagittate, introrse. They have a very thin connective and an endothecium-like tissue is present on the connective side of thecae, also continuous with the endothecium on part of the dorsal side of the connective, arranged as a palissade-like layer of cells (Fig. 24B). Between the two thecae of an anther there is one ventral furrow (Fig. 24C). There is an intrastaminal nectary disc, which elongates only at one side of the flower, forming 
a unilateral (monosymmetric) disc, which encompasses the ovary along its entire lenght but only at the opposite side of staminodes (Figs 23A, F-H, 24D, 25A, F). Carpels are bulged up dorsally above the level of the base of the style, so that the style appears sunken into it (carpels anacrostylous, Figs 23F, 25A, F, 26B). The stigma is inconspicuously five-lobed. It is capitate (only in E. trifolia), covered with short papillae. Differently, the stigmatic region in $E$. bahiensis is covered by unicellular piriform trichomes which also cover most of the style, but are shorter in this latter region (Figs 24F, 25A, B, C, 26A). The style is completely postgenitally fused, except at base where carpels are not fused at the centre, forming a furrow (Fig. 23F). Immediately below, at the uppermost level of ovary (above locules level), carpels are completely free. This free zone extends down the base of the locules, where these become congenitally fused only at center (Fig. 23F-H). The placentation is marginal (Fig. 23G). Ovules are epitropous, and the outer integument is thicker than the inner. An obturator made of unicellular papillae is present on the placenta (Fig. 24D, E).

The main color of the perianth at anthesis is white. Scent was not noticed during field work, during daytime. After anthesis, the tips of the staminodes are slightly exserted while the anthers are placed at the mouth of the corolla tube in E. trifolia. Differently, in E. bahiensis, the tip of the staminodes and anthers are placed at the distal end of the corolla tube (Fig. $2 \mathrm{C}$, D). Even though we were able to analyse only a few flowers, they all showed stigmas recessed below the anthers, and so it is likely that this species present reversal-herkogamy.

\section{Anatomy}

Sepals have one main vascular bundle and may have up to five lateral bundles (in the larger sepal). At floral base, sepals have approximately ten traces. Petals have one to four lateral vascular bundles at their distal free parts (Fig. B). Lower down, petals have one vascular bundle and a single vascular trace (Fig. 23C-J). Stamens possess one vascular bundle and a single vascular trace (Fig. 23J-I). The nectary disc has small phloematic bundles, and at the floral base these merge forming larger disc traces, which are opposite and in an outer level to the carpel traces (Fig. 23I). Carpels have a reduced vascular system. It is composed by only two median dorsal bundles at the ovary level (which merge into one lower down), and no additional lateral bundles is present; only two main lateral bundles are present in the ovary, which merge into one ventral, near to the floral base (Fig. $23 \mathrm{G}-\mathrm{H}$ ). At floral base, the dorsal traces of carpels merge with the ventral traces, forming a central vascular complex (Fig. 23DI). Lower down, disc traces merge with the stamen traces opposite to them and converge to the central vasculature (Fig. 23J). Then the petal traces merge with the central vasculature, 
followed by the calyx traces (apparently the calyx traces of the largest sepal merge at the lowermost level of the floral base), forming the vasculature of the pedicel (Fig. 23K-L).

\section{Histology}

Lignified and non-lignified unicellular to tricellular uniseriate trichomes are present on the calyx, upper part of petals and filaments. In the staminodes of E. trifolia they are denser in their middle region. In E. bahiensis a tuft of hairs is present laterally below the constricted tips of fertile filaments and also at the corresponding level of staminodes (were these are enlarged; Fig. 26G-K). Short lignified unicelullar hairs are present on thecae close to the stomium (Figs 24B, 26I). Multicellular glandular trichomes, hook-shaped, are present on the surface of sepals, petals and ovary (Figs 24G, 25G). Unicellular piriform trichomes cover the stigmatic region and most of the style (Figs 24F, 25D). Unicelullar papillae are present at the upper adaxial side of petals. Tanniferous tissue is present in the connective of anthers and in the outer integument (Fig. 24B, D). Secretory cavities are present in the upper region of petals, in sepals and ovary. Small unicellular papillae are present on the upper adaxial side of petals. The mesophyll of sepals has large intercellular spaces (Fig. 24H) in the upper part. In petals, this tissue is also present but with larger intercellular spaces (eventually forming armlike outgrowths), and along most of their lenght (Fig. 24A). Druses are observed in the disc and styloids crystals are present in sepals, petals and in the floral base (Fig. 24D, I). Small stomata are seen on the upper part of the nectary. 
Figure 23: Ertela bahiensis. Sections of floral buds. (A) Longisection of a young bud. (B-L) Transections of an advanced bud: successive levels, from the top, downward. Morphological surface indicated by thicker continuous lines, vasculature by thinner continuous lines; postgenitally fused areas indicated by broken line; nectariferous tissue, light gray (in the longitudinal section, only morphological surfaces and vascularization are represented). (B) Distal region of the corolla. (C) Upper level of anthers and staminodes. (D) Upper level of fertile filaments. (E) Level of the style. (F) Level of the base of style and uppermost level of ovary. (G) Mid-level of ovary. (H) Lower level of ovary. (I) Level of disc traces and stamen traces. (J) Level of trace complex of stamen plus disc traces. (K) Lower level of floral base, only with petals and calyx traces. (L) Lowermost level of floral base, laterally fused to the pedicels of two adjacent flowers of the inflorescence. Abbreviations: ca, calyx; d, disc; p, petal; pv, pedicel vasculature; s, stamen; st, staminode; tc, dorsal trace of carpel; ste, style; tc, dorsal trace of carpel; tca, trace of sepals; td, trace of disc; tp, trace of petal; ts, trace of stamen; ts $+d$, trace complex of stamen plus disc. Scale bars: $(A)=1 \mathrm{~mm} ;(B-I, J, L)=500 \mu \mathrm{m} ;(K)=250 \mu \mathrm{m}$. 


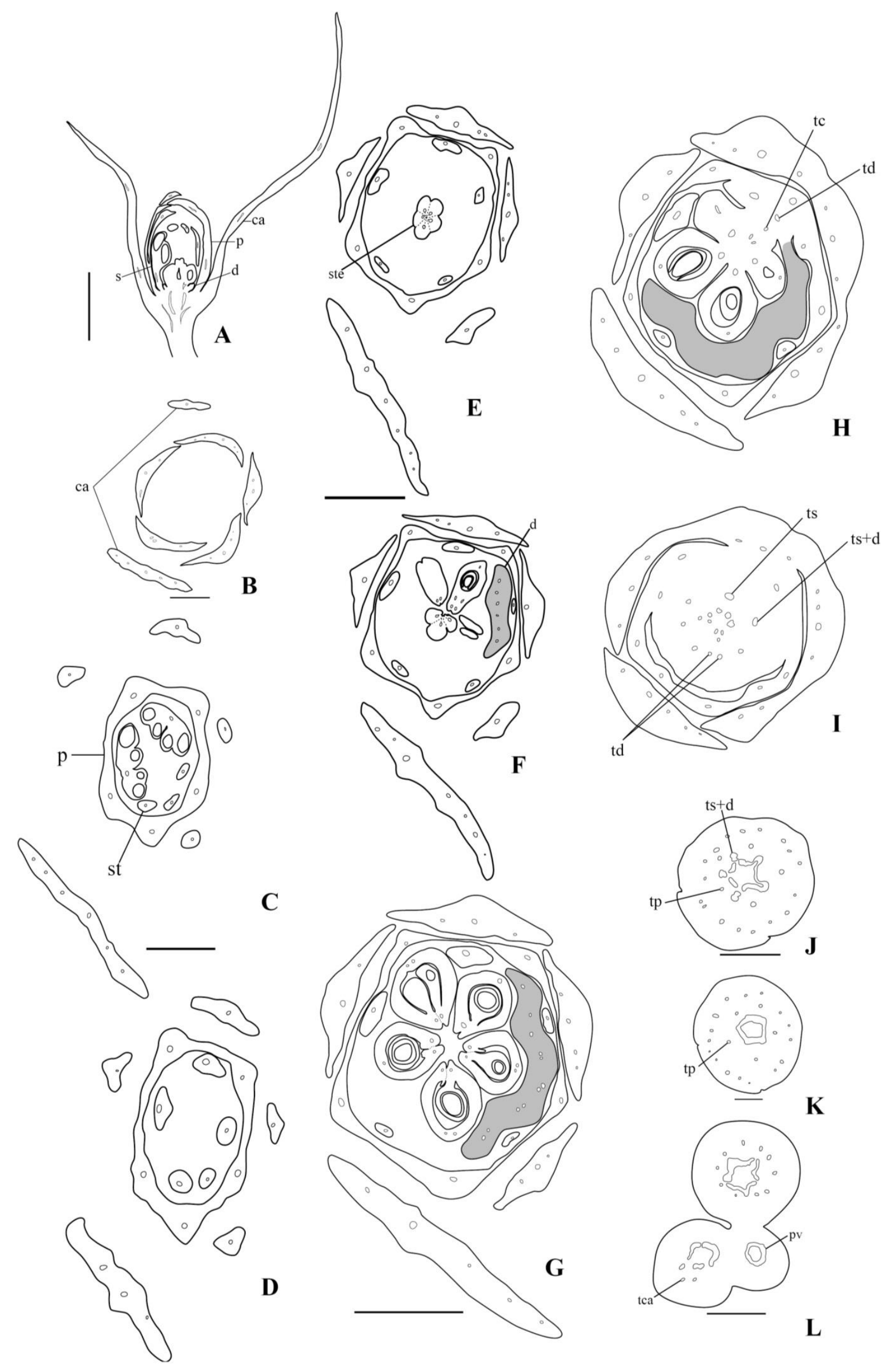



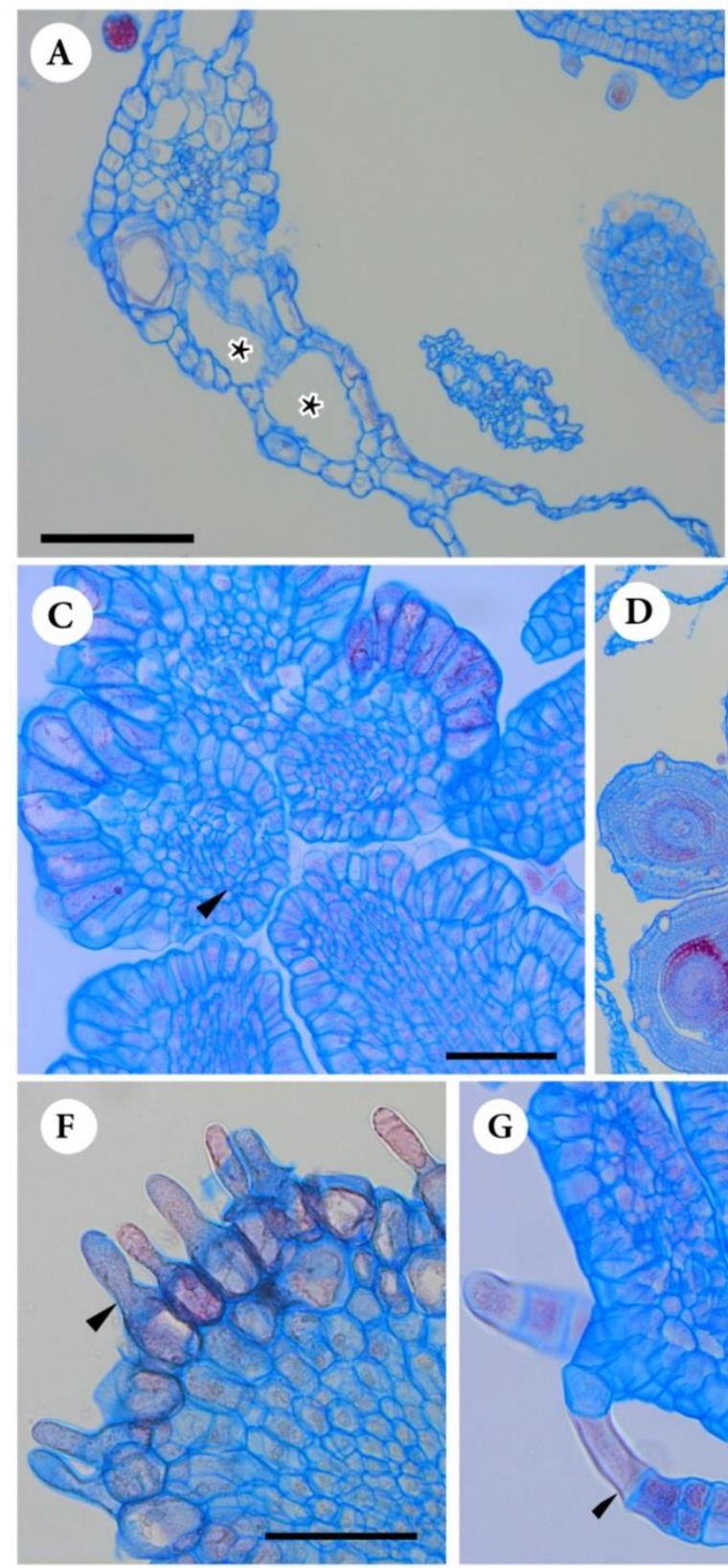
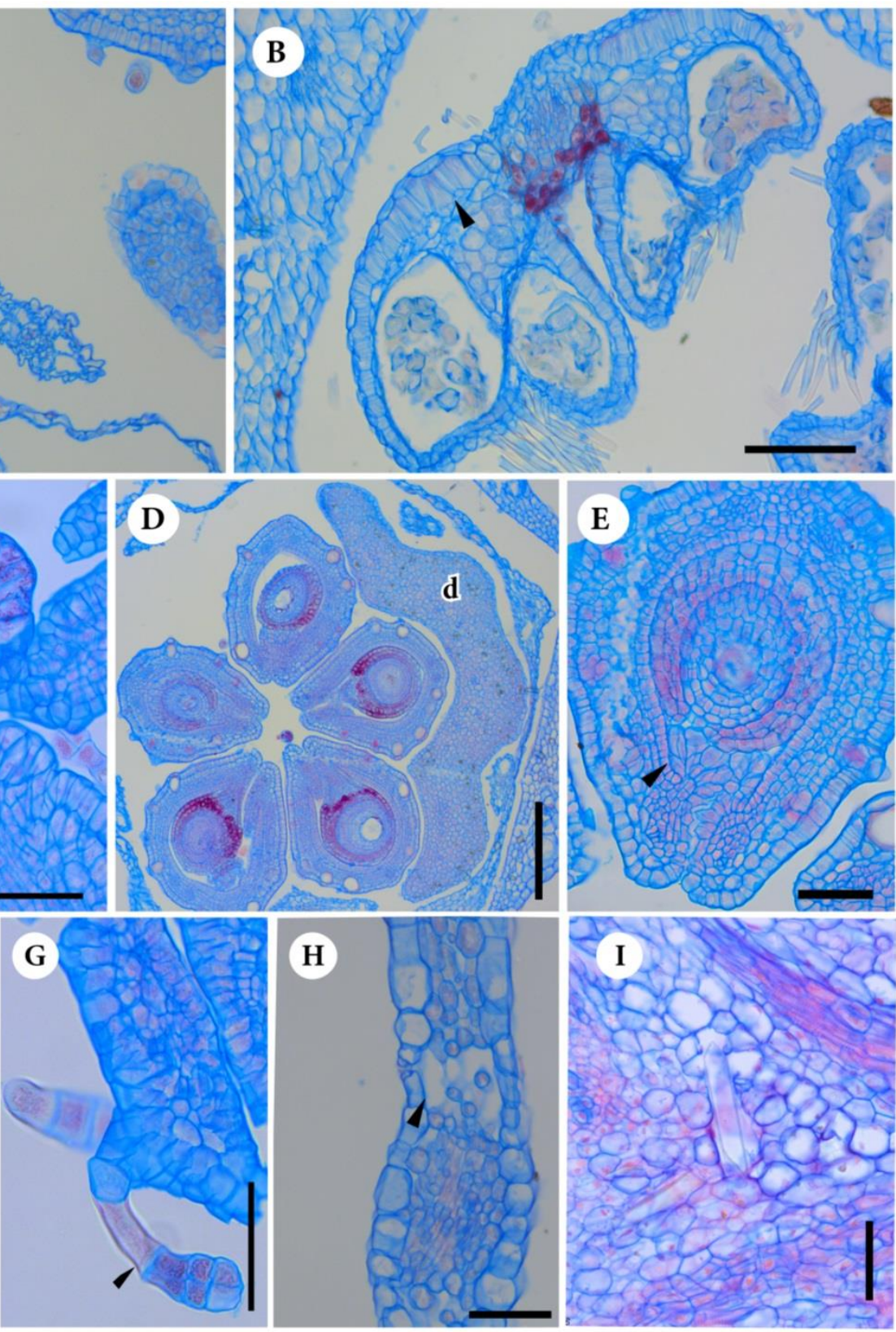

Figure 24: Photomicrographs of microtome transections of floral buds of Ertela bahiensis. (A) Detail of the corolla tube; note the mesophyll with large intercellular spaces (asterisks). (B) Anther, showing the endothecium-like tissue continuous over part of the dorsal side of the connective, as palissade-like layer of cells (arrowhead). (C) Detail of the base of the style, showing the pollen tube transmitting tract (arrowhead). (D) Mid-level of ovary and unilateral disc. (E) Detail of one ovary in D, showing ovule and the obturator (arrowhead). (F) Detail of piriform trichomes on the stigmatic region. (G) Detail of the uppermost part of the ovary, showing one multicellular glandular trichome, hook-shaped. (H) Detail of one sepal, showing large intercellular spaces in the mesophyll. (I) Detail of styloids crystals in the floral base. Scale bars: $(A, B, H)=100 \mu \mathrm{m} ;(C, E-G, I)=50 \mu \mathrm{m} ;(D)=200 \mu \mathrm{m}$. 

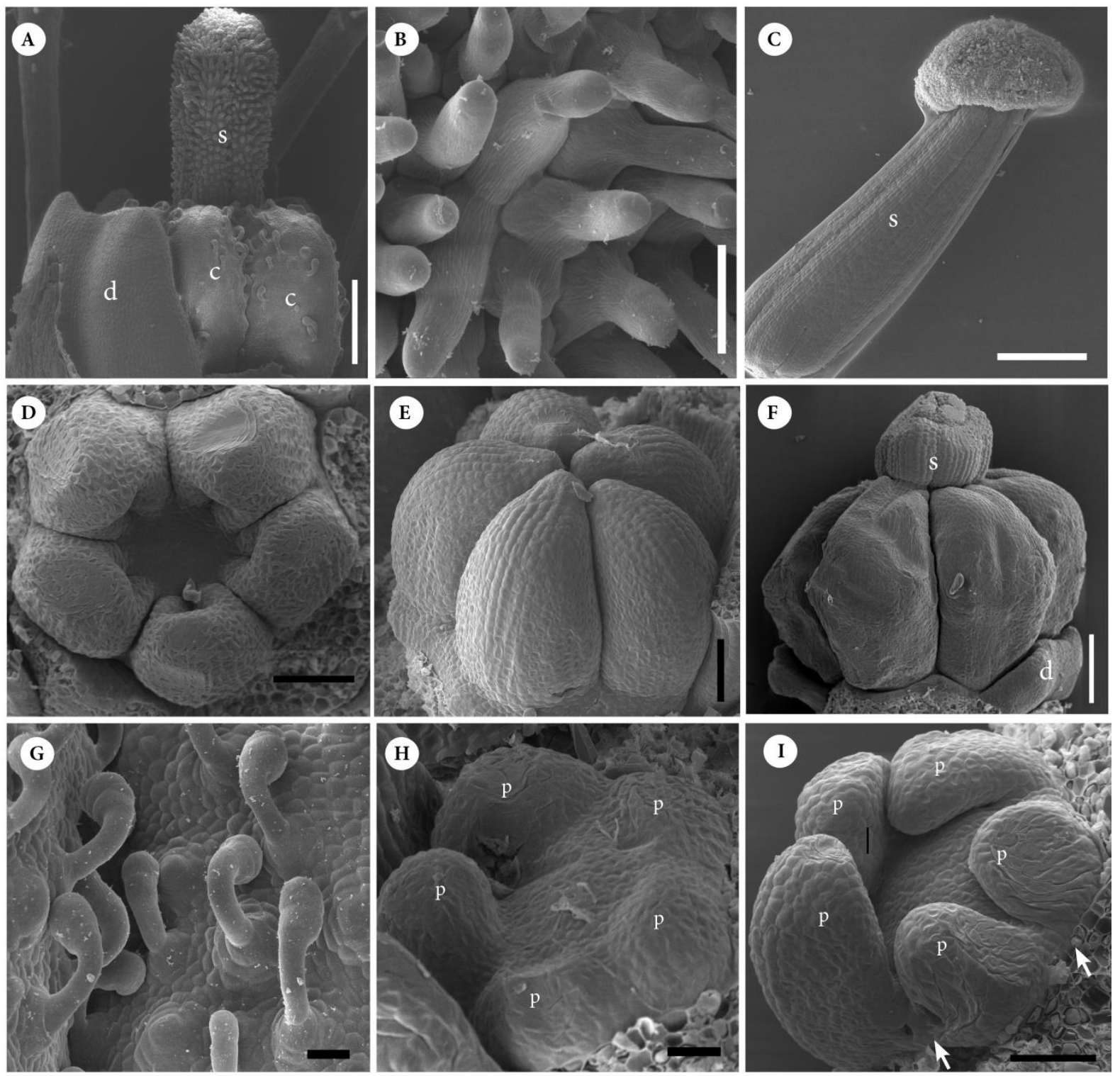

Figure 25: SEM micrographs of Ertela bahiensis (A, B, D-I) and E. trifolia (C). (A) Mature gynoecium (c, carpel; s, style) and unilateral disc (d, from de side). (B) Detail of the stigmatic region, with piriform trichomes. (C) Mature style and stigma of E. trifolia. (D-F) Young carpels. (D) From above. (E) Later stage than D, carpels elongating. (F) Style elongating (s) and young disc (d). (G) Detail of the surface of the ovary, with glandular hook-shaped trichomes. (H-I) Young petals (p), with initially five independent primordial $(\mathrm{H})$, latter becoming congenitally fused at base (I, arrows). Scale bars: $(\mathrm{A}, \mathrm{C})=200 \mu \mathrm{m} ;(\mathrm{B}, \mathrm{G}, \mathrm{H})=20 \mu \mathrm{m} ;(\mathrm{D}, \mathrm{E}, \mathrm{I})=50 \mu \mathrm{m} ;(\mathrm{F})=100 \mu \mathrm{m}$. 

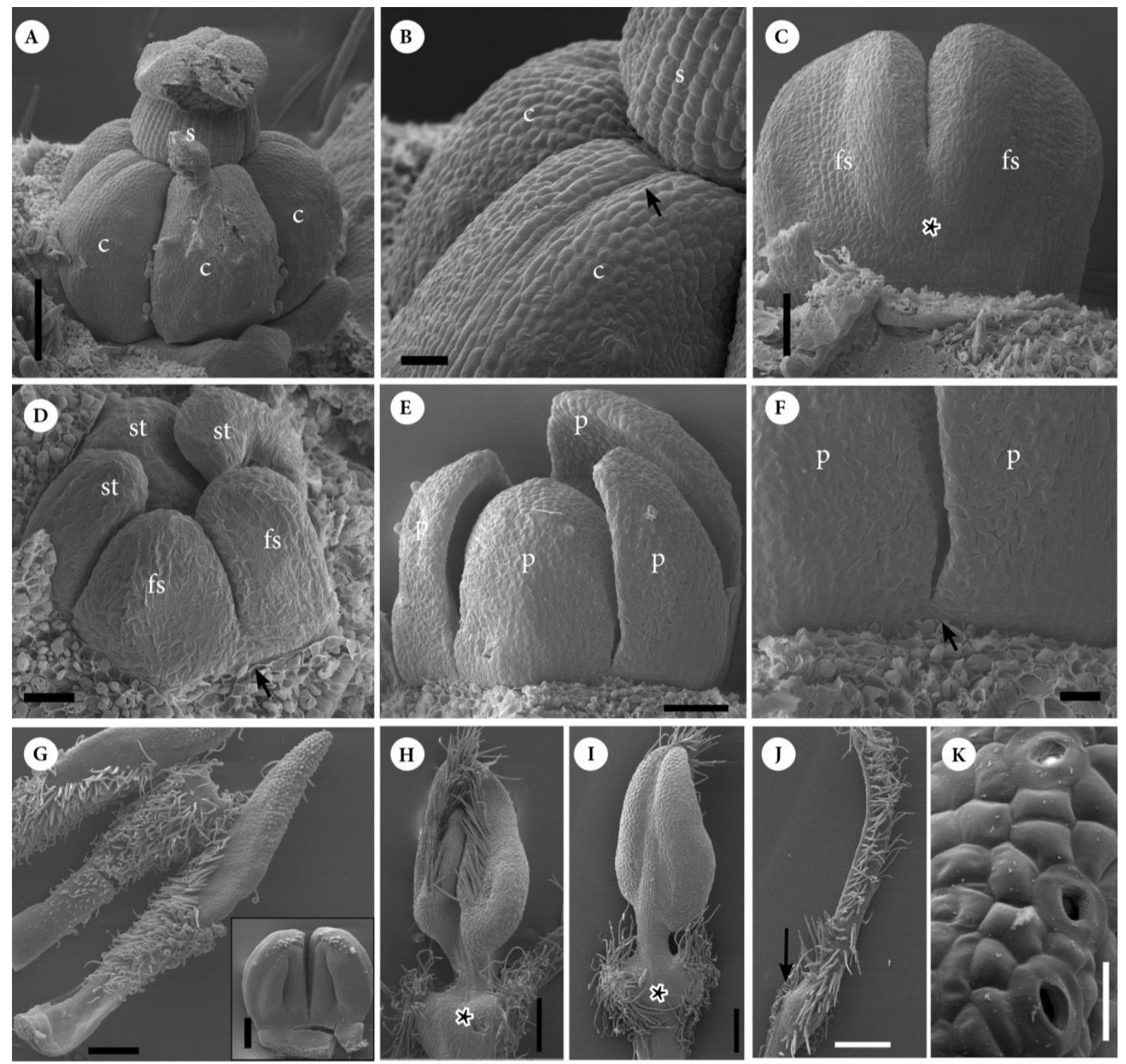

Figure 26: SEM micrographs of Ertela trifolia (A-H) and E. bahiensis (I-K). (A) Young carpel (c), with style (s) elongating and stigma differenting. (B) Detail of the dorsal upper part of ovary, with a narrow furrow close to the base of style (arrow). (C) Detail of two young fertile stamens (fs) congenitally fused at base (asterisk). (D) Younger stage than C, androecium with two fertile stamens fused at base (arrow) and three staminodes (st). (E) Young petals (p), from the side. (F) Detail of petal bases, shortly fused (arrow). (G) Androecium of E. trifoliata, with three dorsiventrally flattened staminodes and two young fertile stamens (inset). (H-J) Androecium of E. bahiensis. Fertile stamen, from the ventral $(\mathrm{H})$ and dorsal side (I, asterisk indicate the thicker zone of filament). (J) Detail of the ventral side of one staminode (upper half), with a conspicuously thicker zone (arrow). (K) Stomata at the upper part of the disc of E. bahiensis. Scale bars: $(A)=100 \mu \mathrm{m} ;(B, D, F, K)=20 \mu \mathrm{m} ;(C, E)=50$ $\mu \mathrm{m} ;(\mathrm{H}, \mathrm{I}, \mathrm{J})=200 \mu \mathrm{m} ;(\mathrm{G})=200 \mu \mathrm{m}$, inset $=100 \mu \mathrm{m}$. 


\section{Neoraputia (N. trifoliata and N. alba) (Figs 2E, F, 27-30)}

\section{Morphology and aspects of floral biology}

The flowers of these two species are monosymmetric. The flower buds are ca. $25 \mathrm{~mm}$ long in N. trifoliata, and ca. $28 \mathrm{~mm}$ in $N$. alba. The floral bud is slightly curved, and the floral tube is short and straight. Sepals are cupular, congenitally fused in most of their lenght, but at their upper part there are five short triangular lobes with open aestivation in advanced buds (Figs 2E, F, 27G-J). Petals are stiff and form five spreading reflexed blades at their distal region during anthesis. The corolla is monosymmetric since the five blades are unequally distributed, so that the uppermost petal lobe is slightly separated from the other four lobes (the two lateral petals and the two abaxial ones). Below this region, approximately from mid-level down to their base, petals form the floral tube together with filaments, through the coherence of petals and adherence of filaments to petals by intertwining trichomes (Fig. 28A). In the distal region of the floral bud, petals overlap each other (Fig. 27B). Corolla aestivation is ascending to slightly oblique cochlear along most of its length. At base the aestivation becomes valvate to open (Fig. 27C-I). Petals are slightly thicker toward the middle region and distally, as seen in transections, becoming thinner and flattened towards the base (Fig. 27F-I). The androecium is monossymmetric. In some of the flowers studied the androecium is haplostemonous with two fertile stamens and three antesepalous staminodes (Fig. 27D).Other flowers may have two fertile stamens and five staminodes, three antesepalous, plus two antepetalous (Fig. 2F). The anthers are located on the posterior side of the flower and are adjacent to the innermost petal. Filaments are free along the entire length, but postgenitally adherent to petals in the floral tube region. The staminodes are somewhat rounded to triangular-shaped in the distal region (Fig. 29B, G); they have an irregular shape bellow, dorsoventrally flattened. At the floral tube region, they gradually become wider and larger, precisely alternating with petals. Close to the floral base, they are narrower and have the shape of somewhat flattened triangles. The filaments of fertile stamens are constricted at their tips, and are wider immediatell below with similar shape, but larger than staminodes (Figs 27C-I, 29C, D). Anthers are large (ca. 4 mm), near-basal dorsifixed (Fig. 30I). They have short sterile basal appendages, which correspond to the prolongation of the thecae bases. In $N$. trifoliata these represent two prolongations, from each theca (Fig. 27E), while in N. alba, they represent only one single prolongation from both thecae (Fig. 29C, D). In N. trifoliata, anther bases and their basal appendages are postgenitally connected by interdigitation of epidermal and subepidermal cells (Figs 27D-E, 28B, C, 30I). Anthers are sagittate, introrse, caducous (only observed for $N$. trifoliata). They have a thin connective, and endothecium-like tissue is continuous over the entire dorsal side of the connective (one to few layers; Fig. 28D, 
29G). Between two thecae of an anther there is a deep ventral furrow along most of the length; a shallow dorsal furrow is present at the base of thecae (Fig. 27D). There is an intrastaminal nectariferous cupular disc, which encompasses the entire ovary. It is thicker at the base, where it has five ridges in the free space in front of petals (Fig. 27A, I). Carpels are abruptly bulged up on the dorsal side above the level of the base of the style, so that the style appears sunken into it for ca. one-fifth to one-quarter of the ovary length (carpels anacrostylous). The upper dorsal wall are markedly thickened in the bulging region (Figs 27A, 28G, 29H). The five-lobed stigma is postgenitally fused, forming a stigmatic plate; the lobes are unequal in size so that all face the anterior side of the flower in bud (Figs 27D, 30G, H). The stigma surface is non-papillose, smooth (Fig. 28E). There is a small slit at its center, which closes just at the transition level to the style. The style is completly postgenitally fused, solid along its entire lenght (Figs 27 E, F, 29E, F). At the upper level of ovary, carpels are postgenitally fused at the center for a very short extent (Fig. 28G); from this level to the level of the gynophore, only the description of $N$. trifoliata could be presented, since this part of the serial transections of $N$. alba were lost. Immediatelly below, carpels are completely free (Fig. 27A, H). This apocarpous zone extends until approximately mid-level of the locules, where first the two anterior carpels became congenitally fused at the flanks, and lower down also at the center., The three posterior carpels become united first at the centre, and then lower down by its flanks. Thus there is a slight monosymmetry in the gynoecium, so that the two posterior carpels are slightly smaller than anterior ones. Also there is a difference in the extension of fusion between their parts. The style and stigma slightly facing the anterior side of the flower also contribute to this monosymmetry (Figs 27 I, 30F). The placentation is marginal and axile (Fig. 27H, I). Ovules are antitropous. The outer integument is thicker than the inner one and an obturator made of papillae appears to be present on the placenta (Figs 27A, I, 28F, G). Below the locules, carpels stand on a short gynophore, which is narrower than the base of the locules (Figs 27A, J, 28G, 29H, 30A). In N. alba, the nectary appears to have a common base with filaments, as seen in longisection (Fig. 29H).

The main colour of the perianth of both species at anthesis is cream to white. In $N$. trifoliata, the flowers appear to be herkogamous since in recently opened flowers the anthers are located at the mouth of the floral tube.Later on, the filaments of fertile stamens curve backwards and the anthers drop off (Fig. 2F). In N. alba the anthers and stigma are seen exserted from the floral tube, but filaments are longer than the style and stigma, thus the flower also appears herkogamous (Fig. 2E). Floral odour is strongly sweet-scented in $N$. trifoliata and garlic-scented in N. alba. Flowers with such contrasting scents may indicate 
strongly distinct pollinators for each species. Floral attributes of $N$. alba, indicate chiropterophily, such as the large, dull colored, tubular flower, with strong unpleasant scent, probably containing sulphur compounds; see Fleming et al., 2009).

\section{Anatomy}

Sepals have one small main vascular bundle and two or three small lateral bundles in the region of the lobes. At the congenitally fused region, sepals may have additionally up to 27 lateral bundles (25 in N. trifoliata). At floral base, sepals have five main traces and five synlateral traces (Fig. 27G- L). Petals may have one to five main vascular bundles (one to three in N. trifoliata) and up to 15 lateral bundles (up to 12 in N. trifoliata). At the floral base, petals have two or three vascular traces, which merge with disc traces, forming five large trace complexes (Fig. 27B-L). Stamens possess one vascular bundle at the distal part. Lower down, staminodes may have additionally one to two small lateral bundles (in the region where these have triangular to irregular shape, Fig. 29B).In N. alba, filaments of fertile stamens may have two to four additional lateral bundles (along most of their length, where these are wider and flattened, Fig. 29A). Lower down, these merge, decreasing in number, and form one vascular trace at floral base. The nectary disc has numerous small vascular bundles along most of its length. At the floral base, these merge and form a broad band of vascular bundles, spliting below into numerous disc traces, radially arranged in front of stamen traces and the petal (Fig. 27G-K). In each carpel, five narrow bands of lateral vascular bundles differentiate in the lower level of the stigmatic region in N. trifoliata, becoming smaller toward the base of the style (Fig. 27E). At the gynophore level, the five ventral bundles of carpels converge toward the center of the gynoecium, forming a five-angled, star-shaped vascular complex. The dorsal bundles of carpels converge to the central vasculature. The stamen traces then merge with some of the disc traces, and converge to the central complex. The petals traces also merge with other disc traces, and these complexes merge to the central vasculature lower down. These are followed by the sepal traces, forming then a stele (Fig. 27J-M).

\section{Histology}

Short unicellular lignified hairs are present on the calyx. Longer lignified hairs are present on the upper part of the ovary (only in N. trifoliata) and on both sides of petals and stamens, which are denser and intertwine at the postgenitally coherent and adherent regions of the floral tube (Fig. 28A). Long non-lignified trichomes are present on the upper half of filaments and on top of the ovary, which appears to be covered by a densely blue to redstained secretion (this may be an artifact, only seen in N. alba, Fig. 29H). Tanniferous cells are dispersed through all floral organs, especially on top of the ovary of $N$. alba. Extensive 
tanniferous tissue is present at the lower level of petals and filaments, also in the entire calyx, gynophore, epidermis of the disc, and around the vascular bundle in the connective region (Fig. 28A, G, D). Blue-stained secretion cells (probably mucilage) are present in the calyx, petals, filaments, and connective region of anthers, as well as in some cells in the epidermis of the disc (Fig. 29A, E, F). Secretory cavities are present in sepals, petals, stamens and carpels (more numerous at the top of the ovary in N. alba, Fig. 29H). Raphides where observed in the ovary and anthers of $N$. trifoliata. No crystal idioblasts were observed in N. alba. Some small stomata are seen on the nectary. The stigma surface is non-papillose, smooth, covered by columnar cells (Fig. 28E).

Figure 27: Neoraputia trifoliata. Sections of floral buds. (A) Longisection. (B-M) Transections: successive levels, from the top, downward. Morphological surface indicated by thicker continuous lines, vasculature by thinner continuous lines; postgenitally fused areas indicated by broken lines; pollen tube transmitting tissue (PTTT), dark grey; nectariferous tissue, light gray (in the longitudinal section, only morphological surfaces and vascularization are represented). (B) Distal level of petals. (C) Upper level of anthers. (D) Lower half of anthers and stigma level. (E) Level of sterile basal appendages of thecae (just below their attachment to filament), and uppermost level of style. (F) Midlevel of style. (G) Base of the style, and carpels dorsally bulged up at the level of the ovary (H) Midlevel of ovary. (I) Lower level of ovary. (J) Level of the gynophore. (K-M) Floral base. (K) Level of trace complexes of stamen plus disc. (L) Level of trace complexes of petals plus disc. (M) Pedicel vasculature. Abbreviations: ba, sterile base of theca; d, disc; f, filament; g, gynophore; p, petal; ste, style; tcm, main trace of sepal; tcl, synlateral trace of sepal; tp+td, trace complex of petal plus disc, ts, trace of stamen; ts $+\mathrm{td}$, trace complex of stamen plus disc. Scale bars: (A) $=2 \mathrm{~mm}$; (B- L) $500 \mu \mathrm{m}$; $(\mathrm{M})=1 \mathrm{~mm}$. 


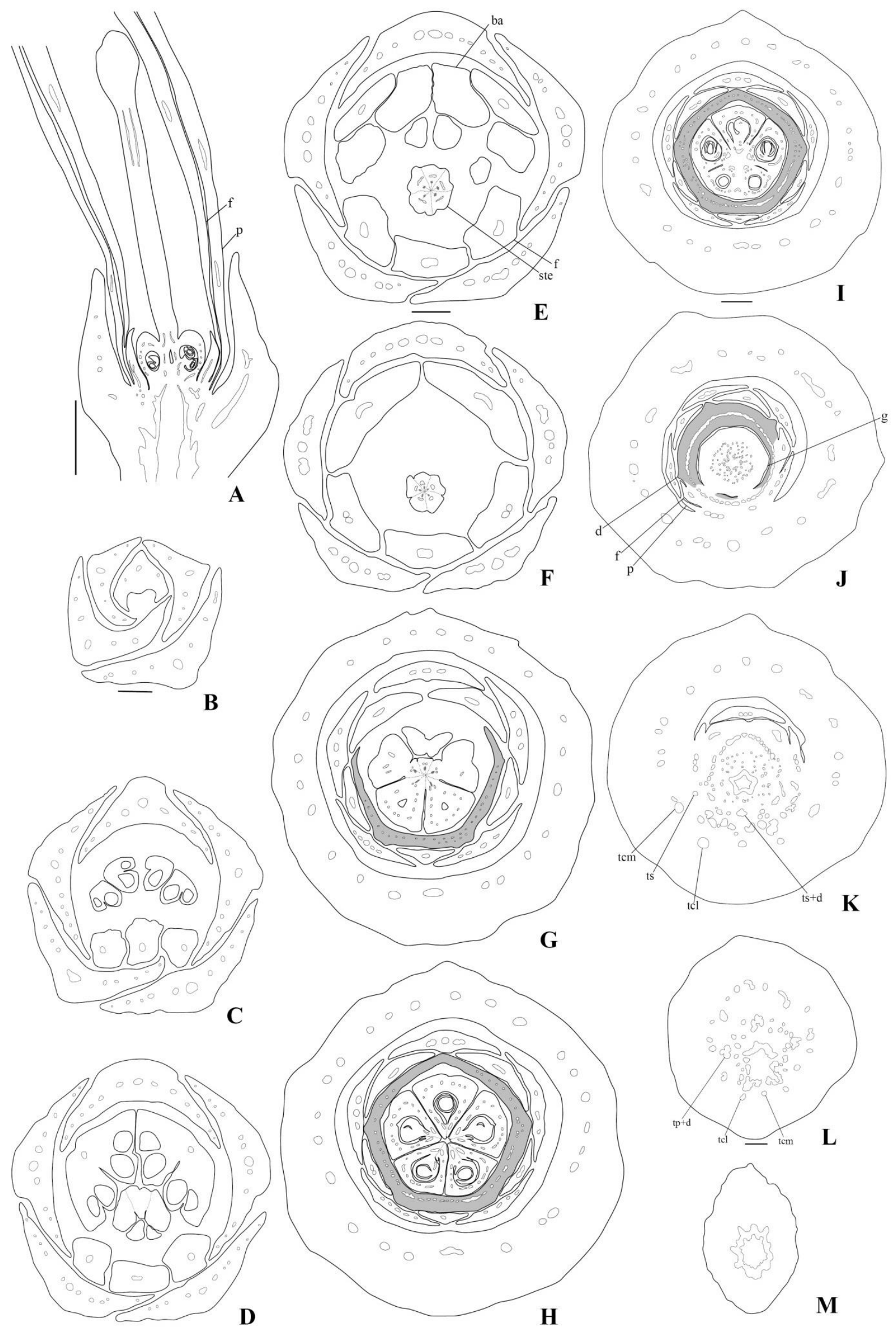




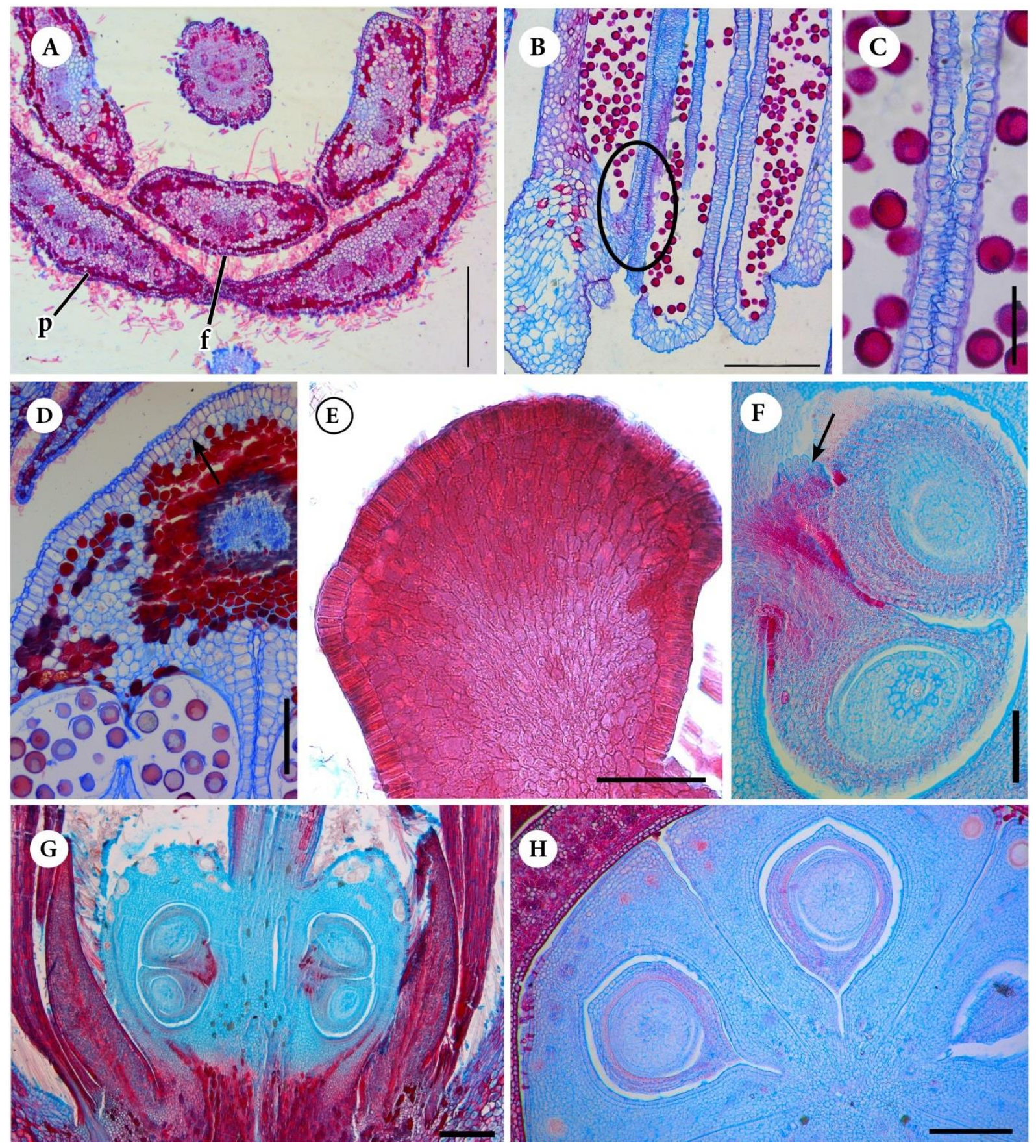

Figure 28: Photomicrographs of microtome sections of floral buds of Neoraputia trifoliata. (A, H) Transections. (B-G) Longisections. (A) Mid-level of floral tube (p, petal; s, stamen). (B) Detail of two anthers laterally postgenitally connected at base (encircled). (C) Detail of the region encircled in B. (D) Detail of one anther, showing the endothecium-like tissue (arrow) over the dorsal side of the connective. (E) Detail of one stigmatic lobe. (F) Detail of one carpel, showing two ovules (arrow indicate papillae on the placenta). (G) Base of floral bud, focusing on the median plane of carpels. $(\mathrm{H})$ Upper level of ovary, showing carpels postgenitally fused at centre. Scale bars: $(A, B)=500 \mu \mathrm{m} ;(\mathrm{C}$, $\mathrm{E}, \mathrm{F})=100 \mu \mathrm{m} ;(\mathrm{D}, \mathrm{G}, \mathrm{H})=200 \mu \mathrm{m}$. 

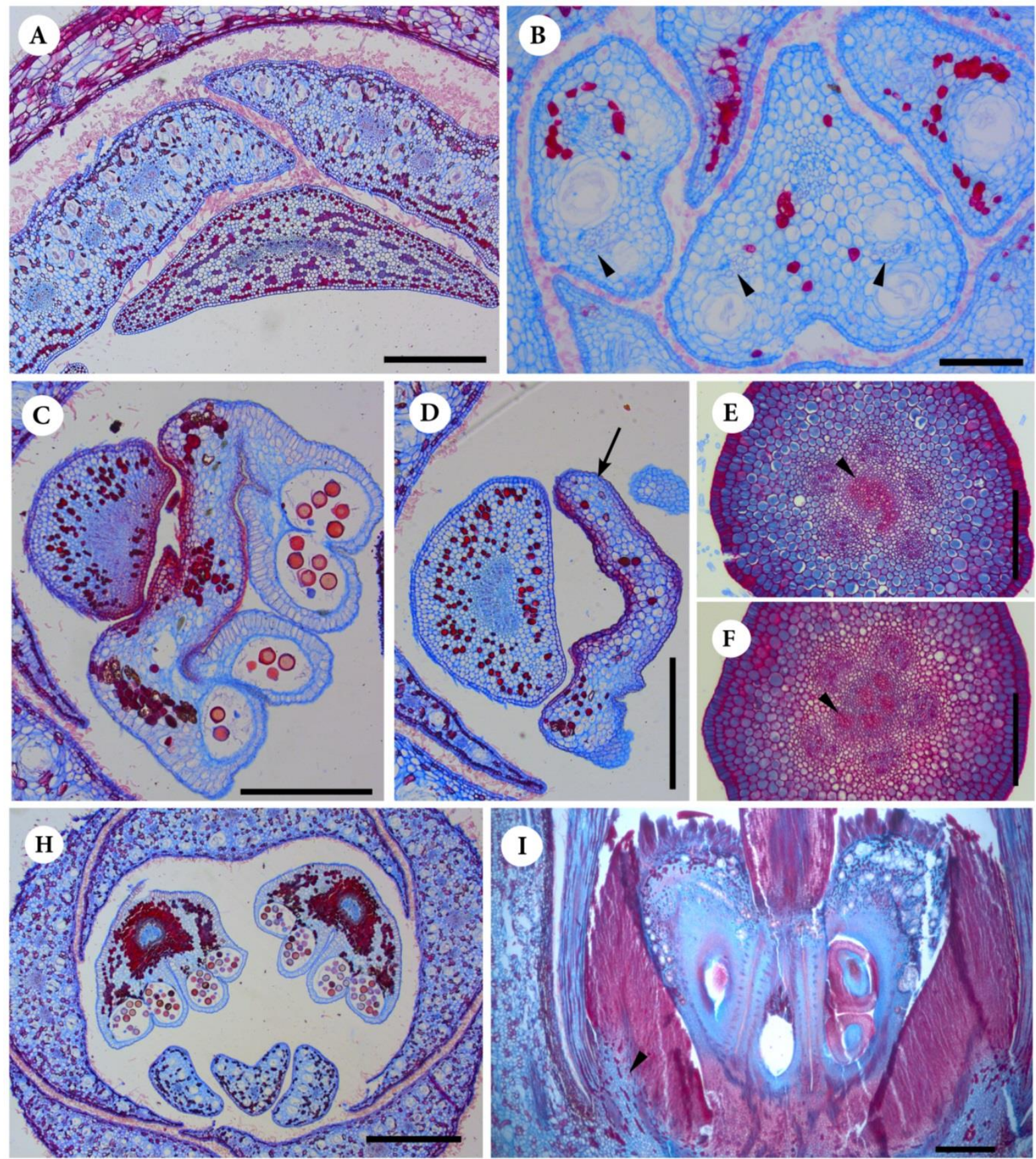

Figure 29: Photomicrographs of microtome sections of floral buds of Neoraputia trifoliata (B) and $N$. alba (A, C-I). (A-H) Transections. (I) Longisection. (A) Detail of lower level of floral tube, showing the intertwining trichomes in petals and filaments. (B) Distal part of the staminodes (arrowheads indicate small lateral bundles). (C-D) Lower level of anther. (C) Detail of thecae bases and uppermost part of one filament. (D) Immediately below C, at the level of sterile prolongation of thecae (arrow). (E-F) Detail of the style. (E) Compitum region (arrowhead). (F) Lower level than E, showing the five strands of pollen tube transmitting tract (arrowhead in one strand). (G) Mid-level of anthers. (H) Base of floral bud, close to the median plane of carpels (arrowhead indicates the oblique base of the disc at the filament). Scale bars: (A, C, D, H) $=500 \mu \mathrm{m} ;(B, E, F)=200 \mu \mathrm{m} ;(\mathrm{G})=1 \mathrm{~mm}$. 

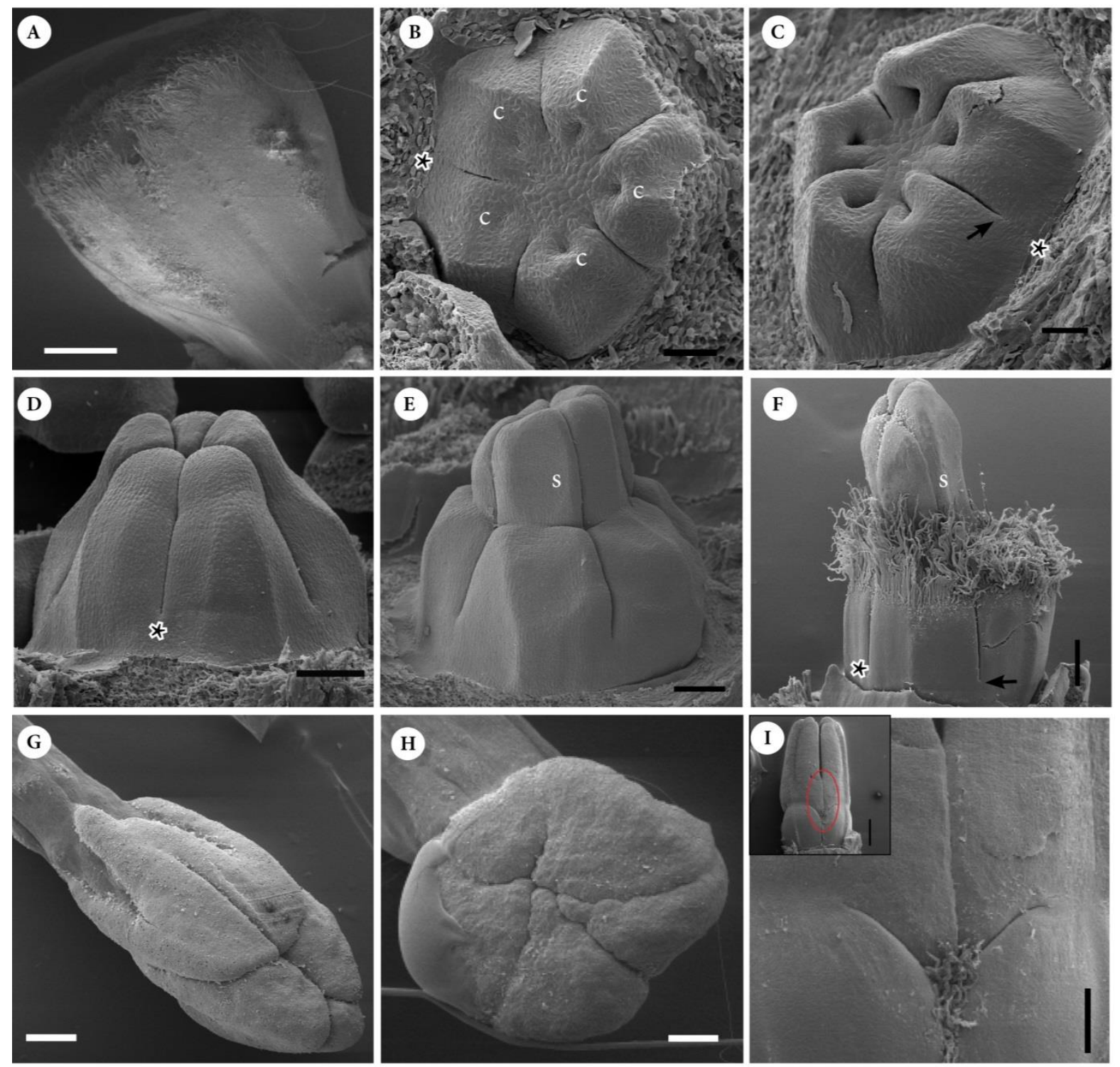

Figure 30: SEM micrographs of Neoraputia. (A) N. alba. Mature gynoecium (style removed). (B-G) N. trifoliata. (B-F) Carpel development (c, carpel). (B-C) Young carpels, from above; note the apparent delay in the initiation of the two anterior carpels (asterisks); arrow in $\mathrm{C}$ indicate the congenital union of carpel bases. (D) Latter stage then D, carpels elongating (lateral view; asterisk at the two antherior carpels). (E) Style (s) elongating. (F) Latter stage than E; note stigmatic region facing the anterior side of the flower (asterisk); arrow indicate the upper end of congenital carpel union. (G-H) Stigmas of anthetic flowers of $N$. trifoliata $(\mathrm{G})$ and $N$. alba (note the five lobes forming a stigmatic plate). (I) N. trifoliata. Detail of the region of postgenital connection between two adjacent anthers (dorsal view); inset, broad view showing two mature fertile stamens (anthers and filaments), from the dorsal side (the region encircled in the inset is the detail magnified out of the inset). Scale bars: (A) $500 \mu \mathrm{m}$; (B,C,G-H) $50 \mu \mathrm{m}$; (D,E) $100 \mu \mathrm{m}$; (F, H) $200 \mu \mathrm{m}, \mathrm{I}=200 \mu \mathrm{m}$, inset $=500 \mu \mathrm{m}$. 


\section{Raputiarana subsigmoidea (Figs 2G, 31-33)}

\section{Morphology and aspects of floral biology}

The flowers of Raputiarana are strongly monosymmetric. Flower buds are ca. $40 \mathrm{~mm}$ long. The floral bud is strongly curved approximately at its lower half in advanced buds, forming a somewhat sigmoidal curvature of the corolla and pollination organs (Figs 2G, 33E). Sepals are cupular, congenitally fused along most of their length, but at their distal part they have five short triangular lobes displaying open aestivation (Figs 2G, 31F-J). Sepals persist during fruit development. Petals are stiff and are unequally distributed. The uppermost adaxial petal lobe is separated from the other four abaxial lobes, which overlap their margins. The four abaxial petals are strongly reflexed and recurved backwards at anthesis, while the single adaxial petal is erect, only slightly reflexed. The petals become reflexed at the level of the sigmoidal curvature in bud, below the floral tube is straight (Fig. 2G). This is formed by the coherence of petals and adherence of filaments to petals by intertwining trichomes (Figs 31D-G, 32A-C). Corolla aestivation is ascending cochlear along most of its length, becoming valvate to open at its lower part (Fig. 31D-G). The apices of petals are rounded, overlapping each other at the uppermost part of the bud (Fig. 31B). Close to the floral base, petals share a common base, first with filaments, and also with the disc plus gynoecium lower down (Fig. 31A, F-J). The androecium is composed of two large fertile stamens and three smaller staminodes, all antesepalous (Fig. 31C), but according to Emmerich (1978) some flowers may have aditionally two antepetalous staminodes on the anterior side of the flower. Anthers are located on the posterior side of the flower and each has a long basal appendage, which is a sterile prolongation from both thecae bases. These are postgenitally connected laterally by minute cuticular projections (Figs 31D-E, 32C, D, E, 33D). In their distal region, where filaments are free, the fertile ones show a somewhat triangular shape in their constricted tip, becoming wider and flattened lower down. Staminodes are rounded and dorsiventrally flattened in their distal free part (Fig. 31C-E). Lower down, filaments are congenitally connated at different levels along their length. First, filaments of the two wider fertile stamens are connated from the lower level of their basal appendages until their bases, while the two adjacent staminodes are connated to them a bit lower, forming a staminal arc; only the abaxial median staminode is free along most of its length. In the lower part, it shares a common base first with petals, and below also with the disc plus carpels (Fig. 31D-I). Anthers are large (ca. $9 \mathrm{~mm}$ in their fertile region), near-basal dorsifixed. They are sterile above the point of insertion of the filament, and also below in their long sterile basal appendages (Figs 32E, 33D). They are sagittate, introrse, caducous. They have a thin connective and endothecium- 
like tissue is continuous over most of the dorsal side of the connective. One to a few layers of endotecium-like cells are visible on the connective side of thecae. Between each theca there is one deep ventral furrow and a shallow dorsal furrow along most of its length (Fig. 32F). There is an intrastaminal nectariferous cupular disc, thicker toward its base. The disc encompasses the ovary, almost exceeding it in its length (Fig. 31A). The internal surface of the disc presents several small lobations of tissue (Fig. 31H-I). Carpels are abruptly bulged up on the dorsal side above the level of the base of the style, so that the style appears sunken into it for ca. one-fifth of the ovary length (carpels anacrostylous, Figs 31A, 32A). The upper dorsal wall are thickened in the bulging region. The total diameter of the ovary decreases gradually towards its constricted base (Fig. 31A). Style and stigma are curved towards the anterior side of the flower (Fig. 2G). The stigma is five-lobed, and soon below becomes postgenitally connected at its flanks, forming a small slit in its centre. The surface of the stigmatic lobes is smooth (Fig. 32G). The style is solid along its entire length (Fig. 31D-F). At the upper level of ovary, carpels are postgenitally united at the centre for a very short extent. Immediately below, carpels are completely free (Figs 31A,G, 33A, B). This free zone extends down the base of the locules, where first the anterior carpels become congenitally fused at the flanks and lower down also at the center. Then the posterior carpels become first united by the centre and also lower down by the flanks. This zone of central congenital union comprises approximately one-seventh of the total length of the ovary (Fig. 31 A, H, I). The gynoecium shows a slight monosymmetry, since at maturity the upper part of style and the stigma are markedly curved towards the anterior side of the flower (Fig. 2G). At base of the locules, the lobations of nectary tissue at the inner side of the disc become united to the ovary walls, first forming small bridges of tissue, and lower down becoming extensively united to the carpels, as well as to stamen and petal bases. At floral base there are small patches of nectary tissue between the vascular traces (Fig. 31H-K). The placentation is marginal (Fig. 31A). Ovules are antitropous, and the outter integument is thicker than the inner one. An obturator made of multicellular trichomes is observed on the placenta (Fig. 33B, C).

Sepals and petals have small pink dots and the petals have a cream-colored background. The flowers present approach herkogamy, since at anthesis the style grows to the outside of the floral tube, thus becoming far exserted, while the anthers are exserted but located closer to the mouth of the tube (the lower part of the basal appendages are placed within the tube). Later on anthesis, anthers drop off (Figs 2H, 33D, E). Floral odour is slightly sweet-scented. 


\section{Anatomy}

Sepals have one main and two secondary bundles at the region of the short lobes (Fig. $31 \mathrm{E})$. At the congenitally fused region of sepals, up to 44 vascular bundles appear. At floral base, sepals have five main traces, approximately six secondary traces, and five synlateral traces (Fig. 31F-L). Petals have one median main vascular bundle and may have three to fourteen secondary bundles (Fig. 31B-C). Stamens possess one vascular bundle, and petals and stamens each have a single vascular trace (Fig. 31J). The disc is provided with numerous small phloematic bundles along most of its length. At its base, at the level of common base with petals and filaments, the disc bundles toward the periphery merge, forming larger traces, radially arranged. These traces have xylem and phoem, while the inner ones are still small and phloematic. Lower down, the larger traces merge with the small disc traces (Fig. 31H-J). At the base of the ovary (below the locules) each ventral bundle splits in two and becomes radially arranged at floral base; lower down these traces merge forming a central trace complex (Fig. 31 I-K). Disc traces in front of stamen traces diverge toward the dorsal traces of carpels, merg with part of them. Lower down, this complex also merges with stamen traces and then with the central vascular complex. Other disc traces in front of petal traces merge with petal traces at lower levels, and then also merge with the central vascular complex. On this same level, some secondary and synlateral traces of calyx diverge from this central vasculature (Fig. 31J-L). Finally, the five main sepal traces merge to the central vasculature at the base of the flower and form a stele with it (Fig. 31M).

\section{Histology}

Short bicellular club-shaped lignified hairs are present on the external surface of the calyx. Unicellular lignified hairs are present on both sides of petals and stamens, which are densely distributed at the postgenitally coherent and adherent regions. Stomata are present on the surface of the nectary disc, at its upper level. Tanniferous cells are dispersed in all floral organs, forming an extensive tissue in stamens (especially in the connective, around the vascular bundle), in the epidermis and hypodermis of the style, external surface of the ovary (most developed at the dorsal bulging areas of the carpels) and in the outer integument (Figs 32 A, 33C). Together with the tanniferous cells, other secretory cells filled with a blue stained secretion (probably mucilage) occur in the filaments, in the epidermis of the disc and in the outer integument. Secretory cavities are present in sepals, petals, filaments and carpels (Fig. $32 \mathrm{~A}, \mathrm{C})$. Raphides are present in all floral organs. The stigmatic surface is linned by columnar cells (Fig. 32G). 
Figure 31: Raputiarana subsigmoidea. Sections of floral buds. (A) Longisection. (B-L) Transections: successive levels, from the top, downward. Morphological surface indicated by thicker continuous lines, vasculature by thinner continuous lines; postgenitally fused areas indicated by broken lines; pollen tube transmitting tissue (PTTT), dark grey; nectariferous tissue, light gray (in the longitudinal section, only morphological surfaces and vascularization are represented). (B) Uppermost level of petals. (C) Mid-level of anthers. (D) Distal level of filaments. (E) Lowermost level of basal appendages of anthers. (F) Level of filaments laterally connated (except for the median anterior one); upper level of calyx. (G) Uppermost level of the ovary. (H) Lower half of the ovary, below the placenta. (I-J) Lower level of ovary locules and level of common base of carpels and nectary. (J-K) Level of patches of nectary in floral base. (L) Level of trace complex of stamens plus disc plus dorsal trace of carpel. (M) Lower level of flower base, with trace complex of petals plus disc, and traces of calyx. Abbreviations: ba, basal appendages of anther; d, disc; f, filaments; g, gynophore; p, petal; ste, style; tca, trace of calyx; td, trace of disc; td+tc, trace complex of disc plus dorsal trace of carpels; tp, trace of petal; ts, trace of stamen; ts+td+tdc, trace complex of stamen plus disc plus dorsal trace of carpels. Scale bars: $(\mathrm{A}-\mathrm{M})=1 \mathrm{~mm}$. 

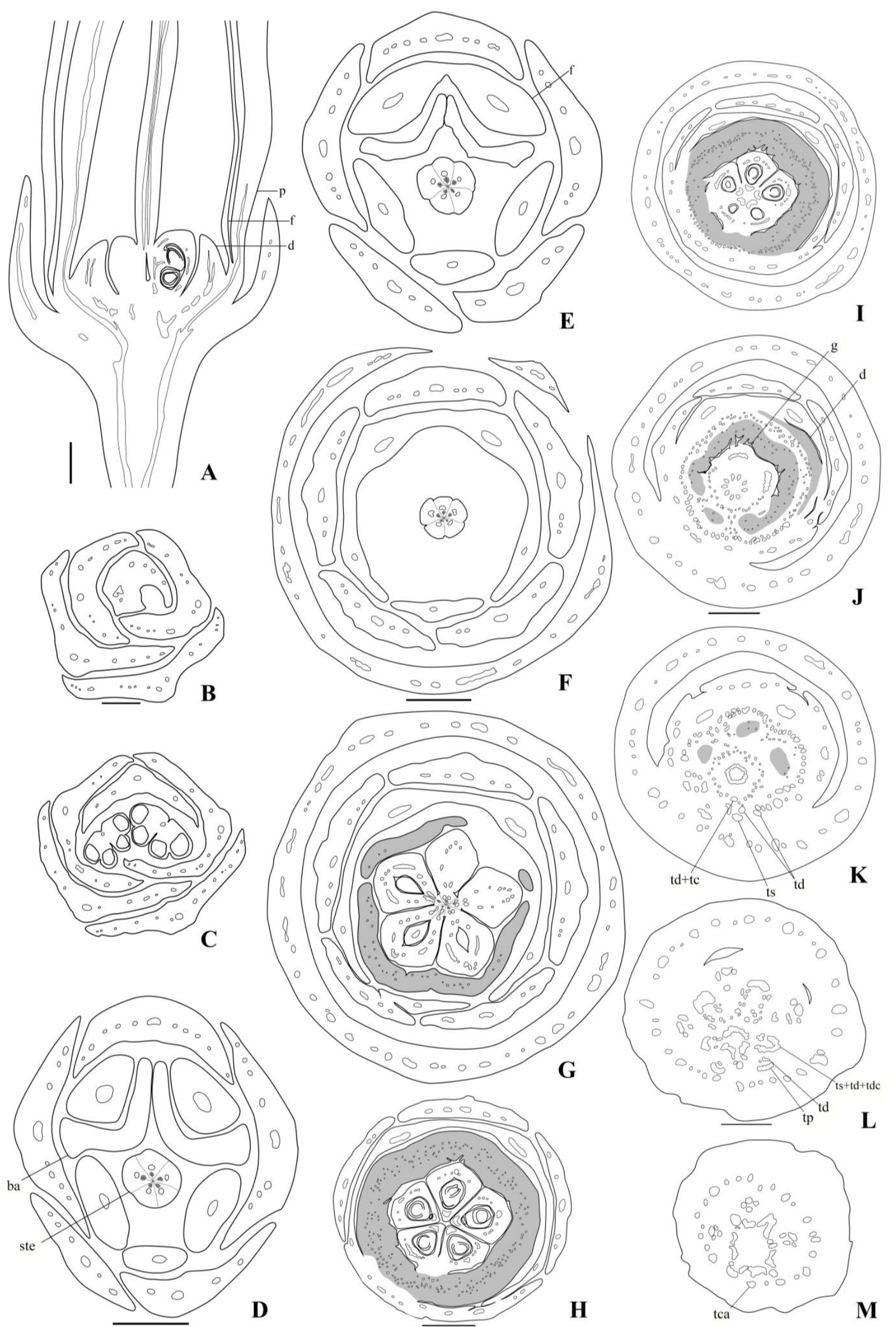

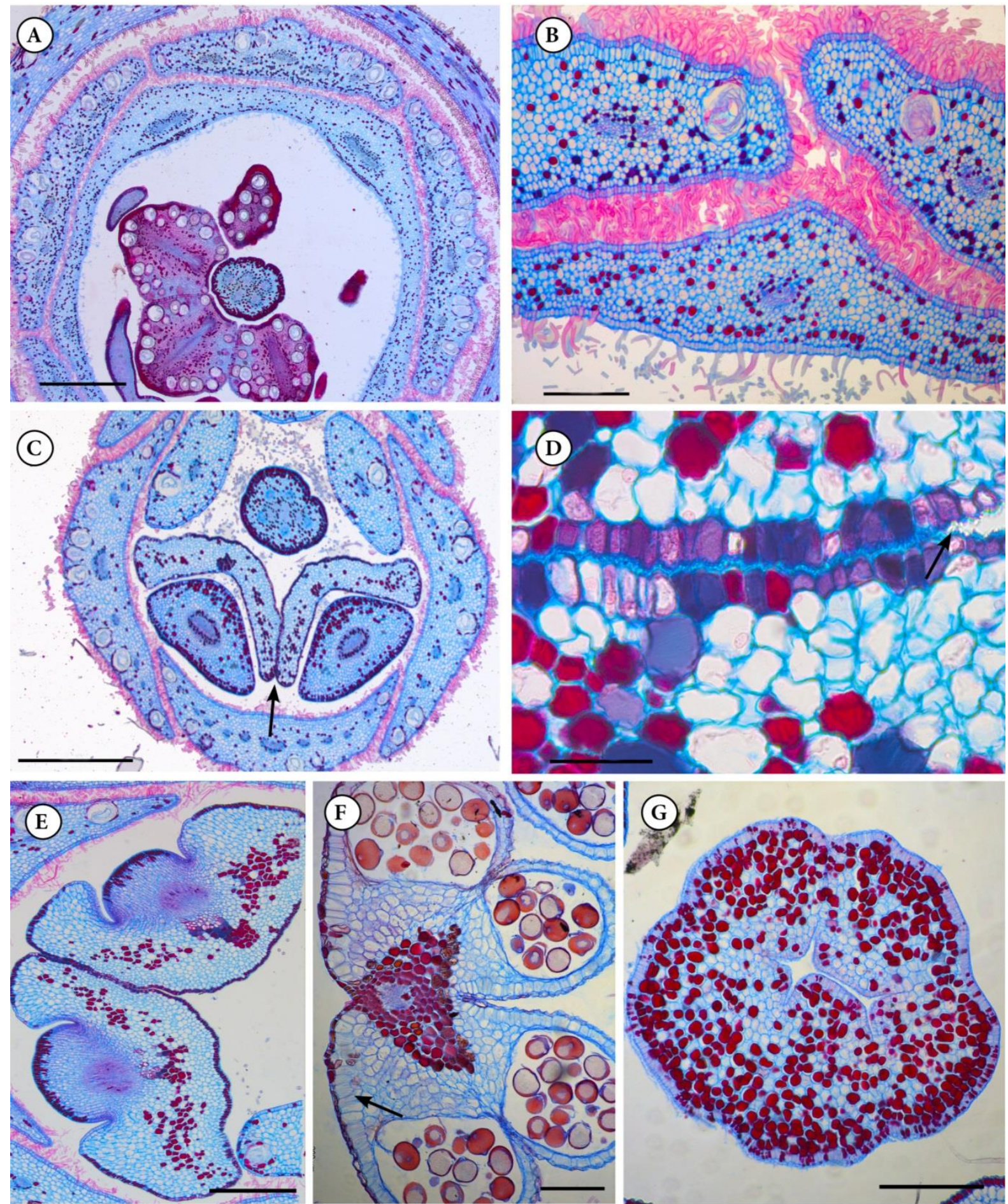

Figure 32: Photomicrographs of microtome sections of floral buds of Raputiarana subsigmoidea. (AE, G) Transections. (F) Longisection. (A) Level of bulging dorsal area of carpels, and valvate petals (arrow). (B) Detail of the coherence of petals and adherence to filaments by the intertwining trichomes. (C) Level of basal appendages of thecae (laterally postgenitally connected, arrow). (D) Detail of the region indicated in $\mathrm{C}$, showing the region of postgenital connection (arrow indicate cuticular projections, in the region where these are most evident). (E) Sterile bases of anthers at the level of attachment to filament. (F) Mid-level of anther, showing the endothecium-like tissue (arrow) over part of the dorsal side of the connective. $(G)$ Detail of the stigmatic region. Scale bars: $(A, C)=$ $1 \mathrm{~mm} ; \mathrm{B}, \mathrm{F}-(\mathrm{G})=200 \mu \mathrm{m} ;(\mathrm{D})=50 \mu \mathrm{m} ;(\mathrm{E})=500 \mu \mathrm{m}$. 


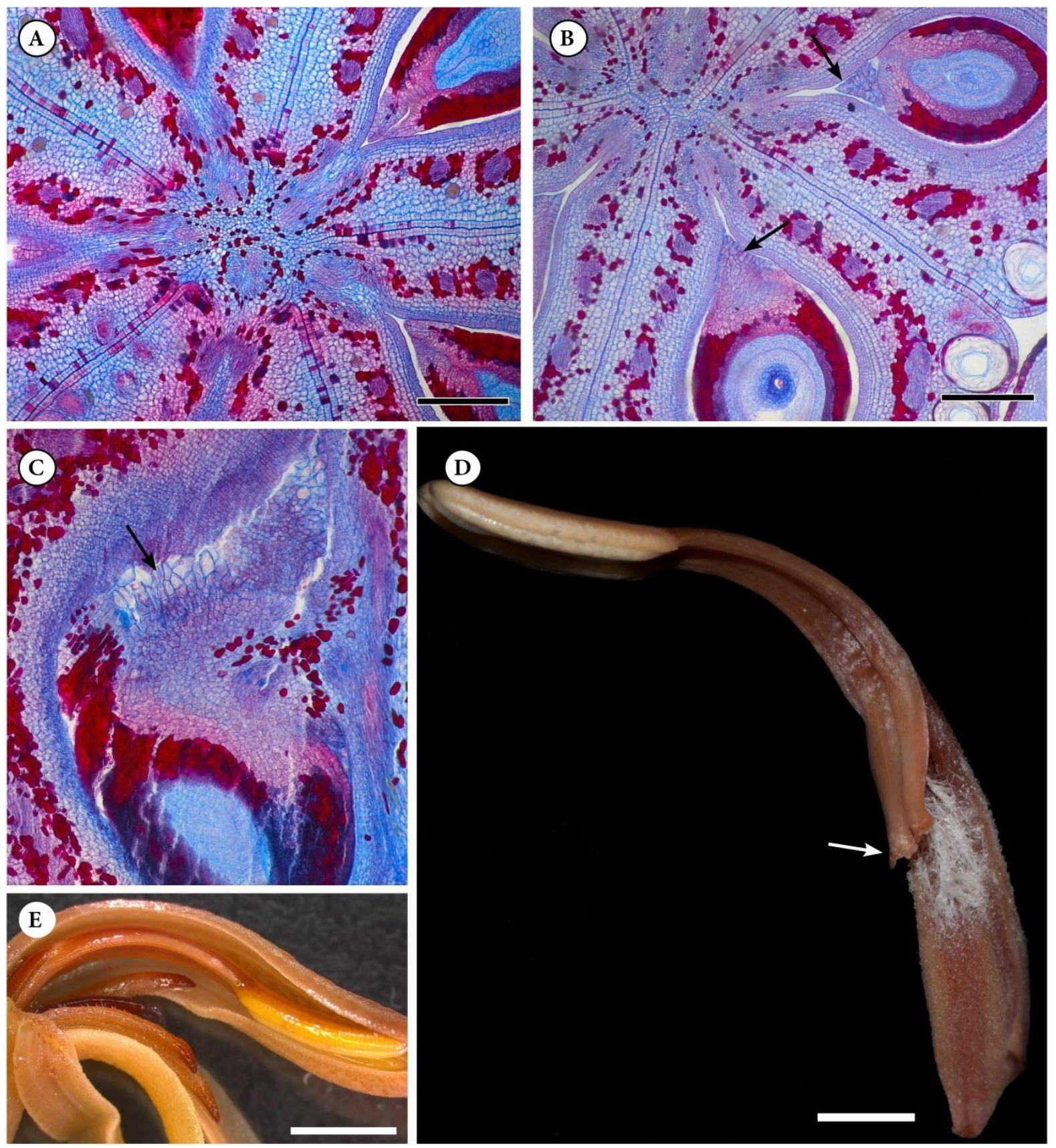

Figure 33: Photographs (D-E) and photomicrographs (A-C) of microtome sections of floral buds of Raputiarana subsigmoidea. (A-B) Transections. (C) Longisection. (A-C) Details of the ovary. (A) Detail of the postgenital union of carpels at centre. (B) Detail of the upper level of ovules, showing part of the obturator (arrows). (C) Detail of the obturator (arrow) and lower ovule. (D) Two fertile stamens, with their long sterile basal appendages (arrow at the lower end of the appendage). (E) Detail of the upper region of an anthetic flower, recently opened. Scale bars: $(A-C)=200 \mu \mathrm{m}$; $(D)=3 \mathrm{~mm}$; $(\mathrm{E})=5 \mathrm{~mm}$. 


\section{Rauia (R. nodosa and $R$. resinosa) (Figs 2H, I, 34-37)}

Morphology and aspects of floral biology

The flowers of Rauia are monosymmetric. Flower buds are ca. $26 \mathrm{~mm}$ long in $R$. nodosa and ca. $11 \mathrm{~mm}$ long in R.resinosa. Advanced buds are slightly curved. Sepals are cupular, congenitally fused along most of their length, but at the upper part have five short triangular lobes displaying open aestivation in advanced buds (Figs 2H, I, 34A, D-G). Petals are stiff, polysymmetric. They form five spreading reflexed blades at the distal region after anthesis. Below this free region, petals form the floral tube, together with filaments (Fig. 34CG), through the coherence of petals and adherence of filaments to petals by intertwining trichomes (Fig. 35A). The apices of petals are rounded, which overlap each other at the uppermost part of the bud (Fig. 34A). Corolla aestivation is ascending to oblique cochlear along most of the length in $R$. resinosa and in most of the buds of $R$. nodosa. However, for $R$. nodosa some irregular flowers were found. These presented a mixed pattern of aestivation, with three imbricated petals (with one side of their margins in and one side out), and two petals with one of their margins valvate and the other margin imbricated. In both species, only the two anterior petals become valvate to open close to their base (the other three remain imbricated; Fig. 34H). Petals are thicker in their distal part, gradually becoming thinner towards their bases (Fig. $34 \mathrm{~B}-\mathrm{H}$ ). In $R$. nodosa, petals may have one lateral protuberance in their abaxial side, where the adjacent petal may become coherent below (Fig. 35A). The androecium is monosymmetric. In Rauia resinosa and in most of the flowers analyzed of $R$. nodosa, the androecium is formed by two fertile antesepalous stamens and five staminodes, three antesepalous and two antepetalous. One irregular flower of $R$. nodosa has four fertile antesepalous stamens (one of them congenitally fused to the adjacent antepetalous stamen in most of the length, except at the upper part of anthers) and three staminodes (two antepetalous and one antesepalous). But haplostemonous flowers may also occur, bearing only two fertile stamens and three antesepalous staminodes. In the uppermost part, all stamens (fertile stamens and staminodes) are closely packed in bud (Fig. 34B). Lower down, in $R$. resinosa and in most of the flowers analyzed of $R$. nodosa, the two fertile stamens are located on the posterior side of the flower and are adjacent to the innermost petal (Fig. 34C-D). Filaments of staminodes are free in their distal part in anthetic flowers. However, in bud these are closely packed and postgenitally connected by epidermal papillae in the upper region (Fig. 35C, D). Each stamen bears an apical sterile appendage, which represents a short, pointed protrusion of anther. These apical sterile appendages are also laterally connected by papillae in their distal part, in bud stage only (Figs 34A, B, 35B). All antesepalous staminodes are free, but at the 
floral tube region these are adherent to petals, while the antepetalous ones become congenitally fused to the immediately opposed petal (Fig. 34C-G). Close to the floral base, filaments of Rauia nodosa are congenitally fused to petals and have a commom base with the nectariferous disc, which has an oblique base with stamens (Fig. 36A, D). The staminodes have an irregular form, closely packed in bud at its distal region (Fig. 34C). Some may be bent at their tips, forming hooked apices (Fig. 36E). Lower down, some of them become dorsiventrally flattened (Fig. 34C-D). Filaments of fertile stamens are wider than staminodes, also flattened at the floral tube region (Fig. 34 D-H). The following description refers only to $R$. resinosa, since for $R$. nodosa, due to excessive presence of tanniferous tissue and hairs, the majority of the serial transections were damaged. In their uppermost part, antepetalous staminodes are placed between the ventral side of anthers and antesepalous staminodes (almost at the centre of the bud). Lower down, they are opposite to the immediately adjacent petals (and adnate to them shortly below), alternating and at the same level with the antesepalous staminodes (Fig. 34 B, C, D). Analysis of young stages of the androecium seen from the dorsal side shows that antesepalous and antepetalous staminodes appear free and have their bases nearly at the same level at the floral base. However, the tips of antepetalous staminodes are slightly bent towards the inner side of the flower, reflecting more or less the future position of these organs in the distal region of mature buds (Figs 37E, 34B). Their congenital fusion to petals occurs later in development. Anthers are mid-sized in $R$. resinosa (ca. $3 \mathrm{~mm}$ long) and very large (ca. 6,5 mm long) in R. nodosa, basifixed. A short sterile prolongation of each thecae base is present in $R$. nodosa (Fig. 35E). Anthers are narrowly sagittate, persistent. They have a thick connective and endothecium-like tissue is continuous over most of the dorsal side of the connective, arranged as a palissade-like layer of cells; also some layers of endotecium-like tissue are present in the connective side of thecae. Anthers have one deep ventral furrow between each theca and a shallow dorsal furrow along most of the length (Figs 35F, 36I, 34C, D). There is an intrastaminal nectariferous cupular disc, which almost encompasses the entire ovary and is thicker toward the base in $R$. resinosa. In $R$. nodosa the discsurpasses the ovary and has similar thickness along its entire extension (Figs 34A, 36B, C). It has an oblique base at filaments and petals in $R$. nodosa (Fig. 36A, D). Carpels are acrostylous, constricted towards base (Figs 34A, 36A). The upper dorsal wall of the ovary are markedly thickened, but are not bulged (Figs 36B, 34A). The stigma is inconspicually five-lobed, mostly postgenitally fused, forming a long and cylindrical stigmatic region (Figs 36C, 37A, 34A; approximately as long as the style in $R$ nodosa). The stigma surface is papillose, with closely packed papillae with ca. $40 \mu \mathrm{m}$ long (Fig. 36F). The style is completely postgenitally fused in $R$. resinosa, and apparently also in $R$. nodosa (as 
seen in longisections of the latter). At the upper level of ovary, carpels are postgenitally fused at the thick upper walls (Figs 34E, 37B, and from longisections observations in R. nodosa). From the upper part of the locules until the mid-level of placenta, carpels are free in $R$. resinosa in the young stage analyzed, and free at least at centre in $R$. nodosa (Figs 34E, 36B). Lower down, carpels are congenitally fused first at centre, and then immediately below by their flanks, with five small slits lined with epidermis between each carpel (corresponding to the morphological surfaces of each adjacent carpels; Figs 34H, 36D). Close to the floral base, these slits gradually decrease in size, disappearing at the commom base of carpels. $R$. resinosa possess ashort gynophore (Figs 34A, I, 37B). Placentation is marginal and axile (Figs 34F, G). Ovules are antitropous, with the outer integument thicker than the inner. A zig-zag micropyle and an obturator made of multicellular papillae and trichomes (on the placenta and funiculus) occurs in $R$. nodosa (Figs 35G, 36H).

The main colour of perianth at anthesis is cream to white in $R$. resinosa and $R$. nodosa. Both species present sweet-scented flowers, with reversal-hercogamy, as flowers have recessed stigmas below the anthers. Some older flowers present their anther partially curved backwards, away from the corolla throat (Fig. 2H-I). Some flowers of R. nodosa were observed to be visited (and probably pollinated) by the butterfly Entheus priassus pralina, the same butterfly observed to pollinate Conchocarpus macrophyllus J.C. Mikan, in a nearby area (El Ottra et al., in prep., Chapter 3).

\section{Anatomy}

At the congenitally fused region, sepals have five main vascular bundles and additionally up to 41 lateral bundles (up to 28 in $R$. resinosa). At floral base, sepals have five main traces and approximately seven lateral traces (Fig. 34K, L). Petals have one to three main vascular bundles in $R$. nodosa, and may have up to 12 lateral bundles (Fig. 34A, up to six bundles in $R$. resinosa). At the floral base, petals have one vascular trace (Fig. 34K, L). Antesepalous and antepetalous stamens have one vascular bundle and a single vascular trace (Fig. 35B, C, E, F). The vascular bundles of antepetalous stamens are locatedvery closely to the main central vascular bundle of the immediately opposite petal in the region where these are adnate to petals (Fig. 34D-H). Contrarily, at floral base, the vascular bundles of antepetalous stamens are located away from petal traces and at the same level as the bundles of antesepalous stamens in $R$. nodosa, and in one antepetalous staminode in $R$. resinosa. In $R$. resinosa the other antesepalous stamen merge with the the petal trace immediately opposed to it (Fig. 34J, K). The nectary disc has numerous small vascular bundles which merge at floral 
base, forming larger disc traces radially arranged in front of stamen and petal traces (this was not seen in $R$. resinosa, since the lower part of the bud analyzed in transverse sections was a young bud, thus the disc was not yet developed, nor was the dorsal or ventral vasculature of carpels). Below the locules, each ventral bundle separates in two and these converge towards the center of the gynoecium, forming a five-angled central vascular complex close to floral base (Fig. 34I). At this same level, the dorsal bundles of carpels become radially arranged around the central vascular complex. At floral base, first the stamen traces (antesepalous and antepetalous) merge with some of the disc traces (only observed in $R$. nodosa). Lower down, these complexes merge with part of the dorsal traces, forming five large trace complexes that converge to the central vascular complex. Additionally, other disc traces merge and form large complexes in front of the petal traces, which also merge with the dorsal bundles below, Together with the petal traces, they merge with the central vasculature. At lower level of the floral base, the sepal traces converge to this central vasculature, forming a stele with it in $R$. nodosa. In $R$. resinosa, first the stamen traces converge towards the central vasculature (including the trace of one antepetalous stamen, which does not merge with petal trace), followed by petal traces (one petal plus antepetalous staminode trace complex - Fig. 34J-K). At the lowermost level, the lateral traces of calyx merge with the central vasculature, followed by the main traces (Fig. 34L).

\section{Histology}

Short lignified hairs are present on the abaxial side of sepals and on the ovary of $R$. resinosa. Long lignified hairs are present on both sides of petals and on the abaxial side of filaments at the lower half (Figs 35A, 37B). Short unicellular papillae are present on the sterile prolongation at the apices of anthers, and on the adaxial side of filaments, except close to their bases (approximately at the lower quarter of their length, Fig. 35 B-D). Tanniferous cells are dispersed through all floral organs. Extensive tanniferous tissue is present at the upper dorsal thick walls of advanced ovaries, style, connective and in the epidermis of anthers. For $R$. nodosa, it is also present in the hypodermis of the calyx, petals, filaments, and in the epidermis of the disc (Figs 35A-F, 36 B, D). Cells with blue-stained secretion (probably mucilage) are present in the calyx, petals, anthers, disc, ovary, and outer integument (Figs 35F, H, 36 A). Secretory cavities are present in sepals, petals, and ovary (conspicuously large in the calyx of $R$. resinosa). Raphides are observed in the filaments and ovary. Small stomata are seen on the top of the nectary of $R$. nodosa. The epidermal cells of anthers are slightly papillose (Fig. 35F, 36I). 
Figure 34: Rauia resinosa. Sections of floral buds. (A) Longisection of advanced bud. (B-M) Transections of a young bud: successive levels, from the top, downwards. Morphological surface indicated by thicker continuous lines, vasculature by thinner continuous lines; postgenitally fused areas indicated by broken lines (in the longitudinal section, only morphological surfaces and vascularization are represented). (B) Upper level of the androecium: distal level of antesepalous staminodes; uppermost level of antepetalous staminodes and sterile tip of anthers. (C) Mid-level of anthers. (D) Basal region of anthers and upper level of antepetalous staminode adnate to petals. (E) Transition level between the base of the style and the thick upper region of ovary (above the locules). (F) Upper region of ovary locules. (G) Mid-level of ovary. (H) Lower region of ovary. (I) Level of the gynophore. (J) Level of antesepalous and antepetalous staminode traces. (K) Level of trace complex of petal plus antepetalous staminode, and other petal traces. (L) Lower level of calyx traces. Abbreviations: a, anther; bsp, vascular bundle of antepetalous staminodes; p, petal; s, staminode, antepetalous staminode; ss, antesepalous staminode; tcm, main trace of calyx; tp, trace of petal; tsp, trace of antesepalous staminode; tss, trace of antesepalous staminode; tp+tsp, trace complex of petal plus antesepalous staminode. Scale bars: $(A)=1 \mathrm{~mm} ;(B-L)=200 \mu \mathrm{m}$. 


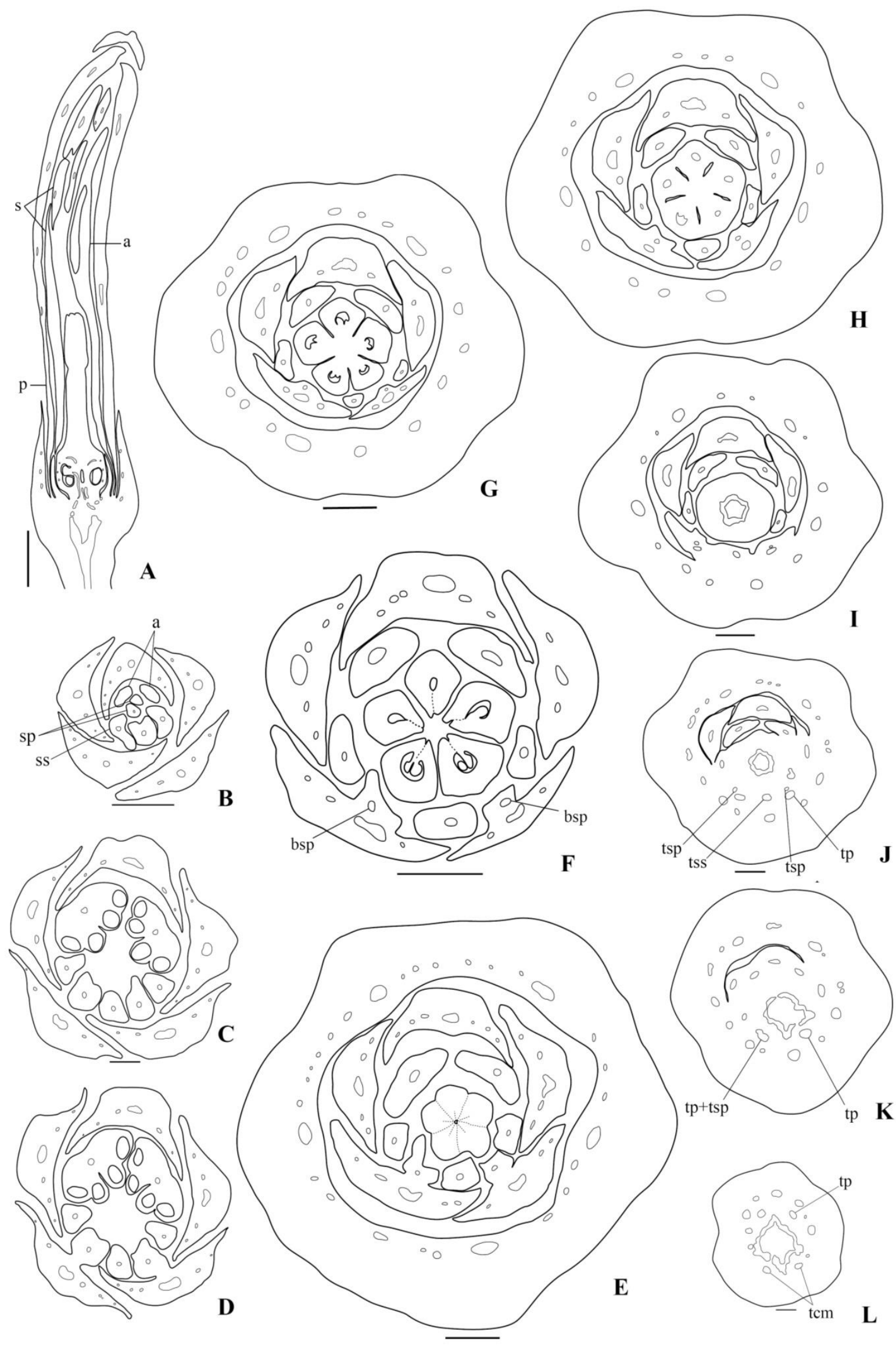



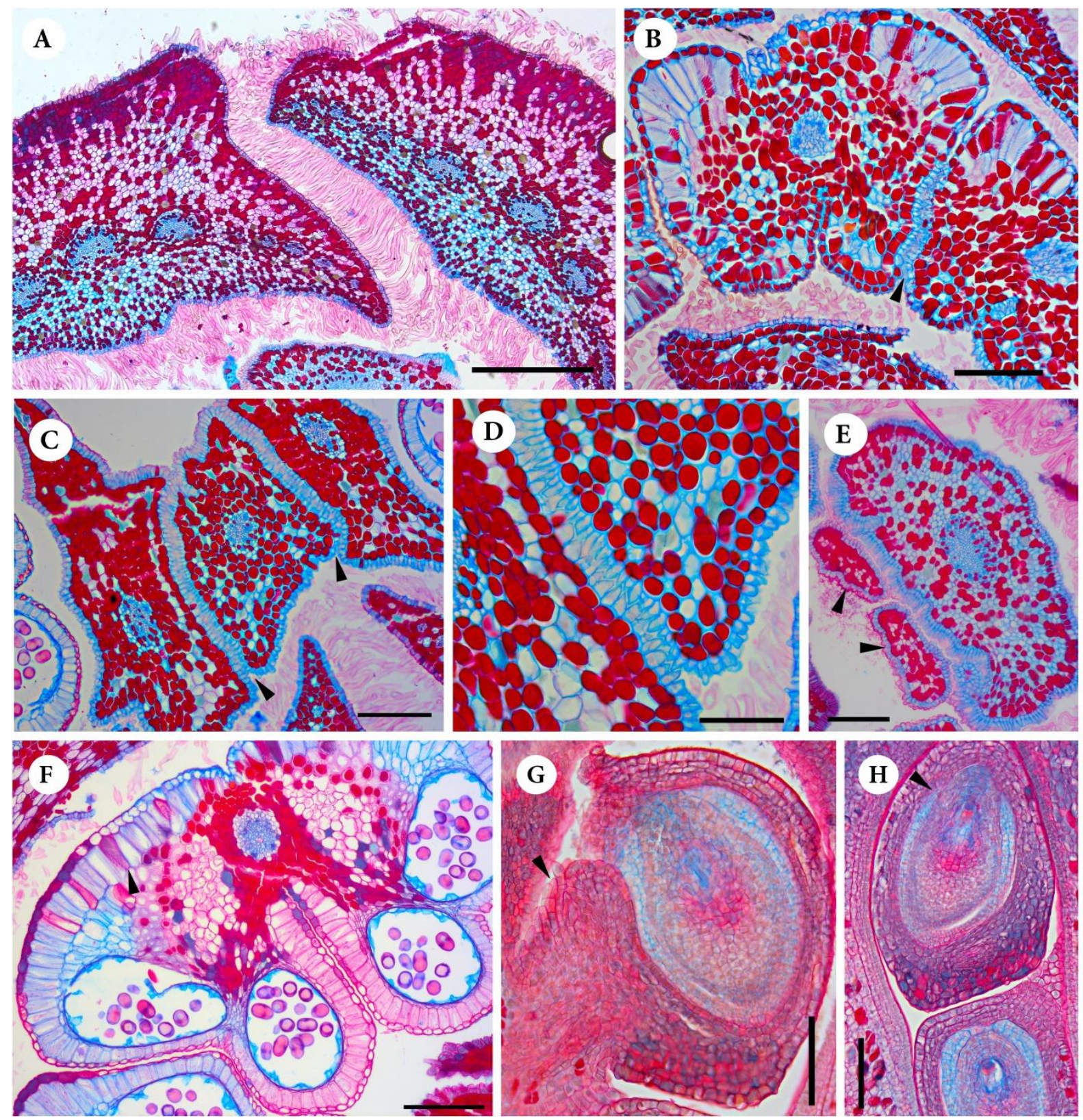

Figure 35: Photomicrographs of microtome sections of floral buds of Rauia nodosa. (A-F) Transections. (G, H) Longisections. (A) Upper part of floral tube, showing the intertwining trichomes in petals. (B) Detail of the sterile tips of two anthers, postgenitally connected by papillae (arrowhead). (C) Distal region of three staminodes, postgenitally connected laterally by papillae (arrowhead). (D) Detail of the region indicated in C. (E) Detail of two short sterile prolongations of thecae (arrowheads), just below the level of filament attachment to anthers. (F) Mid-level of one anther, showing the endothecium-like tissue continuous over the dorsal side of the connective (as palissadelike layer of cells; arrowhead) and endothecium-like tissue on the connective side of thecae. (G) Detail of one ovule (arrowhead indicate papillae of the obturator). (H) Detail of one carpel, with two superimposed ovules (arrowhead indicate the nucellus protuded beyond the inner integument). Scale bars: $(A)=500 \mu \mathrm{m} ;(B, C, E, F)=200 \mu \mathrm{m} ;(D, G, H)=100 \mu \mathrm{m}$. 

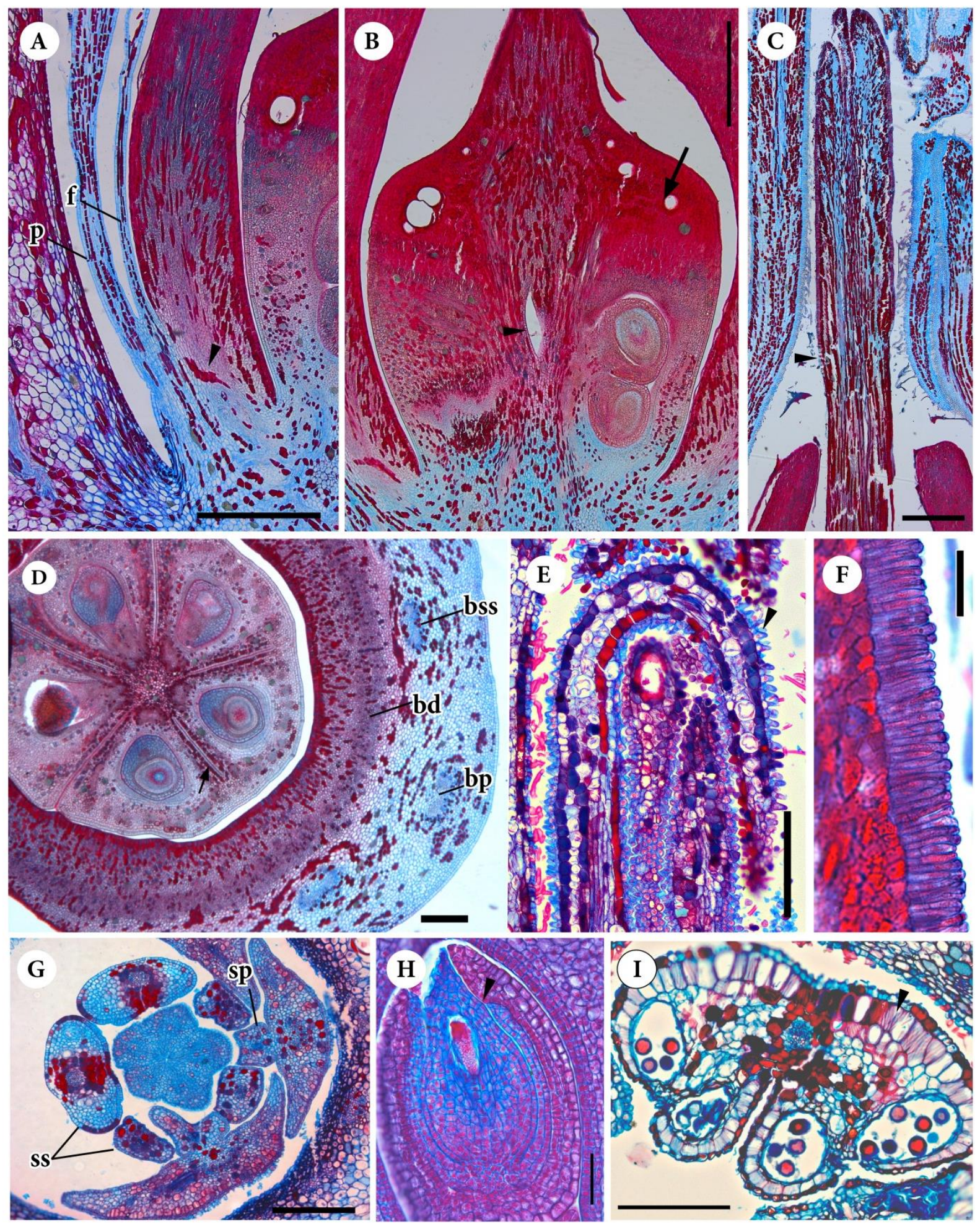

Figure 36: Photomicrographs of microtome sections of floral buds of Rauia nodosa and $R$. resinosa. (A-C, E, F, H) Longisection. (D, G, I) Transection. (A-D) R. nodosa (A) Detail of the base of floral bud, showing the common base of petals filaments and disc (arrowhead). (B) Detail of carpels, at the median plane of one ovary (arrowhead indicate carpels free at centre; arrow, upper thickened dorsal walls of carpels. (C) Detail of carpels, showing the long stigmatic region (arrowhead at the lower end of the stigmatic region). (D) Detail of the lower half of the ovary (arrow indicate small slits between carpel flanks), surrounded by the common base of petals, filaments and disc. (E-I) $R$. resinosa. (E) Detail of the distal part of staminodes, with papilose epidermis (arrowhead). (F) Detail of the papillate stigma. (G) Detail of the androecia, at the level of sterile base of anthers. (H) Detail of one ovule (arrowhead, inner integument). (I) Detail of one anther, showing the endothecium-like tissue continuous over the dorsal side of the connective (arrowhead). Abbreviations: bd, vascular bundles of disc; bp, vascular bundle of petals; bss, vascular bundle of stamens; f, filament; p, petal; sp, antepetalous staminode; ss, antesepalous stamens. Scale bars: $(A-C)=500 \mu \mathrm{m} ;(\mathrm{D}, \mathrm{E}, \mathrm{I}, \mathrm{G})=200 \mu \mathrm{m},(\mathrm{F}, \mathrm{H})=50 \mu \mathrm{m}$. 

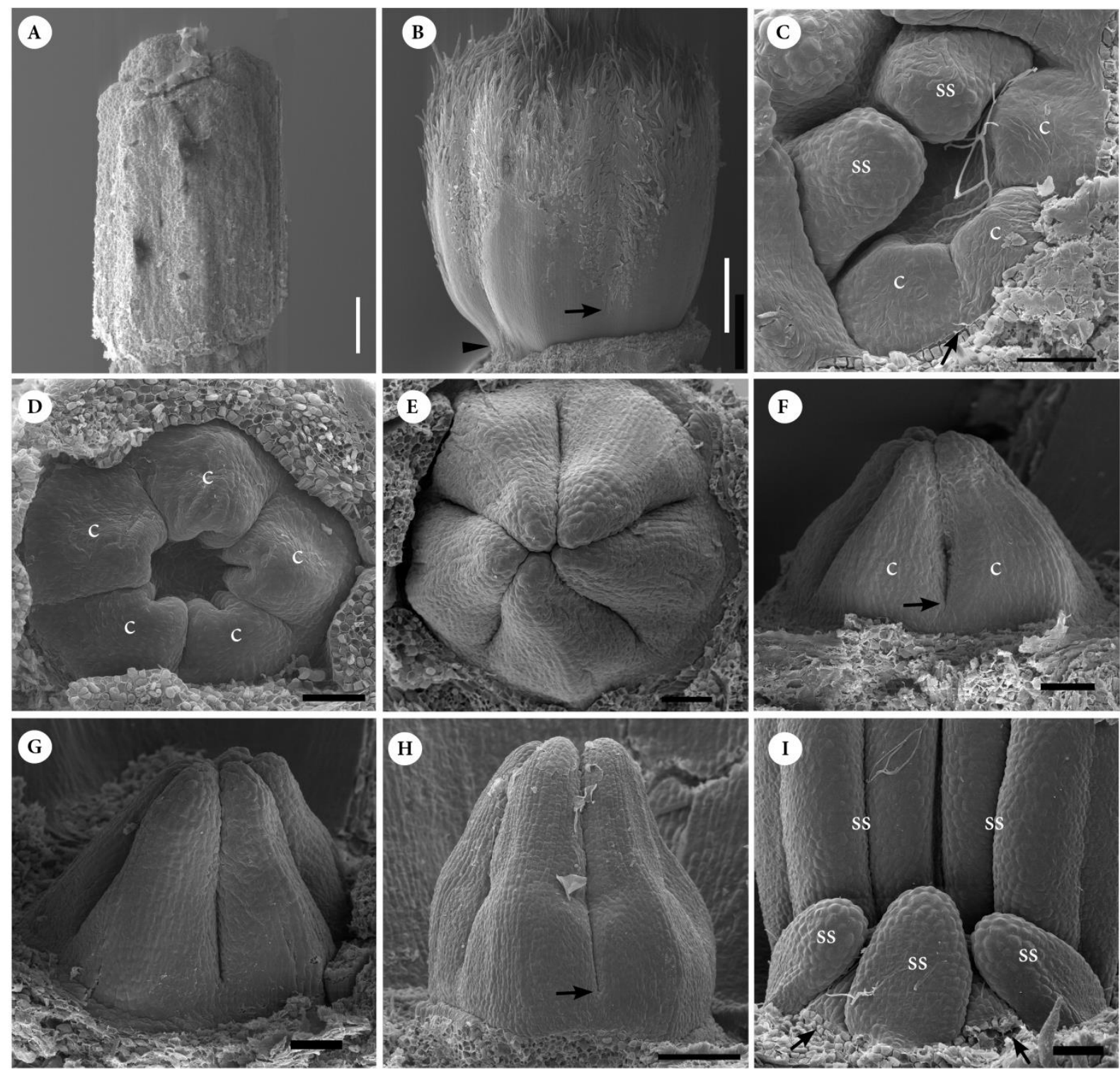

Figure 37: SEM micrographs of Rauia resinosa. (A) Mature stigma. (B-H) Carpel development. (B) Young carpels (c) laterally contiguous at base (arrow; two of the carpels are covered by the antesepalous stamens, ss). (D) Young carpels, from above. (E-F) Latter stage then D, carpels elongating (E, from above; F, from the side). (G-H) Style elongating (arrow indicate the upper end of the lateral congenital fusion of carpels). (I) Young androecium, showing free stamens (ss, antesepalous stamens; arrow at the base of antepetalous stamens, inwardly curved). Scale bars: (A, B) $=200 \mu \mathrm{m}$; (C$\mathrm{I})=50 \mu \mathrm{m}$. 


\section{Ravenia spectabilis (Figs 3A, B, 38, 39)}

\section{Morphology and aspects of floral biology}

Flowers of this species are monossymetric. Advanced floral buds reach ca. $27 \mathrm{~mm}$ long. Floral buds are straight to slightly curved and the floral tube is straight, gradually wider close to the mouth of the tube (campanulate corolla, Fig. 3B, C). Sepals are leaf-like (green, with similar texture to vegetative leavess, resembling bracts), free along most of the length, congenitally connate shortly at base (Fig. 38H-K). Sepals have very unequal size and shape; they thinner at their upper part, and becoming gradually thicker towards their bases. The two outermost lobes are equally large and encompass the other three smaller lobes in most of their length (Fig. 38H-J). Only the distal margins of the two larger sepals are not connate at floral base and are decurrent on the pedicel, forming four wings on it; these wings are vascularized, and thus they could represent bracts congenitally fused to the outer sepals and to the pedicel (see also vascularization below; Fig. 38G-M). Petals are membranaceous, free at their distal region. The apices of petals are rounded, overlapping each other at the uppermost part of the bud (Fig. 38A). Corolla aestivation is slightly oblique cochleate to ascending cochlear. The corolla is monosymmetric since the five blades are unequally distributed, so that the uppermost petal lobe is slightly separated from the other four lobes; also the uppermost petal is slightly larger than the other four (Fig. 38C, 3A, B). At the floral tube region, petals are congenitally connate at their upper level. Lower down, filaments also gradually become congenitally fused to petals: first to the abaxial petals, and lower down also with the adaxial side of petals, forming then a stamen-petal tube (Fig. 38A-E). The androecium is monosymmetric, with some flowers presenting two fertile stamens and five staminodes, three antesepalous, and two antepetalous (Fig. 38B-E). Other flowers may have only four staminodes, three antesepalous, and one antepetalous (Fig. 38F-P). The fertile stamens are located on the posterior side of the flower and are adjacent to the innermost petal. Antepetalous staminodes are in an outer level than the antesepalous ones (Fig. 38B-D). The filaments of staminodes are rounded to dorsiventrally flattened at their free tips (Fig. 38C). Lower down, antepetalous staminodes are congenitally fused to petals and to the adjacent antesepalous staminodes. At the corresponding level, the two anthers are laterally congenitally fused at base to the adjacent antesepalous staminodes; and laterally postgenitally connected with each other, forming a narrower entrance to the floral tube (Figs 3A, 38D-F, 39C, D). Lower down, the filaments of fertile stamens are free from each other, but are still laterally connated to the adjacent staminodes (Fig. 38D). Approximately at their lower third, all stamens are congenitally fused to petals forming a stamen-petal tube (Fig. 38A, E-I). Anthers 
are large (ca. 4,5 mm), basifixed, sagittate. They have a thick connective, and endotheciumlike tissue is continuous over most of the dorsal side of the connective, as well as part of the connective side of thecae. Anthers have one deep ventral furrow between each theca and a shallow dorsal furrow (Fig. 38C). There is an intrastaminal nectary disc, cupular, which encompasses the entire ovary length. Carpels are slightly bulged up on the dorsal side above the level of the base of the style (carpels anacrostylous). The upper dorsal wall are thickened in the bulging region (Fig. 38A). The stigma is five-lobed, with lobes long and narrow and covered by unicellular papillae, except on the concavity at their dorsal side (Fig. 38A, 39F).They are mostly free, except at base, where they become postgenitally fused by their flanks, forming a small furrow in the center of the gynoecium, which soon closes lower down. The style is solid in its entire lenght. At the uppermost part of the ovary, carpels are postgenitally fused at center through the style bases. Immediately below they are free (Fig. $38 \mathrm{~A}, \mathrm{G})$, and this free zone extends until the base of the locules, where they become congenitally fused only at center (Fig. $38 \mathrm{H}$ ). This central union of carpels comprises ca. onefifth the total length of the ovary (Fig. 38A). There is a short gynophore below the locules, which has a commom base with the nectary disc (Fig. 38I). The placentation is marginal (Fig. $38 \mathrm{G})$. The ovules are campylotropous, epitropous. The outer integument is thicker than the inner, and an obturator made of uni- to multicellular papillae and trichomes is seen on the placenta.

The main color of the perianth at anthesis is pink. Scent was not noticed during field work (daytime observation). At anthesis, apparently there is first a male phase, with the tips of staminodes and anthers at the mouth of the corolla tube. Later, apparently during a female phase, anthers separate along this postgenitally connected region and the style grows outside the floral tube, passing between them and making the stigma exserted (see Fig. 3A and also Endress 2010, Fig. 8D, which apparently is upside down). The stigmatic lobes open later in anthesis, suggesting protrandry. The calyx persists during fruit development.

\section{Anatomy}

In their distal parts, sepals have a few small vascular bundles, initially three. Immediately below, where sepals are wider, they have numerous vascular bundles and may have one main vascular bundle, two to four secondary bundles and up to 25 lateral bundles. At their lower fused region, these lateral bundles may merge with the main and secondary bundles, forming 19 larger calyx traces radially arranged around the centre of the floral base, except for the small traces located at the distal margin of the two larger sepals (which enter in 
the four laminar wings on the pedicel, Fig. 38F-I). These traces merge to the pedicel vasculature at lower levels (Fig. 38M, N), and thus are likely to represent the former vasculature of two bracts, congenitally fused to part of the two outer sepals above and to the pedicel. Petals have one main vascular bundle, and up to 30 lateral bundles in their distal region (at the lobes and distal region of the floral tube; Fig. 38C-E). Below they have one vascular bundle and a single vascular trace (Fig. 38F-I). Stamens have one vascular bundle and a single vascular trace (Fig. 38B-J). The vascular bundle of antepetalous staminodes merge with the one of the immediately opposed petal in upper level of the floral tube. The nectary disc presents one ring of phloematic bundles (ca. 30), and at the common base with carpels, one ring of vascular traces composed of xylem and phloem.

In carpel, the five ventral bundles in the stigmatic region form five narrow strips of vascular tissue. Below, at the style level, these bundles become rounded again and extend downwards to the ovary. At the gynophore level the dorsal bundles of carpels merge with the ventral ones, forming a star-shaped central vascular complex surrounded radially by the disc traces (Fig. 38I). Lower down at floral base, the stamen traces merge with part of the disc traces and converge to the central vasculature, followed by the petal traces, which may also merge with part of the disc traces before merging with the central complex. Two to three disc traces converge independently to the central vasculature (Fig. 38J-L). At the level where the calyx traces are arranged radially around the inner floral traces and central vasculature, part of the traces of the larger two sepals form synlaterals with the traces of the smaller inner sepals (Fig. 38J-M). Lower down, these radially arranged calyx traces merge with the central vasculature. The smaller bundles at the distal margin of the two larger sepals run downwards to the pedicel in the four wings of the two putative congenitally fused bracts. These smaller bundles merge with the pedicel vasculature lower down and in different levels (Fig. 38M-P).

\section{Histology}

Lignified and non-lignified unicellular trichomes are present within the floral tube. Dense groups of secretory hairs, each with several short uniseriate stalk and large multicellular head, are present at the inner base of sepals; these hairs are hook to fan-shaped (Fig. 39B). Tanniferous cells are found in all floral organs, forming an extensive tissue in the epidermis of sepals, petals, disc and ovary. They are also present in the outer integument, and in the androecium they occur in the epidermis and in the connective region (Fig. 39C). Secretory cavities with a yellow stained secretion are present in sepals, petals, stamens, disc and carpels (style and ovary region). The mesophyll of sepals has a tissue with large intercellular spaces in its upper part (Fig. 39E). In petals and filaments, this tissue is also 
present, but with larger intercellular spaces (occasionally forming arm-like outgrowths) and along most of their lenght, except closer to the floral base (Fig. 39A). At the base of anthers, these are postgenitally connected by the interlocking of epidermal cells (Fig. 39D). Styloids crystals are present in the sepals, disc and carpels. Small stomata are seen on the upper part of the disc surface.

\section{Ravenia infelix (Figs 3C, D, 40)}

\section{Morphology and aspects of floral biology}

Flowers of this species are monosymmetric. Advanced floral buds are ca. $33 \mathrm{~mm}$ long. They are straight to slightly curved, and the floral tube is straight and wide. Sepals have very unequal size and shape, with the outermost upper larger sepal thick and longitudinally keeled and rugose in the median abaxial region. The second largerst outer sepal is located on lower abaxial position. Sepals have quincuncial aestivation in their lower part; above, the larger upper sepal embraces all other sepal margins. They are free for most of their extent, but congenitally fused lateraly close to the floral base (Figs 3C, 40A, J). Petals are membranaceous, thinner toward their margins. In the distal region of the floral bud, petals are free, and their lobes overlap each other. The corolla aestivation is ascending to slightly oblique cochleate. It is slightly monosymmetric, since the uppermost adaxial petal lobe is slightly larger and separated from the other four lobes (Fig. 3C, D). Below this free region, approximately from the upper quarter to their bases, petals are congenitally connated and form the floral tube. However, only one small antepetalous staminode is congenitally adnate to the corolla tube (Figs 3D, 40A). The androecium is monosymmetric. Some flowers are haplostemonous, with two fertile stamens and three antesepalous staminodes. Other flowers have additionally one antepetalous staminode (four staminodes, three antesepalous, one antepetalous). At their short free distal region, the single antepetalous staminodes are in an outer level than the antesepalous ones. The fertile stamens are located on the posterior side of the flower and are adjacent to the innermost petal. Antesepalous staminodes are free along their entire length, while the filament of the two fertile ones are congenitally fused laterally at their lower half. When present, the single antepetalous staminode is free only at its distal part, becoming congenitally fused to the opposite petals lower down (Figs 3D, 40A). The filaments of fertile stamens are conspiuously wider at their upper part, below their constricted tip (Fig. 40G). At the corresponding level, antesepalous staminodes are also wider. Antesepalous staminodes have an irregular shape at their distal part (Fig. 40E), becoming somewhat 
triangular-shaped and dorsiventrally flattened lower down. The antepetalous staminode is rounded in transection along its short distal part. The filaments of fertile stamens are somewhat triangular and flattened along their entire length, but wider than the staminodes. Anthers are large (ca. $6 \mathrm{~mm}$ long), free, near-basal dorsifixed, sagittate, introrse, versatile (Fig. 3C, D). They have a very thin connective and at their distal part, and an apiculate apex, apparently a connective protrusion. Endothecium-like tissue is continuous over part of the dorsal side of the connective, arranged as a palissade-like layer of cells; also, it is continuous towards the ventral side of the connective. Between the two thecae of an anther there is a deep ventral furrow (Fig. 40B). An intrastaminal nectariferous disc encompasses the entire ovary. It has inflexed tips above the ovary, and is thicker toward its base (Fig. 40A). Carpels are slightly bulged up on the dorsal side above the level of insertion of the style (carpels anacrostylous). The upper dorsal carpel wall is thickened in the bulging region. The stigma is five-lobed, the lobes are wide, slightly papillose, with small unicellular papillae, except on their dorsal concavity below the upper region (Fig. 40C). Below their upper part, the stigma lobes are postgenitally fused at their flanks, and free at center. Close to the style level, the lobes are completely postgenitally fused. The style is solid along its entire length. At the uppermost part of the ovary, carpels are postgenitally fused at center through the style bases. Immediately below, they are free and this free zone extends down to the base of the locules, where these become congenitally fused only at center (Fig. 40A). This central union of carpel bases extends ca. one quarter the total length of the ovary. The placentation is marginal. Ovules are campylotropous, antitropous, with a zig-zag micropyle. The outer integument is thicker than the inner one, and an obturator made of uni- to multicellular papillae and trichomes are present on the placenta (Fig. 39G).

The main colour of the perianth at anthesis is white, contrasting with the large green calyx. The flowers exihibts approach herkogamy. Recently opened flowers present the two anthers exserted releasing pollen (male phase). Later in anthesis, all filaments gradually elongate and curve away from the floral center as the two anthers curve backwards; simultaneously the style elongates to the outside of the floral tube, exposing the wet stigma at the center of the flower and beyond anthers level (female phase, Fig. 40C, D). Floral odor was not noticed during most of daytime, but at the end of the afternoon the flowers started to produce a slightly sweet scent. Moth scales were found attached to mature stigmas with pollen attached; these are putative pollinators of this species. The calyx persists and surrounds the entire fruit during development; their lobes bend over the young carpels just after the senescence of the corolla and stamens, completely enclosing the young fruits, and probably protecting them (Fig. 40C). Additionally, a strong unpleasant smell was noticed from the 
secretion found in the space formed between the inner side of calyx and the young fruit. This secretion is probably produced by the numerous secretory hairs found in the inner base of sepals (see below), as secretion was also observed on them in the histological sections.

\section{Anatomy}

In their distal parts sepals have few small vascular bundles. Immediately below, where sepals are wider, they have numerous lateral vascular bundles and may have one to three main vascular bundles (only the larger upper sepal have three distinct main vascular bundles). At their lower fused region, these lateral bundles may merge, forming larger lateral vascular bundles. At floral base, there are 15 calyx traces. Petals in their distal free parts have one main vascular bundle and several small lateral bundles. At the corolla tube region, these lateral bundles merge forming larger bundles, and then petals may have one main and two lateral vascular bundles at lower levels of the floral tube (Fig. 40A). At floral base, petals have one to three vascular traces. All stamens possess one vascular bundle and a single vascular trace. The antepetalous staminode bundle is located opposite to the main bundle of the adjacent petal in the region where these are adnate to petals; at floral base the antepetalous staminode trace and the trace of the adjacent petal are distinctively apart. The disc has numerous small phloematic bundles along most of its length. At its base, the disc bundles merge, forming larger traces radially arranged around the gynoecium vasculature. These traces have xylem and phloem. In carpel, ca. six to seven small ventral bundles differentiate at the upper region of each stigma lobe, arranged in a V shape in the middle of each lobe (Fig. 40C). At the base of the lobes, these bundles merge, forming narrow a strip of vascular tissue for each carpels. Below, at the style level these bundles become rounded again, and five ventral bundles extend downwards to the ovary. At the base of the ovary locules, the ventral bundles split in the middle and merge with the ventral bundles of adjacent carpels, forming synlaterals close to the floral base. Then the synlaterals converge towards the centre of the flower, while the two dorsal traces are radially arranged around them. Lower down, some of the disc traces may merge with the dorsal traces, while other disc traces merge with stamen traces (with the antesepalous and antepetalous stamen traces). Lower down first the trace complexes of disc plus dorsal carpel traces and dorsal carpel traces alone converge to the center of the flower and merge with the ventral traces of carpels. These are followed lower down by the trace complexes of stamen plus disc, forming a central vascular complex. Other disc traces, located closer to the petal traces, may merge with them. Lower down the trace complex of petal plus disc and petals trace merge with calyx traces immediately opposite them. 


\section{Histology}

Lignified and non-lignified unicellular to bicellular hairs are present in the upper part of petals and in most of the filaments length. In the filaments these hairs are denser below the constricted tips of filaments, where they are wider (Fig. 40G). Some of these hairs are filled with tannins. Dense groups of secretory hairs with short uniseriate stalk and large multicellular heads, club-shaped, are present at the inner base of sepals (Fig. 40I). These trichomes are also present on the ovary, but much more rarely observed. Tanniferous cells are present in all floral organs. Cells filled with a blue-stained secretion (probably mucilage) are present in the calyx, petals, filament, stigma, style, and in the outer integument (Fig. 40D, E). Secretory cavities are present in sepals, petals, stamens and carpels (numerous at the top of the ovary, Fig. 40C). The sepals have at their base large intercellular spaces in the mesophyll. In the upper level of petals and staminodes, this tissue is also present, but with larger intercellular spaces, occasionally forming arm-like outgrowths (Fig. 40D, E). Styloid crystals are found in sepals, filaments, disc and ovary (Fig. 40F). Druses are present in the disc. Small stomata are seen on the upper part of the disc surface. The epidermal cells of anthers are rounded, but shortly papillose close to the stomium region. In the apiculate apex of anthers there is a hollow cavity in the connective region, probably secretory (Fig. 40B). 


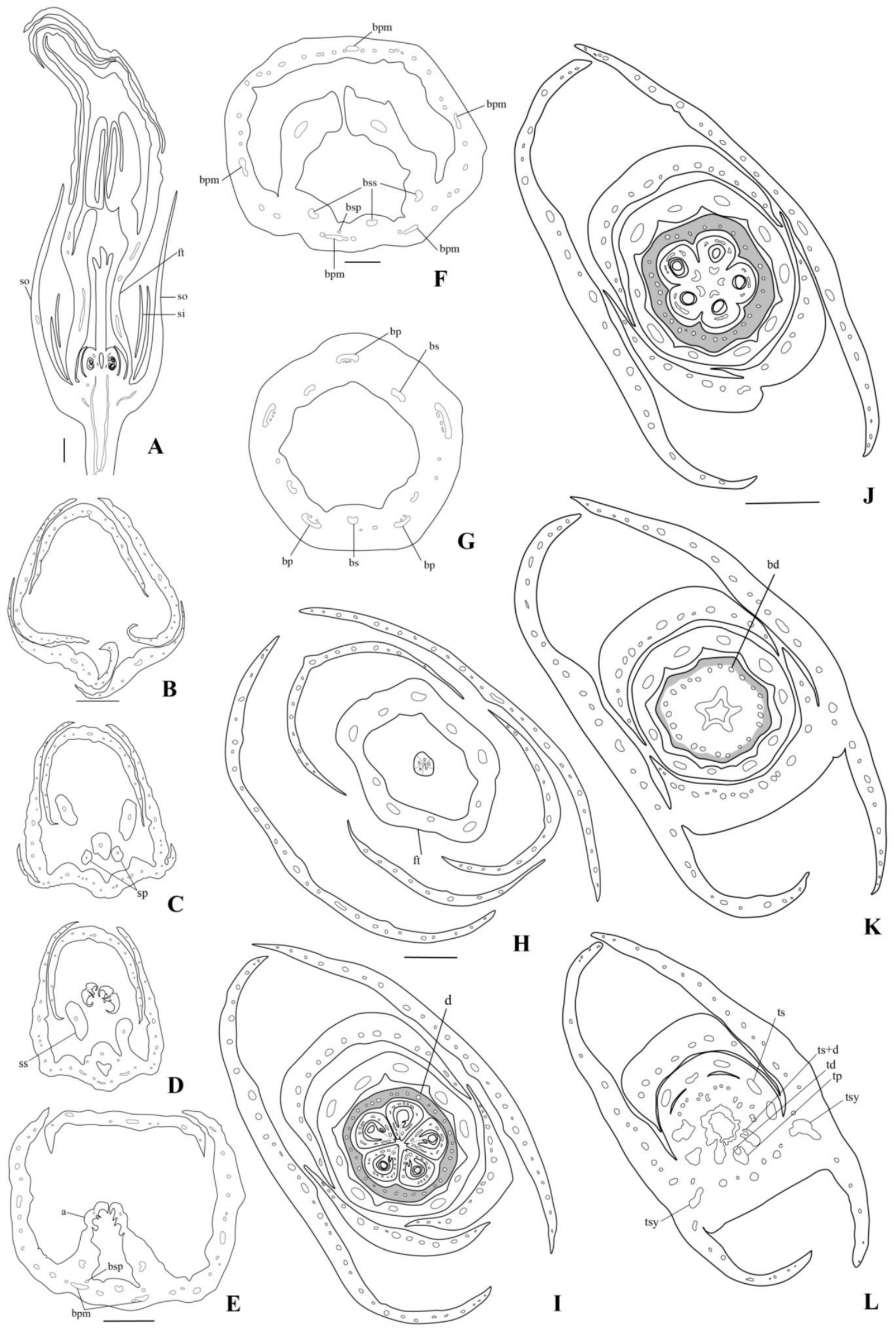




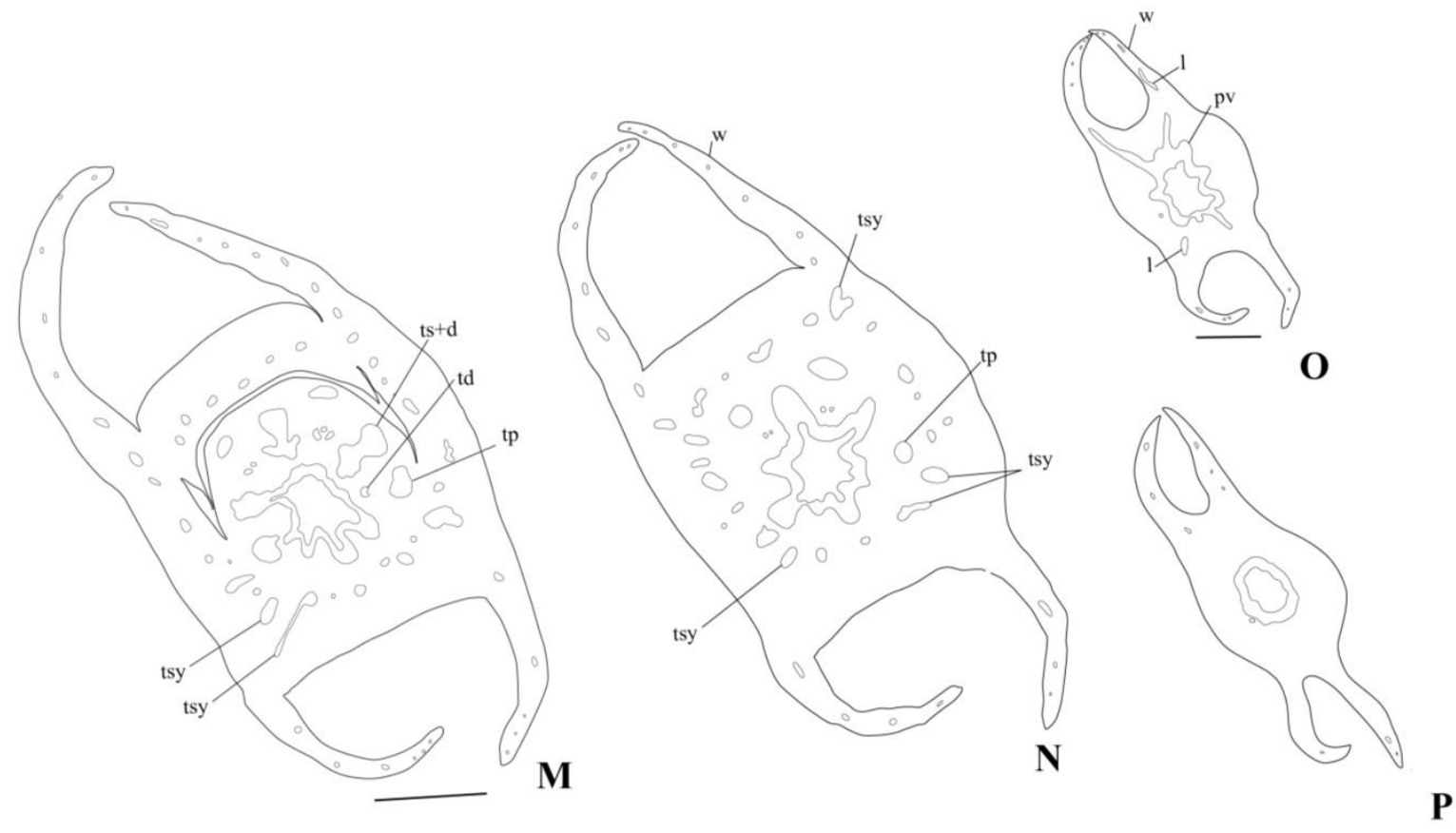

Figure 38: Ravenia spectabilis. Sections of floral buds. (A) Longisection. (B-P) Transections: successive levels, from the top, downward. Morphological surfaces indicated by thicker continuous lines, vasculature by thinner continuous lines; postgenitally fused areas indicated by broken line; nectariferous tissue, light gray (in the longitudinal section, only morphological surfaces and vascularization are represented). (B) Distal region of petals. (C) Upper level of staminodes (antepetalous and antesepalous). (D) Mid-level of anthers. (E) Lower level of anthers. (F) Uppermost level filament of fertile stamens. (G) Upper level of stamen-petal tube. (H) Upper region of calyx. (I) Mid-level of ovary. (J) Lower level of ovary, congenitally fused at centre. (K) Level of common base of carpels plus nectary disc (L, M). Levels of synlateral traces of calyx, and trace complex of stamen plus disc. $(\mathrm{N})$ Level of calyx traces radially arranged around the central vascular complex (O-P) Level of the winged pedicel. (O) Three lateral traces from the putatively fused bract entering the pedicel vasculature. $(\mathrm{P})$ Pedicel vasculature and remainder lateral traces of the winged pedicel. Abbreviations: a, anther; bd, vascular bundle of disc; bp, vascular bundle of petal; bpm, main vascular bundle of petal; bs, vascular bundle of stamen; bps, vascular bundle of antepetalous staminode; bss, vascular bundle of antesepalous staminodes; d, disc; $\mathrm{ft}$ floral tube; 1 , lateral traces of the winged pedicel; pv, pedicel vasculature; so, outer larger sepal; si, inner smaller sepal; sp, antepetalous stamen; ss, antesepalous stamen; td, trace of disc; tp, trace of petal; ts, trace of stamen; ts $+d$, trace complex of stamen plus disc; tsy, synlateral traces of the calyx; $w$, winged pedicel. Scale bars: $(A, C-M)=1 \mathrm{~mm} ;(B)=2 \mathrm{~mm}$. 

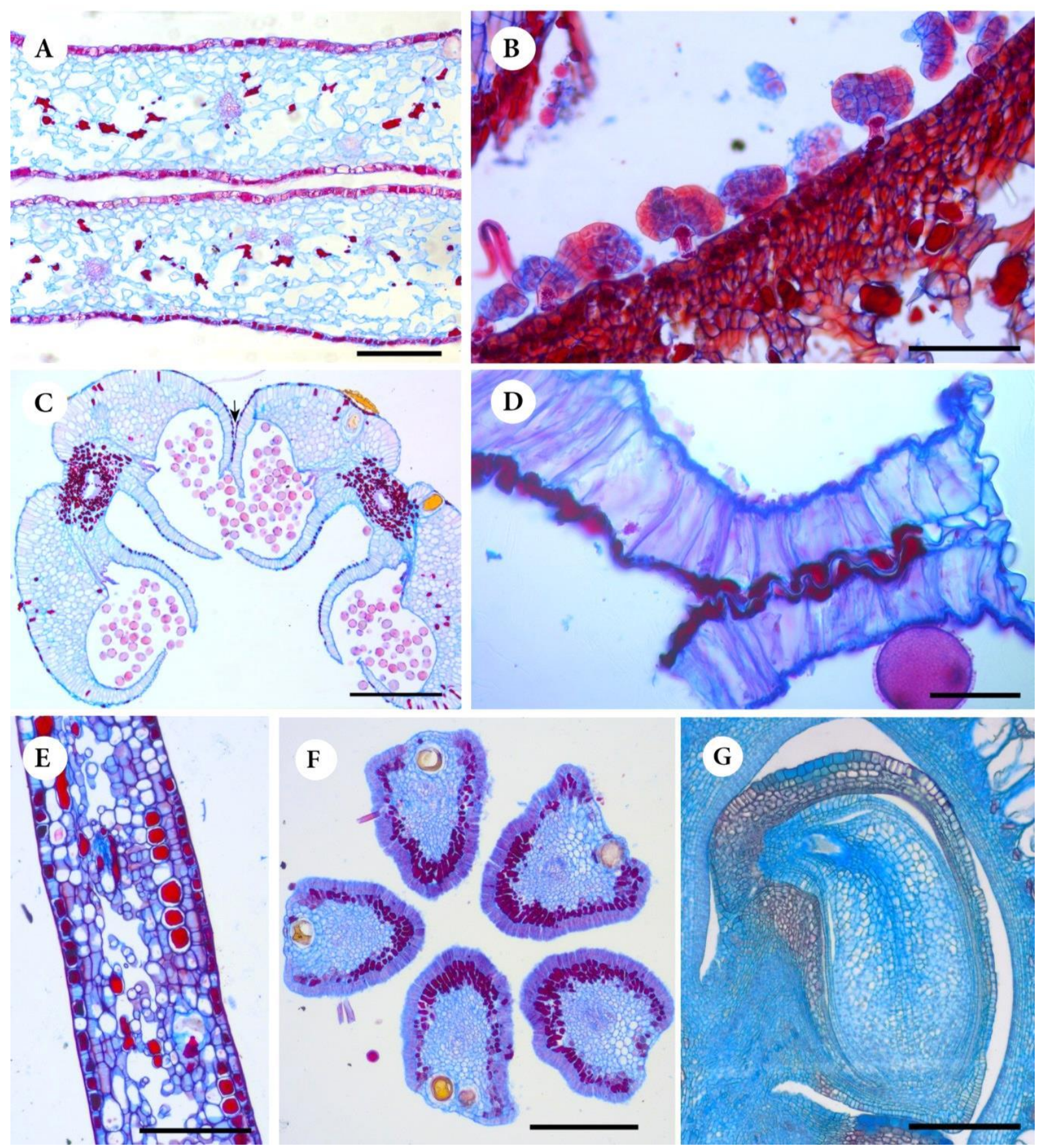

Figure 39: Photomicrographs of microtome sections of floral buds of Ravenia spectabilis (A-F) and $R$. infelix (G). (A, C-F) Transections. (B, G) Longisection. (A) Detail of petals, with large intercellular spaces in the mesophyll. (B) Detail of sepals, with fan-shaped secretory hairs; (C) Two anthers, laterally postgenitally connected (arrow). (D) Detail of the region indicated in C, showing interlocked papillae. (E) Detail of sepals, with large intercellular spaces in the mesophyll. (F) Stigmatic lobes (arrowhead indicates the dorsal area without papillae). (G) Campylotropous ovule. Scale bars: (A, E$\mathrm{G})=200 \mu \mathrm{m} ;(\mathrm{B})=100 \mu \mathrm{m} ;(\mathrm{C})=500 \mu \mathrm{m} ;(\mathrm{D})=50 \mu \mathrm{m}$. 

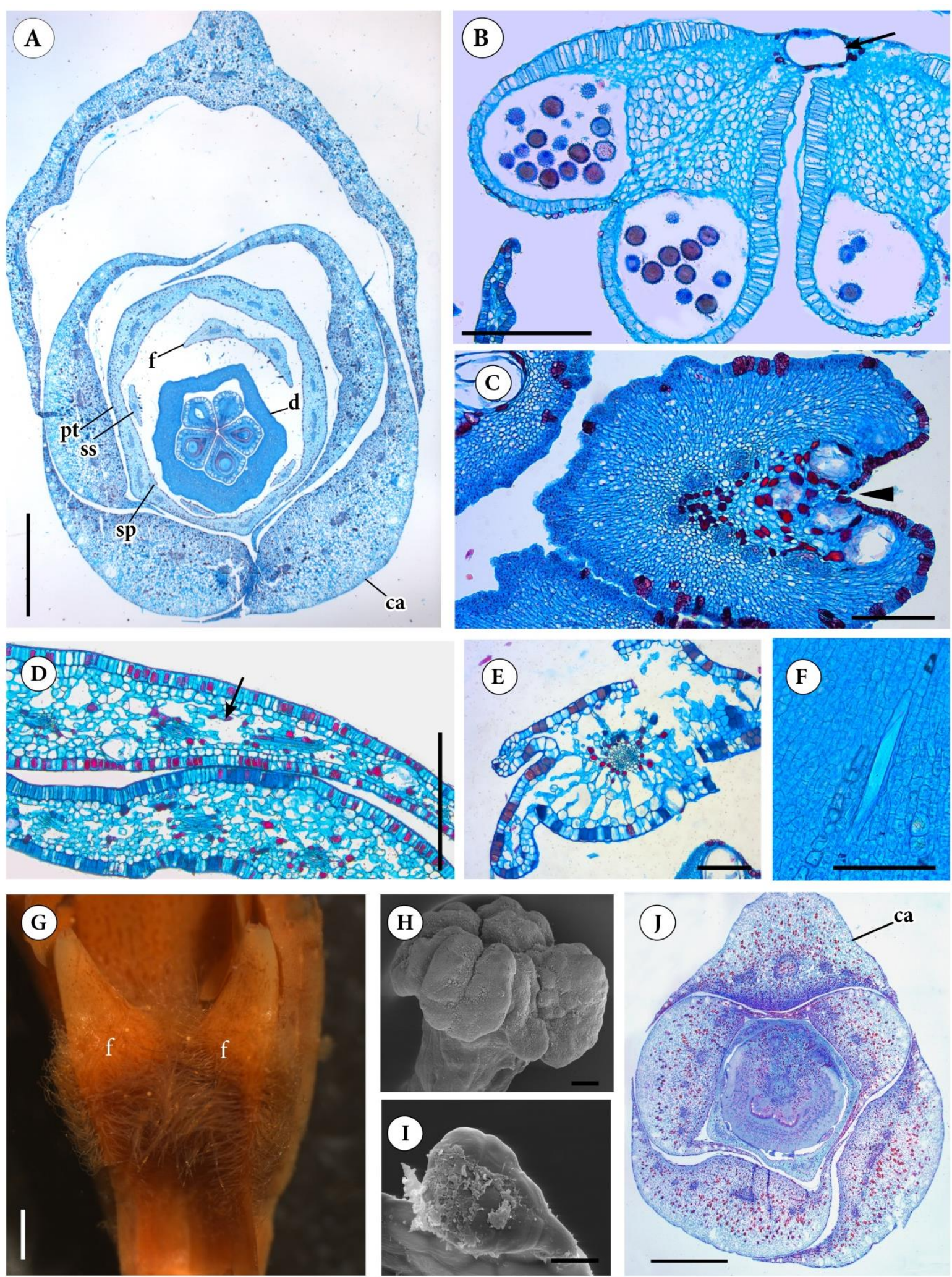

Figure 40: Ravenia infelix. (A-F, J) Photomicrographs of microtome transections of floral buds. (A) Mid-level of calyx and lower level of petal tube (note small antepetalous staminode adnate to petals). (B) Upper region of anthers, with a hollow cavity in the apiculate apex (arrow). (C) One stigmatic lobe (arrowhead indicate dorsal concavity without papillae). (D-E) Detail of petals (D) and staminode (E), with large intercellular spaces in the mesophyll (arrow). (F) Styloids cristals in the disc. (G) Photograph of filament of fertile stamens, with a tuft of hairs below their constricted tips. (H-I) SEM micrographs. (H) Stigmatic region. (I) Secretory trichome, with large multicellular head. (J) Quincuncial aestivation of the calyx, close to its base. Abbreviations: ca, calyx; d, disc; f, filament of fertile stamens; pt, petal tube; sp, antepetalous staminode; ss, antesepalous staminode. $(A, J)=2 \mathrm{~mm}$; $(\mathrm{B})=500 \mu \mathrm{m} ;(\mathrm{C}, \mathrm{E}, \mathrm{H})=200 \mu \mathrm{m} ;(\mathrm{F})=100 \mu \mathrm{m} ;(\mathrm{G})=1 \mathrm{~mm} ;(\mathrm{I})=20 \mu \mathrm{m}$. 


\section{Sigmatanthus trifoliatus (Figs 3E, 41, 42, 43A-F)}

\section{Morphology and aspects of floral biology}

The flowers of Sigmatanthus are strongly monosymmetric. The flower buds are ca. 36 $\mathrm{mm}$ long. The floral bud is strongly curved approximately at its lower third in advanced buds, forming a somewhat sigmoidal curvature. Sepals have five large triangular lobes at the upper part, with open aestivation in advanced buds (Figs. 3E, 41A). At base, sepals are congenitally connate (Fig. 41H, I, L). Petals are stiff and the corolla is strongly monosymmetric, since petals are unequally distributed so that a bilabiate corolla is formed. There is one petal in the upper lip and four in the lower lip at anthesis. The petals become reflexed at the level of the sigmoidal curvature in bud (Fig. 3E). Below, the floral tube is straight, formed along most of its length by the congenital adnation of the staminal filaments to the petals (Fig. 41G-K). Only at the uppermost part of the tube is it formed partially by the coherence of petals and adherence of petals to filaments by intertwining trichomes (Fig. 42D). In the distal region of the floral bud, petals overlap each other (Fig. 41B). They have rounded tips. Corolla aestivation is ascending cochlear in their free upper parts (Fig. 41B-F). The androecium is monosymmetric, with two fertile antesepalous stamens and five staminodes, three antesepalous, and two antepetalous. The fertile stamens are located on the posterior side of the flower and are adjacent to the innermost petal (Figs 3E, 41C, D). Anthers have long basal appendages, which are one sterile prolongation from both thecae bases. The basal appendage of adjacent anthers are postgenitally connected laterally through their striate cuticular projections (Figs 41F, 42F). Antepetalous staminodes in the uppermost level are placed between the ventral pollen sacs of anthers and the inner side of antesepalous staminodes. Lower down, antepetalous staminodes are placed more or less at the same level as the antesepalous staminodes, and lower down slightly at an outer level. Immediately below, the two antepetalous staminodes become congenitally fused to the immediatelly opposite petals (Fig. 41C-E). In their upper part, all staminodes are somewhat rounded. Lower down, they gradually become wider and dorsiventrally flattened at the base of their free tips. Filaments of fertile stamens are wider than the staminodes, also flattened, constricted at their tips (Figs 41C-F, 42A). At the floral tube level, filaments of fertile stamens and staminodes are congenitally connate and adnate to the petals on different levels. This begins with the adnation

of the two antepetalous stamens to petals, and proceeds to their lateral connation to the adjacent antesepalous staminodes (Figs 41E-F, 42D). Lower down, the complete adnation of antesepalous staminodes and fertile stamens to petals proceeds from the anterior part of the tube to their posterior side (Fig. 41G-H). Anthers are large (ca. $8 \mathrm{~mm}$ long), near-basal 
dorsifixed. They are sterile above the region of filament attachment and also below in their sterile basal appendages (Figs 41A, E, F, 42A). They are polysporangiate with ca. 23 to 28 sporangia, separated by several transverse septa (Figs 41A, 42A). They are sagittate, introrse, caducous. Anthers have a mid-thick connective and the endothecium-like tissue is continuous over part of the dorsal and ventral side of the connective (Fig. 43D). Between the two thecae of each anther there is one deep ventral furrow (Fig. 41C). There is an intrastaminal nectariferous cupular disc, which encompasses the ovary along almost its entire length; the disc is thicker toward its base. Carpels slightly bulge up on the dorsal side above the level of insertion of the style (carpels anacrostylous). The upper dorsal wall are thickened in the bulging region (Fig. 41A). The style is curved towards the anterior side of the flower. The stigma has five short lobes unequal in size so that all face the anteiror side of the bud. The surface of the stigma is rugose, slightly papillose, with short unicellular papillae (ca. $20 \mu \mathrm{m}$ ). The lobes are postgenitally connected at flanks forming a small furrow at the center (Figs 41D, 43B). The style is solid in most of its length. At the uppermost level of ovary, carpels are united through the style base, which has a small furrow at its centre on this level (Fig. 42C). Lower down, at the upper level of ovary locules, carpels are postgenitally united at the innermost part of their flanks, but not at centre (Fig. 41H). Immediately below, carpels are completely free, and this free zone extends down to the base of the locules, where carpels become congenitally fused at centre and also at the flanks. This zone of central congenital union comprises approximately one-fifth the total length of the ovary (Fig. 41A, I, J). There is a short gynophore below the locules, which has a short common base with the nectary (Fig. $41 \mathrm{~K}, \mathrm{~L})$. The placentation is marginal (Fig. 41H). Ovules are antitropous, with the outer integument thicker then the inner oneAn obturator made of uni- to multicellular papillae and trichomes is found on the placenta and funiculus (Fig. 43A).

The main color of the perianth at anthesis is light pink. Scent was not noticed during field work (during daytime). After anthesis, the tips of the staminodes are far exserted from the floral tube, while the anthers are closer to the mouth of the tube, which appears to drop-off later. Apparently the flowers present approach-hercogamy, since the analyzed flowers have a much longer style than the filaments of fertile stamens (Fig. 3D). Sepals persist during fruit development.

\section{Anatomy}

Sepals have one main vascular bundle and may have up to twelve lateral bundles at the level of the free lobes. In the congenitally united region, these lateral bundles may merge, forming 42 lateral bundles (Fig. 41H, I, L). At the lowermost level of the floral base ten calyx 
traces are present (Fig. 41O, P). Petals have one main vascular bundle and up to 13 lateral vascular bundles at their distal free parts (Fig. 41B-E). Lower down, these lateral bundles merge, and at the basal region of the floral tube, petals have two to four lateral bundles (Fig. $41 \mathrm{~J}, \mathrm{~K})$. At the floral base, the lateral bundles merge with the main bundle, forming one single petal trace (Fig. 41L, M). Antesepalous and antepetalous stamens have one vascular bundle and a single vascular trace. At the floral tube region the vascular bundles of antepetalous stamens are located very close to the main vascular bundle of the immediately opposite petals, but more or less at the same level to the antesepalous stamens. Antesepalous and antepetalous staminodes traces are located more or less at the same level at the floral base (Fig. 41C-N). The disc has numerous small phloematic bundles along most of its length (Fig. 43C). At its base, the bundles toward the periphery merge, forming numerous larger disc traces. These traces are radially arranged around the carpel traces at the floral base, and are composed of xylem and phloem (Fig. 41M). In carpel, five narrow strips of vascular tissue differentiate at the base of the stigmatic region (Fig. 41D). These strips enlarge lower down and form the five ventral bundles. At the gynophore level, the ventral bundles of carpels converge towards the gynoecium centre, forming a star-shaped central vascular complex. Then the dorsal and additional lateral traces of carpels become radially arranged around this central vasculature, as well as the disc traces in an outer level (Fig. 41K, L). Lower down, the disc traces in the inner level of the flora base merge with the carpel traces, while others located in outer level merge with the stamen traces (antepetalous and antesepalous traces; Fig. 41L, M). The petal traces immediately opposite the trace complex of disc plus antepetalous staminodes merge with them, forming larger trace complexes (Fig. 41N); lower down, other petal traces form complexes with the disc traces (Fig. 41O). The disc plus carpel trace complexes merge to the central vasculature, followed by other trace complexes (antesepalous stamens plus disc trace complexes, e petal plus antepetalous stamens plus disc trace complexes, and the petals plus disc trace complexes). Finally the ten calyx traces merge to the central vascular complex forming the pedicel vasculature (Fig. 41N-P).

\section{Histology}

Lignified unicellular trichomes are present on the calyx, petals and filaments (Fig. 42D). Dense groups of stipitate secretory hairs are found over the entire surface of petals and filament/staminodes. These trichomes have a long uniseriate stalk and a multicellular head (Fig. 43E, F). Also, secretory hairs with short unicellular stalk and multicellular head occur on the ovary (Fig. 43C). Tanniferous cells are present in the mesophyll of all floral organs, forming an extensive tissue in the connective and in the epidermis disc, and anthers. Secretory 
cavities are found in sepals, petals, and ovary (Figs 42A, C, E, 43A-E). Raphides occur in petals, filaments, disc, style and ovary. Small stomata are seen on the upper part of the disc surface. The epidermal cells of anthers are tabulate (Fig. 43D). 


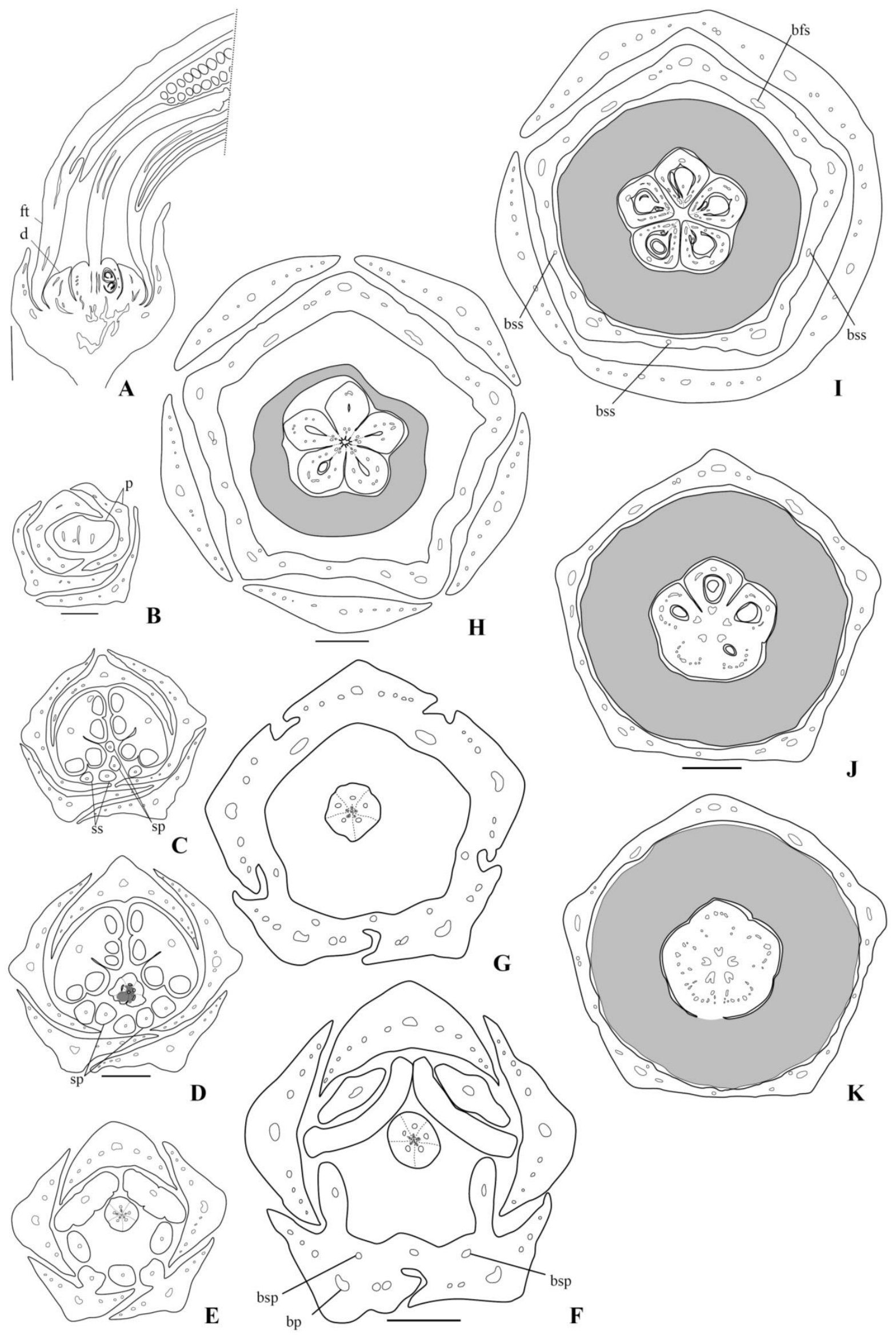




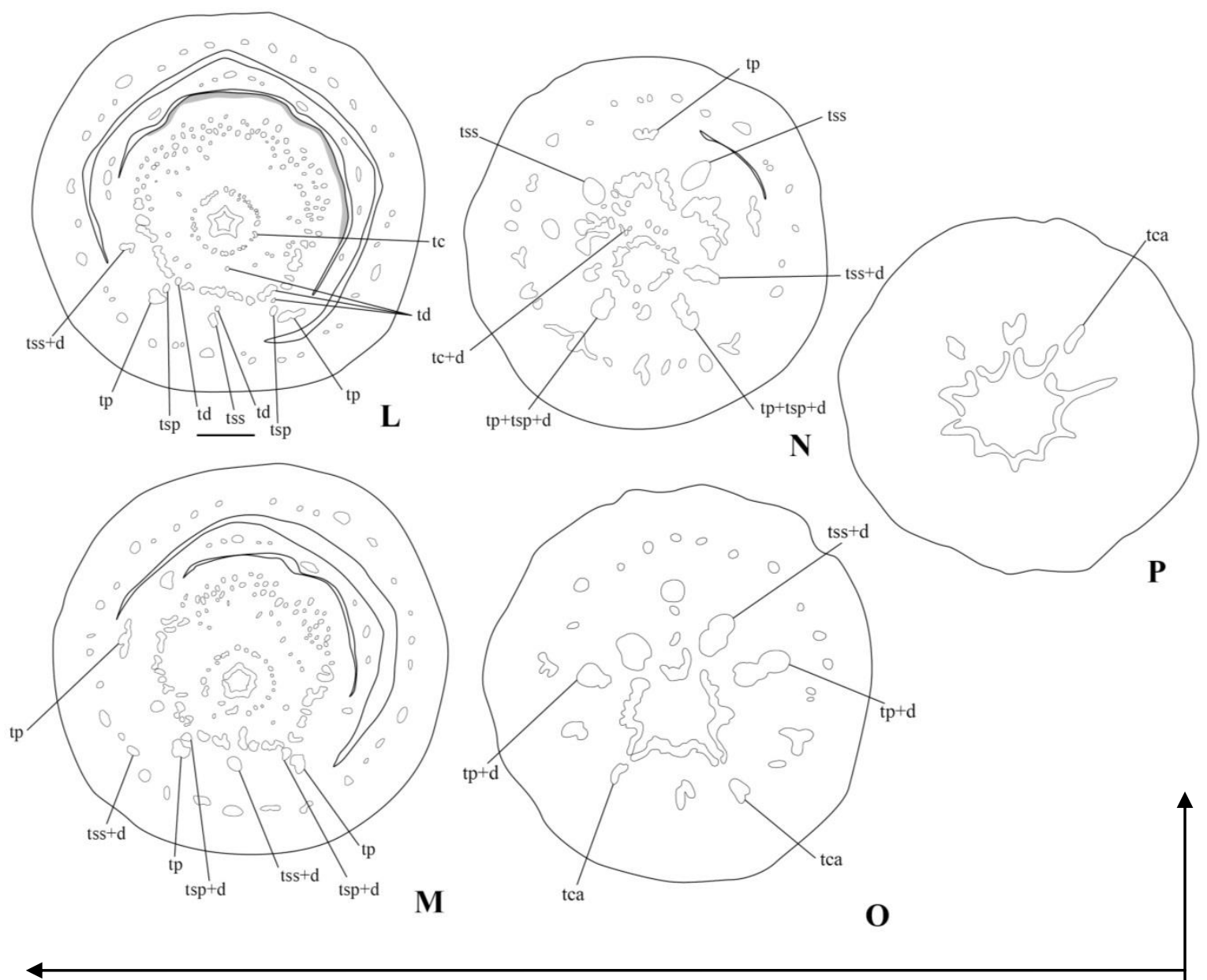

Figure 41: Sigmatanthus trifoliatus. Sections of floral buds. (A) Longisection. (B-P) Transections: successive levels, from the top, downward. Morphological surface indicated by thicker continuous lines, vasculature by thinner continuous lines; postgenitally fused areas indicated by broken lines; pollen tube transmitting tissue (PTTT), dark grey; nectariferous tissue, light gray (in the longitudinal section, only morphological surfaces and vascularization are represented). (B) Distal region of the bud (Uppermost level of petals). (C) Distal region of staminodes. (D) Lower level of the stigmatic region. (E) Level of sterile bases of anthers. (F) Level of sterile basal appendages of thecae. (G) Upper level of the congenitally fused floral tube. (H) Upper level of ovary. (I) Mid-level of ovary. (J) Lower level of ovary (calyx not represented). (K) Gynophore level (calyx not represented). (L) Level of common bases of nectary and carpels. (M) Level of trace complexes of antepetalous stamen plus disc, and antesepalous stamen plus disc. (N) Level of carpel and disc traces merging with the central vasculature of floral base. (O) Level of larger calyx traces. (P) Lowermost levels of floral base and pedicel vasculature. Abbreviations: bfs, vascular bundle of fertile stamen; bp, main vascular bundle of petal; bsp, vascular bundle of antepetalous staminode; bss, vascular bundle of antesepalous staminode; d, disc; f, filaments; ft, floral tube; p, petal; sp, antepetalous staminode; ss, antesepalous staminode; tc $+\mathrm{d}$, trace complex of dorsal carpels traces plus disc; tca, trace of calyx; tc, trace of carpels (dorsal and lateral traces); td, trace of disc; tp, trace of petal; tss, trace of antesepalous stamen; tsp, trace complex of antepetalous stamen; tss+ d, trace complex of antesepalous stamen plus disc; tsp $+\mathrm{d}$, trace complex of antepetalous stamen plus disc; tp+td, trace complex of petal plus disc; tp+tsp+td, trace complex of petals plus antepetalous stamen plus disc. Scale bars: $(\mathrm{A}-\mathrm{M})=1 \mathrm{~mm}$. 

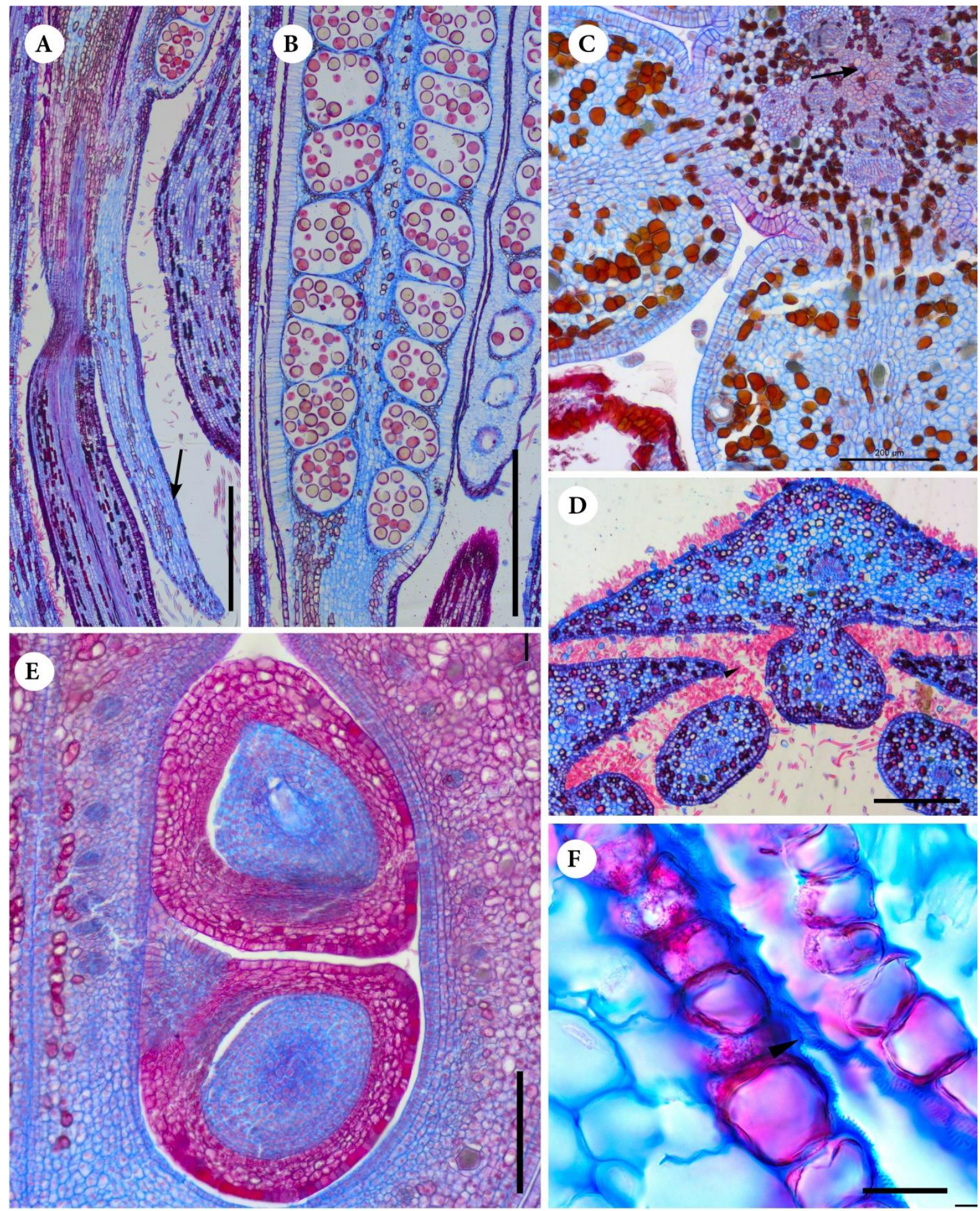

Figure 42: Photomicrographs of microtome sections of floral buds of Sigmatanthus trifoliatus. (A, B, E) Longisection. (C, D, F) Transections. (A) Detail of the base of one anther (arrow in the basal appendage of thecae). (B) Detail of the lower half of one polysporangiate anther. (C) Detail of the base of the style (arrow at the central canal), and ovaries dorsally bulged up. (D) Detail of the uppermost level of the floral tube, showing the intertwining trichomes in petals and filaments (arrowhead). (E) Detail of one carpel, with two superimposed ovules. (F) Detail of adjacent basal appendage of thecae, at the region where these are postgenitally connected laterally by interdentations of their striate cuticular projections (arrowhead). Scale bars: $(A, B)=1 \mathrm{~mm} ;(C, E)=200 \mu \mathrm{m} ;(D)=500 \mu \mathrm{m} ;(F)=20$ $\mu \mathrm{m}$. 


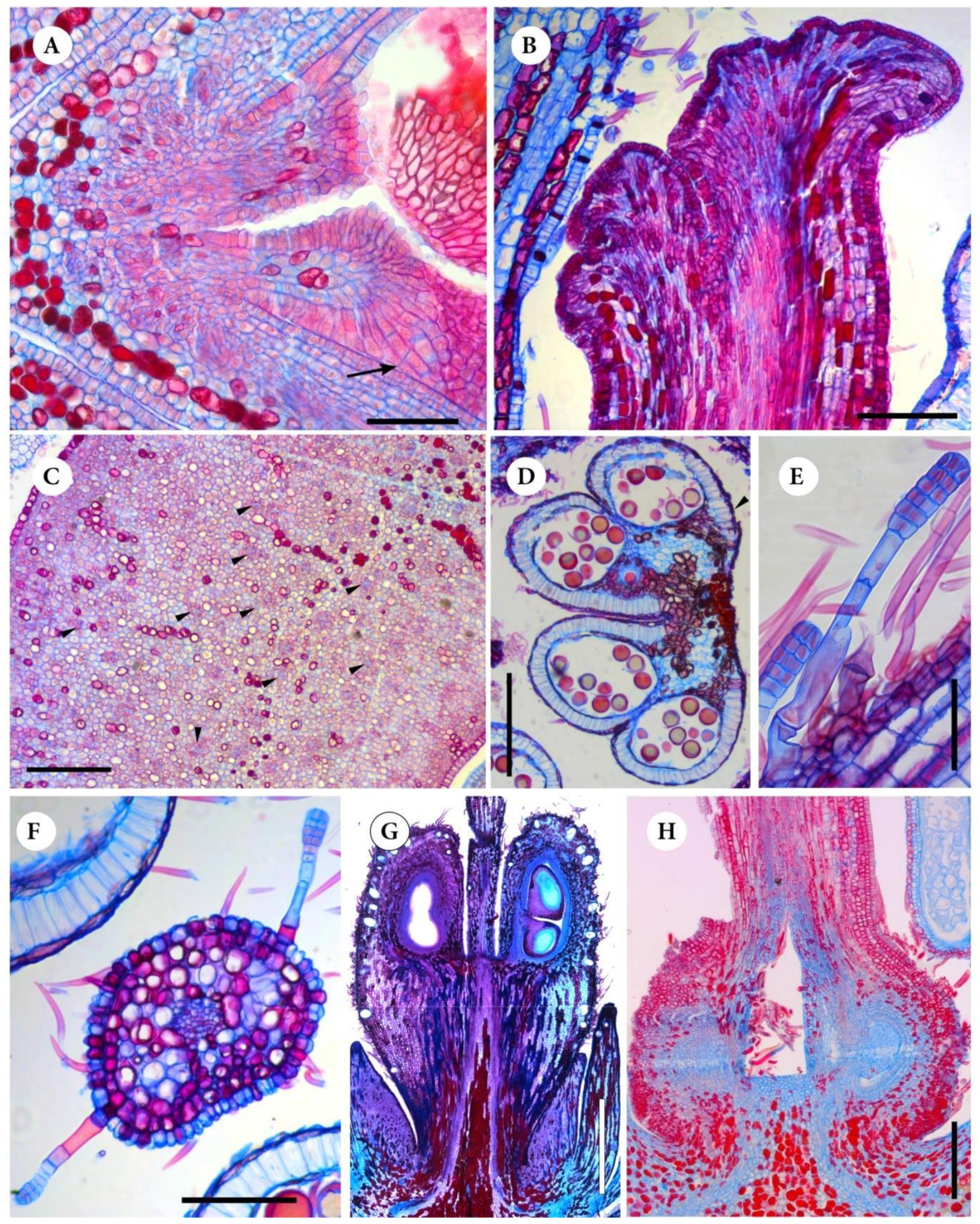

Figure 43: Photomicrographs of microtome sections of floral buds of Sigmatanthus trifoliatus (A-F) and Spiranthera odoratissima (G, H). (A, C, D, F) Transections. (B, E, G, H) Longisection. (A) Detail of the papillae and trichomes (arrow) on the placenta. (B) Detail of the stigmatic region. (C) Detail of the nectary disc (arrow in the small phloematic bundles). (D) Detail of one anther (arrow indicates the endothecium-like tissue continuous over part of the dorsal side of the connective). (E-F) Detail of stipitate secretory hairs on petal (E) and filaments (F). S. odoratissima (G-H). (G) Advanced carpels, with gynophore elongating. (H) Young carpels. Scale bars: $(A, E)=100 \mu \mathrm{m} ;(B, C, F, H)=200 \mu \mathrm{m}$; (D) $=500 \mu \mathrm{m} ;(\mathrm{G})=250 \mu \mathrm{m}$ 


\section{Spiranthera odoratissima (Figs. 3F, G, 43G, H, 43G, H, 44-46)}

\section{Morphology and aspect of floral biology}

Most of the transverse section series of this species was damaged due to the herbivory of the inner parts of the floral buds sectioned, and also due to large amounts of secretory tissue. Thus the structural description is only partially presented below (the anatomical and some morphological features are missing).

These flowers have a polysymmetrical calyx and corolla, and are weak monosymmetrical at the pollination organs, due to upward curvature of the style at anthesis. Flowers are haplostemonous and advanced floral buds are ca. $40 \mathrm{~mm}$ long (Fig. 3F, G). Sepals form five triangular lobes on the upper part of calyx, with open aestivation. Below, sepals are connated, thinner towards their congenitally fused margins (Fig. 44D). Petals are stiff, free, and completely deflexed at anthesis, exposing the floral centre and the pollination organs. Corolla aestivation is ascending cochlear along most of its length, but at base the petals may be valvate to slightly open (Fig. 44C, D). Petals overlap each other at the uppermost part of the floral bud (Fig. 44 B). Transverse sections of the distal part of the corolla show that the middle abaxial region of petals is longitudinally thicker, forming a ridge-like protuberance. This protuberance is larger and narrower from its uppermost part, gradually decreasing in size close to petal base (Fig. 44C, D). The androecium is polysymmetric, with five fertile stamens. Filaments are rounded to polygonal at their bases, as seen in transverse sections (Figs 44D, 45A). They are constricted towards their tips. Anthers are very large (ca. $7 \mathrm{~mm}$ long), near-basal dorsifixed, sagittate, and versatile. Between the two thecae of each anther there is one ventral furrow (Fig. 44B, C). An endothecium-like tissue is broadly developed at the connective side of thecae. There is an intrastaminal nectariferous cupular disc, which encompasses the lower region of the gynophore. It grows after all floral organs are already formed (Fig. 43G, H). The disc is thicker towards its base (abruptly thicker approxymately at its lower half, Fig. 44A); and at its base it occupies part of the free space in front of petals, forming a five-ondulate ring, as seen in transections (Fig. 45 A). Carpels bulge up on the dorsal side above the level of the base of the style (carpels anacrostylous). The upper dorsal carpel walls are thickened at the bulging region (Fig. 44A). The stigma has five short rounded lobes, covered by short unicellular papillae (ca. $25 \mu \mathrm{m}$ long). In advanced buds the stigma is covered by secretion (wet stigma, Figs 45B, 46I). Carpels are mostly apocarpous, postgenitally fused along the style (Figs $43 \mathrm{H}, 46 \mathrm{~F}, \mathrm{G}$ ), and with no postgenital fusion apparent at the ovary region (Figs 44A, 45D). At base, carpels are united into a long 
gynophore, obconically-shaped. The gynophore elongates late in development, reaching approximately $3 \mathrm{~mm}$ in mature buds (Figs 43G- H, 44A, 46G- H). The placentation is marginal (Fig. 43G). Ovules are antitropous. A zig-zag micropyle was observed in one of the upper ovules. The outer integument is thicker than the inner one. An obturator made of uni- to multicellular papillae and trichomes is observed on the placenta and funicullus (Fig. 43B, Fig. 45D, E).

The main colour of perianth at anthesis is cream. Floral odour is strong and sweet scented. Copious nectar production was observed at night; the nectar accumulates at the base of the flower, in the free space between the nectary disc and gynophore, and between the disc and petals/ filaments. Also, nectar accumulates as droplets at the upper part of the gynoecium and at the base of petals, since the flowers were not being visited in the observed nocturnal period. Only nectar and pollen thieves were observed visiting flowers (microlepidoptera at night and bees during the day). According to Silva \& Santos (2008) generalist beetles, bees and antsvisit the flowers of this species during the day. Occasionally bees could pollinate the flowers. However, it is more likely that moths and/or bats also pollinate $S$. odoratissima, since it shows crepuscular anthesis and other floral features that suggest the occurrence of nocturnal pollination. But this was not yet observed in field studies.

\section{Histology}

Calyx, petals, filaments and carpels have uni- to bicellular lignified trichomes; some of them may also be tanniferous trichomes, or filled with an orange-stained or blue-stained secretion (Fig. 45C, D, Fig. 44 G). These trichomes may intertwine on petal margins, however no postgenital coherence between petals is maintained after anthesis (Fig. 45F). Tanniferous cells are dispersed in all floral organs, forming an extensive tissue in the calyx, distal part of petals, epidermis of the disc, connective of anthers, ovary, outer integument and gynophore (Fig. 45B-F, Fig. 43G). Also secretory cells filled with blue-stained secretion (probably mucilage cells) are present in petals, epidermis of the disc, style, ovary, outer integument and gynophore (Fig. 45F, Fig. 43B). Additionally, some secretory cells filled with a dark-stained secretion are present in the style. Secretory cavities are present in the calyx, petals, stamens, style, disc and ovary (Fig. 45A, C, D). Stomata are present on the nectary disc, individually or in small groups close to the inner base of the disc (Fig. 46A). Multicellular glandular trichomes are observed on carpels. The epidermis of anthers has tabular cells. Druses or raphides are not found. 

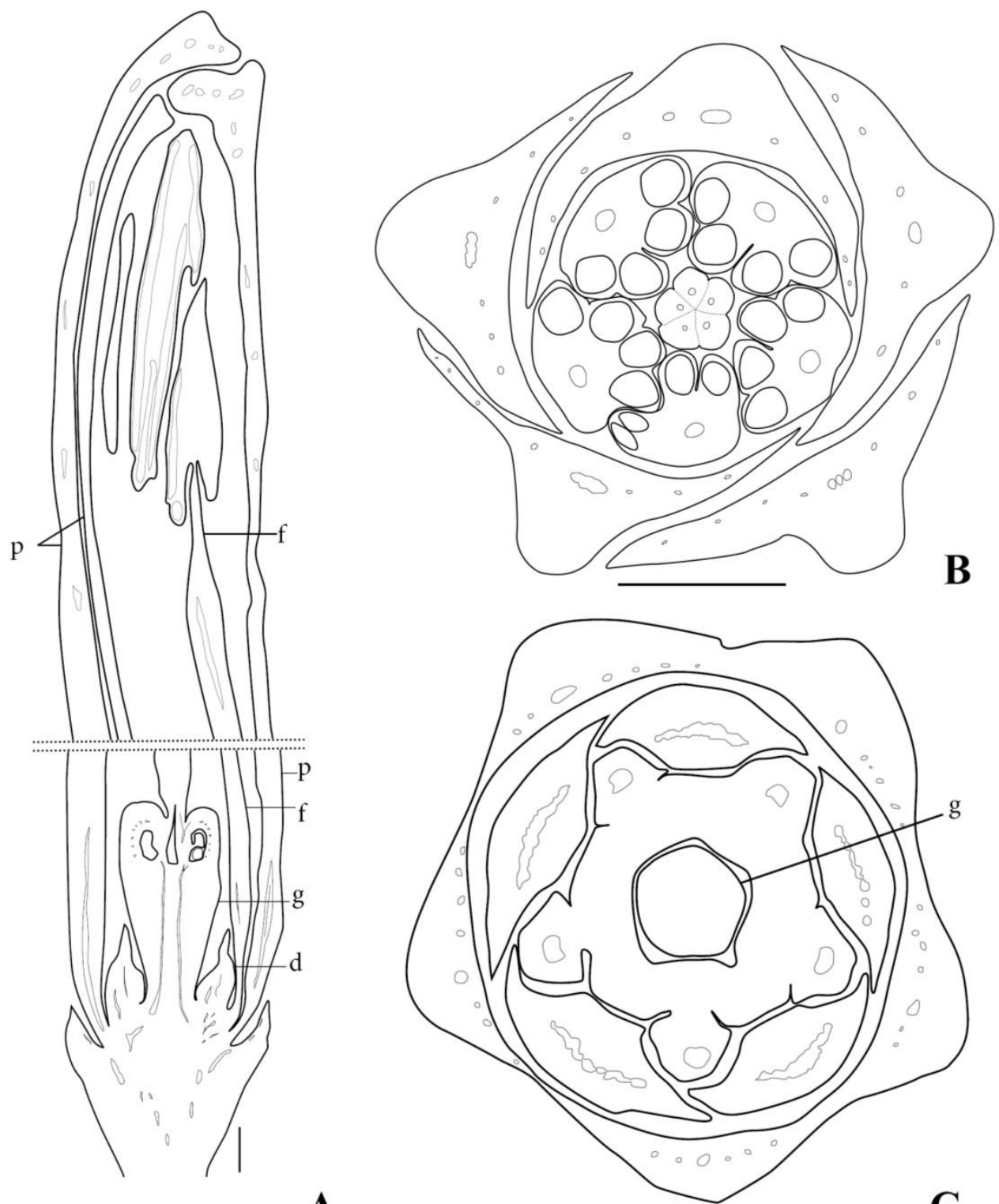

A

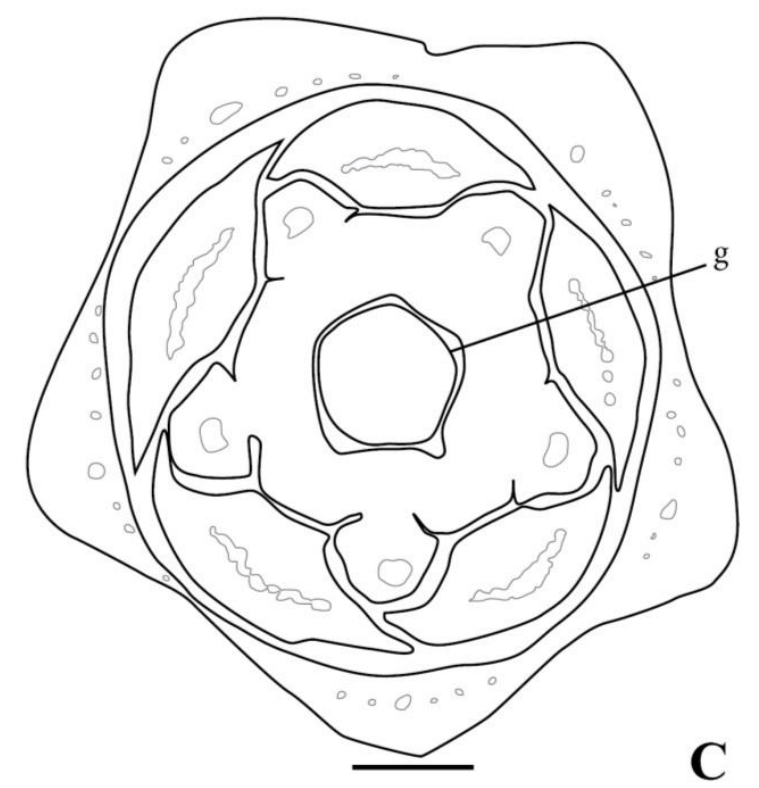

Figure 44: Spiranthera odoratissima. Sections of floral buds. (A) Longisections. (B-C) Transections. Morphological surface indicated by thicker continuous lines, vasculature by thinner continuous lines; postgenitally fused areas indicated by broken lines. (A) Upper and lower part of floral bud (style not represented in the upper region of the floral bud; median region of the bud not represented); dotted lines indicate the limits of the upper and lower part represented. (B) Approximately mid-level of anthers. (C) Level of the gynophore, note common base of filament and disc. Abbreviations: $d$, disc; $f$, filament; g, gynophore; p, petal. Scale bars: $(A-B)=1 \mathrm{~mm} ;(C)=500 \mu \mathrm{m}$. 

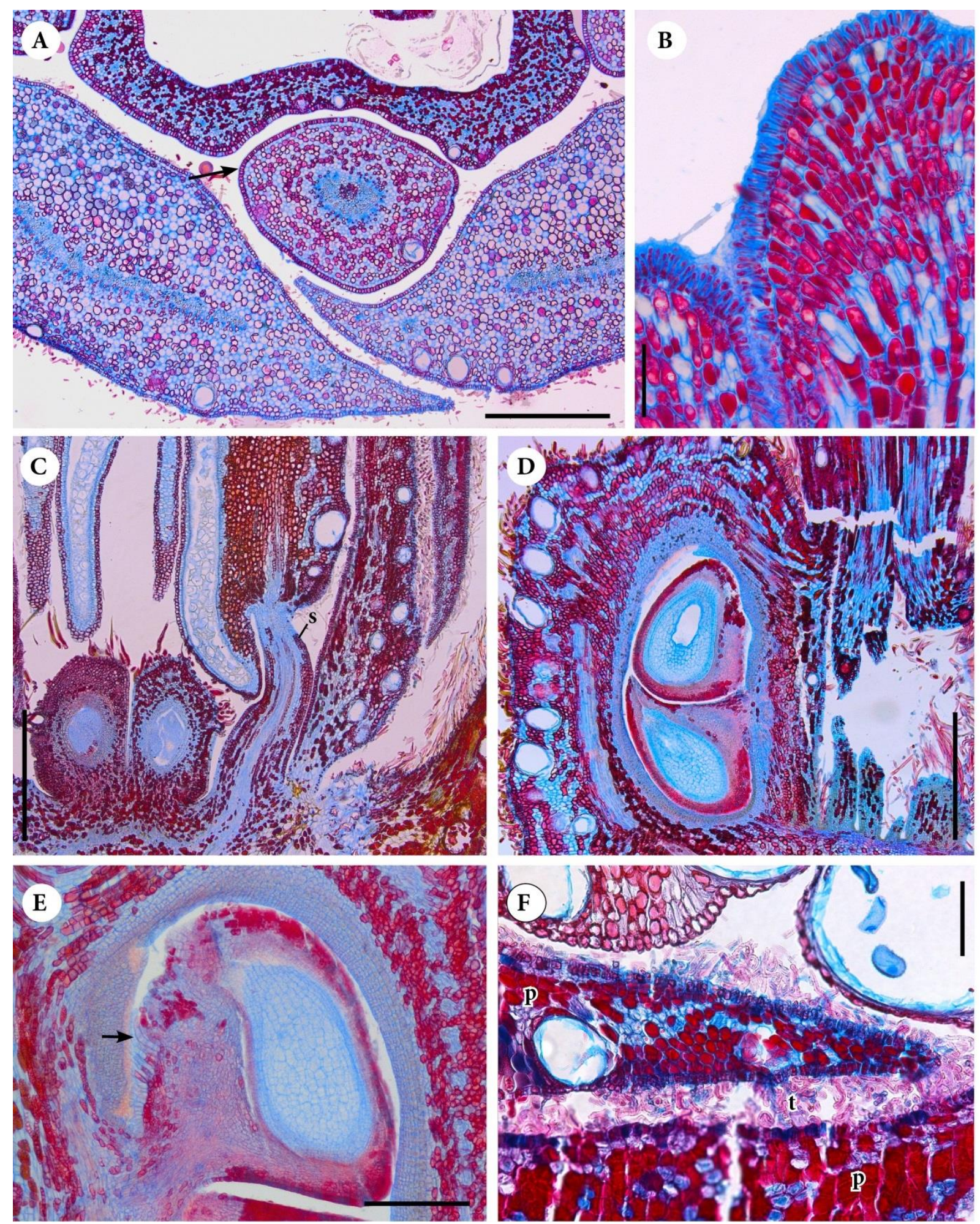

Figure 45: Photomicrographs of microtome sections of floral buds of Spiranthera odoratissima. (A, E) Transections. (B-E) Longisections. (A) Detail of the base of two petals and one filament (arrow). (B) Detail of the papillose surface of the stigma, covered by secretion. (C) Detail of the base of one young floral bud, showing two carpels and stamen (s, stamen). (D) Detail of one carpel, close to the median plane, showing two superimposed ovules. (E) Detail of one ovule, showing the obturator (arrow). (F) Detail of two adjacent petal margins, with intertwining trichomes (p, petal; $t$, trichomes). Scale bars: $(A, C, D)=500 \mu \mathrm{m} ;(B, F)=100 \mu \mathrm{m} ;(E)=200 \mu \mathrm{m}$. 

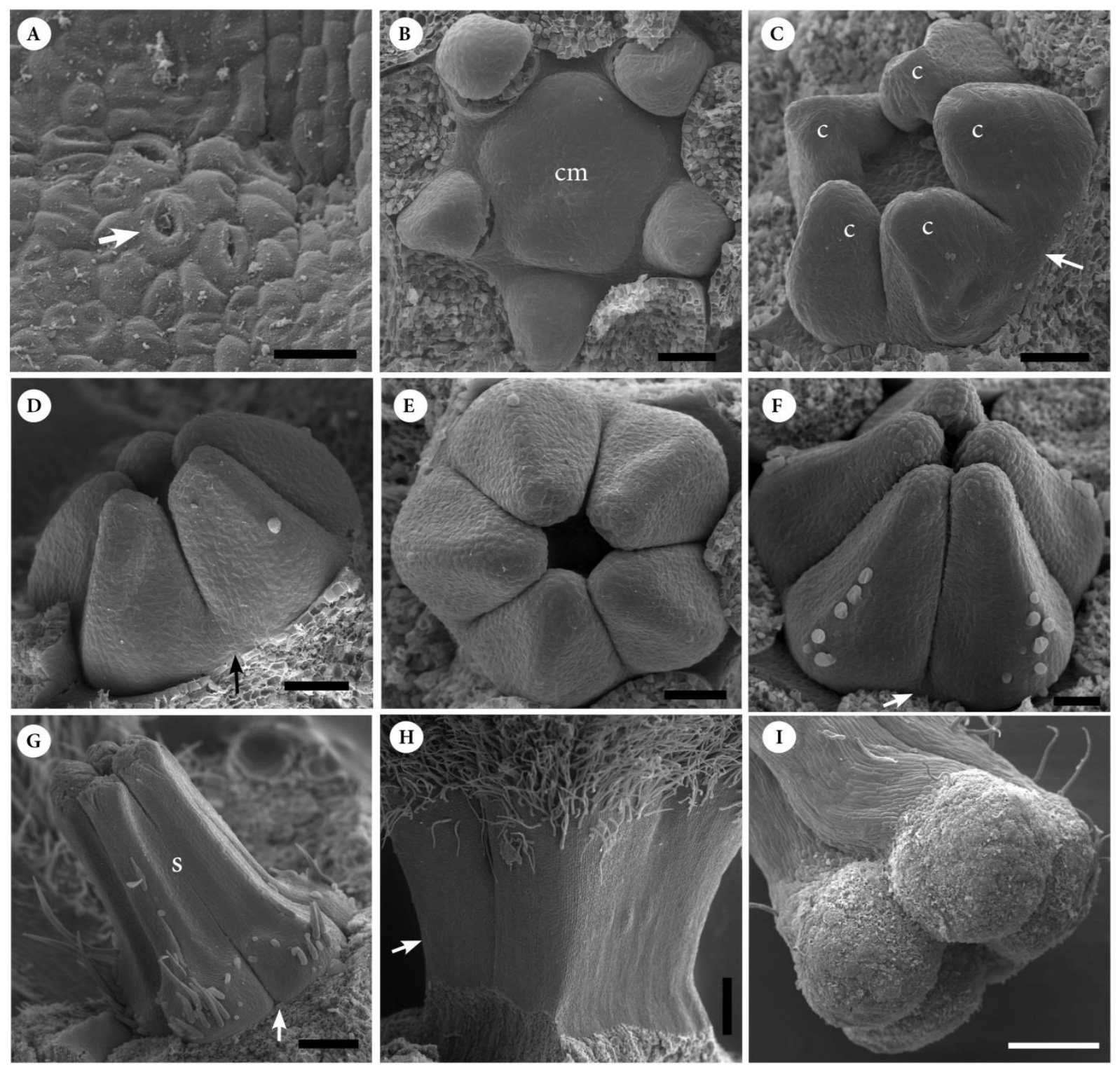

Figure 46: SEM micrographs of Spiranthera odoratissima (A) Group of stomata on the inner side of the nectary (arrow). (B-G) Carpel development (c, carpel; cm, carpels meristem). (B) Pentagonal carpel meristem. (C) Five young carpels (arrow indicates the common bases of carpels). (D-E) Latter stage then $\mathrm{C}(\mathrm{D}$, from the side; $\mathrm{E}$, from above, arrow indicate the common bases of carpels). (F) Carpels elongating. (G) Style elongating (s). (H) Gynophore of advanced bud (arrow). (I) Mature fivelobed stigma. Scale bars: (A) $20 \mu \mathrm{m}$; (B-F) $50 \mu \mathrm{m}$; (G) $100 \mu \mathrm{m}$; (H-I) $200 \mu \mathrm{m}$. 


\section{Galipeeae, former in Pilocarpinae (Engler 1931; currently in a clade that do not include Pilocarpus, Groppo et al., 2008, 2012)}

\section{Metrodorea nigra (Figs 3H, 47-49)}

\section{Morphology and aspects of floral biology}

The flowers of Metrodorea are polysymmetric, haplostemonous. Flower buds are globose, ca. $0.5 \mathrm{~mm}$ long. The flowers are dish-shaped. At anthesis the perianth is wide open and the inner reproductive organs and nectary disc are entirely exposed (Fig. 3H). Sepals are free, short and triangular, displaying open aestivation in mature buds. The internode between sepals and petals is conspicuous (Fig. 47A, F-H). Petals are stiff, free and completely deflexed at anthesis. In bud, they have induplicate-valvate aestivation (Fig. 47C). Petal tips are hooded, shortly bent inwards at centre. Only the petal tips are postgenitally connected with each other by interdigitation of their papillose epidermis in bud stage (Figs 47A, B, 48A, B). Petals are thinner in their distal upper part and gradually become thicker towards the base. At base they have a median ventral protuberance, from which petals are narrowly connected to the common base of filament plus ovary (Fig. 47A, C-G). In this common base, five small furrows are formed between the inner margins of petals and the base of filaments plus gynoecium (where nectar can probably accumulate, Fig. $47 \mathrm{G}$ ). The androecium has five fertile stamens (in antesepalous position). In bud, they are bent towards the floral centre (Fig. 49D). Filaments are round-shaped along their entire free length, as seen in transverse section (Fig. 47A, D, E).At base, filaments share first a common base with carpels, and also with petals lower down (Fig. 47F, G). Anthers are small (ca. 0.7-1mm), dorsifixed in their lower half (but close to their middle), widely sagitatte, versatile, caducous and with an apiculate apex (Figs 49B, C, 47C). The connective is very thin.Between the two theca of an anther there is a shallow ventral furrow along its entire length, and at their base, a deep dorsal furrow is present, embracing partially the distal part of filaments (close to thelevel of anther attachment to filament) Fig. 47A-C). In each thecae, there is a small furrow in the interlocular zone beween the dorsal and ventral pollen sacs. Endothecium-like tissue is continuous over part of the dorsal side of the connective, and also is present at the connective side of thecae (Fig. 48C). The nectary disc is differentiated on the ovary walls. The disc has five cushion-like protuberances distally, which expand lower down around the filaments base as five rounded paddles, as seen in transverse section (Fig. 47F-E). At anthesis the upper part of the nectary forms a more or less short annular disc around the ovary (Fig. 3H). Carpels are abruptly bulged up at the dorsal side above the level of insertion of the style for ca. one-third to half length of the ovary (carpels anacrostylous). The upper dorsal carpel walls are markedly 
thickened in the bulging region, sometimes with rounded to acute glandular emergences (protuberances; Figs 47A, 48D). The stigma is inconspicuously five-lobed, capitate, with short (ca. $60 \mu \mathrm{m}$ ) unicellular papillae (Fig. 48D, E). There is no free zone of carpels, as they are congenitally or postgenitally fused along their entire length. The single style is completely postgenitally fused, entirely solid (Fig. A). From the upper part of the ovary down to midlevel of the locules, carpels are postgenitally fused at center and at their inner flanks, but is not clear if the outer flanks are congenitally or postgenitally fused in advanced buds (no suture visible, Figs 47D, 48D). Lower down in the ovary, carpels are congenitally fused by their flanks and in the floral centre, except for five slits that are seen between the flanks of each carpel (which represent part of the morphological surfaces of adjacent carpels). These slits end as five pockets at the locule base (Figs 47E, F, 48H). The placentation is axile. Each carpel has two ovules, which are mostly collateral, antitropous, with the outer integument thicker than the inner one (Figs 47A, E, F, 48D). One of the ovules presents a zig-zag micropyle. An obturator of uni- to multicellular trichomes is seen on the placenta and funiculus (Fig. 48G, H)

According to Pombal and Morellato (2000), the flowers are protandrous, and filament and style reach the same length at anthesis. By the end of the male phase, the stigma becomes receptive and the filaments curve backwards, placing anthers between petals (Ismar et al. 2004; Fig. 3H). The flowers are pollinated by flies (Diptera) and have mainly brownish-purple color and a slightly unpleasant odour. The flower produces small amounts of nectar, which accumulate below the nectary protuberance and also at the base of the petals (Pombal \& Morellato, 2004). Additionally, at anthesis petals first slacken at their margins, keeping only their tips united, at the region where these are postgenitally connected (Fig. 49A). Only later do petals detache from one another and the flower fully opens (this study, Pombal \& Morellato, 2000).

\section{Anatomy}

Sepals have two to three small bundles each at their uppermost region. At the base of each lobe, there are up to six bundles that merge lower down. At the floral base sepals have ten traces (five main traces and five synlaterals, Fig. 47F-H). Petals have one median main vascular bundle and one to two lateral bundles at their uppermost level. Lower down, these lateral bundles may form up to six bundles (Fig. 47B-C). Toward the petal bases, all lateral bundles merge together with the main median bundle and a single petal trace extends to the floral base (Fig. 47H). Each stamen possesses one vascular bundle along its entire length and 
one trace at floral base (Fig. 47D, G). The nectary has numerous small vascular bundles. In the region where it forms the five-paddle structure, in transverse section, these bundles are close to the periphery of the organ; whereas lower down these bundles are closer to the dorsal vascular bundles of the ovary (Fig. 47E-F). At its base, the nectary is vascularized by xylem and phloem, but from its base upward it is vascularized only by phloem. At the base of ovary locules, the additional lateral bundles converge toward the centre of the gynoecium and merge with the pair of laterals, forming a central vascular complex at this level (Fig. 47F). At the common base of petals plus stamens and gynoecium, the nectary bundles merge with the dorsal bundles of carpels, forming trace complexes that merge with the central vasculature. Lower down, the stamen traces converge to this central complex, and below also the petal traces. Then the calyx traces converge toward this central vasculature and form a stele with it (Fig. 47G-I).

\section{Histology}

Short unicellular secretory trichomes are present on the external surface of the calyx. Petals are provided with short unicellular tanniferous hairs on the adaxial side, and at base the epidermis is shortly papillose. The nectary has small stomata in its external upper part (facing the base of petals) and these are sometimes sunken within epidermal grooves (Fig. 48I). Tanniferous cells are dispersed in the mesophyll of all floral organs. Tanniferous tissue and also a tissue with cells filled with blue-stained secretion (probably mucilage) are present in large amounts in the epidermis and hypodermis of the adaxial side of petals and style, in some regions of the upper part of the nectary, and in the outer integument (Fig. 48A, B, D-I). They are also present in the epidermis of anthers, ventral side of the connective, and in the epidermis of filaments. In carpels, these secretory tissues delineate part of the postgenitally fused regions of carpel (flanks and ventral margins); in the ovary region, it also delineates the epidermis of the five slits between the flanks of each carpel (Fig. 48F, H). Secretory cavities are present in sepals, petals and gynoecium. Large ones are especially conspicuous at the median region of each sepal lobe. Also, large secretory cavities are observed within the emergences (protuberances) in the bulging dorsal region of ovary (Fig. 48D). These, according to Pombal \& Morellato (2000), release lipid substances when pressed. Druses or raphides are not found. 


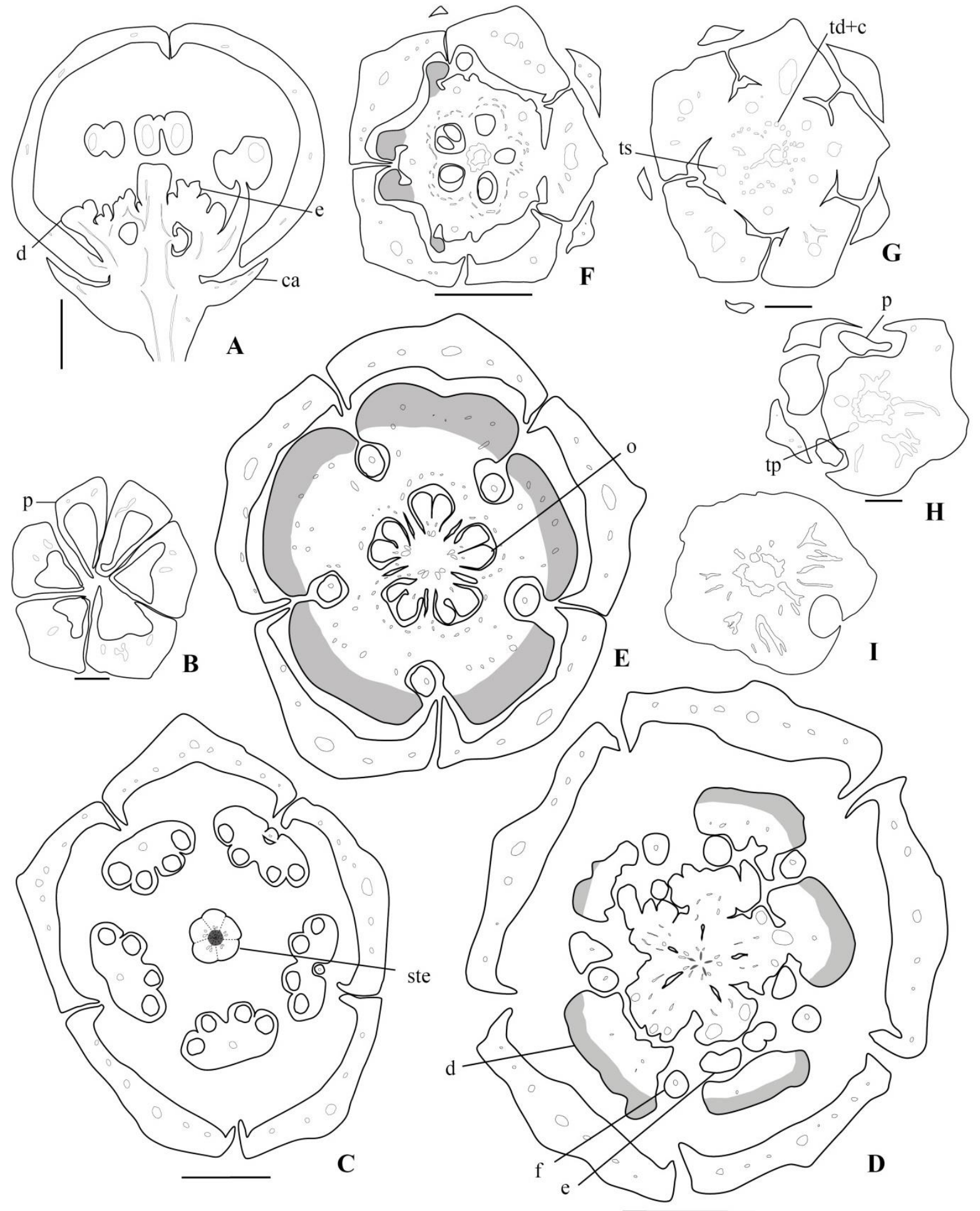

Figure 47: Metrodorea nigra. Sections of floral buds. (A) Longisection. (B-I) Transections: successive levels, from the top, downward. Morphological surface indicated by thicker continuous lines, vasculature by thinner continuous lines; postgenitally fused areas indicated by broken lines (only represented in diagram C); PTTT, dark grey; nectariferous tissue, light gray (in the longitudinal section only morphological surfaces and vascularization are represented). (B) Uppermost level of petals. (C) Mid-level of petals. (D) Uppermost part of the ovary. (E) Mid-level of ovary. (F) Lower level of ovary, with common base with filaments. $(\mathrm{G})$ Lowermost level of petals, with a common base with stamens and gynoecium. (H-I) Lowermost level of sepals and floral base. Abbreviations: ca, calyx; d, nectary disc; e, emergences on the ovary; f, filament; o, ovule; p, petal; ste, style; tp, trace of petal; td+c, trace complex of disc plus dorsal trace of carpel; ts, trace of stamen. Scale bars: (A, C, D$\mathrm{F})=1 \mathrm{~mm} ;(\mathrm{B}, \mathrm{G}, \mathrm{H}, \mathrm{I})=500 \mu \mathrm{m}$. 

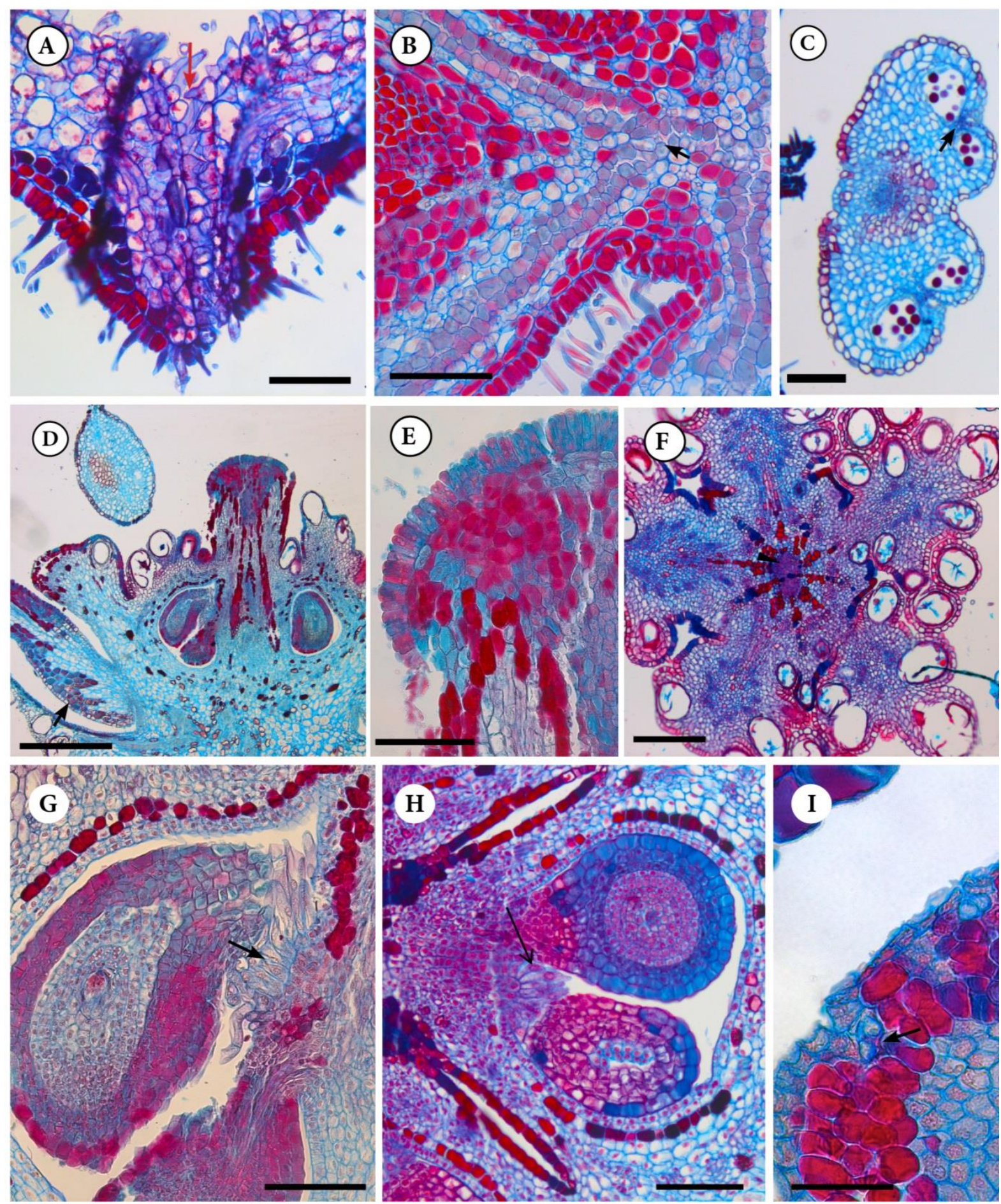

Figure 48: Metrodora nigra. Photomicrographs of microtome sections of floral buds. (A-B) Detail of postgenitally connected apices of petals through interdigitation of papillae (arrow). (A) Longitudinal section. (B) Transection. (C) Transection of anther, showing a small furrow in the interlocular zone (arrow). (D) Longitudinal section of base of floral bud, focusing on the median plane of carpels (arrow at the base of one petal). (E) Detail of the stigmatic region. (F) Transection of carpels, at the level of transition between style and ovary (arrowhead indicates the compitum). (G-H) Ovules and obturator of trichomes (arrows). (G) Longisection. (H) Transection. (I) Detail of the nectary protuberance, where a stomata is evidente (arrow). Scale bars: $(A, B, E, G, H)=100 \mu \mathrm{m} ;(C, D)=500 \mu \mathrm{m} ;(F)=200 \mu \mathrm{m}$; (I) $50 \mu \mathrm{m}$. 

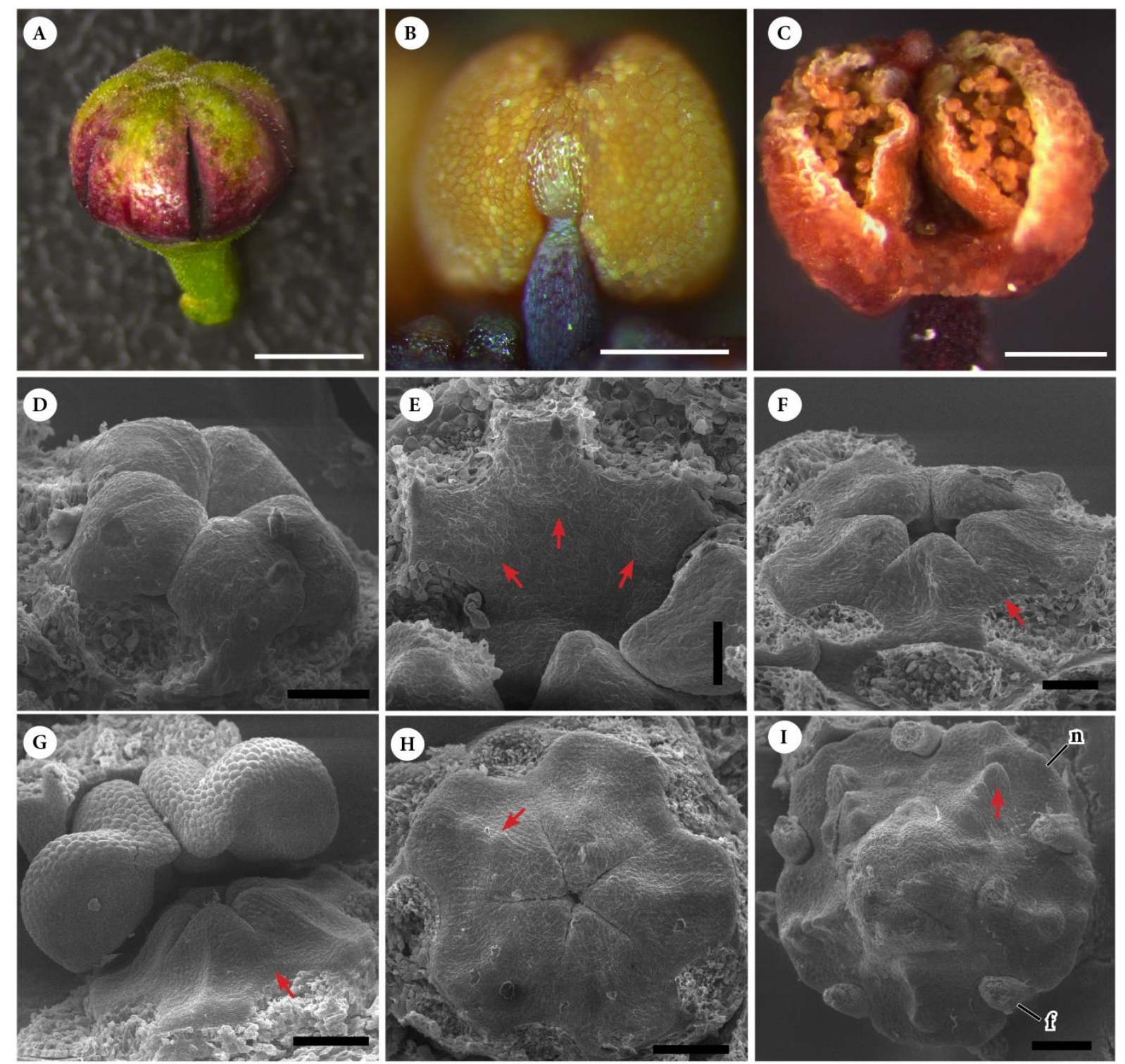

Figure 49: Photographs (A-C) and SEM micrographs (D-I) of Metrodorea nigra. (A) Bud at the beginning of anthesis (note the slackening of petals). (B-C) Dorsal (B) and ventral view (C) of one anther. (D) Young stamens. (E-I) Carpel development. (E) View from above, showing three of the five young carpels on a pentagonal meristem (arrows). (F) Five young carpels (arrow indicates congenitally united flanks). (G) Latter stage than F; carpel bases elongating (arrow, lateral view). (H) Frontal view of the young carpels; beginning of the differentiation of the protuberances on their dorsal side (arrow). (I) Latter stage than $\mathrm{H}$; carpels with beginning differentiation of style, protuberances more developed (arrow). Abbreviations: $n$, nectary protuberance; f, filament. Scale bars: $(A)=2 \mathrm{~mm}$; $(\mathrm{B}-\mathrm{C})=500 \mu \mathrm{m} ;(\mathrm{E}-\mathrm{F})=50 \mu \mathrm{m} ;(\mathrm{D}, \mathrm{G}-\mathrm{H})=100 \mu \mathrm{m}$. 


\section{Former Todaliinae, Toddalieae, Toddalioideae (Engler 1931; currently sister to Adiscanthus in the "American clade", Groppo et al. 2008, 2012).}

\section{Hortia oreadica (Figs 3I, 50-51)}

\section{Morphology and aspects of floral biology}

Flowers of Hortia are polysymmetric, haplostemonous. Floral buds are straight, ovoid, ca. $6.5 \mathrm{~mm}$ long. The flowers are bowl-shaped. At anthesis petals are deflexed, except at base, and the pollination organs are exposed.The calyx and the base of petals surround the base of the filaments, disc and the base of the ovary (Fig. 3I, 50A, E, F). The calyx is congenitally united along most of its length, with five inconspicuous obtuse lobes, sometimes with short apiculate apices (Fig. 50A, D-G). Petals are stiff, deflexed along most of their length at anthesis, except at base. In bud, petals are postgenitally connected by the interlocking of epidermal papillae and their cuticular projections alongthe entire length (Fig. 51C). Corolla aestivation is valvate. Petals have very thick margins in their upper part, which almost overlap each other in this region (Fig. 50B, C), gradually become thinner towards their bases (Fig. 50B-E). Petal tips are bent inward at centre (Fig. 50A, B). In their distal part, petals are thicker and have a short median adaxial ridge and a median abaxial protuberance. From midlength towards the base the petals are thinner, with sinuous surface, and have a large and wide median ventral protuberance from where they unite first to the inner organs at base (as seen in transverse section, Fig. 50B-G). Petals, filaments and the annular nectary disc share a common base, forming a collar around the gynoecium base (Fig. 50F-G). Lower down, the gynoecium also shares a common base with the outer floral organs (a short hypanthium is formed). The androecium has five fertile stamens (in antesepalous position). Filaments are rounded at the apex, more or less triangular downwards their bases, as seen in transverse sections (Fig. $50 \mathrm{C}-\mathrm{F}$ ). Anthers are mid-sized (ca. $2.5 \mathrm{~mm}$ ), dorsifixed at their upper half, persistent, slightly X-shaped, versatile (Fig. 51C). They have a mid-thick connective and an endothecium-like tissue is continuous over part of the dorsal side connective; a few layers of endothecium-like tissue are seen also on the connective side of thecae (Fig. 51E). Anthers have one deep ventral furrow (Fig. 50B-C). The nectary disc is short, with an apical fiveangled annular protrusion between stamens and carpels, which surrounds the ovary at base (Fig. 50A, F). The carpels are acrostylous. There is no free zone of carpels, as they are congenitally or postgenitally fused along their entire length. The stigma is inconspicuoully five-lobed, not dilated in advanced buds, with short (ca. $70 \mu \mathrm{m}$ ) unicellular papillae (Figs 50A, C-E, 51C). The style is short, postgenitally fused, and has a central furrow at its upper part and at base (Fig. 50C). Lower down, above the ovary locules, each carpel has a large 
empty cavity resemblingto a locule at first glance, but not lined with epidermis. These falselocules are histologically similar to lysigenous cavities, since their border are lined with loosely arranged, apparently dead cells (Figs 50 A, D, E, 51F). At this zone of false-locules, carpels are postgenitally united at their inner flanks and at the center for a short extent. Lower down, they are postgenitally fused by their inner flanks only, and free at centre (Fig. 50D). From the upper level of locules to their bases, carpels are completely fused, but it is not clear whether they are congenitally or postgenitally fused (no suture apparent, Fig. 50E-G). The lower part of the ovary is partially inferior for a short extent, ca. one-fifth of the locule length (Fig. 50A, H). Placentation is axile (Fig. 50E-G). Ovules are antitropous, with the outer integument thicker than the inner one (Figs 50A, 51F).

According to Barbosa (1999) the flowers are protandrous and mainly pollinated by perching birds (Passeriformes), secondarily by bees. The perianth at anthesis is mostly light pink to dark-red, and the nectary is protected by the tuft of trichomes at the adaxial side of petal bases. Nectar is copious and the flower has a greasy scent (Barbosa 1999). According to Groppo \& Pirani (2012) anthers move during anthesis, from an initially parallel position to filament, changing to a nearly perpendicular position; they release pollen only after reaching this position.

\section{Anatomy}

Sepal lobes have one to two small vascular bundles in their distal region. Lower down, at the congenitally fused region, there are 22 to 32 vascular bundles of similar size. Close to floral base these bundles merge, and at floral base they form five main traces and five synlateral traces (Fig. 50D-J). Petals possess one to three main vascular bundles and may have five to ten lateral bundles (Fig. 50B-C). At their bases, three main vascular bundles are present, which merge below. At the floral base four petals have one trace, and one have two traces (Fig. 50F-H). Stamens are provided with two vascular bundles at the upper part of the anther, which merge below into one, in their upper half (Fig. 50C). Close to the level of filament attachment, each bundle gives off to two vascular bundles, and these extend downward to the long fertile bases of the thecae (Figs 50C, 51C, E). The uppermost and lowermost regions of anthers are not vascularized (Fig. 50B, D). Each filament has one vascular bundle and a single vascular trace (Fig. 50D-H). The disc is not vascularized at its uppermost part, and lower down it has numerous small vascular bundles radially arranged around the gynoecium (Fig. 50E-F). At floral base the disc traces merge with each other, and also with petal traces and filament traces, forming trace complexes with them (Fig. 50H-I). At 
the base of the locules, dorsal bundles merge into one trace, and lateral bundles form synlaterals (Fig. 50H). Lower down, each dorsal trace merges with the synlateral traces immediately opposed, forming a central vascular complex at the floral base. The disc traces and the disc plus stamen traces merge with this central vasculature, and lower down also the disc plus petal traces. Finally, the synlateral traces of sepals merge with this central vascular complex, followed by the main calyx traces, then forming the pedicel vasculature (Fig. 50I, J).

\section{Histology}

Large secretory cavities are present in the calyx; these are also present, though smaller, in petals, filaments and in the ovary. In the congenitally united region of sepals, 1012 secretory ducts can be found associated to vascular bundles, filled with blue stained secretion, of uncertain nature (probably mucilage). These ducts merge within each other running downwards to the floral base. The same ducts are observed in petals, associated with the main vascular bundle, running downwards from their uppermost level down to its midlevel; also, one of the anthers has these ducts associated with its vasculature (Fig. 51G). At the floral base, these secretory ducts are also present between the vasculature of the pedicel. The epidermal cells of the outer surface of sepals and petals are covered by a thick cuticule and wax (Fig. 51G). Thin walled papillae are present along the entire surface of petals, which are most prominent on their inner side and in their postgenitally connected lateral parts. Also in the same regions, their cuticule shows longer projections (Fig. 51C). Some hypodermal cells have thickened walls, forming a layer of reinforcement on both sides of petals (Fig. 51G). Secretory cells filled with blue-stained secretion (probably mucilage) are observed in sepals, filaments, ovary, and in the outer integument. From mid-level of petals down to their bases, numerous long and thin-walled tanniferous trichomes are present on their adaxial side (Fig. 51G). Anthers present cells with large intercellular spaces on the ventral side of the connective region along their entire length (Fig. 51D). Tanniferous tissue is extensively present at the dorsal side of the connective, filaments, disc and style (Fig. 51A-C, F, G). The disc has small stomata on their inner side, facing the gynoecium. Druses or raphides are not found. 
Figure 50: Hortia oreadica. Sections of floral buds. (A) Longisection. (B-J) Transections: successive levels, from the top, downward; morphological surface indicated by thicker continuous lines, vasculature by thinner continuous lines; postgenitally fused areas indicated by broken lines (represented only in diagrams C, D); pollen tube transmitting tissue (PTTT), dark grey; nectariferous tissue, light gray (in the longitudinal section only morphological surfaces and vascularization are represented). (B) Uppermost level of anthers (note inwardly bent petal tips). (C). Anthers level, and uppermost level of one filament; upper level of style. (D) Uppermost level of ovary (false-locule region). (E) Upper level of locules (lowermost level of false-locules); (F) Mid-level of ovary. (G) Lower half of ovary; common base of filament, petals and nectary. (H) Inferior region of ovary; lowermost level of locules. (I-J) Floral base. (I) Level of trace complexes of stamen plus disc and petal plus disc (J) Lowermost level of calyx traces. Abbreviations: a, anthers; f, filament; fl, false locule; 1 , locule; d, disc; p, petals; sl, synlaterals trace of carpels; td, trace of disc; tp, trace of petals; ts, trace of stamen; tp $+\mathrm{d}$, trace complex of petals plus disc; ts $+\mathrm{d}$, trace complex of stamen plus disc. Scale bars: $(\mathrm{A})=1 \mathrm{~mm} ;(\mathrm{B}-\mathrm{J})=1 \mathrm{~mm}$. 


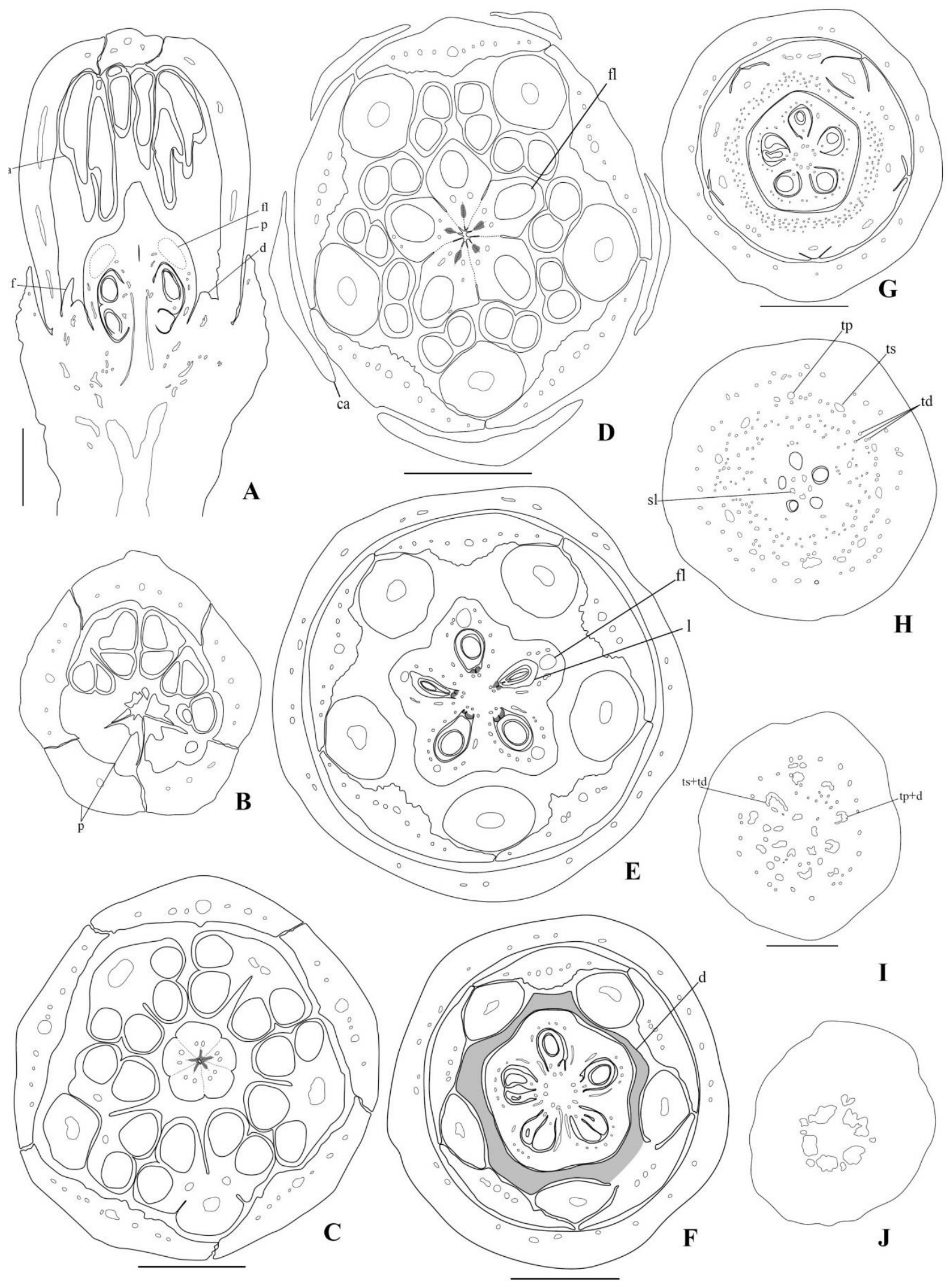



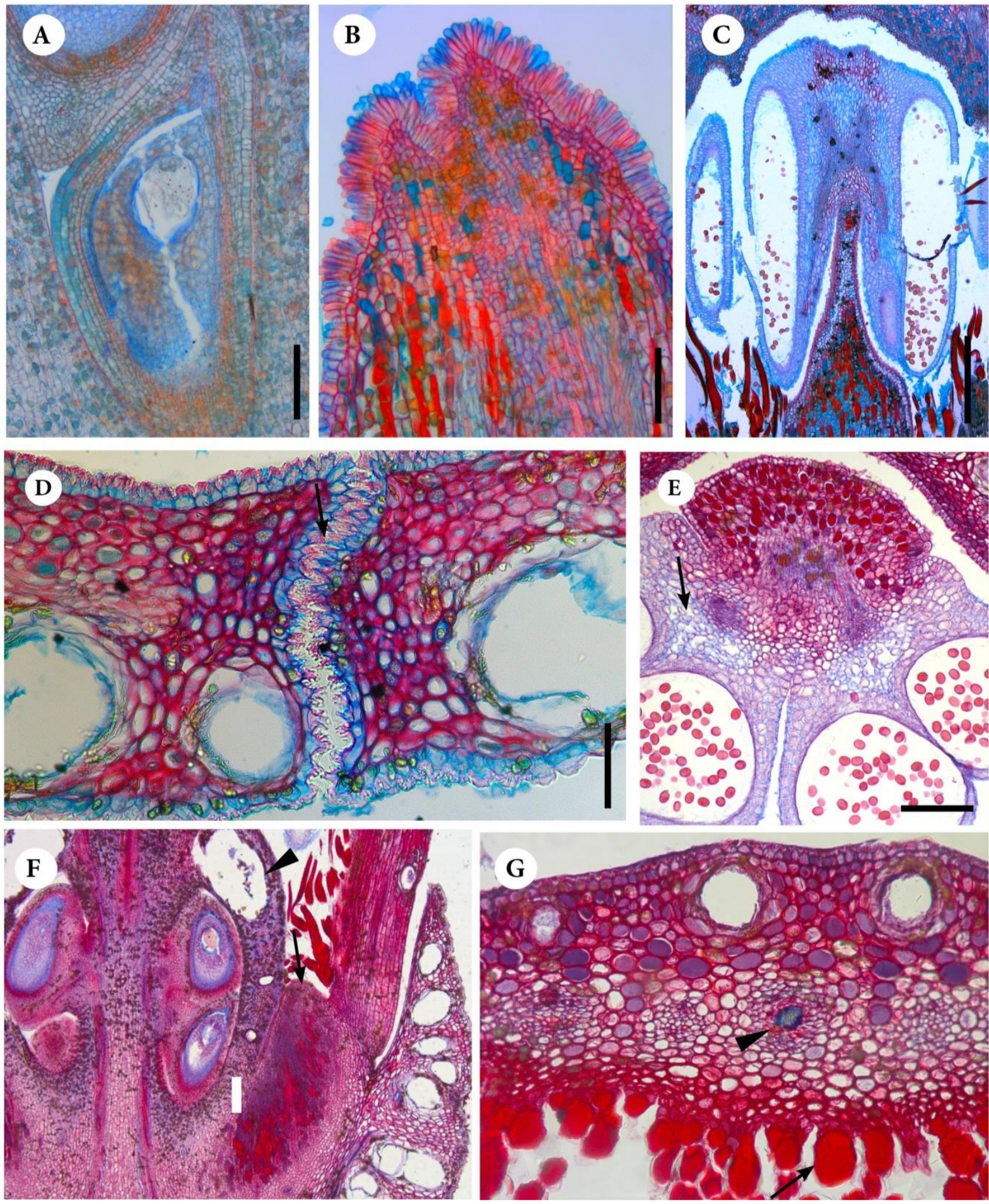

Figure 51: Photomicrographs of microtome sections of floral buds of Hortia oreadica. (A-C, F) Longitudinal sections. (D, E, G) Transections. (A) Detail of one ovule. (B) Detail of the papillose surface of stigma. (C) Detail of one stamen. (D) Transection through the postgenitally connected petals (arrow indicate papillose epidermis and their cuticular projections). (E) Anther, with large intercellular spaces at the connective side of thecae (arrow). (F) Detail of the base of floral bud, showing the ovary partially inferior (white bar), short disc (arrow) and false-locules (arrowhead). (G) Detail of the base of one petal, with numerous tanniferous trichomes in its adaxial surface (arrow), and secretory ducts (probably filled with mucilage; arrowhead). Scale bars: $(A)=50 \mu \mathrm{m} ;(B, F)=500 \mu \mathrm{m}$; $(\mathrm{C}, \mathrm{E}, \mathrm{G})=100 \mu \mathrm{m} ;(\mathrm{D})=200 \mu \mathrm{m}$. 


\section{DISCUSSION}

Based on our comparative work with the Galipeinae subtribe and other closely related species of Rutoideae (Metrodorea nigra and Hortia oreadica) we have found that some floral features are similar between all (or most) species and also shared on a higher taxonomical level with the rest of the family, or with other Sapindales previously studied. Conversely, other features are particular to most Galipeinae species. In general all flowers are pentamerous and isomerous (except in the androecium of some species, see further discussion below); the calyx is frequently congenitally fused, at least at base; the corolla is the protective organ of young and advanced buds; a nectary develops at base of the flower, frequently as a disc between stamens and carpels, or on the gynophore; there is a dorsal bulging area at the upper dorsal side of the ovary in many of the species studied; carpels are antepetalous with the placenta inserted at mid-level of each locule, bearing two anatropous (or campylotropous), superposed ovules. All above-mentioned features are commonly found in other groups of Rutaceae or even in other Sapindales families, such as Simaroubaceae, Anacardiaceae, Burceraceae, Kirkiaceae, Nitrariaceae (Engler, 1931; Ramp, 1988; Bachelier \& Endress, 2008, 2009; Bachelier et al., 2011). As contrasting features of most Galipeinae, flowers are: tubular, monosymmetric (rarely polysymmetric) due to androecium reduction into two, three or five filament-like staminodes placed on the anterior (abaxial) side of the flower; the corolla presents a series of gradation in symmetry, ranging from strictly polysymmetric to strongly monosymmetric; corolla aestivation is cochlear (oblique or ascending); petal tipsare overlapped in bud; the anthers are basifixed or near-basal dorsifixed; the nectary is welldeveloped, forming a cupular nectary disc, occasionally sharing a common base with other floral organs for a short extent ; carpels are mostly apocarpous (Engler, 1931; Ramp, 1988; Pirani et al., 2010; El Ottra et al., 2013; this study).

An exceptional case from all above presented features is the monotypic Adiscanthus fusciflorus (traditionally placed in Galipeinae by Engler, 1931). Except for the mostly apocarpous gynoecium, this species has a general floral structure fairly different from all other Galipeinae. Instead, flowers of A. fusciflorus show an overall similarity to the other closely related members of Rutoideae, Hortia oreadica and Metrodorea nigra. Flowers of these three genera are strictly polysymmetric, haplostemonous with fully fertile stamens, valvate corolla aestivation, petal tips bent inwards and postgenitally connected in bud, and anthers that are dorsifixed close to their half or upper half (Engler, 1931; Kallunki, 2005; Groppo et al., 2008; Groppo \& Pirani, 2012; this study). The resemblance in the floral structure is in accordance to the recent molecular phylogenetic findings, which place 
Adiscanthus in a different clade from all other Galipeinae, but both nested within a larger clade containing several genera of American Rutoideae (the "American clade", Groppo et al., 2012). Notably, Adiscanthus and Hortia are sister groups and both are more closely related to Metrodorea than to Galipeinae (Groppo et al., 2008, 2012, in prep.). Thus, the flower structure provides further support to the newly found monophyletic groups of Neotropical Rutoideae. That the traditional subfamiliar division of Engler (1931) for Rutaceae is artificial for most of its groups was already shown by molecular phylogenies and previously indicated by chemotaxonomic, cytogenetic and structural phylogenetic studies (Silva et al., 1988; Stace, 1993; Chase et al., 1999; Pirani, 1999; Scott et al., 2000; Poon et al., 2007; Groppo et al., 2008, 2012). Other floral features found here appear to support monophyletic groups in the American clade or are shared in broader systematic scales. Additionally, some characteristics repetitively are present or absent in closely related groups or occur exclusively in single species or genera. These will be discussed in detail within the following topics.

General floral structure (merism, histology, floral size, shape, architecture), herkogamy and pollination

Floral merism is rather uniform in all species analyzed. The calyx, corolla and carpels are isomerous and pentamerous in all species. The androecium is pentamerous in haplostemonous flowers with five fertile stamens (Adiscanthus, some Almeidea rubra specimens, A. limae, Hortia oereadica, Metrodorea nigra, Spiranthera odoratissima), or in haplostemonous flowers in which two or three stamens are sterilized into filament-like antesepalous staminodes (some flowers of Almeidea rubra, A. coerulea, Conchocarpus concinnus, C. cyrtanthus, C. obovatus, C. odoratissimus, C. mastigophorus, Ertela species, some flowers of Neoraputia trifoliata, N. alba, and Raputiarana). However there were some flowers with the five antesepalous staminodes plus two (rarely one or three) antepetalous staminodes (Angostura bracteata, Galipea species, some flowers of Neoraputia trifoliata, N. alba, Ravenia infelix, Rauia nodosa, R. resinosa, Ravenia spectabilis, and Sigmatanthus; Pirani et al., 2010, this study). Considering that the overall floral merism is pentamerous, the antepetalous staminodes may be viewed as an incomplete whorl of antepetalous stamens, derived from an obdiplostemonous flower (some antepetalous stamens would be missing, for further discussion, see the androecium topic). Most Rutaceae have pentamerous flowers, but tetramerous or more rarely trimerous flowers may also occur (Engler, 1931; Kubitzki et al., 2011). Most genera of Galipeinae are pentamerous, with the exception of the rare monotypic 
tetramerous genus Leptothyrsa Hook. F. Deviations in the pentamerous species of Galipeinae were rarely found (few tetramerous or hexamerous flowers may occur in some species of Conhocarpus, Erythrochiton brasiliensis and Galipea carinata Pirani; Kubitzki et al., 2011; Pirani et al., 2010; J. H. L. El Ottra, pers. obs.). In other members of the American clade, the floral merism is more variable, often tetramerous (in Baufourodendrum, Raulinoa, Pilocarpus, some species of Helietta, and some flowers of Choisya), or pentamerous (Metrodorea, Esenbeckia, Adiscanthus, Hortia, most flowers of Choisya, Kaastra, 1982; Pirani, 1998; Kubitzki et al., 2011). One single flower of Metrodorea nigra analyzed in this study was hexamerous.

As general histological features, we could point out that a variety of secretory structures were found in the floral tissues of nearly all species. Secretory cavities are widely present in the floral organs, as in other vegetative tissues of Rutaceae. They are usually described as containing volatile oils and referred to as a distinctive feature of the family (Engler, 1931; Metcalfe \& Chalk, 1950; Ramp, 1988; Kubitzki et al., 2011). Additionally, tannins, either isolated in idioblasts cells or present as an extensive tissue in the flower, were found in several species. In fact the occurrence of floral tissue rich in tannins was previously reported for several other groups of Rutaceae, and occasionally also for Burseraceae, Anacardiaceae, Nitrariaceae and Simaroubaceae (Ramp, 1988; Bachelier \& Endress, 2009; Bachelier et al., 2011). Glandular hairs, either unicellular or multicellular, were also previously reported for several groups of the family, in floral or vegetative organs (Engler, 1931; Metcalfe \& Chalk, 1950; Ramp, 1988; Souza et al., 2003; Kubitzki et al., 2011). Differently mucilage (either in cells, canals or in intercellular spaces, as may be the case in Hortia oreadica) and resins (in secretory cavities, as may be the case in Ravenia spectabilis, or cells) were only reported for vegetative parts of Rutaceae (Metcalfe \& Chalk, 1950; Matthews \& Endress, 2006, and references therein). A variety of crystal idioblasts were found here in flower parts of most studied taxa, and these have also been cited in previous studies for vegetative organs (Engler, 1931; Metcalfe \& Chalk, 1950; Kubitzki et al., 2011). Druses and raphides are present in floral tissue of several species of Galipeinae and closely related genera, but styloid crystals were only found in Ertela and Ravenia. In fact, Engler (1931) previously reported the exclusive occurrence of styloid crystals in these two genera, but only for their vegetative parts (further discussion on the histology of specific floral organs are presented in their respective topics: calyx, petals, androecium, gynoecium and ovules).

Floral size, here measured as length, is diverse among the Neotropical Rutoideae analyzed. Flowers can be small (ca. 6mm in Ertela species) to medium-sized (6-25 mm; 
Adiscanthus, Almeidea species, Angostura bracteata, Conchocarpus species, Hortia oreadica, Metrodorea nigra, Neoraputia trifoliata, Rauia resinosa), or large exclusively in some Galipeinae (up to $25 \mathrm{~mm}$; Neoraputia alba, Raputiarana, Rauia nodosa, Ravenia infelix, $R$. spectabilis, Sigmatanhus, Spiranthera). Other genera of Galipeinae also have large flowers (i.e. Desmotes, Erythrochiton, Nycticalanthus, Toxosiphon and some species of Ticorea; Kallunki 1992, 2005; Pirani 1999, Kubitzki et al., 2011) or small flowers (i.e. Conchocarpus minutiflorus Groppo \& Pirani, El Ottra pers. obs.). Diversity in floral size was already reported for other groups of Rutaceae. Engler (1931) considered the flowers of the subtribes Evodiinae, Decatropidinae, Lunassinae and Pteleinae as small, while the Choisynae were large (all Rutoideae, Groppo et al., 2012, Kubitzki et al., 2011). Similarly in the Citrus group (Aurantieae, Groppo et al., 2012), flowers can have different sizes, increasing in some species (e.g. Citrus aurantium L., Merrillia species). In this group, larger flowers are commonly associated with an increase in stamen and carpel merism (polystemonous and multicarpellary flowers), as well as with ovule number and fruit size (Kubitzki et al., 2011; Swingle \& Reece, 1967). The functional implication of different size classes of flowers is unknown for Galipeinae, but they could be related to aspects of pollination biology. All other genera of Rutoideae in the American clade commonly present small to mid-sized flowers. These are Adiscanthus, Hortia, Metrodorea, and also Balfourodendron, Helietta (former Toddalioideae, subtribe Pteleinae), Choisya (Zanthoxylae, Choysinae), and Esenbeckia (Galipeeae, Pilocarpinae; Engler 1931; Kaastra, 1982; Pirani, 1998, 1999; Groppo \& Pirani, 2012). Thus, large flowers appear to have evolved only in some genera of the Galipeinae in the America clade. Maybe larger flowers could be related to the formation and concealment of larger nectaries (as observed in Neoraputia alba, Raputiarana, Rauia nodosa, Ravenia infelix, $R$. spectabilis, Sigmatanhus, Spiranthera), and consequently larger amount of nectar produced, which could sustain the energetic needs of large vertebrate pollinators (e.g. hummingbirds and bats). It would be interesting to comparatively evaluate the significance of variation in floral size in the floral biology of the group.

Floral architecture is interestingly variable among Galipeinae, Hortia and Metrodorea, and a gradation of types can be found relative to the exposure of inner floral organs. The most common architectural floral type in Galipeinae is the tubular flower, usually formed by the synorganization of petals and filaments (with or without organ fusion; found in species of Almeidea, Conchocarpus, Neoraputia, Raputiarana, Rauia, Ravenia, Sigmatanthus), or less often by the synorganization of petals exclusively in Ertela bahiensis and Ravenia infelix (El Ottra et al., 2013; this study). In the tubular flowers of Galipeinae, the disc is entirely hidden 
at the bottom of the floral tube while the pollination organs may be totally hidden (in species with recessed stigmas, Conchocarpus cyrtanthus, C. concinnus, $C$. odoratissimus, $C$. macrocarpus, C. mastigophorus) or partially hidden (in species with recessed stigmas only in the male phase, i.e. Angostura bracteata, Galipea jasminiflora, Neoraputia trifoliata; or in species with anthers placed at mouth of the floral tube; this study). The floral tube in the Galipeinae is usually straight, occasionally curved, and presents a variable width and length between species, with similar diameter along their entire length (Kallunki, 1994, 2005; Kubitzki et al., 2011; El Ottra, et al., 2012, this study). Only in a few species the tube gradually becomes wider close to the mouth of the corolla, forming a campanulate floral tube (in Naudinia, Ravenia and Ertela, Kubitzki et al., 2011; this study). A type diametrically opposed to tubular flowers would be the widely open, dish-shaped flower of Metrodorea nigra, with the pollination organs and nectary entirely exposed.

Another two architectural types observed could be seen as intermediate types between the floral tube and the open dish-shaped flower. The first was observed in Adiscanthus, whose subglobose lower part of the corolla hides the nectariferous gynophore and the entire length of carpels, while the anthers are presented exserted above this region. Since the petals are valvate and slightly slackened in this subglobose region in fully opened flowers, a tube as that of other Galipeinae is not formed (Fig. 1A). The second type was observed in Hortia oreadica, with a bowl-shaped flower, with a longer cupular calyx that surrounds the base of petals and filaments, slightly hiding the short annular disc and the base of the gynoecium (Fig. 3I).Contrasting, Spiranthera odoratissima, the only Galipeinae species here analyzed with free, reflexed petals, presents pollination organs entirely exposed. However, part of the nectary disc and lower region of ovary and gynophore are hidden at the base of sepals, petals and stamens (Fig. 3F).

Tubular flowers are reported elsewhere in the family in the tribe Boronieae (Rutoideae), in most of the species of Correa (subtribe Correinea), Leionema sympetalum, and Nematolepsis phebalioides (tribe Boronieae; Engler, 1931; Hartl, 1957; Armstrong, 1979; Kubitzki et al., 2011). Since these groups are distantly related to Galipeinae, the floral tube is likely to have convergently evolved within the family (El Ottra et al., 2013). Wide open flowers very similar to Metrodorea are common in remaining genera of the American clade of Rutoideae, as in its sister genus Esenbeckia and in the closely related Balfourodendron, Helietta and Choisya. The unusual lower subglobose region of the corolla of Adiscanthus was not previously described, and similar shape of corolla is unknown to occur elsewhere in the family so far. 
Floral architecture may influence the access to floral reward by pollinators (Faegri \& van der Pijl, 1979; Endress, 1994). In Galipeinae and closely related groups nectar is the main floral reward, as expected from groups provided with an intrastaminal disc (Barbosa, 1999; Piedade \& Ranga, 1993; Pombal \& Morellato, 2000; Lopes, 2002; Silva \& Santos, 2008; Kubitzki et al., 2011; El Ottra et al., submitted, Chapter 2; El Ottra et al., in prep., Chapter 3, this study). Therefore, since the nectary disc in Galipeinae is hidden at the bottom of the floral tube, it is expected that nectar-seeking animals with long proboscises, and/or long-beaked birds, would pollinate its flowers. This has been demonstrated for some Galipeinae species in which pollination by Lepidoptera (nocturnal and diurnal), hummingbirds, and occasionally long-tongued bees, was reported (for Galipea jasminiflora, Piedade \& Ranga, 1993; Erythrochiton brasiliensis, Lopes, 2002; Almeidea rubra, Angostura bracteata and Conchocarpus macrophyllus, El Ottra et al., submitted, Chapter 2; El Ottra et al., in prep., Chapter 3; C. cyrtanthus, Rauia nodosa and probably Ravenia infelix, this study). Other Rutaceae with tubular flowers are also reported as being pollinated by long-beaked Meliphagidae birds, as in Correa (Armstrong, 1979). In contrast, the open, dish-shaped flowers of Metrodorea nigra and M. stipularis Mart. are pollinated by nectarivorous shorttonged flies, which land on the five cushions formed by the upper part of the disc to probe the nectar accumulated in this region (Pombal \& Morellato, 2000). Additionally, the bowl-shaped flowers of Hortia oreadica are pollinated effectively by short-beaked perching birds (Passeriform birds) and bees (the short-tonged Trigona spinipes and the long-tonged Xylocopa). Thus the floral tube in the Galipeinae appears as a functional attribute restricting access to the nectar (and also anthers, when at the mouth of the corolla) by shorttongued/short-beaked animals, and thus may lead to specialization towards long proboscis and/or long-beaked pollinators. However, the scarce data about pollination biology for most representatives of the American clade prevent clear conclusions, and further ecological studies and associated evolutionary studies are needed in order to better support this hypothesis.

A widespread feature found in nearly all Galipeinae is markedly herkogamous flowers (i.e., with the stigma and anthers spatially separated within the flower, in the case of bisexual flowers, Webb \& Lloyd, 1986). Previously this was only reported for Galipea jasminiflora (Piedade \& Ranga, 1993) and could be inferred by taxonomical descriptions for some other taxa (e.g. for Conchocarpus fissicalyx Pirani, anthers are "exserted from the throat at anthesis" and the stigma "not exserted from the throat at anthesis", Kallunki \& Pirani, 1998). This widespread feature was also found to present two different conditions in relation to type 
of herkogamy. In the first, which is the reverse hercogamy (i.e., "pollen placed forward in pollinator path", Webb \& Lloyd, 1986), the stigma is recessed within the floral tube and anthers are close to or at the mouth of floral tube during the entire anthesis, as observed in Conchocarpus cyrtanthus, C. concinnus, Conchocarpus macrocarpus, C. obovatus, C. odoratissimus, Rauia resinosa, $R$. nodosa, and probably also in C. mastigophorus, Ertela trifolia, E. bahiensis. The second condition constitutes the approach herkogamy (i.e., "stigmas placed forward in pollinators path", Webb \& Lloyd, 1986), and we observed in Almeidea rubra, Angostura bracteata, Neoraputia trifoliata, Raputiarana subsigmoidea, Ravenia infelix (probably also in Neoraputia alba, Ravenia spectabilis and Sigmatanthus trifoliatus, this study), Galipea jasminiflora (Piedade \& Ranga, 1993), Conchocarpus heterophyllus and Erythrochiton brasiliensis (El Ottra pers. Obs.). Herkogamy occurs in several other Angiospems and it is seen as a device that reduces self-pollination, and as a consequence enhances outcrossing. Additionally, it may also decrease the interference between the male (pollen) and female (stigma) functions within a flower (Webb \& Lloyd, 1986).

In flowers with approach herkogamy, anthers, filaments, style and stigma may change their relative positions in flower due to elongation and/or recurvingof these organs during anthesis. This was not observed only in Almeidea rubra, where the style and stigma do not change their position. In species with approach herkogamy, anthesis begins with the male phase of the flower, presenting anthers at the mouth of the floral tube or exserted from it. In this phase the stigma is recessed below anther level, within the floral tube. Later, the flower gradually passes to the female phase, with style elongating to the outside of the floral tube, exposing the stigma above anther level, more or less at the centre of the flower. Also during this phase, the filament and anthers elongate and recurve (Angostura bracteata), and/or anthers usually fall off (Galipea jasminiflora, Piedade \& Ranga, 1993; other species, El Ottra et al., in prep., Chapter 3, this study). Thus it appears that the tubular part of the flowers contributes to an efficient mechanism of herkogamy, since it participates in the spatial segregation of anthers and stigma in both types of herkogamy. Aditionally, it may also compel floral visitors to touch the pollination organs in an ordered way, especially in the reverse type of herkogamy (Webb \& Lloyd, 1986).

Reverse hercogamy, as found for several Conchocarpus species, is a much more rarer phenomenon than other types of herkogamy. In fact it appears to be related to flowers with a tubular part, as this was only reported for few groups with this type of floral architecture, as in Daphne (Thymeleaceae), Tulbargia violaceae (Liliaceae), Drachophyllum (Epacridaceae; Webb \& Lloyd, 1986; Müller, 1875). Additionally, reverseherkogamy is assumed to be 
associated with pollination by Lepidoptera (Webb \& Lloyd, 1986; Barret \& Harder, 2005). This is partially supported by our findings, as in Conchocarpus macrophyllus and $C$. cyrtanthus several butterflies are pollinators, but long-tongued bees can also be considered as pollinators. Differently, approach herkogamy is a much more common phenomenon in Angiospems, and is associated with several groups of pollinators (Webb \& Lloyd, 1986).

As herkogamy is such a widespread feature, it commonly occurs together with dichogamy (temporal separation of pollen and stigma presentation, either protandry or protogyny, Faegri \& van der Pijl, 1979; Lloyd \& Webb, 1986). In Galipeinae, exclusively herkogamous flowers presenting male and female phases (with the stigma receptive even when recessed within the floral tube in the male phase), have been reported in Galipea jasminiflora (Piedade \& Ranga, 1993). Differently, herkogamy and protandry were now found in Almeidea rubra, Erythrochiton brasiliensis and Angostura bracteata flowers (El Ottra et al., submitted, in prep., Chapters 2 and 3, pers. obs). However, the information of occurrence of dichogamy is still lacking for most Galipeinae species. On a familiar level, protandry is considered a common phenomenom (Kubitzki et al., 2011). Contrastingly, herkogamy has previously rarely been observed in Rutaceae, superficially described only for Aegles marmelos (L.) Corrêa (Aurantieae; Singal et al., 2011). Thus herkogamy may be considered as a putative synapomorphy for Galipeinae with tubular flowers.

However, observation of different types of herkogamy inGalipeinae leads to an interesting hypothesis regarding the evolution of this feature in the American clade. In fact, outside the clade of Galipeinae with tubular flowers, all other members do not have herkogamous flowers, except Adiscanthus (Groppo et al., 2008, 2012). The flowers in this genus are reverse herkogamous, and thus this indicates that herkogamy is a homoplasic feature in the American clade. Also, the observations that reverse herkogamy occurs in Adiscanthus and in some Galipeinae with tubular flowers, and that approach herkogamy occurs exclusively in some Galipeinae, indicate that reverse herkogamy may be the plesiomorphic state in the evolution of this feature, while approach herkogamy would be a derived feature.

The developmental observations of the style and stigma in the different types of herkogamy at anthesis indicate that heterochronic events may be involved in the evolution of this feature (i.e., innovations caused by modifications in the timing or rate of development, Gould, 1992). The fact that taxa with reverse herkogamy present at maturity style and stigma recessed within the tube, while in others with approach herkogamy these are exserted from the 
tube during the entire anthesis - or elongate to the outside at maturity (in the female phase) indicates the developmental steps in which heterochronicl changes may have occurred. Considering the potential ancestral feature of herkogamy in the clade as reverse herkogamy (i.e., stigma recessed), then the exserted stigmas (found in approach herkogamy) may have evolved due to peramorphosis, i.e., heterochronic event where a novel feature arises due to additional ontogenenetic steps (in this case, elongation of the style). In contrast, if one were to consider the ancestral feature as approach herkogamy (exserted stigma), then reverse herkogamy could have evolved due to paedomorphosis, i.e. heterochronic event caused by the loss of ontogenetic steps during the evolution of a feature (in this case, elongation of the style; Li \& Johnston, 2000). However, to accurately establish the likely ancestral state of herkogamy in the American clade and its evolutionary pathway, it is still necessary to analyze these features in the light of a robust phylogenetic context.

\section{Calyx}

The structure of the calyx in Galipeinae and closely related groups has systematic implications for groups of species or genera (e.g., Kallunki \& Pirani, 1998; Kubitzki et al., 2011). In most species we have basically found that sepals have a lower congenitally fused region and an upper free region forming the lobes, but the extention of these zones vary between species. The lower congenitally fused region is usually cupular in shape, and the lobes are denticulate, triangular, rounded, or they are very short and thus inconspicuous in few cases (some Adiscanthus and Hortia flowers). Metrodorea nigra does not have a cupular calyx, and instead has very short triangular lobes. Also, we found four major types of calyxes for the Galipeinae members and closely related groups, associated to its relative size to petals in advanced buds and extent of the lower congenitally fused zone. In the type found in Adiscanthus, the entire calyx is considerably reduced in size in relation to petals, the lower congenitally fused region very short and embracing the base of petals only close to the floral base. A second type was found in Hortia oreadica, Neoraputia trifoliata, N. alba, Rauia resinosa, $R$. nodosa, and Raputiarana, whose sepals are smaller than petals but large enough to embrace the lower region of petals, with a lower congenitally fused zone for most of their extent and the lobes short to very short. A third type was found in Almeidea coerulea, A. rubra, A.limae, Angostura bracteata, Conchocarpus cyrtanthus, C. concinnus, C. odoratissimus, C. obovatus, C. macrocarpus, C. mastigophorus and Sigmatanthus, where similarly there is also a lower congenitally fused region, but the lobes are substatially larger than this lower zone, both regions also embracing the base of petals. In this latter type, the 
lobes are usually triangular, except in Conchocarpus cyrtanthus and C. concinnus, whose sepals have rounded tips. In the forth type, found in Ertela trifolia, E. bahiensis, Ravenia spectabilis and $R$. infelix, sepals are irregular in size and shape, substantially larger than petals, as the two outer larger lobes embrace up to the lower third of the petals (in $E$. bahiensis the tip of the larger outer sepal may reach the upper half of the bud, but not embrace it). Also in these two genera, sepals are shortly connate only very close to the floral base, and thus free in most of their length, as previously reported for these genera (Kallunki, 2005; Kubitzki et al., 2011). The calyx in other Galipeinae and closely related genera (Pilocarpinae, Hellieta, Balfourodendrum and Hortia) are usually described as cupular, cotyliform or cupuliform, with variable shape of its apex (deltoid, dentate, triangular, denticulate, subentire, Kasstra, 1982; Kallunki, 1992, 1998, 2005; Pirani, 1998, 1999; Kubitzki et al., 2011; Groppo \& Pirani, 2012). According to Engler (1931) sepals in Rutaceae are mostly united at base and imbricated.

Markedly imbricated sepals were exceptionally found in this study, and instead the most common type of aestivation was either valvate to open. In fact, several Galipeinae are reported as having valvate sepals or subentire calyxes (Kallunki 1992, 1998a, 2005, 2009; Pirani, 1999, 2004; Kubitzki et al., 2011). Exceptionally, we found slightly imbricated sepals (only close to their bases), as in Conchocarpus cyrtanthus, C. concinnus and Ertela species; and markedly imbricated sepals were found only in Ravenia species. In fact, "overlapped sepal lobes" are reported only for the bud stage in Angostura and Conchocarpus, as this is not apparent at anthesis for most species. Overlapped sepal lobes at anthesis have been previously reported only for a group of species formed by Conchocarpus cyrtanthus, C. concinnus, $C$. gaudichaudianus (A.St.-Hil) Kallunki \& Pirani, C. hirsutus Pirani and C. insignis Pirani, which are closely related species according to morphological and molecular analysis (Kallunki \& Pirani, 1998; Groppo et al. in prep.). Also, Angostura and Conchocarpus are reported as having quincuncial sepals, but with "the lobes not overlapping at anthesis" (Kallunki \& Pirani, 1998), thus having open aestivation as found here. We did not fiund quincuncial sepals in these latter two genera, probably because this feature was analyzed in advanced buds only. Aditionally, we found advanced buds of Ertela and Ravenia species with the quincuncial pattern of aestivation only at some levels of the sepals, and unequal lobes (in size and shape) with the two outermost lobes larger than the inner three. Other Galipeinae described with quincuncial sepals (conspicuously overlapped at anthesis) are Decagonocarpus, Raveniopsis, and Raputia (the latter two also with two larger outer lobes, Kallunki, 1994, 2005; Kubitzki et al., 2011). Similarly unequal imbricated sepals, with the 
two outermost larger lobes (suggesting quincuncial pattern of aestivation) are also found in Apocaulon and Lubaria (Engler, 1931; Kallunki, 2005; Kubitzki et al., 2011). Thus, calyx features appear to support the putatively close relationship between the genera Apocaulon, Decagonocarpus, Ertela, Lubaria, Raputia, Ravenia and Raveniopsis, as indicated by morphological analysis (Kubitzki et al., 2011). However, it becomes clear that the calyx aestivation should be evaluated in detail in distinct stages of flower development, since this character may change at anthesis (Kallunki \& Pirani, 1998; probably due to the expansion of the corolla in this stage). Thus, a, quincuncial calyx at anthesis may be a feature not restricted only to seven genera of Galipeinae. In a broader scale, considering the eudicots clade, the quincuncial pattern is the most common type of calyx aestivation (Endress, 2011a).

Other particular calyx features have their occurrence restricted to single species, such as the undulated surface of the calyx of Angostura bracteata, and the occurrence of "wings" in the pedicel of Ravenia spectabilis. The morphology and vascularization of these "wings" indicate that these are probably formed by the congenital fusion of two lateral bracts to the two outermost sepal lobes in this species. Congenital fusion of segments of the calyx to parts of the inflorescence bracst was not previously reported for any Galipeinae. Similarly in Ertela bahiensis, lateral fusion of the three pedicels in one partial inflorescence was not known to occur in the group. It would be interesting to comparatively study the development of the calyx and inflorescences in these Galipeinae members, in order to understand how these structural modifications may have arisen.

An interesting functional feature in the calyx of Almeidea species is the occurrence of extrafloral nectaries at the tip of the sepal lobes. These structures are histologically inconspicuous, and thus could be classified as "Gestaltlosennektarien", i.e., nectaries characterized by possessing no well-defined secretory structure (Zimmerman, 1932; Fahn, 1979). An apparently similar phenomenon was already described in sepals of Cattleya (Orchidaceae) and Paeonia albilflora Pall. (Paeoniaceae, Frey-Wyssling and Häusermann, 1960), and for floral bracts of Costus (Costaceae) and other species of Paeonia (Elias, 1983). However, there are some histological differences. In these examples the nectar is secreted to the outside through modified stomata at the surface of the organs, while in Almeidea no stomata were observed. Instead, a necrotic tissue or an empty cavity was frequently observed in this region, between the vascular bundle and the rounded aperture at the surface of sepals. This observation suggests that the exudate from the extrafloral nectaries of Almeidea may be formed by the lysis of the nectariferous tissue, as reported for other plants in which lysigenous cavities in extrafloral nectaries occur (Fahn, 1979, 1987; Bernadello, 2007). However, further 
detailed studies on the ultrastructure and development of these extrafloral nectaries are needed in order to corroborate this idea. Differently, their function appears to be equal to many other extrafloral nectaries, since ants were seen exploring the nectar produced in this region of sepals. Thesesame ants were observed aggressively reacting once the flower was touched (El Ottra et al., submitted, Chapter 2), indicating that these structures might play a role in the anti-herbivore defense of $A$. rubra, as usually reported for extrafloral nectaries in other plant groups (Hey and McKey, 2003).

Extrafloral nectaries at the tip of the sepal lobes in Galipeinae were previously reported not only for Almeidea species, but also for some Conchocarpus species (Bruniera, 2010). According to a character reconstruction made by Bruniera (2010), this feature is a putative synapomorphy for Almeidea, as it is present in all species of the genus. Differently, it would be a homoplastic feature within the subtribe, since some species of Conhocarpus also present similar extrafloral nectaries in the calyx [i.e., C. heterophyllus (A.St.-Hil.) Kallunki \& Pirani, C. minutiflorus Groppo \& Pirani, C. pentandrus (A.St.-Hil.) Kallunki \& Pirani, and C. furcatus Kallunki, Bruniera, 2010; J.H.L. El Ottra pers. obs.]. However, this structure was only studied in Almeidea (this study) and hence suitable comparison with the extrafloral nectaries of Conhocarpus requires detailed structural studies on the species of this latter genus with such nectaries.

Regarding calyx vascularization, a main pattern found is the formation of synlaterals close to the floral base. Even though there may be numerous vascular bundles in the upper region of sepals, at floral base five main traces and five synlateral traces are usually present (this study). This deviates from the common pattern found for other Angiosperms and rosids, where usually three traces per sepal are present (Puri, 1955; Bachelier \& Endress, 2008). Other Sapindales members with synlateral traces occur in Burseraceae (Bachelier \& Endress, 2009).

Calyx histology provides further features that support the putative relationship between Ertela and Ravenia (Kubitzki et al., 2011; Groppo et al., in prep.). Secretory hairs with short uniseriate stalk and large multicellular heads were only found in the species of these genera. However, they somewhat form a carpet of hairs only in sepals of Ravenia species. Their shape ranges from hook- (Ertela bahiensis), club- (R. infelix) to fan-shaped (fan-shaped only in R. spectabilis). However, similar glandular trichomes were observed in sepals of Erythrochiton species (Kallunki, 1992; J. H. L. El Ottra pers. obs.). In Ravenia they occur only at the inner base of sepals, suggesting that they might have a specific biological 
function. In fact a strong unpleasant smell emanating from the secretion within a fruiting calyx was noticed in live material. Kallunki (1992) similarly reported a "bitter and strongsmelling" liquid within the calyx for two Erythrochiton species, but in bud stage. It would be interesting to investigate the functional role of these glandular trichomes in both genera. Glandular trichomes on sepals are reported to have the function of helping fruit dispersion by animals (in acrescent calyces; Weberling, 1989). In several Galipeinae species the calyx is persistent during fruit development, including Ravenia (Kallunki, 1992, 1998b, 2005; Pirani, 1999; Kubitzki et al., 2011; this study). However, since in Galipeinae the fruits are not dispersed by animals and the seeds are autochorically dispersed, it is unlikely that these structures assitis fruit dispersion by animals.. Instead, they may act in anti-herbivore defense for the bud or young fruit. More studies are necessary to test this hypothesis. Glandular hairs with short uniseriate stalk and large uni- to multicellular heads were also found in other floral organs in Galipeinae, as similarlyfound in floral organs of other members of Rutaceae, Burseraceae and Anacardiaceae (Engler, 1931; Ramp, 1988; Souza et al., 2003, Bachelier \& Endress, 2009; Kubitzki et al., 2011; this study).

Another feature that supports the putative relationship between Ertela and Ravenia is the presence of large intercellular spaces in the mesophyll of sepals (resembling a spongy parenchyma). In these genera, sepal lobes are similar to foliage leaves, as they are usually, green, membranaceous or with similar texture to foliage leaves, and relatively larger than in other Galipeinae. Thus their leaf-like anatomy is probably related to their photosynthetic function.

\section{Corolla}

In Galipeinae and closely related groups, the union of petals is more structurally diverse than previously described in the literature. Both congenital and postgenital union may occur, and in the cases of postgenital union, petals may be connected only during bud stage (as in Adiscanthus fusciflorus, Metrodorea nigra and Hortia oreadica), or may maintain their union at anthesis (as in most of the Galipeinae, this study, El Ottra et al., 2013). The postgenitally united floral tube of Galipeinae is a structure formed by the synorganization of filaments and petals, which is maintained at anthesis and along most of their length (except at their upper part, where the lobes are spreading). El Ottra et al. (2013), while studying the floral tube structure in five members of the subtribe, found three main structural patterns of synorganization of petals and filaments. Basically, the first pattern involves the marginal 
coherence/adherence of petals and filaments due to intertwining trichomes, the second pattern is related to the congenital fusion of petals to filaments, and the third pattern is a mixture of the first two patterns. In this latter pattern, the floral tube is formed proximally by the congenital union of stamens and petals, and distally by the coherence/adherence of petals and filaments. In this study we may add a fourth pattern: the floral tube formed solely by the congenital union of petals (a corolla tube, not a stamen-petal tube), found in Ertela bahiensis and Ravenia infelix. In the latter species there may be a single staminode congenitally fused to the petal tube, but it does not contribute substantially to the tube structure, since it is an antepetalous staminode. All other species of Galipeinae studied with a stamen-petal tube fit in any of the first three patterns found by El Ottra et al. (2013). Thus, all species analyzed of Almeidea (though some flowers have only slightly coherent petals, see further details below), Conchocarpus macrocarpus, C. mastigophorus, C. obovatus, C. odoratissimus, $C$. heterophyllus, C. minutiflorus, Neoraputia alba, N. trifoliata, Raputiarana, Rauia resinosa and $R$. nodosa fit into the first pattern. The second pattern occurs only in Ravenia spectabilis and Erythrochiton brasiliensis, and the third pattern in Angostura bracteata, Conchocarpus cyrtanthus, C. concinnus, C. macrophyllus, all Galipea species (G. jasminiflora, G. ciliata, G. dasysperma, G. carinata, and G. laxiflora) and Sigmatanthus (Pirani et al., 2010, El Ottra et al., 2013, this study). Within the third pattern, only in C. macrophyllus and C. concinnus is the floral tube formed by the adnation of the staminal filaments to petals up to their lower half, while in all other species it is formed by the adnation of the staminal filaments to petals up to their upper half (El Ottra et al., 2013, this study).

The taxonomic descriptions of several other Galipeinae genera apparently indicate that they may also fit into the patterns described above. Other Conchocarpus species, Leptothryrsa, Ticorea, Toxosiphon and Desmotes probably fit into the first pattern, while other species of Erythrochiton and Ravenia may fit into the second pattern. Finally, flowers of Naudinia, Apocaulon, Decagonocarpus, Raveniopsis and Raputia may be formed according to the third pattern (Engler, 1931; Kallunki 1992, 1998, 2005; Kallunki \& Pirani, 1998; Kubitzki et al., 2011, Pirani 1999). The description of Lubaria indicates that the floral tube in this genus may be different from all other previously reported, since it has one free petal and the other four petals connated (Engler, 1931; Kubitzki et al., 2011). However, further detailed microscopic analysis of Lubaria flowers are needed, as well as with flowers of all the above mentioned genera, because stereomicroscopy does not allow to detect to what extent the floral organs are really united (El Ottra et al., 2013). In Galipeinae, the union of petals is rarely fragile or absent at anthesis. Adiscanthus, as previously reported, has free petals at anthesis, 
postgenitally connected only in bud stage (this study). These features provide further support to its sister relationship to the dialipetalous genus Hortia, outside the clade where all other Galipeinae are placed in molecular phylogenies (Groppo et al., 2008, 2012). However, only a few other Galipeinae genera have petals free at anthesis, as Spiranthera, Euxylophora, Nycticalanthus and Andreadoxa (Kallunki, 1998a; Kubitzki et al., 2011; this study). Additionally, in A. coeruela, A. limae and some flowers of A. rubra, the union between petals and filaments to petals is fragile, as very few trichomes are present at petal and stamen margins (this study). In fact, apparently in some flowers of $A$. rubra the imbrication of petals is the main responsible factor for the maintenance of the floral tube structure (this study). Since in Almeidea species the floral tube structure is lost during the herborization process (as petals, filaments and their trichomes shrink and detach when dried), they are usually described as dialipetalous with free filaments (Brunieira, 2010; Kubitzki et al., 2011).

Contrasting with the majority of Galipeinae, the petals of Adiscanthus, Hortia oreadica and Metrodorea nigra are postgenitally connected only in bud stage, free at anthesis. In the latter species, only at the tip of petals there is postgenital connection by the interlocking of papillae in the petal margins. Furthermore, Adiscanthus and $H$. oreadica have postgenitally connected petals along their entire length by the interlocking of short epidermal cells (papillate in $H$. oreadica) and their cuticular projections. Thus, an additional difference between these genera and Galipeinae representatives is that the postgenital connection occurs by the interlocking of short epidermal cells and their cuticular projections, while in the Galipeinae it is caused by intertwining trichomes. In Rutaceae, the postgenital connection of petal margins formed by the interlocking of papillate epidermal cells and cuticular projections was already reported only for Correa speciosa (Hartl, 1957; Boronieae, placed in a distant clade from Galipeinae, Groppo et al., 2008, 2012). However, in Correa this connection is kept at anthesis, forming the floral tube. It is quite striking that Hortia oreadica presents similar histological features to C. speciosa, but Hortia petals does not retain their union at anthesis. This fact raises questions related to floral architecture, as which are than the fundamental differences in the corolla structure of both groups that makes one sympetalous and the other dialipetalous at anthesis? This may be answered in comparative studies with the flower structure of other species of Correa, since one of its eleven species is secondarily dialipetalous (C. alba Andr., Wilson, 1961; Duretto pers. com.). We may suggest that the maintenance of the petal union at anthesis is related to cuticle fusion between the adjacent epidermis of petals; or related to petal size, aestivation, or the region where they become deflexed at anthesis (or even a combination of all these factors). In Sapindales, a similar histological feature was observed in some Anacardiceae, Burseraceae and Nitrariaceae, where 
the postgenital connection of petal margins in bud is caused by interdentation of their papillae surface and striate cuticular ornamentation (Bachelier \& Endress, 2009; Bachelier et al., 2011).

Diversity in the petal union of Galipeinae taxa and closely related neotropical Rutoideae encompasses a series of gradation, ranging from postgenitally connected at the tip of the corolla only in bud stages and free at anthesis, to congenitally fused in the floral tube at anthesis (forming a stamen -petal tube, or rarely, a corolla tube). In the tubular-flowered Galipeinae a gradual pathway of evolution could be suggested, in whichthe petal and filament union at anthesis would have departed from a plesiomorphic state "free petals and filaments at anthesis" to an apomorphic state "coherent petal, filaments adherent to petals" and finally to the most derived states "congenitally fused petals to filaments", as assumed by El Ottra et al. (2013). However, observations of the floral tube structure of Almeidea species and the dialipetalous Spiranthera odoratissima point out that the evolutionary history of these features may be more complex. Since there is no clear evidence at present that these two latter genera are closely related (Kubitzki et al., 2011, M. Groppo et al., in prep.), free petals, petals only slightly coherent/adherent to filaments, or even imbricated petals may not have evolved in a gradual sequence. Reversals might have occurred from the apomorphic states "synorganized petals and filament" more than once within the subtribe, since other few genera of the subtribe are described as dialipetalous (Euxylophora, Andreadoxa, Nycticalanthus; Kubitzki et al., 2011). Thus, some of the genera with free petals may be secondarily dialipetalous in terms of their evolution. Future studies on character state reconstructions are required in order to clarify the evolution of these features.

However, an interesting evolutionary pathway may be hypothesized in relation to the evolution of postgenital connection of petals formed by epidermal cells and their projections. As previously discussed, postgenital coherence of petals formed by intertwining trichomes is a common feature in several Galipeinae genera. Contrastingly, the clade formed by Hortia and Adiscanthus has postgenitally connected petals formed by the interlocking of short epidermal cells and cuticular projections along their entire length. Thus, in the American clade the evolution of epidermal cell union between petal margins appears to have evolved from a plesiomorphic state "short, interlocked cells" (as in Hortia and Adiscanthus, and at the apex of the bud in Metrodorea nigra) to a derived state where these cells elongate, forming the postgenital connection by intertwining trichomes, the latter found in several Galipeinae. Aditionally, as in Galipeinae this connection is kept at anthesis, it is possible that this postgenital union is stronger than a similar one achieved through shorter epidermal cells and 
cuticle projections. Nevertheless, the fact that in most Galipeinae the stamens are also synorganized together with petals indicates that other structural factors may contribute to the maintenance of the postgenital union of petals at anthesis, such as filament shape (wide and dorsiventrally flattened in most Galipeinae, this study), position, and their union to petals (for further details see the androecium topic). Corolla aestivation may also play a role in the stability of the tube structure at anthesis, since in some Almeidea rubra petals are only slightly coherent, and the tube apparently is maintained by the imbricated petal margins. Furthermore, the fact that the large petals of Spiranthera odoratissima show a similar pattern of aestivation but are free at anthesis indicates that several structural factors may probably be responsible for the resulting architecture of the flower - and not a single one. In the case of $S$. odoratissima, these could be petal size, level of petal deflection at anthesis, and filament shape. Additionally, since petals are in most cases synorganized with filaments in the floral tube of Galipeinae, they have probably evolved in a modular pattern (correlated character evolution). Further testing of this idea upon a phylogenetic context would be interesting.

In all species, petals were found to be responsible for the protection of inner organs in bud throughout most of its stages (young to late bud), as they become longer than sepals early in development (except Ravenia and Ertela, only in late bud). This feature was not previously reported for neotropical Rutaceae, but is very common in Sapindales families. In fact it is considered a putative synapomorphy for the order (Ronse De Craene \& Haston, 2006; Bachelier \& Endress, 2009). Conversely, in many other Angiosperms, sepals usually are the protective organs of inner floral whorls in bud (Weberling, 1989). In Galipeinae and closely related groups the overall shape of the bud is given by petals, which are relatively longer than sepals. In the American clade and putatively related groups, apparently there are two main shapes for the buds: while in most of the Galipeinae and Hortia, buds are more or less oblong to linear (sometimes dilatated at tip or in the case of Adiscanthus, at base in advanced buds), in Pilocarpinae (Metrodorea, Esenbeckia, Pilocarpus and Raulinoa), Helietta and Baulfourodendron (former Toddalioideae, Toddalieae, Pteleinae) they are globose (Kaastra, 1982; Pirani 1998, see also Figs 1-3). Exceptionally in Galipeinae, sepals are the protective organ in bud, covering the inner organs until shorlty before anthesis. This was observed in Erythrochiton brasiliensis (J. H. L. El Ottra pers. obs, see also Fig. 2A in El Ottra et al., 2013); and apparently also in other species of this genus, such as Toxosiphon and Desmotes in which the calyx is relatively larger than petals in advanced buds (Kallunki 1992).

Corolla aestivation was found to be remarkably similar in all Galipeinae (except Adiscanthus): always cochlear, either ascending or slightly oblique (Kubitzki et al., 2011; El 
Ottra et al., 2013, this study). Only at base, petals become narrow and at this level there they have valvate to open aestivation for a short extent (i.e., all species analyzed of Almeidea, Conchocarpus macrocarpus, C. mastigophorus, C. obovatus, C. odoratissimus, Neoraputia alba, N. trifoliata, Raputiarana, Rauia resinosa and $R$. nodosa). Contrastingly, corolla aestivation in Adiscanthus, Hortia oreadica is valvate, and in Metrodorea nigra induplicatevalvate in its entire length (this study). Thus, cochlear aestivation is a putative synapomorphy for the clade of Galipeinae without Adiscanthus. However, more genera of the American clade should be studied to further support this idea. In other groups of Rutaceae, corolla aestivation is referred to as either valvate or imbricated, rarely imbricated contort (Eichler, 1878; Engler, 1931; Kubitzki et al., 2011; Endress, 2012). Imbricate petals with open aestivation at base were already reported for some other Sapindales (Anacardiaceae and Burseraceae, Bachelier \& Endress, 2009). However, this feature may occur more frequently in Rutaceae than previously reported. In the American clade, Balfourodendron is described with petal "at base attenuate to subunguiculate" (Pirani, 1998). Similarly, other members of the family distantly related to the neotropical groups have unguiculate petals (e.g., Ruta L., Chloroxylum DC, Engler, 1931; Groppo et al., 2012). All these terms may correspond to the same feature, but have been described through different terminology.

Apparently, corolla aestivation is more variable outside Galipeinae (without Adiscanthus). Other genera in the American clade, including Adiscanthus, Balfourodendron, Helietta, Hortia, Esenbeckia, Metrodorea,Choisya, and putatively related groups (Raulinoa and Pilocarpus, Galipeeae, Pilocarpinae, according to the phylogeny of Dias et al., in press) are either valvate or imbricated. Corolla aestivation in Hortia, Adiscanthus, Metrodorea, Esenbeckia subgen. Lateriflorens and Pilocarpus is generally referred to as valvate (induplicate-valvate in Pilocarpus and probably similar to $M$. nigra). Differently in Esenbeckia subgen. Esenbeckia, E. subgen. Oppositifolia, Raulinoa, Balfourodendron, Helietta and Choisya, the corolla aestivation is described as imbricate (Engler, 1931; Kaastra, 1982; Pirani, 1998). Similarly, the corolla aestivation in the Galipeinae (without Adiscanthus) is generally described as imbricate (Engler, 1931; Kubitzki et al., 2011). In fact, Groppo et al. (2008) already recognized the valvate type of aestivation as a putatively synapomorphy for the "Hortia-Adiscanthus" clade. However this was not considered for the clade where Metrodorea and Esenbeckia were placed. Thus, further detailed studies with the corolla of those groups are necessary in order to refine the imbricate type of aestivation (whether it corresponds to the cochlear type or else), and the valvate type (whether it corresponds to the 
valvate or involute-valvate), and finally to properly understand the evolutionary implication of this feature to Neotropical Rutoideae.

An interesting systematic implication was found for the relative position of petal tips in bud stage. In all Galipeinae (without Adiscanthus), petals overlap at the tip of the buds (this study). Exceptions would be E. brasiliensis, in which large petals are individually folded at their tips, and maybe Ticorea, which is described as having "inflexed" petal tips (Kallunki, 1998b). Contrastingly, in Adiscanthus, Hortia oreadica and Metrodorea nigra petals are bent inwards in centre at their tips. While "petal tips overlapped in bud" is another putative synapomorphy for the Galipeinae clade (without Adiscanthus), petals inwardly bent in bud are also present in other Pilocarpinae genera. In Pilocarpus this is clearly seen in the illustrations of $P$. pennatifolius Lem. by Souza et al. (2003) and also inferred from the description of the whole genus (petals with "uncinately inflexed tips", Kaastra, 1982). Similarly in species of Hortia, this region of the corolla is described as "apex with one inflexed apicule" (Groppo \& Pirani, 2012), which correspond to the same feature hereby mentioned. Additionally, an analysis of the descriptions and illustrations of Groppo \& Pirani (2012) shows that the bending of petal tips is retained after anthesis. In Rutaceae the inward bend of petal tips appears to occur in other groups, as in Euodia, Melicope, Pitaviaster, Picrella, Neoschmidea, Tetradium, Geijera (described as "hooked petal tips" in Kubitzki et al., 2011, and see also the illustrations of Engler, 1931, for these same genera). Petals inwardly bent in bud also occur in other Sapindales, such as in some genera of Anarcardiaceae (Bachelier \& Endress, 2009). This feature co-occurs with valvate aestivation of the corolla and petals protecting the inner floral organs in advanced bud, as observed in this study and for several other core eudicots (Endress \& Matthews, 2012). It would be interesting to test the correlated character evolution of these features for core eudicots.

Petal morphology has systematic importance for Almeidea species. According to the traditional taxonomy of the genus, the diagnostic feature of A. limae is the conspicuous, very thick, longitudinal abaxial petal ridge (Silva, 1988). However we found here that in some $A$. rubra specimens, this rigde is also conspicuously developed, and there is a continuous variation in the thickness of this structure in this species. Thus it seems that the presence of a longitudinal abaxial ridge is not an adequate feature to the circumscription of A. limae, which additionally shows no substancial difference in the flower structure in relation to other Almeidea here analyzed, except for the floral size (much smaller in A. coerulea, variable in A. rubra). In fact recent molecular studies show that $A$. rubra is not a monophyletic taxon, which 
should be synonymized together with A. limae and A. lilacina A.St.-Hil. (Bruniera, 2010; Bruniera \& Groppo, in prep.). Our findings further support this taxonomical decision.

The anatomy and histology of petals present some features commonly found in other members of Rutaceae or higher taxonomical hierarchies, while others are very particular to some specific groups of genera or species. Petals commonly have one single vascular trace in all flowers, a common pattern found in Rosids and other Angiosperms (Puri, 1951; Bachelier \& Endress, 2009). Hairs in petals may be tanniferous, lignified, glandular, simple, stellate or echinoid. Numerous long tanniferous hairs at the lower half of the adaxial side of petals are a marked feature of Adiscanthus and Hortia oreadica. This was previously described by Groppo \& Pirani (2012) for nearly all other species of Hortia, as a tuft of trichomes in this same region (or as "bearded petals"). Kubitzki et al. (2011) already recognized that Adiscanthus and Hortia shared "bearded petals", further corroborating their close relationship. Thus tanniferous hairs concentrated in this specific region of petals is a putative synapomorphy for this pair of sister genera. However it would be necessary to verify if these hairs are tanniferous in all other species of Hortia. As these hairs are placed above the region of the nectary, they may have the function of nectar protection from nectar robbers, dilution from rain or evaporations, as previously stated for other Angiosperms (Endress, 1994; Nicolson \& Thomburg, 2007).

Contrastingly, in most of the Galipeinae (except Adiscanthus) uniseriate lignified hairs are abundantly present and participate in the coherence of petals in the floral tube structure (El Ottra et al., 2013, this study). Less frequently, stellate and echinoid hairs are present exclusively in the perianth of Angostura bracteata, and are a marked feature of this genus (Kallunki \& Pirani, 1998). While stellate trichomes are reported for some other members of the family, echinoid trichomes are absent in other groups (Engler, 1931; Kubitzki et al., 2011). Similarly, the long stipitate glandular trichomes found in petals of Sigmatanthus are also a unique case found in the family thus far. Since these glandular trichomes form a dense cover on both sides of petals (and filaments), it would be interesting to study their functional role in the floral biology of this species. Glandular trichomes in flowers may produce attractants or deterrents to animals, and also may protect the flower from extreme temperatures, excessive light and droughts (Werker, 2000; Espigares \& Peco, 1995). Interesting S. trifoliatus is one of the few Galipeinae species that occurs in dry forests or open vegetation ("carrascos" and "capoeiras") in the northeast of Brazil (Pirani, 1999; Kubitzki et al., 2011); thus the function of those trichomes could be related to the protection of the flowers against extreme environmental conditions. 
Other histological features found may be related to the formation of optically attractive surfaces in petals. In Ertela and Ravenia species, the presence of large intercellular spaces in the corolla was found. This tissue, differently from similar ones found in other floral organs (in anthers of Hortia oreadica and in sepals of the same genera mentioned above) has larger intercellular spaces, and cells may be irregularly branched forming arm-like outgrowths, resembling an aerenchyma. The presence of such tissue in petals is associated with the enhancement of color in perianth organs (Weberling, 1989). Similarly, the presence of papillae found in the upper region of petals in Conchocarpus species (C. macrocarpus, C. mastigophorus, C. odoratissimus, C. obovatus) and Rauia species may be related to the formation of optically attractive velvety surfaces (Weberling, 1989).

In most species analyzed, the main color of the perianth is given by petal colour. In Galipeinae the most common color of the corolla is white and/or cream (Kubitzki et al., 2011, this study), though the color of petals is lacking in descriptions of several taxonomical treatments. Less frequently, petals may have other colors, such as: green (some Raputia, Ravenia and Neoraputia species, Kallunki, 1994; Kubitzki et al., 2011); rarely pink (few Conchocarpus species, Kallunki \& Pirani, 1998); pink to lilac (Almeidea species, though in several cases they may fade to white by the end of anthesis, Brunieira, 2010; El Ottra et al., submitted, Chapter 3); light pink (Ravenia spectabilis and Sigmatathus, this study); red (Naudinia, Kubitzki et al., 2011); red to salmon-pink (Neoraputia paranesis, N. caliantha Kallunki, Desmotes, Kallunki, 1992; Kallunki, 2009); yellow (Conchocarpus silvestris, Andreadoxa flava, Kallunki, 1998a; Kallunki \& Pirani, 1998), orange to red (Decagonocarpus, Kallunki, 2005); and pink to orange or red in Raveniopsis (Kallunki, 2005). An interesting pattern of color was found in Raputiarana, where small pink or lilac dots, corresponding to secretory colored cavities in the hypodermis, occur scattered throughout the cream colored background of petals (this study). Similar pattern of color occurs in the petaloid staminodes of Calodendrum capensis (Diosmae, Engler, 1931; Ramp, 1988). While light colors like white may indicate nocturnal Lepidoptera attraction, yellow colors could be associated with bee attraction, and pink to red tones could be associated with hummingbirds or butterfly attraction (Faegri \& van der Pij1, 1979). However, the association of petal colors and floral visitors has to be taken with caution, since only floral biology studies may corroborate which are the effective floral visitors of each species. Additionally, other floral attributes may be involved in the attraction of floral visitors. Yet it is noteworthy that all of the above-mentioned functional groups of animals were observed as pollinators in Galipeinae: Erythochiton brasiliensis with its white corolla and red calyx is pollinated by hummingbirds (Lopes, 2002); Conchocarpus species with light pink to cream colored corolla 
are pollinated and by diurnal Lepidoptera and also bee species (C. macrophyllus, $C$. cyrtanthus, El Otrra et al., in prep., Chapter 3); Almeidea rubra is pollinated by both butterflies and hummingbirds; and Angostura bracteata by butterflies, moths, and one hummingbird species (El Otrra et al., submitted, Chapter 2; Chapter, El Otrra et al., in prep., Chapter 3).

\section{Androecium}

The androecium in Galipeinae and closely related groups is basically pentamerous, haplostemonous, or additionally with two (rarely one) antepetalous staminodes. Haplostemonous flowers may have all five fertile stamens (as found in Almeidea limae, most flowers of A. rubra, Spiranthera odoratissima, Adiscanthus, Hortia oreadica and Metrodorea nigra), or three (A. coerulea, some flowers of A. rubra) to two fertile stamens in posterior (adaxial) position, and then two to three antesepalous staminodes in anterior (abaxial)

position, respectively (Conchocarpus concinnus, C. cyrtanthus, C. macrocarpus, C. mastigophorus, C. obovatus, C. odoratissimus, Ertela trifolia, E. bahiensis, some flowers of Neoraputia alba, some flowers of $N$. trifoliata, some flowers of Ravenia infelix). When additionally two antepetalous staminodes are present, flowers always have two (posterior) fertile stamens and then five (anterior) staminodes (the three antesepalous plus two antepetalous, as found in Angostura bracteata, Raputiarana, $R$. resinosa, Sigmatanthus trifoliatus, some flowers of Neoraputia alba, N. trifoliata, Rauia nodosa and Ravenia spectabilis). Rarely, some deviation was observed in this latter pattern, as in the flowers of $R$. spectabilis and $R$. infelix with occasionally only one single antepetalous staminode, or in the abnormal flower $R$. nodosa with four fertile antesepalous stamens, one antesepalous staminodes, and two antepetalous staminodes. Some Galipea species with rare hexamerous flowers, or normal pentamerous flowers, may have three antepetalous staminodes (Pirani et al., 2010).

Haplostemonous flowers with full fertile stamens is a marked feature in genera of the American clade outside Galipeinae. All species of Metrodorea, Esenbeckia, Helietta, Baulfourodendron, Adiscanthus, Hortia and the putatively related genera of Pilocarpinae, Pilocarpus and Raulinoa (Dias et al., in press) are haplostemonous with full fertile stamens (Engler, 1931; Kasstra, 1982). Similarly, Choisya, the single obdiplostemonous genus of the American clade, has both whorls of fertile stamens (Engler, 1931; Gut, 1966; Ramp, 1988). Differently, the presence of staminodes is a marked feature in Galipeinae, absent only in few 
genera or species (Engler, 1931; Kubitzki et al., 2011). Besides the species studied here, other Galipeinae with all five fertile stamens are Euxylophora, Leptothyrsa, Nycticalanthus, few Conchocarpus species, most Almeidea species, all other Spiranthera species, some species of Erythrochiton, and most species of Ticorea (Bruniera, 2010; Kallunki, 1992, 1998b; Kallunki \& Pirani, 1998; Kubitzki et al., 2011, Pirani, 1999). Contrastingly, the majority of member of the subtribe have two fertile stamens and three antesepalous staminodes (besides the species and genera hereby studied, they are present in Apocaulon, most Conchocarpus species, Decagonocarpus, Lubaria, Naudinia, Raveniopsis, Raputia, some flowers of Galipea, one species of Ticorea, some species of Erythrochiton and Toxosiphon, other species of Neoraputia, Rauia and Ravenia), or s two additional antepetalous staminodes (Andreadoxa, Desmotes, some flowers of Erythrochiton, Toxosiphon, Galipea, Neoraputia, Rauia, Ravenia ; all other species of Angostura; Engler, 1931; El Ottra et al., 2013; Kallunki, 1990, 1992, 1998a, 1998b, 2005; Kallunki \& Pirani, 1998; Kubitzki et al., 2011; Pirani, 1999, 2004, Pirani et al., 2010). Lubaria, similarly to Ravenia infelix and $R$. spectabilis, rarely presents flowers with a single antepetalous staminode (Engler, 1931; Kubitzki et al., 2011).

The presence of these additional antepetalous staminodes in Galipeinae flowers intrigues botanists who have studied the family since Engler (1931). This author remarks that the addition of these two staminodes in Galipeinae is striking, since no closely related group has vestiges of an obdiplostemonous androecium, in its classification. However, obdiplostemony commonly occurs in other members of Rutaceae (Engler, 1931). Differently, Pirani et al. 2010, studying the floral structure of Galipea species concluded that these two (or three) antepetalous organs may not be homologous to sterilized stamens, but may represent petal appendages. This idea was based mainly on the strong morphological similarity and vascular association of these staminodes to petals. The authors observed that the vascular bundle of antepetalous staminodes become fused to the main vascular bundle of the immediately opposite petals at lower level of the floral tube in most cases, while antesepalous staminodes were not (see Figs 23-24, 33-42 in Pirani et al., 2010). Additionally, since they were adnate to petals in upper regions of the flower when compared to the antesepalous ones, they superficially appear to "arise as branches from petals" (see Figs 60-63 in Pirani et al., 2010). Finally, another aspect that led to this idea was that in the upper part of the floral buds of Galipea, these antepetalous staminodes were placed further inside than the antesepalous ones, contrary to what was expected in obdiplostemonous flowers (see Figs 37-42, 62-63 in Pirani et al., 2010). According to the original concept of Chatin (1855), the antepetalous whorl should be further out than the antesepalous whorl in obdiplostemonous flowers. 
Similarly, Kubitzki et al. (2011), following the conjectures of Pirani, named these additional staminodes as "pseudostaminodes" in the descriptions of the genera of the "Angostura Alliance" (the informal group in which Galipeinae are included in their work).

However, in this study we choose to name these structures as antepetalous staminodes, since they appear to us as homologous to normally sterilized stamens. This decision was based not only to their overall resemblance to antesepalous staminodes (filament-like, dorsiventrally-flattened and narrower than the filament of fertile stamens), but also based on the new evidence found in this and previous work (El Ottra et al., 2013), plus discussions related to obdiplostemony (Eckert, 1966; Gut, 1966; Ronse De Craene \& Smets, 1995; Endress, 2010a). First, young developmental stages of the androecium of Angostura bracteta, Conchocarpus macrophyllus and Rauia resinosa show that the antesepalous stamen arises later than petals as independent primordia, at least at the beginning of their development (this study and see also Fig. 8 in El Ottra et al., 2013). Second, the young antesepalous stamen whorl is larger than the two antepetalous ones, which indicates a delay in the development of the antepetalous staminodes, as part of the process which generates obdiplostemony (delay in the development of the petal sector of the flower). Additionally, this indicates that antepetalous stamens may arise later in development than antesepalous ones, as reported for other obdiplostemonous flowers (Leins, 1964; Eckert, 1966; Endress, 2010a; Wei et al., 2011). Finally, carpels are antepetalous, a fact used as evidence for obdiplostemony (Bachelier \& Endress, 2009; Endress, 2010a); but this may be dubious in this case, as the androecium is not isomerous in these Galipeinae species.

The unusual position of the tips of antepetalous staminodes of Galipea cannot be used as an argument for its non-homology to staminodes, since close to their attachment area to petals (i.e. at the upper level of the floral tube where these are congenitally fused) they are more or less in the same series with the antesepalous staminodes (i.e. at the same level, not further inside or outside the flower; see Figs 37, 60-61 in Pirani et al., 2010 and Fig. 4L in El Ottra et al., 2013). Similarly, several studies with other groups show that it is not always possible to clearly establish which whorl is further inside or outside in obdiplostemonous flowers, even looking at their attachment area in the floral base. This happens because this basal area may change dimensions during development, and both whorls my change their relative position in upper parts of the flower as these organs grow (Leins, 1964; Endress, 2010a). This is apparently the case for Galipea, Rauia resinosa, Angostura bracteta and Sigmatanthus, where the tips of young antepetalous staminodes are further inside than outside of the flower, while their attachment area is more or less at the same level as the antesepalous 
stamens (see Figs 14C, D, 37I, and also the microtome series, Figs 12B-E, 34B-D, 41C-E). Interestingly, there is some variation regarding the position of antepetalous staminode tips in other Galipeinae. While in the three above-mentioned genera they are more inside the flower, in Conchocarpus macrophyllus, Ravenia infelix and $R$. spectabilis they are more to the outside. Just at the base of their free parts they become positioned more or less in one single series with the antesepalous staminodes; and also lower where they are congenitally fused to antesepalous stamens (except Ravenia infelix, the latter whorl is free, and only the antepetalous staminode fuses to petals in the lower region of the corolla tube; Figs 38C, D, 40A, and also Fig. 3I-K in El Ottra et al., 2013). Further detailed ontogenetic studies are necessary to better understand the development of these differences in position of the tips of antepetalous staminode in Galipeinae.

The fusion of the vascular bundle or vascular trace of the antepetalous staminodes to the immediately opposed petal is commonly reported in other obdiplostemonus flowers of Rutaceae, and other obdiplostemonous Angiosperms (Saunders, 1934; Moore 1936; Tilson \& Bamford, 1938; Gut, 1966; Puri, 1951). This bundle fusion should not be used as evidence for its homology to petals, since it commonly occurs in floral organs that occupy the same radii in flowers (Endress, pers. com.). The formation of trace complexes of antesepalous stamens plus petals was already reported to obdiplostemonous Rutoideae, for members of Aurantieae (Tilson \& Bamford, 1938), Agasthoma (Diosmae) and Cneoridium (Toddalieae; Saunders, 1934; Moore, 1936). Differently, we have found here that sometimes (and even in the same flower) the antepetalous staminode bundles may run independently through its course to the floral base (i.e. one of the antesepalous stamen in Angostura bracteata, Rauia resinosa, and both in Sigmatanthus trifoliatus), as reported for obdiplostemonous Ruteae (Ruta and Psilopeganum, Wei et al., 2011). Interestingly in Coleonema (Rutoideae, Diosmae) not only the congenital fusion of antepetalous staminodes to petals occur, but also their bundle fusion in lower region of flower (Engler, 1931; Gut, 1966; Ramp, 1988). Similarly in Ruteae, the antepetalous stamen whorl becomes adnate to petals close to the floral base (Wei et al., 2011). Thus, in Coleonema and Ruteae antepetalous staminodes are similarly united to petals, as in several Galipeinae. However, in Galipeinae, the congenital fusion of stamens to petals usually occurs in upper levels of the floral tube (Pirani et al., 2010, this study), while in Coleonema and Ruteae it occurs at the base (Wei et al., 2011). Thus, according to the available evidence, we think that it is unlikely that these antepetalous structures are homologous to petal appendages as previously assumed (Pirani et al., 2010). Additionally, we think that it is not necessary to create another new term for them in the systematic literature, such as 
"pseudostaminode" (Kubitzki et al., 2011). This may cause confusion, since in previous systematic treatments they are normally named as staminodes.

In fact, what still intrigue us is the fact that when antesepalous staminodes are not fused to the corolla tube, the antepetalous ones are, as observed in Rauia species and Ravenia infelix. This could be related to developmental and/or phylogenetic constraints, since both Rauia and Ravenia infelix appears to have a close relationship with species/genus where petals are congenitally fused to both antesepalous and antepetalous stamens. Rauia may be closely related to Galipea, and $R$. infelix to other Ravenia species such as $R$. spectabilis (Groppo et al., in prep.). Similarly, other obdiplostemonous flower may present common primordia of petals plus antepetalous stamens (Endress, 2010a); however, in these cases there is a strong delay in development of both organs, which apparently is not the case here. It is probable that future Evo-devo studies with androecium gene expression may clarify these unusual features of the staminodes of Galipeinae.

The absence of the antepetalous staminodes on the posterior side of the flower in all Galipeinae species is quite striking, since in other obdiplostemonous Rutaceae a complete whorl of antepetalous staminodes is usually present, rather than an incomplete whorl (Engler, 1931; Gut, 1966; Ramp, 1988; Kubitzki et al., 2011). Contrastingly, Choisya, the single genus in the American clade with obdiplostemonous flowers, (more closely related to Galipeinae than other obdiplostemonous Rutaceae), have a complete and fully fertile antepetalous stamen whorl. Most Rutaceae have haplostemonous or (ob)diplostemonous flowers. In fact obdiplostemonous flowers constitute a common feature in Sapindales (Engler, 1931; Bachelier \& Endress, 2009). However, in Rutaceae diplostemonous flowers are reported for a few groups (e.g. in Aurantieae, apparently in Aegle, Citrus, Triphasia, Penzing, 1887; Engler, 1931; in Boronieae, in Eryostemon, Ramp, 1988). In the family, obdiplostemonous flowers with a complete whorl of antepetalous staminodes commonly occur in several Diosmeae (Dictamnus, Coleonema, Agasthoma, Barosma), and less frequently in other tribes (Engler, 1931; Kubitzki, 2011). Interestingly, in Boronia (Boronieae) one antesepalous staminode may sometimes be missing (Ramp, 1988; Gut, 1966). Different from Galipeinae, in Diosmeae these antepetalous staminodes often may be petaloid, and thus may have assumed attractive functions for pollinators (Engler, 1931; Kubitzki, 2011).

Normally, staminodes are quickly lost in flower evolution if they do not take over new functional roles (Walker-Larsen \& Harder, 2000). Since their occurrence is a marked feature in Galipeinae, occurring in the majority of the genera and species in the anterior (abaxial) side 
of the flower, one may assume that they take over important roles in the floral biology of the group. This is true of some species for which there is such available information. For instance, in Angostura bracteata, all staminodes may secondarily present pollen, together with the posterior (adaxial) stamens, which causes pollen deposition in the anterior region of the floral visitors, or in both anterior and posterior regions (nototribic and sternotribic pollen deposition; El Ottra et al., in prep., Chapter 3). However the lack of studies on floral biology and pollination in Galipeinae limits further discussion about the functional role of staminodes.

Filaments of fertile stamens and staminodes in Galipeinae display distinct shapes along their extension, as seen in transections. They are usually wide and dorsiventrally flattened, more or less triangular along most of their length. Additionally, in species where these are free but postgenitally adherent to the corolla, they precisely alternate with petals, and are most wider and larger in the floral tube region (i.e., in Almeidea species, Conchocarpus macrocarpus, C. mastigophorus, C. odoratissimus, C. obovatus, Neoraputia trifoliata, N. alba, Rauia nodosa, R. resinosa, in this latter two species this applies only for the antesepalous stamens). Apparently, this unusual shape of filaments could be related to the overall architecture of the flower, especially in tubular flowers without organ fusion. This would not only facilitate the adherence of filaments to petals (El Ottra et al., 2013), but also no furrow in the floral tube would be left for the easy entrance of nectar thieves, especially in species with open to valvate aestivation at base of the corolla. Interestingly, even in species with congenitally fused stamen petal-tube (i.e. in Angostura bracteata; Conchocarpus cyrtanthus, C. macrophyllus, Galipea species, Sigmatanhus; El Ottra et al., 2013, Pirani et al., 2010, this study), filaments are usually dorsiventrally flattened at the basal region of their free tips, but not as wide as in species where there is no fusion.

The apparent correlation among filament shape and tubular flowers has further support when analyzing filament shape in closely related species without this floral architecture. For instance, in other genera of the American clade with non-tubular flowers (open, flat, dishshaped flowers or bowl-shaped flowers), filament shape is usually described as terete or subterete. In this study, we found that in the open flat flowers of Metrodorea nigra, filaments are rounded in transections along their entire length. Similarly in Adicanthus and Hortia oreadica, they are rounded at their upper level and more or less triangular close to their base, but in these species filaments never are wide as in the Galipeinae with tubular flowers. Similarly, the few species of Galipeinae without a tubular flower do not have wide dorsiventrally flattened stamens, as in Spiranthera odoratissima (this study); and apparently also in Euxylophora, Leptothyrsa and Nycticalanthus, which are usually described as having 
"terete or subterete" filaments. Contrastingly, for most genera and species of Galipeinae filaments are described as "flattened" (species of Conchocarpus, Almeidea, Naudinia, Toxosiphon, Lubaria; Engler, 1931; Kallunki, 1992, 2005; Kallunki \& Pirani, 1998; Kubitzki et al., 2011).

Similarly to petals, filament union in Galipeinae and related groups displays a quite variable structural diversity, ranging from free to completely congenitally fused. In Metrodorea nigra, Hortia oreadica, Adiscanthus and Spiranthera odoratissima filaments are completely free and may have common bases with other floral organs for a short extent (ovary, disc and petals). Differently, filaments are free (non-fused) but postgenitally adherent to the corolla in most of its extension in several Conchocarpus species (C. macrocarpus, $C$. mastigophorus, C. odoratissimus, C. obovatus), Almeidea species (A. coerulea, A. limae, A. rubra), Ertela bahiensis, Neoraputia trifoliata, N. alba, Rauia nodosa, R. resinosa and Ravenia infelix (in these latter two genera, only antepetalous staminodes are congenitally fused to the opposite petal), and also apparently in Desmotes, Toxosiphon, Ticorea, Raputia, other Conchocarpus species, Neoraputia and Rauia species (see descriptions of Kallunki, 1992, 1994, 1998; Kallunki \& Pirani, 1998; Kubitzki et al., 2011). Filaments are congenitally fused to the corolla up to their lower half and postgenitally adherent to it above only in Conchocarpus concinnus and in C. macrophyllus (in the latter species also forming a short staminal tube; this study, El Ottra et al., 2013). Contrarily, filaments are congenitally fused to petals up to their upper half and only shortly distally adherent to petals in Angostura bracteata, C. cyrtanthus, Galipea species and Sigmatanthus (Pirani et al., 2010; El Ottra et al., 2013; this study). Only the two fertile stamens appears to be connated in Lubaria (fused at base; Engler, 1931; Kubitzki et al., 2011), and apparently also in Ertela trifolia (congenitally fused at the upper region of the filament up to the base of the anther, this study). Erythrochiton brasiliensis is so far the species with the highest degree of congenital fusion of filaments, forming a staminal tube that extends beyond the stamen-petal tube (also congenitally formed, El Ottra et al., 2013). Other Galipeinae described as having filaments connated in a tube are Naudinia (only at base), Decagonocarpus and Raveniopsis (Kallunki, 2005; Kubitzki et al., 2011).

Besides the five main patterns mentioned above, single variations regarding filament union were found in Raputiarana and Ravenia spectabilis. In Raputiarana there is one median anterior staminode, free in most of its length and postgenitally adherent to the corolla; while all other four filaments (two posterior fertile stamens and the two adjacent staminodes) are also adherent to the corolla but congenitally fused in their lower half, forming a staminal 
arc. Differently, in upper levels of the flower of Ravenia spectabilis a partial staminal tube is formed by the congenital fusion of the five lower anterior staminodes to petals, and also laterally to the large filament of fertile stamens. These latter two unite laterally only at anther level by postgenital connection of their bases, forming then a closed androecium tube. It is interesting to note that this mixed pattern of congenital fusion and postgenital connection of the androecium forms a narrower entrance to the floral tube (at the level of anthers, the stamen-petal tube is much narrower than the space formed alone by petals on the posterior side of the flower, see Fig. 38E-F). This unusual androecium display apparently is related to structural changes during the female phase of the flower: anthers and filaments separate along this postgenitally connected region, so that the style and stigma may pass between them and become exserted from the floral tube (see Fig. 3A and also Endress 2010b, Fig. 8D, which apparently is upside down).

The connation of filaments is reported for some other Rutaceae groups. The congenital union is mostly extensive in members of Aurantieae tribe (former Citroideae, Engler, 1931; Endress \& Stumpf, 1991), where they may form a staminal tube (Atalantia) or even a polyadelphous androecium (some Citrus species, Kubitzki et al. 2011). Within the American clade and putatively related groups (Raulinoa and Pilocarpus, Dias et al., in press), the connation of filaments and their union to the corolla are not reported outside the Galipeinae clade (without Adiscanthus). Thus, one could assume that the evolution of this feature shifted from the plesiomorphic state "free filaments" towards a variety of modes of filament union; from postgenital connection to congenital fusion, or even a combination of both. However, the way in which the above-mentioned patterns shifted from one to another in evolution would be more clearly understood in future phylogenetic studies.

A common feature found in the filament of staminodes in Conchocarpus species $(C$. macrocarpus, C. mastigophorus, C. odoratissimus and C. obovatus) and Rauia (Rauia nodosa, R. resinosa) is the presence of papillae in their distal region. They occur all around the surface and also in the corresponding level on petals. Additionally, the papillae on staminodes connect to the papillae of adjacent staminodes in bud stage. However, after anthesis staminodes are free and exserted from the corolla in this region. Thus, differently from the lignified trichomes in the floral tube region, the presence of these papillae could have other implications not related to floral architecture. Perhaps these papillae are related to the formation of optically attractive velvety surfaces, as reported for other Angiosperm flowers, but usually found in the perianth (Weberling, 1989). 
Anther structure presents a variety of interesting features in the studied taxa. In all species anthers are dithecal, with a septum between the two pollen sacs, tetrasporangiate (except Sigmathanthus trifoliatus, polysporangiate), longitudinally dehiscent, introrse, sagittate to slightly X-shaped. Also, size of anthers ranges from very small (Ertela) to very large (Spiranthera odoratissima); the connective thickeness ranges from very thin to thick. A deep ventral furrow is usually present, while a dorsal furrow is observed in some species. The level of anther attachment to the filament ranges from basifixed to dorsifixed in their upper half. Similar anther morphology was already reported for other Rutaceae (several groups of Rutoideae and in Cneorum tricoccon L., Cneoroideae, Endress \& Stumpf, 1991). Additionally, anthers sagittate, basifixed to dorsifixed introrse and longitudinally dehiscent are frequently found in Rosids (Bachelier \& Endress, 2009).

While analyzing the level of anther attachment to the filament in detail, some differences between Galipeinae and related Neotropical groups were found that may have interesting systematic implications. In all Galipeinae except Adiscanthus, anthers are basifixed to near-basal dorsifixed. In contrast, Adiscanthus and Hortia oreadica are dorsifixed at their half or upper half, while in Metrodorea nigra, they are dorsifixed near their half. In fact, all other genera and species of Galipeinae are described as having near-basal dorsifixed anthers (Almeidea, Euxylophora) or basifixed anthers (all other Galipeinae species and genera; Engler, 1931; Kallunki, 1992, 1994, 1998a, 1998b, 2005; Kallunki \& Pirani, 1998; Kubitzki et al., 2011; Pirani 1999, 2004). In contrast, other members of the American clade and putatively related genera have dorsifixed anthers "usually near their middle, never basifixed" (Kaastra, 1982, for the Pilocarpinae genera, Metrodorea, Esenbeckia, Pilocarpus and Raulinoa). Differently, Pirani (1998) states the following for Helietta and Baulfourodendrum: "anthers dorsifixed below the middle". Thus, the level of anther attachment to filament may characterize some groups within the American clade. Further detailed structural studies are nedded for the proper codification of filament insertion, especially for Choisya and other species of Hortia, which constitutes the remainder genera of the American clade for which this information is lacking (Kubitzki et al., 2011; Groppo \& Pirani, 2012).

Anthers in Galipeinae commonly bear sterile basal appendages, which represent a prolongation of thecae (Engler, 1931; Kubitzki et al., 2011). These appendages may be short (Angostura and Neoraputia, Kallunki \& Pirani, 1998; Kallunki, 2009; this study) to long (the longest in the subtribe are found in Raputiarana and Sigmatanthus, Emmerich, 1978), free (A. bracteata, $N$. alba) or laterally (postgenitally) connected to the adjacent appendage $(N$. 
trifoliata, R. subsigmoidea, S. trifoliatus), or postgenitally fused (Galipea species, El Ottra et al., 2013; Pirani et al., 2010). Other genera of the subtribe that have sterile basal appendages are Andreadoxa, Apocaulon, Decagonocarpus, Desmotes, Erythrochiton, Lubaria, Raputia, Raveniopsis, Ticorea, Toxosiphon, as well asgenera studied herein. Differently, these are absent in other genera of the subtribe, such as Spiranthera, Nycticalanthus, Leptothyrsa, Adiscanthus, Euxylophora, Almeidea, Conchocarpus, Naudinia, Ertela and Rauia (Engler, 1931; Kallunki, 1990, 1992,1998a, 1998b, 2005; Kallunki \& Pirani, 1998; Kubitzki et al., 2011, Pirani 1999, 2004, Pirani et al., 2010, this study). In no other group in the American clade or elsewhere in Rutaceae are similar appendages found.

Few species have sterile anthers above the attachment region to the filament as well as below in their basal appendages (i.e., Raputiarana subsigmoidea, Sigmatanthus trifoliatus, A. bracteata). This was already reported for other Galipeinae genera, such as Galipea, Naudinia, and Ticorea (Kallunki, 1998b; Kubitzki et al., 2011; Pirani, 1999, 2004, Pirani et al., 2010). Differently, Adiscanthus and Hortia oreadica have long fertile bifid anther bases (i.e. below the level of anther attachmentto the filament, the two thecae separate at base for a long extent), vascularized along most of their extension. Though at first glance the fertile bases of these latter genera appear to be homologous to the sterile bases of Galipeinae, there are some differences between these structures. In most cases, the sterile appendages of Galipeinae represent a single non-vascularized prolongation from both thecae along most of their extension. Exceptions were found in Neoraputia trifoliata, in which two separate short prolongations of thecae were found, as is similarly the case for Galipea, and probably the bilobed appendage of Desmotes (Kubitzki et al., 2011; Pirani et al., 2010; this study). Further ontogenetic studies with the anthers of both groups are necessary in order to clarify the homology among these structures.

The lateral union of the base of the anthers and their sterile basal appendages in Galipeinae is histologically variable when analyzed in detail. While in Raputiarana and Sigmatanthus only the region of the basal appendages are postgenitally connected by minute cuticular projections on the epidermis of the appendages, in Neoraputia trifoliata they are connected by interdigitation of short epidermal and subepidermal cells in the appendages and at the fertile bases of anthers. Similarly in Galipea species, the postgenital union comprises the lower region of the anthers and their sterile basal appendages. However, it is histologically different, since only at base are the epidermal cells interlocked, while higher up postgenital fusion is complete (epidermal cells undifferentiated and similar to hypodermal cell; in $G$. ciliata the fusion is even more complete with no vestiges of the suture between the epidermis 
of adjacent anthers at anthesis, Pirani et al., 2010; El Ottra et al., 2013). Other Galipeinae genera described with anthers laterally connated by basal appendages are Andreadoxa, some Erythrochiton and Tososiphon species (described as "coherent" anthers in these latter two genera; Kallunki, 1992, 1998; Kubitzki et al., 2011). Although the function of the sterile basal appendages in the floral biology of the groups is unknown (Kubitzki et al., 2011), it is probably related to pollen economy and stability of the fertile anthers during foraging of pollinators (El Ottra et al., 2013). This was shown for other groups with similar flower architecture and stamen display (Faegri \& van der Pijl, 1979; Westerkamp \& ClaßenBockhoff, 2007). Additionally, since the position of the basal appendages may narrow the entrance of the floral tube for a greater extent (in species in which anthers are placed at the mouth of the floral tube), this could be another functional implication of their presence.

Differently, other genera lacking basal appendages may have laterally united anthers. This occurs in Decagonocarpus, Lubaria, Raputia and Raveniopsis (Engler, 1931; Kallunki, 1990, 1994, 2005; Kubitzki et al., 2011). In this study we found that the anthers of Ravenia spectabilis, which are unappendaged, are laterally postgenitally connected with each other at base by the interlocking of short epidermal cells. Also, the unappendaged anthers of some specimens of $A$. rubra are postgenitally connected laterally by the interlocking of short papillae. Similar papillae are also present in the anthers of other Almeidea species, Conchocarpus odoratissimus, C. obovatus, C. macrocarpus, C. mastigophorus, and in the sterile tips of anthers of Rauia species. Contrastingly, we found that the unappendaged anthers of Ertela trifolia are laterally congenitally fused to each other from their bases until the tips of filaments. This is so far the single case known in the subtribe of congenital fusion of anthers.

At the apex of anthers sterile prolongation was found more rarely, forming a protrusion of variable extension and shape with pointed tips. In Conchocarpus concinnus there is an apiculate apex, while in $C$. odoratissimus, $C$. obovatus and $C$. macrocarpus the protrusion gradually narrows toward its apex (apical sterile appendage, Kallunki \& Pirani, 1998). Rauia species have an apical protrusion of similar shape. Apiculate apices were already reported for some other Galipeinae genera such as Andreadoxa. Similarly, apical sterile appendages or flattened sterile apex of anthers were reported for several Conchocarpus species (Kallunki \& Pirani, 1998; Pirani et al., 2012). Connective protrusion may include internal secretory organs, usually a terminal gland in Rutaceae (Endress \& Stumpf, 1991, Kubitzki et al., 2011). This apparently occurs in the apiculate apex of anthers in Ravenia infelix (this study) and in Pilocarpus species, but it is non-glandular in the putative closely 
related Metrodorea, Esenbeckia and Raulinoa (Pilocarpinae; Kaastra, 1982). Curiously, a large terminal secretory cavity, making the tips of the five staminodes spherical, was found only in Angostura bracteata, not present at the tips of fertile stamens. This is a common feature of Angostura species (Kallunki \& Pirani, 1998). Since these terminal glands in staminodes are deeply stained with neutral red, this indicates that they may play a role in scent emission (osmophores, El Ottra et al., in prep., Chapter 3).

In most studied species stamen vascularization consists of a single vascular bundle, unbranched throughout its course, and at floral base a single vascular trace. This is the most common pattern found for Rosids andAngiosperms (Puri, 1951; Bachelie \& Endress, 2009). However, some deviation from this pattern was observed. In the anthers of Adiscanthus and Hortia oreadica the single vascular bundle forks into two branches toward the tip of the anther; similarly, this same bundle branches off to two lateral bundles, which supply the long fertile bases of anthers (Fig. 51C). In other Rutaceae two vascular bundles at the apex of the anther were reported only for Citrus species (treated as Poncirus, in Endress \& Stumpf, 1991). These unusual patterns of anther vascularization were associated with large to midsized anthers, and X-shaped anthers (Endress \& Stumpf, 1991). While this correlation exists regarding to anther size in Adiscanthus and Hortia oreadica, it is not the case regarding anther shape: while in the first case it is sagittate, in the second it is only slightly X-shaped.

Another unusual pattern of vascularization is found in the androecium of Neoraputia and Conchocarpus odoratissimus. Here the filaments or fertile stamens and staminodes may have two to four lateral vascular bundles at certain levels. In Neoraputia trifoliata and $C$. odoratissimus, these are only present in the upper part of staminodes and in N. alba, present in filaments of fertile stamens and staminodes along most ot their length. Branching of the vascular bundle in filaments is rarely observed (some Monocots, Puri, 1951). In Neoraputia this feature could be related to the shape and size of filaments, which are large and wide (as is the entire flower). However, $C$. odoratissimus has a medium-sized flower and the branching of its stamen's vascular bundle occurs only at the tips of the staminodes, where they are triangular-shaped in transection. Additionally, since other species with large flowers have wide dorsiventrally flattened stamens with only one unbrached stamen vascular bundle (e.g. Raputiarana subsigmoidea), the correlation between lateral bundles in stamens and flower size may not exist.

Endothecium-like tissue (i.e. a tissue which is similar to the endothecium, but not located at the periphery of the pollen sacs; Hufford \& Endress, 1989 ) broadly developed in different sites of the anther, as found here, was previously reported for other groups of 
Rutaceae. In the family it is usually present around each theca, over the dorsal and ventral sides of the connective (Endress \& Stumpf, 1991; Souza et al., 2003). In Galipeinae the endothecium-like tissue is always present, but in slightly different distributions: it is usually located on the connective side of thecae but not over the dorsal or ventral side of the connective in Almeidea species, Conchocarpus odoratissimus, C. obovatus, C. macrocarpus, C. mastigophorus; it is located on the connective side of thecae and also continuous with the endothecium over part of the dorsal side of the connective in Raputiarana, Metrodorea nigra and Hortia oreadica; it is present continuously with the endothecium over part of the dorsal side of the connective in Ravenia infelix, R. spectabilis and Sigmatanthus; it occurs on the connective side of thecae and also continuous with the endothecium over the entire dorsal side of the connective in Neoraputia alba, N. trifoliata, C. cyrtanthus and C. concinnus; and finally, it is present on the connective side of thecae, and also continuous with the endothecium over part of the dorsal side of the connective as a palisade-like layer of cells in Angostura bracteata, Ertela bahiensis, Rauia resinosa and $R$. nodosa. The functional implication of the endothecium-like tissue is unknown, but it could be related not only to thecae dehiscence (as is the endothecium) but also with anther alterations in position and shape at anthesis, as reported here for some Galipeineae. In fact, in A. bracteata and Rauia species, where this tissue is mostly developed as a palisade-like layer on the dorsal side of the connective, we observed that older flowers completely or partially curved their anthers backwards, away from the corolla throat (and in the case of A. bracteata also the filaments recurve). However, further functional studies, together with structutural studies, are necessary in order to corroborate this idea.

Another unusual histological feature of the anthers are the large intercellular spaces at the connective region found exclusively in Adiscanthus fusciflorus and Hortia oreadica. Large intercellular spaces in floral tissues are usually associated with light interaction, forming optically attractive surfaces. However, this is usually found in the perianth (Weberling, 1989). Thus, one could argue that here their function could be different. Anther movements were already reported for other Hortia species. According to Groppo \& Pirani (2012), "pollen mass are liberated when anther assume an almost perpendicular position in relation to filament". Similarly, anther versatility apparently occurs in Adiscanthus. Thus the unusual presence of this tissue in the connective could be related to anther movement at anthesis. Differently, much larger intercellular spaces (resembling an aerenchyma) are found at the upper part of the filaments of staminodes of Ravenia infelix, R. spectabilis and Ertela 
bahiensis. Further floral biology studies are needed to better understand the functional implication of these large intercellular spaces in the androecium of Galipeinae.

Secretory cells or tissue are usually present in the androecium of Galipeinae and closely related groups. Tanniferous tissue is notably abundant in stamens of most species analyzed. It is often found in the connective of anther (around the vascular bundle), but it may be also present in the filaments, staminodes, and in the epidermis of anthers. This secretion was absent only in the androecium of Almeidea species and C. mastigophorus. Previously, tanniferous tissue was reported as usually absent in Rutaceae, occasionally present in the epidermis of anthers, or rarely in the connective (Endress \& Stumpf, 1991, in which Galipeeae were only represented by Pilocarpus pennatifolius and Erythrochiton brasiliensis). Since this tanniferous tissue is present in stamens of most Galipeinae and closely related groups herein analyzed, this could be another marked feature for the American clade. Another type of secretory cell, with a blue-stained secretion — probably mucilage — was observed in stamens of several species in this study (Conchocarpus odoratissimus, C. obovatus, C. macrocarpus, Neoraputia alba, N. trifoliata, Raputiarana, Rauia, Ravenia infelix, Metrodorea, Hortia oreadica, in this latter species apparently produced within ducts in anther). Mucilage cells were not previously reported for flowers of Rutaceae, only for the leaves (Matthews \& Endress, 2006).

Hairs on filaments are present in most Galipeinae species (except Adiscanthus). This could be related to the overall floral architecture of the flower, since in several species hairs participate in the adherence with petals at the floral tube structure. However, many other Rutaceae also have hairy filaments and non-tubular flowers (Engler, 1931). In many groups of Angioperms, the presence of hairy filaments and flowers with open architecture (i.e. dish- or bowl-shaped flowers, in which the access to the floral centre is open) are associated with nectar protection (Endress \& Stumpf, 1991; Endress, 1994). Thus hairy filaments may have different functional aspects in the family. However, this should be carefully evaluated in each case, considering overall flower architecture, location of hairs and nectary position. Hairs in anthers were found in Ertela species, and were previously reported for Erythrochiton and Conchocarpus species (Endress \& Stumpf, 1991; Kallunki, 1992; Kallunki \& Pirani, 1998). In C. macrophyllus part of the pollen is retained in those hairs after anther dehiscence (J. H. L. El Ottra et al., in prep., Chapter 3). It would be interesting to study the role of these hairs in the floral biology of other Galipeinae species.

Stamens with more than four pollen sacs are only found in the large anthers of Sigmatanthus trifoliatus. In this species the thecae are subdivided by several transverse septa, 
forming polysporangiate stamens. This feature is not common in Angiosperm flowers and it was not previously reported for Rutaceae. The closest member in Sapindales with similar anther structure is found in Meliaceae (Harms, 1940; Endress \& Stumpf, 1990, 1991). Polysporangiate anthers may be functionally linked to the occurrence of large anthers, since there is an assumption that a limitation exists in the sporangium size and/or sporangium/tapetum ratio that would lead to the development of multiple sporangia once this size or ration is too large. However, there are some cases in which this association does not occur, i.e. large anthers with normal tetrasporangiate structure or small polysporangiate anthers (Endress \& Stumpf, 1990, 1991). Even in Galipeinae, this correlation is often lacking, as in the large tratrasporangiate anthers of Adiscanthus, Erythrochiton brasiliensis, Neoraputia alba, N. trifoliata, Raputiarana and Spiranthera odoratissima (Endress \& Stumpf, 1991, this study). Thus, so far the polysporangiate anthers of Sigmatanthus may be considered an autapomorphy for this monotypic genus.

Anther and filament alterations during anthesis were found to be very common in Galipeinae and related groups regarding their abscission, movement, position and shape. Versatile anthers are found in Adiscanthus (and also coiled according to Kallunki, 2005), Ravenia infelix, Spiranthera odoratissima, Metrodorea nigra, Hortia oreadica. Anthers and filaments bending outwards in the female phase were observed in A. rubra (but anther persistent in the female phase), Angostura bracteata and Ravenia infelix. Caducous anthers were also found in N. trifoliata, Raputiarana subsigmoidea, Sigmatanthus and Metrodorea nigra. All of the above species with caducous anthers also presented protandry and/or a female phase of the flower, in which the stigma is exserted from floral tube (except Metrodorea nigra, which is protrandrous but with dish-shaped flowers). Caducous anthers are often associated with protandry, since it is an efficient way to avoid interference of anthers in the female phase of anthesis in bisexual flowers (Lloyd \& Webb, 1986; Endress \& Stumpf, 1991). This phenomenon is neither frequent in Sapindales nor in Rutaceae (Endress \& Stumpf, 1991). However, apparently it is very often in other member of the American clade and putatively closely related groups, in which anther shedding and filament movements during anthesis were already reported for several genera (in Esenbeckia, other species of Metrodorea, Raulinoa, Pilocarpus, Helietta and Balfourodendron; Kaastra, 1982; Pirani, 1998; Pombal \& Morellato, 2000). Differently, persistent (non-caducous) anthers in Galipeinae were observed for some Conchocarpus species (C. cyrtanthus, C. macrocarpus, C. obovatus, this study, C. macrophyllus, El Ottra et al., in prep., Chapter 3). In these species also the stigma is recessed in the floral tube below anther level throughout anthesis and 
without clear male or female phase of flowers. These features may indicate a different floral mechanism avoiding male and female interference in these species. Further comparative floral biology and reproductive studies evaluating these aspects in Galipeinae would be of interest.

\section{Nectary bearing structures}

In Galipeinae (except Adiscanthus), most of the nectariferous tissue differentiates in an intraestaminal cupular nectary disc. Occassionally the nectary has an oblique base around petals and filaments and the nectariferous tissue may extends downwards around the gynophore, even reaching the floral base for a short extent (in Almeidea rubra, A. coerulea, Conchocarpus concinnus, C. odoratissimus, Neoraputia alba, Rauia nodosa, Raputiarana, Sigmatanthus). Hortia oreadica presents an annular nectary disc, while Adiscanthus presents most of the nectariferous tissue at the periphery of the thick gynophore, extending downwards to the common base of petals and filaments. Contrastingly, Metrodorea nigra presents most part of the nectariferous tissue on the dorsal side of the ovary walls, but at its upper region, it embraces the base of the filaments and projects obove the ovary, forming an annular disc in this region-. Thus three main types of nectaries can be recognized, related to the region where most of the nectariferous tissue occurs: a nectary disc (most Galipeinae and H.oreadica), a gynophorous nectary (Adiscanthus), and an ovarian nectary plus annular disc (M. nigra).

Nectary disc and gynophorous nectaries are usually reported for several groups of Rutaceae and Simaroubaceae (Engler, 1931; Ramp, 1988; Kubitzki et al., 2011). In Galipeinae, the nectary disc, cupular or more rarely tubular (in Erythrochiton species, Kallunki, 1992) is found in most species of the subtribe. Engler (1931), reported as lacking only in Euxylophora, and as a "very low cushion subtending the ovary" in Leptothyrsa (Kubitzki et al., 2011). Differently, the ovarian nectary found in Metrodorea is usually reported as a "nectary disc adnate to the ovary", similarly described for all other Pilocarpinae genera (Kaastra, 1982; Souza et al., 2003). Exception is found in Pilocarpus, in which the nectary was either referred to as a disc completely adnate to the ovary, or as a spherical gynophore (Kaastra, 1982; Ramp, 1988), or even as a disc extending above the ovary in eight sectors ( $P$. pennatifolius, Gut, 1966). Contrarily, the disc of Hortia species (former Toddalioideae, Todaliinae, currently in the American clade) is described as a "5-lobed disc, completely adnate or nearly so to a short gynophore" (Groppo \& Pirani, 2012). However, herein we found no gynophore in $H$. oreadica; instead the ovary is partially inferior. Further detailed studies on the disc of Pilocarpinae genera and Hortia are necessary for an adequate 
comparison, and to establish putative homologies of these nectary types in the Neotropical groups.

Previous studies on the development and vascular anatomy of the disc and gynophores in Rutaceae discussed whether the nectary would represent an independent structure, originated by the proliferation of the "floral axis" or "receptacle" between stamens and carpels, or appendages of organs, or even vestigial floral whorls (stamens or carpels; Saunders, 1934; Moore, 1936; Tilson \& Bamford, 1938; Puri, 1951; Gut, 1966; Guédés, 1973; Souza et al., 2004; Pirani et al., 2010). Moore (1936), based on the observations of Saunders (1934), questioned whether the formation of trace complexes of the disk plus stamens in some species should be seen as evidence of its origin from a sterilized whorl of stamens. Differently, when the disc traces form trace complex with the carpel traces, or even if these run independently to the floral base, it was assumed that the disc could represent a series of sterile carpels (Moore, 1936; Tilson \& Bamford, 1938), or even be evidence of its receptacular or axillar origin (Tilson \& Bamford, 1938; Pirani et al., 2010). Here we found that disc traces often merge with the traces that are closer to them at the floral base, especially with the traces that are in the same radius at floral base (and this apparently is determined by the shape of the floral apex, i.e., whether it is flatter or convex). Our data show that disc traces often form complexes with the stamen traces (either antesepalous or antepetalous), but sometimes they also form complexes with the petal traces or dorsal carpel traces. More rarely, these run independently to the central vasculature at the floral base. We think that it is unlikely that the disc represents vestigial sterilized organs, especially if considering that multicarpellary and polystemonous flowers are rarely found in the family (only in some Aurantieae and in Peltostigma, Zanthoxylae; Kubitzki et al., 2011), and that the disc occurs in both haplostemonous and (ob)diplostemonous flowers (Engler, 1931). Additionally, the nectary disc and gynophores grow late in development (after all floral organs are formed) and independently from gynoecium development (Ramp, 1988, this study). Thus, it appears that the nectary disc is formed as an independent protrusion in Rutaceae, not clearly originated from one of the floral organs, as shown in other Angiosperms with disc nectaries (Endress, 2010b). It differentiates in the small space available from the base of the stamens to the base of the gynoecium (eventually sharing common bases with them, Ramp, 1988; this study) and present variable shape in the family (annular, cupular, tubular, cushion-shaped, pulvinate, Kubitzki et al., 2011). When it differentiates in most parts of the gynoecium, the nectary often occurs around the gynophore and/or on the ovary, on which it may (or not) form an annular protusion (disc) at apex (this study, Ramp, 1988). Even though nectary discs 
ocasionally present a common base with other floral organs, it seems more reasonable for the group to consider the nectary as an independent structure, considering the available evidence fromdevelopmental and structural studies (Ramp, 1988, this study). This idea follows the present knowledge from molecular developmental studies, which shows that the formation of the nectary in model plants is independent from ABC genes (Baum et al., 2001).

\section{Gynoecium and ovules}

Comparative analysis shows that Galipeinae have mostly apocarpous carpels, with a (short) basal syncarpous zone, a median free zone, and an upper apocarpous but postgenitally fused zone. The basal syncarpous zone comprises the base of the locules and usually a short gynophore (when present), while the upper apocarpous postgenitally fused zone occurs from the upper region of the ovary to the style and stigma in most cases. However these zones vary in extent among species. The zone of basal congenital union comprises approximately half of the total length of the ovary in Adiscanthus, Conhocarpus odoratissimus, C. mastigophorus, Rauia resinosa, $R$. nodosa and Neoraputia trifoliata. This same region comprises ca. onethird of the total length of the ovary in Almeidea rubra, A. limae, A. coerulea, and $C$. minutiflorus; one-quarter in $C$. heterophyllus and Ravenia spectabilis; one-fifth in $C$. macrocarpus, C. obovatus, Ravenia spectabilis, Sigmatanthus and Erythrochiton brasiliensis; and one-seventh in C. macrophyllus and Raputiarana. In Angostura bracteata, C. concinnus, Ertela bahiensis and Spiranthera odoratissima this zone is shorter than one-seventh, and in $C$. cyrtanthus it is lacking (El Ottra et al., 2013; this study). Thus in the majority of species analyzed, the basal syncarpous zone is shorter than half-lenght of the ovary, and apocarpous from this region to the tip of the carpels (free or postgenitally fused). At the ovary level, the shortest median free zone is observed in Rauia and Neoraputia species. Contrastingly, carpels of Metrodorea nigra (Pilocarpinae), Hortia oreadica (former Toddalioideae, currently in the American clade) and Galipea (Galipeinae) have no zone of free carpels, as they are congenitally or postgenitally fused in variable degree along their entire length (Pirani et al., 2010; El Ottra et al., 2013, this study). These observations suggest that the apocarpy in Galipeinae, with a short basal zone of congenital fusion (usually shorter than half-lenght of the ovary), is an apomorphic feature shared by most species of the group. Additionally, reversals from the plesiomorphic state may have occurred in Galipea. However this hypothesis has to be considered with caution, as detailed structural studies of carpel union are still lacking for most other genera of American clade outside the Galipeinae. 
Further support for this idea is the fact that most Galipeinae genera are described with carpels apocarpous or, less frequently, united only at base and at apex in the style region (Engler, 1931; Kallunki, 1992, 1994, 1998b, 2005; Kallunki \& Pirani, 1998; Kubitzki et al., 2011; Pirani, 1999, 2004). Contrastingly, other genera in the American clade are described as having "connate carpels" (Helietta, Baulfourodendron, Pirani, 1998) or "completely connate" carpels (Metrodorea, Raulinoa and some species of Esenbeckia, Kaastra, 1982). However, further ontogenetic studies on the carpels of M. nigra, Hortia oreadica and Galipea species, as well as on other genera of Pilocarpinae, are necessary. In this way, it will be possible to clarify whether they are truly sincarpous (i.e. with congenital fusion between carpels, and postgenital fusion within carpels, Leinfellner, 1950; Weberling, 1989), and to what extent they are congenitally or postgenitally fused, allowing a proper comparison with the gynoecium of other genera in the American clade. Similarly, several other Rutaceae possess apocarpous or syncarpous gynoecia, with variable degrees of congenital and postgenital fusion (Ramp, 1988; Gut, 1966). Other apocarpous genera of Rutoideae already described are: Zanthoxylum, Euodia, Tetradium, Eriostemon, Boronella, Boronia, Dictamnus, Ziehria, Correa, Choisya, Ruta, Boenninghausenia and Pilocarpus (Gut, 1966; Ramp, 1988; Souza et al., 2003). Inversely, truly syncarpous carpels occur in most in genera of Aurantieae (former Aurantioideae, Engler, 1931, currently in expanded Rutoideae; Groppo et al., 2012) and in Calodendrum, Coleonema, Ruta, Ptelea, Skimmia, Phelodendrum and Harrisonia (all Rutoideae; Gut, 1966; Ramp, 1988). In Aurantieae, the congenital union of carpels is most extensive, reaching the style and stigmatic region in Citrus and Murraya (Ramp, 1988). In Sapindales, syncarpous gynoecium is a widespread feature, while apocarpous gynoecia are more restricted to Simaroubaceae and Rutoideae (Bachelier \& Endress, 2009, and references therein).

Carpels postgenitally fused distally (style and stigma) are found in all species analyzed, as similarly reported for most Rutaceae (Endress et al., 1983; Ramp, 1988; Caris et al., 2006; Wei et al., 2011; El Ottra et al., 2013). The functional implicance of the postgenital fusion of carpel apices in mostly apocarpous gynoecium is that it enables the formation of a compitum at anthesis in this region. As the compitum provides enhancement of pollen tube selection, the postgenitally fused carpel apices in apocarpous gynoecium may have been positively selected during floral evolution (Endress et al., 1983; Endress, 2011a). The occurrence and structure of the compitum was extensively discussed earlier for several Sapindales and other core eudicots with similar gynoecium structure (Endress et al., 1983; Ramp, 1988; Matthews \& Endress, 2005; Bachelier \& Endress, 2008; Bachelier \& Endress, 
2009; Matthews et al., 2012). In Galipeinae and closely related groups, we found that in advanced buds the presence of the compitum is not always clear (union of the five PTTT) in the style or stigmatic region. However, Ramp (1988), while studyng anthetic flowers of Rutaceae, reported the compitum for one Galipeinae species (Erythrochiton brasiliensis) and to several other groups of the family.

Stigmas in Galipeinae and closely related groups are usually 5-lobed, postgenitally fused in most of its extent, papillate or less often smooth. Carpel tips may be inconspicuously five-lobed, not enlarged or slightly enlarged, as found in Metrodorea nigra, Hortia oreadica, Adiscanthus fusciflorus, Almeidea coerulea, Conchocarpus concinnus, C. odoratissimus, C. macrocarpus, C. mastigophorus, C. obovatus, Ertela bahiensis, Rauia resinosa and $R$. nodosa. All other species have a markedly enlarged 5-lobed stigma. Apparently, there is a relation in the occurrence of conspicuously enlarged stigmas with the exserted position of the stigma, because species showing this latter condition (at least in the female phase of the flower), always presented relatively enlarged stigmatic lobes (Neoraputia trifoliata, N. alba, Raputiarana, Ravenia infelix, R. spectabilis, Sigmatanthus, Angostura bracteata, Almeidea rubra). Stigmatic surface is more often papillate than smooth, as already reported for other Rutaceae (Heslop- Harrison \& Shivanna, 1977; Ramp, 1988; Caris et al., 2006; Souza et al., 2003). In fact, papillose stigmas are present in all families of Sapindales (Bachelier \& Endress, 2009).

However when analyzing the stigmatic surface in detail, important differences are noticed. Three major types of stigmatic surfaces could be recognized in Galipeinae and closely related groups: clearly papillate stigmas (in H. oreadica, M. nigra, Adiscanthus, Ertela bahiensis, E. trifolia, Rauia resinosa, $R$. nodosa, Ravenia spectabilis and Spiranthera odoratissima); slightly papillate stigmas (the cells shortly papillate or only bullate, as in Almeidea coerulea, A. rubra, A. limae, C. odoratissimus, C. macrocarpus, C. mastigophorus, C. obovatus, Ravenia infelix, Sigmatanthus trifoliatus); and smooth (non-papillate) stigmas (Conchocarpus cyrtanthus, C. concinnus, Angostura bracteata, Raputiarana, Neoraputia trifoliata, N. alba ). Smooth stigmas were first recorded in Galipeinae for Erythrochiton brasiliensis. Elsewere in Rutaceae, smooth stigmas are referred only to Correa and Ptelea (Heslop- Harrison \& Shivanna, 1977; Ramp, 1988). Since most Galipeinae and other closely related genera of the American clade have papillate stigmas (i.e. Pilocarpus, Hortia, Metrodorea and Adiscanthus, this study, Ramp, 1988; Souza et al., 2003, 2004), smooth stigma is probably a derived character state for Galipeinae. 
Additionally, a rugose surface (forming reentrances) was found only in the stigmas of Almeidea species (except some specimens of A. rubra and A. limae), Conchocarpus odoratissimus, C. macrocarpus, C. mastigophorus, C. obovatus, and less markedly also in Ravenia infelix and Sigmatanthus trifoliatus. These features appear to be more widespread among other Conchocarpus species (C. minutiflorus and C. heterophyllus, J. H. L. El Ottra, pers. obs.). The functional implication of this elaboration is unknown, but probably is related to enhancement of the receptive surface in a same area. Another structural elaboration of stigmatic surface was found in Ravenia species (this study). In their stigma, each lobe has a dorsal concavity, not covered by papillae, and this region is probably not receptive at anthesis. Stigmatic lobes are postgenitally fused along most of their extent in the majority of species. Exceptions are found only in Ravenia spectabilis, Almeidea limae and some A. rubra flowers, where the stigmatic lobes are free along most of their extent. Also, these occasionally open out at anthesis (this study), probably exposing the receptive surface of the stigma. Other Rutaceae with free stigmas have rarely been reported (Agasthoma, Phelodendrum and Ptelea, Ramp, 1988).

According to Heslop-Harrison \& Shivanna (1977) and Ramp (1989) four major types of stigmas can be found in Rutaceae: dry non-papillate stigmas, dry papillate stigmas, wet non-papillate stigmas and wet papillate stigmas. For Galipeinae and closely related groups, wet papillate stigma are found in Spiranthera odoratissima, Conchocarpus macrophyllus, Metrodorea nigra, Hortia oreadica, Pilocarpus pennatifolius and Choysia ternata (Ramp, 1988; Barbosa, 1999; Pombal \& Morellato, 2000; Souza et al., 2003; El Ottra et al., in prep. Chapter 3; this study); wet non-papillate stigmas are found in Erythrochiton brasiliensis, Galipea jasminiflora, Angostura bracteata and Ravenia infelix (El Ottra et al., in prep., Chapter 3; El Ottra pers. obs.). In Galipeinae wet stigmas may develop later on at anthesis, since in some species stigmatic secretion starts only during the female phase of the flower, as observed in Erythrochiton brasiliensis, Angostura bracteata and Ravenia infelix (El Ottra et al., in prep. Chapter 3; El Ottra pers. obs.). Other species present wet stigmas since the beginning of anthesis (C. macrophyllus, El Ottra et al., in prep., Chapter 3) or even in buds shortly before anthesis (Spiranthera odoratissima, this study). Thus in the subtribe the actual occurrence of wet stigmas must be analyzed along the whole anthesis period, otherwise they may be misclassified as dry. This was similarly noticed by Heslop-Harrison \& Shivanna (1977) for other Angiosperm groups, and probably occurred in the case of Erythrochiton brasiliensis, reported by Ramp (1989) as having dry stigma. Other Ravenia species have been reported with wet non-papillate stigmas by Heslop-Harrison \& Shivanna (1977), differently 
from our observations for $R$. infelix and $R$. spectabilis, provided with papillate stigma (wet in $R$. infelix, not observed for $R$. spectabilis). These authors also found that wet stigmas, either papillate (shortly or long papillate) or non-papillate (smooth or with slightly bullate cells), are usually associated with markedly protandrous flowers. This matches with our observations and records available for Angostura bracteata, Hortia oreadica and Metrodorea nigra (Barbosa, 1999; Pombal \& Morellato, 2000; El Ottra et al., in prep., Chapter 3), but not for Galipea jasminiflora, which is reported as having simultaneous maturation of pollination organs (Piedade \& Ranga, 1993).

A partially (slightly) inferior ovary is a rare feature in Rutaceae. This was found in Galipeinae and closely related groups, for Conchocarpus cyrtanthus, C. concinnus and Hortia oreadica (this study). Most Conchocarpus species studied so far have normally superior ovaries (El Ottra et al., 2013; this study). Since C. cyrtanthus and C. concinnus are closely related species, which together with $C$. gaudichaudianus form a clade (Groppo et al., in prep.), the partially inferior ovary is possibly a synapomorphy for this group of species. Additionally, morphological data indicate that $C$. insignis and $C$. hirsutus are also close related to the above-mentioned specie (Kallunki \& Pirani, 1998). Thus, it is still necessary to study the structure of the ovary of $C$. gaudichaudianus, C.insignis and C. hirsutus to further support this idea. Elsewhere in Rutaceae, a partially inferior ovary develops only at anthesis in Coleonema (Rutoideae, Diosmeae; Gut, 1966). In Sapindales, slightly inferior or semiinferior carpels occur in some Burseraceae and Anacardiaceae (Commiphora, Canarium, Santiria and Semecarpus, Bachelier \& Endress, 2009).

In Galipeinae, carpels are usually completely united below the locule, forming a short and inconspicuous gynophore (El Ottra et al., 2013; this study). When the gynophore is absent in Galipeinae, at least a slight constriction at the ovary base is found, as in Rauia nodosa, Raputiarana, Almeidea species, Conchocarpus obovatus, C. macrocarpus, C. mastigophorus and Ravenia infelix. Regarding gynophore structure, four major types are found: a stout gynophore, broader than the base of the locules, as found in Adiscanthus; a short gynophore, more or less with the same diameter of the base of the locules, as in Erythrochiton brasiliensis, Conchocarpus odoratissimus, Ravenia spectabilis, and Sigmatanthus; a short gynophore, markedly narrower (constricted) than the base of the ovary,as in Angostura bracteata, Rauia resinosa, Neoraputia trifoliata, N. alba and Galipea jasminiflora; and finally long and thin gynophores, which gradually become more constricted towards the base, found so far only in Spiranthera odoratissima and Nycticalanthus (Kubitzki et al., 2011; El Ottra et al., 2013; this study). Since the large and thin gynophores of these two 
latter genera are similar to the small and constricted gynophores reported in other Galipeinae, one may assume a hypothetical pathway of evolution of this structure for the subtribe. Since gynophores are usually absent in the American clade (as in Hortia oreadica and Metrodorea nigra), the most likely plesiomorphic state is the absence of the gynophore, followed by an appearance of small and inconspicuous gynophores (maybe multiple times), and later followed by an increase in the activity of the intercalary meristem below the ovary locules, leading to the formation of long and thin gynophores, as observed in Spiranthera and Nycticalanthus. However this idea needs further testing upon a phylogenetic context, as well as additional detailed studies on gynophores of other genera of the American clade. The gynophore of Adiscanthus probably is not a homologous structure with the gynophores of other Galipeinae, giving their differences in structure and position in the American clade, where Adiscanthus is closer related to Hortia than to the Galipeinae (Groppo et al., 2012). Although Hortia was described as possessing a gynophore (Groppo \& Pirani, 2012), this was not found for $H$. oreadica (this study). Within the American clade, gynophores are rarely reported, as for Pilocarpus (a spherical gynophore; Kaastra, 1982; Ramp, 1988) and Choisya (Engler, 1931). Short inconspicuous gynophores and long and thin gynophores are commonly found in other groups of Rutaceae (Gut, 1966; Ramp, 1988). In Galipeinae, short gynophores were first observed by El Ottra et al. (2013), and additional species with similar structure were hereby found. Considering a broader systematic scale, gynophores (or "at least a constriction between the ovary and the next outer floral organ") are frequent in several malvids (Endress \& Matthews, 2006). In Sapindales gynophores were reported for members of seven families (Anacardiaceae, Burseraceae, Meliaceae, Rutaceae, Simaroubaceae, Kirkiaceae, Nitrariaceae, Ramp, 1988; Endress \& Matthews, 2006, and references therein; Bachelier \& Endress, 2008, 2009; Bachelier et al., 2011).

The presences of gynophores are usually associated with the occurrence of herkogamy. In this way, long gynophores would lift the style and stigma above stamen level, generating spatial separation of pollination organs (Weberling, 1989). However our study shows that there is no marked separation of pollination organs in Spiranthera, and that in fact nectar may accumulate between the inner side of the disc and gynophore. Since the flower of this genus are widely opened and have a long thin gynophore with a cupular disc surrounding its base, nectar accumulation may be a potential function for this structure. However for the short and inconspicuous gynophores of other Galipeinae there is no apparent function and herkogamy is structurally formed in different modes, as previously mentioned (see "General structure, herkogamy and pollination" topic). Additionally in some species, nectar was seen to 
accumulate at the bottom of the floral tube and above the disc and ovary, not between the disc and gynophore (there is no available space in this region). Thus we believe that these short gynophores present no floral function, differently from larger gynophores. Therefore, maintenance within the flower could be due to the phenomenon of phylogenetic inertia (when a certain feature is retained because it was present in a previous common ancestor, but having no adaptative function at the present moment for the species; Orzack \& Sober, 2001; Bloomberg \& Garland, 2002). Furthermore, the presence of long and thin gynophores apparently evolved multiple times in the family, as they occur within Galipeinae and in other distantly related groups (e.g. Dictamnus albus L., Rutoideae, outside the American clade, Groppo et al., 2012).

Anacrostylous carpels occur in several Galipeinae genera and closely related groups. In fact anacrostyly is a widespread feature in Rutaceae and Simaroubaceae (Gut, 1966; Ramp, 1988; Beurton, 1994; Caris et al., 2006), and is caused by an increase in the growth of the dorsal upper parts of ovaries in relation to their ventral parts. This dorsal overgrowth leads to the formation of a dorsal bulging area in carpels which frequently hides the style base at the centre of the ovary region, in a more basal condition than the ovary apices (Gut, 1966; Ramp, 1988). Gut (1966) named the shape of this dorsal bulging area of carpels as "ovary - caps". However, two types of anacrostyly may occur in Rutaceae, according to the structure of the ovary in the dorsal bulging region: one that is formed by a marked enlargement and elevation of the ovary locules above the level of the style base (as observed in Adiscanthus), and another formed by a slight to marked thickening of the upper dorsal walls of the ovary (as in all other Galipeinae species with anacrostylous carpels and Metrodorea nigra, this study, El Ottra et al., 2013). The bulging dorsal area in the latter taxon is most extense and similar to the ovary "horns" described for other Rutoideae genera, such as Eriostemon, Calodendrum and Coleonema (Gut, 1966; Ramp, 1988; Kubitzki et al., 2011). In Conchocarpus, both acrostylous carpels and anacrostylous carpels are reported for several species ("ovary attenuate " or "umbilicate", respectively, Kallunki \& Pirani, 1998). Acrostylous carpels with thickened upper dorsal walls of the ovaries (but not bulging) are also found in $C$. odoratissimus, C. macrocarpus, C. mastigophorus, C. obovatus, Rauia resinosa, Rauia nodosa and Galipea jasminiflora (this study, El Ottra et al., 2013). Similar features occur in Murraya (Aurtantieae) and Ptelea (Rutoideae, former Toddalioideae, currently in the RTF clade). In fact, acrostylous carpels are more frequent in Aurantieae and former Toddalioideae genera of Rutoideae (as Hortia) than in other groups of Rutoideae (Ramp, 1988). In Sapindales, besides Rutaceae and Simaroubaceae, the ovary dorsally bulged up is reported in Kirkiaceae and Nitrariaceae (Bachelier \& Endress, 2008; Bachelier et al., 2011). 
The ovary apices of Hortia oreadica are singular in that they have acrostylous carpels and the presence of false locules. Similarly a "false septum" was previously reported for other Hortia species (Groppo \& Pirani, 2012). However, this was described as being the funiculus ("locules transversally divided in two by the funiculus, forming a false and incomplete septum", Groppo \& Pirani, 2012). For H. oreadica we observed that the false locule (or "false septum") is not the funiculus, as it appears above the ovules and not in continuity with them. Instead they appear to us as large secretory or lysigenous cavities. Further developmental studies of the "false septum" of Hortia may clarify the nature of this structure.

The histology of the gynoecium in Galipeinae and closely related groups is very similar to that of other Rutaceae. In fact, tanniferous tissue and/or tanniferous cells are observed in the gynoecium of several species and genera (especially abundant in Conchocarpus cyrtanthus, Neoraputia alba, Rauia nodosa, $R$. resinosa, Spiranthera odoratissima and Metrodorea nigra). While tanniferous cells may be dispersed in several parts of the gynoecium, tanniferous tissue is usually found in the epidermis and hypodermis of the outer surface of carpels, especially in the ovary on the upper dorsal side. This same tissue is present in the outer integument of the ovules (this study, in several Rutoideae, Ramp, 1988). Similarly, there are numerous secretory cavities close to the outer epidermis of carpels, especially in the ovary region. According to Ramp, these may be either small or conspicuously large at the dorsal bulging area of carpels. Secretory cavities are rarely found on the style and stigma (this study; Ramp, 1988). In some species, a thick cover of lignified hairs may be present on the upper dorsal side of the ovary and at the base of the style (Conchocarpus macrocarpus, Neoraputia alba, N. trifoliata, Rauia resinosa, R. nodosa, Spiranthera odoratissima, this study; Choisya, Clausena, Ramp, 1988). Short glandular hairs on the ovary are found in few species (in Ertela, Almeidea rubra, Sigmatanthus, this study, and in Pilocarpus, Souza et al., 2003). Epidermal emergences with secretory cavities within are only found in the dorsal side of the ovary in Metrodorea nigra, and were similarly reported for Calodendrum (Diosmae; Ramp, 1988). It would be interesting to study the role of all these types of secretory structures and hairs in relation to the biology of the species. In fact, the epidermal emergences of $M$. nigra are reported to release a lipid substance when pressed (Pombal \& Morellato, 2000). Differently, histochemical studies on some species of Boronia (Boronieae, Rutoideae) suggest that the volatile oils and tannins in the style and stigma may play a role in scent emission, produced by osmophores (Bussel et al., 1995). The secretory tissue or cells filled with blue-stained secretion (probably mucilage), found in carpels and teguments of several species were not previously reported for the floral organs of 
the family (M. nigra, C. obovatus, C. concinnus, $C$. cyrtanthus, Raputiarana, $R$. resinosa, $R$. nodosa, Ravenia infelix, Sigmatanthus, and Hortia oreadica).

Vascularization of the gynoecium of the taxa studied herein presents a complex pattern, as similarly reported for other groups of Rutaceae (Gut, 1966; Ramp, 1988). In Rutaceae it is commonly reported carpels with areduced, poorly differentiated dorsal vasculature, with one to two median dorsal bundles, which frequently divides into several smaller dorsal bundles (this study; Ramp, 1988, Gut 1966, Pirani et al., 2010, El Ottra et al., 2013). A similar pattern of reduced dorsal vasculature apparently is common in Sapindales (Ronse De Craene \& Haston, 2006; Bachelier \& Endress, 2008, 2009; Bachelier et al., 2011). Additionally, the dorsal and lateral bundles apparently reduce in number as the flower decreases in size, since in the small flowers of Ertela only one to two median dorsal bundles are observed, and no lateral bundles exist. Differently, in genera with larger flowers (e.g. Raputiarana, Sigmatanthus) there are numerous dorsal and lateral bundles in the ovary (this study). In fact, lateral bundles (or "transversal” bundles, Gut, 1966) are commonly numerous in the family (Gut, 1966). Similarly, two lateral bundles in the style and ovary, which may form one single ventral bundle at the ovary base (usually below the placenta) are commonly found in other Rutoideae. The formation of synlaterals at the ovary base is not frequently observed in Galipeinae, although previously reported for other Rutaceae (Ramp, 1988; Gut, 1966).

Placentation is quite similar in nearly all studied species. There are two (almost) collateral placentas at the mid-level of ovary, usually bearing two superposed ovules. Only in Metrodorea nigra were the placentasmarkedly collateral, as similarly the two ovules. Two almost collateral placentas, with two superposed ovules are common in some Sapindales, as observed in Meliaceae, Sapindaceae, Kirkiaceae and in a few Burseraceae. In contrast, two collateral placentas with two ovules, as occurs in M. nigra, are less frequent in Sapindales (Bachelier \& Endress, 2008, 2009 and references therein).The placentas are exclusively marginal in Galipeinae (when carpels are free at the level of placentas: Almeidea rubra, A. limae, A. coerulea, Angostura bracteata, Conchocarpus cyrtanthus, C. concinnus, $C$. obovatus, C. macrocarpus, Ertela bahiensis, Neoraputia alba, N. trifoliata, Raputiarana, Ravenia spectabilis, $R$. infelix, Sigmatanthus, and Spiranthera odoratissima) or less frequently both marginal and axile (when carpels are connated at least in center at mid-level of ovary: Adiscanthus, Conchocarpus odoratissimus, C. mastigophorus, and Rauia resinosa, R. nodosa). Exclusively axile placentas are only found in Metrodorea nigra (Pilocarpinae) and Hortia oreadica (former Toddalioideae), as a consequence of the higher degree of 
syncarpy of those species. Other Galipeinae species with axile placenta are only found in Galipea, in which carpels are either congenitally or postgenitally fused along their entire length (as occurs in H. oreadica and M. nigra, El Ottra et al., 2013, this study). Considering that except for Galipea, the other genera of Galipeinae have mostly apocarpous carpels (most species are described as united only at the base or at apex, at the ovary level), the predominant type of placentation in the subtribe appears to be marginal (Engler, 1931; Kubitzki et al., 2011; see El Ottra et al., 2013 for Erythrochiton and other Conchocarpus species). Similarly, other Rutoideae also bear two lateral placentas at mid-level of ovary (Euodia, Choisya, Boronia, Eriostemon). Differently, exclusively axile placentas at mid-level (Coleonema, Calodendrum, Ptelea, Citrus), or at upper level of the ovary (Murraya, Phellodendron, Skimmia), also occur in the family (Ramp, 1988; Gut, 1966).

The ovules in Galipeinae and closely related groups are very similar to the ovules of other Rutaceae representatives, and some of their features are also common on broader systematic scales. The anatropous ovules found for most studied species correspond to a widespread feature in eudicots (Endress \& Matthews, 2006). Differently, the campylotropous ovules found in some species (Conchocarpus obovatus, Raputiarana, Rauia nodosa, Spiranthera odoratissima, Ravenia infelix, R. spectabilis, Hortia oreadica) are putatively the apomorphic state for ovule curvature in rosids (Endress \& Matthews, 2006). The increasing curvature of the ovule, leading to campylotropy, may occurs in many cases at the time of fertilization. Therefore, the real distribution of these features in the analyzed species should be evaluated in future seed developmental studies, since here only the ovules of advanced buds were studied (Endress \& Matthews, 2006; Bouman \& Boesewinkel, 1991). In fact, campylotropous seeds are reported for several Galipeinae (Kubitzki et al., 2011) indicating that campylotropy may be more widespread in the group than here observed. Anatropous ovules are common in other Rutaceae, but campylotropous ovules are also reported (Boesewinkel 1977, 1978; Ramp, 1988; Souza et al. 2003; Kubitzki et al., 2011). Slightly campylotropous ovules occur in other Sapindales (Burseraceae, Simaroubaceae and Kirkiaceae, Bachelier \& Endress, 2008, 2009, and references therein). Zig-zag micropyles observed for some species of Galipeinae (Adiscanthus, Almeidea rubra, Rauia nodosa, Ravenia infelix, Spiranthera odoratissima) and Metrodorea nigra were similarly reported for other Pilocarpinae (Pilocarpus, Souza et al., 2003). Zig-zag micropyles are also found in other members of Sapindales (Simaroubaceae, Burseraceae, Meliaceae, Kirkiaceae, Nitrariaceae, Bachelier \& Endress, 2008, 2009, and references therein; Bachelier et al., 2011). Though zig-zag micropyles commonly co-occur with campylotropous ovules in rosids, due to 
a probable functional link beteween these features (as a by product of excessive ovule curvature), this association was not found here (Endress \& Matthews, 2006). However, further studies with anthetic flowers are required to verify the occurrence of zig-zag micropyles and campylotropous ovules, since here only the ovules from advanced buds were analyzed.

Two superposed, crassinucellate, bitegmic ovules, here observed in most species, are also common in other Rutaceae (Engler, 1931; Ramp, 1988; El Ottra et al., 2013; Souza et al. 2003; Kubitzki et al., 2011). Rarely one single ovule per carpel develops (observed in one locule of Adiscanthus, Metrodora nigra and Angostura bracteata). Collateral ovules as found in Metrodora nigra are not common in the family, but were observed in Zanthoxylum simulans (Ramp, 1988). Clearly bitegmic ovules were not found only in Conchocarpus cyrtanthus and $C$. concinnus. In the former species the inner integument is reduced and only present on the convex side; while in the latter, it is seemingly unitegmic. Unitegmic ovules are rarely found in rosids (Endress \& Matthews, 2006). In Sapindales this character was previously reported for Rutaceae (Glycosmis, Aurantieae, Boesewinkel \& Bouman, 1978) and for a few other cases in the order (Endress \& Matthews, 2006; Bachelier \& Endress, 2009, and references therein).

Antitropous ovules occur in nearly all studied species except in Conchocarpus cyrtanthus and $C$. concinnus, in which the lower ovules are syntropous. Antitropous ovules are a widespread feature in rosids, and commonly found in Sapindales (Rutaceae, Simaroubaceae, Burseraceae, Kirkiaceae, Meliaceae, Eichler, 1878; Engler, 1931; Ramp, 1988; Bachelier \& Endress, 2008, 2009 and references therein). Differently, syntropous ovules are less common in Sapindales (Sapindaceae, Nitraniaceae and Anacardiceae, Bachelier \& Endress, 2009 and references therein; Bachelier et al., 2011). In Rutaceae this was reported for Dictamnus, in which the two upper ovules are antitropous and the lower one is syntropous (Jardin, 1894). Apparenlty syntropous ovules occur in several genera of Cneoroideae (for Spathelia, Cedrelopsis, Harrisonia, Cneorum, see Ramp, 1988, Caris et al., 2006; Kubitzki et al. 2011). Antitropous ovules are usually linked with the presence of an obturator, since in such type of ovule curvature the obturator reduces the distance between the micropylar region and the placenta (opposed to syntropous ovules, in which the micropyle is closer to the placenta; Endress \& Matthews, 2006, 2012). An obturator made of papillae and/or trichomes was found in several Galipeinae species (Almeidea rubra, Conchocarpus odoratissimus, C. obovatus, C.macrocarpus, Angostura bracteata, Neoraputia alba, N. trifoliata, Ertela bahiensis, Raputiarana, Rauia nodosa, Ravenia spectabilis, $R$. infelix, 
Sigmatanthus, Spiranthera) and Metrodorea nigra (this study). A similar type of obturator wasa previously reported for other Pilocarpinae (Pilocarpus and Esenbeckia, Souza et al., 2003; Silva \& Paoli, 2006), as well as in other groups of Rutaceae (Ramp, 1988; Boesewinkel, 1977, 1978; Boesewinkel \& Bouman, 1978). Some species lack an obturator (C. mastigophorus, Rauia resinosa, Hortia oreadica, this study), as already reported by Ramp (1989) for other groups of Rutaceae. According to this latter author, in these cases the PTTT become in close contact with the micropyle of the upper ovule through the layers of small cells that line the inner side of the locules (Ramp, 1988).

\section{Floral symmetry}

Several forms of floral symmetry were found for Galipeinae and closely related groups. Six main types could be recognized in relation to the corolla and androecium, as in these whorls symmetry is more pronouncedly expressed. Petals and stamens may basically be either polysymmetric or monosymmetric in different combinations and degrees between species. In the first type of symmetry observed in a few Galipeinae (A. limae, most flowers of Almeidea rubra, Spiranthera odoratissima, Erythrochiton brasiliensis, Adiscanthus, this study, El Ottra pers. obs.), Metrodorea nigra and Hortia oreadica, flowers are strictly polysymmetric, with fully fertile androecium and polysymmetric corolla (Figs 1A, B, 3A, B, F, 52A-C, I). The second type is found in Almeidea coerulea and in a few A. rubra flowers (and also in C. heterophyllus and C. minutiflorus, El Ottra pers. obs., see Figs 1I in El Ottra et al., 2013), in which flowers are monosymmetric due to androecium reduction (with two anterior staminodes and three fertile stamens), having slight unequal disposition of the corolla lobes (at anthesis), with two lobes on the posterior (adaxial) side of the flower and three on the anterior (abaxial) side (pattern 2:3). Additionally, the monosymmetry plane may be median or slightly oblique (then the corolla may be ascending or more often oblique cochlear; Figs 1C, 8A, 52 D, D' III). The third type occurs in Conchocarpus odoratissimus, C. obovatus, Rauia resinosa and $R$. nodosa, whose flowers are monosymmetric due to androecium reduction, but with a higher number of sterilized stamens, three to five anterior staminodes, and two posterior fertile stamens. However, here the corolla is polysymmetric (or nearly so) and the monosymmetry plane may be median to oblique (the corolla may be ascending or oblique cochlear, Figs 1I, 2B, H, I, 52E, E', I). The fourth type is only found in Galipea jasmiflora and some flowers of Angostura bracteata, in which the androecium is also reduced into staminodes in a similar fashion to the third type; but here the corolla monosymmetry pattern is different: three petals are disposed at the posterior side (one median and two laterals) and two at the anterior side, forming the pattern 3:2. In this type, the 
monosymmetry plane may be median to slightly oblique (the corolla ascending or slightly oblique cochlear; Figs 52E, E', II, this study, also see Fig. 5C in El Ottra et al, 2013). The fifth type is present in most of the species (Conchocarpus macrocarpus, some flowers of $C$. macrophyllus, C. mastigophorus, C. cyrtanthus, C. concinnus, some flowers of Ravenia infelix and R. spectabilis, Ertela bahiensis, E. trifolia, Neoraputia alba, N. trifoliata; this study, El Ottra pers. obs., see Figs 3L, 5B in El Ottra et al., 2013) in which flowers are monosymmetric due to androecium reduction, like the third and fourth type. The difference is that here the monosymmetry of the corolla forms a 1:4 pattern, with one petal usually located on median posterior position (or nearly so when the monosymmetry plane is slightly oblicue), separated from the other four lobes. These latter, with the two lowermost lobes located on the anterior side of the flower and the two lateral lobes also on the anterior side (in most of its parts), or in between both sides of the flower. The monosymmetry plane may also be median (more often) or slightly oblique (and then the corolla may be ascending cochlear, or more rarely, oblique; Figs 1F, H, J, K, 2D, E, F, 3A, D, 52E, E', IV). Finally, the sixth pattern, found only in Raputiarana and Sigmatanthus, is similar to the fifth type regarding androecium reduction into staminodes, but here the monosymmetry of the corolla lobes is greatly increased. This pattern is similar to $1: 4$ pattern, yet the lateral petals overlap with the lowermost two petals on the anterior side of the flower, forming a somewhat single unit on this side. Since there is also one petal located at median posterior position, a 1:1 pattern is formed. In this pair of genera bilabiate corolla is formed (Figs 2E, 3G, K, 52 E-E', V; Kubitzki et al., 2011). Similar patterns of monosymmetry of the corolla were already reported for several Asterids (Donoghue et al., 1998). Differently, the most common pattern found was $2: 3$ in this large group (two posterior petals separated from the two laterals and the median anterior; Donoghue et al., 1998), and in several of its families lip flowers are formed (Endress, 1994). Contrastingly, in Galipeinae, a lip flower (i.e. a bilabiate corolla plus pollination organs on the posterior side of the flower) was not found here, since only anthers are located in this position in some Galipeinae, while the stigma usually occupy a central position in the flower. Within Sapindales, oblique monosymmetry occurs not only in Rutaceae, but also in Sapindaceae (Engler, 1931; Endress \& Matthews, 2006; Ronse De Craene \& Haston, 2006). Engler (1931) mentioned that in Galipenae species, as monosymmetry of the androecium increases due to its reduction into staminodes, apparently the corolla follows the same pattern, becoming increasingly monossymmetric. However, this correlation was not always found here, since polysymmetric corollas may occur toghether with monosymmetric androecium (third type of monosymmetry, see above). 
Additionally to the six main types of symmetry here described for the corolla and androecium, other subtypes of monosymmetry may occur in some of the studied species regarding other floral organs. However, these contribute visually to the overall floral monosymmetry to a lesser extent than the corolla and staminodes. In Spiranthera odoratissima, the pollination organs (style and filaments) are slightly upwardly curved (Fig. $3 \mathrm{G})$, resulting in a slight monosymmetry of the flower.Nevertheless, this monosymmetry is superposed in the polysymmetric background of the corolla and fully fertile androecium, and thus constitutes a weak type of monosymmetry. This was similarly reported for other Angiosperm groups, and is especially common in flowers with horizontal orientation (Endress, 2012). Differently in Raputiarana and Sigmatanthus, the style is sigmoidally curved (following the curvature of the corolla), and the stigma faces the anterior side of the flower (Figs 2G, 33F, 41A). Similarly in Neoraputia, the stigma also faces the anterior side of the corolla in bud. Additionally, the two anterior young carpels appear to have their development slightly retarded in relation to the other three carpels, and are thus conspicuously monosymmetric in early stages (Fig. 30B-F); but this pattern is less conspicuous in advancede buds and is clearly visible only in the stigma in this stage (Fig. 27D, I). In Rutaceae, the sigmoidal curvature of pollination organs was already reported for the monosymmetric flowers of Dictamnus (Ruteae, Engler, 1931; Endress, 2012). We could add that the corolla of Dictamnus albus is also monosymmetric in a pattern $4: 1$, an inverted position regarding the pattern found for several Galipeinae (Engler, 1931; Ramp, 1988; this study). In relation to monosymmetry of the nectary disc, a unique case reported for the family so far refers to the unilateral disc of Ertela (Eichler, 1875; Engler, 1931, Fig. 23G, Fig. 25A).

Asymmetric flowers are seldom found in Galipeinae. This may occur in some flowers of Ravenia infelix and $R$. spectabilis, when only one single antepetalous staminode is present (Figs 3D, 40A). In both species, other flowers analyzed are not asymmetrical, as they have two antepetalous staminodes or none (Fig. 38C, D). Also, for flowers in which this asymmetry occurs, it is superposed upon the monosymmetric pattern of the corolla and antesepalous staminodes. A few asymmetric flowers occasionally appear in Almeidea rubra, as occurs when there is a mismatch between the monosymmetry of the androecium (especially when only one antesepalous staminode is present) and the symmetry of the corolla (when not polyssymmetric, in a pattern 2:3). In this study we do not consider the calyx for determining the patterns of floral symmetry, since it is usually shorter than the other organs and therefore does not constitute an importan component of floral symmetry (Neal et al., 1998). But if we consider the calyx, most Galipeinae have polysymmetric sepals, since they are usually 
described as valvate or subentire, with the exception of seven genera in which sepals are strongly unequal (Kallunki 1992, 1998a, 1998b, 2005, 2009; Pirani, 1999, 2004; Kubitzki et al., 2011). Ravenia and Ertela are two of these genera with strongly unequal sepal lobes (in size and shape). Their calyx then could be considered asymmetric, superposed (in most flowers) upon the monosymmetric pattern of the corolla and stamens. Similar minor asymmetry in sepals often occurs in eudicots, since in several groups the quincuncial calyx has unequal lobes (Endress, 2012). In Rutaceae minor asymmetry has been reported for some groups due to contort aestivation of the corolla (Endress, 2012, and references therein).

Other genera of Galipeinae and closely related genera of the American clade not analyzed here apparently fit into one or more of the main symmetry patterns previously described. Outside the Galipeinae clade, polysymmetric flowers with five fertile stamens predominate, as reported for Pilocarpus, Helietta, Baulfourodendron, Esenbeckia, other Metrodorea and Hortia species. Choisya is also polysymmetric, but with both whorls of fertile stamens (ten). Contrastingly, few Galipeinae are polysymmetric, while monosymmetry predominates in the groups. Besides the genera studied, most Ticorea species, Euxylophora, Leptothyrsa, some Conchocarpus, and Erythrochiton species are described as polysymmetric, with fully fertile stamens (Kallunki \& Pirani, 1998; Kallunki 1998b; Kubitzki et al. 2011). These may fit in the first pattern above-mentioned (Fig. 52C, C' or C'), as similarly Nycticalanthus. But this latter genus may present some differences: even though it has five fertile stamens it is described as having unequal petals and monosymmetric flowers (Kubitzki et al., 2011). Likewise in Pilocarpinae, the flowers of Raulinoa are described as having a "slightly monosymmetric perianth" (Kaastra, 1982).

All other genera of the subtribe apparently have at least a monosymmetric androecium and occasionally also monosymmetric corollas (Fig. 52D, D', E, E'). In Ticorea diandra, Naudinia and Decagonocarpus only the monosymmetry of the androecium is reported (reduced into staminodes), while in other genera monosymmetry of the corolla often occur (Kallunki, 1998b, 2005; Kubitzki et al., 2011). Two-lipped corollas were already reported for Apocaulon, Lubaria, Raputia, and Raveniopsis (Engler, 1931; Kallunki, 1990, 1994, 2005; Kubitzki et al., 2011). Also, Desmotes,Toxosiphon, Lubaria, and Raputia apparently present the 1:4 pattern (or pattern 4:1 in Desmotes) in relation to the distribution of petal lobes at anthesis (Engler, 1931; Kallunki, 1992, 1994, 2005; for Toxosiphon lindenii see photos of living plant in "Florula Digital de la Estación Biológica de la Selva"; for Desmotes incomparabilis see photos of living plant in Tropicos database, in the herbarium sheet col. Albáñes 2689, but with the orientation of the flower dubious; for Lubaria, see the isotype 
herbarium sheet in the Virtual Herbarium of the New York Botanical Garden, col. Pittier 6368). Similar to G. jasminiflora, other Galipea species may also present the pattern 3:2 (Pirani et al., 2010; Pirani, 2004). Differently, Andreadoxa has petal lobes with unequal size (Kallunki, 1998a), and Raveniopsis has "subequal petal lobes" (Kallunki, 2005), which may indicate that the corolla if both genera are monosymmetric. Some species of Erythrochiton have monosymmetric corollas (especially in E. fallax, which presents the pattern 1:4, Kallunki, 1994; also monosymmetry was observed on a few flowers of E. brasiliensis, El Ottra pers. obs.). Raveniopsis acarensis and some Raputia species have the tip of the style and stigma facing one side of the flower (see Fig. 1 in Kallunki \& Steyermark, 1987, and Fig. 73 in Kubitzki et al. 2011), similar to Neoraputia, Sigmatanthus and Raputiarana (this study). Hence, during this study it becomes clear to us that while androecium monosymmetry is more easily observed on herbarium material, corolla monosymmetry is not, especially in respect to the distribution of the petal lobes in anthetic flowers. Thus, more studies are necessary on corolla symmetry in genera for which it is reported as having "unequal" petals in order to clarify what are the structural factors that may influence their symmetry pattern (whether they are unequal in size, in the distribution of the lobes, among other factors).

Differently from most Galipeinae, elsewere in Rutaceae polysymmetric flowers are predominate (Engler, 1931; Kubitzki et al., 2011). Thus monosymmetry in the family is likely a derived feature. However since there are different patterns of monosymmetric flowers in several groups (Engler, 1931), monosymmetry has probably evolved multiple times from polysymmetry. In fact, in the America clade monosymmetric flowers are reported for Galipeinae and Raulinoa (Pilocarpinae), suggesting that it is a homoplastic feature for this clade. Even within Galipeinae, polysymmetric flowers predominate in some species within a genus, while in others monosymmetric flowers are the most common form (i.e. Ticorea, Erythrochiton, Conchocarpus, Almeidea species, Kallunki, 1994, 1998b; Kallunki \& Pirani, 1998; this study). This suggests that within the subtribe monosymmetry may have also evolved more than once. Elsewere in the family monosymmetric flowers are reported for Dictamnus and Calodendrum (Rutoideae, Diosmae, distantly related to the American clade, Groppo et al. 2008, 2012), caused by the sigmoidal curvature of filaments and style, and additionally in Dictamnus by unequal arrangement of petals (in the 4:1 pattern, median monosymmetry; Engler, 1931; Eichler, 1875; Ramp, 1988; Endress, 2012). Differently in flowers of Cneoridium, Empleurum, Zanthoxylum and Ptelea, reduced merism of carpels in relation to the outer floral organs (androecium and perianth) causes monosymmetry due to reduction (Engler, 1931; Endress, 2012; Kubitzki et al., 2011). In summary, in Rutaceae the 
main types of monosymmetry that were found are: monosymmetry caused by androecium reduction; monosymmetry caused by unequal petals (their arrangement and/or size); monosymmetry caused by sigmoidal curvature of pollination organs (style, stigma and filaments); monosymmetry caused by carpel reduction (Eichler, 1875; Engler, 1931; Endress, 2012, this study).

Since monosymmetry is a widespread feature in Angiosperm flowers, several hypotheses have been raised as explanations for its evolution (Neal et al., 1998; Endress, 2012). Most of them are related to the floral biology of the species and biotic pollination, and some of them may apply to the monosymmetric flowers of Galipeinae. Flowers differentiated in an anterior and posterior plane may create landing platforms where pollinators are enabled to land (Faegri \& van der Pijl, 1979; Endress, 1994, 1999). The landing platforms of Galipeinae members may be formed by the petals and filaments of staminodes on the anterior side of the flower, where bees, butterflies and non-hovering moths were seen landing (Piedade \& Ranga 1994; El Ottra et al., submitted, Chapter 2, in prep., Chapter 3; El Ottra pers. obs.). Contrastingly, in some groups the abaxial petals are strongly recurved backwards and no clear landing platform is formed (Raputiarana and Sigmatanthus). Maybe in these species hovering pollinators are acting (e.g., hummingbirds, hawkmoths, some species of bats and bees).

Another functional aspect of floral monosymmetry involves the androecium reduction into two fertile stamens in posterior position. The evolution of this androecium display is assumed to be related to the reduction of pollen wastage to pollen-collecting bees, as reported for other Angiospem groups with bilabiate flowers (Westerkamp \& Claßen-Bockhoff, 2007). In this way, the precision of pollen placement in the bodies of pollinators is also increased (nototribic pollination), as is the contact of the stigma with the pollinator's body (when the stigma is in the same symmetry plane, Faegri \& van der Pij1, 1979; Neal et al., 1998; Endress, 1999). On the other hand, the pollinator's movements are restricted in monosymmetric flowers as they approach (Neal et al., 1998, and references therein; Endress, 2012). In Galipeinae not only would the corolla and androecium display canalyze the pollinator's movements, but also the nectary, as one could assume for the unilateral disc of Ertela species. A different functional aspect in floral symmetry is the innate preference of pollinators. Even though few groups of animals have been studied regarding this matter (Neal et al., 1998, and references therein), specialized bees may have an innate preference for monosymmetric flowers, likely having pushed initially its evolution in some groups (Neal et al., 1998; Donoughe et al., 1998; Cronk \& Moller, 1997). However, evolution of floral monosymmetry is also assumed to be related to other groups of pollinators, such as moths, birds and bats 
(Westerkamp \& Claßen-Bockhoff, 2007). In fact, in Galipeinae, moths, bees and birds were reported as pollinators for some species (but not exclusively pollinated by them; Lopes, 2002; El Ottra et al., submitted, Chapter 2, in prep., Chapter 3; El Ottra pers. obs.). However, since there are so many explanatory theories for the evolution of floral monosymmetry, it is not possible to pick a single one as the most likely to have occurred in Galipeinae, especially considering that pollination studies are scarce for this group.

Floral monosymmetry is commonly assumed as a key innovation feature, since it has evolved multiple times in several species rich clades of Angiosperms (Coen \& Nougent, 1994; Endress, 2001, 2011a, 2012). Since monosymmetry is known in most of the Galipeinae, the most diversified group of Neotropical Rutaceae, it is possible that floral monosymmetry represent a key innovation for the subtribe. Additionally synorganization of organs (by fusion or postgenital connetion) are often associated with androecium reduction and elaborate forms of monosymmetry, since this may stabilize the flower structure in relation to pollinator activities, especially large ones (Stebins, 1974; Endress, 1999). It would be interesting to test the correlation between the above-mentioned floral traits and pollinators groups in a phylogenetic context. Also, comparing pollinator groups in pairwise of closely related species differing in floral symmetry (as found in Almeidea, Conchocarpus, Ticorea and Erythrochiton, with both polysymmetrical and monosymmetrical flowers) would help elucidate to what extent pollinators could be linked to evolutionary shifts in floral symmetry. Since floral evolution is known to be influenced by a variety of factors (including ecological, structural, developmental, and phylogenetic constraints; Fenster, 2004; Knapp, 2010; Endress, 2011a), these studies would help to better understand the evolution of floral symmetry in the group.

Figure 52: Schematic diagrams of the main patterns of corolla aestivation and floral symmetry (corolla and androecium symmetry) in Galipeinae and closely related genera. All flower diagrams are oriented so that the subtending leaf (or bract) is below the flower and the inflorescence axis above. (A-C, C', C') Polysymmetric flowers (with five fertile stamens). (A) Valvate-involute aestivation of the corolla. (B) Valvate aestivation of the corolla. (C, C', C') Cochlear aestivation of the corolla. (C) Ascending cochlear. (C', C') Oblique cochlear. (D, D', E, E') Cochlear aestivation of the corolla, and monosymmetric androecium by reduction of stamens to staminodes; direction of monosymmetry indicated in each diagram (full line circles correspond to antesepalous staminodes and dotted line circles to antepetalous staminodes). (D, D') Androecium with two staminodes. (D) Median monosymmetry. (D') Oblique monosymmetry. (E-E'). Androecium with three to five staminodes. (E) Median monosymmetry. (E') Oblique monosymmetry. (I-V) Main patterns of symmetry of the corolla: distribution of the petal lobes in anthetic flowers. (I) Polysymmetric (lobes equally distributed). (II-V) Monosymmetric corollas. (II) Lobes distributed in a pattern 3:2. (III) Lobes distributed in a pattern 2:3. (IV) Lobes distributed in a pattern 1:4. (V) Lobes distributed in a pattern 1:1 (the two lateral lobes and the two lowermost lobes overlap in the anterior side of the flower). 

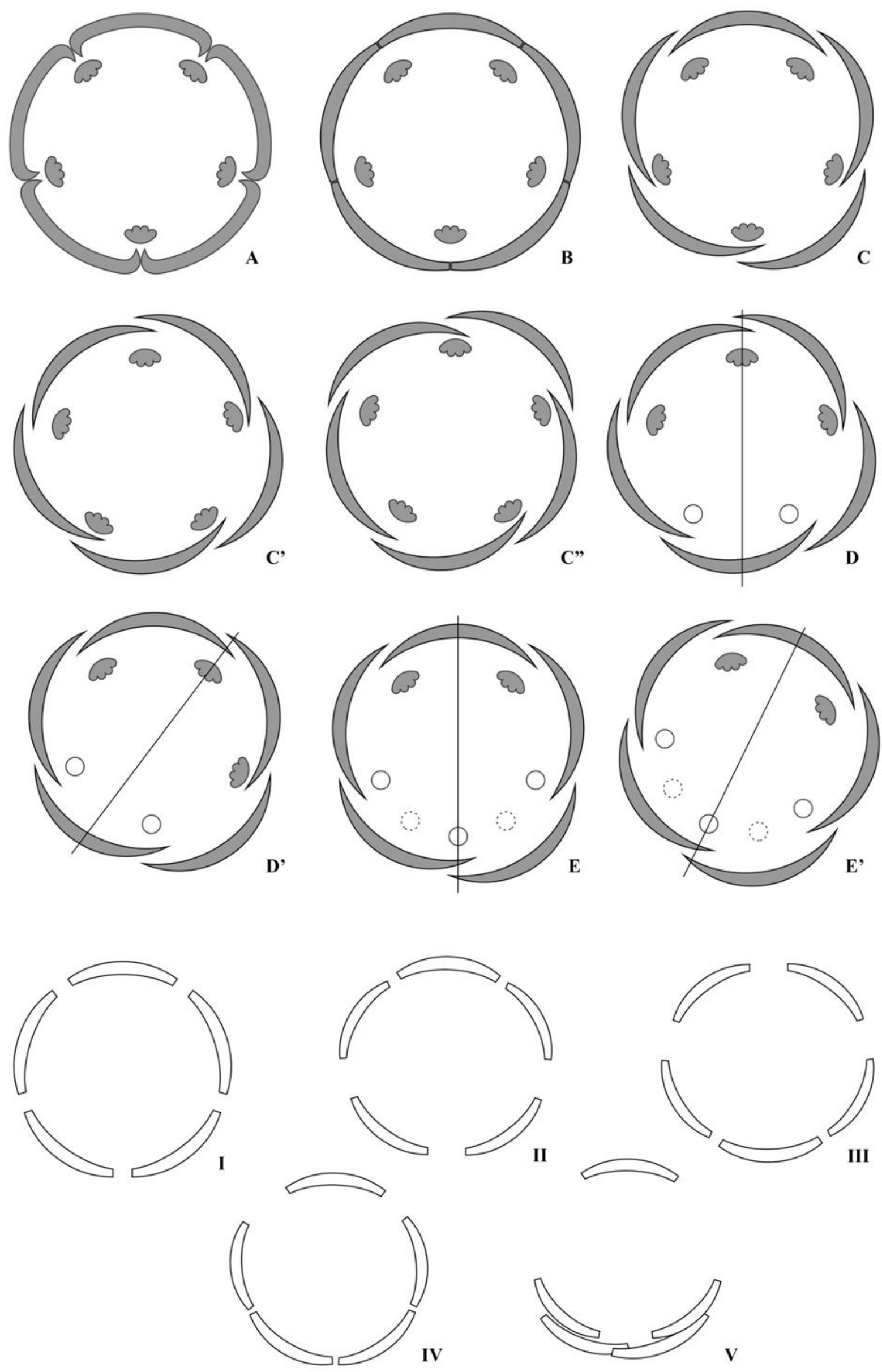


\section{Floral structure and systematics}

In the following sections we list the floral structural features selected as potential synapomorphies for the monophyletic groups of Galipeinae and closely related American genera, according to recent molecular studies (i.e. Groppo et al., 2008, 2012, in prep.). The main criteria used in the elaboration of the list rely upon the floral features shared by groups of genera or species, or at least shared by most of the species and genera of Galipeinae (and thus their absence in few species would be seen as reversals, new apomorphies, or novel states of a feature). Additionally, putative symplesiomorphies shared by Metrodorea nigra, Hortia oreadica and Adiscanthus fusciflorus are also indicated. The features are presented separately on different levels of systematic hierarchy.

The floral features found to support the monophyletic group formed by Galipeinae without Adiscanthus are:

1. Cochlear aestivation of petals, either ascending or oblique;

2. Petal tips overlapped at the apex of the bud;

3. Petals united in bud stage and at anthesis, either postgenitally connected and/or congenitally fused;

4. Floral tube, either a corolla tube, or a petal-tube;

5. Androecium monosymmetric due to reduction into staminodes;

6. Filaments dorsiventrally flattened;

7. Anthers near-basal dorsifixed or basifixed;

8. Nectariferous tissue (mostly) within a long cupular intrastaminal disc;

9. Short syncarpous zone at the base of the carpels (less than half-length of the ovary).

Contrarily, potential synapormophies found to support the sister group formed by Adiscanthus and Hortia are:

1. A tuft of long and thin tanniferous trichomes in the lower adaxial region of petals;

2. Postgenital connection of petals formed by interlocking of short epidermal cells and cuticle projections; 
3. Anthers with vascular bundle forked at their apex and base;

4. Anthers with long bifid fertile bases;

5. Large intercellular spaces in the region of the connective.

Additionally floral features shared by Adiscanthus, Hortia and Metrodorea, (as putative symplesiomorphies) are:

1. Valvate aestivation of petals (of the subtype induplicate-valvate in Metrodorea);

2. Petal tips bent inwards in the centre of the bud;

3. Petals postgenitally connected only in bud stage (and only at their tips in Metrodorea);

4. Flowers strictly polysymmetric (all whorls);

5. Anthers dorsifixed near their middle or upper half.

Although the exact relashionship among most Galipeinae species is not known to date, recent molecular studies (Kallunki \& Groppo, 2007; Groppo et al., in prep.) help to clarify this for part of the genera. This is the case for the sister genera Ertela and Ravenia. In fact Kubitzki et al. (2011), based on morphological analysis, already recognized the close relashionship of Ertela and Ravenia, together with Apocaulon, Raveniopsis, Decagonocarpus, Lubaria, and Raputia. We found the following floral structural features as potential synapomorphies for Ertela and Ravenia:

1. Styloid crystals in the floral tissue;

2. Large intercellular spaces in the mesophyll of sepals;

3. Large intercellular spaces in the mesophyll of petals and filaments, forming arm-like outgrowths;

4. A campanulate floral tube shape (gradually wider towards the mouth of the corolla);

5. A corolla tube;

6. Larger sepals in relation to the corolla, quincuncial at some levels. 
Another monophyletic group recovered in recent molecular phylogenies is formed by Almeidea plus Conchocarpus species without C. cyrtanthus, C. concinnus and $C$. gaudichaudianus (Bruniera, 2010; Groppo et al., in prep.). For this group, we found the following potential synapomorphies:

1. Extrafloral nectaries at the apices of sepals (though probably lost in part of the species of Conchocarpus studied herein);

2. Anthers with a papillose epidermis on their entire surface;

3. Stigmas slightly papillate (bullate cells);

4. A rugose stigmatic surface.

Conchocarpus cyrtanthus, C. concinnus and C. gaudichaudianus form a clade that stands apart from other Conchocarpus species (Groppo et al., in prep.). Kallunki \& Pirani (1998, page 301) already referred to this three taxa, together with C. insignis and C. hirsutus, as a group of five closely related species. These share a calyx of free or only shortly connate, rounded, overlapping sepals, anthers broadly attached to the filament, and a glabrous, umbilicate ovary (Kallunki \& Pirani, 1998). Additional floral features listed below found in the present study do support the close relationship between $C$. cytanthus and $C$. concinnus; their occurrence still need to be investigated in the remaining three taxa of this putative monophyletic group.

1. Smooth stigmatic surface;

2. Partially inferior ovary;

3. Syntropous lower ovules;

4. Inner integument reduced or absent.

Finally, some floral features were found exclusively in single species and/or genera analyzed. These are here considered as potential autapomorphies as follows: 
1. In Angostura bracteata, the undulate calyx surface and the presence of echinoid and stellate trichomes on the calyx and petals;

2. In Spiranthera odoratissima, the wide open corolla and pollination organs sigmoidally curved upwards;

3. In Ravenia species, a carpet of secretory hairs on the inner base of sepal, and a concavity on the dorsal side of the stigmatic lobes;

3a. In R. spectabilis, wings on the pedicel;

4. In Ertela species, small-sized flowers;

4a. In E. bahiensis, fusion of the pedicels in a partial inflorescence;

5. In Raputiarana, small pink dots on the calyx and surface of petals;

6. In Rauia species, a cylindrical stigmatic region;

7. In Sigmatanthus, polysporangiate anthers;

8. In Metrodorea nigra, valvate-involute aestivation of petals, the ovarian nectary plus disc surrounding the filament bases and the collateral ovules;

9. In Adiscanthus fusciflorus, the subglobose lower region of the corolla, the dorsal bulging area of carpels with marked elevation of locules above the style base and pulvinate nectariferous gynophore.

\section{CONCLUSIONS}

The present study is the first broad comparative account on the floral structure of the Neotropical groups of Rutoideae, partially filling the gap related to the knowledge of floral diversity in the family. Here we found that floral features (morphological, anatomical and histological) strongly support the relationships within the American clade of Rutoideae, as the Galipeinae clade without Adiscanthus, and the sister group relationship between Adiscanthus and Hortia recovered by molecular phylogenetic studies (Groppo et al., 2008, 2012, in prep.). Similarly, floral structure supports the close relationship between Ravenia and Ertela, Conchocarpus cyrtanthus and C. concinnus, Almeidea and part of the Conchocarpus species. Also, we would like to point out that comparative studies focusing on the floral structure of other American genera that have not been equally studied in detailed are necessary (e.g. 
Esenbeckia, Raulinoa, Pilocarpus, Hellieta, Baulfourodendron and Choisya). As such, the potential synapomorphies, autapomorphies, polarizations of characters, and evolutive pathways of floral features hereby discussed would be better established. Additionally, these would be further corroborated once tested in future studies of character evolution.

Some floral features explored are similar between nearly all (or all) species analyzed, but show special relevance in providing further support for the floral structural characterization of higher level clades, as in Sapindales and rosids groups. These were mainly related to gynoecium features, such as gynophores (several Sapindales; Ramp, 1988; Endress \& Matthews, 2006, and references therein; Bachelier \& Endress, 2008, 2009; Bachelier et al., 2011), apocarpy (restricted to Simaroubaceae and Rutoideae without Aurantieae; Bachelier \& Endress, 2009, and references therein), and compitum (several Sapindales; Endress et al., 1983; Ramp, 1988; Matthews \& Endress, 2005; Bachelier \& Endress, 2008; Bachelier \& Endress, 2009; Matthews et al., 2012). Also, antitropous ovules, with zig-zag micropyles and campylotropous ovules as hereby described are all widespread features in rosids (Endress \& Matthews, 2006). Regarding perianth features, we found the protection of inner floral organs in advanced buds made by petals to be of special interest. This was not previously reported for neotropical Rutaceae, though considered a potential synapomorphy for Sapindales (Ronse De Craene \& Haston, 2006; Bachelier \& Endress, 2009).

Other floral features occurring in nearly all representatives of Galipeinae have functional implication, such as tubular flowers, monosymmetry and herkogamous flowers. Interestingly, monosymmetric flowers and/or fusion of petals are considered to be as triggers for diversification in certain Angiospem lineages, and thus likely are key innovations (e.g. Orchidaceae, Fabaceae, Lamiales; Endress, 2011, 2012). These would create novel, diverse and efficient ways by which species could interact with pollinators or other environmental factors, through the evolution of distinct morphologies, shapes, and varied floral biology mechanisms (Sargent, 2004; Gavrilets \& Losos, 2009; Knapp, 2010). Galipeinae representatives are conspicuously diverse regarding to organs fusion, floral symmetry, herkogamy among other features. Therefore one could assume that one or more of these features may represent key innovations for the group. In fact Galipeinae is the most speciose subtribe in the traditional classification (Engler, 1931). However the lack of ecological studies focusing on the group limits our understanding of how all this diversity of floral features influences on the biology and evolution of the species. Thus, more studies on comparative floral biology and pollination studies on members of the group are necessary. Additionally, testing the key innovation hypothesis upon a phylogenetic context, as well as evolutive 
studies involving the characters found herein would be very of great relevance to iprove our knowledge on evolution and diversification of Rutaceae.

\section{ACKNOWLEDGEMENTS}

Thanks are due to the technicians of the Plant Anatomy Laboratory (IB-USP), Gisele R. O. Costa, Tássia C. Santos, and Irwandro R. Pires, for their assistance to the first author. The first author also thanks Dr. Milton Groppo Jr. (FFCLRP), MSc. Carla Bruniera (FFCLRP), Dra. Elza M. Guimarães Santos (UNESP); Dr. Anselmo Nogueira (USP), MSc. Cíntia Luiza da Silva Luz (USP), Lukas Daneu (CEPEC), MSc. Rafael Almeida (UEFS), MSc. Wallace M. B. São Mateus (UFRN), MSc. Alan Araújo (UFRN), MSc. Eduardo P.L. Mattar (UFAC), and Dr. Marcus V. A. Liesenfeld (UFAC) for assistance during field work and material collection. Dra. Rafaella Forza (RB), Dra. Alice Calvente (UFRN) and Dr. Jomar Jardim (UFRN) are thanked for providing logistical assistance for the collection of Ravenia spectabilis and Sigmatanthus trifoliatus. We also thank Raquel Koch and Keyla Rodrigues for support with microtome sectioning; and Marcelo Kubo and Thomas de Barros Rose for graphic work. We acknowledge Vale Natural Reserve (Linhares, Brazil) for its logistical and financial support during field work. This work was supported by grants from Fundação de Amparo à Pesquisa do Estado de São Paulo [FAPESP, grants numbers 09/54569-9, and 09/08764-4] awarded to J.H.L. El Ottra and J.R. Pirani; and Conselho Nacional de Desenvolvimento e Pesquisa [CNPq productivity Grant, awarded to J.R. Pirani].

\section{REFERENCES}

Almeida J, Rocheta M, Galego L. 1997. Genetic control of flower shape in Antirrhinum majus. Development 124: 1387-1392.

Angiosperm Phylogeny Group. 2009. An update of the Angiosperm Phylogeny Group classification for the orders and families of flowering plants: APG III. Botanical Journal of the Linnean Society 161:105-121.

Appelhans MS, Smets E, Razamfimandimbison SG, et al. 2011. Phylogeny, evolutionary trends and classification of the Spathelia-Ptaeroxylon clade: Morphological and molecular insights. Annals of Botany. 107: 1259-1277.

Armstrong JA. 1979. Biotic pollination mechanism in the Australian flora - a review. New Zealand Jornal of Botany 17: 467-508.

Bachelier JB, Endress PK. 2008. Floral structure of Kirkia (Kirkiaceae) and its position in Sapindales. Annals of Botany 102: 539-550. 
Bachelier JB, Endress PK. 2009. Comparative floral morphology and anatomy of Anacardiaceae and Burseraceae (Sapindales), with a special focus on gynoecium structure and evolution. Botanical Journal of the Linnean Society 159: 499-571.

Bachelier JB, Endress PK, Ronse de Craene, L. 2011. Comparative floral structure and development of Nitrariaceae (Sapindales) and systematic implications. In: Wanntorp L, Ronse de Craene L, eds. Flowers on the tree of life. Cambridge: Cambridge University Press.

Barbosa AAA. 1999. Hortia brasiliana Vand. (Rutaceae): polinização por aves Passeriformes no cerrado do sudeste brasileiro Revista Brasileira de Botânica 22: 99-105.

Barret SCH, Harder LD. 2005. The evolution of polymorphic sexual systems in daffodils (Narcissus). New Phytologist 165: 45-53.

Baum FB, Eshed Y, Bowman JL. 2001. The Arabidopsis nectary is an ABC-independent floral structure. Development 128: 4657-4667.

Bernadello G. 2007. A systematic survey of floral nectaries. In: Nicolson SW, Nepi M, Pacini E, eds. Nectaries and Nectar. Springer: Dordrecht, 215-249.

Beurton, C. 1994. Gynoecium and perianth in Zanthoxylum s.l. (Rutaceae). Plant Systematics and Evolution 189: 165-191.

Bloomberg SP, Garland TJr. 2002. Tempo and mode in evolution: phylogenetic inertia, adaptation and comparative methods. Journal of Evolutionary Biology 15: 899-910.

Boesewinkel, FD. 1977. Development of ovule and testa in Rutaceae I: Ruta, Zanthoxylum and Skimmia. Acta Botanica Neerlandica 26: 193-221.

Boesewinkel FD. 1978. Development of ovule and testa in Rutaceae III. Some representatives of the Aurantioideae. Acta Botanica Neerlandica 27: 341-354.

Bouman F, Boesewinkel FD. 1991. The campylotropous ovules and seeds, their structure and functions. Botanische Jahrbücher für Systematik 113: 255-270.

Bruniera CP. 2010. Estudos filogenéticos e sistemáticos em Rutaceae: análise cladística e posicionamento de Almeidea A.St.-Hil. entre as Galipeinae (Galipeae, Rutoideae) com o uso de dados morfológicos e moleculares. MSc Thesis, Universidade de São Paulo, Brazil.

Bukatsch F. 1972. Bemerkungen zur Doppelfärbung Astrablau-Safranin. Mikrokosmos 61:255.

Bussel BM, Considine, JA, Spadek ZE. 1995. Flower and volatile oil ontogeny in Boronia megastigma. Annals of Botany 76: 457-463.

Caris P, Smets E, De Coster K, Ronse De Craene LP. 2006. Floral ontogeny of Cneorum tricoccon L. (Rutaceae). Plant Systematics and Evolution 257: 223-232.

Carr SGM, Carr DJ. 1961. The functional significance of syncarpy. Phytomorphology 11: 249-256.

Chase MW, Morton MM, Kallunki JA. 1999. Phylogenetic relationships of Rutaceae: a cladistic analysis of the subfamilies using evidence from rbcL and atpB sequences variations. American Journal of Botany 86: 1191-1199.

Chatin A. 1855. Sur les types obdiplostémone et diplostémone direct, ou de l'existence et des caractères de deux types symétriques distincts chez les fleurs diplostémones. Bulletin de la Société Botanique de France 2: 615-625. 
Coen ES, Meyerowitz EM. 1991. The war of the whorls: genetic interactions controlling flower development. Nature 353: 31-37.

Coen ES, Nugent J. 1994. Evolution of flowers and inflorescences. Development Suppl.: 107-116.

Cronk Q, Moller M. 1997. Genetics of floral symmetry revealed. Trends Ecolology and Evolution 12: $85-86$.

Dias P, Udulutsch RG, Kallunki, JA, Pirani, JR. in press. Molecular phylogeny and biogeography of Metrodorea (Rutaceae): biogeographic implications for South America. Turkish Journal of Botany.

Donoghue MJ, Ree RH, Baum, DA.1998. Phylogeny and the evolution of flower symmetry in the Asteridae. Trends in plant science perspectives 3: 311-317.

Eckert G. 1966. Entwicklungs geschichtliche und blütenanatomische Untersuchungen zum Problem der Obdiplostemonie. Botanische Jahrbücher für Systematik 85: 523-604.

Eichler AW. 1878. Blüthendiagramme II. Engelmann: Leipzig.

El Ottra JHL, Pirani JR, Panzarin ER. 2012. Floral biology of the Neotropical Galipeinae (Rutaceae): morphology, pollination and flower specialization. $49^{\circ}$ Annual Meeting of the Association for Tropical Biology and Conservation, Abstract book, 190.

El Ottra JHL, Pirani JR, Endress PK. 2013. Fusion within and between whorls of floral organs in Galipeinae (Rutaceae): structural features and evolutionary implications. Annals of Botany 111: 821-837.

Elias TS. 1983. Extrafloral nectaries: their structure and functions. In: Bentley B, Elias TS., eds. The Biology of Nectaries. Columbia University Press: New York.

Emmerich M. 1978. Contribuição ao conhecimento da tribo Cusparieae (Rutaceae) nova conceituação de Raputia e gêneros derivados. Rodriguésia 30, 45: 223-307.

Endress PK. 1994. Diversity and evolutionary biology of tropical flowers. Cambridge: Cambridge University Press.

Endress PK.1999. Symmetry in flowers: diversity and evolution. International Journal of Plant Sciences 160 (Suppl. 6): S3-S23.

Endress PK. 2001. Evolution of floral symmetry. Current Opinion in Plant Biology 4: 86-91.

Endress PK. 2010a. Synorganisation without organ fusion in the flowers of Geranium robertianum (Geraniaceae) and its not so trivial obdiplostemony. Annals of Botany 106: 687-695.

Endress, PK. 2010b. Flower structure and trends of evolution in eudicots and their major subclades. Annals of the Missouri Botanical Garden 97: 541-583.

Endress PK. 2011a. Evolutionary diversification of the flowers in angiosperms. American Journal of Botany 98: 370-396.

Endress PK. 2011b. Angiosperm ovules: diversity, development, evolution. Annals of Botany 107: $1465-1489$.

Endress PK. 2012. The immense diversity of floral monosymmetry and asymmetry across angiosperms. Botanical Review 78:345-397. 
Endress PK, Igersheim A. 2000. Gynoecium structure and evolution in basal angiosperms. International Journal of Plant Sciences 161: S211-S223.

Endress PK, Jenny M, Fallen ME. 1983. Convergent elaboration of apocarpous gynoecia in higher advanced angiosperms (Sapindales, Malvales, Gentianales). Nordic Journal of Botany 3: 293-300.

Endress PK, Matthews ML. 2006. First steps towards a floral structural characterization of the major rosid subclades. Plant Systematics and Evolution 260: 223-251.

Endress PK, Matthews ML. 2012. Progress and problems in the assessment of flower morphology in higher-level systematics. Plant Systematics and Evolution 298:257-276.

Endress PK, Stumpf S. 1990. Non-tetrasporangiate stamens in the angiosperms: structure, systematic distribution and evolutionary aspects. Botanische Jahrbücher für Systematik 112: 193-240.

Endress PK, Stumpf S. 1991. The diversity of stamen structure in 'Lower' Rosidae (Rosales, Fabales, Proteales, Sapindales). Botanical Journal of the Linnean Society 107: 217-293.

Engler A. 1874. Rutaceae. In Martius, CPF, Eichler, AG, eds. Flora brasiliensis, 12. Leipzig: Friedrich Fleischer, 75-196.

Engler A. 1931. Rutaceae. In: Engler A, Prantl K, eds. Die natürlichen Pflanzenfamilien, 2nd edn, 19a. Leipzig: Engelmann, 187-359.

Espigares T, Peço, B. 1995. Mediterranean annual pasture dynamics: impact of autumn drought. Journal of Ecology 83: 135-142.

Fay MF, Cameron KM, Prance GT, Chase MW. 1997. Familial relationships of Rhabdodendron (Rhabdodendraceae): plastid rbcL sequences indicate a caryophyllid placement. Kew Bulletin 52: 923-791.

Faegri L, van der Pijl L. 1979. The principles of pollination ecology, 3rd edn. New York: Pergamon Press.

Fahn A. 1979. Secretory tissues in plants. Academic Press: Londres.

Fahn A. 1987. The extrafloral nectaries of Sambucus. Annals of Botany 60: 299-308.

Fenster CB, Armbruster WS, Wilson P, Dudash MR, Thomson, JD. 2004. Pollination syndromes and floral specialization. Annual Review of Ecology Evolution and Systematic 35: 375-403.

Fleming TH, Geiselman C, Kress WJ. 2009. The evolution of bat pollination: a phylogenetic perspective. Annals of Botany 104: 1017-1043.

Florula Digital de la Estación Biológica de la Selva. URL: sura.ots.ac.cr/local/florula4/find_sp2.php?customer=Toxosiphon+lindenii\&busca=Busca\#. Date of last access: 30 Mar. 2014.

Frey-Wyssling A, Häusermann E. 1960. Deutung der gestaltlosen Nektarien. Bericht der Schweizerischen Botanischen Gesselschaft 70: 150-162.

Gavrilets S, Losos JB. 2009. Adaptive radiation: contrasting theory with data. Science 323: 732-737.

Glover B. 2007. Understanding flowers and flowering: an integrated approach. Oxford: Oxford University Press. 
Gould SJ. 1992. Ontogeny and phylogeny: revisited and reunited. BioEssays 14: 275-279.

Groppo M, Pirani JR, Salatino MLF, Blanco SR, Kallunki JA. 2008. Phylogeny of Rutaceae based on two noncoding regions from cpDNA. American Journal of Botany 95: 985-1005.

Gropo M, Pirani JR. 2012. A revision of Hortia. Systematic Botany 37:197-212.

Groppo M, Kallunki JA, Pirani JR, Antonelli, A. 2012. Chilean Pitavia more closely related to Oceania and Old World Rutaceae than Neotropical groups: evidence from two cpDNA non-coding regions, with a new subfamilial classification of the family. PhytoKeys 19: 9-29.

Guédès, M. 1973. Carpel morphology and axis-sharing in syncarpy in some Rutaceae, with further comments on "New Morphology". Botanical Journal of the Linnean Society 66: 55-74.

Guerra M, Santos KGB, Silva AEB, et al. 2000. Heterochomatinbanding patter in RutaceaeAurantioideae- A case of parallel chromosomal evolution. American Journal of Botany 87: 735747.

Gut BJ. 1966. Beiträge zur Morphologie des Gynoeceums und der Blütenachse einiger Rutaceen. Botanische Jahrbücher für Systematik 85: 151-247.

Harms H. 1940. Meliaceae. In: Engler A, Prantl K, eds. Die natürlichen Pflanzenfamilien, 2nd edn 19bI. Leipzig: Engelmann, 1-172.

Hartl D. 1957. Die Pseudosympetalie von Correa speciosa (Rutaceae) und Oxalis tubiflora (Oxalidaceae). Abhandlungen der Mathematisch-Naturwissenschaftlichen Klasse, Akademie der Wissenschaften und der Literatur Mainz 2: 1-13.

Heil M, McKey D. 2003. Protective ant-plant interactions as model systems in ecological and evolutionary research. Annual Reviewof Ecology, Evolution, and Systematics 34: 425-453.

Heslop-Harrison Y, Shivanna KR. 1977. The receptive surface of the angiosperm stigma. Annals of Botany 41:1233-1258.

Hufford LD, Endress PK. 1989.The diversity of anther structures and dehiscence patterns among Hamamelididae. Botanical Journal of the Linnean Society 99: 301-346.

Jardin F. 1984. Contribution à l'étude des Térébinthacées. Montpellier: Serre et Roumégous.

Johansen DA. 1940. Plant Microtechnique. New York: McGraw-Hill Book Company.

Kaastra RC. 1982. Pilocarpinae (Rutaceae). Flora Neotropica Monographs 33:1-198.

Kallunki JA, Steyermark, JA. 1987. A new species of Raveniopsis (Rutaceae), a genus new to Brazil. Brittonia 39: 409-411.

Kallunki JA. 1990. An emended description of and new combination in Raputia (Cuspariinae, Rutaceae). Brittonia 42: 175-177.

Kallunki JA. 1992. A revision of Erythrochiton sensu latu (Cuspariinae, Rutaceae). Brittonia 44: 107139.

Kallunki JA. 1994. Revision of Raputia Aubl. (Rutaceae, Cuspariinae): Brittonia 46: 279-295.

Kallunki JA. 1998a. Andreadoxa flava (Rutaceae, Cuspariinae): a new genus and species from Bahia, Brazil. Brittonia 50: 59-62. 
Kallunki JA. 1998b. Revision of Ticorea Aubl. (Rutaceae, Galipeinae). Brittonia 50: 500-513.

Kallunki J. 2005. Rutaceae. In: Berry P, Holst BK, Yatskievych, K, eds. Flora of the Venezuelan Guayana. Volume 9. Rutaceae- Zygophyllaceae. St. Louis: Missouri Botanical Garden Press; Portland: Timber Press, 1-39.

Kallunki JA. 2009. Validation of Neoraputia (Galipeae, Rutaceae) and description of two new species from Eastern Brazil. Brittonia 61(1): 28-34.

Kallunki JA, Groppo M. 2007. Phylogenetic analyses of the subtribe Galipeinae (Rutaceae).URL:2007.botanyconference.org/engine/search/index.php?func=detail\&aid=1344. Date of last access: 12 Mar. 2014.

Kallunki JA, Pirani JR. 1998. Synopses of Angostura Roem. \& Schult. and Conchocarpus J. C. Mikan. Kew Bulletin 53: 257-334.

Knapp S. 2010. On 'various contrivances': pollination, phylogeny and flower form in the Solanaceae. Philosophical Transactions of the Royal Society, B, Biological Sciences. 365: 449-460.

Kubitzki K, Kallunki JA, Duretto M, Wilson PG. 2011. Rutaceae. In: Kubitzki K, ed. Flowering Plants. Eudicots: Sapindales, Cucurbitales, Myrtaceae (The Families and Genera of Vascular Plants). Hamburg: Springer, 276-356.

Leinfellner W. 1950. Der Bauplan des synkarpen gynoeceums. Österreichische Botanische Zeitschrift 97: 403-436.

Leins P. 1964. Entwicklungsgeschichtliche Studien an Ericales-Blüten. Botanische Jahrbücher für Systematik 83: 57-88.

Li P, Johnston MO. 2000. Heterochrony in Plant Evolutionary Studies through the Twentieth Century. Botanical Review 66: 57-88.

Lopes A. 2002. Polinização por beija-flores em remanescentes da Mata Atlântica Pernambucana, nordeste do Brasil. MSc Thesis, Universidade of Campinas, Brazil.

Lloyd DG, Webb CJ. 1986. The avoidance of interference between the presentation of pollen and stigmas in angiosperms I. Dichogamy. New Zealand Journal of Botany 24: 135-162.

Marquete O. 1981. Anatomia e vascularização foliar e floral de Pilocarpus organensis Occhioni \& Rizzini (Rutaceae). Arquivos do Jardim Botânico do Rio de Janeiro 25: 117-159.

Matthews ML, Endress PK. 2005. Comparative floral structure and systematics in Crossosomatales (Crossosomataceae, Stachyuraceae, Staphyleaceae, Aphloiaceae, Geissolomataceae, Ixerbaceae, Strasburgeriaceae). Botanical Journal of the Linnean Society 147: 1-46.

Matthews ML, Endress PK. 2006. Floral structure and systematics in four orders of rosids, including a broad survey of floral mucilage cells. Plant Systematics and Evolution 260: 199-221.

Matthews ML, Amaral MCE, Endress PK. 2012. Comparative floral structrue and systematics in Ochnaceae s.l. (Ochnaceae, Quiinaceae, Medusagynaceae; Malpighiales). Botanical Journal of the Linnean Society 170: 299-392.

Metcalfe CR, Chalk L. 1950. Anatomy of the dicotyledons. Oxford: Clarendon Press.

Moore JA. 1936. Floral anatomy and phylogeny in the Rutaceae. New Phytologist 35: 318-322. 
Morton CM, Kallunki JA. 1993. Pollen Morphology of the subtribe Cuspariinae (Rutaceae). Brittonia 45: 286-314.

Morton CM, Grant M, Blackmore S. 2003. Phylogenetic relationships of the Aurantioideae inferred from chloroplast DNA sequence data. American Journal of Botany 90: 1463-1469.

Müller H. 1875. Fertilization of flowers by insects VIII. Nature 11:110-112.

Neal PR, A Dafni, M Giurfa. 1998. Floral symmetry and its role in plant-pollinator systems: terminology, distribution, and hypotheses. Annual Review of Ecology Evolution and Systematic 29:345-373.

Nicolson SW, Thornburg WR. 2007 . Nectar chemistry. In Nicolson SW, Nepi M, Pacini E, eds. Nectaries and Nectar. Springer: Dordrecht, 215-249.

Orzack SH, Sober E. 2001. Adaptation, phylogenetic inertia, and the method of controlled comparisons. In: Orzack SH, Sober E, eds. Adaptationism and Optimality. Cambridge University Press: Cambridge.

Penzing, O. 1887. Studi botanici suggli aggrumi e sulle piante affini. Annali di Agricoltura: Roma.

Piedade LH, Ranga NT. 1993. Ecologia da polinização de Galipea jasminiflora Engler (Rutaceae). Revista Brasileira de Botânica 16: 151-157.

Pirani JR. 1998. A revision of Helietta and Balfourodendron (Rutaceae, Pteleinae). Brittonia 50: 348380.

Pirani JR. 1999. Estudos taxonômicos em Rutaceae: revisão de Helietta e Balfourodendron (Pteleinae). Análise cladística de Pteleinae. Sinopse de Rutaceae do Brasil. Habilitation thesis, Universidade de São Paulo, Brazil.

Pirani JR. 2004. Three new species of Galipea (Rutaceae, Galipeinae) from Brazil. Botanical Journal of the Linnean Society 144: 365-373.

Pirani JR, El Ottra JHL, Menezes NL. 2010. Morfoanatomia de flores de cinco espécies de Galipea Aubl. e seu significado na evolução de flores tubulosas entre as Rutaceae neotropicais. Revista Brasileira de Botânica 33: 301-318.

Pirani JR, Groppo M, Kallunki JA. 2012. Two new species and a new combination in Conchocarpus (Rutaceae, Galipeeae) from eastern Brazil. Kew Bulletin 66: 1-7.

Pombal ECP, Morrelato PC. 2000. Differentiation of floral color and odor in two fly pollinated species of Metrodorea (Rutaceae) from Brazil. Plant Systematics and Evolution 221: 141-156.

Poon WS, Shaw PC, Simmons MP, et al. 2007. Congruence of molecular, morfological, and biochemical profiles in Rutaceae : A cladistic analysis of the subfamilies Rutoideae and Toddalioideae. Systematic Botany 32: 837-846.

Porter DM, Elias TS. 1979. Flora of Panama: Rutaceae. Annals of the Missouri Botanical Garden 66: 123-164.

Puri V. 1951. The role of floral anatomy in the solution of morphological problems. Botanical Review 17: 471-553.

Ramp E. 1988. Struktur, Funktion und systematische Bedeutung des Gynoeciums bei den Rutaceae und Simaroubaceae. PhD Thesis, Universität Zürich: Switzerland. 
Ronse De Craene LP, Smets EF. 1995. The distribution and systematic relevance of the androecial character oligomery. Botanical Journal of the Linnean Society 118: 193-247.

Ronse de Craene LP, Haston E. 2006. The systematic relationships of glucosinolate-producing plants and related families: a cladistic investigation based on morphological and molecular characters. Botanical Journal of the Linnean Society 151: 453-494.

Salvo G, Bacchetta G, Ghahremaninejad F, Conti E. 2008. Phylogenetic relationships of Ruteae (Rutaceae): New evidence from the chloroplast genome and comparisons with non-molecular data. Molecular Phylogenetics and Evolution 49: 736-748.

Sargent , R. D. 2004 . Floral symmetry affects speciation rates in angiosperms. Proceedings of the Royal Society of London, B, Biological Sciences 271 : 603 - 608 .

Saunders ER. 1934. On carpel polymorphism VI. Annalsof Botany 48:643-692.

Scholz H. 1964. Sapindaceae. In: Melchior HA. Engler's Syllabus der Pflanzenfamilien, vol. 2. Berlin: Gebrüder Borntraeger, 282-284.

Schönenberger J, Balthazar M. 2012. Modern plant morphological studies. Botanical Journal of the Linnean Society 169: 565-568.

Scott KD, McIntyre CL, Playford J. 2000. Molecular analysis suggest a need for a significant rearrangment of Rutaceae subfamilies and minor reassessment of species relationships within Flindersia. Plant Systematics and Evolution 223: 15-27.

Silva IM. 1988. Revisão taxonômica do gênero Almeidea Saint-Hilaire (Rutaceae). MSc Thesis, Universidade Federal do Rio de Janeiro, Brazil.

Silva LL, Paoli AAS. 2006. Morfologia e anatomia da semente de Esenbeckia grandiflora Mart. (Rutaceae). Revista Brasileira de Sementes 28: 1-6.

Silva MFGF, Gottlieb OR, Ehrendorfen F. 1988. Chemosystematics of the Rutaceae: suggestions for more natural taxonomy and evolutionary interpretation of the family. Plant Systematics and Evolution 161: 97-134.

Silva CSP, Santos ML. 2008. Comportamento fenológico no evento pós-queima e biologia reprodutiva de Spiranthera odoratissima A. St.-Hil. (Rutaceae). Biotemas 21: 29-39.

Singhal VK, Salwan A, Kumar P, Kaur J. 2011. Phenology, pollination and breeding system of Aegle marmelos (Linn.) correa (Rutaceae) from India. New Forests 42:85-100.

Souza LA, Mourão KSM, Moscheta IS, et al. 2003. Morfologia e anatomia da flor de Pilocarpus pennatifolius Lem. (Rutaceae). Revista Brasileira de Botanica 26: 175-184.

Souza LA, Moscheta IS, Mourão KSM, Rosa SM. 2004. Morphology and anatomy of the flowers and anthesis of Metrodorea nigra St. Hill (Rutaceae). Brazilian archives of Biology and Technology. 47: 107-112.

Souza A, Mourão KSM, Souza LA. 2005. Morfologia e anatomia do fruto e da semente em desenvolvimento de Pilocarpus pennatifolius Lem. (Rutaceae). Revista Brasileira de Botanica 28: 745-754.

Stace HM, Armstrong JA, James SH. 1993. Cytoevolutionary patterns in Rutaceae. Plant Systematics and Evolution 187: 1-28. 
Stebbins GL. 1974. Flowering Plants: Evolution above the species level. Cambridge: Harvard University Press.

Stevens PF. 2001 onwards. Angiosperm Phylogeny Website, Version 12, July 2012 [and more or less continuously updated since]. Available at http://www.mobot.org/MOBOT/research/APweb/ (accessed April 2014).

Swingle WT, Reece, PC . 1967. The botany of citrus and its wild relatives of the orange subfamily. In: ReutherW,Webber HJ, BatchelorLD, eds. The citrus industry, 2nd ed, vol. 1. Berkeley: University of California, $190-430$.

Tropicos. URL:http://www.tropicos.org. Date of last access: 30 Mar. 2014.

Tilak VD, Nene PM. 1976. The disc in the Rutaceae. Journal of the University of Bombay 45: 49-53.

Tilak VD, Nene PM. 1978. Floral anatomy of the Rutaceae. Indian Journal of Botany 1: 83-90.

Tilson AH, Bamdford R. 1938. The floral anatomy of the Aurantioideae. American Journal of Botany 25: 780-793.

Virtual Herbarium of the New York Botanical Garden. URL: http://sweetgum.nybg.org/vh/specimen.php?irn=767304. Date of last access: 30 Mar. 2014.

Walker-Larsen J, Harder LD. 2000. The evolution of staminodes in angiosperms: patterns of stamen reduction, loss, and functional re-invention. American Journal of Botany. 87: 1367-1384.

Webb CJ, Lloyd DG. 1986. The avoidance of interference between the presentation of pollen and stigmas in angiosperms II: Herkogamy. New Zealand Journal of Botany 24: 163-178.

Weberling F. 1989. Morphology of flowers and inflorescences. Cambridge: Cambridge University Press.

Wei L, Wang WZ, Li, ZY. 2011. Floral ontogeny of Ruteae (Rutaceae) and its systematic implications. Plant Biology 14: 190-197.

Westerkamp C, Claßen-Bockhoff R. 2007. Bilabiate flowers: the ultimate response to bees? Annals of Botany 100: 361-374.

Werker E. 2000. Trichome diversity and development. Advances in Botanical Research 31: 1-35.

Wilson PG. 1961. A taxonomic revision of the genus Correa (Rutaceae). Transactions and proceedings of the Royal Society of South Australia 85:21-53.

Yamazaki, T. 1988. Floral anatomy of the genus Zanthoxylum L. Journal of Japanese Botany 63: 7.

Zimmerman JG. 1932. Über die extrafloralen Nektarien der Angiosperm. Beihefte zum Botanischen Centralblatt 49A: 99-196. 

CAPÍTULO 2 



\section{Tackling pollination of tubular flowers in Rutaceae: a case study of}

\section{Almeidea rubra A.St.-Hil. (Galipeinae, Rutaceae)}

Juliana Hanna Leite El Ottra ${ }^{1 *}$, José Rubens Pirani ${ }^{1}$, Emerson Ricardo Pansarin ${ }^{2}$

${ }^{1}$ Universidade de São Paulo, Instituto de Biociências, Departamento de Botânica. Rua do Matão 277, 05508-090, São Paulo, São Paulo, Brasil.

${ }^{2}$ Faculdade de Filosofia, Ciências e Letras de Ribeirão Preto, Departamento de Biologia. Av. Bandeirantes, 3900, 14040-901 Ribeirão Preto, São Paulo, Brasil.

*Corresponding author: Email juliana.ottra@usp.br

(manuscrito submetido à revista Australian Journal of Botany em 30/08/2014) 



\begin{abstract}
In Rutaceae, tubular flowers are only found in two distantly related groups of Rutoideae: the mainly Australian tribe Boronieae and the Neotropical subtribe Galipeinae (tribe Galipeeae). It is assumed that these nectar-rewarded, tubular flowers arose from convergent evolution driven by pollinator pressures. However, the paucity of ecological studies in Rutaceae limits our understanding about the relationship between pollen vectors and floral features. In the present study we provide new information about the floral biology and pollination of Almeidea rubra A.St.-Hil. (Galipeinae), and also about their nectarsecreting floral structures. Additionally, we aim to compare these new findings with the pollination systems reported for Boronieae and to discuss the functional relationship between floral features and the pollination mechanism found for both groups. Almeidea rubra is mainly pollinated by a single species of hermit hummingbird and, secondarily, by butterflies. Comparing the pollination system of A. rubra with representatives of Boronieae having similar flower architecture, we found that both groups are mainly bird-pollinated, Meliphagidae and Trochilidae, respectively. Besides a floral tube, other floral features may be linked to this type of pollination, related not only to birds attraction (nectar features, attractive colors), but also to insect exclusion (sensory exclusion, absence of landing platforms, pendant flowers or nodding inflorescences). Our findings indicate evolutionary flower specialization toward the nectar-seeking pollinators in both groups of Rutaceae.
\end{abstract}

Keywords: floral biology, non-structural nectaries, butterfly pollination, hummingbird, bird pollination, Galipeinae, Boronieae, Brazilian Atlantic Forest, flower specialization 



\section{INTRODUCTION}

Tubular flowers are present in several Angiosperm groups (Endress and Matthews 2012). A floral tube may be defined as a tubular part of the flower through which the floral centre can be reached. It is usually formed by petals and/or sepals, and occasionally by stamens (El Ottra et al. 2013). Across Angiosperms, sympetaly evolved multiple times within several families or orders, but it is most commonly found among the eudicots clade (Endress and Matthews 2012). In narrower systematic scales, sympetaly circumscribes large monophyletic groups, such as the asterids (APG 2009; Endress 2010). Within rosids, sympetaly is found scattered within some families, as in some representatives of Rutaceae (Engler 1931; Kubitzki et al. 2011; Endress and Matthews 2012). Since the floral tube is traditionally a component of some floral syndromes, it has been assumed that the multiple arising of floral tubes in Angiosperms resulted from convergent evolution (Faegri and van der Pijl 1979). While the validity of this concept has been questioned in the last decades (e.g., Waser et al. 1996), some authors support the view of floral syndromes as specialized floral morphologies that evolved toward a subset of functionally grouped potential pollinators (Fenster et al. 2004).

From a functional point of view, a tubular floral architecture is usually associated with efficient concealment of nectar and narrowing the spectrum of floral visitors able to collect this floral resource (Faegri and van der Pijl 1979; Endress 1994; Proctor et al. 1996; Kay et al. 2006). As this structure usually bears the nectar-secreting structures within it, a floral tube may protect the nectar from biotic and abiotic factors. For instance, accumulation of nectar at the bottom of the tube is assumed to reduce nectar evaporation and dilution by rain (e.g., Endress 1994). Also, it may prevent some nectar thieves from taking this resource from flowers (Faegri and van der Pijl 1979; Endress 1994; Bernadello 2007, and references therein). In fact, nectar production is energetically highly costly for plants, especially in species where it is abundantly produced, and its loss should be avoided by plants (Bernadello 2007). Thus, the presentation of floral nectar at the base of the tubes is considered to be a plant adaptation for the efficient concealment of floral nectar and its presentation to pollinators that possess appropriate mouth parts to reach it (e.g., long tongues). In this sense, it is expected that nectar-seeking animals would act as pollinators of tubular flowers, but only when animal and flower are morphologically matched, e.g., mouthpart features and nectary position, resulting in pollen deposition and stigma contact, thereby restricting the number of groups that may successfully manipulate the flower (Faegri and van der Pijl 1979; Endress 1994; Proctor et al. 1996; Kay et al. 2006). 
Pollinators able to explore nectar concealed in floral tubes generally possess several morphological and anatomical features in their mouthparts that make it possible to reach the sunken nectaries and efficiently imbibe nectar from flower (Proctor et al. 1996). Among insects, there are informal groups denominated as "short-tongued" and "long-tongued" (e.g. some species of Bombyliidae flies, Xylocopa bees), the latter capable of probing and pollinate tubular flowers of variable length (Proctor et al. 1996). Among these, the Lepidoptera, including moths, halkmoths and butterflies, are considered most likely to pollinate the longer and narrower tubular flowers (Faegri and van der Pijl 1979; Nilsson 1987; Nilsson et al. 1985). Among vertebrates, bats may also possess elaborate mouth parts to explore concealed nectar in floral tubes, such as the long-tongued Glossophaginae bats (Sazima et al. 1999). Also, birds with long bills and/or long tongues have multiple lineages specialized in nectar feeding, thus playing an important role as pollinators of tubular flowers. Among these, hummingbirds (Trochilidae) are considered the most specialized nectar feeders in the American tropics. Other nectarivorous birds with comparatively less specialized diet may also possess certain structures in their mouth parts that make them apt to the efficient exploitation of concealed floral nectar, such as the brush-tongues of some short-billed Meliphagidae birds in the Australian region (Proctor and Yeo 1973; Stiles 1981; Endress 1994).Thus, species with tubular flowers could be seen as relatively specialized pollination systems, since they restrict access to floral reward (nectar) to functional groups of animals with unspecialized mouthparts, especially the short-tongued groups. On the contrary, long-tongued animals may also visit other plants with different floral architectures and a relatively more generalized pollination system (Fenster et al. 2004; Renner 2006). However, it should be noted that some animals, termed nectar robbers, may circumvent the floral tube opening by piercing the base of the tube to reach the nectar. However, in these cases, animals are considered antagonists of the plants, or cheaters in the plant-pollinator mutualistic relationship, as they do not make contact with anthers and/or stigmas in many cases (Darwin 1872; Zhu et al. 2010; Irwin et al. 2010). As a consequence, plants may possess several devices to deter nectar robbing, including morphological traits, such as thick calyces, or chemical traits, such as toxic secondary compounds in floral organs (Irwin et al. 2004; 2010), but this subject is beyond the scope of this work.

In Rutaceae, tubular flowers are only found in two distantly related groups: in some species and genera traditionally placed in the tribe Boronieae (Rutoideae, Engler 1931) and in the subtribe Galipeinae (Galipeeae, Rutoideae, Kallunki and Pirani, 1998; Groppo et al. 2008). These two groups are not only phylogenetically distant, but also geographically. That 
is, while the 22 genera of Boronieae are Paleotropical, occurring mainly in several environments of the Australian region, but also in New Caledonia and New Zealand, the Galipeinae are exclusively Neotropical, distributed from South America to southern Mexico and the West Indies, mostly in moist lowland forests (Groppo et al. 2008; Kubitzki et al. 2011). Within the Boronieae, tubular flowers apparently evolved multiple times in unrelated genera (Armstrong 1979). In contrast, most members of the subtribe Galipeinae have tubular flowers, with only a few exceptions (Engler 1931), and as such, this floral architecture is possibly homologous within the group. When comparing the floral tubes of the Boronieae and Galipeinae, one may assume that their overall resemblance was caused by the phenomenon of convergent evolution, presumably driven by pollinator selective pressure (El Ottra et al. 2013). Thus, it is expected that species of Galipeinae and Boronieae with tubular flowers offer nectar as a reward and that they are similarly pollinated by nectar-seeking animals with long tongues and/or long bills. However, the paucity of studies about pollination in Rutaceae, especially among the Galipeinae, limits our understanding of the relationship between pollinators and flower architecture and, consequently, its implication in ecology and evolution of the groups (El Ottra et al. 2013).

Almeidea A.St.-Hil. (Rutaceae) is one of the 26 genera in the Neotropical subtribe Galipeinae (Groppo et al. 2008). The genus comprises five species distributed mostly along the Brazilian Atlantic Forest. Almeidea rubra A.St.-Hil. shows the widest distribution, occurring in the states of Bahia, Minas Gerais, Espírito Santo, Rio de Janeiro, São Paulo and Paraná, with a recent record in forests of Bolivia. Species of Almeidea are usually trees or treelets of the forest understory. Their pink, lilac or white coloured flowers are produced in terminal or subterminal thyrsoid inflorescences (Bruniera et al. 2011).

Two different types of nectaries have been reported for Almeidea. The first type, a intraestaminal nectary disc, is most commonly found among Rutaceae (Engler 1931) and is probably directly related to pollination. However, a second type of nectary, termed as extrafloral nectary, has been found on the apices of sepals and apparently is unrelated to pollination (Silva 1988; Bruniera 2010). However, studies describing nectaries of Almeidea are based on stereomicroscopy analysis and scarce field observations. No details on morphoanatomical structure of those nectaries are available. Furthermore, the presence, quantity and sugar concentration of the nectar produced by both types of nectaries are unknown. The presence of nectaries on apices of sepals has systematic importance, and it was considered as a putative synapomorphy of Almeidea (Bruniera 2010). 
Among genera of the subtribe Galipeinae, the sole study of pollination biology was performed with Galipea jasminiflora A.St.-Hil., a species mainly pollinated by moths (Piedade and Ranga 1993). Furthermore, sparse data are available for Erythrochiton brasiliensis Mart. ex Nees, which is pollinated by hummingbirds (Lopes 2002). Data on the floral biology and pollination for Almeidea are absent in the literature.

Based on records of floral morphoanatomy, reward production, pollinator behavior and pollination mechanisms, we aim here to report the floral biology and pollination of Almeidea rubra of southeastern Brazil. We also aim to compare these new findings for the Galipeinae with the pollination records and floral features of other Rutaceae with tubular flowers, notably among representatives of the tribe Boronieae. With this comparison, we expect to provide a better understanding of factors that might have influenced the evolution of this unusual floral architecture in the family.

\section{MATERIAL AND METHODS}

Study site

We studied the floral biology of Almeidea rubra in a mesophytic semi-deciduous forest in São João do Petrópolis (SJP), in the municipality of Santa Teresa, state of Espírito Santo (southeastern Brazil). The forest is a natural area of the Instituto Federal do Espírito Santo (approx.19 $48^{\prime} \mathrm{S}, 40^{\circ} 40^{\prime} \mathrm{W} ; 193 \mathrm{~m}$ a.s.1.), and it is part of the Brazilian Atlantic Forest biome (Morellato and Haddad 2000). The climate of the SJP is tropical humid 'Aw.' according to Köppen (1948), with an annual rainfall of about $1275 \mathrm{~mm}$ and a mean annual average temperature of $20^{\circ} \mathrm{C}$. The dry months range from June to September, and the rainy season extends from October to April. May is one partially dry month (data source: Instituto Capixaba de Pesquisa Assistência Técnica e Extensão Rural). The studied population grows in the forest understory, on rocky soils at the slopes of the hills.

\section{Floral features and pollinators}

Features of flower opening, its duration, and pollinators were gathered by visiting the study areas during the 2010, 2011 and 2014 flowering periods. For the study of floral morphology, we collected 10 fresh flowers at different stages of development, and they were analyzed and recorded under a Leica M125 stereomicroscope equipped with a digital camera (Leica DFC 425). The measurements were made directly from floral structures using a caliper 
and the LAS Software (Leica). The morphological study included observations on the shape, symmetry, layout and size of floral parts, such as sepals, petals, stamens and pistils, considering possible variations throughout the flower's life (Faegri and Van der Pij1 1979). Additionally, stigma receptivity of these flowers was determined by adding a drop of hydrogen peroxide and checking for bubble formation (Zeisler 1938). Data on pollen availability, floral orientation and variation in flower morphology were also recorded in all open flowers during field observations. Floral scent was determined in fully opened flowers that were enclosed in glass jars from 10 min to 1 hour (Kearns and Inouye 1993).

For anatomical study of the nectariferous structures, we collected fresh flowers of $A$. rubra at SJP, and after immersing them in formalin-acetic acid-alcohol (FAA) 50\%, we placed them under low vacuum to ensure penetration of the fixative. Flowers were then stored in $70 \%$ ethanol. Light microscopy investigations were made on material dehydrated in an ethanol-butanol series and embedded in paraffin (Johansen 1940). Cross sections were obtained using a rotary microtome. Sections $10-12 \mu \mathrm{m}$ thick were stained with Astra Blue $1 \%$ and Safranin O 1\% (Bukatsch 1972). The slides were analyzed using a Leica DM 4000B microscope. Scanning Electron Microscopy (SEM) analysis was carried out after the fixed material was dissected, dehydrated in ethanol series and critical-point dried. The material was then mounted in stubs and sputter-coated with gold. Observations were made in a Zeiss DMS940 Scanning Electron Microscope.

We determined nectar production in the putative nectariferous structures by bagging 36 flowers (8 plants) during a 24-hour period. For exudates of sepals, 18 flowers were bagged. To confirm these secretions as nectar, Combur®strips were laid on exudates, and positive reaction to glucose was verified (Galetto and Bernadello 2005). To quantify floral nectar produced by the nectary disc, we measured nectar volume using a $10 \mu \mathrm{L}$ syringe (Hamilton, NV, USA) and estimated its concentration using a hand-held refractometer (Sugar/Brix Refractometer Eclipse, 0-50\%, BellighamStanley, UK). To quantify the nectar from the apices of sepals, we measured nectar volume using $5 \mu \mathrm{L}$ capillary tubes.

Detailed observations of the pollination process, visitation frequencies, visitors and capture of pollinators on flowers of A. rubra were carried out from 22 to 23 February 2010, 27 to 30 March 2011, and 16-19 March 2014, totaling 90 hours. In 2010 and 2011, the daily observation period was from 9:00 to 17:00 hs. In 2014, observations were made from 6:00 to 13:00 hs and from 16:00 to 2:00 hs. For all nocturnal observations (from 18:00 to 2:00 hs), we 
used two video cameras: Sony Handycam DCR-SR42 with infrared night vision, and Sony Handycam DSR-SR21 (coupled with red lights).

Time and duration of each visit, number of flowers visited, type of reward collected and contact with anthers or stigma were recorded. Insects visiting flowers were photographed and collected for later identification. Hummingbirds were identified by comparing pictures taken during field work with guides on Brazilian hummingbirds (Grantsau 1988; Ruschi 1989). The insects collected were deposited at the Natural History Museum of the University of Campinas (ZUEC). The plant voucher was deposited at the Herbarium of the University of São Paulo (SPF) - J.R.L. El Ottra 94.

Pollination records of the tribe Boronieae were obtained from the literature, especially in Paton \& Ford (1976), Ford et al. (1979), Armstrong (1979) and Paton (1993). Data on the floral structure of the Boronieae were taken mainly from Engler (1931), Wilson (1961), Wilson (2013a-f) and Armstrong (2013a,b).

\section{RESULTS}

The inflorescences of Almeidea rubra possess several flowers opening in succession, which are oriented horizontally, vertically (upwards) or semi-pendantly to pendantly (Fig. 2CE). The flowers are pentamerous, mostly monosymmetric due to androecium reduction into filiform staminodes (usually two). The corolla occasionally is monosymmetric due to unequal disposition of corolla lobes. However, some flowers present polysymmetric corollas (Fig. 1A, B). More rarely, some flowers are slightly asymmetrical as a consequence of a mismatch between the androecium and the corolla monosymmetric plane. Calyx and corolla are bright pink coloured. The calyx is dentate, bearing five nectaries that are visible macroscopically as round and cream-whitish coloured areas in the apex of sepals (Fig. 1D). The base of the corolla forms a short and tubular structure of ca. $6.6 \mathrm{~mm}$ long, while the distal portion of petals are free and spreading (Figs. 1A and 2B). Most flowers of the studied population present three stamens (ca. $9.5 \mathrm{~mm}$ long) and two staminodes (ca. $9.8 \mathrm{~mm}$ long). Flowers with four fertile stamens and one staminode, or all five fertile stamens were rarely found (only two flowers during this study), although Almeidea flowers are usually reported as isomerous, with five fertile stamens. The stamens are upright and centrally positioned in recently opened flowers. The flat filaments have their margins closely positioned to each other and the anthers are laterally contiguous, forming a somewhat tubular structure (Figs. 1A and 2C). As soon as 
the flower is visited by animals, the contiguity between anthers is lost. The filaments, anther and pollen are white. Anthers are rimose, introrse, and pollen grains are released in the first day of flower opening. The 5-carpellate gynoecium measures ca. $11.9 \mathrm{~mm}$ in length and presents one style surrounded by the tube formed by the androecium. The ovary is yellowgreenish, the style is white, and the 5-lobed stigma is bright yellow (Fig. 1A). A white nectary disc surrounds the ovary base (Fig. 1E).

Flower opening occurs during night (after 2:00 am) or in early morning (from 6:00 to 8:30 hs). Each flower lasts 4-5 days. The flowers of $A$. rubra release a slightly citric odour perceptible in the warmest hours of the day, or they are scentless. They are bright pink during the first two days and discoloured from the third to the fourth day. As the senescence of the flower begins, petals and stamens wilt and soon after falling off (Fig. 1A-B).

The flowers are protandrous. The male phase starts with dehiscence of the introrse anthers soon after flower opening. Practically all pollen produced is released in first-day flowers (Fig. 1A). In first-day flowers, the stigma is opaque and nonreceptive. The start of female phase begins in second-day flowers when the stigma doubles its size and becomes receptive and shiny due to stigmatic secretion. Simultaneously, the three stamens start to bend outward. On the fourth day, the anthers start to fall down, and the stigma shrinks and is no longer receptive (Fig. 1A, B).

Almeidea rubra offers floral nectar as a reward that is produced by the nectary disc disposed around the ovary base. The nectar is probably secreted through the modified stomata in the upper region of the disc (Fig. 1E, F), which is vascularized basally by xylem and phloem and distally only by phloem. Nectar was observed to be accumulated on top of the ovary and also between the disc and base of stamens and petals. Mean nectar volume produced during a 24-hour period was $10.1 \mu \mathrm{L}$ (SD $6.2 \mu \mathrm{L}$ ), and its mean sugar concentration was $22.72 \%$ (SD $4.11 \%)$.

The studied species also possess extrafloral nectaries in the external surface of apices of sepals. Bagged flowers during 24 hours accumulated a mean of $1.7 \mu \mathrm{L}$ (SD $0.79 \mu \mathrm{L}$ ) of viscous nectar on the apical portion of sepals (Fig 1C). Mean nectar sugar concentration was $31.5 \%$ (SD 9.02\%). We observed that the ants Dolichoderus sp. and Ectatomma sp. exclusively explore the calycine extrafloral nectaries (Fig. 1C, D), never touching the flower's reproductive organs. The structure of these extrafloral nectaries is inconspicuous. Macroscopically, their surface is characterized as a rounded aperture in the epidermis (Fig. 1C, D), but transections of buds show no nectar-secreting cells below the rounded apertures. 
Instead, a necrotic area with apparently dying cells or cells filled with phenolic compounds is visible, extending from the surface of sepal tips to their main vascular bundles, as seen in transections (Fig. 1G). Stomata were not found in this part of sepals.

In the studied population, Almeidea rubra was pollinated by a single species of hermit hummingbird, Phaethornis idaliae (Bourcier and Mulsant 1856), and two diurnal Lepidoptera species, namely Glennia pylotis (Godart 1819; Pieridae) and an unidentified Pyrginae (Hesperiidae). We consider the hummingbird $P$. idaliae to be the main pollinator of $A$. rubra, since it regularly visited the flowers during the flowering periods in both 2010 and 2011, presenting trapliner behavior, while foraging the floral nectar at regular times and all day long. P. idaliae visited all open flowers every 20 to 40 minutes. Each visit on a single flower lasted 1-3 seconds. During the probation of nectar, $P$. idaliae contacted the anthers and stigma with its beak, where loads of pollen was observed (Fig. 2A, B). The pollination occurred while the tip of the beak covered with pollen touched the stigma.

The two species of butterflies observed pollinating Almeidea rubra, Glennia pylotis and Pyrginae sp., were recorded in the first period of observation (2010). Both species present similar behavior on flowers. They land on the lower petals and, immediately afterwards, uncoil their proboscis and probe into the floral tube, where the nectar is accumulated. The time between the visits varied and occurred at irregular intervals. G. pylotis was sometimes observed visiting all open flowers of each inflorescence and the same flower more than once. The visitation varied between 2-10 seconds. Conversely, Pyrginae sp. probed the nectar in regular periods of 2 to 3 seconds in each flower. Butterflies can pollinate A. rubra when their proboscides occasionally touch the anthers or stigma (Fig 2C-E). As such, they were considered as occasional pollinators. Furthermore, little pollen was removed during the visitation of the butterflies in comparison to $P$. idaliae.

We additionally observed one visit of an unidentified species of Meliponini (Apidae, Apinae) stealing pollen from A. rubra anthers during the observation period. This bee occasionally touched the yellow stigma in female flowers (Fig. 2F). 

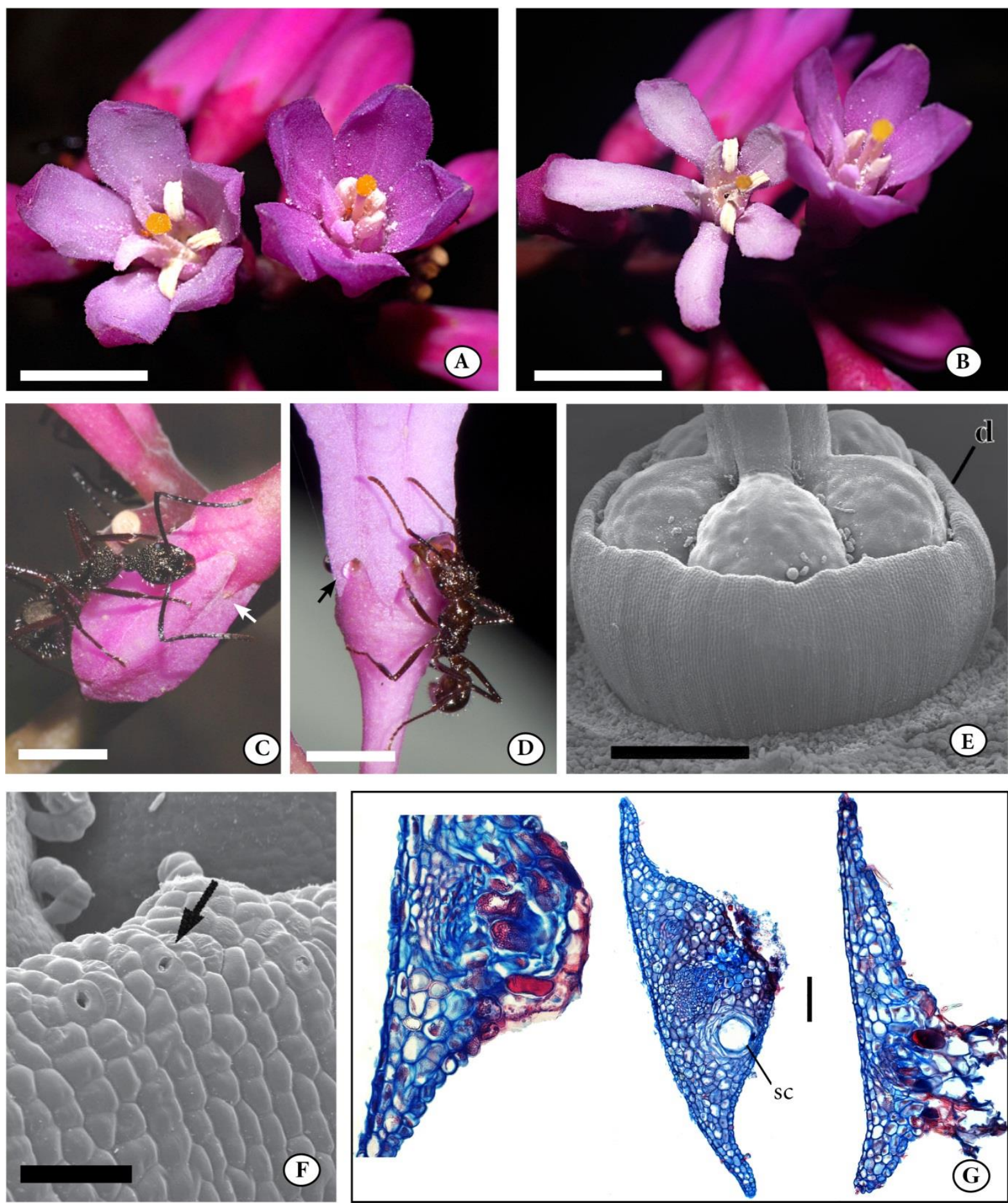

Figure 1: Photographs, photomicrographs and SEM micrographs of Almeidea rubra. (A-B) Flowers of A. rubra at different stages of development. (A) First-day flower (right) shortly after anthesis; thirdday flower (left). (B) Second-day flower (right); fourth-day flower (left), during the beginning of senescence. (C-D) Ant Dolichoderus sp. exploring an extrafloral nectary (arrow). (D) Ant Ectatomma sp. exploring an extrafloral nectary (arrow indicates nectar drop). (E-F) Intraestaminal nectary disc surrounding the ovary ( $\mathrm{d}=$ disc). (F) Stomata (arrow) in the distal part of the disc. (G) Three successive transversal sections of the sepaline extrafloral nectary (sc, secretory cavity). Scale bars: (A$\mathrm{B})=1 \mathrm{~cm} ;(\mathrm{C}-\mathrm{D})=0.5 \mathrm{~cm} ;(\mathrm{E})=100 \mu \mathrm{m} ;(\mathrm{F})=250 \mu \mathrm{m} ;(\mathrm{G})=100 \mu \mathrm{m}(\mathrm{A}, \mathrm{B}, \mathrm{C}$, photos by Emerson R. Pansarin). 

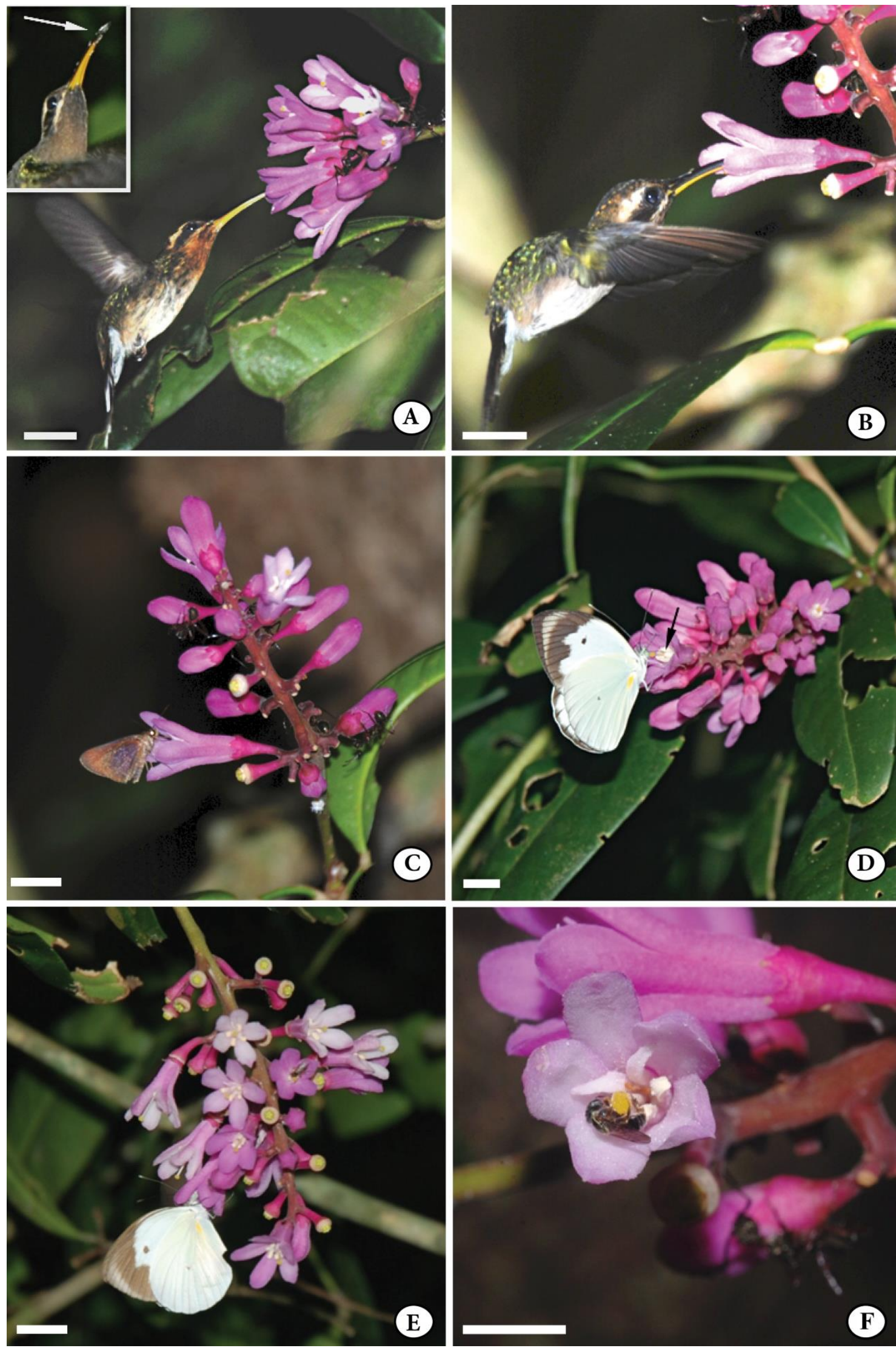

Figure 2: (A-F): Floral visitors of Almeidea rubra. (A) General view of Phaethornis idaliae visiting a flower. Detail indicates an individual with pollen deposited on the beak (arrow). (B) Detail of $P$. idaliae visiting a flower. (C) Pyrginae sp. foraging floral nectar. (D) Glennia pylotis foraging floral nectar. Note their proboscis inserted between anthers (arrow). (E) Glennia pylotis inserting their head within the floral tube. (F) Meliponini collecting pollen (all photos by Emerson R. Pansarin). 


\section{DISCUSSION}

Floral biology and pollination of Almeidea rubra

The flowers of Almeidea rubra are protandrous and also herkogamous. The species presents an intrafloral asynchronous dichogamy, i.e., inflorescences bearing flowers in female and male phases, with the individual flowers being protandrous (definition of Lloyd and Webb 1986). In Rutaceae, protrandry is a very common phenomenon (Bertin and Newman 1993; Pombal and Morellato 2000; Kubitzki et al. 2011), similar to other Angiosperms species pollinated through biotic vectors (Lloyd and Webb 1986). In contrast, herkogamy is very rare in this family, and, to the best of our knowledge, it has only been superficially described for Aegle marmelos [(Linn.) Singal et al. 2011]. The flowers of A. rubra present "approach herkogamy", whereby the stigma is placed forward of the pollinator's path (Webb and Lloyd 1986). Dichogamy and herkogamy are reported to be mechanisms that minimize the interference between male and female functions and reducing self-fertilization in flowers (Lloyd and Webb 1986; Webb and Lloyd 1986; Cruden 1988; Proctor et al. 1996).

Several entomophilous pollinating systems have been reported to the Rutaceae (Engler 1931; Kubitzki et al. 2011). In moist forests, Hymenoptera and Diptera are considered the main order of pollinators within the family (Kubitzki et al. 2011). Pollination by flies was recorded for species of Metrodorea (Pombal and Morellato 2000), Esenbeckia leiocarpa Engl. (Crestana 1983) and Pilocarpus spicatus A.St.-Hil. (Skorupa 1996). Zanthoxylum species are assumed to be pollinated by a variety of small insects (Bawa et al. 1985). Pollination by Lepidoptera, as found here for Almeidea rubra, was only previously reported for Galipea jasminiflora (Galipeinae; Piedade and Ranga 1994) and some boronioid genera (Armstrong 1979). Furthermore, Armstrong (1979) reported several other pollen vectors of Australian Boronieae, including beetles, bees, flies and birds from the family Meliphagidae ("honeyeaters").

Bird pollination has been more rarely reported for Rutaceae. Apart from Australian boronioids, it was previously reported only for some Neotropical species of Rutoideae. Perching birds from the families Fringillidae, Thraupidae and Mimidae were reported as main pollinators of Hortia oreadica Groppo, Kallunki \& Pirani (treated as H. brasiliana Vand. ex DC. by Barbosa 1999), with bees acting as secondary pollinators (Barbosa 1999). Pollination by hummingbirds (Trochilidae), which occurs in A. rubra, has been reported for Erythrochiton brasiliensis (Lopes 2002). 
The flowers of Almeidea rubra have features that allow pollination by two functional groups of animals: hummingbirds, namely, P. idaliae, and butterflies, both Pyrginae sp. and G. pylotis. The pink corolla and nectar hidden in short floral tubes are features that have already been reported in species pollinated both by hummingbirds and butterflies (e.g., Faegri and van der Pijl 1979; Opler 1981; Stiles 1981; Machado and Sazima 1987; Aona et al. 2006). In fact, Faegri and van der Pijl (1979), considering the traditional floral syndrome concept, pointed out that differences between ornitophilous flowers and psycophilous flowers are often indistinct in American plants. Additionally, Stiles (1981) noticed that Neotropical plant species with relatively small and short corollas are commonly pollinated by both small hummingbirds and other insects, such as butterflies and bees. Indeed, P. idaliae is a small hummingbird, measuring ca. $92 \mathrm{~mm}$, commonly denominated as "Minute hermite" (Ruschi 1989). Another floral feature that allows pollination of $A$. rubra by both groups of animals is the timing of the flower opening, which corresponds with the beginning of foraging time for butterflies (morning; Faegri and van der Pijl 1979) and, presumably, also for P. idaliae (during night, after 2:00 h., probably by the end of night to dawn). In fact, $P$. idaliae was observed to start its foraging rounds at 5:40 hours in another study (Varassin et al. 2001). On the other hand, the five spreading petal lobes of A. rubra flowers were only used by butterflies to alight, while hummingbirds hover. We consider the hummingbird $P$. idaliae to be the main pollinator of $A$. rubra because it seems to be the most efficient pollinator of this species. This is inferred mainly upon its higher frequency of visitation and larger amounts of pollen carried, when compared to butterflies. In fact, when compared to insects, vertebrate pollinators, like birds and bats, can carry larger amounts of pollen (Fleming et al. 2009). In this case, the androecium layout of A. rubra contributes to the larger pollen loads removed by the hummingbird. This is provided by a morphological match between the hummingbird's beak by its thickness and width and the inner space formed by the anthers, which allow that most parts of the hummingbird beak inserted within the flower contact the released pollen. The proboscis of butterflies is, however, much thinner than the space formed by the contiguous anthers, thus allowing only occasional contact with anthers and providing a much smaller surface area for pollen deposition. Pollinators that are both relatively most effective and most frequent are usually considered as the most important selective force over species (Stebbins 1970; Fenster et al. 2004). However, butterflies as secondary pollinators may be important for the reproductive success of A. rubra, as they can fly over long distances and establish foraging routes, thus maintaining gene flow among individuals of plant species (Waddington 1976; Cruden and Hermann-Parker 1979; Araujo et al. 2011). 
Furthermore, nectar features indicate that flowers of Almeidea rubra are ecologically specialized toward pollination by hummingbirds. First, the trapliner behavior of Phaethornis idaliae on flowers of A. rubra suggests that small quantities of floral nectar are produced and available all day long. Thus, it would be interesting to evaluate nectar secretion patterns in future studies with Almeidea. Additionally, the concentration of sugars in nectar indicates that flowers of A. rubra may be more suitable for feeding hummingbirds. In fact, nectar concentration is in the high range found for some butterfly-pollinated species (i.e., 15-25\%; Proctor et al. 1996), while it is approximately in the median range for hummingbirdpollinated taxa (approx. 10-46\%; Baker 1975; Snow and Snow 1980, 1986; Snow and Teixeira 1982; Cruden et al. 1983; Sazima et al. 1995, 1996; Buzato 2000; Lopes 2002). In this case, the main floral feature that makes $P$. idaliae the main pollinator of A. rubra is probably constancy of nectar production throughout the day, which is consistent with the energy requirements of the hummingbird.

It has already been reported that species of Phaetornis are efficient trapliner pollinators, visiting flowers at regular intervals (Stiles 1975; Feinsinger and Colwell 1978; Sazima et al. 1995, 1996), which could favour cross-pollination of many tropical species (Janzen 1971). The importance of P. idaliae in pollen transference of flora in Espírito Santo State has been registered by the naturalist Augusto Ruschi, who reported the visitation of this hermit hummingbird in species of Rutaceae, even though the author did not specify any particular one (Ruschi 1982). Also, the trapliner behavior of $P$. idaliae was previously reported in the pollination of Passiflora speciosa Gardner (Passifloraceae; Varassin et al. 2001).

A possible role of bees in the pollination system of Almeidea rubra is difficult to evaluate because we only observed a single bee visiting its flowers. Although the Meliponini bee was primarily stealing pollen from a female phase flower where some pollen was left, it did make contact with the stigma, indicating its ability to occasionally pollinate the flower. However, in this case pollination would be more likely to happen if the flowers are selfcompatible. Since the reproductive biology of A. rubra was not evaluated in this study, we can only speculate that the Meliponini bee is an occasional pollinator if $A$. rubra flowers are, indeed, self-compatible.

Two types of nectaries were reported for A. rubra: one nectary disc that produces a resource for pollinators and extrafloral nectaries in the apices of sepals, where ants forage for nectar. An intrastaminal nectary disc is a widespread feature in Rutaceae (Engler 1931; Ramp 
1989; Kubitzki et al. 2011). The function of this nectary disc has been previously discussed for some species of Galipeinae, including Galipea jasminiflora, Erythrochiton brasiliensis and Spiranthera odoratissima A.St.-Hil. (Piedade and Ranga 1993; Lopes 2002; Silva and Santos 2008, respectively), as well as other closely related American Rutoideae, like Pilocarpus pennatifolius Lem. (Sousa et al. 2005), Esenbeckia leiocarpa (Crestana 1983), Metrodorea spp. (Pombal and Morellato 2000) and Hortia oreadica (Barbosa 1999). However, secretion of nectar through modified stomata on the disc was only reported in the family for Citrus limon ("nectarostomata", Fahn 1952) and, presumably, also for Almeidea rubra in this study. A nectary mainly vascularized by phloematic bundles as found for $A$. rubra was previously reported for P. pennatifolius (Sousa et al. 2003). In contrast, other Rutaceae possess the nectary disc vascularized solely by phloematic bundles (Fahn 1979).

The sepaline extrafloral nectaries studied in A. rubra are morphologically inconspicuous and thus could be classified as non-structural nectaries, i.e., devoid of welldefined secretory structures (Zimmerman 1932; Fahn 1979; Elias 1983). Additionally, we observed that neither all sepal tips of the flowers analyzed presented the rounded apertures from where nectar was secreted, nor all sepals were actively secreting nectar during the studied period. In fact, non-structural nectaries usually produce nectar in an irregular fashion (Bernadelo 2007). The observation of necrotic tissue, or dying cells, in the region of the rounded aperture of the extrafloral nectary and also below, in the parenchyma of sepals, suggests that the exudate from the extrafloral nectaries of $A$. rubra may be, in part, formed by the lysis of this tissue, as reported for other plants (Fahn 1979, 1987; Bernadello 2007). However, further detailed studies on the ultrastructure and development of these extrafloral nectaries are needed in order to clarify where and how this secretion is formed. Non-structural nectaries are rarely reported in Angiosperms and, so far, they have only been found in eight families, including Bromeliaceae, Cactaceae, Costaceae, Fabaceae, Melastomataceae, Orchidaceae, Paeoniaceae and Ranunculaceae (Bernadello 2007, and references therein). The non-structural nectary of $A$. rubra reported in this study represents the first record for Rutaceae.

The nectaries in the apices of sepals constitute a putative synapomorphy of the genus Almeidea, but according to Bruniera (2010), it is a homoplastic feature at the subtribal level, since some species of the closely related genus Conchocarpus also present a similar structure. However, no detailed structural studies have ever been conducted in those Conchocarpus species. Therefore, more studies on the structure of extrafloral nectaries are necessary in order to allow suitable comparison between these two genera. The observations of ants exploring 
the nectar produced in sepals of A. rubra, which aggressively react once the plant is touched, indicate that these nectaries might play a role in the anti-herbivore defense of this species, as reported for other groups of plants (Hey and McKey 2003).

\section{Tubular flowers in Rutaceae: implications in pollination}

This study and a few other pollination studies with Galipeinae species corroborate the expectation regarding the functional groups of animals that are able to explore floral nectar concealed at the bottom of the floral tubes. Among the functional groups of animals with long tongues and/or long beaks, hummingbirds and lepidopterans usually pollinate tubular flowers of several groups of plants (e.g., Vogel 1954; Faegri and van der Pijl 1979; Endress 1994). However, other closely related American Rutoideae with nontubular flowers possess a pollination system that is comparatively more generalist or specialized towards different functional groups of pollinators. For instance, Hortia oreadica (Pilocarpinae, Galipeeae, Engler 1931) has bowl-shaped, nectar flowers pollinated by perching birds from three families and both short- and long-tongue bees (Trigona and Xylocopa, respectively; Barbosa 1999), representing a relatively generalist pollination system. This same species also stands with a broader spectrum of nectar robbers which only casually may pollinate, specifically, wasps, butterflies, flies, ants and the exotic bee Apis melifera $\mathrm{L}$. On the other hand, the small, wideopen and star-shaped flowers of Metrodorea species are mainly pollinated by small nectarivorous flies of several families and occasionally by a few Hymenoptera (Pombal and Morellato 2000). This is apparently also the case for Esenbeckia leiocarpa (Crestana 1983) and Pilocarpus spicatus (Skorupa 1996), but as the pollination records of these species are based on limited time of observations or on single records of visitation, detailed pollination studies are still necessary to properly determine their pollination systems.

When floral visitors are pollen-seeking bees, like the Meliponini bee in Almeidea rubra, floral features that are linked to the foraging of these animals are less clear. In fact, in these cases, tongue length has no correlation with floral shape, and the easily accessible anthers facilitate pollen collection by bees in the flower (Proctor et al. 1996). Additionally, in tropical forests, Meliponini bees are usually reported as flower commensals, taking pollen removed by other pollinators, such as vertebrates (e.g., birds, bats) and other insects (Roubik 1989). In fact, after some visits of the hummingbird $P$. idaliae, we noticed that small amounts of pollen were left dispersed on flowers of A. rubra, which could be consumed by the Melipinini bee. 
Elsewhere in Rutaceae, species with tubular flowers are reported for some species and genera of the tribe Boronieae whose pollination system has also been documented (Engler 1931; Armstrong 1979). However, among these groups, more detailed information is only available for Correa species in relation to their floral biology and pollination. Basically, ten of the eleven species of Correa are mainly pollinated by nectar-seeking Meliphagidae birds and occasionally by the exotic bee Apis melifera (Paton and Ford 1976; Armstrong 1979; Ford et al. 1979; Paton 1993). That large bird family presents all of its diversity in the Australasian region, and some of them are important pollinators of several species in this region (Armstrong 1979; Stiles 1981). Correa species are mainly pollinated by Meliphaga, Phylidonyris, Acanthorhynchus, and occasionally by Melithreptus and Anthochaera. All these birds have long bills (20 $\mathrm{mm}$ or more) and/or long special brush-tipped tongues, some extending 10-37 mm outside the beak, while probing for nectar (Ford et al. 1979; Proctor et al. 1996).

Floral characters of the ten Correa species that are reported as common features to other specialized bird-pollinated Australian plants are as follows: corolla, mainly red to green coloured, or a combination of both; a floral tube; weak (fruity) scent; copious nectar, about (ca. 5-20 cal per flower per day); and nectaries distantly placed from anther and stigma (ca. 20-30 mm). Moreover, other floral features commonly assumed as adaptations toward bird pollination are reported for these ten species of Correa, including the common orientation of flowers downward, i.e., pendant, even though other orientations may occur, such as erect to horizontal, and the absence of a landing place for insects in flowers, which usually have erect or shortly reflexed lobes (Wilson 1961, 2013a; Faegri and van der Pijl 1979; Ford et al. 1979; Cronk and Ojeda 2008). Both of these features, combined with a relatively long floral tube (ca. 10-30 mm, Wilson 1961, 2013a), which conceals the nectar disc at the bottom, would presumably restrict access to floral nectar and prevent pollination by insects that need to alight. Also, birds with inappropriate short mouth parts would be excluded. In fact, the honeybee A. melifera was only seen collecting pollen from tubular flowers of Correa, and parrots (Lorikeets; Psittaciformes) were seen "chewing" and destroying the flowers of Correa to take nectar because they could not reach it with their curved beaks and short tongues (Proctor et al. 1996; Paton 1993). It is important to highlight that A. melifera was introduced in Australia ca. 200 years ago (Paton 1993); therefore, it is unlikely that it has had any influence on the evolution of the actual floral features of Correa in such a short length of time, as similarly assumed in studies with other plant groups (Martén-Rodríguez et al. 2009). 
The Meliphagidae birds that effectively pollinate tubular-flowered species of Correa are perching birds, and for a landing place, they all use a certain part of the inflorescence or vegetative plant parts, while probing for floral nectar. They insert their mouth parts within the floral tube, consequently making contact with the anthers and stigma with their beaks and facial feathers (Paton and Ford 1976; Armstrong 1979; Ford et al. 1979). Pollen is received in these areas of the bird's body because the anthers and stigmas of the ten Correa species with tubular flowers are at or near the mouth of the tube, and in some species, far from it (Wilson 1961, 2013a).

Interestingly, Armstrong (1979), in a comparative study of the pollination systems among Australian boronioids, found that the single dialipetalous species Correa alba Andr. possesses a generalist pollination system, differing from the other ten Correa species with tubular flowers. In fact, C. alba specimens also have an unusual floral mechanism of secondary dialipetaly in which the young flowers are mostly sympetalous, similar to the rest of the species of the genus, but at maturity, the petals become free and spread outward (Armstrong 1979, Wilson 1961, 2013a). Armstrong (1979) related this phenomenon to the shift towards an "entomophilous" pollination system, with a variety of main pollen vectors, such as pollen- and nectar-seeking flies, pollen-collecting beetles and nectar-seeking bees. These animals may use the spreading corolla lobes of $C$. alba as a landing stage, which appears to be further facilitated by the orientation of the flowers, usually horizontal to erect (not pendulous; see photos of live plants in the Australian Plant Image Index). Armstrong (1979) further stated that butterflies can act as pollen vectors of Correa species, but did not clarify if this referred to $C$. alba. Not only wide-open flower architecture may be related to the shift towards entomophily, but also to the changing in flower color, since C. alba is reported as having white to pale pink coloured petals. In fact, while the mainly red to dull green colour of petals of the other ten Correa species would be conspicuous to bird's vision, these colours may, at the same time, be inconspicuous to the vision of some insects, thereby excluding them as floral visitors. This idea was previously assumed for other plant groups and experimentally tested in a few cases (Raven 1972; Bradshaw et al. 1995; Lunau and Maier 1995; Cronk and Ojeda 2008; Lunau et al. 2011). Thus, floral morphology, orientation and colour are features that seemingly contribute to the shift of $C$. alba towards a generalist entomophilous pollination system. It would be important that nectar features of $C$. alba also be comparatively studied, along with other Correa species, since these may also play a role in the ecological and evolutionary changes in the pollination systems of this genus. 
Additionally, other Boronieae representatives have sympetalous flowers, or at least cylindrical corollas, i.e., with imbricated erect petals or laterally contiguous petals, forming a somewhat tubular structure. For these species, there are some records of pollination by Meliphagidae birds, such as Nematolepis phebalioides Turcz., Leionema sympetalum (Paul G. Wilson), Paul G. Wilson (treated as Phebalium sympetalum in Armstrong 1979), L. carruthersii (F. Muell.) Paul G. Wilson, L. viridifolium (Paul G. Wilson) Paul G. Wilson, Muiriantha and Rhadinothamnus euphemiae (F. Muell.). Furthermore, besides a floral tube, one or all the above-mentioned floral features of Correa related to bird pollination or restriction of insect visitation may also occur in these taxa (e.g., dull green to red corolla erect, petal lobes not spreading, pendant flowers or nodding inflorescence; Armstrong 1979, 2013a; Wilson 2013b; Wilson 2013e).

It is important to point out that a staminal tube is another floral feature that may effectively exclude short-tongued visitors and conceal nectar in other Australian boronioid. In some species of Crowea and Philotheca, staminal tubes are formed by the overlapping of filament margins in the first genus and by fusion in the latter. In both genera, some records of butterfly pollination can be found. In P. tubiflora A.S. George and P. coccinea (C.A. Gardner) Paul G. Wilson petals are also shortly connate (Armstrong 1979; Wilson 2013d). Other Australian boronioids with nontubular corollas or nontubular filaments are pollinated by a variety of different functional groups of insects (e.g., Eriostemon australasius Pers.), or mainly by single functional groups of insects, like pollen-seeking bees (some Phebalium species; Armstrong 1979). Only for Diplolaena and Chlorilaena there are records of exclusive bird pollination (Classen-Blockhoff et al. 1991; Armstrong 2013b; Wilson 2013f). However, these genera possess a different "bird-blossom type" that would be the brushshaped flowers or brush pollination units (Faegri and van der Pijl 1979; Westerkamp 1990). Still, for most of the Boronieae with nontubular flowers, detailed pollination records are scarce.

When comparing the pollination systems of tubular flowers of the Australian Boronieae and the Neotropical Almeidea rubra (Galipeinae), a general resemblance is highlighted in that they are mainly bird-pollinated. This may be associated with the fact that both Meliphagidae and Trochilidae are the most diverse families of flower-feeding birds in the areas where these plants occur (Stiles 1981; Cronk and Ojeda 2008), being reliable pollinators which efficiently perform outcrossing (Armstrong 1979; Fleming et al. 2009). As a consequence, some of the floral features in both groups indicate floral specialization towards these pollen vectors. Besides the floral tube, which would exclude animals with short 
tongues and/or bills, copious and dilute nectar would favor bird pollination over insect pollination, as found for both Correa species and A. rubra. Furthermore, floral colours in these species, such as red, green, or pink, may cause sensory exclusion of some insects, especially some bees (Lunau et al. 2011). However, as a common floral feature among all Boronieae, mainly bird-pollinated, flowers were usually oriented pendantly or semipendantly, either single flowers or the entire inflorescence. Flowers oriented horizontally to vertically upwards were more rarely reported (Wilson 1961; Armstrong 1979; Wilson 2013a, 2013b). Together with floral orientation, the absence of any obvious floral structures that may be used by insects to land on the flower, e.g., spreading petals, to probe for nectar may contribute to these presumably more specialized bird-pollinated systems of Boronieae. Differently, some floral features in A. rubra, such as spreading petals and the bright yellow stigma, may contribute to secondary insect pollination by butterflies and, perhaps, small bees.

For the Galipeinae, floral orientation is not usually reported in morphological descriptions, but to the best of our knowledge, especially for Brazilian species, flowers are mostly oriented horizontally to vertically, more rarely semi-pendant or pendant (J.H.L. El Ottra and J.R. Pirani pers. obs). Butterflies that are secondary pollinators of A. rubra use the lower part of the corolla as a landing place since petal lobes are spreading at their distal part. In contrast with the bird-pollinated Boronieae, floral orientation of A. rubra appears comparatively more variable, as all orientations were seen. Also, butterflies were seen probing pendant to semi-pendant flowers of A. rubra, but they apparently lose pollination efficiency in these cases. This may take place because in flowers with such orientation, when butterflies probe for nectar, their entire body and proboscis are placed farther away from the central stigma than in flowers oriented horizontally to vertically upward. Nonetheless, hummingbirds can probe and pollinate Almeidea flowers in any orientation. In fact, pendant flowers are considered a floral adaptation which excludes or otherwise makes insect visitation difficult, as an indicator of floral specialization towards hummingbird pollination (Faegri and van der Pijl 1979; Snow and Snow 1980). Among the Galipeinae, besides A. rubra, detailed pollination records are available only for Galipea jasminiflora which, in contrast to the first species, is exclusively pollinated by Lepidoptera, mainly moths and only one single butterfly species (Piedade and Ranga 1993). G. jasminiflora is seemingly a pollination system specialized towards moth pollination by the presence of a narrow and relatively long floral tube (ca. 20 $\mathrm{mm}$ ), nocturnal anthesis, and white, sweet-scented flowers. Finally, in addition to the horizontal orientation of flowers, landing platforms are formed by the lower petals, which are used by lepidopterans to land (Piedade and Ranga 1993). 
In summary, our findings indicate that the evolution of floral tubes in representatives of Rutaceae may have resulted from floral specialization toward a subset of nectar-seeking pollinators, such as birds (Meliphagidae, Trochilidae) and/or lepidopterans (moths and butterflies). In fact, pollen-seeking bees have played a minor role as occasional pollinators in Correa and probably also in A. rubra, and their visits were mainly associated with androecia features, such as the easily accessible anthers in both groups. Bees are also less effective pollinators than birds, as already reported for some Correa species (Paton 1993). Therefore, at least for Correa, this implies that the flowers appear specialized towards their principal pollinator, i.e., the one that is most effective and most frequent (Stebins 1970; Fenster et al. 2004). While the hummingbird appears to be the current principal pollinator of A. rubra, as most frequent and more effective, its floral features, except nectar, indicate that it could be specialized to both small hummingbirds and butterflies with its short floral tubes and spreading petals as landing place. Thus, floral features of $A$. rubra indicate that birds and lepidopterans may have played important roles in shaping floral evolution in this species. In fact, not always floral features represent the selection of most effective pollinators, but secondary pollinators may also have influenced floral evolution, among other factors (Schemske and Horovitz 1989).

Furthermore, although floral features indicate floral specialization of Boronieae species with tubular flowers and A. rubra towards the nectar-seeking pollinators with specialized mouthparts, this does not seem to apply from the perspective of the animals. That is, those animals does not exclusively forage these plant species, showing no specificity in their behavior. In fact, all Meliphagidae birds are pollen vectors of several other plants in Australia, including other generalist plant groups, such as species from Eucalyptus (Armstrong 1979; Ford et al. 1979). Similarly, the butterfly Glennia pylotis was seen visiting other plant species in the area where A. rubra occurs (e.g., Galipea jasminiflora). Also, the hermit hummingbird $P$. idaliae was occasionally seen pollinating other plant species from Galipeinae (e.g., Angostura bracteata, in the same or other forest sites; Conchocarpus cyrtanthus Kallunki, in another forest site; J.H.L. El Ottra pers. obs) and species of Bromeliaceae and Passiflora speciosa (in another forest site in the state, G. Siqueira, pers. obs; Varassin et al. 2000, respectively). Also, Phaethornis idaliae was seen visiting flowers of representatives of eight other plant families in Atlantic Rain Forest sites of Espírito Santo (Ruschi 1986). In Neotropical forests, it is well known that hummingbirds are the main vertebrate pollinators of many plant species (Bawa 1990). Notably, in other Atlantic Forest sites of southeastern Brazil, hermit hummingbirds are the main pollinators of many plants in 
the understory of the forest, such as A. rubra, while perching birds are commonly observed visiting flowers from species in the canopy (Rocca and Sazima 2008). These findings are in accordance with recent community ecology studies, which have shown an asymmetry in plant-pollinator interactions. More specifically, in some cases, while the plant species are rather specialized toward a few groups of pollinators, such pollinators are, on the other hand, generalists, visiting several plant species, as similarly to the results reported herein (Vázquez and Aizen 2006, and references therein).

\section{Concluding remarks}

The pollinator groups of the tubular flower of Rutaceae reported herein and in the literature match with the expectations regarding the functional groups of animals that are able to access the concealed floral nectar in flowers with such architecture, and while doing so, contact the floral reproductive structures (Meliphagidae, Trochilidae and Lepidoptera species). Pollen- seeking bees presented a minor role in both pollination systems reported, if compared to the nectar-seeking pollinators. Since the floral features of the Galipeinae and Boronieae with tubular flowers indicate evolutionary specialization towards their nectarseeking groups of pollinators, our data provide further support to the convergent evolution hypothesis of the floral tubes in Rutaceae. Additionally, several Boronieae species appear to have a relatively more specialized pollination system toward bird pollination, especially by their mostly pendant flowers or nodding inflorescences and absence of landing place for insects. In fact, as previously noted by Armstrong (1979), bird pollination in Boronieae appears to have evolved multiple times in the history of the group. Even though the tribe Boronieae is not monophyletic according to recent phylogenies, when analyzing the placement of the genera and species with tubular flowers in recent phylogenies, there is also evidence that the assumptions of Armstrong (1979) were correct (e.g., see Correa, Nematolepsis phebalioides and Leionema in the phylogenies of Mole et al. 2004 and Groppo et al. 2008). On the contrary, the evolution of floral tubes in the Galipeinae seems to constitute a unique event among Neotropical Rutoideae (Groppo et al. 2008, 2012, in prep.). Nevertheless, to further support the hypothesis of convergent evolution, additional studies on floral biology and pollination systems are needed for both groups, and also their interpretation in a phylogenetic context, notably for closely related groups with different floral architectures. In this way, other forces molding floral evolution could be better understood, as morphological, developmental and phylogenetic constraints, and other ecological factors. 


\section{ACKNOWLEDGEMENTS}

We thank the technicians of the Plant Anatomy Laboratory (IB-USP), including Gisele R. Oliveira Costa, Tássia Cristina dos Santos, and Irwandro Roberto Pires, for their assistance to the first author, as well as Ludmila M. Pansarin (FFCLRP, São Paulo) for assistance during fieldwork. The first author also thanks Pietro K. Maruyama and Felipe W. Amorin for their helpful suggestions on nocturnal pollination records. We thank Instituto Federal do Espírito Santo for allowing us to work in their forest area. This work was supported by Fundação de Amparo à Pesquisa do Estado de São Paulo [grant numbers 09/54569-9 and 09/08764-4 awarded to J.H.L. El Ottra and J.R. Pirani] and Conselho Nacional de Desenvolvimento e Pesquisa productivity grant awarded to J.R. Pirani.

\section{REFERENCES}

Aona LYS, Machado M, Pansarin ER, Castro CC, Zappi DC, Amaral MCE (2006) Pollination biology of three Brazilian species of Micranthocereus Backeb. (Cereeae, Cactoideae) endemic to the "campos rupestres". Bradleya 24, 39-52.

Angiosperm Phylogeny Group (2009) An update of the Angiosperm Phylogeny Group classification for the orders and families of flowering plants: APG III. Botanical Journal of the Linnean Society 161, 105-121.

Araujo LD, Quirino ZG, Machado IC (2011) Fenologia reprodutiva, biologia floral e polinização de Allamanda blanchetii, uma Apocynaceae endêmica da Caatinga. Revista Brasileira de Botânica 34, 211-222.

Armstrong JA (1979) Biotic pollination mechanism in the Australian flora - a review. New Zealand Jornal of Botany 17, 467-508.

Armstrong JA (2013a) Muiriantha. In` Flora of Australia Vol.26: Rutaceae‘. (Ed A Wilson) pp. 447. (ABRS/CSIRO: Melbourne)

Armstrong JA (2013b) Chorilaena. In'Flora of Australia Vol.26: Rutaceae'. (Ed A Wilson) pp. 456458. (ABRS/CSIRO: Melbourne)

Australian Plant Image Index. Avaliable at http://www.anbg.gov.au/photo/genus-photo-search.html [Verified 14 May 2014]

Barbosa AAA (1999) Hortia brasiliana Vand (Rutaceae): polinização por aves Passeriformes no cerrado do sudeste brasileiro. Revista Brasileira de Botanica 22, 99-105.

Baker HG (1975) Sugar concentration in nectar from hummingbirds flower. Biotropica 7, 37-41.

Bawa KS, Perry DR, Beach JH (1985) Reproductive biology of tropical lowland rain forest trees. IIPollination systems. American Journal of Botany 72, 346-356.

Bawa KS (1990) Plant-pollinator interactions in tropical rain forests. Annual Review of Ecology and Systematics 21, 399-422. 
Bernadello G (2007) A systematic survey of floral nectaries. In 'Nectaries and Nectar'. (Eds SW Nicolson, M Nepi, E Pacini) pp. 215-249. (Springer: Dordrecht)

Bertin RI, Newman CM (1993) Dichogamy in Angiosperms. Botanical Review 59, 112-152.

Bradshaw HD, Jr Wilbert SM, Otto KG, Schemske DW (1995) Genetic mapping of floral traits associated with reproductive isolation in monkeyflowers (Mimulus). Nature 376, 762-765.

Bruniera CP (2010) 'Estudos filogenéticos e sistemáticos em Rutaceae: análise cladística e posicionamento de Almeidea A. St.-Hil. entre as Galipeinae (Galipeae, Rutoideae) com o uso de dados morfológicos e moleculares. MSc Thesis‘. (Universidade de São Paulo: São Paulo)

Bruniera CP, Silva CI, Groppo M (2011) A new species of Almeidea (Galipeinae, Galipeeae, Rutaceae) from Eastern Brazil. Brittonia 63, 281-285.

Bukatch A (1972) Bemerkungen zur Doppel färburng Astrablau-Safranin. Mikrokosmos 61, 255.

Buzato S, Sazima M, Sazima I (2000) Hummingbird-pollinated floras at three Atlantic forest sites. Biotropica 32, 824-841.

Classen-Blockhoff R, Armstrong JA, Ohligschläger M (1991) the inflorescence of the Australian genera Diplolaena R. Br. and Chorilaena Endl. (Rutaceae). Australian Journal of Botany 39, 3142 .

Crestana CSM, Dias IS, Kageyama PY (1983) Biologia floral do Guarantã, Esenbekia leiocarpa Engl. (Rutaceae). Silvicultura 28, 35-38.

Cronk QCB, Ojeda I (2008) Bird-pollinated flowers in an evolutionary and molecular context. Journal of Experimental Botany 59, 15-27.

Cruden RW (1988) Temporal dioecism: systematic breadth, associated traits, and temporal patterns. Botanical Gazette 149, 1-15.

Cruden RW, Hermann-Parker SM (1979) Butterfly pollination of Caesalpinia pulcherrima, with observations on a psychophilous syndrome. Journal of Ecology 67, 155-168.

Cruden RW, Hermann-Parker SM, Peterson S (1983) Patterns of nectar production and plantpollinator coevolution. In 'The Biology of Nectaries'. (Eds B Bently, T Elias) pp. 80-125. (Columbia University Press: New York)

Darwin C (1872) 'The effects of cross and self-fertilization in the vegetable kingdom'. (Murray: London)

El Ottra JHL, Pirani JR, Endress PK (2013) Fusion within and between whorls of floral organs in Galipeinae (Rutaceae): structural features and evolutionary implications. Annals of Botany 111, 821-837.

Endress PK (1994) 'Diversity and evolutionary biology of tropical flowers'. (Cambridge University Press: Cambridge)

Endress, PK (2010) Flower structure and trends of evolution in eudicots and their major subclades. Annals of the Missouri Botanical Garden 97, 541-583.

Endress PK, Matthews ML (2012) Progress and problems in the assessment of flower morphology in higher-level systematics. Plant Systematics and Evolution 298, 257-276. 
Engler A (1931) Rutaceae. In ' Die natürlichen Pflanzenfamilien.Vol. 19a, 2nd edn'. (Eds A Engler, K Prantl) pp. 187-359. (Leipzig: Engelmann)

Elias TS (1983) Extrafloral nectaries: their structure and functions. In 'The Biology of Nectaries'. (Eds 'B Bentley, TS Elias) pp. 174-203. (Columbia University Press: New York)

Faegri L, van der Pijl L (1979) 'The principles of pollination ecology. 3rd edn'. (Pergamon Press: New York)

Fahn A (1952) On the structure of floral nectaries. Botanical Gazette 113, 464-470.

Fahn, A (1979) 'Secretory tissues in plants'. (Academic Press: Londres)

Fahn A (1987) The extrafloral nectaries of Sambucus. Annals of Botany 60, 299-308.

Feinsinger P, Colwell RK (1978) Community organization among neotropical nectar feeding birds. American Zoologist 18, 779-795.

Fenster CB, Cheely G, Dudash MR, Reynolds RJ (2006) Nectar Reward and Advertisement in hummingbird-pollinated Silene virginica (Caryophyllaceae) American Journal of Botany 93: 18001807.

Fenster CB, Armbruster WS, Wilson P, Dudash MR, Thomson, JD (2004) Pollination syndromes and floral specialization. Annual Review of Ecology, Evolution and Systematic 35, 375-403.

Fleming TH, Geiselman C, Kress WJ (2009) The evolution of bat pollination: a phylogenetic perspective. Annals of Botany 104, 1017-1043.

Ford AH, Paton DC, Forde N (1979) Birds as pollinators of Australian plants. New Zealand Journal of Botany 17, 509-519.

Galleto L, Bernadello G (2005) Rewards in Flower - Nectar. In 'Practical Pollination Biology'. (Eds A Dafni, PG Kevan, BC Husband) pp. 261-313. (Cambridge: Ontario)

Grant KA (1966) A hypothesis concerning the prevalence of red coloration in California hummingbird flowers. American Naturalist 100, 85-97.

Grantsau R (1988) ‘Os Beija-flores do Brasil’. (Expressão e Cultura: Rio de Janeiro)

Groppo M, Pirani JR, Salatino MLF, Blanco SR, Kallunki JA (2008) Phylogeny of Rutaceae based on two noncoding regions from cpDNA. American Journal of Botany 95, 985-1005.

Groppo M, Kallunki JA, Pirani JR, Antonelli, A (2012) Chilean Pitavia more closely related to Oceania and Old World Rutaceae than Neotropical groups: evidence from two cpDNA non-coding regions, with a new subfamilial classification of the family. PhytoKeys 19, 9-29.

Heil M, Mckey D (2003) Protective ant-plant interactions as model systems in ecological and evolutionary research. Annual Review of Ecology, Evolution and Systematics 34, 425-53.

Instituto Capixaba de Pesquisa Assistência Técnica e Extensão Rural. Avaliable in http://hidrometeorologia.incaper.es.gov.br (Acess in $14 \mathrm{Jul}$ 2012)

Irwin RE, Adler LS, Brody AK (2004) The dual role of floral traits: pollinator attraction and plant defence. Ecology 85, 1503-1511.

Irwin RE, Bronstein JL, Manson JS, Richardson L (2010) Nectar Robbing: Ecological and Evolutionary Perspectives. Annual Reviews of Ecology, Evolution, and Systematics 41, 271-291 
Janzen DH (1971) Euglossini bees as long-distance pollinators of tropical plants. Science 171, 203205.

Johansen DA (1940) 'Plant Microtechnique'. (McGraw-Hill Book Company: New York)

Kearns C, Inouye W (1993) 'Techniques for pollination biologists'. (University Press of Colorado: Niwot)

Kallunki JA, Pirani JR (1998) Synopses of Angostura Roem. \& Schult. and Conchocarpus J. C. Mikan. Kew Bulletin 53, 257-334.

Kay KM, Voelckel C, Yang JY, Hufford KM, Kaska DD, Hodges SA (2006) Floral characters and species diversification. In 'Ecology and evolution of flowers'. (Eds LD Harder, SCH Barrett) pp. 311-325. (Oxford University Press: Oxford)

Köppen W (1948) 'Climatologia: com um estúdio de los climas de la tierra'. (Fondo de Cultura Econômica: México)

Kubitzki K, Kallunki JA, Duretto M, Wilson PG (2011) Rutaceae. In 'The Families and Genera of Vascular Plants. Vol 10: Flowering Plants. Eudicots: Sapindales, Cucurbitales, Myrtaceae'. (Ed K Kubitzki ) pp. 276-356. (Springer: Hamburg)

Lopes A (2002) 'Polinização por beija-flores em remanescentes da Mata Atlântica Pernambucana, nordeste do Brasil. MSc Thesis'. (Universidade of Campinas: Brazil)

Lloyd DG, Webb CJ (1986) The avoidance of interference between the presentation of pollen and stigmas in angiosperms. New Zealand Journal of Botany 24, 135-162.

Lunau K, Maier EJ (1995) Innate colour preferences of flower visitors. Journal of Comparative Physiology A 177, 1-19.

Lunau K, Papiorek S, Eltz T, Sazima M (2011) Avoidance of achromatic colours by bees provides a private niche for hummingbirds. The Journal of Experimental Biology 214, 1607-1612.

Machado ICS, Sazima M (1987) Estudo comparativo da biologia floral em duas espécies invasoras: Ipomoea hederifolia e I. quamoclit (Convolvulaceae). Revista Brasileira de Biologia 47, 425-436.

Martén-Rodríguez S, Almarales-Castro A, Fenster CB (2009) Evaluation of pollination syndromes in Antillean Gesneriaceae: evidence for bat, hummingbird and generalized flowers. Journal of Ecology 97, 348-359.

Mole BJ, Udovicit F, Ladiges PY, Duretto MF (2004) Molecular phylogeny of Phebalium (Rutaceae: Boronieae) and related genera based on the nrDNA regions ITS 1+2. Plant Systematic and Evolution 249,197-212.

Morellato PC, Haddad CFB (2000) Introduction: The Brazilian Atlantic Forest. Biotropica 32, 786792.

Nilsson LA (1987) Angraecoid orchids and hawkmoths in central Madagascar: specialized pollination systems and generalist foragers. Biotropica 19, 310-318.

Nilsson LA, Jonsson L, Randrianjohany E (1985) Monophily and pollination mechanisms in Angraecum arachnites Schltr. (Orchidaceae) in a guild of long tonged hawk-moths (Sphingidae) in Madagascar. Biological Journal of the Linnean Society 26, 1-19. 
Opler PA (1981) Nectar production in a tropical ecosystem. In 'The Biology of Nectaries'. (Ed TS Elias, B Bentley) pp. 30-79. (Columbia University Press: New York)

Paton DC (1993) Honeybees in the Australian Environment: Does Apis mellifera disrupt or benefit the native biota ? BioScience 43, 95-103.

Paton DC, Ford HA (1976) Pollination by birds of native plants in south Australia. Emu 77, 7385.

Piedade LH, Ranga NT (1993) Ecologia da polinização de Galipea jasminiflora Engler (Rutaceae). Revista Brasileira de Botânica 16, 151-157.

Pombal ECP, Morrelato PC (2000) Differentiation of floral color and odor in two fly pollinated species of Metrodorea (Rutaceae) from Brazil. Plant Systematics and Evolution 221, 141-156.

Porch O (1931) Grellrot als Vogelblumenfarbe. Biologia Generalis 7, 647-674.

Proctor M, Yeo P (1973) ‘The Pollination of Flowers'. (Collins: London)

Proctor M, Yeo P, Lack A (1996) 'The natural history of pollination'. (Harper Collins Publishers: London)

Ramp E (1988) 'Struktur, Funktion und systematische Bedeutung des Gynoeciums bei den Rutaceae und Simaroubaceae. PhD Thesis'. (Universität Zürich: Switzerland)

Renner S (2006) Rewardless flowers in angiosperms and the role of insect cognition in their evolution. In 'Plant-pollination interactions : from specialization to generalization' (Eds NM Waser, J Ollerton) pp. 123-138. (The University Press of Chicago: Chicago and London)

Rocca MA, Sazima M (2008) Ornithophilous canopy species in the Atlantic rain forest of southeastern Brazil. Journal of Field Ornithology 79, 130-137.

Raven PH (1972) Why are bird-visited flowers predominantly red? Evolution 26, 674.

Roubik DW (1989) 'Ecology and natural history of tropical bees'. (Cambridge University Press: Cambridge)

Ruschi A (1982) 'Hummingbirds of State of Espírito Santo’. (Editora Rios: São Paulo)

Ruschi A (1989) ‘Aves do Brasil, Beija-flores. Vol. IV’. (Editora Expressão e Cultura: Rio de Janeiro)

Sazima I, Buzato S, Sazima M (1995) The saw-billed hermit Rhamphodon naevius and its flowers in southern Brazil. Journal of Ornithology 136, 195-206.

Sazima M, Buzato S, Sazima I (1999) Bat-pollinated Flower Assemblages and Bat Visitors at Two Atlantic Forest Sites in Brazil. Annals of Botany 83, 705-712.

Sazima I, Buzato S, Sazima M (1996) An assemblage of hummingbird-pollinated flowers in montane forest in southeastern Brazil. Botanical Acta 109, 149-160.

Schemske DW, Horovitz CC (1989) Temporal variation in selection in a floral character. Evolution 43, 461- 465 .

Silva IM (1988) 'Revisão taxonômica do gênero Almeidea Saint-Hilaire (Rutaceae). MSc Thesis'. (Universidade Federal do Rio de Janeiro: Brazil)

Silva CSP, Santos ML (2008) Comportamento fenológico no evento pós-queima e biologia reprodutiva de Spiranthera odoratissima A. St.-Hil. (Rutaceae). Biotemas 21, 29-39. 
Singhal VK, Salwan A, Kumar P, Kaur J (2011) Phenology, pollination and breeding system of Aegle marmelos (Linn.) correa (Rutaceae) from India. New Forests 42, 85-100.

Skorupa LA (1996) 'Revisão taxonômica de Pilocarpus Vahl (Rutaceae). PhD Thesis'. (Universidade de São Paulo: São Paulo)

Snow DW, Teixeira DL (1982) Hummingbirds and their flowers in the coastal mountains of southeastern. Brazilian Journal of Ornithology 123, 446-450.

Snow BK, Snow DW (1980). Relationships between hummingbirds and flowers in Andes of Colombia. Bulletin of the British Museum Natural History (Zoology) 38, 105-139.

Snow DW, Snow BK (1986) Feeding ecology of hummingbirds in the Serra do Mar, southeastern Brazil. El Hornero 12, 286-296.

Souza LA, Mourão KSM, Moscheta IS (2003) Morfologia e anatomia da flor de Pilocarpus pennatifolius Lem. (Rutaceae). Revista Brasileira de Botânica 26, 175-184.

Souza A, Mourão KSM, Souza LA (2005). Morfologia e anatomia do fruto e da semente em desenvolvimento de Pilocarpus pennatifolius Lem. (Rutaceae). Revista Brasileira de Botanica 28, 745-754.

Stebbins GL (1970) Adaptive radiation of reproductive characteristics in angiosperms: pollination mechanisms. Annual Review of Ecology and Systematics 1, 307-326.

Stiles FG (1975) Ecology, flowering phenology and hummingbird pollination of some Costa Rican Heliconia species. Ecology 56, 285-301.

Stiles FG (1981) Geographical aspects of bird-flower coevolution, with particular reference to Central America. Annals of the Missouri Botanical Garden 68, 323-51.

Varassin IG, Trigo JR, Sazima M (2001) The role of nectar production, flower pigments and odour in the pollination of four species of Passiflora (Passifloraceae) in south-eastern Brazil. Botanical Journal of the Linnean Society 136, 139-152.

Vázquez PV, Aizen MA (2006) Community-wide patterns of specialization in plant-pollinator interactions revealed by null models. In 'Plant-pollinator interactions: from specializations to generalization'. (Eds J Ollerton, NM Waser) pp. 200-219. (The University of Chicago Press, Chicago)

Vogel S (1954) Blütenbiologische Typen als Elemente der Sippengliederung: dargestellt anhand der Flora Südafrikas. Botanische Studien 1, 1-338.

Waddingto KD (1976) Pollination of Apocynum sibicum (Apocynaceae) by Lepidoptera. The Southwestern Naturalist 21, 31-36.

Waser NM, Chittka L, PriceMV, Williams NM, Ollerton J (1996) Generalization in pollination systems, and why it matters. Ecology 77, 1043-60.

Webb CJ, Lloyd DG (1986) The avoidance of interference between the presentation of pollen and stigmas in Angiosperms. I. Dichogamy. New Zealand Journal of Botany 24, 135-162.

Westerkamp C (1990) Bird-flowers: hovering versus perching exploitation. Botanica Acta 103, 366371. 
Wilson PG (1961) A taxonomic revision of the genus Correa (Rutaceae). Transactions and proceedings of the Royal Society of South Australia 85, 21-53.

Wilson PG (2013a) Correa. In` Flora of Australia. Vol.26: Rutaceae‘. (Ed A Wilson) pp. 337-361. (ABRS/CSIRO: Melbourne)

Wilson PG (2013b) Leionema. In` Flora of Australia. Vol.26: Rutaceae‘. (Ed A Wilson) pp. 431-446. (ABRS/CSIRO: Melbourne)

Wilson PG (2013c) Nematolepis. In' Flora of Australia. Vol.26: Rutaceae‘. (Ed A Wilson) pp. 447 452. (ABRS/CSIRO: Melbourne)

Wilson PG (2013d) Philotheca. In`Flora of Australia. Vol.26: Rutaceae‘. (Ed A Wilson) pp. 396-414. (ABRS/CSIRO: Melbourne)

Wilson PG (2013e) Rhadinothamnus. In“ Flora of Australia. Vol.26: Rutaceae‘. (Ed A Wilson) pp. 452-454. (ABRS/CSIRO: Melbourne)

Wilson PG (2013f) Diplolaena. In‘ Flora of Australia. Vol.26: Rutaceae‘. (Ed A Wilson) pp. 484-494. (ABRS/CSIRO: Melbourne)

Zeisler M (1938) Über die Abgrenzung der eigentlichen Narbenfläche mit Hilfe von Reaktionen. Beihefte zum Botanischen Centralblatt 58, 308-318.

Zimmerman JG (1932) Über die extrafloralen Nektarien der Angiosperm. Beihefte zum Botanischen Centralblatt 49A, 99-196.

Zhu XF, Wan JP, Li QJ (2010) Nectar robbers pollinate flowers with sexual organs hidden within corollas in distylous Primula secundiflora (Primulaceae). Biological Letters 6, 785-787. 


\section{CAPÍTULO 3}

Biologia floral e polinização de duas espécies de Galipeinae (Galipeeae,

Rutaceae) endêmicas de Mata Atlântica, com ênfase nos aspectos funcionais das estruturas florais 



\section{RESUMO}

Galipeinae é o grupo mais diversificado de Rutaceae neotropicais, apresentando grande diversidade floral. No entanto suas características florais foram pouco estudadas no contexto da ecologia das espécies, o que dificulta o entendimento do papel dessas estruturas na biologia e evolução floral do grupo. Neste trabalho estudamos a biologia floral e polinização de Angostura bracteata e Conchocarpus macrophyllus (Galipeinae, Rutaceae), bem como a implicação das estruturas florais no contexto ecológico observado. As duas espécies são coocorrentes em uma área de Mata Atlântica do sudeste do Brasil, com sobreposição de floração ao longo do período de estudo. Ambas apresentam flores monossimétricas, tubulosas, com nectário no fundo do tubo, dois estames férteis na porção posterior da flor, e estaminódios exsertos da corola. C. macrophyllus é principalmente polinizado por lepidópteros diurnos (notadamente, espécies de Heliconius), bem como secundariamente por abelhas (Osiris sp. e Paratetrapedia fervida). A. bracteata é principalmente polinizada por lepidópteros diurnos (em maior frequência, Ascia bulnae), bem como por mariposas (Piralidae e Noctuidae) e secundariamente por beija-flores (Phaethornis idaliae). A maioria dos atributos florais analisados indicam uma maior especialização floral voltada aos principais grupos de polinizadores em ambas espécies (lepidópteros), notadamente feições do néctar e do tubo floral. As funções desempenhadas pelos estaminódios são reportadas de modo inédito para as Galipeinae, bem como para Rutaceae, destacando-se que estes apresentam secundariamente o pólen na porção ventral da flor em Angostura bracteata. Já em C. macrophyllus, a função dos estaminódios parece estar mais relacionada à retenção de grãos de pólen em seus tricomas, o que evitaria a autopolinização espontânea e/ou auxiliaria a remoção do pólen da língua dos polinizadores. Diferentemente do esperado pela conformação do androceu, a polinização nototríbica não é o único modo de polinização, e foram observados variados locais de deposição do pólen. Os resultados encontrados indicam que funções assumidas pelos estaminódios na biologia das espécies tenham influenciado sua manutenção ao longo da evolução floral de Galipeinae.

Palavras-chave: flores tubulosas, Rutaceae, hercogamia, apresentação secundária do pólen, lepidópteros, sistemas mistos de polinização. 



\section{INTRODUÇÃOO}

A subtribo Galipeinae, da tribo Galipeeae [anteriormente Cuspariinae e Cusparieae em Engler (1931); nomes inválidos de acordo com Kallunki \& Pirani (1998)] é o grupo de Rutoideae (Rutaceae) mais diversificado da região Neotropical. Atualmente o grupo compreende 26 gêneros e cerca de 130 espécies, exclusivamente neotropicais, com numerosos casos de endemismos restritos a área de pequena extensão. Sua ocorrência geográfica abrange desde o sul do México e ilhas do Mar do Caribe, até a América do Sul (Groppo et al. 2008; Kubitzki et al. 2011). As plantas dessa subtribo são caracterizadas principalmente pelas flores geralmente tubulosas, polissimétricas a mais comumente monossimétricas, com estaminódios e anteras basifixas (geralmente duas), apendiculadas em muitos gêneros. Os órgãos florais exibem grande variação quanto ao tamanho, cores e indumentação, havendo variados graus de união entre os verticilos florais, muitas vezes apenas superficial, entre filetes e entre estes e as pétalas, sendo tais características tradicionalmente utilizadas para o reconhecimento dos gêneros do grupo (Engler 1931; Kubitzki et al. 2011). Atualmente a maioria das espécies de Galipeinae formam um grupo monofilético bem sustentado por evidências moleculares, exceto por uma espécie (Adiscanthus fusciflorus Ducke, Groppo et al. 2008, 2012; Kallunki e Groppo 2007; Groppo et al. in prep.).

A maioria dos representantes de Galipeinae ocorre no interior de florestas úmidas de terras baixas, apresentando maior diversidade na América do Sul, desde o norte deste continente até o sul da região brasileira (Pirani 1999; Kubitzki et al. 2011). No Brasil, a subtribo é representada por 22 gêneros, havendo grande diversidade de espécies na região dos biomas de Floresta Amazônica e Mata Atlântica do país (Kallunki 1992, 1994, 1998a, 1998b, 2009; Kallunki e Pirani 1998; Pirani 1999, 2004, Pirani et al. 2012). A Mata Atlântica brasileira é considerada um dos hotspots mais ricos em endemismos do mundo, porém muito ameaçado, devido às pressões antrópicas sofridas desde a colonização do país, que perduram até os dias de hoje (Myers et al. 2000; Morellato e Haddad 2000). Em relação à sua extensão original, restam atualmente apenas ca. de 7, 6\% de remanescentes da Mata Atlântica (Morellato \& Haddad 2000), sendo que na região onde este estudo foi feito (no estado do Espírito Santo) e em remanescentes próximos (no estado da Bahia), existem altos níveis de endemismo reportados para diversos organismos (e.g: aves, Silva et al. 2004; mamíferos, Costa et al. 2000; borboletas, Tyler et al. 2004; e plantas lenhosas Prance 1982).

Conchocarpus é o gênero mais diversificado da subtribo Galipeinae (ca. 45 espécies), sendo que a maioria de suas espécies ocorre na Mata Atlântica brasileira. Conchocarpus macrophyllus J.C. Mikan, uma das espécies focadas neste estudo, apresenta ampla 
distribuição geográfica, ocorrendo desde Pernambuco até Rio de Janeiro, Minas Gerais e Distrito Federal. Esta espécie forma populações agregadas e densas de arbustos não ramificados, crescendo na submata das florestas geralmente em conjunto com outras espécies do gênero, bem como com espécies de outros gêneros de Galipeinae (notadamente Angostura, Almeidea, Galipea, Ravenia, Rauia; Kallunki e Pirani 1998; Pirani 1999; J.H.L. El Ottra e J.R. Pirani pess. obs.). Angostura bracteata, outra espécie de Galipeinae incluída neste estudo, pode co-ocorrer com C. macrophyllus, porém em menor densidade, e formando subarbustos a pequenas árvores na submata (Pirani 1999; Kallunki e Pirani 1998; J.H.L. El Ottra e J. R. Pirani obs. pess). Angostura bracteata apresenta distribuição geográfica relativamente ampla no leste do Brasil (Bahia, Espírito Santo, Rio de Janeiro e São Paulo), porém é a única das seis espécies do gênero a ocorrer na Mata Atlântica. As análises de trabalhos taxonômicos referentes a essas duas espécies indicaram que não apenas as espécies ocorrem em simpatria no interior da Floresta Atlântica ao longo do Brasil, mas também que estas co-florescem ao menos em parte de seu período de florada (Kallunki e Pirani 1998; Pirani 1999). No entanto tal fenômeno nunca antes foi estudado sob um enfoque ecológico.

O que se tem reportado hoje sobre a polinização de Galipeinae, provem de predições baseadas na morfologia ou da biologia floral de alguns representantes, de dois estudos detalhados sobre o assunto, e de escassos registros de observações pontuais para algumas espécies. Piedade e Ranga (1994) e El Ottra et al. (submetido, Capítulo 2) ao estudarem a biologia floral e polinização de Galipea jasminiflora (A.St.-Hil.) Engl. e de Almeidea rubra A.St.-Hil., respectivamente, reportaram que na primeira espécie a polinização é feita principalmente por mariposas pousadoras, e na segunda, principalmente por beija-flores. Em ambas espécies, borboletas foram consideradas polinizadores secundários. Ainda, a polinização por alguns beija-flores foi reportada para Erythrochiton brasiliensis Nees \& Mart. (Lopes 2002), e presumida para E. fallax Kallunki, devido à presença de um grande cálice vermelho, característica essa comum nas flores do gênero (Kubitzki et al. 2011). Também existe registro de visitação por duas espécies de beija-flores em Toxosiphon lindenii (Planch.) Baill.(Kubitzki et al. 2011). Ainda Kubitzki et al. (2011), baseando-se na morfologia e em alguns aspectos da biologia floral, presumiram que Nycticalanthus speciosus Ducke e Erythrochiton gymnanthus Kallunki seriam espécies polinizadas por mariposas. Notadamente nas duas espécies supracitadas, a ocorrência de polinização noturna é suposta devido às características falenófilas observadas em suas flores, como a cor branca/creme, a antese crepuscular e o odor forte e adocicado (relacionadas a falenofilia por Faegri e van der Pijl 
1979). Finalmente, há alguns dados sobre visitação de borboletas em Conchocarpus oppositifolius Kallunki (Kubitzki et al. 2011).

As flores geralmente tubulosas dotadas de um nectário conspícuo no fundo levam à suposição geral de que as Galipeinae sejam polinizadas por animais nectarívoros (porém não apenas por eles) de língua ou bico longo o suficiente para alcançar o néctar no fundo do tubo, o que de fato tem sido observado segundo os escassos registros de polinização para o grupo (El Ottra et al. submetido, Capítulo 2). Apenas algumas abelhas e dípteros atuando primariamente como pilhadores de pólen foram observadas em Galipea jasminiflora e Almeidea rubra, sendo que apenas nesta última as abelhas teriam o potencial de polinizar raramente as flores (Piedade e Ranga 1994; El Ottra et al. submetido, Capitulo 2).

Há atualmente um crescente aumento no conhecimento da morfologia, anatomia e histologia floral das espécies de Galipeinae. Em decorrência, muitas questões a respeito da funcionalidade das estruturas florais na biologia das espécies, bem como suas implicações evolutivas, têm sido melhor discutidas. No entanto, as hipóteses elaboradas até o momento a esse respeito carecem de comprovação de estudos de campo, pois esses ainda são escassos (El Ottra et al. 2013; El Ottra et al. submetido, Capítulo 2; El Ottra et al. em prep., Capítulo 1). Notadamente pode-se destacar a presença pouco usual de estaminódios filiformes e alongados, presentes na grande maioria das flores de Galipeinae. Engler (1931) já considerava curiosa a ocorrência de tais estruturas florais, especialmente quando estas ultrapassavam o número esperado pelo merisma do androceu, o que foi observado em alguns representantes da subtribo, como A. bracteata e C. macrophyllus. De fato, estaminódios podem assumir funções na biologia floral, como já reportado para outras espécies de Angiospermas. Por exemplo, estaminódios podem ter as seguintes funções: produção de corpúsculos alimentares; recipientes de néctar; apresentação secundária do pólen; estruturas que impedem a autopolinização; estruturas atrativas a polinizadores, devido à coloração, odor ou calor (Endress 1984, 1986, 1994; Walker-Larsen e Harder 2000; Ronse Decraene e Smets 2001). Adicionalmente, a ocorrência comum de apenas dois estames férteis na porção posterior (dorsal) da flor na maioria dos representantes de Galipeinae (Kubitzki et al. 2011; El Ottra et al. 2013) levaria a suposição de polinização exclusivamente nototríbica das espécies, conforme reportado para grupos com conformação semelhante das anteras (e.g. Lamiaceae, Westerkamp e Claßen-Bockhoff 2007). Ainda há variação quanto ao tipo de simetria floral observada na subtribo, onde ocorrem desde flores estritamente polissimétricas a flores fortemente monosimétricas. Dentre as estruturas responsáveis por tal variação na simetria floral, a esterilização dos estames em estaminódios filiformes é o principal fator gerador da 
monossimetria floral, conjuntamente com a distribuição desigual dos lobos da corola em alguns táxon, em diferentes padrões morfológicos (El Ottra et al., em prep., Capítulo 1). No entanto a estrutura floral de Galipeinae raramente foi estudada considerando as possíveis funções que tais feições florais poderiam assumir na biologia e polinização das espécies (El Ottra et al. 2013). Esta falta de conhecimento acerca da funcionalidade das estruturas florais impede avanços no entendimento da evolução floral neste grupo tão diverso de Rutaceae neotropicais.

Os objetivos deste trabalho são: (a) caracterizar a morfologia e biologia floral de Angostura bracteata e Conchocarpus macrophyllus em um remanescente de Floresta Atlântica no sudeste do Brasil; (b) reportar os grupos funcionais de visitantes florais das espécies, bem como seu comportamento sobre as flores, categorizando-os em polinizadores ou pilhadores de recurso das flores; (c) documentar aspectos funcionais das estruturas florais das espécies no contexto da biologia floral e sistemas de polinização observados.

\section{MATERIAIS E MÉTODOS}

\section{Local de estudo}

O estudo foi conduzido nas florestas de tabuleiro, na área pertencente à Reserva Natural Vale, Espírito Santo, Brasil. Essas florestas, também conhecidas como florestas altas de terra firme (Peixoto e Gentry 1990), ou florestas ombrófilas densas de terras baixas (Vicenz et al. 2003), são parte do Domínio da Mata Atlântica, e têm características particulares. Ocorrem desde o norte do Rio de Janeiro até o sul da Bahia, sobre os sedimentos continentais costeiros terciários do grupo Barreiras (Peixoto e Gentry 1990; Vicenz et al. 2003), sob clima tropical úmido com uma estação seca bem marcada, e apresentam grande abundância de lianas lenhosas. Diferem ainda de outras florestas neotropicais pela maior riqueza de espécies e composição florística diversa (Peixoto e Gentry 1990). A Reserva Natural Vale (RNV) localiza-se entre os municípios de Linhares e Jaguaré (Espírito Santo, sudeste do Brasil), e abrange ca. de 23 mil hectares de área preservada, entre as coordenadas

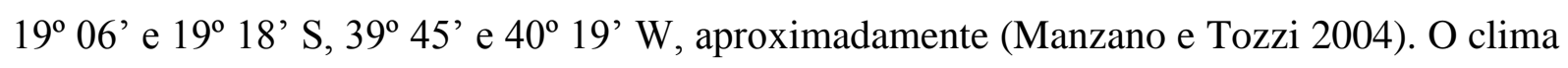
da região é do tipo quente e úmido ('Awi’, de acordo com a classificação de Köppen 1948), com média anual de temperatura de $23,6^{\circ} \mathrm{C}$. A média anual de precipitação é de $1.214 \mathrm{~mm}$ (Peixoto et al. 2008), com estação seca entre os meses de maio e setembro. A área da RNV é contígua á área da Reserva Biológica de Sooretama, constituindo em conjunto o maior remanescente de floresta contínua entre os estados do Rio de Janeiro a Bahia (ca. de 46 mil 
hec.; Peixoto et al. 2008). A floresta de tabuleiro da região apresenta um dossel de ca. de 30 a $40 \mathrm{~m}$ de altura (Peixoto e Gentry 1990; IPEMA 2005).

\section{Biologia floral e visitantes florais}

Obtivemos os dados sobre a biologia floral e visitantes florais das duas espécies durante visitas à área de estudo nos períodos de florada das populações, nos anos de 2011 a 2014. Localizamos ao longo do trabalho 81 indivíduos floridos de Conchocarpus macrophyllus e 22 indivíduos de Angostura bracteata nas florestas da RNV. Realizamos o estudo detalhado da morfologia floral considerando possíveis alterações ao longo da antese (Faegri e van der Pijl 1979), tanto em flores analisadas in situ, bem como em flores coletadas e fixadas em etanol, para posterior análise em laboratório. O estudo morfológico consistiu na observação da orientação e simetria floral, cor, formato, tamanho e indumento dos verticilos florais. Analisamos as flores fixadas (30 flores de C. macrophyllus; 20 flores de A. bracteata) sob estereomicroscópio Leica M125, equipado com uma câmera digital (Leica DFC 425), tomando fotografias de alguns detalhes das flores. Medimos as estruturas florais utilizando paquímetro ou o software LAS (Leica), e calculamos os valores médios obtidos.

Determinamos o momento da antese a partir do monitoramento em diferentes períodos do dia de botões previamente marcados de C. macrophyllus (28 botões, de 16 indivíduos) e de A. bracteata (65 botões, de15 indivíduos). A longevidade das flores foi observada desde a fase inicial de abertura até a senescência floral (28 flores de 31 indivíduos em $C$. macrophyllus; 28 de 15 indivíduos em A. bracteata), que ema ambas espécies caracterizou-se pela desidratação, murchamento e queda do tubo floral. A receptividade estigmática foi testada em botões $(n=10)$ e flores $(n=20)$ de diferentes idades, utilizando-se três substâncias diferentes: solução aquosa de peroxido de hirdrogênio 10\% (Zeisler 1938), solução aquosa com fita indicadora de peroxidase ("Peroxtesmo", Dafni et al. 2005) e solução aquosa de diaminobenzidina ("DAB reaction", Dafni et al. 2005). Adicionalmente observamos a presença de secreção estigmática nos botões e ao longo da antese. Também verificamos o momento de deiscência da antera e a liberação do pólen em botões e flores de diferentes idades, e a emissão de odores florais em flores totalmente abertas e previamente acondicionadas em frascos de vidro fechados, pelo período de dez minutos a uma hora (Kearns e Inoye 1993). Este teste foi feito no período da manhã e ao início da noite com ambas espécies. No caso da havermos percebido odor floral, posteriormente utilizamos 
também o teste de vermelho neutro, como um teste preliminar para localização da região floral portadora de osmóforos (Heidi et al. 2005).

Para o estudo do néctar produzido pelo disco, flores recém-abertas de C. macrophyllus (33 flores de 31 plantas) e A. bracteata (25 flores de 15 indivíduos) foram ensacadas pelo período de 24 horas, sendo então coletadas. As medições do volume do néctar foram feitas por meio de microcapilares de $5 \mu 1$ ou $2 \mu l$ (Drummond), e sua concentração foi medida utilizando-se um refratômetro portátil (Sugar/Brix Refractometer Eclipse, 0 -50\%, BellighamStanley, UK). No entanto, o método adotado para medição do volume e concentração do néctar teve que ser adaptado a partir de outros já descritos na literatura, dadas as dificuldades encontradas na coleta do mesmo. O pequeno volume de néctar, especialmente em C. macrophyllus, fazia com que não fosse possível efetuar a leitura da concentração em refratômetro, na maioria dos casos. Executamos então dois métodos diferentes, que consistiram na adaptação dos métodos descritos em Galetto e Bernadello (2005). No primeiro, anota-se o volume de néctar coletado inicialmente pelo capilar, para depois introduzir apenas um pouco de água destilada no mesmo (resultando em néctar diluído). A solução final (néctar diluído), variando de 0,7 a 1,3 $\mu \mathrm{L}$, era então colocada para medição no refratômetro. De posse do valor de concentração e volume do néctar diluído, mais o valor do volume inicial do néctar não diluído, estimou-se, por meio da equação de diluição de soluções, a concentração inicial do néctar (não diluído). Uma segunda abordagem executada consistiu em coletar o néctar de várias flores com um mesmo microcapilar, medindo-se o volume adicionado após a coleta do néctar de cada flor. Uma vez que era alcançado um volume suficiente para medição em refratômetro (ca. $0,7 \mu \mathrm{L}$ ), este então tinha sua concentração medida, sendo o valor obtido uma estimativa para todas as flores cujo néctar foi adicionado no mesmo capilar. Adicionalmente, devido à constrição existente na fauce do tubo floral dificultar a inserção do microcapilar por essa via, especialmente em C. macrophyllus, a coleta foi feita sob estereomicroscópio (Olympus X), removendo o tubo floral inteiro, para então coletar o néctar acumulado na porção interna do tubo floral e sobre o ovário.

Em relação aos visitantes florais, monitoramos as flores em diferentes momentos do dia ao longo dos períodos de florada, totalizando 100 horas de observação em plantas de $A$. bracteata (ao longo de todos os períodos do dia e da noite), e 83 horas em plantas de $C$. macrophyllus (das 5:40 até 2:00 hs). As observações diurnas foram integralmente presenciais, enquanto que as observações noturnas foram presenciais (das 18:30-2:00 hs) e não presenciais, estas gravadas por meio de duas câmeras de vídeo, em todos os períodos da noite (Sony Handycams, DCR-SR42 com luz infravermelho, e DSR-SR21 acoplada a luzes 
vermelhas). As observações presenciais noturnas foram feitas com auxílio de óculos de visão noturna, bem como com luz vermelha. O comportamento dos visitantes foi descrito baseandose nas observações de campo, análise de fotografias e vídeos. Foram registrados a hora, duração e frequência das visitas, número de flores visitadas, tipo de recurso coletado, e partes do corpo que fazem contato com estigma ou anteras (quando visível). Alguns visitantes foram capturados para posterior identificação, enquanto que outros foram identificados por análise de fotografias e vídeos (e.g. beija-flores e mariposas), até a categoria taxonômica de menor nível hierárquico possível. Quando coletados, observamos a presença ou ausência de grãos de pólen sobre a língua ou outras partes do corpo dos insetos que visitaram as flores, sob estereomicroscópio. Adicionalmente, nos casos onde foi observada deposição de pólen, este foi removido do corpo do inseto, corado com a solução de Calberla ("modified Calberlas's solution", Dafni et al. 2005) e montado em lâminas temporárias, para posterior análise sob microscópio (Leica DM4000B). Para verificar a presença do pólen das plantas estudadas nas lâminas, foi utilizado para comparação o estudo de morfologia polínica de Galipeinae feito por Morton e Kallunki (1993). Parte dos insetos coletados foram depositados na Coleção Entomológica da Reserva Natural Vale. Os espécimes-testemunho das espécies vegetais foram depositados no Herbário da Universidade de São Paulo (SPF), sob o $\mathrm{n}^{\mathrm{o}}$ de coleta J.R.L El Ottra 98 e 107.

\section{RESULTADOS}

\section{Conchocarpus macrophyllus}

C. macrophyllus possui inflorescências multifloras do tipo tirso, axilares, com longo pedúnculo, posicionadas ou bem acima da folhagem ou ao nível da mesma, ou às vezes também abaixo da mesma (Fig. 1A). As flores são orientadas geralmente de modo horizontal, e menos comumente na vertical ou de modo semi-pendente (Figs 1E, 2A, B, D-H). As flores são bissexuadas, pentâmeras (raramente tetrâmeras, uma flor observada, Fig. 1E), monossimétricas principalmente devido à redução de parte do androceu em estaminódios filiformes exsertos, localizados na porção mediana e anterior da flor (Fig. 1B). O cálice é cupular, denticulado no ápice, com ca. 2,36 mm de comprimento total, coberto externamente por tricomas peltados glandulares diminutos e de coloração castanho-escuro. A corola rosaclara, com poucos tricomas glandulares diminutos, apresenta arquitetura tubular com ca. $12,39 \mathrm{~mm}$ de comprimento total e tubo de ca. 6,25 $\mathrm{mm}$ de comprimento. No ápice, as pétalas são livres, formando cinco lobos reflexos utilizados como local de pouso pelos visitantes 
florais (Fig. 2A, B, D-L). Na base de cada lobo da corola, foi observado um friso rosado mais escuro, em sua porção mediana adaxial, alcançando até bem próximo da fauce da corola; estes frisos possivelmente representam guias de néctar (Fig. 1B). O androceu é constituído por sete estames alvos, epipétalos, exceto nos ápices livres. Dois deles são férteis, com ca. 5,95 mm de comprimento, posicionados na porção posterior (dorsal) na flor. As anteras localizam-se inclusas no ápice do tubo floral, sendo apenas sua porção apical visível na fauce da corola; medem ca. 2,3 mm de comprimento, e são cobertas por tricomas tectores em sua porção ventral. As anteras são introrsas, longitudinalmente deiscentes e lateralmente muito próximas, de modo que suas partes ventrais quase se tocam (Fig. 1 B-D); o pólen é alvo. As demais peças do androceu são cinco estaminódios, achatados e destituídos de anteras, alcançando ca. $7,89 \mathrm{~mm}$ de comprimento, situados em posição anterior na flor firmemente justapostos aos lobos da corola na flor aberta. O gineceu é branco, incluso no tubo floral ao longo de toda antese, com ca. 3,03 mm de comprimento. A região estigmática apresenta uma leve dilatação, de formato clavado. Um disco nectarífero intrastaminal cupular envolve o ovário. O tubo floral é bem constrito na região próxima à fauce da corola, onde tem diâmetro ca. $0,31 \mathrm{~mm}$. Esta constrição ocorre abaixo do nível das anteras, ao nível do ápice dos filetes, onde há tricomas tectores eretos em maior densidade. O estigma fica posicionado logo abaixo desta constrição (Fig. 1C, D). Dado que nenhum visitante floral foi visto adentrando todo o corpo no tubo floral desta espécie, assumiu-se que apenas sua língua poderia passar por essa constrição. Assim, com base nas observações da morfologia floral durante a antese, concluise que Conchocarpus macrophyllus apresenta flores com hercogamia reversa (i.e. anteras apresentadas na fauce do tubo floral, e estigma abaixo destas), do tipo homomórfico ordenado (i.e. todas as flores de uma mesma planta apresentam o mesmo tipo de hercogamia, sendo o contato com o pólen e estigma feito de um modo geralmente único e ordenado; Webb e Lloyd 1986).

A duração da antese foi de aproximadamente quatro dias. Foram observadas flores abrindo tanto a noite ( 9 flores abriram entre 19:00h e 5:40 h) como pela manhã (15 flores abriram entre $6 \mathrm{~h}$ e $9 \mathrm{~h}$ ). A abertura foi considerada a partir do momento em que os lobos da corola se distendiam o suficiente para expor a fauce da corola, o que ocorria geralmente a partir da distensão do segundo ou terceiro lobo. O lobo superior da flor é cuculado no início da antese, distendendo-se totalmente após um dia na maioria das flores observadas (Fig. 1E, B). A coloração rósea da corola torna-se um pouco mais esmaecida nas flores de 3 a 4 dias de antese (Fig. 1E). As flores não exalam odor perceptível ao sentido humano, nem no período diurno e nem no noturno. 
A espécie não apresenta dicogamia marcada. O estigma é aparentemente receptivo em flores recém-abertas, coincidindo com o início de liberação do pólen pelas anteras. O estigma aparentemente mantém-se receptivo e úmido ao longo de toda vida da flor (Fig. 1C). Diferentemente, a liberação do pólen é gradual ao longo dos dois primeiros dias de antese, aproximadamente. Em flores recém-abertas (com menos de um dia) o início da deiscência das anteras se dá com apenas uma teca deiscente ou então apenas com parte das tecas abertas. Somente nas flores com dois dias de vida ou mais, ocorre a liberação de praticamente todo o conteúdo das anteras. Nesta fase, os grãos de pólen se acumulam no estreito espaço disponível entre as duas anteras, mas também um pouco do pólen foi observado sobre os estaminódios, na porção ao mesmo nível das anteras (ápice do tubo floral). Na região de deposição do pólen há muitos tricomas presentes tanto nas anteras como nos estaminódios, entre os quais o pólen é retido em flores não visitadas (Fig. 1C). Enquanto que nenhum pólen foi observado abaixo da constrição do tubo floral em flores isoladas, flores já visitadas apresentavam um pouco de pólen nos tricomas eretos no ápice dos filetes e sobre o estigma (Fig. 1D).

A maioria dos visitantes florais de Conchocarpus macrophyllus obtém néctar nas flores (tabela 1). O néctar é produzido pelo disco nectarífero ao redor do ovário. O nectário secreta pequenas gotículas de néctar acumuladas tanto sobre o ovário como na base do tubo floral, ao nível do ovário (Fig. 1C). Os botões em pré-antese (com apenas um lobo da corola distendido) já apresentam produção de néctar. As flores apresentam um volume médio de néctar produzido em 24 horas de $0,16 \mu \mathrm{L}$ (DP 0,13 $\mu \mathrm{L}$ ) de néctar. Em relação a concentrações de açúcares obtidas com as duas técnicas de medição testadas, obtivemos os valores médios de $13,70 \%$ (DP 5,70\%) com o método de diluição inicial do néctar, e de 12,16 \% (DP 1,22 $\%)$ com a estimativa coletiva do néctar de várias flores.

Em relação às observações dos visitantes florais, $C$. macrophyllus foi exclusivamente visitado por insetos em período diurno, sendo estes 10 espécies de borboletas e três espécies de abelhas (tabela 1). Os lepidópteros foram os visitantes mais frequentemente observados no período de estudo, enquanto que as abelhas foram comparativamente menos frequentes (tabela 1). Todas as borboletas potencialmente polinizam C. macrophyllus, devido à morfologia floral e à presença de pólen observada nas suas probóscides (Fig.1C, E, G). A constrição no ápice do tubo floral, com nectário na base, somada à posição dos órgãos reprodutivos (anteras no ápice do tubo, estigma incluso e abaixo delas) faz com que os lepidópteros, ao inserirem as longas probóscides para coletar o néctar, contatem ordenadamente primeiro as anteras e posteriormente o estigma. Ao retirarem a probóscide do tubo também ocorreria contato com estes órgãos. Nos animais em que foi possível coletar e 
analisar o pólen, constatamos a presença de pólen de C. macrophyllus. É importante ressaltar que Heliconius sara apseudes (Hübner, 1813) e H. melpomene nanna [(Stichel, 1899) Nymphalidae: Heliconiinae], as espécies de borboletas que mais frequentemente visitaram $C$. macrophyllus, coletavam pólen além do néctar, hábito típico de representantes deste gênero (Fig. 2D, E). Todas as espécies de borboletas observadas apresentam comportamento similar ao forragear as flores: pousam ou sobre os lobos inferiores da corola, com suas patas traseiras, apoiando-se as demais patas também nos lobos superiores da corola (Fig. 2A, B, E-G), ou, no caso das borboletas maiores, agarram-se a estes e às vezes também nas flores adjacentes, para então tomar o néctar (Fig. 2D). Após o pouso, esses lepidópteros inserem sua probóscide no tubo floral e tomam o néctar e/ou coletam o pólen (no caso dos Heliconius). O tempo de visita variou entre os lepidópteros, de 1 a 7 segundos por flor. Todas as espécies observadas visitaram mais de uma flor por inflorescência e/ou mais de um indivíduo da população observada. As visitas dos lepidópteros iniciaram-se a partir das 7:30 horas da manhã, porém ocorreram com maior frequência no período entre 10:00 e 14:00 horas, tornando-se mais esporádicas no restante da tarde.

Visitas a flores de C. macrophyllus por três espécies de abelhas foram menos frequentemente, comparadas aos lepidópteros como um todo (tabela 1). As abelhas Paratetrapedia fervida, Osiris sp. e espécie não identificada de Meliponini, pousavam de modo semelhante sobre os lobos da corola, eventualmente agarrando-se a estes ou apoiandose nos lobos de flores adjacentes (Fig. 2H, J, L), para então inserirem sua porção cefálica na fauce da corola (Fig. 2H, J, L). Estas abelhas foram observadas visitando flores de mais de um indivíduo da população de $C$. macrophyllus. Porém o papel de cada das espécies na biologia floral da espécie foi interpretado de maneira diversa. Paratetrapedia fervida é um potencial polinizador de C. macrophyllus, uma vez que além de termos observado pólen da planta nas escopas desta abelha, esta apresenta língua longa o bastante $(4,02 \mathrm{~mm})$ para alcançar as anteras, o estigma e possivelmente também o néctar (Fig. 2J, K). Outro indicativo de que a espécie coleta não apenas o pólen, mas também o néctar, é que sua glossa e outras partes do corpo (exceto as escopas) não apresentavam pólen aderido após várias visitas sequenciais às flores, previamente à sua coleta. Diferentemente Osiris sp. não apresentou pólen aderido a nenhuma parte do corpo após várias visitas sequenciais às flores, previamente a sua coleta (Fig. 2L). No entanto, esta espécie também pode polinizar C. macrophyllus, dado que sua língua é longa o suficiente $(3,72 \mathrm{~mm})$ para alcançar o estigma e possivelmente também o néctar. O tempo de visita de Osiris sp. e P. fervida varia entre 4 a 6 segundos. Apenas a abelha Meliponini parece agir primariamente como pilhadora de pólen (tabela 1; Fig. 2H, I). 
Dada sua baixa frequência de visita (vista apenas em um momento durante as observações) e ao seu porte comparativamente menor, conclui-se que provavelmente ela seja incapaz de alcançar o estigma e o néctar abaixo da constrição do tubo floral. Além disso, esta abelha visita principalmente flores em posição vertical, nas quais ficam pousadas por mais tempo (até 10 seg.), raspando com seus segmentos bucais e pernas o ápice das anteras, que acabam posteriormente por ficar levemente danificados. Enquanto o Meliponíneo foi visto visitando as flores apenas no início da manhã (7:00 hs), as outras duas espécies foram vistas visitando as flores entre 10:00 e 15:00 horas.

Baseando-se nass observações de visitas mais frequentes a flores de C. macrophyllus pelos lepidópteros diurnos, associadas à constatação de seu pólen nas probóscides, consideramos este grupo como o principal grupo funcional de polinizadores dessa planta. Diferentemente, as abelhas observadas, que apresentaram comparativamente menor frequência que os lepidópteros como um todo, foram consideradas polinizadores secundários da espécie (Osiris e P. fervida) ou pilhadoras apenas, no caso da abelha Meliponini).

No período de florada de 2014, plantas de uma das populações estudadas de $C$. macrophyllus (ca. 28 indivíduos) floresceram lado a lado a três indivíduos de Angostura bracteata. Nessa situação, enquanto algumas das espécies de borboleta visitavam as flores de ambas espécies [i.e., Melina ludovica paraiya (Reakirt, 1866), Ascia buniae (Hübner, 1816), Aeria olena (Weymer, 1875)] outras apenas visitavam ou C. macrophyllus ou A. brateata (vide tabela 1 e 2). De modo semelhante, ao voar próximo das flores de ambas espécies, a abelha Osiris sp. visitava apenas as de C. macrophyllus.

\section{Angostura bracteata}

Angostura bracteata apresenta inflorescências multifloras do tipo tirso terminal, algumas posicionadas acima do nível da folhagem e outras ao mesmo nível dos ápices de ramos vegetativos (Fig. 3A). As inflorescências apresentam a maioria das flores orientadas de modo horizontal, e menos comumente na vertical ou de modo semi-pendente (Figs. 3A, C, 4A-J). As flores são bissexuadas, pentâmeras, monossimétricas, principalmente devido à redução de parte do androceu a estaminódios filiformes (Fig. 3B, C). A simetria da corola varia entre polissimétrica (Fig. 3B) a levemente monossimétrica, dado que em algumas flores os lobos da corola dispõem-se desigualmente, três posicionados na porção posterior da flor e dois na porção anterior (Fig. $3 \mathrm{C}$ ). O cálice é verde-claro, esbranquiçado próximo às margens, recoberto por tricomas estrelados translúcidos; possui lobos triangulares e uma curta porção 
conata na base, com ca. 5,21 mm de comprimento total (Fig. 3C). A corola alva, com tricomas equinoides e estrelados translúcidos, apresenta arquitetura tubular com ca. 23,35 mm de comprimento total, sendo no ápice as pétalas livres, com cinco lobos reflexos. O tubo floral é reto, apresentando ca. $1,09 \mathrm{~mm}$ de diâmetro e ca. $14,5 \mathrm{~mm}$ de comprimento. O androceu é constituído por sete estames epipétalos, exceto em sua porção distal onde são livres e exsertos; há duas anteras férteis de cor acastanhada, e cinco estaminódios brancos. Os dois estames férteis posicionam-se na porção posterior (dorsal) da flor, com ca. 19,76 mm de comprimento na fase masculina e um pouco mais alongados na fase feminina da flor (ca. 23,25 mm). O pólen é alvo, as anteras são longitudinalmente deiscentes, ambas com a porção ventral voltada para os estaminódios na porção anterior da flor. Os estaminódios são filiformes, destituídos de anteras mas com ápice de formato globoso, com ca. 20,46 mm de comprimento na fase masculina, alcançando ca. $23,61 \mathrm{~mm}$ de comprimento na fase feminina (Fig. 3B, C). O gineceu alvo mede ca. $12 \mathrm{~mm}$ na fase masculina, e chega a ca. 21,05 $\mathrm{mm}$ de comprimento na fase feminina. O estilete fica incluso no tubo floral na fase masculina, mas torna-se exserto na fase feminina. O estigma capitado e levemente pentalobado, possuindo a maioria das flores lobos estigmáticos voltados para porção posterior (dorsal) da flor (Fig. 3 B, D, E). Um disco nectarífero intrastaminal de coloração amarelada envolve o ovário.

A duração da antese estende-se por aproximadamente dois dias e meio. O momento da antese se dá predominantemente entre o período crepuscular e noturno (35 botões abriram entre 17:00 e 21:30 hs, 20 botões abriram posteriormente no decorrer da noite), com poucas flores em antese diurna (10). A flor apresenta odor adocicado em todos os períodos do dia, acentuado no início da noite. O resultado do teste de vermelho neutro sugere a ocorrência de osmóforos na porção distal da corola e dos estaminódios, o que coincide com as regiões onde análises histológicas preliminares indicam a ocorrência de osmóforos (J.H. L. El Ottra obs. pess.). Angostura bracteata oferece néctar como principal recurso floral (tabela 2). O néctar produzido pelo disco acumula-se em forma de gotículas tanto sobre o ovário como na porção do tubo floral ao nível do ovário. Não foi observada produção de néctar nos botões em préantese. O volume médio de néctar produzido em 24 horas por flor é de $0,80 \mu \mathrm{L}$ (DP 0,59 $\mu \mathrm{L}$ ). Em relação à concentração de açúcares obtida com duas técnicas de medição testadas, chegou-se ao valor médio de 18,34 \% (DP 5,13\%), com o método de diluição inicial do néctar, e ao valor de 15,44\% (DP 2,65\%), com a estimativa coletiva do néctar de várias flores.

Angostura bracteata apresenta flores hercogâmicas e dicogâmicas, com duas fases florais morfologica e funcionalmente bem distintas. Primeiramente, a fase masculina da flor 
inicia-se já em botões em pré-antese, dado que ocorre liberação de pólen pelas anteras nesta fase, enquanto o estigma apenas torna-se receptivo posteriormente, caracterizado-se assim flores protândricas. À medida que a flor inicia sua abertura, o pólen é depositado tanto na porção ventral das anteras, como na porção ventral e distal dos estaminódios (Fig. 3B). Esta deposição secundária do pólen sobre os estaminódios ocorre devido ao posicionamento prévio destas estruturas antes da antese, possibilitado pelo fato de os estaminódios estarem justapostos às anteras em botões em pré-antese, momento em que o pólen é liberado. A medida que a flor completa sua abertura, os estaminódios se alongam bem á frente e a um nível acima dos lobos inferiores da corola, apresentando secundariamente o pólen na porção ventral (anterior) da flor, enquanto que as anteras o apresentam na porção dorsal (posterior) da flor (Fig. 3C). Ao longo da fase masculina os estames férteis vão gradativamente curvando-se para cima e os estaminódios para baixo. Ao final da fase masculina da flor, com duração aproximada de 18 e 24 horas, os estames férteis e os estaminódios enrolam-se para trás e passam a se posicionar justapostos aos lobos da corola (Fig. 3D, E). Concomitantemente a esta alteração na conformação espacial do androceu, o estilete, antes incluso no tubo floral, gradativamente começa a alongar-se. A fase feminina da flor tem início quando o estile se torna exserto do tubo corolino e o estigma fica maior e brilhante devido à secreção estigmática, momento em que se constata assim sua receptividade. Na fase feminina, o estilete localiza-se em posição central do tubo floral, alongando-se de modo a estender-se além do nível das anteras (na fase masculina; Fig. 3B-D). À medida que a fase feminina avança, os lobos da corola e a porção distal dos estaminódios tornam-se acentuadamente recurvados, expondo ainda mais o estigma à frente da flor (Fig. 3E). A fase feminina tem duração aproximada de 24 a 36 horas, sendo seguida pelo final da antese, caracterizado pela senescência e queda do tubo floral. Eventualmente pode ocorrer a sobreposição do final da fase masculina e o início da feminina, dado que em algumas flores o estigma já mostra-se exserto enquanto as anteras e estaminódios ainda não se recurvaram totalmente (Fig. 4A). As fases florais acima mencionadas permitem tratar a dicogamia de Angostura bracteata como protandria intrafloral e assincrônica (Lloyd e Webb 1986). Já a hercogamia da espécie é do tipo hercogamia de aproximação (“approach herkogamy”, Webb e Lloyd 1986), dado que o estigma posiciona-se à frente do caminho do polinizador (Figs. 3D, 4E), e também do tipo homomórfico ordenado (i.e. todas as flores de uma mesma planta apresentam o mesmo tipo de hercogamia, sendo o contato com o pólen e estigma feito de um modo geralmente único e ordenado pelo visitante, Webb e Lloyd 1986).

Em relação aos visitantes florais, A. bracteata é visitada tanto por insetos como por uma espécie de beija-flor. Dentre os insetos, foram observadas 10 espécies de Lepidoptera, 
sendo oito espécies de borboletas (Papilionoidea), duas espécies de mariposas noturnas (Pyralidae sp. e Noctuidae sp.), e uma espécie não identificada de abelha diurna (Apidae) visitando as flores (tabela 2). Os lepidópteros exibiram a maior frequência de visitas, e dentre estes os lepidópteros diurnos foram os mais frequentes. Notadamente Ascia buniae (Hübner, 1816) foi a borboleta avistada com maior frequência, sendo as demais borboletas comparativamente menos frequentes. Todos os lepidópteros são polinizadores efetivos de $A$. bracteata, já que ao pousarem para tomar o néctar, ou contatam o local de deposição do pólen (anteras/estaminódios) ou tocam o estigma (Fig. 4A-E, H-J). Adicionalmente, estes animais (exceto um Noctuidae sp.) foram observados visitando flores de diferentes indivíduos ao longo do período de estudo. Esses lepidópteros geralmente pousam sobre os lobos da corola, bem como apoiam o abdômen ou patas também nos estaminódios, especialmente nas flores em fase masculina (pois nestas os estaminódios estão em um nível mais elevado as pétalas; Fig. 4 A, B, E). Consequentemente estes insetos carregam pólen na porção anterior do tórax ou nas pernas. Assim os estaminódios na fase masculina da flor apresentam a dupla função de apresentar o pólen e servir como local de apoio para os polinizadores. Apenas Eurybia halimede apresentou-se como pilhadora ocasional de néctar (Fig. 4H), uma vez que sua longa probóscide permite que ela recolha o néctar pousando eventualmente por fora do tubo floral em algumas visitas, aparentemente sem tocar as anteras ou estaminódios em algumas visitas. $\mathrm{Na}$ fase feminina da flor, também os lepidópteros ao pousar se agarram aos lobos da corola e/ou estaminódios para então tomar o néctar. Mas, dado que nesta fase estes órgãos encontram-se bem recurvados, os lepidópteros acabam por contactar previamente ao pouso o estigma longamente exserto. As partes do corpo destes animais que tocam o estigma são as patas, porção anterior do tórax, abdômen ou cabeça (Fig. 4A, C-E). Eventualmente os lepidópteros ao se aproximarem da flor, se apoiam também nos lobos da corola ou estaminódios/estigma de flores adjacentes (Fig. 4B). O tempo de visita das borboletas variou de 3-6 segundos, enquanto que as mariposas visitaram as flores por no máximo 5 segundos. As visitas das borboletas se iniciaram às 8:15 horas, intensificando-se no período das 10:00 e 14:00 horas, tornando-se mais esporádicas nas demais partes da tarde. As mariposas foram vistas visitando ás flores no período das 20:00 a 22:30 horas, e também por volta das 2:00 h. Adicionalmente foram notadas diversas (15) flores com escamas de mariposa aderidas aos estigmas na fase feminina.

O beija-flor Phaetornis idaliae foi o único vertebrado observado visitando a espécie, e em uma frequência considerada mediana (tabela 2). Este animal foi considerado polinizador e pilhador ocasional de A. bracteata, dado que nem sempre este tocava as anteras ou 
estaminódios. Ao inserir a língua no tubo floral, este beija-flor ocasionalmente toca apenas os estaminódios ou estígma com o bico, pois se aproximava da flor vindo de uma posição ligeiramente mais abaixo dela, para depois ascender frontalmente até alinhar-se à fauce da corola e então tomar o néctar (Fig. 4G). Foi observada pequena quantidade de pólen depositado na porção distal do bico da ave, após várias visitas (Fig. 4F). As visitas de $P$. idaliae foram esporádicas ao longo dos dias, ocorrendo no período da manhã (entre 7:50 e 10:40 horas) e ao final da tarde (17:40 horas). O beija-flor visitava todas as flores abertas dos indivíduos observados de A. bracteata, levando ca. de 2-3 segundos de tempo de visita a cada flor.

Uma espécie não identificada de abelha agiu primariamente como pilhadora de pólen (tabela 1). Esta foi vista em apenas em um momento de observação, ocasião em que pousou nos estaminódios para então pilhar o pólen das anteras levemente curvadas para cima, em flores em fase masculina.

Dado Nossas observações de frequência e contato com as estruturas reprodutivas levam a concluir que os lepidópteros devam constituir o principal grupo funcional de polinizadores de A. bracteata, Diferentemente, consideramos o beija-flor $P$. idaliae um polinizador secundário, por ter sido comparativamente menos frequente e por eventualmente pilhar a flor (tabela 2).

Sobre algumas das flores e botões de A. bracteata foram observadas aranhas "Crab spider" (Epicadus sp., Thomisidae), que permaneciam imóveis e mimetizadas com as pétalas, devido a sua coloração alva (Fig. 1F). Estas provavelmente aguardavam por potenciais presas vindo pousar nas flores, hábito típico deste grupo de aranhas (Oxford e Gillespie 1998). 
Tabela 1: Visitantes florais de Conchocarpus macrophyllus (Galipeinae, Rutaceae), em uma área de Mata Atlântica (Reserva Natural Vale, ES, Brasil)

\begin{tabular}{llll}
\hline Animais visitantes & Comportamento de visita & Recurso coletado & Frequência* \\
\hline Lepidoptera & & & \\
Heliconius sara apseudes & Polinizador & néctar e pólen & alta \\
Heliconius melpomene nanna & Polinizador & néctar e pólen & alta \\
Oleria aquata & Polinizador & néctar & média \\
Entheus priassus pralina & Polinizador & néctar & média \\
Melina ludovica paraiya** & Polinizador & néctar & média \\
Ascia buniae $* *$ & Polinizador & néctar & baixa \\
Eurema albula $* *$ & Polinizador & néctar & baixa \\
Aeria olena & Polinizador & néctar & baixa \\
Herperiidae $(2$ espécies não & Polinizador & néctar & baixa \\
identificadas) & & & \\
Apidae & & néctar e pólen & média \\
Paratetrapedia fervida & Polinizador & néctar & média \\
Osiris sp. & Polinizador & pólen & baixa \\
Meliponini sp & Pilhador & & \\
\hline
\end{tabular}

Tabela 2: Visitantes florais de Angostura bracteata (Galipeinae, Rutaceae) em uma área de Mata Atlântica (Reserva Natural Vale, ES, Brasil)

\begin{tabular}{llll}
\hline Animais visitantes & Comportamento de visita & Recurso coletado & Frequência* \\
\hline Lepidoptera & & & \\
Ascia buniae $* *$ & Polinizador & néctar & alta \\
$\begin{array}{l}\text { Melinaea ludovica paraiya } * * \\
\text { Aeria } \text { olena } * *\end{array}$ & Polinizador & néctar & media \\
Astraptes fulgerator & Polinizador & néctar & baixa \\
Astraptes sp. & Polinizador & néctar & baixa \\
Eurybia sp. & Polinizador & néctar & baixa \\
Pyrginae sp. & Polinizador/pilhador ocasional & néctar & média \\
Pyralidae sp. & Polinizador & néctar & baixa \\
Noctuidae sp. & Polinizador & néctar & baixa \\
Trochilidae & Polinizador & néctar & baixa \\
Phaetornis idaliae & & & \\
Apidae & Polinizador/pilhador ocasional & néctar & média \\
espécie não identificada & Pilhador & & baixa \\
\hline
\end{tabular}

*Frequência: alta $\left(\leq 10\right.$ visitas $\left.\mathrm{d}^{-1}\right)$, média $\left(1-5\right.$ visitas $\left.\mathrm{d}^{-1}\right)$, baixa $\left(<1\right.$ visita $\left.\mathrm{d}^{-1}\right)$.

$* *$ Borboletas que visitam as flores de ambas as espécies 

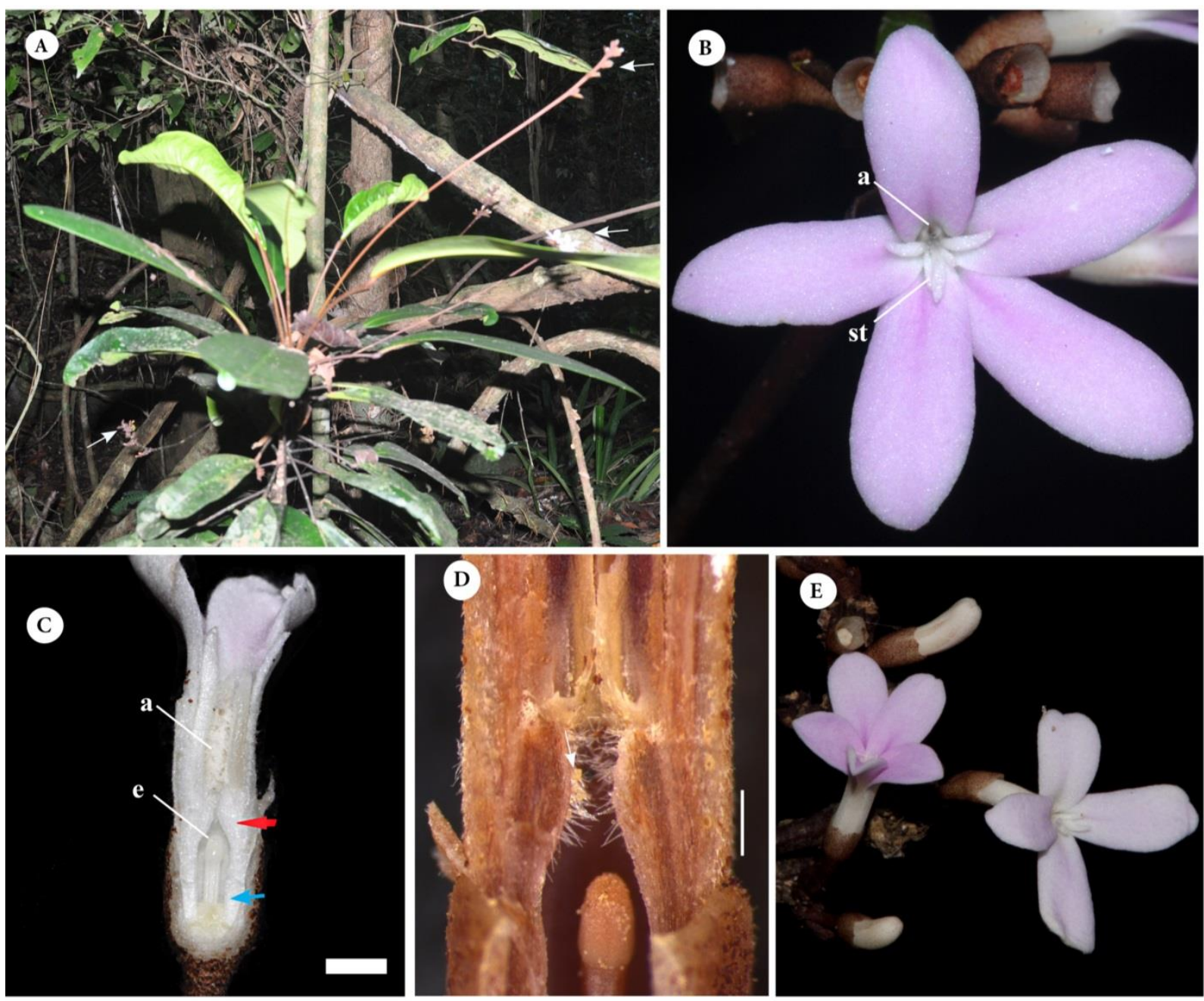

Figura 1: Conhocarpus macrophyllus, Rutaceae. (A) Hábito e inflorescências (setas). (B) Flor em vista frontal. (C) Flor em secção longitudinal, notar a constrição do tubo floral acima do estigma (seta vermelha) e a porção basal do tubo, acima do ovário (seta azul). (D) Detalhe da região de constrição do tubo floral, notar tricomas dos filetes, com pólen aderido (seta). (E) Flor recém-aberta (a esquerda) e flor com 3 dias de vida (a direita). Legendas: a, anteras; e, estigma; st, estaminódios. Barras de escala: $(C)=2 \mathrm{~mm},(\mathrm{D})=500 \mu \mathrm{m}$. 

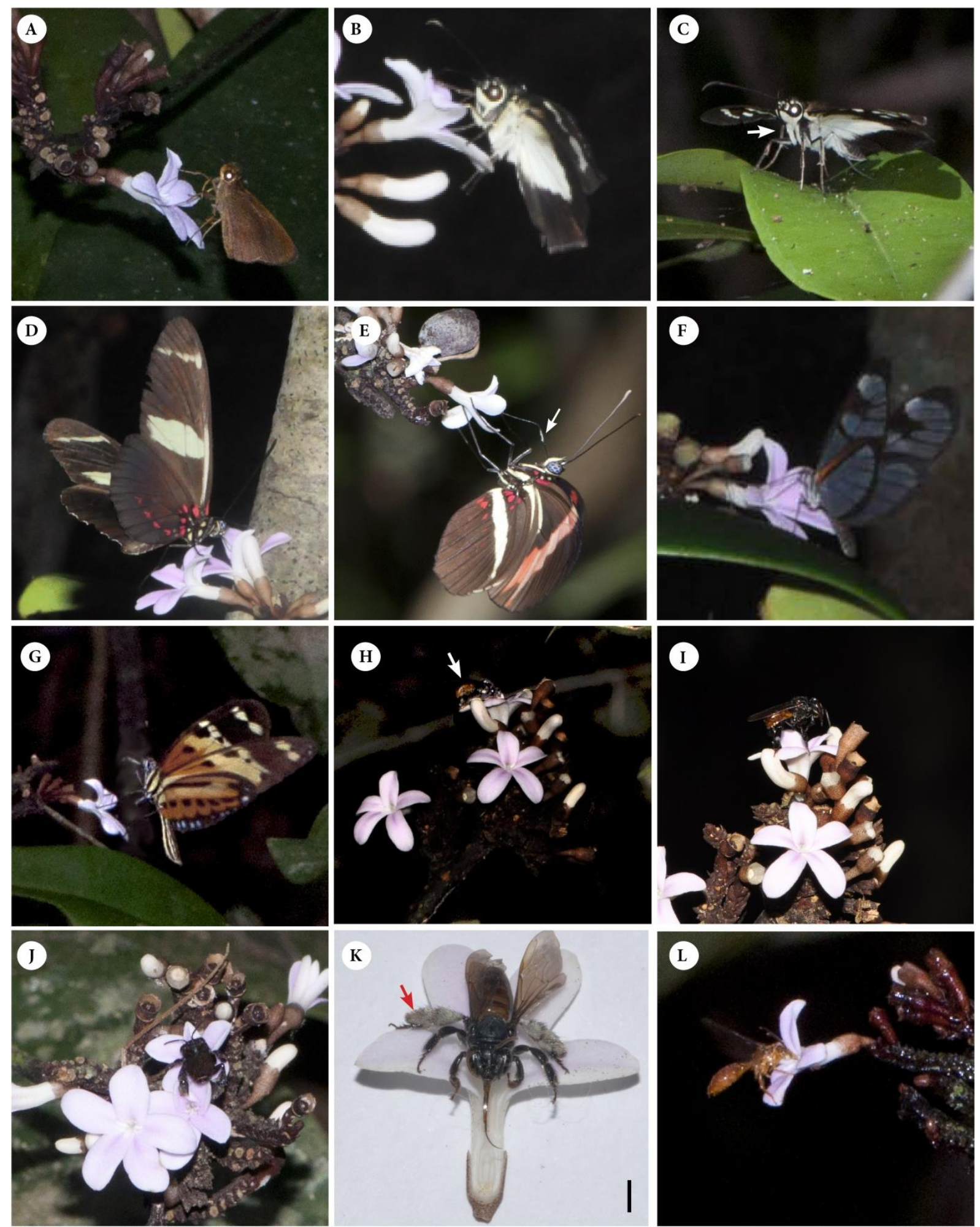

Figura 2: Visitantes florais de Conchocarpus macrophyllus, Rutaceae. (A) Hesperiidae. (B, C) Entheus priassus pralina. (D) Heliconius sara apseudes. (E) Heliconius melpomene nana (notar pólen acúmulado na probsócide, seta). (F) Oleria aquata. (G) Melina ludovica paraiya. (H, I) Meliponini (J, K) Paratrapedia fervida. (J) Espécime vivo, vistanto a flor. (K) Mesmo espécime de J, em simulação de visita, em flor seccionada longitudinalmente (notar escopas com pólen, seta). (L) Osiris sp. Barra de escala: $(K)=2 \mathrm{~mm}$. 

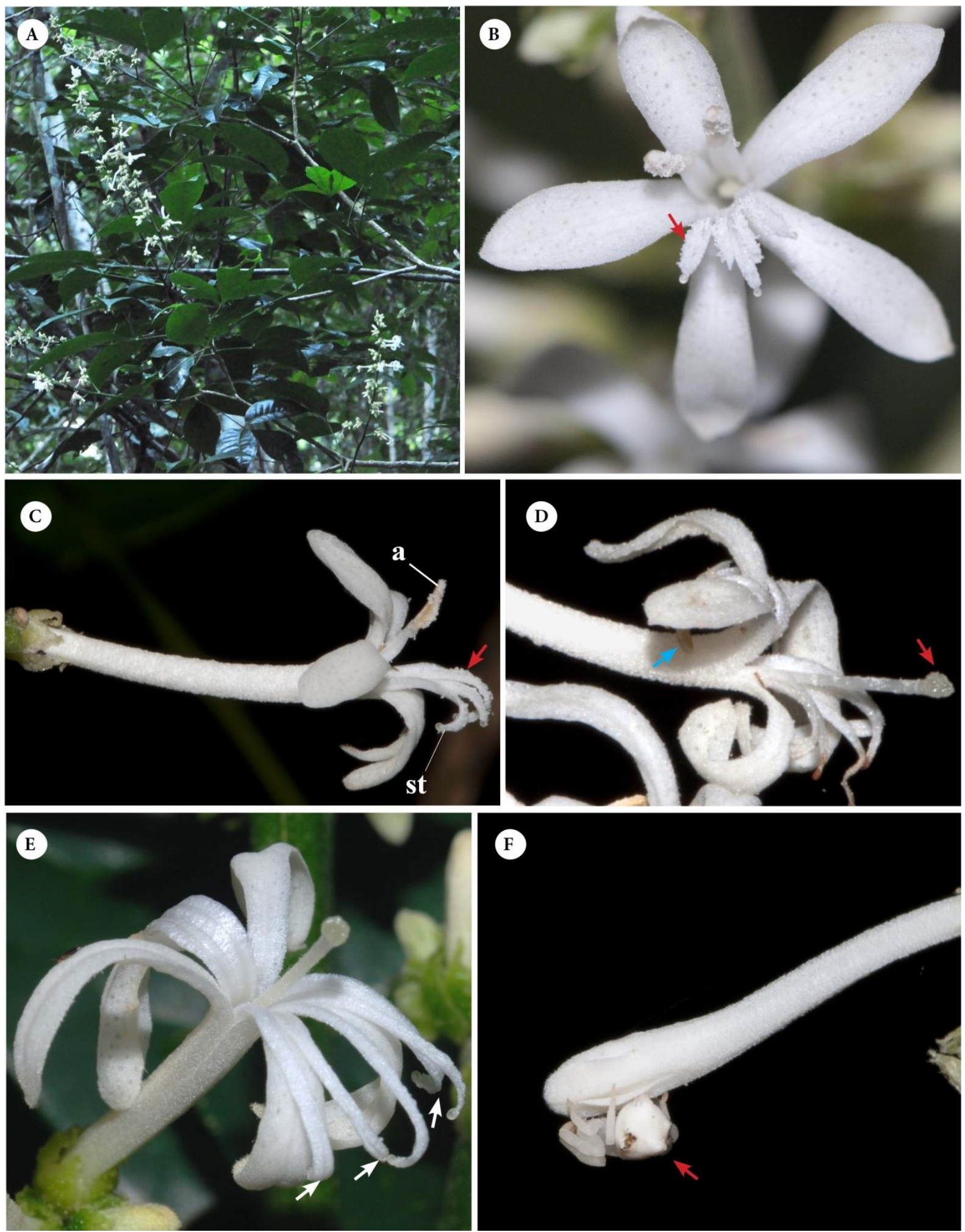

Figura 3: Angostura bracteata, Rutaceae. (A) Ramos com folhas e inflorescências. (B, C) Flores em fase masculina (seta indicando pólen sobre estaminódios). (B) Flor recém-aberta (C) Flor aberta, início da elevação das anteras para trás (C) Flor em fase feminina. (D, E) Flores em fase feminina. (D) Notar antera enrolada para trás (seta azul) e estigma exserto (seta vermelha). (E) Notar estaminódios enrolados para trás (setas). (F) Aranha Epicadus sp. sobre botão em pré-antese. Legendas: a, anteras; st, estaminódios (E, foto de Emerson R. Pansarin). 

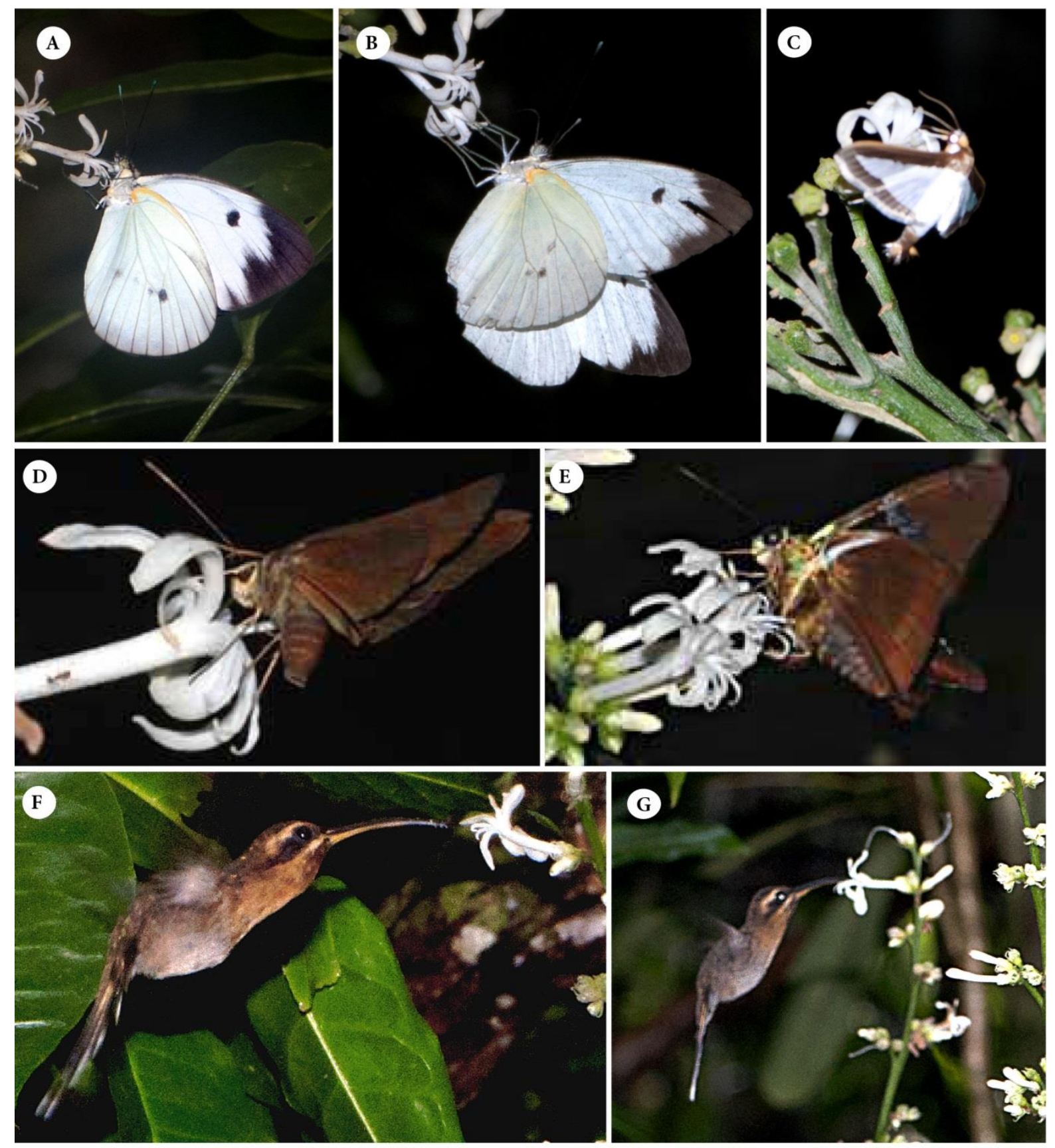

(G)

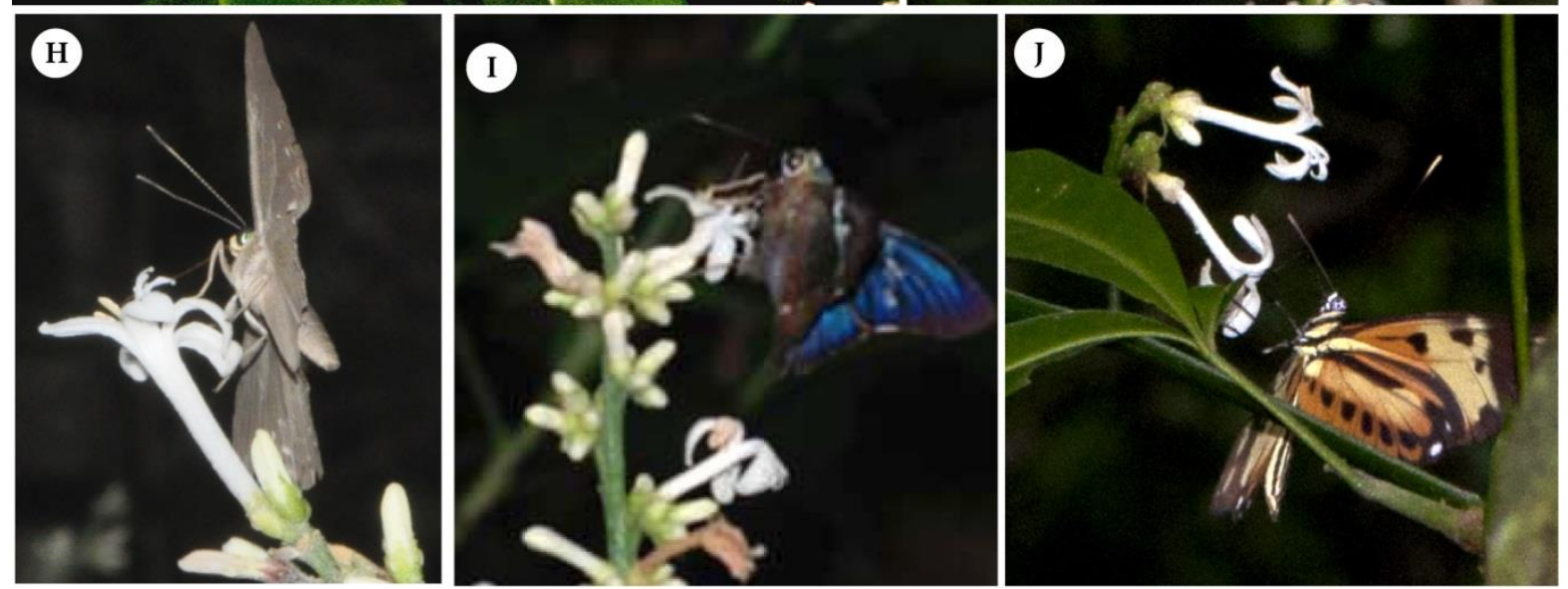

Figura 4: Visitantes florais de Angostura bracteata, Rutaceae. (A, B) Ascia buniae. (C) Pyralidae. (D) Astraptes fulgerator. (E) Pyrginae sp. (F, G) Phaetornis idaliae. (H) Eurybia halimede (I) Astraptes sp. (J) Melinaea ludovica paraiya (D, E, I, fotos de Emerson R. Pansarin). 


\section{DISCUSSÃO}

Biologia floral e polinização de Conchocarpus macrophyllus

Conchocarpus macrophyllus apresenta lepidóteros diurnos como principal grupo funcional de polinizadores. Dentro deste grupo, espécies do gênero Heliconius (Nymphalidae, Heliconiinae) são consideradas os principais polinizadores pela sua maior frequência de visitas. Este gênero de borboletas exclusivamente neotropical apresenta a particularidade de coletar néctar bem como pólen das flores. Estas, diferentemente das demais borboletas nectarívoras, extraem aminoácidos provenientes do pólen para sua dieta (Gilbert 1972). De fato foi demonstrado que, ao visitar flores sem pólen, espécies de Heliconius rapidamente as abandonam (Krenn 2008). Assim sendo, talvez o motivo da maior frequência de visitas de Heliconius às flores de C. macrophyllus seja devido à maior disponibilidade de recurso floral para este animal (pólen e néctar), frente às demais espécies de borboletas que coletam apenas néctar. A quantidade de néctar por flor é efetivamente bastante baixa em C. macrophyllus (ca. $0,16 \mu \mathrm{m}$ ), a mais baixa registrada até o momento para as Galipeinae (considerando-se néctar acumulado em média, durante 24 horas: ca. 67,7 $\mu \mathrm{m}$, em Erythrochiton brasiliensis, Lopes 2002; ca. 10,1 $\mu \mathrm{m}$ em Almeidea rubra, El Ottra et al. em prep.; ca. $3 \mu \mathrm{m}$ em Conchocarpus cyrtanthus; ca. $18 \mu \mathrm{m}$ Spiranthera odoratissima, J.H.L.El Ottra obs. pess.). No entanto, pequena quantidade de néctar por flor é uma característica comumente reportada em espécies principalmente polinizadas por borboletas, sendo que em alguns casos seu volume não é possível de ser medido (Opler 1983; Aguiar et al. 2012 Araujo et al. 2014). Ainda, considerando a faixa de variação na concentração do néctar comumente reportada para flores polinizadas por borborletas (15-25\%, Proctor et al. 1996), o valor obtido em C. macrophyllus é próximo, apenas um pouco mais diluído que o valor mínimo esperado (13,70 \% ou 12,16\%, dependendo do método usado).

Adicionalmente, as abelhas consideradas como polinizadoras secundárias de $C$. macrophyllus - Osiris sp. e Paratetrapedia fervida (ambas Apidae, pertencente às tribos Osirini e Tapinotaspidinae, respectivamente, Silveira et al. 2002) - são abelhas de médio porte $(0.9 \mathrm{~cm}$ e $1,2 \mathrm{~cm}$ de comprimento corporal, respectivamente; Opler 1983; Silveira et al. 2002). Paratetrapedia é um grupo de abelhas exclusivamente neotropical, reportado coletando óleos florais de certas espécies de Malpighiaceae, bem como pólen de diversas outras famílias de plantas. Dentre estas, sua visita foi reportada em diversos grupos de flores tubulosas (e.g. espécies de Rubiaceae, Asteraceae, Gesneriaceae; Aguia e Mello 2011). Por este motivo, admite-se que certas características morfológicas de Paratetrapedia, como certas 
grossas e curvas no primeiro palpômero e nas estípites, sejam estruturas funcionalmente associadas à coleta de pólen em flores tubulosas (Aguia e Mello 2011; Alves-dos-Santos 2002). Diferentemente, as espécies de Osiris são abelhas consideradas cleptoparasitas, por invadirem ninhos aprovisionados de outras abelhas, onde depositam seus ovos (notadamente ninhos de Tapinotaspidinae, como Paratetrapedia; Shanks 1986; Camilo et al. 1993). Assim sendo, possivelmente a coleta de recursos florais, como pólen, para sua ninhada seria a princípio desnecessário, e a visita a flores um hábito apenas ocasional (R.B. Gonçalves, com. pess.). No entanto Osiris sp. já foi observada visitando flores de outra espécie de Conchocarpus [C. acuminatus (Pilg.) Kallunki \& Pirani; J.H.L. El Ottra obs. pess.], bem como espécies de Osiris e Paratetrapedia foram reportadas como polinizadoras das pequenas flores tubulosas de Erythrodes arietina (Rchb. F. \& Warm.) Ames (Orchidaceae, Singer e Sazima 2001). Seria interessante avaliar se o comportamento de visita ás mesmas espécies de flores por ambos os grupos de abelhas teria alguma relação com o hábito parasítico de Osiris a Paratetrapedia.

Enquanto algumas características florais de C. macrophyllus estariam associadas à polinização por lepidópteros diurnos e/ou abelhas (psicofilia, melitofilia, respectivamente), outras não estão claramente associadas a qualquer destes grupos de animais. A polinização por abelhas de flores com tubo floral curto e coloração clara, com guias de néctar, é relativamente comum (Faegri e van der Pijl 1979; Frankie et al. 1983; Endress 1994; Proctor et al. 1996). No entanto flores com tubo floral bastante constrito, de cor rosa, com pouco néctar e este de concentração relativamente diluída, são características que em conjunto estão relacionadas à polinização por lepidópteros diurnos (Faegri e van der Pijl 1979; Baker e Baker 1982; Opler 1983; Endres 1994; Proctor et al. 1996; Araújo et al. 2014). Adicionalmente, a presença de plataformas de pouso delicadas, no caso os lobos da corola de C. macrophyllus, é uma característica floral já reportada para sistemas de polinização especializados em borboletas, dado que estas seriam inadequadas a animais que necessitam de plataformas mais robustas para pouso, como abelhas de grande porte (Castellanos et al. 2004; Araújo et al. 2014). Abelhas maiores (com mais de $1,2 \mathrm{~cm}$ de comprimento corporal) habitam a localidade de estudo, porém só foram observadas visitando outras espécies florescendo na área (J.H. L. El Ottra obs. pess.). Também características do néctar de C. macrophyllus indicaria que este é mais adequado à nutrição dos lepidópteros que às abelhas. De fato, em outras espécies tropicais principalmente polinizadas por abelhas, o néctar geralmente tem maior concentração de açúcares (21 a $46 \%$, Baker e Baker 1982), bem como maior volume apresentado por flor (variando de $0,63 \mu 1$ até 9, $75 \mu 1$ em flores polinizadas por abelhas de variados portes; Opler 
1983). Diferentemente, o horário de antese das flores de C. macrophyllus está apenas parcialmente relacionado à polinização por estes dois grupos de animais. De fato, tanto flores polinizadas por abelhas como por lepidópteros diurnos geralmente se abrem no período matutino (e.g. Faegri e van der Pij1 1979), como observado neste estudo. Porém, dado que foi também notado um número considerável de flores com antese noturna, é possível que esteja ocorrendo a polinização noturna de $C$. macrophyllus. Tal suposição seria reforçada pela observação do compartilhamento de algumas borboletas como polinizadoras de $C$. macrophyllus e A. bracteata (tabela 1 e 2), bem como pela ocorrência no local do estudo de outras espécies de Galipeinae co-florescentes e com características florais semelhantes a $C$. macrophyllus [flores tubulosas, nectaríferas, de coloração clara; e.g. Rauia nodosa (Engl.) Kallunki, Conchocarpus cyrtanthus Kallunki, J.H.L. El Ottra obs. pess.; Angostura bracteata, este estudo], mas com odor adocicado. Nesse sentido, se a polinização noturna ocorrer, esta poderia ser considerado como por engano, dado que as mariposas seriam atraídas a longa distância pelo odor de outras plantas da comunidade, e apenas a curta distância, localizariam e visitariam as flores sem aroma e com pouco recurso de C. macrophyllus. Porém talvez esse seja um fenômeno mais raro, que só poderia ser registrado com mais horas de observações noturnas. Em relação à ausência de odor floral perceptível, apesar de a princípio esta característica não estar relacionada à polinização por lepidópteros diurnos, dentro do conceito tradicional de síndromes de polinização (Faegri e van der Pijl 1979), os raros estudos com sistemas de polinização especializados em borboletas, ou com polinizadores como borboletas e abelhas apenas, reportaram também ausência de odor floral perceptível em espécies neotropicais de plantas (algumas Orchidaceae e Apocynaceae; Pansarin e Amaral 2008; Araújo et al. 2011; Araújo et al. 2014).

A constrição no ápice do tubo floral e a liberação gradual do pólen observadas em $C$. macrophyllus indicam que a espécie apresenta um interessante mecanismo que restringe ou impede a autopolinização. Esta constrição, acima do nível do estigma, somado a presença de tricomas nesta região e nas anteras, impedem que o próprio pólen da flor caia sobre seu estigma. De fato, foi observado que flores ensacadas e não visitadas por toda a antese, apresentam seu pólen inteiramente retido na superfície das duas anteras bem como nos estaminódios neste mesmo nível, e o estigma abaixo sem nenhum depósito de pólen. Estas observações indicam que a autopolinização espontânea não ocorre em C. macrophyllus, sendo as peças do androceu (seu posicionamento e indumentação) responsáveis pela retenção do pólen acima do estigma. Os tricomas sobre essa região do androceu podem também ter a função de reter o pólen da probóscide dos polinizadores. Este fenômeno poderia ocorrer pela atração eletrostática do pólen aos tricomas, como já assumido de modo semelhante para 
tricomas em outras partes da flor de Angiospermas (e.g. estigmas, Endress 1994). Adicionalmente, a liberação gradual do pólen nos primeiros dois dias de antese, bem como a oferta de pouco néctar por flor em $C$. macrophyllus poderiam ser vistos como uma estratégia que reduz as chances de autogamia. Isso faria com que os visitantes florais tivessem que provar muitas flores para obterem quantidade adequada de recursos, aumentando assim as chances de polinização cruzada. De fato, tal comportamento foi observado, sendo que os lepidópteros diurnos, os principais polinizadores de C. macrophyllus, foram reportados como eficientes vetores de pólen a longa distância, promovendo a polinização cruzada (Waddington 1976; Cruden e Hermann-Parker 1979; Araujo et al. 2011). Ainda, o oferecimento de poucos recursos por flor, como estratégia estimuladora de polinização cruzada, já foi reportado para outras plantas polinizadas por borboletas (Araújo et al. 2014). No entanto, a ocorrência de flores adicogâmicas com estigma incluso abaixo do nível das anteras é intrigante, pois indicaria que uma vez visitadas, as flores poderiam apresentar elevadas taxas de autogamia. Assim, é possível que exista algum tipo de sistema de autoincompatibilidade em $C$. macrophyllus, e seria interessante elucidar isso por meio de futuros estudos sobre o sistema reprodutivo da espécie.

Biologia floral e polinização de Angostura bracteata

A observação de visitas legítimas às flores de Angostura bracteata tanto no período noturno como no diurno indicam que o sistema de polinização da espécie seja do tipo misto, com diferentes grupos funcionais de polinizadores atuando durante o dia e noite. De modo semelhante a Conchocarpus macrophyllus, os lepidópteros diurnos foram o grupo mais frequente de polinizadores observados, e principais visitantes diurnos de A. bracteata. Como polinizador secundário no período diurno, foi observado o beija-flor Phaethornis idaliae. Por fim, o terceiro grupo funcional de polinizadores observado no período noturnoé consituído de mariposas pousadoras (Noctuidae e Pyralidae; tabela 2). Apesar da menor frequência das mariposas, se comparadas ás borboletas, a morfologia semelhante destes animais, somada á sua adequação á morfologia floral, tocando sempre as estruturas reprodutivas nas visitas, fez com que considerássemos as mariposas conjuntamente com as borboletas os principais polinizadores de A. bracteata. Ainda, é importante ressaltar que nossas observações noturnas foram apenas parcialmente presenciais, e por isso a frequência e número de espécies de mariposas documentadas podem estar subestimadas. Isto se deveria principalmente pelo fato 
das gravações noturnas registrarem apenas um número limitado de flores (ca. 2-3 inflorescências por noite).

Considerando-se apenas o conceito tradicional de síndromes de polinização, as características florais de $A$. bracteata indicariam a ocorrência de falenofilia. Flores de coloração branca, com tubo relativamente longo e estreito, odor adocicado especialmente à noite e antese predominantemente crepuscular ou noturna, são características que em conjunto estão associadas à polinização por mariposas (Faegri e van der Pijl 1979; Proctor et al. 1996). No entanto, três grupos funcionais de polinizadores foram observados nessa espécie, e um exame mais aprofundado da sua biologia floral indica que outras características tornam a flor capaz de atrair polinizadores durante o dia, notadamente a duração da flor por mais de uma noite, com fases masculina e feminina funcionais por mais que 12 horas, com emissão de odor adocicado durante toda a antese. Apesar do padrão de produção de néctar não ter sido avaliado neste estudo, as frequentes visitas por animais nectarívoros diurnos se dão pela presença deste recurso no período do dia. Apenas não é claro se este seria produzido também durante o dia, ou se é acumulado do período noturno. As características florais relacionadas a essa relativa generalização do sistema de polinização da espécie, como a duração da antese e disponibilidade de recurso durante o dia, já foram reportadas para outras plantas com sistemas mistos de polinização (e.g. espécies de Rubiaceae, Maruyama et al. 2010; Avila e Freitas 2011; Cactaceae, Alondo-Pedano e Ortega-Baes 2012; Inga, Fabaceae, Amorin et al. 2013). Ainda, se considerarmos o conceito tradicional de síndromes de polinização, nota-se que tanto a psicofilia como a falenofilia são muito semelhantes em relação às feições florais como tubo floral estreito, relativamente longo e odor adocicado (sendo este considerado mais fraco em flores polinizadas por borboletas Faegri e van der Pij1 1979). Diferentemente, características florais como anteras e estigmas exsertos do tubo floral, e flores de coloração branca, são características também muito reportadas para plantas polinizadas por beija-flores e mariposas que adejam (i.e. Sphingidae; Silberbauer-Gottsberger e Gottsberger 1975; Endress 1994; Thomson et al. 2000; Wilson et al. 2006; Lunau et al. 2011,e referências nele contidos). No entanto, apenas mariposas pousadoras foram observadas neste estudo.

De modo contrário, características relacionadas ao volume de néctar e liberação do pólen indicam que o sistema de polinização de A. bracteata estaria ecologicamente mais especializado em polinização por mariposas pousadoras e borboletas. O pequeno volume de néctar produzido pela espécie (em média $0,8 \mu \mathrm{m}$ acumulado em 24 horas) indicar que este provavelmente é mais adequado à nutrição destes grupos de lepidópteros do que ao beija-flor $P$. idaliae. O volume de néctar encontrado estaria mais próximo ao reportado para outras 
plantas de floresta tropical polinizadas por mariposas pousadoras e borboletas $(0,84$ e $0,93 \mu 1$, respetivamente; Opler 1983). Beija-flores geralmente necessitam de maior volume de néctar para manter a alta taxa de consumo energético de seu metabolismo (Stiles e Freeman 1993; Fleming et al. 2009). No entanto, P. idaliae é um colibri de pequeno porte (Ruschi 1989). Beija-flores menores em teoria necessitariam de menor quantidade de recursos, se comparado aos beija-flores maiores. Tal fato explicaria a razão de pequenos beija-flores serem comumente reportados visitando flores relativamente pequenas e compartilhadas com outros insetos, como borboletas e abelhas (Stiles 1981; Opler, 1981). Porém, dados de observações do forrageamento por este beija-flor na área de estudo deixam claro que este não depende apenas do escasso néctar de A. bracteata. A ave foi observada apresentando comportamento do tipo "rota de forrageamento" (trapliner), visitando periodicamente ao longo do dia flores com maior volume de néctar, (Passiflora speciosa Gardner, Passifloraceae, Varassin et al. 2001; Almeidea rubra A.St.-Hil. e Conchocarpus cyrtanthus, J.H.L. El Ottra obs. pess.), na mesma localidade e em outras áreas do estado. Diferentemente, P. idaliae foi observado visitando as flores de $A$. bracteata apenas no início da manhã e ao final da tarde. Este fato indicaria que estas visitas representariam a tomada do néctar deixado pelos lepidópteros - os principais polinizadores da espécie. O aproveitamento por beija-flores de sobras de néctar não consumido por polinizadores noturnos, já foi reportado para outros sistemas de polinização de flores tubulosas relativamente generalistas (i.e. algumas espécies de Gesneria e Rhytidophyllum, Gesneriaceae, Martén-Rodrígues et al. 2009). Em relação ao pólen, dado que este é totalmente liberado já nas flores recém-abertas supõe-se que os vetores que visitam estas flores nesta fase, notadamente as mariposas noturnas, transportem maior quantidade de pólen. Isto ocorreria devido ao horário predominante de antese crepuscular ou noturna, fazendo com que as mariposas sejam o primeiro grupo funcional a visitar a maioria das flores masculinas recém-abertas.

Sistemas de polinização com visitantes noturnos e diurnos são vistos como uma estratégia que contribui para garantir a reprodução de espécies em ambientes onde a disponibilidade de um dos grupos funcionais de polinizadores (diurnos ou noturnos) é inconstante ao longo do tempo e espaço (Walter 2010, Ortega-Baes et al. 2011; Amorin et al. 2013). De fato, dentre os três grupos funcionais de polinizadores relacionados a A. bracteata (mariposas pousadoras noturnas, borboletas e beija-flores), as mariposas não foram observadas com alta frequência, se comparado às borboletas. Outros trabalhos sobre espécies com flores de características falenófilas e sistemas mistos de polinização, revelaram de modo semelhante menor frequência de mariposas em relação aos polinizadores diurnos (Wolf et al. 
2003; Maruyama et al. 2010; Amorin et al. 2013), o que , no entanto, não diminui a importância destes animais na reprodução das espécies. Tal fato se deve possivelmente pela capacidade das mariposas em promover polinização cruzada a longas distâncias (Miyake e Yahara 1999). Contudo, polinizadores como borboletas e beija-flores também são reportados como eficientes animais na promoção de polinização cruzada de espécies vegetais (Waddington 1976; Cruden e Hermann-Parker 1979; Fleming et al. 2009; Araujo et al. 2011). Portanto, restam muitas questões para estudos futuros sobre o sistema reprodutivo de Angostura bracteata, no sentido de avaliar a efetividade de cada um dos grupos de polinizadores, diurnos e noturnos, bem como a contribuição destes no sucesso reprodutivo da espécie.

Em Galipeinae, a polinização por lepidópteros diurnos e noturnos já foi relatada apenas para Galipea jasminiflora (A.St.-Hil.) Engl. (Piedade \& Ranga 1994). Esta espécie apresenta diversas espécies de mariposas como polinizadores noturnos, e uma espécie de borboleta como polinizador diurno. Sua biologia floral e morfologia são bastante semelhantes às de Angostura bracteata, com tubo floral longo e fino, antese noturna, flores brancas com odor adocicado ao longo de toda antese, que dura também aproximadamente 48 horas. As observações de Piedade \& Ranga (1994), associadas às suas semelhanças com a biologia floral de A. bracteata, sugerem que ambas teriam sistema de polinização misto. Mas esta ideia não foi considerada por Piedade e Ranga (1994), possivelmente pela maior frequência das mariposas noturnas frente à única espécie de borboleta considerada como polinizadora diurna. No entanto, diversas outras espécies de borboletas foram observadas durante o dia por essas autoras visitando as flores de G. jasminiflora. Porém estas foram consideradas pilhadoras de néctar, pelo fato de não tocarem as duas anteras com a cabeça ou tórax. A evolução de flores com antese noturna e polinizadores noturnos para flores com polinizadores diurnos e com duração da antese até o dia seguinte, é vista como evidência de que a seleção natural favoreceria a adição de novos grupos funcionais de polinizadores, sem, no entanto perder os antigos (no caso os noturnos), dado que isto não traria grandes custos adicionais à espécie (Fenster et al. 2004). Seria interessante avaliar tal hipótese em um estudo com representantes de Galipeinae, quanto à evolução dos sistemas de polinização diurnos, noturnos e mistos neste grupo.

A deposição do pólen nos estaminódios da flor de A. bracteata, e sua apresentação conjunta com as anteras durante a antese, permite concluir que nesta espécie ocorre a apresentação secundária do pólen (i.e. apresentação do pólen aos seus vetores por outra estrutura que não sejam anteras, Faegri e van der Pijl 1979). Poucas angiospermas exibem a 
apresentação secundária do pólen, contudo este fenômeno evoluiu múltiplas vezes na história do grupo, ocorrendo em representantes de clados como asterídeas (e.g. Asteraceae, Rubiaceae, Apocynaceae), monocotiledôneas (e.g. Araceae, Maranthaceae) e em algumas rosídeas (e.g. Myrtaceae, Proteaceae; Faegri \& van der Pij1 1979, Endress 1994, Howell et al.1993). Em Rutaceae, o fenômeno foi antes reportado apenas para Adenandra (Marloth 1920), onde diferentemente de A. bracteata, o pólen é apresentado secundariamente pelo estilete.

Dentre os diferentes tipos de apresentação secundária do pólen relatados na literatura, o de A. bracteata se adequaria à categoria de "apresentação via androceu" ("androecial presenters", Howell et al.1993). Este tipo seria caracterizado pela apresentação do pólen por partes do androceu que não as anteras, e foi apenas reportado para Santalanum acuminatum (Santalaceae) por Sedgley (1982), onde os tricomas presentes na base dos filetes capturam o pólen liberado pelas anteras. Apesar de Howell et al. (1983) assumirem a existência de outras espécies onde a apresentação via androceu seria feita pelos filetes ou estaminódios, o significado adaptativo em deslocar a apresentação do pólen dentro dos componentes do próprio androceu não parece claro para os autores.

Entretanto, considerando os dados obtidos com o comportamento dos polinizadores sobre as flores de A. bracteata, somados à apresentação secundária do pólen na porção ventral da flor, e a primária na porção dorsal, pode-se inferir que tal fenômeno favoreça a deposição do pólen de uma maneira mais abrangente no corpo dos polinizadores. Esta ocorreria não apenas na porção dorsal dos vetores, como esperado a priori, considerando apenas o posicionamento das duas anteras, mas também em sua porção ventral. Assim, a apresentação do pólen também pelos estaminódios em A. bracteata permite que este seja depositado não apenas na cabeça do visitante, mas também pelas suas patas, tórax e abdômen. De modo semelhante, o contato com o estigma pode ser feito também por estas mesmas partes do corpo dos polinizadores. Se compararmos os sistemas de polinização de A. bracteata ao de Galipea jasminiflora, ambas com características falenófilas, mas esta última sem a apresentação secundária do pólen e com estaminódios bem mais curtos e achatados, nota-se uma diferença marcante. Em G. jasminiflora, apenas a polinização nototríbica ocorre, com a deposição do pólen na cabeça e superfície dorsal do tórax dos polinizadores, na maioria mariposas (e apenas uma espécie de borboleta; Piedade e Ranga 1994). Assim, pode-se concluir que a deposição secundária do pólen também na região ventral da flor, contribui para uma maior amplitude de locais para deposição do pólen nos polinizadores, e, portanto geraria uma maior generalização do sistema de polinização de A. bracteata frente a espécies sem esta feição. Diversas Galipeinae apresentam morfologia semelhante do androceu - i.e. dois estames férteis em 
posição dorsal e três a cinco estaminódios filiformes e alongados em posição mediana e ventral na flor (e.g. espécies de Conchocarpus, Angostura, Ertela, Raputiarana, Sigmatanthus, Ravenia, Neoraputia, El Ottra em prep., Capítulo1) - com isto seria interessante investigar se ocorre apresentação secundária do pólen em outras espécies da subtribo.

\section{Aspectos funcionais dos estaminódios e simetria floral em Galipeinae}

Em Galipeinae, os estaminódios estão presentes na maioria dos representantes e são bem peculiares a este grupo em Rutaceae (Engler 1931; Kubitzki et al. 2011), sendo ausentes nos demais gêneros de parentesco próximos. Estudos mostram que uma vez que os estames perdem sua função na produção de pólen, logo são perdidos no decorrer da evolução do grupo, exceto em casos em que assumem outras funções dentro da biologia floral da espécie (Walker-Larsen \& Harder 2000). Assim, considerando os estudos de biologia floral realizados, algumas evidências surgem quanto à função dos estaminódios nas Galipeinae. Em Angostura bracteata, os estaminódios atuam como local onde partes do corpo do lepidóptero se apoiam ao pousar, e na apresentação secundária do pólen (este estudo), bem como possivelmente são portadores de osmóforos. Já em Conhocarpus macrophyllus a função dos estaminódios parece ser outra. Os tricomas na superfície dos filetes dos estames férteis e estaminódios, na porção dilatada do ápice do tubo floral, contribuiriam para a retenção do próprio pólen em flores não visitadas, evitando que este caia no estigma e reduzindo assim as chances de autopolinização espontânea. Alternativamente, estes poderiam remover o pólen aderido à probóscide dos polinizadores, no caso, borboletas e abelhas. De fato, tricomas com função de coletar o pólen ("pollen-collecting hairs”) já foram reportados sobre outros órgãos florais (Proctor e Yeo 1973). Também em outros grupos de plantas foi reportado que o tamanho, cor e indumentação dos estaminódios podem estar associados ao tipo de polinizador, sendo que estaminódios grandes e "barbados" no ápice foram especialmente associados à polinização por insetos, de modo semelhante ao aqui observado (Wilson et al. 2006). Diversas espécies de Conchocarpus apresentam tricomas em maior densidade em uma porção dilatada no ápice dos filetes dos estames férteis, e ao mesmo nível, nos estaminódios (Kallunki \& Pirani 1998), o que indicaria que a retenção de pólen nesta região seja possivelmente um fenômeno mais comum nas espécies do gênero do que previamente reportado. Ainda, pode-se supor outra consequência da presença dos estaminódios na biologia floral: dado que a porção dilatada dos filetes e estaminódios no ápice do tubo floral contribui para a redução do diâmetro do tubo nesta região, sua presença ali poderia estar relacionada à manutenção de um tubo floral bastante constrito, resultando na restrição do acesso ao interior do tubo floral por outras partes do corpo, que não a probóscide dos polinizadores. 
Em outras Galipeinae já estudada, como Almeidea rubra (El Ottra et al. submetido, Capítulo 2), os estaminódios não parecem ter qualquer função na biologia floral. Tal fato pode ser explicado por fenômenos evolutivos não relacionados à adaptação. Face à ampla presença de estaminódios em Galipeinae, o fenômeno de inércia filogenética (Orzack e Sober 2001; Bloomberg e Garland 2002) poderia explicar a presença dos estaminódios aparentemente sem função nessa espécie. Nesse sentido, A. rubra possuiria estaminódios apenas por ter herdado tal característica de um ancestral prévio, sem apresentar função atual na biologia da espécie. De fato, em plantas principalmente polinizadas por aves, como é o caso de A. rubra, estudos experimentais demonstram que a remoção dos estaminódios não altera a eficiência de polinização dos beija-flores, e por isso são considerados órgãos vestigiais nestas espécies (Walker-Larsen e Harder 2000). No entanto, em outras populações de A. rubra, bem como em outras espécies do gênero, predominam flores com todos cinco estames férteis e estaminódios ausentes (Pirani 1999, Bruniera et al. 2011), o que demonstra que a esterilização dos estames observada em populações de A. rubra é atualmente uma característica polimórfica na espécie. Adicionalmente, tal fato indicaria que a aquisição dos estaminódios seria recente na história evolutiva de Almeidea, como demonstrado em estudos de outros grupos com polimorfismo quanto à presença de estaminódios nas flores (Walker-Larsen \& Harder 2000).

O plano de monossimetria observado nas flores de A. bracteata e C. macrophyllus é uma característica muito comum em representantes de Galipeinae (Engler 1931, El Ottra et al. em prep., Capitulo 1). Neste grupo o principal fator gerador da monossimetria floral é a redução de parte do androceu a estaminódios, restando geralmente apenas dois estames férteis na porção posterior (dorsal) da flor (Kubitzki et al. 2011; El Ottra et al. 2013, em prep., Capítulo 1). Ainda, nestas espécies os lobos da corola podem ser levemente monométricos, por sua sutil distribuição desigual, mas esta feição não parece ter qualquer influência na biologia floral das espécies. Funcionalmente, os lobos reflexos da corola foram utilizados como local de pouso para os insetos, como já reportado para outras Galipeinae (i.e. A. rubra, El Ottra et al. submetido, Capítulo 2). Mas a distribuição destes não pareceu influenciar de alguma maneira o comportamento do visitante floral ao pousar na flor.

Como a monossimetria floral é amplamente distribuída em Angiospermas, existem diversas hipóteses sobre as possíveis razões de seu surgimento na evolução do grupo, a maioria delas relacionadas à polinização (Neal et al. 1998; Endress 2012). Notadamente a polinização por abelhas é correntemente considerada fator causador da evolução de monossimetria, ao menos em algum momento da evolução dos grupos, e isso ocorreria devido aos hábitos destes animais. De fato, o posicionamento das anteras na porção dorsal da flor é 
considerado como uma estratégia propiciando redução da perda de pólen para abelhas que buscam tal recurso como alimento (Westerkamp e Classen-Bockhoff 2007). Também a precisão de deposição do pólen no corpo do polinizador, bem como a formação de plataformas de pouso a insetos, são considerados fatores que devem ter influenciado a evolução da monossimetria floral (Faegri e van der Pijl 1979; Neal et al. 1998; Endress 1999). No entanto, as delicadas plataformas de pouso formadas pelos lobos da corola nas Galipeinae observadas até o momento não parecem ser grandemente influenciadas funcionalmente pela leve monossimetria apresentada pela corola em algumas flores (i.e. algumas flores de $A$. bracteata, A. rubra e C. macrophyllus). No entanto, já que outras espécies de Galipeinae apresentam lobos da corola fortemente monossimétricos (e.g. Conchocarpus cuneifolius, Raputiarana subsigmoidea; El Ottra et al. in prep., Capítulo 1), tal característica teria ainda que ser funcionalmente avaliada nestas espécies para melhor aferir sua influência nestes sistemas de polinização.

Os fatores expostos acima podem constituir evidências de que a evolução da monossimetria floral de Galipeinae tenha sido influenciada pelas funções assumidas pelos estaminódios na biologia floral do grupo. Uma vez que a monossimetria no grupo é principalmente causada pela presença dos estaminódios (principal componente visual da monossimetria; El Ottra et al. em prep., Capítulo 1), pode-se supor que a manutenção destes na evolução das flores do grupo seja devida principalmente aos aspectos funcionais observados em tais estruturas (apresentação secundária do pólen, local de apoio aos insetos, produção de odor, retenção de pólen, redução do diâmetro do tubo floral). Como já mencionado, assume-se que nos casos onde estaminódios não são funcionais em Angiospemas estes são logo perdidos na evolução dos grupos (Walker-Larsen \& Harder 2000), porém isso não ocorreu na maioria das espécies de Galipeinae. Por isso inferimos que suas funções, e consequentemente a monossimetria floral gerada pela sua presença, provavelmente acarretaram ou influenciaram a retenção dos estaminódios neste grupo. No entanto, se considerarmos as outras hipótese acima apresentadas, sobre os fatores influenciando a evolução da monossimetria floral, estas também poderiam ter atuado, dado que foi observado em alguns casos a polinização por abelhas no grupo, bem como a polinização nototríbica (Piedade e Ranga 1994; El Ottra et al. in prep., este estudo). Apenas com mais estudos da biologia floral e polinização de mais espécies do grupo, abrangendo maior variação na simetria floral dos diferentes órgãos, e considerando a filogenia destas, será possível ter uma ideia mais clara acerca dos variados fatores que podem ter afetado a evolução da monossimetria no grupo. 
Hercogamia, dicogamia e aspectos funcionais do tubo floral em Rutaceae

Em Conchocarpus macrophyllus e Angostura bracteata foi constatado o fenômeno da hercogamia (i.e. a separação espacial da apresentação do pólen em relação à recepção do mesmo entre flores ou na mesma flor, no caso das flores bissexuadas; Webb e Lloyd 1986), porém de diferentes tipos. Em C. macrophyllus ela é do tipo "hercogamia reversa" caracterizada pelo estigma incluso e anteras na fauce da corola -, enquanto em A. bracteata é do tipo "hercogamia de aproximação", uma vez que na fase feminina da flor o estigma é apresentado à frente do nível das anteras. A hercogamia tem ampla ocorrência em Angiospermas e é vista como um mecanismo que restringe a auto-fecundação, promovendo assim a fecundação cruzada, bem como um mecanismo que reduziria a interferência entre o componente masculino (pólen) e feminino (estigma) das flores (Webb e Lloyd 1986). Particularmente a hercogamia reversa, como encontrada em Conchocarpus macrophyllus, já foi observada em outras Galipeinae como C. obovatus Nees \& Mart., C. macrocarpus Kallunki \& Pirani, C. cyrtanthus, C. odoratissimus (Lindl.) Kallunki \& Pirani, C. concinnus Kallunki , $R$. nodosa e $R$. resinosa Ness \& Mart. (El Ottra et al. em prep., Capítulo 1). Por outro lado, a hercogamia de aproximação foi observada não só em A. bracteata, mas também em Galipea jasminiflora (Piedade e Ranga 1993), Almeidea rubra (El Ottra et al. submetido, Capítulo 2), Neoraputia trifoliata (Engl.) Emmerich, Raputiarana subsigmoidea (Ducke) Emmerich, Ravenia infelix Vell. (El Ottra et al. em prep.), Erythrochiton brasiliensis Nees \& Mart e Conchocarpus heterophyllus (A.St.-Hil.) Kallunki \& Pirani (J.H.L. El Ottra obs. pess.). Assim a posse de flores hercogâmicas foi considerada uma possível sinapomorfia para o clado das Galipeinae de flores tubulosas, dado que está é amplamente distribuída no grupo (El Ottra et al. em prep., Capítulo 1). Adicionalmente, em grupos com parentesco próximo ao clado das Galipeinae de flores tubulosas (Groppo et al. 2012), a hercogamia não é relatada na literatura e nem é evidente pela morfologia das flores destes representantes (El Ottra et al., em prep., Capítulo 1). De modo semelhante, em outras Rutaceae a hercogamia é um fenômeno raramente observado, e superficialmente descrito apenas para Aegle marmelos (Rutoideae, Aurantieae; Singal et al. 2011).

Sendo tão amplamente distribuída em Angiospermas, a hercogamia é frequentemente encontrada em conjunto com o fenômeno da dicogamia (Faegri \& van der Pijl 1979), como observado agora em Angostura bracteata. Nesta espécie a hercogamia e a protrandria são acompanhadas por grandes alterações referentes ao posicionamento e alongamento do estilete e androceu, caracterizando duas fases florais bem marcadas: a masculina, com anteras exsertas liberando pólen, e a feminina, com o estigma exserto do tubo floral e receptivo. Tais 
fases foram observadas também em Erythrochiton brasiliensis, Conchocarpus heterophyllus (J.H.L. El Ottra obs. pess.). De modo semelhante, a mudança na conformação dos órgãos de polinização ao longo da antese (anteras exsertas seguido de estigma exserto) também se observa em Neoraputia trifoliata, Raputiarana subsigmoidea e Ravenia infelix (El Ottra et al. em prep., Capítulo 1). Na flor de Galipea jasminiflora observa-se mudança na conformação dos estames e estilete, porém sem a ocorrência de protrandria (Piedade e Ranga 1994). Alternativamente, a presença de protrandria e a hercogamia de aproximação, sem alterações marcadas no posicionamento dos órgãos de polinização durante a antese, foi reportada apenas para Almeidea rubra (El Ottra et al. submetido, Capítulo 3). A ocorrência conjunta de protrandria e hercogamia em flores é vista como um mecanismo eficiente em evitar a autopolinização espontânea em espécies autocompatíveis (SanMartin-Gajardo e Freitas 1999; SanMartin-Gajardo e Sazima 2003). Seria interessante testar esta ideia por meio de futuros estudos sobre o sistema reprodutivo de A. bracteata e outras Galipeinae com fases florais semelhantes. Diferentemente da hercogamia, a protrandria é considerada um fenômeno comum em flores de Rutaceae (Kubitzki et al. 2011).

A existência de relação entre a ocorrência de flores tubulosas conjuntamente com a hercogamia já foi aventada em alguns sistemas de polinização. A hercogamia reversa foi reportada apenas para alguns grupos com corolas tubulosas, como Daphne (Thymeleaceae), Tulbaghia violaceae (Liliaceae), Drachophyllum (Epacridaceae; Webb e Lloyd 1986, Müller 1875), enquanto a hercogamia de aproximação é um fenômeno mais comum, amplamente distribuído em Angiospermas, em flores de diferentes arquiteturas (Webb \& Lloyd 1986). Adicionalmente, alguns estudos já feitos sobre a evolução de polimorfismo estilar indicam que a hercogamia de aproximação estaria associada a muitos tipos de visitantes florais, enquanto que a hercogamia reversa, além de ser menos comum, estaria associada à polinização por lepidópteros (mariposas e borboletas; Barret e Harder 2005). De fato, como observado no presente estudo, os lepidópteros são o principal grupo funcional de polinizadores de C. macrophyllus, porém não os únicos, o que sustenta apenas parcialmente essa associação. No entanto, nossas observações da biologia floral e comportamento dos polinizadores no acesso ao néctar demonstram que o tubo floral tem participação na funcionalidade da hercogamia nas espécies estudadas. Este pode promover a eficiente segregação espacial dos órgãos reprodutivos ao longo da antese, no caso das espécies com fases de estigma incluso e exserto. Também, no caso das espécies com hercogamia reversa, e anteras e estigmas inclusos em um tubo floral estreito, este contribui para o contato ordenado dos polinizadores aos órgãos reprodutivos dentro do tubo. 
Comparando-se os achados deste estudo com outros já feitos sobre a biologia floral e polinização de representantes de Galipeinae, conclui-se que os grupos funcionais de polinizadores encontrados até o momento são em maioria os esperados, considerando a ocorrência de flores tubulosas e nectário no fundo do tubo. No caso, estes grupos correspondem a animais de língua ou bico longo o suficiente para alcançar o néctar, como beija-flores (Erythrochiton brasiliensis, Lopes 2002; Almeidea rubra El Ottra et al. submetido Capítulo 2, Angostura bracteata, este estudo), borboletas (Galipea jasminiflora, Piedade e Ranga 1994; Almeidea rubra El Ottra et al. submetido, Capítulo 2; Angostura bracteata e Conchocarpus macrophyllus, este estudo), mariposas pousadoras (Piedade e Ranga 1994; Angostura bracteata, este estudo) e abelhas médio porte e língua relativamente longa (Conchocarpus macrophyllus, este estudo). O pólen é menos frequentemente coletado como recurso, não havendo relação com o comprimento das partes bucais do animal com esse hábito, especialmente nas espécies onde as anteras são relativamente expostas (Proctor et al. 1996). Ainda em algumas espécies as abelhas apresentam-se primariamente como pilhadoras de pólen (Galipea jasminiflora, Piedade e Ranga 1994; Almeidea rubra El Ottra et al. submetido, Capitulo 2; Angostura bracteata e Conchocarpus macrophyllus, este estudo). Exceção seria o caso de C. macrophyllus, onde ambos os recursos (pólen e néctar) são oferecidos aos polinizadores mais frequentes da espécie (Heliconius) bem como a alguns polinizadores secundários, no caso abelhas ( $P$. fervida, este estudo). Porém, dado que nesta espécie as anteras estão inclusas no ápice do tubo floral, este muito estreito em $C$. macrophyllus, mesmo o acesso ao pólen parece restrito a animais que possuam partes bucais relativamente especializadas para acessá-lo, como é o caso de P. fervida e Heliconius (Aguiar e Melo 2001; Krenn 2010). Em outras espécies de Rutoideae com parentesco próximo às Galipeinae, a ocorrência de flores com livre acesso ao néctar e pólen (não tubulosas) é comum (El Ottra et al. em prep., Capítulo 1). Nestas espécies tais feições florais parecem estar relacionadas aos sistemas de polinização comparativamente mais generalistas observados, com amplo espectro de grupos funcionais de pilhadores, ou alternativamente, especializados em polinização por moscas (Barbosa 1999; Pombal e Morellato 2000).

Analisando comparativamente os registros de polinização existentes sobre a família Rutaceae, nota-se que enquanto a entomofilia é considerada o tipo de polinização mais comum (Engler, 1931; Kubitzki et al. 2011), a ornitofilia é mais raramente reportada (i.e. Paton e Ford 1976; Armstrong 1979; Ford et al. 1979; Lopes 2002; El Ottra et al. em prep., Capítulo 1). Porém, os estudos sobre a polinização por aves em Rutaceae provêm exclusivamente das regiões Neotropical e Australiana, onde há grande diversidade de aves 
especializadas na dieta nectarívora (notadamente Throchilidae e Meliphagidae, respectivamente), e por isso é possível que este modo de polinização seja mais comum nestas regiões do que previamente reportado para a família. Também a ocorrência em Rutaceae de grupos com flores tubulosas coincide com estas duas regiões do globo: representantes de Boronieae na região Australiana, e de Galipeinae na região Neotropical. As flores de Boronieae principalmente polinizadas por aves apresentam presumivelmente maior especialização nas características florais relacionadas a esse modo de polinização (Armstrong 1979; El Ottra et al. em prep. Capítulo 2). Estas características florais seriam principalmente o néctar copioso e diluído, tubo floral relativamente longo e largo, flores usualmente pendentes e destituídas de plataforma de pouso para insetos (El Ottra et al. submetido, Capítulo 2). Diferentemente, nas Galipeinae com flores tubulosas a situação de especialização floral a um único grupo funcional de polinizadores não foi reportada até o momento.

Nos casos reportados com representantes da subtribo Galipeinae até o momento, há sempre de dois a três grupos funcionais de polinizadores atuando nas espécies, em diferentes frequências e, supostamente, importância nos sistemas de polinização, a saber: borboletas, beija-flores, e possivelmente abelhas, em A. rubra (El Ottra et al. submetido, Capítulo 2); lepidópteros (diurnos e noturnos) e beija-flores em A. bracteata; lepidópteros diurnos e noturnos em G. jasminiflora (Piedade e Ranga 1994); borboletas e abelhas em $C$. macrophyllus. No entanto, G. jasminiflora parece ter um sistema o sistema de polinização comparativamente mais especializado à polinização por lepidópteros, notadamente aos noturnos. Isto porque estes animais apresentaram grande frequência e diversidade de espécies observadas na polinização de G. jasminiflora, frente à única espécie de borboleta observada polinizando-a durante o dia (Piedade e Ranga 1994). Quanto às características florais que indicariam esta especialização, a espécie apresenta feições tipicamente falenófilas (cor branca, antese noturna, tubo longo e fino, entre 15 e $17 \mathrm{~mm}$ de comprimento, odor adocicado). Não fica claro no estudo porque os lepidópteros diurnos foram tão pouco frequentes, dado que a flor dura dois dias. Uma possível explicação seria que a fauna de borboletas poderia ser reduzida na área por conta das perturbações antrópicas na região, dado que o estudo foi feito em um fragmento de Mata Atlântica muito próximo à área urbana (Campinas, São Paulo). Ainda, características do néctar não foram estudadas por Piedade e Ranga (1994), sendo apenas mencionado sua produção em pouca quantidade, ao longo do dia e noite. Por tanto, mais estudos são necessários para se entender este aspecto da polinização de G. jasminiflora. Tubos florais longos e constritos são vistos como atributos indicativos da especialização a lepidópteros (Nilsson 1987, Nilsson et al. 1985). A ocorrência de outras Galipeinae com tubos florais comparativamente mais longos e finos do que os de G. jasminiflora, como espécies de 
Ticorea (Kallunki 1998, alcançando ca. de $40 \mathrm{~mm}$ de comprimento ou mais, e ca de 1,5mm de diâmetro, J.H. L. El Ottra obs. pess.), leva à suposição de que possa haver espécies do grupo com sistema de polinização especializado em lepidópteros.

\section{Co-florescência e polinização}

Nas populações co-florescentes analisadas neste estudo, enquanto alguns grupos de polinizadores são compartilhados pelas espécies vegetais, outros visitam exclusivamente uma ou outra espécie. C. macrophyllus e A. bracteata compartilham três espécies de lepidópteros diurnos (tabela 1 e 2), enquanto que as abelhas Osiris sp e $P$. fervida visitaram apenas $C$. macrophyllus, mesmo quando ambas as espécies de plantas encontravam-se lado a lado em florescimento. A ausência da participação de abelhas na polinização de Angostura bracteata, pode ser devida a características morfológicas das flores, bem como do néctar. Tubos florais relativamente longos e finos, como os de $A$. bracteata, poderiam ser vistos como estruturas morfológicas que impediriam a tomada do néctar por abelhas sem língua suficientemente longa para alcançar o recurso, como as duas espécies de abelhas observadas. Também plataformas de pouso delicadas, como as formadas pelos lobos da corola/estaminódios desta espécie poderiam ser inadequadas ao pouso de abelhas maiores. Estas potencialmente possuiriam probóscide longa o bastante para alcançar este recurso em flores de tubo relativamente longo (Endress 1994; Proctor et al. 1996). De fato, abelhas de variados portes foram observadas na área onde as espécies floresciam, porém estas ou visitaram apenas $C$. macrophyllus, ou visitaram outras espécies nas proximidades (e.g. C. cyrtanthus, J.H.L. El Ottra obs. pess.). Também outra característica que poderia evitar a visita das abelhas maiores seriam relativas ao néctar. Este apresentou concentração relativamente diluída, e abelhas deste porte apresentariam preferência a um néctar mais concentrado em açúcares e em maior volume (Bolton e Feinsinger 1978; Opler 1983; Baker e Baker 1982). Ainda é reportado que flores brancas visitadas por beija-flores, como as de A. bracteata, geralmente são pouco visíveis a abelhas em decorrência de suas propriedade UV-refringentes (Lunau et al. 2011), o que poderia indicar também a ocorrência de exclusão sensorial de pelo menos parte das abelhas (uma espécie não identificada de Apidae foi vista pilhando as anteras de A. bracteata neste estudo).

De modo semelhante, o beija-flor $P$. idaliae, visitou apenas flores de Angostura bracteata mesmo quando C. macrophyllus encontravam-se lado a lado em florescimento. A ausência da participação do beija-flor na polinização de C. macrophyllus pode ser devida 
também a características morfológicas das flores, bem como do néctar. Neste caso tanto o estreito tubo floral, como o pequeno volume de néctar apresentado por flor, podem ser atributos que tornariam a flor C.macrophyllus inadequada à visitação por $P$. idaliae. Considerando que na área de estudo há outras espécies com maior volume de néctar por flor, bem como com tubo floral comparativamente mais largo (e.g. Passiflora speciosa Gardner, Passifloraceae, Varassin et al. 2001; Conchocarpus cyrtanthus, J.H.L. El Ottra obs. pess.), esta ave possivelmente rejeitaria as flores de C. macrophyllus frente a estas espécies com recurso e/ou morfologia mais adequada ao seu forrageio.

Face às observações acerca do sistema de polinização de $C$. macrophyllus e $A$. bracteata e do fenômeno de sobreposição de floração destas, questões interessantes dentro do contexto da ecologia de comunidades no interior das florestas de tabuleiro da região Sudeste brasileira poderiam ser abordadas em futuros estudos. O compartilhamento parcial das espécies de borboletas foi apenas observado no ano de observação em que indivíduos de ambas as espécies floresceram lado a lado, em uma área de aproximadamente $60 \mathrm{~m}^{2}$, e conjuntamente com uma outra espécies de Galipeinae que não era foco deste estudo $(C$. cyrtanthus). Tendo em vista tal fato, duas hipóteses alternativas poderiam ser testadas em relação às interações ecológicas que poderiam estar ocorrendo na comunidade: as espécies estariam competindo entre si por parte dos polinizadores, o que alteraria de modo negativo a taxa de visitação destas, ou estaria ocorrendo o fenômeno de facilitação. Teoricamente esta facilitação poderia ser acarretada pelo aumento da atratividade da área gerada pelo florescimento conjunto das espécies, e consequentemente elevando o número total de polinizadores para todas as espécies, mesmo compartilhando polinizadores (Moeller 2004). No entanto, estudos de frequência de polinização mais detalhados considerando a fenologia das espécies, seriam necessários para testar tais hipóteses. Porém, flores com tão pouca quantidade de recurso, como as flores de C. macrophyllus, co-florescendo com flores de comparativamente mais recurso, além de odor adocicado e morfologia geral semelhante (i.e. A. bracteata e C. cyrtanthus) indicaria que pelo menos com relação a esta espécie a facilitação seria a hipótese mais provável, bem como possivelmente polinização por engano por parte de alguns polinizadores. O fato da coloração das flores de $C$. macrophyllus esmaecer ao final da antese, tornando-se quase brancas, reforçaria a ideia de polinização por engano, especialmente no período noturno. Semelhante esmaecimento da cor em flores mais velhas também foi observado em A. rubra (J.H. L. El Ottra et al. submetido, Capítulo 2). No entanto, se tal fenômeno ocorre, é raro pois não foi observado em qualquer das espécies no período de estudo. Outra característica que poderia favorecer a facilitação para C. macrophyllus seria um período extenso de floração. De fato, algumas das suas populações apresentaram período de 
florada relativamente longo na área, chegando a seis meses, o que não foi observado nas outras duas espécies co-florescentes na área, com período de florada relativamente mais breve (A. bracteata e C. cyrtanthus).

Outro aspecto que poderia ser estudado quanto à co-florescência das espécies refere-se ao resultado da mistura e transferência de pólen heteroespecífico dentre as espécies. Dado o compartilhamento de alguns polinizadores, seria necessário avaliar o efeito do depósito de pólen heteroespecífico nos estigmas de cada uma das espécies de Galipeinae, e suas consequências no sucesso reprodutivo destas. Há raros estudos reportando as consequências de tal interação pólen-pistilo em populações co-florescentes, e ainda os efeitos resultantes desta interação não são claramente previsíveis (Ashman e Arceo-Gómez, 2013).

\section{Considerações finais}

Neste trabalho descrevemos pela primeira vez a biologia floral e polinização das duas espécies co-florescentes de Galipeinae em Mata Atlântica brasileira. Adicionalmente, reportamos pela primeira vez características funcionais aos estaminódios, uma feição tão amplamente distribuída na subtribo. Com nossas observações, foi possível concluir que enquanto algumas características florais contribuem para o compartilhamento de alguns grupos de polinizadores entre A. bracteata e C. macrophyllus, outras parecem restringir alguns grupos funcionais de animais a polinizarem uma ou outra espécie. Realmente, seria esperado que flores basicamente semelhantes quanto à arquitetura (flores tubulosas) e recurso (néctar) e coloração (cores claras) compartilhassem ao menos parte dos polinizadores na área, no caso algumas espécies de borboleta. No entanto, é interessante notar que são as pequenas variações nesse plano básico da morfologia floral, bem como no recurso oferecido, que parecem restringir a visita de um ou outro grupo de animais a apenas uma destas espécies, no caso abelhas apenas em C. macrophyllus, e beija-flores apenas em A. bracteata. Notadamente características relacionadas ao comprimento e diâmetro do tubo floral e ao volume do néctar parecem claramente relacionadas e essa restrição: enquanto tubos longos e finos como o de $A$. bracteata restringiriam a visitação e abelhas de porte menor, o néctar diluído e em pouca quantidade evitariam a visita das abelhas maiores. Diferentemente a não participação do beijaflor na polinização de $C$. macrophyllus poderia estar relacionada ao tubo floral muito estreito bem como à pouca quantidade de recursos oferecidos por flor. Além disso, todas as características acima citadas indicam que há maior especialização floral relacionada aos grupos principais de polinizadores observados para ambas as espécies - os lepidópteros. No 
entanto, não fica clara a razão de apenas algumas espécies de borboletas serem compartilhadas entre as espécies, enquanto que a maioria visita ou uma ou outra. Tal fato poderia indicar diferenças na preferência dentre as espécies de borboletas em relação a certas características florais, porém isso não é claro face ao atual conhecimento ainda parcial deste grupo de polinizadores. De fato, há poucos estudos detalhados sobre o papel das borboletas como polinizadoras (Proctor e Yeo 1976; Bawa 1990; Weiss 2001; Araujo et al. 2014), o que dificulta o entendimento da existência de preferência floral dentre os representantes deste grupo.

Ainda restam muitas questões para estudos futuros sobre o sistema reprodutivo de Angostura bracteata, no sentido de avaliar qual dos grupos de polinizadores - diurnos ou noturnos- seriam o mais efetivo na polinização da espécie. Acredita-se que o polinizador mais eficiente seja aquele que determina a força de seleção maior sobre as características florais ao longo da evolução (Fenster et al. 2004). Se assim considerarmos, seria esperado que mariposas possam ser os polinizadores mais importantes moldando a evolução floral de diversas espécies de Galipeinae, dado que não apenas A. bracteata, bem como outras espécies do gênero, espécies de Galipea e Ticorea, apresentam características florais relacionadas à falenofilia (flores brancas a creme, tubo floral longo e fino, odor adocicado; Faegri e van der Pijl 1979; Kallunki 1998b; Kallunki e Pirani 1999; Pirani 1999; Pirani 2004). No entanto tal hipótese ainda carece de comprovação por meio de estudos ecológicos, considerando-se também o contexto filogenético das espécies.

\section{AGRADECIMENTOS}

Agradecemos a José Simplício (RNV) e ao Dr. Marcelo Duarte (MZUSP) pelo auxílio na identificação dos lepidópteros; a Dra. Silvia Pedro (FFCLRP) e ao Dr. Antonio Aguiar (UnB), pelo auxílio na identificação das abelhas; ao MSc. Pietro Maruyama (Unicamp), pelo auxílio na identificação do beija-flor; a MSc. Camila Vieira pela identificação das aranhas (Unicamp). O primeiro autor agradece a MSc. Pietro K. Maruyama e ao Dr. Felipe W. Amorin (UNESP) pelas discussões e sugestões a respeito de polinizadores noturnos e seu registro em campo. O primeiro autor também agradece a Rachel Koch (USP), MSc. Cíntia Luiza da Silva Luz (USP), MSc. Marcelo Devechi (USP) e Geovane Siqueira (RNV) pelo auxílio durante os trabalhos de campo. Agradecemos à Reserva Natural Vale (Linhares Brasil) pela permissão em trabalhar na área da reserva, bem como ao apoio logístico e financeiro aos tabalhos de campo. Este trabalho foi principalmente financiado pela Fundação de Amparo à 
Pesquisa do Estado de São Paulo, pelas bolsas concedidas a J.H. L. El Ottra e J. R. Pirani (Processo FAPESP no 09/54569-9 e 09/08764-4), e pelo Conselho Nacional de Desenvolvimento e Pesquisa, com a bolsa de produtividade concedida a J.R. Pirani.

\section{REFERÊNCIAS}

Aguiar AJC, Melo GAR (2011) Revision and phylogeny of the bee genus Paratetrapedia Moure, with description of a new genus from the Andean Cordillera (Hymenoptera, Apidae,Tapinotaspidini). Zool. J. Linn. Soc. 162: 351-442

Aguiar JMRBV, Pansarin LM, Ackerman JD, Pansarin ER (2012) Biotic versus abiotic pollination in Oeceoclades maculate (Lindl.) Lindl. (Orchidaceae) Plant Species Biol. 27: 86-95

Alondo-Pedano M, Ortega-Baes P (2012) Generalized and complementary pollination system in the Andean cactus Echinopsis schickendantzii. Plant Syst. Evol. 298: 1671- 1677

Alves-dos-Santos I (2002) Flower-visiting bees and the breakdown of the tristylous breeding system of Eichhornia azurea (Swartz) Kunth (Pontederiaceae). Biol. J. Linn. Soc. 77: 499-507.

Amorin F, Galetto L, Sazima M (2013) Beyond the pollination syndrome: nectar ecology and the role of diurnal and nocturnal pollinators in the reproductive success of Inga sessilis (Fabaceae). Plant Biol. 15: 317-327

Araújo LDA, Quirino ZGM, Machado IC (2014) High specialisation in the pollination system of Mandevilla tenuifolia (J.C. Mikan) Woodson (Apocynaceae) drives the effectiveness of butterflies as pollinators. Plant Biol. doi: 10.1111/plb.12152. [in press]

Araujo LD, Quirino ZG, Machado IC (2011) Fenologia reprodutiva, biologia floral e polinização de Allamanda blanchetii, uma Apocynaceae endêmica da Caatinga. Rev. Bras. Bot. 34: 211-222

Armstrong JA (1979) Biotic pollination mechanism in the Australian flora - a review. New Zeal. J. Bot. 17: 467-508

Ashman TL, Arceo-Gómez, G (2013) Toward a predictive understanding of the fitness costs of heterospecific pollen receipt and its importance in co-flowering communities. Am. J. Bot. 100: $1061-1070$

Avila RS Jr, Freitas L (2011) Frequency of visits and efficiency of pollination by diurnal and nocturnal lepidopterans for the dioecious tree Randia itatiaiae (Rubiaceae). Aust. J. Bot 59: 176184

Baker HG, Baker I (1982) Chemical constituents of nectar in relation to pollination mechanisms and phylogeny. In: Nitecki HM (ed) Biochemical aspects of evolutionary biology. University of Chicago Press, Chicago, 137-171

Barbosa AAA (1999) Hortia brasiliana Vand (Rutaceae): polinização por aves Passeriformes no cerrado do sudeste brasileiro. Rer. Bras. Bot. 22: 99-105.

Barret SCH, Harder LD (2005) The evolution of polymorphic sexual systems in daffodils (Narcissus). New Phytol. 165: 45-53

Bawa S (1990) Plant-pollinator interactions in tropical rain forests. Annu. Rev. Ecol. Syst. 21: 399422. 
Bloomberg SP, Garland TJr (2002) Tempo and mode in evolution: phylogenetic inertia, adaptation and comparative methods. J. Evolution. Biol. 15: 899-910

Bolton AB, Feinsinger P (1978) Why do hummingbird flowers secrete dilute nectars ? Biotropica 10:307-309

Bruniera CP, Silva CI, Groppo M (2011) A new species of Almeidea (Galipeinae, Galipeeae, Rutaceae) from Eastern Brazil. Brittonia 63: 281-285

Camillo E, Garófalo CA, Serrano, JC (1993) Hábitos de nidificação de Melitoma segmentaria, Centris collaris, Centris fuscata e Paratetrapedia gigantea (Hymenoptera, Anthophoridae). Rev. Bras. entomol. 37:145-156

Castellanos MC, Wilson P, Thomson JD (2004) 'Anti-bee' and 'pro-bird' changes during the evolution of hummingbird pollination in Penstemon flowers. J. Evol. Biol. 17: 876-885

Costa LP, Leite YLR, da Fonseca GAB, da Fonseca MT (2000) Biogeography of South American forest mammals: endemism and diversity in the Atlantic Forest. Biotropica 32:872-881

Cruden RW, Hermann-Parker SM (1979) Butterfly pollination of Caesalpinia pulcherrima, with observations on a psychophilous syndrome. J. Ecol. 67: 155-168

Dafni A, Pacini E, Nepi M (2005) Pollen and stigma biology. In: Dafni A, Kevan PG, Husband BC (eds) Practical Pollination Biology. Cambridge, Ontario, pp. 83-146

El Ottra JHL, Pirani JR, Endress PK (2013) Fusion within and between whorls of floral organs in Galipeinae (Rutaceae): structural features and evolutionary implications. Ann. Bot. 111: 821-837

Endress PK (1984) The role of inner staminodes in the floral display of some relic Magnoliales. Pl. Syst. Evol. 146: 269-282

Endress PK (1986) Reproductive structures and phylogenetic significance of extant primitive angiosperms. Pl. Syst. Evol 152: 1-28

Endress PK (1994) Diversity and evolutionary biology of tropical flowers. Cambridge University Press, Cambridge

Endress PK (1999) Symmetry in flowers: diversity and evolution. Int. J. Pl. Sci. 160(Suppl. 6): S3S23

Endress PK (2012) The immense diversity of floral monosymmetry and asymmetry across angiosperms. Bot. Rev. 78: 345-397

Engler A (1931) Rutaceae. In: Engler A, Prantl K (eds) Die natürlichen Pflanzenfamilien.Vol. 19a, 2nd edn. Engelmann, Leipzig, pp. 187-359

Faegri L, van der Pijl L (1979) The principles of pollination ecology, 3rd edn. Pergamon Press, New York

Fenster CB, Armbruster WS, Wilson P, Dudash MR, Thomson, JD (2004) Pollination syndromes and floral specialization. Annu. Rev. Ecol. Evol. Syst. 35: 375-403

Ford AH, Paton DC, Forde N (1979) Birds as pollinators of Australian plants. New Zeal. J. Bot. 17:4, 509-519 
Frankie GW, Haber WA, Opler PA, Bawa KS (1983) Characteristics and organization of the large bee pollination system in the Costa Rican dry forest. In: Jones CE, Little RJ (eds) Handbook of Experimental Pollination Biology. Scientific and Academic Editions, New York, 411-447

Fleming TH, Geiselman C, Kress WJ (2009) The evolution of bat pollination: a phylogenetic perspective. Ann. Bot. 104: 1017-1043

Galleto L, Bernadello G (2005) Rewards in Flower - Nectar. In: Dafni A, Kevan PG, Husband BC (eds) Practical Pollination Biology. Cambridge, Ontario, pp. 261-313

Gilbert LE (1972) Pollen feeding and reproductive biology of Heliconius butterflies. Proc. Natl. Acad. Sci. 69: 1403-1407

Groppo M, Pirani JR, Salatino MLF, Blanco SR, Kallunki JA (2008) Phylogeny of Rutaceae based on two noncoding regions from cpDNA. Am. J. Bot. 95: 985-1005

Groppo M, Kallunki JA, Pirani JR, Antonelli, A (2012) Chilean Pitavia more closely related to Oceania and Old World Rutaceae than Neotropical groups: evidence from two cpDNA non-coding regions, with a new subfamilial classification of the family. PhytoKeys 19: 9-29

Heidi EMD, Raguso RA, Knudsen JT, Ayasse M (2005) Scent as an attractant. In: Dafni A, Kevan PG, Husband BC (eds) Practical Pollination Biology. Cambridge, Ontario, pp. 83-146

Howell GJ, Slater AT, Knox RB (1993) Secondary Pollen Presentation in Angiosperms and its Biological Significance. Austral. J. Bot. 41: 417-438

IBGE (2014). Instituto Brasileiro de Geografia e Estatística. ftp://ftp.ibge.gov.br/Cartas_e_Mapas/Mapas_Murais. Acesso em 12 Mar. 2014

Instituto de Pesquisas da Mata Atlântica (IPEMA) (2005) Conservação da Mata Atlântica no Espírito Santo: cobertura florestal e unidades de conservação. IPEMA, Vitória

Kearns C, Inouye W (1993) Techniques for pollination biologists. University Press of Colorado, Niwot

Köppen W (1948) Climatologia: com um estúdio de los climas de la tierra. Fondo de Cultura Econômica, México

Krenn HW (2008) Feeding behaviours of neotropical butterflies (Lepidoptera, Papilionoidea). Stapfia 80: $295-304$

Krenn HW (2010) Feeding mechanisms of adult Lepidoptera: structure, function, and evolution of the mouthparts. Annu. Rev. Entomol. 55: 307-327

Kallunki JA (1992) A revision of Erythrochiton sensu latu (Cuspariinae, Rutaceae). Brittonia 44: 107139

Kallunki JA (1994) Revision of Raputia Aubl. (Rutaceae, Cuspariinae): Brittonia 46: 279-295

Kallunki JA (1998a) Andreadoxa flava (Rutaceae, Cuspariinae): a new genus and species from Bahia, Brazil. Brittonia 50: 59-62

Kallunki JA (1998b) Revision of Ticorea Aubl. (Rutaceae, Galipeinae). Brittonia 50: 500-513

Kallunki JA (2009) Validation of Neoraputia (Galipeae, Rutaceae) and description of two new species from Eastern Brazil. Brittonia 61: 28-34 
Kallunki JA, Pirani JR (1998) Synopses of Angostura Roem. \& Schult. and Conchocarpus J. C. Mikan. Kew Bull. 53: 257-334

Kallunki JA, Groppo M (2007) Phylogenetic analyses of the subtribe Galipeinae (Rutaceae).URL:2007.botanyconference.org/engine/search/index.php?func=detail\&aid=1344. Acesso em: 12 Mar. 2014

Kubitzki K, Kallunki JA, Duretto M, Wilson PG (2011) Rutaceae. In: Kubitzki K (ed) The Families and Genera of Vascular Plants. Vol 10: Flowering Plants. Eudicots: Sapindales, Cucurbitales, Myrtaceae. Springer, Hamburg, pp. 276-356

Lopes A (2002) Polinização por beija-flores em remanescentes da Mata Atlântica Pernambucana, nordeste do Brasil. Dissertation, Universidade of Campinas

Lunau K, Papiorek S, Eltz T, Sazima M (2011) Avoidance of achromatic colours by bees provides a private niche for hummingbirds. J. Exp. Biol. 214: 1607-1612

Martén-Rodríguez S, Almarales-Castro A, Fenster CB (2009) Evaluation of pollination syndromes in Antillean Gesneriaceae: evidence for bat, hummingbird and generalized flowers. J. Ecol. 972: 348359

Maruyama PK, Amorin FW, Oliveira PE (2010) Night and day service: distyly and mixed pollination system in Faramea cyanea (Rubiaceae). Flora 205: 818-834

Manzano, VF, Tozzi AMGA (2004) Swartzia (Leguminosae, Papilionoideae, Swartzieae s.1.) na Reserva Natural da Companhia Vale do Rio Doce, Linhares, ES, Brasil. Rodriguésia 55: 95-113

Miyake T, Yahara T (1999) Theoretical evaluation of pollen transfer by nocturnal and diurnal pollinators: when should a flower open ? Oikos 86: 223-240

Moeller DA (2004) Facilitative interactions among plants via shared pollinators. Ecology 85: 32893301

Morton CM, KAllunki JA (1993) Pollen morphology of the subtribe Cuspariinae (Rutaceae). Brittonia 45: $286-314$

Morellato PC, Haddad CFB (2000) Introduction: The Brazilian Atlantic Forest. Biotropica 32: 786792

Müller H (1875) Fertilization of flowers by insects VIII. Nature 11:110-112

Myers N, Mittermeier RA, Mittermeier CG, Fonseca GAB, Kents J (2000) Biodiversity hotspots for conservation priorities. Nature 403: 853-858

Neal PR, A Dafni, M Giurfa (1998) Floral symmetry and its role in plant-pollinator systems: terminology, distribution, and hypotheses. Annu. Rev. Ecol. Syst. 29:345-373

Nilsson LA (1987) Angraecoid orchids and hawkmoths in central Madagascar: specialized pollination systems and generalist foragers. Biotropica 19: 310-318

Nilsson LA, Jonsson L, Randrianjohany E (1985) Monophily and pollination mechanisms in Angraecum arachnites Schltr. (Orchidaceae) in a guild of long tonged hawk-moths (Sphingidae) in Madagascar. Biol. J. Linn. Soc. 26: 1-19

Opler PA (1981) Nectar production in a tropical ecosystem. In: Elias TS, Bentley B (Eds) The Biology of Nectaries. Columbia University Press, New York, pp. 30-79 
Opler PA (1983) Nectar production in a tropical ecosystem. In: Bentley B, Elias, T (Eds) The biology of nectaries. Columbia University Press, New York, pp. 30-79

Ortega-Baes P, Saravial M, Sühring S, Godínez-Alvarez H, Zamar M (2011) Reproductive biology of Echinopsis terscheckii (Cactaceae): the role of nocturnal and diurnal pollinators. Plant Biol. 13: 3340

Orzack SH, Sober E (2001) Adaptation, phylogenetic inertia, and the method of controlled comparisons. In: Orzack SH, Sober E (eds) Adaptationism and Optimality. Cambridge University Press, Cambridge.

Oxford GS, Gillespie RG (1998) Evolution and ecology of spider coloration. Ann. Rev. Entomol. 43:619-643.

Pansarin ER, Amaral MCE (2008) Reproductive biology and pollination mechanisms of Epidendrum secundum (Orchidaceae). Floral variation: a consequence of natural hybridization? Plant Biol. 10: 211-219.

Paton DC, Ford HA (1976) Pollination by birds of native plants in south Australia. Emu 77, 7385

Peixoto AL, Gentry A (1990) Diversidade e composição florística da mata de tabuleiro na Reserva Florestal de Linhares (Espírito Santo, Brasil). Rev. Bras. Bot. 13: 19-25

Peixoto AL, Silva IM, Pereira OJ, Simonelli M, Jesus RM, Rolim SG (2008) Tabuleiro Forests North of the Rio Doce Natural Reserve, Espírito Santo, Brazil. In: Thomas WW, Britton EG (eds) The Atlantic Coastal Forest of Northeastern Brazil. Mem. New York Bot. Gard Vol. 100. The New York Botanical Garden, New York, pp. 137-141

Piedade LH, Ranga NT (1993) Ecologia da polinização de Galipea jasminiflora Engler (Rutaceae). Rev. Bras. Bot. 16: 151-157

Pirani JR (1999) Estudos taxonômicos em Rutaceae: revisão de Helietta e Balfourodendron (Pteleinae). Análise cladística de Pteleinae. Sinopse de Rutaceae do Brasil. Tese de livre-docência, Universidade de São Paulo, São Paulo

Pirani JR (2004) Three new species of Galipea (Rutaceae, Galipeinae) from Brazil. Bot. J. Linn. Soc. 144: $365-373$

Pirani JR, Groppo M, Kallunki JA (2012) Two new species and a new combination in Conchocarpus (Rutaceae, Galipeeae) from eastern Brazil. Kew Bull. 66: 1-7

Pombal ECP, Morrelato PC (2000) Differentiation of floral color and odor in two fly pollinated species of Metrodorea (Rutaceae) from Brazil. Pl. Syst. Evol. 221: 141-156

Prance GT (1982) Forest refuges: evidence from Woody angiosperms. In: Prance GT (ed) Biological diversification in the tropics. Columbia University Press, New York, pp 137-158

Proctor M, Yeo P (1973) The pollination of flowers. William Collins, Glasgow

Proctor M, Yeo P, Lack A (1996) The natural history of pollination. Harper Collins Publishers, London

Ronse Decraene LP, Smets EF (2001) Staminodes: Their Morphological and Evolutionary Significance. Bot. Rev. 67: 351-402

Ruschi A (1989) Aves do Brasil, Beija-flores. Vol. IV. Editora Expressão e Cultura, Rio de Janeiro 
SanMartin-Gajardo I, Freitas L (1999) Hummingbird pollination in Besleria longimucronata Hoehne (Gesneriaceae) in southeastern Brazil. Biociências 7:13-24

SanMartin-Gajardo I, Sazima M (2003) Non-euglossine bees also function as pollinators of Sinningia species (Gesneriaceae) in southeastern Brazil. Plant Biol. 7:1-7

Sedgley M (1982) Floral anatomy and pollen tube growth in the quandong Santalum acuminatum (R.Br.) A.DC. Austral. J. Bot. 30: 601-609

Shanks SS (1986) A revision of the Neotropical bee genus Osiris (Hymenoptera: Anthophoridae). Wasm. J. Biol. 44:1-56

Silberbauer-Gottsberger I, Gottsberger G (1975) Uber sphingophile angiospermen brasiliens. Pl. Syst. Evol. 123: 157-184

Silva JMC, de Sousa MC, Castelletti CHM (2004) Areas of endemism for passerine birds in the Atlantic Forest, South America. Glob. Ecol. Biogeogr. 13:85-92

Silveira FA, Melo GAR, Almeida EAB (2002) Abelhas brasileiras: sistemática e identificação. Fundação Araucária, Belo Horizonte

Singhal VK, Salwan A, Kumar P, Kaur J (2011) Phenology, pollination and breeding system of Aegle marmelos (Linn.) correa (Rutaceae) from India. New Forest 42:85-100

Singer RB, Sazima M (2001) Flower morphology and pollination mechanism in three sympatric Goodyerinae orchids from southeastern Brazil. Ann. Bot. 88: 989-997

Stiles FG (1981) Geographical aspects of bird-flower coevolution, with particular reference to Central America. Ann. Miss. Bot. Gard. 68: 323-51

Stiles GR, Freeman CE (1993) Patterns in floral nectar characteristic of some bird-visited plant species from Costa Rica. Biotropica 25: 191-205

Thomson JD, Wilson P, Valenzuela M, Malzone M (2000) Pollen presentation and pollination syndromes, with special reference to Penstemon. Plant Species Biol. 15:11-29

Tyler H, Brown KSJ, Wilson K (1994) Swallowtail butterflies of the Americas. A study in biological dynamics, ecological diversity, biosystematics and conservation. Scientific Publishers, Gainesville

Varassin IG, Trigo JR, Sazima M (2001) The role of nectar production, flower pigments and odour in the pollination of four species of Passiflora (Passifloraceae) in south- eastern Brazil. Bot. J. Linn. Soc. 136: 139-152

Vicenz RS, Agarez FV, Garay I (2003) A Região da REBIO Sooretama e da Reserva de Linhares e seu entorno: das características fisico-geográficas ao usa da terra. Parte 1. Diversidade Funcional da Cobertura Arbórea. In: Garay I, Rizzini CM (orgs) A Floresta Atlântica de Tabuleiro: diversidade funcional da cobertura arbórea. Vozes, Petrópolis, pp. 7-15

Waddingto KD (1976) Pollination of Apocynum sibicum (Apocynaceae) by Lepidoptera. Southw. Nat. 21: $31-36$

Walker-Larsen J, Harder LD (2000) The evolution of staminodes in angiosperms: patterns of stamen reduction, loss, and functional re-invention. Am. J. Bot. 87: 1367-1384

Walter HE (2010) Floral biology of Echinopsis chiloensis ssp. chiloensis (Cactaceae): Evidence for a mixed pollination syndrome. Flora 205: 757-763 
Webb CJ, Lloyd DG (1986) The avoidance of interference between the presentation of pollen and stigmas in Angiosperms. I. Dichogamy. New Zeal. J. Bot. 24: 135-162.

Weiss MR (2001) Vision and learning in some neglected pollinators: beetles,flies, moths and butterflies. In: Chittka L, Thomson JD (eds) Cognitive ecology of pollination. Cambridge University Press, Cambridge, pp. 171-190

Westerkamp C, Claßen-Bockhoff R (2007) Bilabiate flowers: the ultimate response to bees? Ann. Bot. 100: $361-374$

Wilson P, Castellanos MC, Wolfe AD, Thomson JD (2006) Shifts between bee- and bird-pollination among Penstemons. In: Waser NM, Ollerton J (eds) Plant-pollinator interactions: from specialization to generalization. Chicago University Press, Chicago, pp. 47-68

Wolf D, Braun N, Liede S (2002) Nocturnal versus diurnal pollination success in Isertia laevis (Rubiaceae): a sphingophilous plant visited by hummingbirds. Plant Biol. 5:71-78

Zeisler M (1938) Über die Abgrenzung der eigentlichen Narbenfläche mit Hilfe von Reaktionen. Beih. Bot. Centralbl. 58: 308-318 


\section{CONSIDERACÕES FINAIS}

Neste trabalho realizamos um estudo detalhado da estrutura floral de Galipeinae (morfologia, anatomia e histologia), buscando subsídios para sistemática e evolução do grupo, e também analisamos alguns aspectos funcionais das feições florais, por meio do estudo da biologia floral e polinização de alguns táxons. Com a integração destes dois tipos de estudo, buscamos contribuir para um entendimento mais abrangente sobre as características florais de Galipeinae.

O grande número de espécies de Galipeinae analisadas quanto à sua estrutura floral preencheu consideravelmente a lacuna de conhecimento sobre a diversidade neste grupo. Adicionalmente a análise detalhada e comparativa dos resultados possibilita agora que muitos dos caracteres florais da subtribo sejam codificados com maior precisão em futuros estudos de evolução de caracteres. Também, as hipóteses levantadas acerca da evolução dos mesmos poderão ser testadas em futuros estudos filogenéticos. Em relação à sistemática de Galipeinae, algumas características florais aqui estudadas vêem corroborar as relações de parentesco recuperadas pelas análises filogenéticas moleculares recentes, sobretudo dentro do "clado americano" de Rutoideae. Notadamente, encontramos sustentação dos dados florais à hipótese de monofilia do clado das Galipeinae excluindo-se Adiscanthus, e à relação de Adiscanthus e Hortia como grupos-irmãos. Ainda, encontramos que a estrutura floral corrobora a relação próxima de parentesco entre Ravenia e Ertela, bem como em relação à segregação de parte das espécies de Conchocarpus (C. cyrtanthus e C. concinnus) deste gênero, além da inclusão das espécies de Almeidea como parte de Conhocarpus (Capítulo 1).

Considerando a implicação das feições florais aqui estudadas em níveis hierárquicos mais abrangentes da sistemática, podemos destacar que características observadas no gineceu foram bastante relevantes nesse sentido. Características relacionadas aos óvulos, ginóforos, apocarpia e cômpito forneceram maior suporte à caracterização da estrutura floral para os clados contendo representantes de Sapindales, bem como de rosídeas. Adicionalmente a função protetora das pétalas aos órgãos internos dos botões foi aqui reportada pela primeira vez para representantes neotropicais de Rutaceae, sendo esta característica uma potencial sinapomorfia morfológica para ordem Sapindales (Capítulo 1). Diferentemente, com relação a outras características estudadas, encontramos claras evidências indicando evolução homoplástica, notadamente a presença de tubos florais na família. Ao elucidarmos as diferenças estruturais entre os tubos florais de Galipeinae e de Boronieae australianas (i.e., Correa), encontramos forte sustentação para a não homologia entre os mesmos (Anexo). 
Ainda, o estudo detalhado sobre a simetria floral de Galipeinae forneceu evidência de que alguns tipos de simetria observados sejam homoplásticos, ao menos na história evolutiva de alguns gêneros (Capítulo 1).

Em relação às características florais avaliadas sob uma perspectiva funcional (Capítulos 1, 2 e 3), podemos destacar sete, para as quais encontramos evidência de desempenharem importantes funções florais: monossimetria, tubo floral, hercogamia, odor floral, plataformas de pouso formadas pelos lobos da corola e estaminódios, e volume e concentração do néctar. Apesar da monossimetria floral ser gerada por variados fatores estruturais (Capítulo1), nas diversas espécies analisadas o principal componente da monossimetria é a conformação do androceu em muitos táxons. Nestes, comumente observamos a ocorrência de dois estames férteis na porção posterior da flor, e estaminódios na porção anterior da flor. Destacamos a função dos estaminódios em Angostura bracteata, relacionados à apresentação secundária do pólen na porção ventral da flor, e consequentemente ampliando as possibilidades de locais de deposição do pólen no corpo dos polinizadores (Capítulo 3). As funções observadas ou inferidas para os estaminódios nos táxons analisados nos levam a crer que sua ocorrência quase que universal nas flores de Galipeinae deve estar relacionada às funções assumidas por eles ao longo da evolução floral do grupo (Capítulo 1 e 3). Porém tal hipótese ainda deve ser avaliada por meio de mais estudos ecológicos com outras espécies, conjuntamente com estudos comparativos filogenéticos.

Em relação à hercogamia, mostramos no Capítulo 1 que tal feição é mais amplamente distribuída no grupo do que previamente reportado na literatura. Ainda, encontramos evidência de que a hercogamia do tipo reversa provavelmente esteja funcionalmente ligada à ocorrência do tubo floral, dado que este aumentaria a precisão no mecanismo de segregação espacial dos órgãos reprodutivos e contato ordenado destes aos polinizadores. Esta ideia baseou-se na observação das anteras e/ou estigmas inclusos no tubo floral, ao longo da antese ou em parte desta, conforme observado em várias espécies (Capítulo 1 e 3). Ainda, a hercogamia é vista como um mecanismo que reduz tanto a autopolinização espontânea como a interferência do componente feminino e masculino da flor (Capítulo 3). Tal aspecto seria interessante de ser abordado em futuros estudos sobre a biologia reprodutiva das espécies, bem como em estudos sobre possíveis padrões evolutivos desta característica.

Ainda em relação aos aspectos funcionais do tubo floral, sua ocorrência indicaria uma morfologia floral relativamente especializada, na medida em que restringe o espectro de 
animais aptos a prestar o serviço de polinização (Capítulo 2). Adicionalmente, dado a observação de que um disco principalmente vascularizado por floema está presente no fundo do tubo floral de todas as Galipeinae aqui analisadas (Capítulo 1), podemos inferir que o néctar é um importante recurso floral oferecido pelas flores do grupo, conforme observado nos estudos de biologia floral das espécies estudadas (Capítulo 2 e 3). Porém este seria acessível aos polinizadores com partes bucais apropriadas a alcançá-lo no fundo do tubo floral, notadamente aos animais nectarívoros com língua e/ou bico longo. De fato, nos estudos feitos até o momento em Galipeinae, borboletas, mariposas, beija-flores e alguns grupos de abelhas de língua relativamente longa foram os principais grupos funcionais de polinizadores observados, ou então foram polinizadores secundários, mas vistos em maior frequência do que outros animais que atuaram apenas como pilhadores de pólen (no caso outras abelhas; Capitulo 2, 3).

Considerando todos os grupos funcionais de polinizadores das espécies analisadas no Capítulo 3, observamos que pequenas diferenças na estrutura do tubo floral e no volume e concentração do néctar podem indicar especialização floral ao principal grupo funcional de polinizadores de cada espécie. Tanto em Conhocarpus macrophyllus, como em Angostura bracteata, o néctar é produzido em muito pouco volume e em baixa concentração. Tal fato, somado à ocorrência de atributos como um tubo curto e muito constrito no ápice, ausência de odor, e delicadas plataformas de pouso formadas pelos lobos da corola, no caso de $C$. macrophyllus, foram vistos em conjunto como evidência uma maior especialização floral às borboletas. Já A. bracteata, espécies coocorrente e com floração simultânea na área da espécie acima citada, apresentou além das delicadas plataformas de pouso, um tubo floral comparativamente mais longo, porém menos fino, e odor floral acentuadamente adocicado à noite, dentre outras características falenófilas. Estes atributos foram então considerados como evidência de uma maior especialização floral a lepidópteros como um todo (borboletas e mariposas noturnas; Capítulo 3).

Buscamos com estes estudos incrementar o conhecimento a respeito da biologia floral e polinização de Galipeinae, concatenados aos estudos sobre a estrutura floral. O volume de resultados obtidos nos permitiu discutir extensivamente a estrutura floral da subtribo, bem como investigar a funcionalidade de algumas das feições florais do grupo para um número mais restrito de espécies. Como consequência, interessantes questões foram levantadas ao longo do trabalho, notadamente as relacionados à polinização, biologia e evolução floral da subtribo. Dessa maneira, esperamos que diversidade de formas, odores, cores, simetrias, 
dentre outras características aqui descritas, sejam motivadoras para novos estudos futuros sobre as flores notáveis e belas de Galipeinae. 


\section{ANEXO}

(Manuscrito publicado na revista Annals of Botany em março de 2013, vol. 111, pp. 821-837) 



\title{
Fusion within and between whorls of floral organs in Galipeinae (Rutaceae): structural features and evolutionary implications
}

\author{
Juliana Hanna Leite El Ottra ${ }^{1, *}$, José Rubens Pirani ${ }^{1}$ and Peter K. Endress ${ }^{2}$ \\ ${ }^{1}$ Universidade de São Paulo, Instituto de Biociências, Departamento de Botânica, Rua do Matão 321, Trav. 14, 05508-900 São \\ Paulo, SP, Brazil and ${ }^{2}$ Institute of Systematic Botany, University of Zurich, Zollikerstr. 107, 8008 Zurich, Switzerland \\ * For correspondence. Email juliana.ottra@usp.br
}

Received: 8 November 2012 Returned for revision: 13 December 2012 Accepted: 14 January 2013

\begin{abstract}
- Background and Aims Most genera of the neotropical Galipeinae (tribe Galipeeae, Rutoideae) exhibit several forms and degrees of fusion between the floral organs, including the union of petals into an apparently sympetalous corolla, the joining of the stamens among themselves and to the corolla, and the partial to complete connation of carpels. Though these and others floral traits are currently used in the circumscription of species in Galipeinae, few studies have shown in detail in which way (postgenital or congenital) and to what extent these fusions occur. To elucidate these anatomical conditions, a structural study of the flowers of the Galipeinae species was carried out. - Methods Flowers of six species from three genera of Galipeinae were studied in their morphology, anatomy and development with stereomicroscopy, light microscopy and scanning electron microscopy (SEM).

- Key Results The floral tube is formed by synorganization of stamens with petals in all species, and exhibits three main patterns: (1) Conchocarpus heterophyllus and $C$. minutiflorus have a floral tube formed by marginal coherence/adherence of petals and filaments due to interwining trichomes (postgenital connection); (2) Erythrochiton brasiliensis has a tube formed by congenital fusion of petals and filaments; and (3) Galipea jasminiflora and Conchocarpus macrophyllus have a tube formed distally with the first pattern, and proximally with the second pattern. Although floral tubes seem to be homologous within Galipeinae, this is not true at the level of the family: the floral tube of Correa (from an only distantly related clade of the family) is formed by postgenital union of the petals representing a convergent structure. The gynoecium of the studied species of Galipeinae shows a great variability in the extent of fusion of carpel flanks. Even though different structures for the mature gynoecium were found in each genus, all genera show postgenitally fused carpel apices, which is related to the formation of a compitum, as described earlier for other members of Rutaceae.

- Conclusions The degree and diversity of fusions of floral organs in Galipeinae is unique within the order Sapindales. A study of the amount of diversification of Galipeinae in South America and comparison with other clades of Rutaceae would be of interest.
\end{abstract}

Key words: Floral anatomy, floral tubes, floral morphology, false sympetaly, partial apocarpy, syncarpy, postgenital union, floral development.

\section{INTRODUCTION}

Galipeinae are one of the two subtribes in the tribe Galipeeae [formerly Cuspariinae and Cusparieae in Engler (1931); invalid names according to Kallunki and Pirani (1998)] of the subfamily Rutoideae (Rutaceae). Galipeinae comprise approx. 26 exclusively Neotropical genera and 130 species (Groppo et al., 2008; Kubitzki et al., 2011). The group is distinguished from the rest of the subfamily by its flowers, which are usually tubular and slightly to pronouncedly zygomorphic, with a variable number of staminodes (usually three), and mostly two stamens with anthers commonly bearing basal appendages (Morton and Kallunki, 1993; Kallunki and Pirani, 1998). In many genera, the fertile stamens (usually two) are located on the posterior side of the monosymmetric flower. Since corolla aestivation is ascending cochlear, these two anthers are adjacent to the innermost petal or the innermost two petals (Kubitzki et al., 2011).

Several forms and degrees of fusion between the floral organs have been reported in Galipeinae and these features are currently used to distinguish genera and species in the group. Notably the union of petals into a sympetalous corolla, the union of the stamens among themselves and their fusion with the petals, the union of anthers and their basal appendages, and the partial to complete connation of carpels have been described (e.g. Engler, 1874, 1931; Ramp, 1988; Kallunki, 1992, 1998; Kallunki and Pirani, 1998; Pirani, 1999, 2004; Pirani and Kallunki, 2007; Pirani et al., 2010). In several systematic treatments for genera of Galipeinae, Kallunki and Pirani have reported the participation of trichomes in the connection of floral organs and have used a special terminology for it (e.g. Kallunki, 1992, 1994, 2009; Kallunki and Pirani, 1998; Pirani et al., 2010). In addition to the traditional terms applied for types of union of floral whorls (connation and adnation), they use the term 'coherent' when segments of the same whorl are joined only through intertwining trichomes, and 'adherent' for the same condition between organs of different whorls. Because in most of these studies the observations were based on stereomicroscopic analysis alone, for the majority of species it is not yet clear how and to what extent the floral organs are really united, and whether or not there is fusion of the organs.

Although not explicitly stated in the works of Kallunki and Pirani, it is clear by their descriptions that in some species the 
coherence and adherence of perianth organs in Galipeinae are forms of union with a combination of congenital fusion and postgenital coherence. Tube formation in flowers with postgenital coherence was reported from some other eudicots, such as Correa (Rutaceae) (Hartl, 1957). Even a case of tube formation without any coherence was shown for Geranium robertianum (Endress, 2010a). The anatomy of the floral tube of some Galipea species has been described previously (Pirani et al., 2010). Thus it would be of interest to know how such tubes in other genera of Galipeinae are formed.

Recent phylogenetic studies based on molecular data indicate that floral features in Galipeinae are important for the circumscription of some clades emerging from the analyses. Groppo et al. (2008) found that even though the subtribe as currently circumscribed is not monophyletic, the group of species with tubular flowers form a robust clade, suggesting that this feature may be a morphological synapomorphy for this group. Groppo et al. (2008) also showed that Engler's (1931) subfamilial circumscription in Rutaceae based mainly on the degree of carpel connation and fruit dehiscence is inadequate because these characters have been reconstructed as having evolved multiple times in the family. However, their discussion was limited by the lack of detailed information on the kind of union of organs for most species studied. For example, the clade in which tubular corolla species emerged was characterized by the presence of ' $a$ more or less tubular corolla', and the optimization of gynoecium characters in the phylogeny was made in the same way: 'ovary with some degree of apocarpy vs. full syncarpy' (Groppo et al., 2008). This lack of precision in the morphological states of the analysis is a consequence of the lack of detailed floral studies in Galipeinae.

The only studies that have demonstrated these unions in some detail for a few species of Galipeinae were those by Ramp (1988) and Pirani et al. (2010), who both reported different types of unions between floral whorls. Ramp (1988) studied gynoecium development and anatomy of several members of Rutaceae, including only a single member of Galipeinae, Erythrochiton brasiliensis, in which postgenital fusion of carpel apices was described, but only for anthetic flowers. Pirani et al. (2010) analysed the floral structure (based on microtome sections) of five species of Galipea, and found that the floral tube is formed by adnation of stamens to petals in their basal third and by coherence of petals and adherence of stamens to petals in their upper part. They also found that the gynoecium in these species is not completely syncarpous as previously described. These findings indicate that the fusion within and between whorls in Galipeinae flowers is quite complex. The need for studies of more taxa in order to better understand flower structure and its variation among related groups, and consequently its evolution, motivated the present study. Our aim is to investigate how and to what extent the floral organs are united in five selected species of three different genera of Galipeinae, using macroscopic and microscopic analysis, and to discuss the evolutionary implications of the results.

\section{MATERIALS AND METHODS}

Flowering material of the following taxa was studied: Conchocarpus heterophyllus (A.St.-Hil.) Kallunki and Pirani, Conchocarpus minutiflorus Groppo and Pirani, Conchocarpus macrophyllus J.C. Mikan, Erythrochiton brasiliensis Nees and Mart. and Galipea jasminiflora (A.St.-Hil.) Engl. Materials were collected in the Atlantic Forest of Espírito Santo, Brazil (C. minutiflorus, collection number Groppo 1617 and Pirani 6126; C. macrophyllus, Zuntinni 151, El Ottra 96; G. jasminiflora, El Ottra 137), Minas Gerais (G. jasminiflora, Pirani 4923) and São Paulo (G. jasminiflora, El Ottra 233). Flowers of $C$. heterophyllus (El Ottra 11) and E. brasiliensis (El Ottra 236) were collected from cultivated plants at the garden of the Instituto de Biociências da Universidade de São Paulo (São Paulo, Brazil). Voucher specimens are deposited in the herbarium of the Universidade de São Paulo (SPF).

Young floral buds and mature flowers were fixed in $50 \%$ FAA (Johansen, 1940), and stored in $70 \%$ ethanol. The morphology of the flowers, especially with respect to the fusion of organs, was analysed using a Leica M125 stereomicroscope. For light microscopy, the material was dehydrated in an ethanol-butanol series and then infiltrated and embedded in paraffin (following the protocol of Johansen, 1940). The embedded material was sectioned using a rotary microtome and a standard microtome knife $\mathrm{D}$. The sections were stained with $1 \%$ astra blue and $1 \%$ safranin in $50 \%$ ethanol (following the protocol of Bukatsch, 1972), and mounted in Canada balsam. The slides were analysed using a Leica DM 4000B microscope, and photomicrographs were taken with a Leica DFC 425 digital camera. Additionally, diagrams of the outline of floral organs and the main vascularization patterns of the serial microtome sections of floral buds were illustrated.

For scanning electron microscopy (SEM) studies, the fixed material was dissected, dehydrated in an ethanol series and critical-point dried. The floral organs were mounted on stubs and sputter-coated with gold. Observations were made with a Zeiss DMS-940 scanning electron microscope.

\section{Terminology}

Floral tube: an architectural term; tubular part of the flower through which the floral centre can be reached. A floral tube may be formed by different parts of the flower, mostly by sepals and/or petals (and sometimes also stamens).

Congenital fusion: connection of organs by confluence of their primary meristems.

Postgenital coherence: connection of floral organs of a whorl by intertwining trichomes of their contiguous surface.

Postgenital adherence: connection of floral organs of different whorls by intertwining trichomes of their contiguous surface.

Postgenital fusion: connection of contiguous organs by epidermal fusion.

\section{RESULTS}

\section{Floral tube}

In all species studied, a shorter or longer floral tube is formed by the petals and stamens. Antesepalous stamens are present in all studied species, but antepetalous stamens only in G. jasminiflora and $C$. macrophyllus. Interestingly, the construction of the floral tube is not uniform in the group. 
Conchocarpus heterophyllus and $C$. minutiflorus show a similar floral morphology and anatomy (Figs 1 and 5A, E, F). Although they have a floral tube, the petals and stamens are free from each other along the entire length (Fig. 1A-I). However, transverse sections of the region of the floral tube show that the tube is formed by the coherence of petals and adherence of filaments to petals by intertwining trichomes (Fig. 5E, F). This connection is also facilitated by the form and position of the petals and stamens; in transverse section, they have a somewhat triangular flat shape, with both whorls precisely alternating (Fig. $1 \mathrm{~F}-\mathrm{H}$ ). Higher up, the petals and stamens are free, and the petals form five blades (Fig. 5A). Thus, even though there is no fusion between petals or filaments, the corolla is seemingly sympetalous due to the intertwining trichomes of the margins of the alternating petals and filaments.

In $E$. brasiliensis the floral tube is formed by congenital union of the stamen filaments and their congenital fusion with the petals as shown in transverse section series (Figs 2 and $5 \mathrm{D}, \mathrm{G})$. In the tube, the stamen vascular bundles alternate

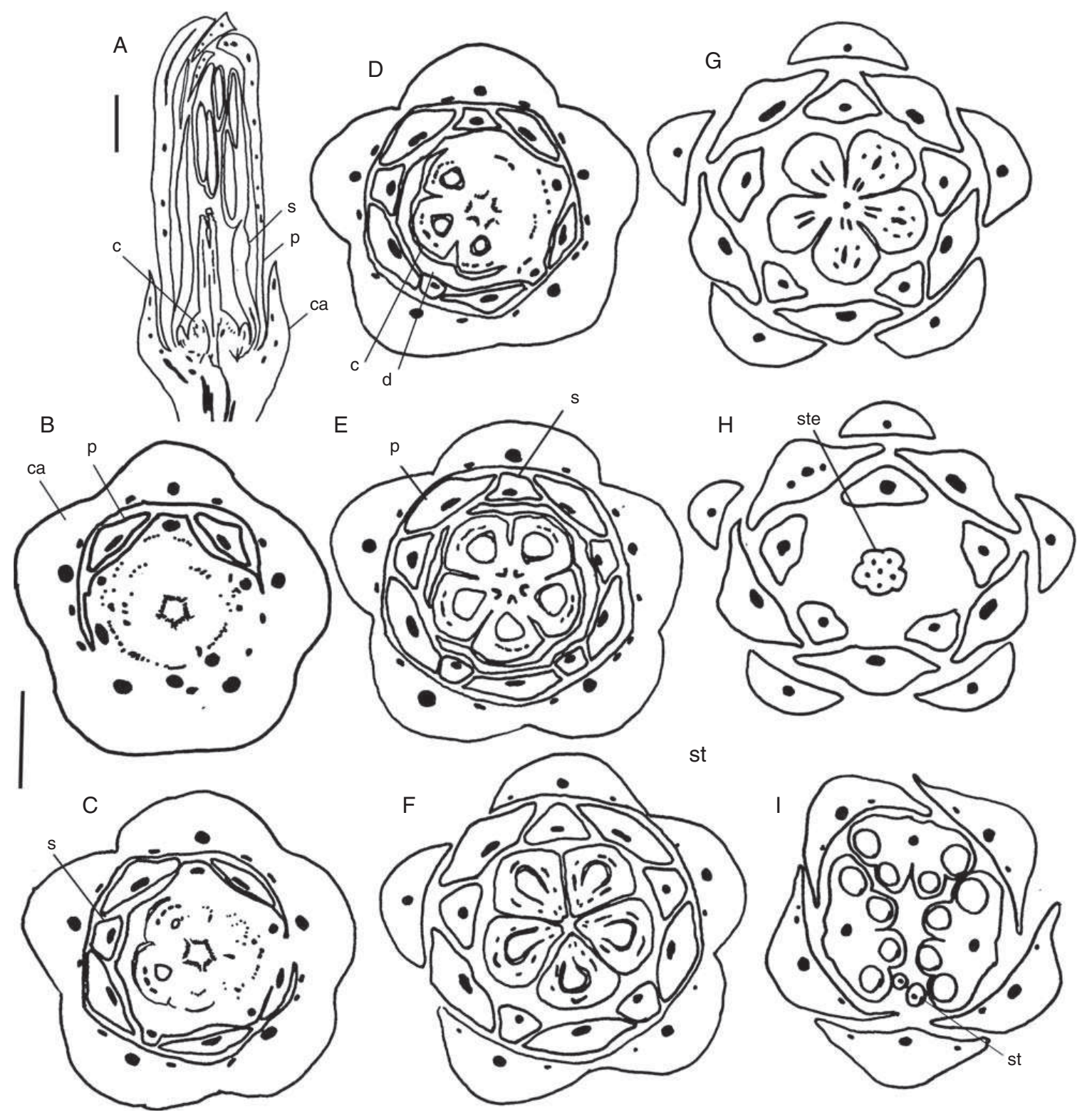

FIG. 1. Conchocarpus heterophyllus and C. minutiflorus. Sections of floral buds. (A) Longisection of C. heterophyllus. (B-I) Transections of C. minutiflorus, successive levels, from the base upwards. (B-E) Transition from floral base to ovary. (F) Mid-level of ovary. (G) Uppermost level of ovary. (H) Basal level of style. (I) Level of the anthers. Abbreviations: ca, calyx; c, carpel; d, disc; s, stamen; p, petal; st, staminode; ste, style. Scale bars: $(\mathrm{A})=1 \mathrm{~mm}$; $(\mathrm{B}-\mathrm{I})=0.5 \mathrm{~mm}$. 
Page 4 of $17 \quad$ El Ottra et al. - Fusion within and between whorls of floral organs in Galipeinae
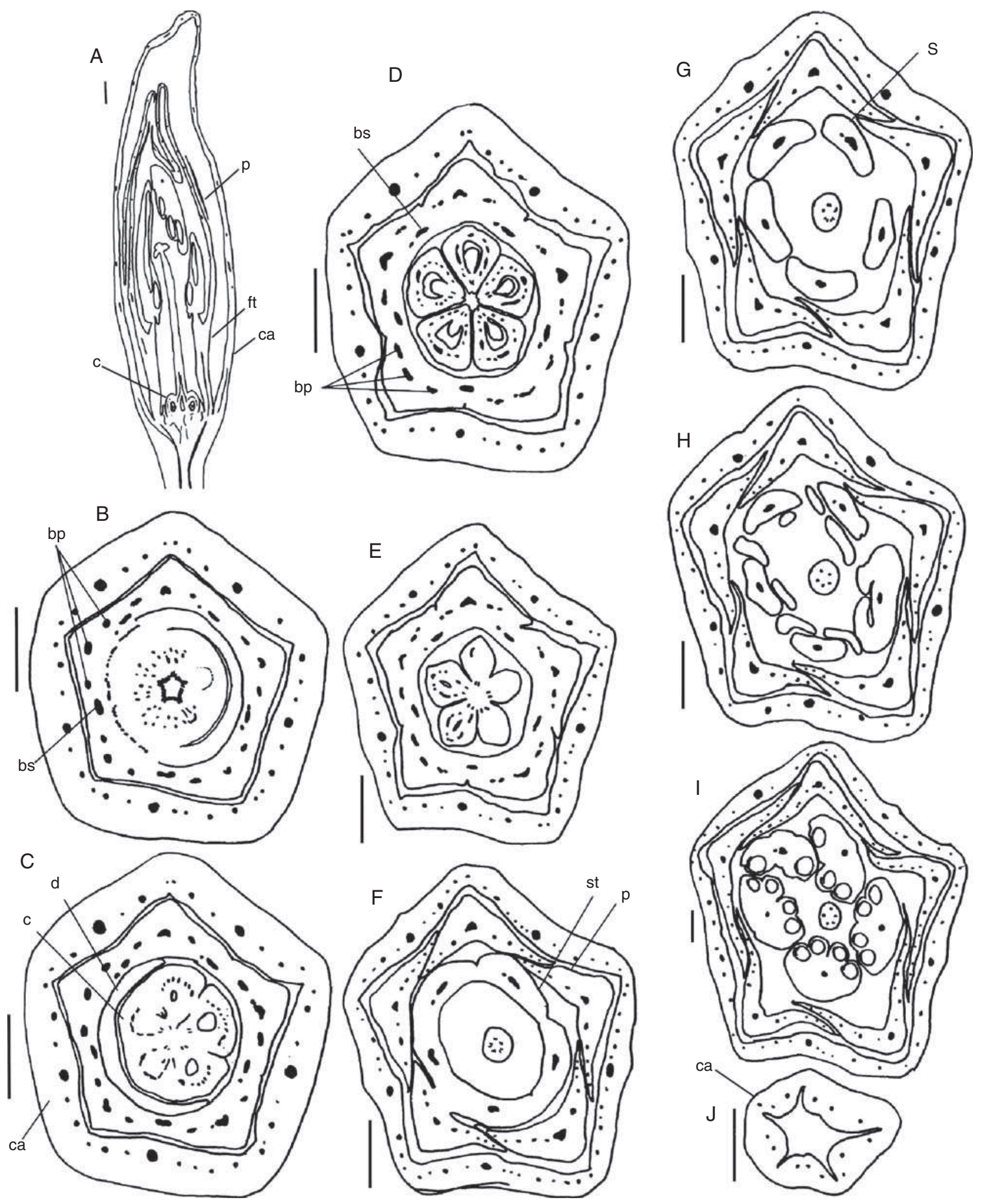

FIG. 2. Erythrochiton brasiliensis. Sections of floral buds. (A) Longisection. (B-I) Transections: successive levels, from the base upwards. (B) Transition from floral base to ovary. (C) Basal level of ovary. (D) Mid-level of ovary. (E) Uppermost level of ovary. (F) Level of staminal tube. (G, H) Level of free petals and stamens. (I) Level of anthers. (J) Distal region of bud. Abbreviations: ca, calyx; c, carpel; d, disc; fl, floral tube; p, petal; bp, vascular bundle of petal; bs, vascular bundle of stamen; s, stamen; st, staminal tube. Scale bars: $(A)=1 \mathrm{~mm} ;(B-D)=1 \mathrm{~mm} ;(\mathrm{E}-\mathrm{H})=1 \mathrm{~mm} ;(\mathrm{I})=1 \mathrm{~mm} ;(\mathrm{J})=0 \cdot 5 \mathrm{~mm}$. 

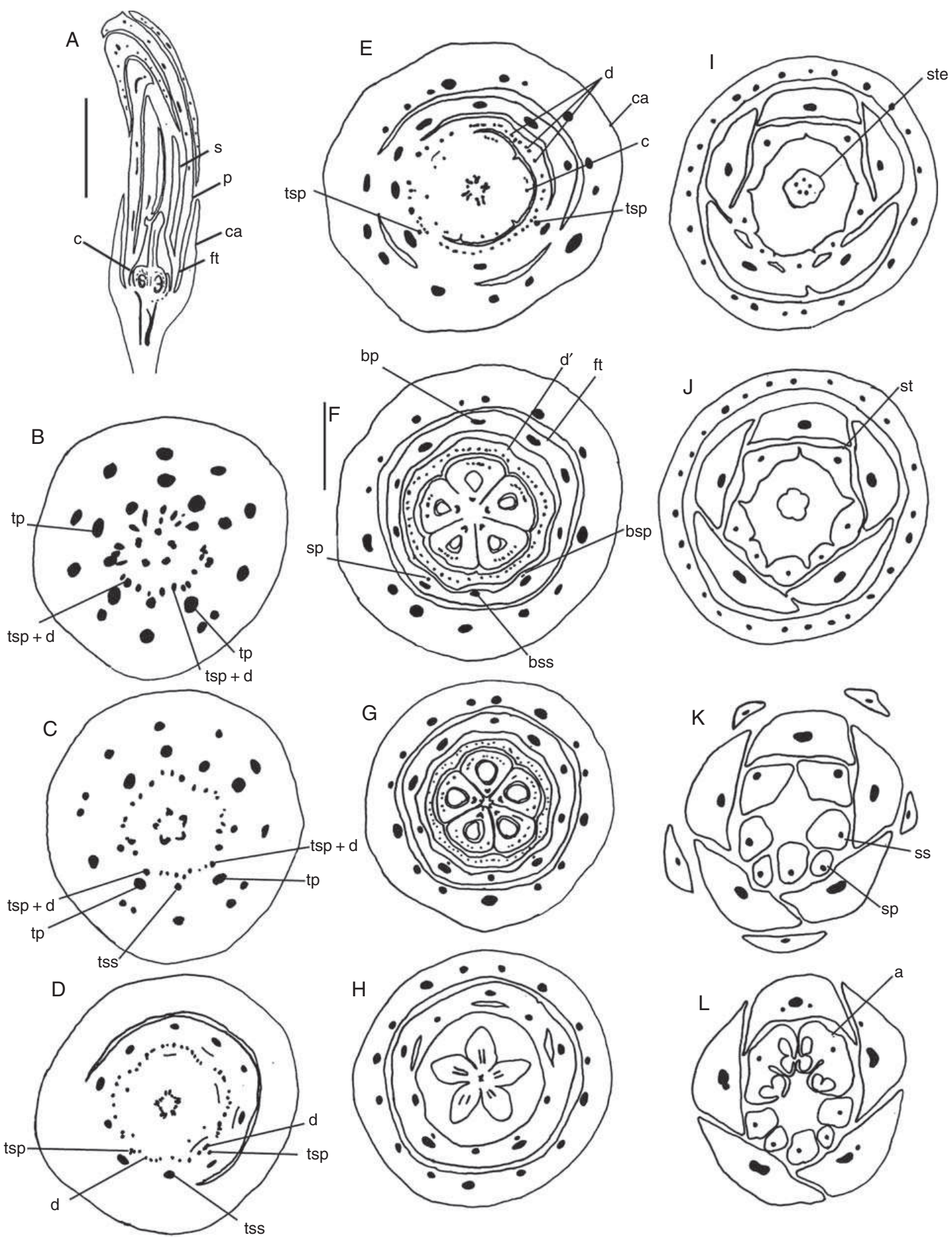

FIG. 3. Conchocarpus macrophyllus. Sections of floral buds. (A) Longisection. (B-L) Transections: successive levels, from the base upwards. (B-F) Transition from floral base to ovary. (F) Basal level of ovary. (G) Mid-level of ovary. (H) Uppermost level of ovary. (I) Level of separation of petals from stamens. (J) Level of staminal tube. (K) Level of free petals and stamens. (L) Level of anthers. Abbreviations: a, anther; bp, vascular bundle of petal; bsp, vascular bundle of antepetalous stamen; bss, vascular bundle of antesepalous stamen; c, carpel; ca, calyx; d, vascular bundle of disc; d', disc; fl, floral tube; p, petal; s, stamen; sp, antepetalous stamen; ss, antesepalous stamen; st, staminal tube; ste, style; tp, trace of petal; tsp, trace of antepetalous stamen; tss, trace of antesepalous stamen; tsp $+d$, trace complex of antepetalous stamen plus disc. Scale bars: $(A)=2 \mathrm{~mm} ;(B-L)=1 \mathrm{~mm}$. 
Page 6 of $17 \quad$ El Ottra et al. - Fusion within and between whorls of floral organs in Galipeinae

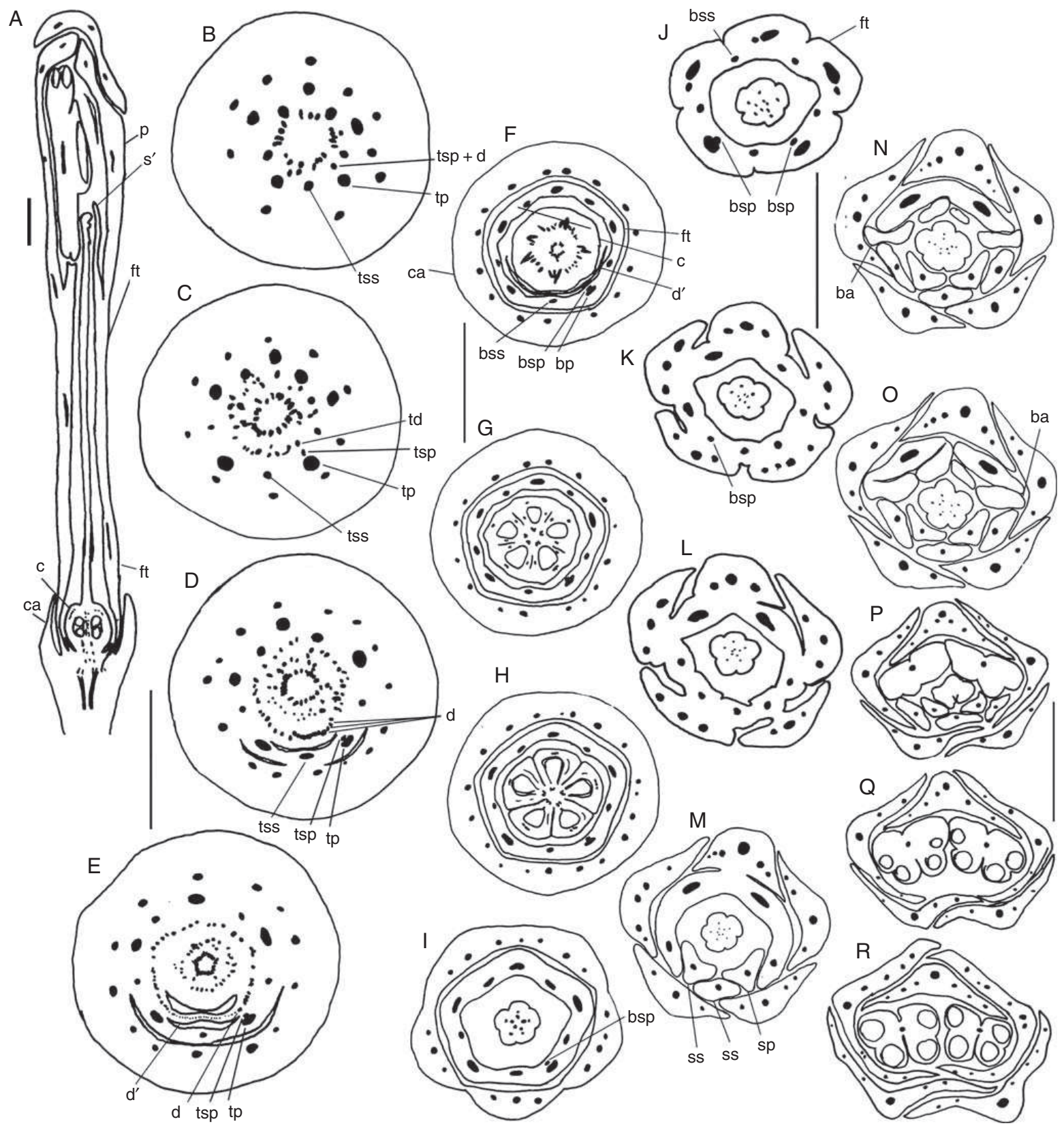

FIg. 4. Galipea jasminiflora. Sections of floral buds. (A) Longisection. (B-R) Transections: successive levels, from the base upwards. (B-F) Transition from floral base to ovary. (F) Below the locules. (G) Basal level of ovary. (H) Mid-level of ovary. (I) Basal level of style. (J) Mid-level of style. (K-M) Levels of gradual separation of petals from stamens. $(\mathrm{N}, \mathrm{O})$ Level of basal appendages of anthers. (P, Q) Level of postgenitally united anthers. (R) Region of free anthers. Abbreviations: a, anther; ba, basal appendage of anther; bp, vascular bundle of petal; bsp, vascular bundle of antepetalous stamen; bss, vascular bundle of antesepalous stamen; c, carpel; ca, calyx; d, vascular bundles of disc; d', disc; fl, floral tube; p, petal; s', staminode; sp, antepetalous stamen; ss, antesepalous stamen; st, staminal tube; ste, style; td, traces of disc; tp, trace of petal; tsp, trace of antepetalous stamen; tss, trace of antesepalous stamen; tsp $+\mathrm{d}$, trace complex of antepetalous stamen plus disc. Scale bars: $(A)=1 \mathrm{~mm} ;(B-E)=1 \mathrm{~mm} ;(\mathrm{F}-\mathrm{I})=1 \mathrm{~mm} ;(\mathrm{J}-\mathrm{O})=1 \mathrm{~mm} ;(\mathrm{P}-\mathrm{R})=1 \mathrm{~mm}$.

with the median vascular bundles of the petals (Figs 2B-E and $5 \mathrm{G})$. Higher up, the petals are free, forming five spreading blades (Figs $2 \mathrm{~F}-\mathrm{I}$ and $5 \mathrm{D}$ ). The staminal tube extends slightly higher up than the stamen-petal tube (Fig. 2F, G). In the distal part of the androecium, the stamens are free (Fig. 2G-I). In young stages seen from the dorsal side, petals and stamens 

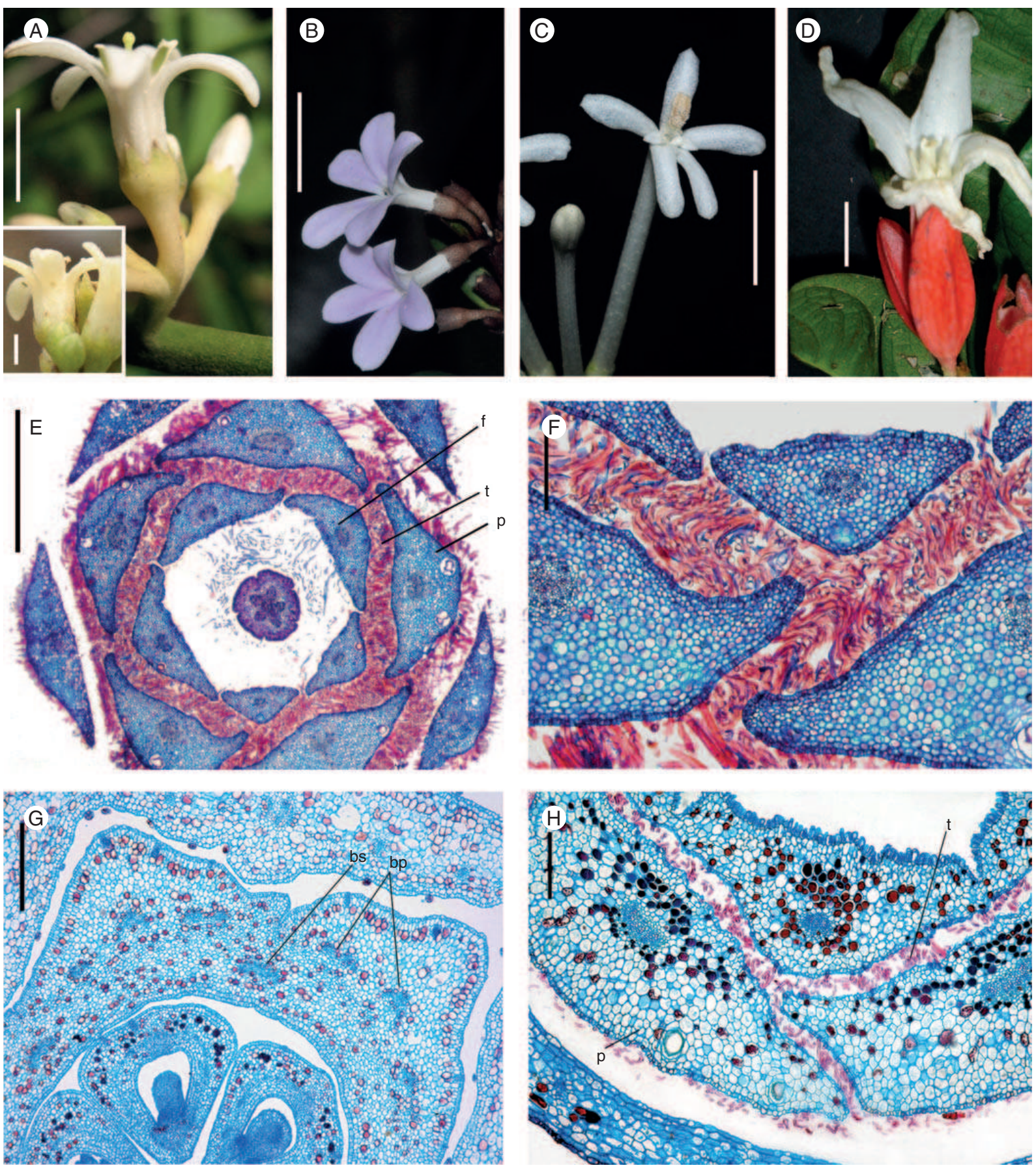

FIG. 5. Galipeinae. Photographs of flowers at anthesis. (A) Conchocarpus heterophyllus and C. minutiflorus (bottom-left); (B) C. macrophyllus; (C) Galipea jasminiflora; (D) Erythrochiton brasiliensis. Microtome transections of floral buds: (E) Region of floral tube in Conchocarpus heterophyllus. (F) Detail of E, showing the intertwining trichomes in petals and filaments. (G) Detail of the floral tube of E. brasiliensis, showing the congenital fusion of stamens and petals. (H) Detail of the upper half of the floral tube of C. macrophyllus, showing the intertwining trichomes in petals and filaments. Abbreviations: $\mathrm{f}$, filament; bs, vascular bundle of stamen; bp, vascular bundle of petal; p, petal; st, staminal tube; t, trichomes. Scale bars: $(A)=1 \mathrm{~cm}, i n s e t=2 \mathrm{~mm} ;(B-D)=1.5 \mathrm{~cm}$; $(\mathrm{E}, \mathrm{H})=200 \mu \mathrm{m} ;(\mathrm{F})=400 \mu \mathrm{m},(\mathrm{G})=300 \mu \mathrm{m}$. 
Page 8 of $17 \quad$ El Ottra et al. - Fusion within and between whorls of floral organs in Galipeinae
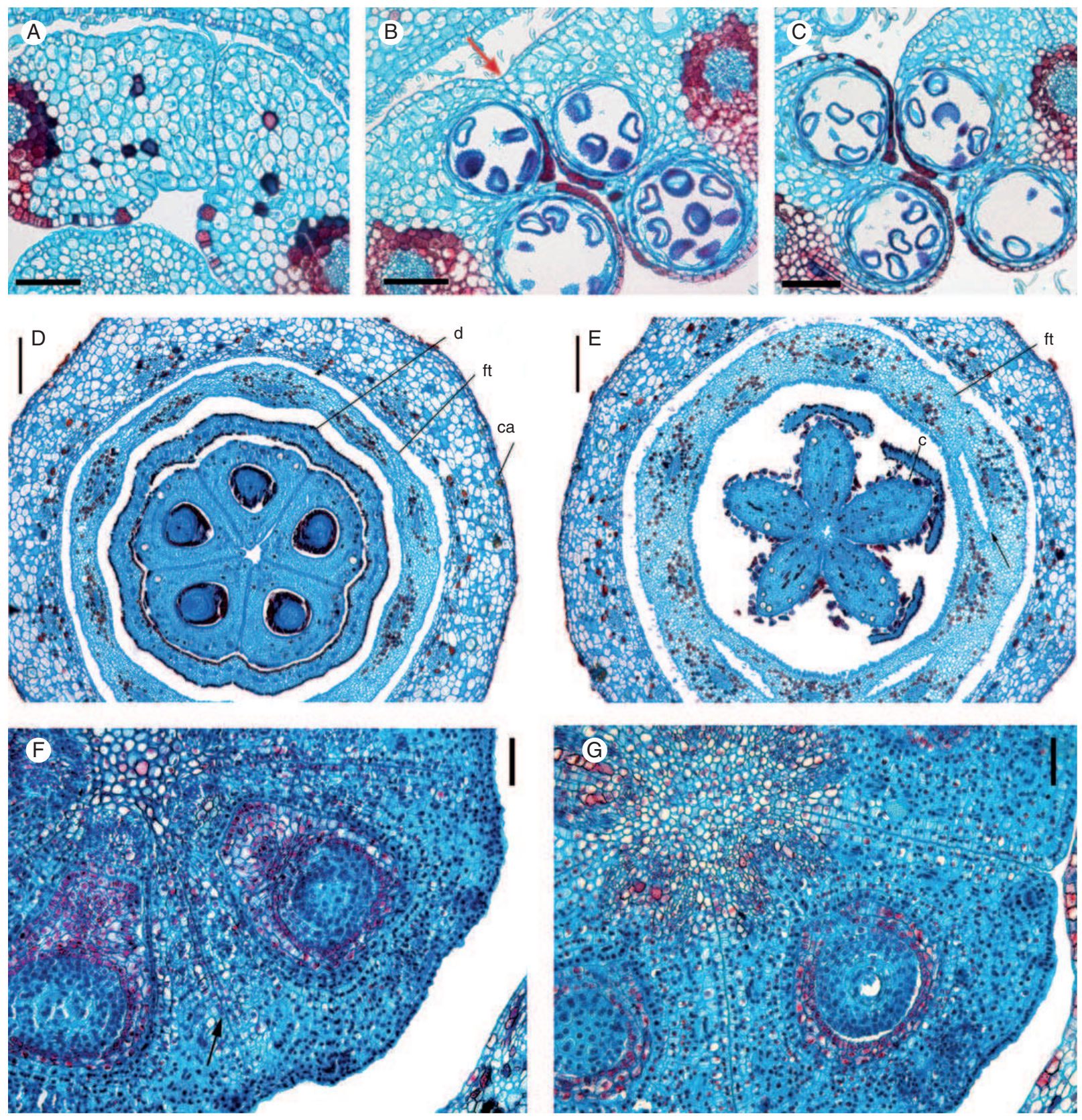

FIg. 6. Photomicrographs of microtome sections of floral buds. (A-C) Transections of the anthers of Galipea jasminiflora. (A, B) Detail of anthers, below the thecae (A) and at mid-level of thecae (B), where postgenital fusion is evident (arrow). (C) Upper half of thecae, showing free anthers. (D, E) Conchocarpus macrophyllus. (D) Apocarpous zone of ovary and floral tube. (E) Uppermost level of ovary, showing postgenitally united carpels; beginning of separation of stamens from petals (arrow). (F, G) Galipea jasminiflora, carpels. (F) Basal region of ovary, showing the morphological surfaces of adjacent carpels as narrow slits (arrow). (G) Upper half of ovary, showing postgenital union of carpels in the centre of the gynoecium. Abbreviations: a, anther; ba, basal appendage; c, carpel; ca, calyx; d, disc; ft, floral tube. Scale bars: (A, B, D, E) $=100 \mu \mathrm{m} ;(\mathrm{C})=200 \mu \mathrm{m} ;(\mathrm{F}, \mathrm{G})=500 \mu \mathrm{m}$.

appear free (Fig. 8G, H). However, on the ventral side, there is fusion from the beginning between petals and stamens, and this becomes apparent later also on the dorsal side (Fig. 8I).

In C. macrophyllus (Fig. 5B) and G. jasminiflora (Fig. 5C), the floral tube is formed by adnation of the staminal filaments to the petals, in Galipea, up to their upper half, and in C. macrophyllus up to their lower half (Figs $4 \mathrm{~A}-\mathrm{L}$ and $3 \mathrm{~A}-\mathrm{H}$ ). In the floral tube, the staminal vascular bundles alternate with the median petal bundles (Figs 3B-G, 4B-I and $6 \mathrm{D}, \mathrm{E})$. Higher up, the floral tube is formed by the coherence 

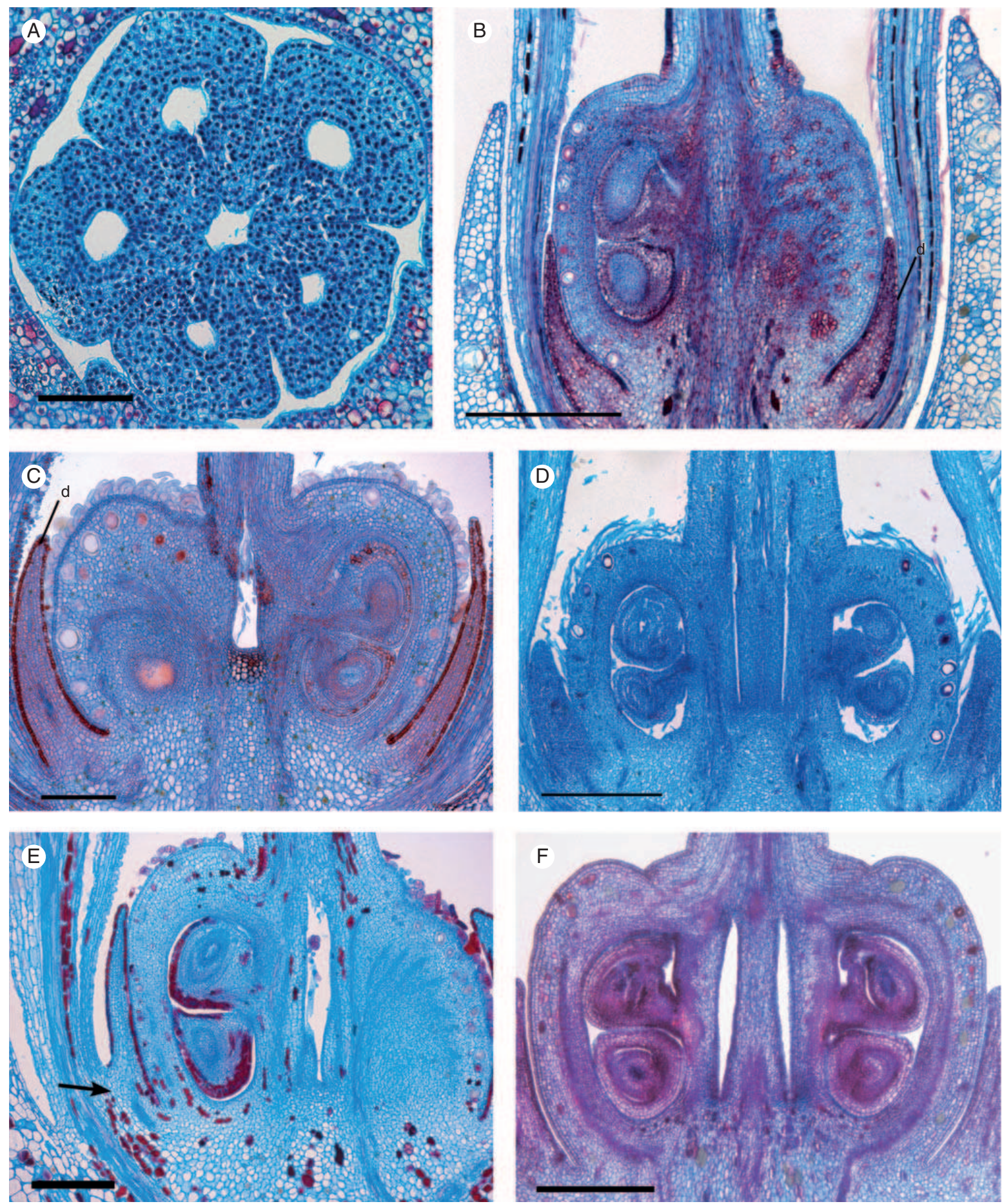

FIg. 7. Photomicrographs of microtome sections of floral buds. (A) Galipea jasminiflora, transection of young ovary, above the level of placenta, showing postgenital union of carpel flanks. (B-F) Longitudinal sections of base of floral buds, focusing on the median plane of carpels. (B) Galipea jasminiflora. (C) Conchocarpus minutiflorus. (D) Conchocarpus heterophyllus. (E) Conchocarpus macrophyllus (arrow indicates the oblique base of the disc at the floral tube). (F) Erythrochiton brasiliensis. Abbreviation: d, disc. Scale bars: (A) $=100 \mu \mathrm{m} ;(\mathrm{B}, \mathrm{D}, \mathrm{F})=500 \mu \mathrm{m} ;(\mathrm{C}, \mathrm{E})=200 \mu \mathrm{m}$. 
Page 10 of $17 \quad$ El Ottra et al. - Fusion within and between whorls of floral organs in Galipeinae
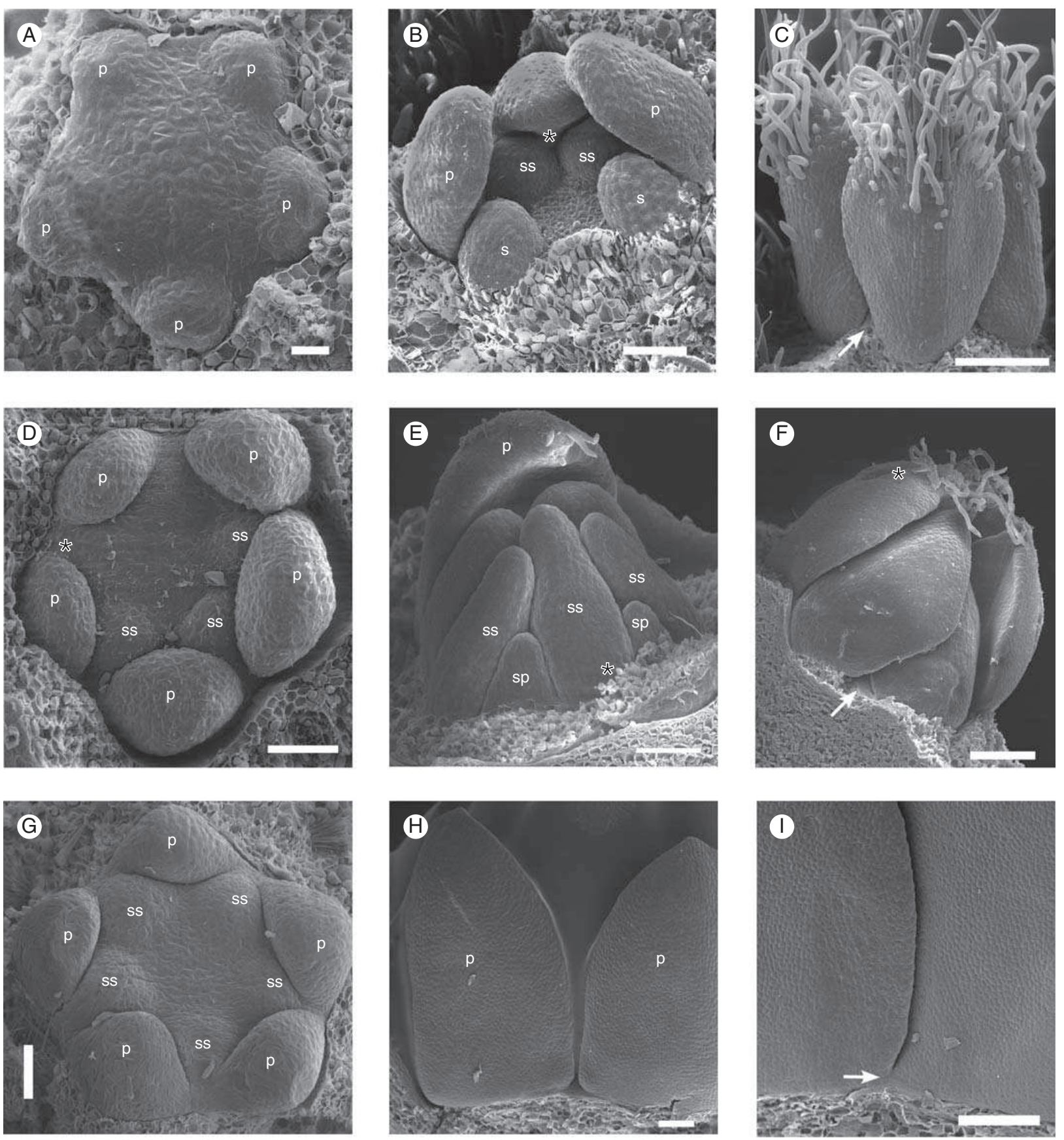

FIG. 8. SEM micrographs of young floral buds. (A-C) Galipea jasminiflora. (A) View from above, with sepals removed, showing young free petals. (B) View from the side, with sepals, one petal and stamen removed, showing young free stamens. (C) Lateral view of young free petals (arrow points to free base), later stage than B (calyx removed). (D-F) Conchocarpus macrophyllus. (D) View from above, with sepals removed, showing young free petals and emergence of three stamens. (E) View from the side, with young free stamens in a later stage than D. (F) Young free petals (arrow points to free base), in a later stage than D. (G-I) Erythrochiton brasiliensis. (G) View from above, with sepals removed, showing young free petals and five stamens. (H) View from the side, with sepals removed, showing young free petals, later stage than G. (I) Later stage, where basal congenital fusion of petals becomes visible from the surface (arrow). Abbreviations: p, petal; sp, antepetalous stamen; ss, antesepalous stamen; asterisk indicates posterior side of the flower. Scale bars: (A) $=20 \mu \mathrm{m}$; $(\mathrm{B}, \mathrm{D})=50 \mu \mathrm{m} ;(\mathrm{C}, \mathrm{E}-\mathrm{I})=100 \mu \mathrm{m}$. 

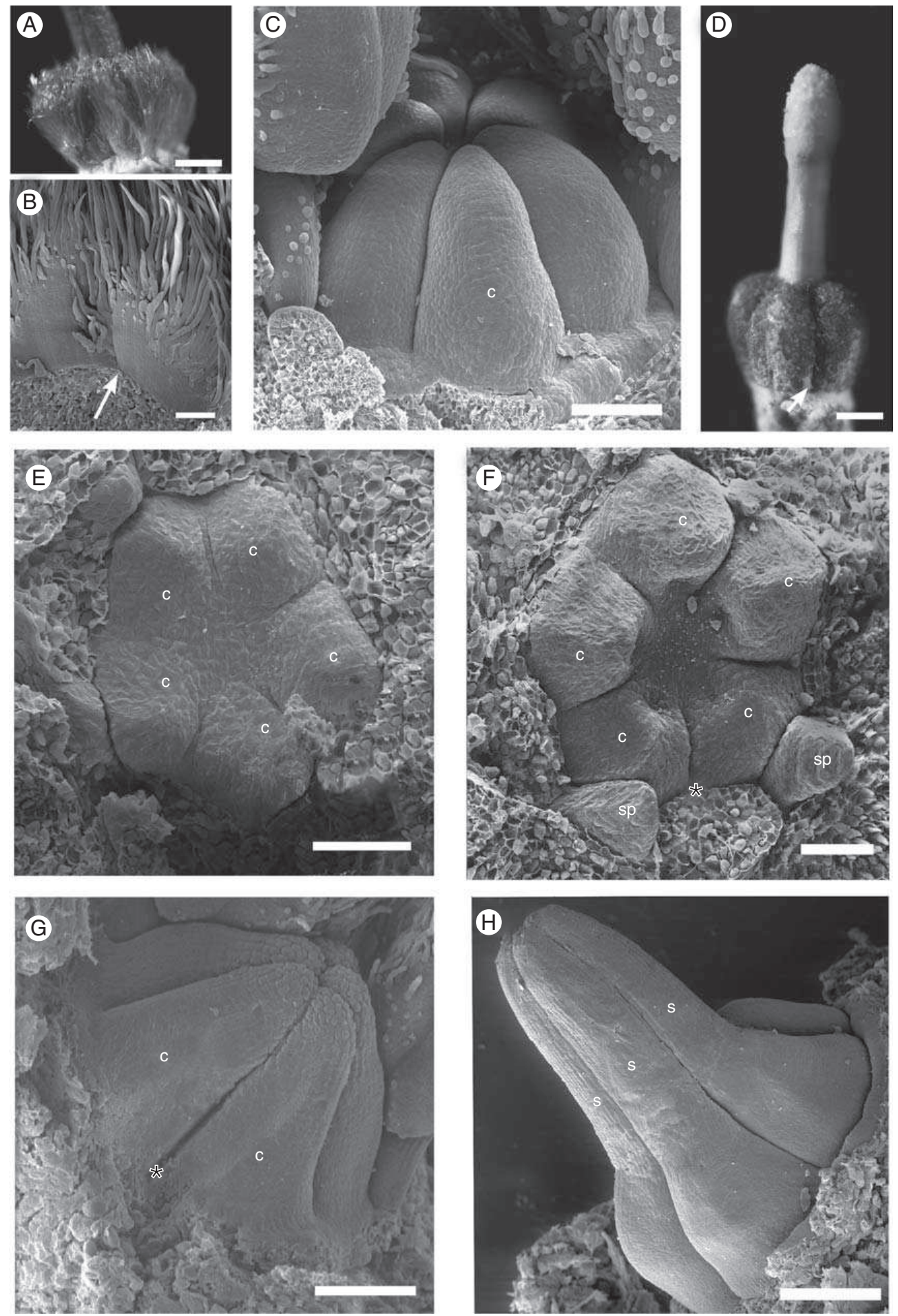

FIG. 9. Carpel development of Conchocarpus heterophyllus (A-C) and C. macrophyllus (D-H). (A) Photograph of mature gynoecium (ovary and style base). (B, C) SEM micrographs. (B) Detail of (A), at the base of ovary (arrow indicates free carpel flanks). (C) Young free carpels. (D) Photograph of mature gynoecium; arrow indicates base of ovary with free carpel flanks. (E-H) SEM micrographs. (E) View from above, showing five young carpels. (F) Later stage than E. (G) Carpels elongating (lateral view). (H) Style elongating. Abbreviations: c, carpel; sp, antepetalous stamen; s, style; asterisk indicates posterior side of the flower. Scale bars: $(\mathrm{A}-\mathrm{D}, \mathrm{F}-\mathrm{H})=100 \mu \mathrm{m} ;(\mathrm{G})=50 \mu \mathrm{m}$. 
Page 12 of $17 \quad$ El Ottra et al. - Fusion within and between whorls of floral organs in Galipeinae
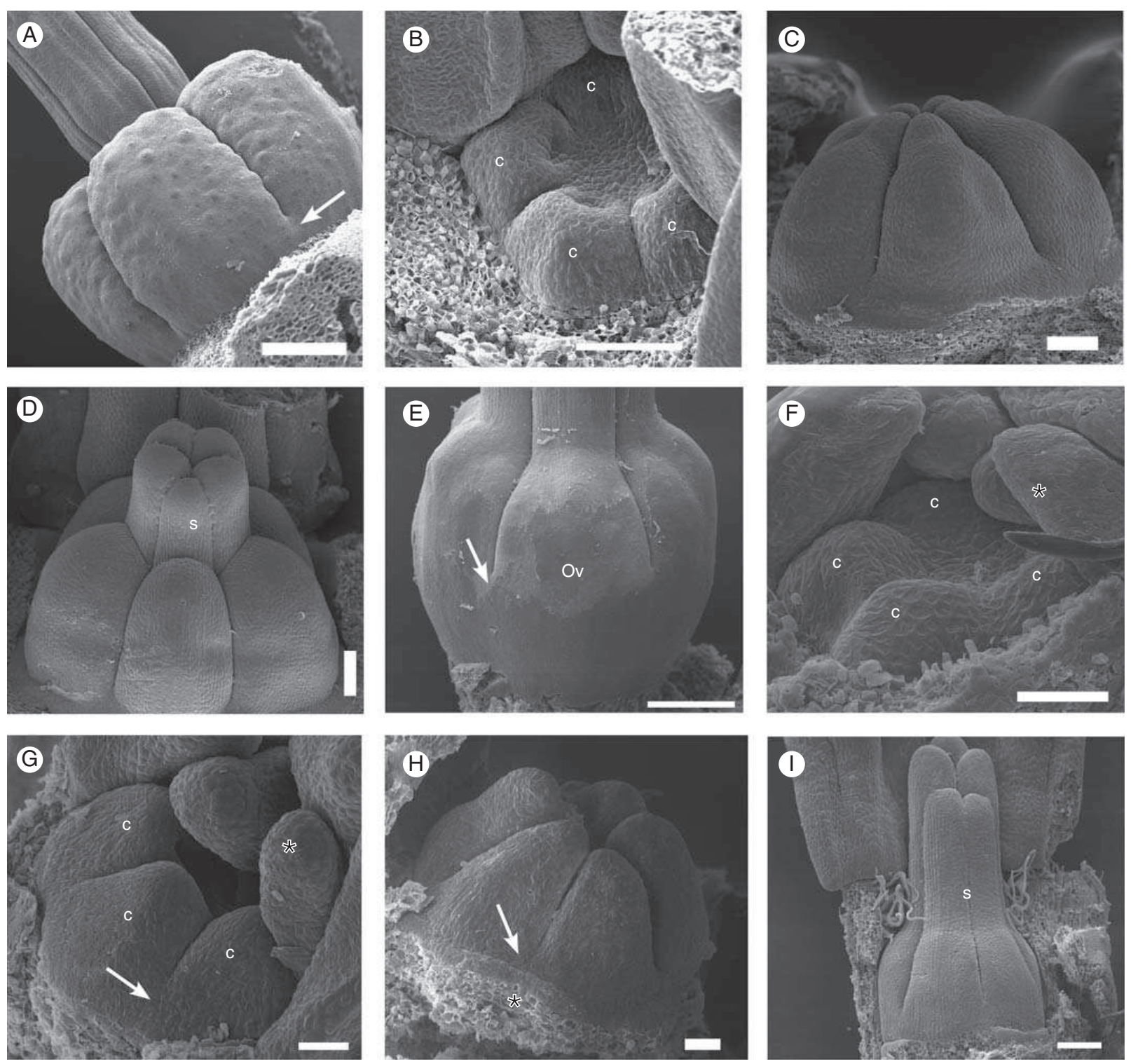

FIG. 10. SEM micrographs of carpel development of Erythrochiton brasiliensis (A-D) and Galipea jasminiflora (E-I). (A) Mature gynoecium (side view); arrow indicates where carpels are congenitally united at base. (B) Young carpels, from above. (C) Young carpels, from the side. (D) Carpels with beginning differentiation of style, from the side. (E) Galipea jasminiflora, mature gynoecium from the side (arrow indicates the upper end of congenital carpel union). (F) Carpel primordia (G) Side view of young carpels, showing the congenital union of their bases (arrow). (H) Farther advanced stage than 'G' (arrow points to basal congenital union). (I) Carpels with beginning differentiation of style, from the side. Abbreviations: c, carpel; ov, ovary; s, style; asterisk indicates posterior side of the flower. Scale bars: $(A)=500 \mu \mathrm{m} ;(B-E)=100 \mu \mathrm{m} ;(F-I)=50 \mu \mathrm{m}$.

of petals and adherence of petals and filaments by intertwining trichomes in both taxa (Figs $4 \mathrm{M}, \mathrm{N}$ and $5 \mathrm{H}$ ). In C. macrophyllus, the nectary disc and the floral tube have a common base for a short distance (approx. $150 \mu \mathrm{m}$; Fig. 7E). In their distal portion, the petals are free, forming five spreading blades (Fig. 5B, C), and the filaments are free from the corolla. In C. macrophyllus, the filaments form a short tube (Fig. 3J), but they are free just above (Fig. 3K). In this same region, the filaments of G. jasminiflora are gradually released from their union and fusion to the corolla. This begins with the staminodes, and proceeds to the filaments of the two fertile anthers (Fig. 4L-O).

Confluence of the meristems of the young floral organs, resulting in congenital union of their lower parts, occurs relatively late, when the upper free parts of the organs are already visible (Fig. 8A-F). Thus, the floral tube in C. macrophyllus 
and Galipea species is partially formed by congenital fusion of petals and stamens, and partially by postgenital coherence and adherence of these organs.

\section{Anthers}

The anthers of all species studied are free, except for those of G. jasminiflora. Galipea has only two fertile stamens, whose thecae bear a basal sterile appendage; the two fertile stamens are firmly attached to each other laterally, from the region of the basal appendages up to the middle of the anthers (Figs 4P, Q and 6A-C). Anther fusion is postgenital as the epidermis of the two organs is still apparent in advanced stages at the base of the anthers. The epidermal surfaces are interlocked, with epidermal cells undifferentiated and similar to hypodermal cells (Fig. 6A, B).

\section{Gynoecium}

In all species studied, the carpels are congenitally and postgenitally united to various degrees. In $C$. minutiflorus, C. heterophyllus and C. macrophyllus, the carpels are connate in the centre at the base of the ovary. Five shallow furrows at the periphery of the ovary between adjacent carpels delineate the flanks of the five carpels at their bases (Figs 1C-E and 3E, F). This zone of basal congenital union varies in extent between species, comprising approximately one-third of the total length of the ovary in $C$. minutiflorus, approximately onequarter in $C$. heterophyllus and approximately one-seventh in C. macrophyllus (Fig. 7C-E). This zone is not seen externally (Fig. 9A-C). Above this zone, the ovaries are completely free from each other (Figs 1F, 3D, 6D, 7C-E and 9E, F). However, in the distal zone of the ovary, close to the base of the style, and up to the stigma, the carpels are again united in the centre. However, here the union is postgenital (Fig. 1G, H, 3H, I and $6 \mathrm{E})$. That this upper fusion zone is postgenital is also evident from young stages in which the carpels are free in the uppermost part (Fig. 9C, G). As they widen and elongate, they become postgenitally united to form a single style and stigma (Fig. 9D, $\mathrm{H})$. Thus the gynoecium is apocarpous for most of its length but the carpels are postgenitally united in the upper apocarpous zone.

In E. brasiliensis, the gynoecium is similar to that of Conchocarpus. The postgenital union in the apocarpous zone extends from immediately above the ovary up to the stigma (Figs 2A, E-I, 7F and 10A, D). Postgenital union of carpels becomes apparent from the surface when the uniform style develops (Fig. 10D). Also here, in early development, the five carpels appear to be free (Fig. 10B-C); they are congenitally united at their bases only in the centre, for a short extent (approximately one-fifth of the length of the ovary; Figs $2 \mathrm{~B}, \mathrm{C}$ and 7F). However, in contrast to Conchocarpus, the gynoecium has a short gynophore (Figs 2B, C and 10A).

The gynoecium of $G$. jasminiflora differs from that of the other taxa in the degree of syncarpy. There is no zone where the carpels are free (Fig. 7B). They are congenitally or postgenitally united along their entire length. In the ovary, the carpels are congenitally united in the floral centre but they appear free at the flanks (Figs $4 \mathrm{H}$ and $6 \mathrm{G}$ ). This zone of free flanks ends at the base as short pockets between the flanks when carpels are also united at the periphery for a short distance (Figs $4 \mathrm{G}$ and
$6 \mathrm{~F})$. These pockets look like the slits of septal nectaries in monocots; however, here they are not nectariferous. As seen from the surface, the lateral connation of the carpels appears to reach up to half the length of the ovary (Fig. 10E). However, the lowermost part is below the locules and thus is a short gynophore (Figs $4 \mathrm{~F}$ and $7 \mathrm{~B}$ ). The uniform style is formed by the upper part of the five postgenitally united carpels (Fig. 4I). In G. jasminiflora, in early development, the carpels appear to arise as five independent organs, but they soon become united laterally at the base (Fig. 10F-H). This united zone elongates during gynoecium development (Fig. 10E, I) compared with E. brasiliensis (Fig. 10A). The carpels also appear united in the centre of the gynoecium (Fig. 7B). The free apical parts later become postgenitally united and differentiate into the apical portion of the ovary and the united style and stigma (Figs 7A and 10E, I).

\section{DISCUSSION}

Floral tube in Galipeinae: structure and possible evolutionary implications

All Galipeinae species studied have a floral tube formed by the synorganization of the stamen filaments with the petals. However, the connection of these organs is conspicuously diverse in detail in the studied genera, and three main patterns were found.

In the pattern found in C. heterophyllus and C. minutiflorus, the floral tube is formed by postgenital connection of stamens and petals by intertwining trichomes. A case of postgenital connection of petals was reported for another member of Rutaceae, Correa speciosa Donn ex Andrews (Boronieae, Rutoideae), by Hartl (1957), in which the tubular corolla is formed by the close interlocking of epidermal papillate projections and by cuticular protuberances from the petal magins. Hartl (1957) called this postgenital connection of petals 'false sympetaly'. With regard to histological details, the term 'dentonection' was used (Weberling, 1989). However, Conchocarpus differs from Correa in the participation of filaments, and the coherence of petals by interwining trichomes, instead of interlocking epidermal cells and cuticular projections. Postgenital connection of petals also occurs in some other rosids, such as some members of Oxalidales (Matthews and Endress, 2002), Celastraceae (Matthews and Endress, 2005a), Rhizophoraceae, Erythroxylaceae and Linaceae (Matthews and Endress, 2011).

A second pattern of tube formation was found in E. brasiliensis, in which the petals are congenitally united via the filaments of the neighbouring stamens. This kind of tube is also known from other angiosperm groups, such as Bruniaceae (Leinfellner, 1964; Quint and Claßen-Bockhoff, 2006), Commelinaceae (Rohweder, 1969) and, among rosids, from Dichapetalaceae (Matthews and Endress, 2008). Leinfellner (1964) also called this pattern 'false sympetaly'. However, it should be emphasized that this is completely different from how the term was used by Hartl (1957). The term 'stapet' is used to designate congenital fusion of stamens to petals (Ritterbusch, 1991), which is found commonly in association with sympetaly in core eudicots. However, this phenomenon is rarely found in rosids (Endress and Matthews, 2012). 
The third pattern, observed in C. macrophyllus and G. jasminiflora, is a mixture of the first two patterns. In its basal portion, the floral tube is similar to that of E. brasiliensis, and in the upper portion it is similar to $C$. heterophyllus and C. minutiflorus. Such a mixed pattern of congenital and postgenital fusion is also known from other angiosperms (some Gentianales; Fallen, 1986; Robbrecht, 1988; Endress, $2010 b)$. The features described for the floral tube of G. jasminiflora have been reported earlier for other Galipea species (G. carinata Pirani, G. ciliata Engl., G. dasysperma Gómez-Laur. and Q. Jiménez, G. laxiflora Engl.; Pirani et al., 2010). As all 14 species of Galipea have flowers of a remarkably similar general aspect, it is likely that a floral tube with a mixed pattern is a general characteristic of this genus. The three Conchocarpus species studied show an intriguing heterogeneity in the structure of the floral tube: pattern 1 (with only postgenital coherence) in $C$. heterophyllus and C. minutiflorus, and a mixed pattern in C. macrophyllus. This heterogeneity probably reflects the putative non-monophyly of the genus. Conchocarpus is the largest genus of Galipeinae (48 species) and also the most heterogeneous for other mainly flora morphological features, specifically with differences in number of fertile stamens and staminodes, in floral symmetry and in the shape of the sepals (Kallunki and Pirani, 1998; Pirani et al., 2012). The results of a systematic treatment of the genera of Galipeinae (Kallunki and Pirani, 1998) and recent molecular phylogenetic studies (Kallunki and Groppo, 2007; Bruniera, 2010; Groppo, 2010) suggest that Conchocarpus is not monophyletic and that its circumscription should be re-evaluated. Thus the study of floral structure may contribute with more characters to elucidate the systematic relationships between Conchocarpus species and to help in the new circumscription of monophyletic genera in Galipeinae.

The three main structural patterns found in the floral tube of Galipeinae species studied seem to be inter-related because of the presence of an intermediate 'mixed' pattern. Thus one may reconstruct the hypothetical pathway of evolution of these structures. Since the majority of Galipeinae possess tubular flowers, which are absent from most other members of Rutaceae, the presence of tubes is here considered a synapomorphy of Galipeinae, and the floral tubes are thus homologous between species. The following structural transformations during the evolution of Galipeinae may be assumed: (1) the ancestral state in the group was a floral tube formed by mere postgenital coherence of petals and stamens by intertwining trichomes (the pattern observed in C. heterophyllus and C. minutiflorus); (2) congenital fusion of petals and stamens at the base of the tube, but retaining postgenital coherence higher up, would have led to the mixed pattern of Galipea species and C. macrophyllus; and (3) complete loss of the trichomes from the margins of petals and stamen filaments and congenital fusion along the entire length of the tube would finally form the tube pattern found in E. brasiliensis. However, this evolutionary hypothesis has to be considered with caution as our subtribal taxonomic sampling was limited (nine species; five from this study and four additional ones from Pirani et al., 2010) and as a robust phylogeny of Galipeinae is still not available (M. Groppo, unpubl. res., pers. comm.). The evolutionary shift may have occurred in the reverse direction and/or with additional transitions (if other, unknown floral tube structures would be found in genera not yet studied).

At a broader systematic scale, in the context of the family, the postgenitally united floral tubes in Correa, as mentioned above, are only superficially similar to those of Galipeinae. In Correa, the tube is formed by the postgenital interlocking of papillate epidermal cells and cuticular projections, whereas in Galipeinae it is formed by the intertwining trichomes and congenital fusion of petals and stamens. Considering these morphological differences, together with phylogenetic studies which show that Correa and Galipeinae belong to distantly related clades (Groppo et al., 2008, 2012), it may be assumed that the floral tubes of $C$. speciosa and Galipeinae are not clearly homologous and their resemblance is a case of convergence.

Assuming that convergent evolution occurred, it can be speculated that similar selective pressures may have acted upon Correa and Galipeinae flowers, and that they might have been associated with pollination. The majority of cases reported for fusion of floral whorls comes from studies of petals and carpels, which are often associated with reproductive success (Stebbins, 1950; Verbeke, 1992; Endress, 2006). A possible reproductive advantage of having a floral tube is the restriction of the access to the floral reward for nectar robbers (Faegri and van der Pijl, 1966); in addition, the accumulation of nectar in the bottom of the tube may reduce nectar evaporation and dilution by rain (Endress, 1994). One may expect that the flowers of Galipeinae and C. speciosa offer nectar as a reward and are pollinated by nectar-seeking insects with a long proboscis and/or long-beaked birds. This has been shown by field studies for both groups: Armstrong (1979) reported that ten Correa species are pollinated by several Meliphagidae birds; $G$. jasminiflora is pollinated by species of Lepidoptera (Piedade and Ranga, 1993), and E. brasiliensis is pollinated by the hummingbird Glaucis hirsuta (Lopes, 2002). In addition, we observed pollination by two butterfly species and by the hummingbird Phaethornis idaliae in Almeidea rubra A.-St.Hil. (J. H. L. El Ottra et al., unpubl. res.), and several butterfly visits in C. macrophyllus and Angostura bracteata (J. H. L. El Ottra and E. Pansarin, pers. obs.; all Galipeinae). However, the paucity of studies about pollination of Galipeinae limits our evolutionary inferences about the factors that might have had an influence on the generation of the different floral tubes present in the subtribe.

Partially apocarpous gynoecium and its consequences: compitum and the fruit stage

The comparative gynoecium analysis of Galipeinae shows a conspicuous variability in the extent of carpel union. In the mature gynoecium of $G$. jasminiflora, carpels are connate along most of their length. Pirani et al. (2010) obtained the same results for four other species of Galipea. Conversely, carpels of C. heterophyllus, C. minutiflorus, C. macrophyllus and $E$. brasiliensis have an unfused zone, which comprises a large part of the ovary, but carpels are congenitally united basally in the centre of the ovary. Additionally, in G. jasminiflora and E. brasiliensis, the carpels are completely united below the locule, forming a short, inconspicuous gynophore, as is common in Rutaceae (Gut, 1966; Ramp, 1988), but has not yet been described for these genera. Therefore, the mature gynoecium is different in each of the three genera as to 
the extent of the syncarpous zone and the postgenitally united part of the apocarpous zone.

Such diversity in the degree of carpel union, including congenital and postgenital union, is well known in general for Rutaceae. In the extreme, the carpels may be completely congenitally united, such as in Aurantioideae, or completely free (not even with postgenital union), such as in part of the genus Zanthoxylum (Engler, 1931; Tilson and Bamford, 1938; Gut, 1966; Guédès, 1973; Ramp, 1988; Beurton, 1994; Kubitzki et al., 2011). Molecular phylogenetic studies (Groppo et al., 2008) indicate that the change in carpel fusion extent is labile in evolution. However, more structural studies are needed to clarify the complex evolutionary history of the gynoecium in Rutaceae.

As the floral apex in Galipeinae is convex when the carpels are initiated, the area of the base of the carpels is oblique (Figs 6F, 7C-F, 9E, F and 10F, G). Therefore, sections of the gynoecium base perpendicular and parallel to the longitudinal axis of the flower show an area of larger celled tissue in the centre that is not involved in carpel formation. The same is present in other Rutaceae and was discussed earlier (Gut, 1966; Ramp, 1988).

A shared feature of all three genera studied here is the presence of postgenitally united carpel tips (style and stigma), as known from most other Rutaceae (Endress et al., 1983; Ramp, 1988; Caris et al., 2006; Wei et al., 2012). In Galipeinae, it was first observed in E. brasiliensis by Ramp (1988). The occurrence of gynoecia that are more or less apocarpous but with a postgenitally united upper part is associated with the presence of a compitum at anthesis, which is assumed to provide the advantage of centralized pollen tube selection as opposed to a gynoecium without a compitum (Endress et al., 1983; Endress, 2011). Families with this gynoecium architecture are especially common in Sapindales. In addition to Rutaceae, they also occur in Simaroubaceae (Endress et al., 1983; Ramp, 1988), Kirkiaceae (Bachelier and Endress, 2008) and occasionally in Anacardiaceae (Bachelier and Endress, 2009). They were also found in other core eudicots, such as Malvaceae, Loganiaceae and Apocynaceae (Endress et al., 1983), and more recently in some Crossosomatales (Matthews and Endress, 2005b) and some Ochnaceae (Matthews et al., 2012).

Apocarpous gynoecia with a postgenitally united upper part and compitum are features that in combination have been assumed to be secondarily apocarpous in terms of evolution in Rutaceae and other groups because of their phylogenetic position within eudicots (Endress et al., 1983). However the extreme variability in the extent of carpel fusion found in the crown group of the Rutaceae makes this hypothesis difficult to corroborate in a phylogenetic context (Kubitzki et al., 2011). For many clades within the family, detailed structural data on the gynoecium are still lacking, which makes the analysis of evolutionary pathways of gynoecium traits difficult. The study of smaller clades may help gradually to untangle the evolutionary history of the gynoecium in Rutaceae. Also the apparent lability of carpel fusion indicates that secondary apocarpy may have evolved multiple times in the family (Ramp, 1988).

During fruit development, the postgenitally united style breaks off at its base, and the carpels in the apical part of the ovary become separated in the postgenitally united zone. This was observed in this study and is commonly found in other Rutoideae (Gut, 1966; Ramp, 1988; Pirani et al., 2010). However, we found that this separation varies according to the extent of the apocarpous zone (regardless of whether or not it is postgenitally united). Thus the apical parts of the ovaries of Conchocarpus and Erythrochiton become much more divergent at fruit maturity than those of Galipea. This is a consequence of the greater extent of syncarpy in Galipea.

\section{Postgenital union of the anthers in Galipea}

The postgenital union of the anthers and their sterile basal appendages found in this study only for G. jasminiflora was similar to the observations of Pirani et al. (2010) for three other species of Galipea. Thus this feature may occur in the majority of the species of the genus, except for G. dasysperma and G. panamensis, which have free anthers. The only difference between our study and that of Pirani et al. (2010) was in the histology of the fusion of the anthers. In G. ciliata, the histological union between adjacent anther appendages and thecae was complete: the epidermal layers of both anthers were no longer visible along the suture region at anthesis (Pirani et al., 2010), whereas G. jasminiflora still shows vestiges of the suture between the epidermis of adjacent anthers in mature buds (Fig. 6B). These differences could be a consequence of the timing with which both anthers come into close contact. Sutures tend to remain evident at maturity only when the organs to be fused come into contact relatively late in floral development (Verbeke, 1992). Whether in the two fertile stamens of $G$. ciliata the fusion process begins earlier than in the other Galipea species in which less complete fusion occurs, needs developmental investigation.

Although only five species were anatomically analysed, the presence of two connate anthers and sterile basal appendages is a conspicuous feature in Galipea (Pirani, 2004), and occurs less frequently in other genera of Galipeinae. This feature may have a functional importance for the floral biology of the group (Pirani et al., 2010). The presence of only two fertile, connate stamens, with an upright position at anthesis, has been traditionally associated with pollen economy and precise pollen deposition on the dorsal parts of the body of pollinators, as in some Gesneriaceae and Labiatae (Faegri and van der Pijl, 1979; Westerkamp and Claßen-Bockhoff, 2007). The study of floral biology and pollination of G. jasminiflora indicates that nototribic pollination actually occurs as expected by their anther display (Piedade and Ranga, 1994). Additionally, the fusion of part of the anthers and its basal appendages may contribute to the stabilization of the whole structure during foraging of pollinators.

\section{Conclusions}

The structural floral features studied here are shared by groups of genera and species of Galipeinae, which could be used in future studies of character evolution. They may also represent possible synapomorphies for clades in these groups. However, the limited taxonomic sampling still prevents accurate testing at the subtribal level. Further investigation of floral features of a greater number of species and genera of Galipeinae, as well as interpretation of the data based on a phylogenetic framework, are needed in order to evaluate the findings and to better understand their role in the evolutionary history of this interesting neotropical group of Rutaceae. 
Page 16 of $17 \quad$ El Ottra et al. - Fusion within and between whorls of floral organs in Galipeinae

\section{ACKNOWLEDGEMENTS}

Thanks are due to the technicians of the Plant Anatomy Laboratory (IB-USP), Gisele R. O. Costa, Tássia C. Santos and Irwandro R. Pires, for assisting the first author. The first author also thanks Maria F. Calió and José E. A. R. Marian for assistance with SEM techniques, Diego Demarco for assistance with histological techniques, Milton Groppo and Alexandre Zuntinni for pickled plant material, and João Semir, Marcelo M. Egea and Julie H. A. Dutilh for their assistance in the collection of G. jasminiflora. We thank Mary Endress for her linguistic suggestions. This work was supported by Fundação de Amparo à Pesquisa do Estado de São Paulo [grants nos 06/ 609900, 09/54569-9 and 09/08764-4] to J.H.L.E.O. and J.R.P. and Conselho Nacional de Desenvolvimento e Pesquisa productivity grant to J.R.P.

\section{LITERATURE CITED}

Armstrong JA. 1979. Biotic pollination mechanism in the Australian flora - a review. New Zealand Journal of Botany 17: 467-508.

Bachelier JB, Endress PK. 2008. Floral structure of Kirkia (Kirkiaceae) and its position in Sapindales. Annals of Botany 102: 539-550.

Bachelier JB, Endress PK. 2009. Comparative floral morphology and anatomy of Anacardiaceae and Burseraceae (Sapindales), with a special focus on gynoecium structure and evolution. Botanical Journal of the Linnean Society 159: 499-571.

Beurton C. 1994. Gynoecium and perianth in Zanthoxylum s.l. (Rutaceae) Plant Systematics and Evolution 189: 165-191.

Bruniera CP. 2010. Estudos filogenéticos e sistemáticos em Rutaceae: análise cladística e posicionamento de Almeidea A. St.-Hil. entre as Galipeinae (Galipeae, Rutoideae) com o uso de dados morfológicos e moleculares. MSc Thesis, Universidade de São Paulo, Brazil.

Bukatsch F. 1972. Bemerkungen zur Doppelfärbung Astrablau-Safranin Mikrokosmos 61: 255.

Caris P, Smets E, De Coster K, Ronse De Craene LP. 2006. Floral ontogeny of Cneorum tricoccon L. (Rutaceae) Plant Systematics and Evolution 257: $223-232$.

Endress PK. 1994. Diversity and evolutionary biology of tropical flowers. Cambridge: Cambridge University Press.

Endress PK. 2006. Angiosperm floral evolution: morphological developmental framework. Advances in Botanical Research 44: 1-61.

Endress PK. 2010a. Synorganisation without organ fusion in the flowers of Geranium robertianum (Geraniaceae) and its not so trivial obdiplostemony. Annals of Botany. 106: 687-695.

Endress PK. 2010b. Flower structure and trends of evolution in eudicots and their major subclades. Annals of the Missouri Botanical Garden 97: $541-583$.

Endress PK. 2011. Evolutionary diversification of the flowers in angiosperms. American Journal of Botany 98: 370-396.

Endress PK, Matthews ML. 2012. Progress and problems in the assessment of flower morphology in higher-level systematics. Plant Systematics and Evolution 298: 257-276.

Endress PK, Jenny M, Fallen ME. 1983. Convergent elaboration of apocarpous gynoecia in higher advanced angiosperms (Sapindales, Malvales, Gentianales). Nordic Journal of Botany 3: 293-300.

Engler A. 1874. Rutaceae. In: Martius CPF, Eichler AG. eds. Flora brasiliensis. Leipzig: Friedrich Fleischer, 12: 75-196, tabs. 14-39.

Engler A. 1931. Rutaceae. In: Engler A, Prantl K. eds. Die natürlichen Pflanzenfamilien, 2nd edn, 19a. Leipzig : Wilhelm Engelmann, 187-359.

Faegri L, van der Pijl L. 1979. The principles of pollination ecology, 3rd edn. New York: Pergamon Press.

Fallen ME. 1986. Floral structure in the Apocynaceae: morphological, functional and evolutionary aspects. Botanische Jahrbücher für Systematik 106: $245-286$.

Groppo M. 2010. Estudos filogenéticos em Rutaceae Neotropicais: presente e futuro. In: Simpósio de Sapindales. X Congresso Latinoamericano de Botánica. La Serena, Chile.
Groppo M, Pirani JR, Salatino MLF, Blanco SR, Kallunki JA. 2008 Phylogeny of Rutaceae based on two noncoding regions from cpDNA. American Journal of Botany 95: 985-1005.

Groppo M, Kallunki JA, Pirani JR, Antonelli A. 2012. Chilean Pitavia more closely related to Oceania and Old World Rutaceae than Neotropical groups: evidence from two cpDNA non-coding regions, with a new subfamilial classification of the family. PhytoKeys 19: 9-29.

Guédès M. 1973. Carpel morphology and axis-sharing in syncarpy in some Rutaceae, with further comments on 'New Morphology'. Botanical Journal of the Linnean Society 66: 55-74.

Gut BJ. 1966. Beiträge zur Morphologie des Gynoeciums und der Blütenachse einiger Rutaceen. Botanische Jahrbücher für Systematik 85: $151-247$.

Hartl D. 1957. Die Pseudosympetalie von Correa speciosa (Rutaceae) und Oxalis tubiflora (Oxalidaceae). Abhandlungen der MathematischNaturwissenschaftlichen Klasse, Akademie der Wissenschaften und der Literatur Mainz 1957 (2): 1-13.

Johansen DA. 1940. Plant microtechnique. New York: McGraw-Hill Book Company.

Kallunki JA. 1992. A revision of Erythrochiton sensu lato (Cuspariinae, Rutaceae). Brittonia 44: 107-139.

Kallunki JA. 1994. Revision of Raputia Aubl. (Cuspariinae, Rutaceae). Brittonia 46: 279-295.

Kallunki JA. 2009. Validation of Neoraputia (Galipeae, Rutaceae) and description of two new species from Eastern Brazil. Brittonia 61: 28-34.

Kallunki JA, Groppo M. 2007. Phylogenetic analyses of the subtribe Galipeinae (Rutaceae). http://2007.botanyconference.org/engine/search/ index.php?func=detail\&aid=1344. Last accessed 12 October 2012.

Kallunki JA, Pirani JR. 1998. Synopses of Angostura Roem. \& Schult. and Conchocarpus J. C. Mikan. Kew Bulletin 53: 257-334.

Kubitzki K, Kallunki JA, Duretto M, Wilson PG. 2011. Rutaceae. In: Kubitzki K. ed. The families and genera of vascular plants, Vol. 10 Berlin: Springer, 276-356.

Leinfellner W. 1964. Über die falsche Sympetalie bei Lonchostoma und anderen Gattungen der Bruniaceen. Österreichische Botanische Zeitschrift 111: 345-353.

Lopes AVF. 2002. Polinização por beija-flores em remanescentes da Mata Atlântica Pernambucana, nordeste do Brasil. MSc Thesis, Universidade de Campinas, Brazil.

Matthews ML, Endress PK. 2002. Comparative floral structure and systematics in Oxalidales (Oxalidaceae, Connaraceae, Brunelliaceae, Cephalotaceae, Cunoniaceae, Elaeocarpaceae, Tremandraceae). Botanical Journal of the Linnean Society 140: 321-381.

Matthews ML, Endress PK. 2005a. Comparative floral structure and systematics in Celastrales (Celastraceae, Parnassiaceae, Lepidobotryaceae). Botanical Journal of the Linnean Society 149: 129-194.

Matthews ML, Endress PK. 2005b. Comparative floral structure and systematics in Crossosomatales (Crossosomataceae, Stachyuraceae, Staphyleaceae, Aphloiaceae, Geissolomataceae, Ixerbaceae, Strasburgeriaceae). Botanical Journal of the Linnean Society 147: 1-46.

Matthews ML, Endress PK. 2008. Comparative floral structure and systematics in Chrysobalanaceae s.l. (Chrysobalanaceae, Dichapetalaceae, Euphroniaceae, Trigoniaceae; Malpighiales). Botanical Journal of the Linnean Society 157: 249-309.

Matthews ML, Endress PK. 2011. Comparative floral structure and systematics in Rhizophoraceae, Erythroxylaceae and the potentially related Ctenolophonaceae, Linaceae, Irvingiaceae and Caryocaraceae (Malpighiales). Botanical Journal of the Linnean Society 166: 331-416.

Matthews ML, Amaral MCE, Endress PK. 2012. Comparative floral structure and systematics in Ochnaceae s.l. (Ochnaceae, Quiinaceae, Medusagynaceae; Malpighiales). Botanical Journal of the Linnean Society 170: 299-392.

Piedade LH, Ranga NT. 1993. Ecologia da polinização de Galipea jasminiflora Engler (Rutaceae). Revista Brasileira de Botânica 16: 151-157.

Pirani JR. 2004. Three new species of Galipea (Rutaceae, Galipeinae) from Brazil. Botanical Journal of the Linnean Society 144: 365-373.

Pirani JR, Kallunki JA. 2007. Two new species of Galipea (Rutaceae, Galipeae) from Bolivia, Ecuador, and Peru. Brittonia 59: 343-349.

Pirani JR, El Ottra JHL, Menezes NL. 2010. Morfoanatomia de flores de cinco espécies de Galipea Aubl. e seu significado na evolução de flores tubulosas entre as Rutaceae neotropicais. Revista Brasileira de Botânica 33: $301-318$ 
Pirani JR, Groppo M, Kallunki JA. 2012. Two new species and a new combination in Conchocarpus (Rutaceae, Galipeeae) from eastern Brazil. Kew Bulletin 66: 1-7.

Quint M, Claßen-Bockhoff R. 2006. Floral ontogeny, petal diversity and nectary uniformity in Bruniaceae. Botanical Journal of the Linnean Society 150: 459-477.

Ramp E. 1988. Struktur, Funktion und systematische Bedeutung des Gynoeciums bei den Rutaceae und Simaroubaceae. PhD Thesis, Universität Zürich, Switzerland.

Ritterbusch A. 1991. Morphologisches Beschreibungsmodell tubiflorer Kronen, ein Beitrag zur Terminologie und Morphologie der AsteridenBlüte. Botanische Jahrbücher für Systematik 112: 329-345.

Robbrecht E. 1988. Tropical woody Rubiaceae. Opera Botanica Belgica 1: 1-271.

Rohweder O. 1969. Beiträge zur Blütenmorphologie und -anatomie der Commelinaceen mit Anmerkungen zur Begrenzung und Gliederung der
Familie. Berichte der Schweizerischen Botanischen Gesellschaft 79: 199-220.

Tilson AH, Bamford R. 1938. The floral anatomy of the Aurantioideae. American Journal of Botany 25: 780-793.

Stebbins GL. 1950. Variation and evolution in plants. New York: Columbia University Press.

Verbeke JA. 1992. Fusion events during floral morphogenesis. Annual Reviews of Plant Physiology and Plant Molecular Biology 43: 583-598.

Weberling F. 1989. Morphology of flowers and inflorescences. Cambridge: Cambridge University Press.

Wei L, Wang YZ, Li ZY. 2012. Floral ontogeny of Ruteae (Rutaceae) and its systematic implications. Plant Biology. 14: 190-197.

Westerkamp C, Claßen-Bockhoff R. 2007. Bilabiate flowers: the ultimate response to bees? Annals of Botany 100: 361-374. 